RODRIGO RAMINA DE LUCCA

A MOTIVAÇÃO DAS DECISÕES JUDICIAIS CIVIS EM UM ESTADO DE DIREITO: NECESSÁRIA PROTEÇÃO DA SEGURANÇA JURÍDICA

DISSERTAÇÃO DE MESTRADO

ORIENTADOR: PROF. TITULAR FLÁVIO LUIZ YARSHELL

FACULDADE DE DIREITO DA UNIVERSIDADE DE SÃO PAULO

SÃO PAULO

2013 


\title{
A MOTIVAÇÃO DAS DECISÕES JUDICIAIS CIVIS EM UM ESTADO DE DIREITO: NECESSÁRIA PROTEÇÃO DA SEGURANÇA JURÍDICA
}

\author{
Dissertação de Mestrado apresentada à \\ Faculdade de Direito da Universidade de \\ São Paulo para obtenção do título de \\ Mestre. \\ Área de Concentração: Direito \\ Processual. \\ Subárea: Direito Processual Civil. \\ Orientador: Professor Titular Flávio Luiz \\ Yarshell
}

FACULDADE DE DIREITO DA UNIVERSIDADE DE SÃO PAULO

SÃO PAULO 


\section{TERMO DE APROVAÇÃO}

RODRIGO RAMINA DE LUCCA

\section{A MOTIVAÇÃO DAS DECISÕES JUDICIAIS CIVIS EM UM ESTADO DE DIREITO: NECESSÁRIA PROTEÇÃO DA SEGURANÇA JURÍDICA}

Dissertação aprovada como requisito parcial para a obtenção do grau de Mestre em Direito Processual Civil no Programa de Pós-Graduação Strictu Sensu da Faculdade de Direito da Universidade de São Paulo, pela seguinte Banca Examinadora:

Orientador: $\quad$ Professor Titular Flávio Luiz Yarshell

Membros: $\quad$ Prof.

Prof.

São Paulo, de de 2013. 


\section{RESUMO}

RAMINA DE LUCCA, Rodrigo. A motivação das decisões judiciais em um Estado de Direito: necessária proteção da segurança jurídica. Dissertação de Mestrado. Faculdade de Direito. Universidade de São Paulo, 2013.

Este trabalho trata do papel desempenhado pelo dever de motivação das decisões judiciais na realização do Estado de Direito e, consequentemente, dos princípios da segurança jurídica e do devido processo legal. Partindo de uma concepção "fina" do Estado de Direito, busca-se demonstrar, inclusive mediante dados históricos, que a motivação das decisões judiciais é fundamental ao controle da atividade jurisdicional, reduzindo o arbítrio e o subjetivismo a que todo exercício de poder está sujeito. Para que a motivação possa desempenhar tal função, deve ser dotada de algumas características essenciais, que incluem: racionalidade, estrutura lógico-argumentativa e natureza declaratória e retrospectiva; cada uma delas estudada especificamente. Em relação à promoção da segurança jurídica, explica-se que apenas decisões motivadas são aptas a gerar precedentes judiciais, cuja observância é fundamental para se proporcionar estabilidade e previsibilidade ao ordenamento jurídico. Além disso, defende-se que as razões dadas pelos órgãos judiciais para a tomada de decisões geram expectativas legítimas no jurisdicionado que devem ser tuteladas.

Palavras-chave: Motivação; fundamentação; decisão judicial; Estado de Direito; segurança jurídica; devido processo legal; confiança legítima; precedente; ratio decidendi; estabilidade; previsibilidade; controle judicial; racionalidade. 


\begin{abstract}
RAMINA DE LUCCA, Rodrigo. Reasoned Judgments in the Rule of Law: realizing legal certainty. Master in Law. Law School. Universidade de São Paulo, 2013.

This essay faces the role performed by obligatory reasoned judgments in the Rule of Law and its consequences to legal certainty and due process of law. Accepting a "thin" theory of the Rule of Law, the author intends to show, through the appointment of historical facts, that giving reasons for judgments is essential to control the jurisdictional activity and restrict the arbitrary power. Giving reasons, however, shall only attend its expected role if some exigencies are fulfilled, including: rationality, logical-argumentative structure and declaratory and retrospective nature of the reasons given. The author also explains that judgments may not be precedents if they are not reasoned; and following precedents is essential to assure legal certainty. Besides that, it is sustained that reasoned judgments generate legitimate expectations to the citizens that should be protected.
\end{abstract}

Keywords: Reasoned judgments; reasons for deciding; Rule of Law; legal certainty; due process of law; justified reliance; precedent; ratio decidendi; rationality. 


\section{SUMÁRIO}

INTRODUÇÃO.

CAPÍTULO PRIMEIRO - ESTADO DE DIREITO, SEGURANÇA JURÍDICA E PROCESSO

1. Estado de Direito e o controle do poder estatal.

1.1. As origens do Estado de Direito moderno: proteção da liberdade, jusnaturalismo e segurança jurídica. 26

1.2. A ascensão do positivismo radical e o esvaziamento do conceito do Estado de Direito. .29

1.3. O desenvolvimento do Rule of Law na Inglaterra do século XIX. 31

1.4. A retomada do conteúdo substancial do Estado de Direito após a Segunda Guerra Mundial e o declínio da expressão. 32

1.5. Estado de Direito formal e Estado de Direito substancial...................................... 34

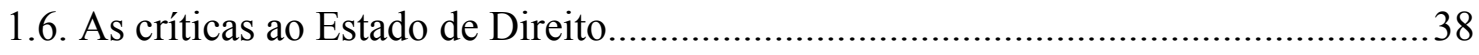

1.6.1. Expressão inútil e pleonástica .......................................................................... 38

1.6.2. Pluralidade de significados: expressão meramente retórica.

1.7. O 'conteúdo mínimo’ do Estado de Direito: proteção da liberdade e da segurança jurídica. 40

2. A segurança jurídica: atributo e finalidade do Estado de Direito. 45

2.1. A trilogia dos objetivos do Direito: segurança jurídica, justiça e progresso social. 48

2.2. Segurança jurídica pelo Direito e segurança jurídica do Direito. .50

2.3. Ainda sobre as relações entre segurança jurídica e justiça. 51

2.4. O conceito de segurança jurídica .52

3. A jurisdição e o processo no Estado de Direito: o devido processo legal. 53

3.1. O processo como instrumento de racionalização do poder. 57

3.2. Processo justo e devido processo legal. 60

CAPÍTULO SEGUNDO - O DEVER DE MOTIVAR AS DECISÕES JUDICIAIS COMO GARANTIA INERENTE A UM ESTADO DE DIREITO. .62

4. O dever de motivar as decisões judiciais. 
4.2. A natureza normativa do dever de motivação.

4.2.1. A obrigatória motivação das decisões judiciais é uma 'regra' jurídica

4.2.2. A importância de se conceber o dever de motivação como regra, e não como princípio 70

4.2.3. A imponderabilidade do dever de motivação. .72

5. A consolidação do dever de motivação como garantia fundamental após a Revolução Francesa e panorama contemporâneo.

5.1. Controvérsia sobre a motivação das decisões judiciais no Direito Romano e seu suposto papel de controle da atividade judicial em relação à aplicação das leis imperiais 74

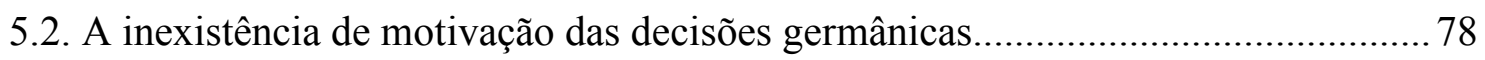

5.3. A formação de uma jurisprudência dos tribunais europeus medievais. .80

5.4. A recomendação de que o juiz, por prudência, não deveria motivar suas decisões.

5.5. O declínio da motivação das decisões judiciais no início do absolutismo e seu renascimento no século XVI

5.6. A contribuição da Revolução Francesa para o dever de motivar as decisões judiciais.

5.6.1. O periodo francês pré-revolucionário. 87

5.6.2. O legado da Revolução Francesa.

5.7. A influência imediata dos ideais revolucionários na motivação das decisões judiciais no século XIX.

5.8. Panorama atual.

6. Motivação das decisões judiciais e Estado de Direito. 104

6.1. A legitimação da atividade jurisdicional.

6.2. O controle da atividade jurisdicional 108

6.2.1. Controle em relação aos fatos: livre convencimento racional e motivado à luz dos autos.

6.2.2. Controle em relação ao Direito. 111

6.2.3. O controle das decisões judiciais pelas partes e pelos Tribunais. 118

6.2.4. O controle das decisões judiciais pela sociedade. 


\section{CAPÍTULO TERCEIRO - AINDA SOBRE AS RELAÇÕES ENTRE MOTIVAÇÃO DAS DECISÕES JUDICIAIS E ESTADO DE DIREITO: NATUREZA,

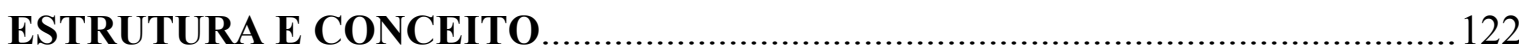

7. A natureza declaratória da motivação das decisões judiciais................................ 122

7.1. A motivação das decisões judiciais possui natureza declaratória e retrospectiva..... 123

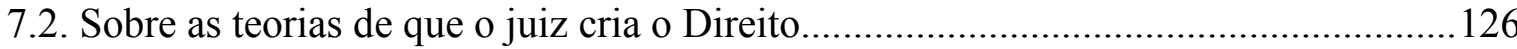

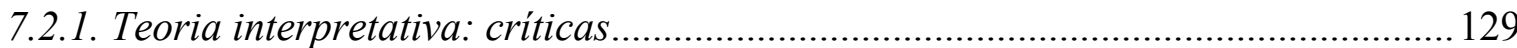

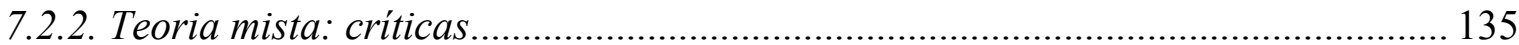

7.2.3. Teoria da eficácia vinculante dos precedentes: críticas........................................ 137

8. A estrutura da motivação das decisões judiciais: o silogismo judicial e a

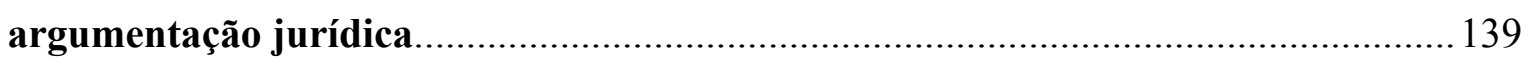

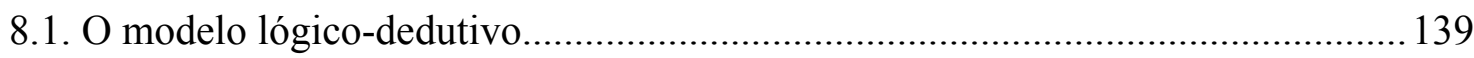

8.2. As críticas ao modelo lógico-dedutivo e o desenvolvimento de modelos

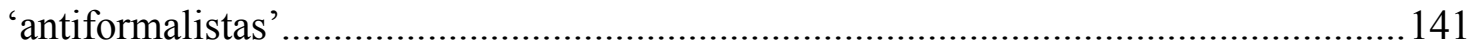

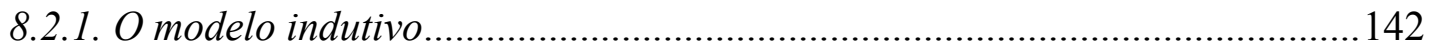

8.2.2. A inaptidão do modelo indutivo como modelo de raciocínio judicial............ 144

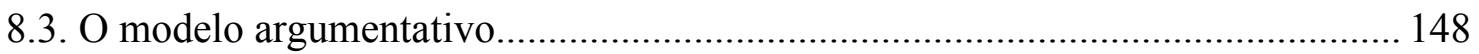

8.3.1. A teoria standard da argumentação judicial............................................... 150

8.3.2. A teoria de Jerzy Wróblewski-justificação interna e a justificação externa da motivação.

8.3.3. A teoria de Neil MacCormick - necessária conciliação entre o Estado de Direito e a argumentação jurídica.

8.3.4. A teoria de Robert Alexy - as regras do discurso prático e do discurso jurídico 154

8.3.5. A teoria de Aulis Aarnio - racionalidade e aceitabilidade da motivação.....156

8.4. A conjugação entre lógica e argumentação: as teorias de Ricardo Luis Lorenzetti e Pierluigi Chiassoni 160

8.4.1. A teoria de Ricardo Luis Lorenzetti - diferentes modelos para a decisão de casos fáceis e casos difíceis.

8.4.2. A teoria de Pierluigi Chiassoni - a reconstrução silogística da argumentação judicial

8.5. Lógica e argumentação: a estrutura da motivação das decisões judiciais. 170 
9. A motivação das decisões judiciais: exposição e justificação - o referencial do Estado de Direito

9.1. A motivação é uma exposição de razões 174

9.2. A motivação é uma justificação formal do exercício da atividade jurisdicional...... 174

9.3. Sobre a dissociação entre a motivação e as razões de decidir. 175

9.3.1. A motivação não é a justificação de uma decisão intuititva. 176

9.3.2. Críticas à teoria de que a motivação é uma fonte de indícios - a racionalidade e a aceitabilidade da motivação. 180

9.3.3. A motivação e as razões de decidir - a regra da sinceridade. 181

\section{CAPÍTULO QUARTO - DELINEAMENTOS PROCESSUAIS DO DEVER DE MOTIVAÇÃO 183}

10. O dever de motivação como instrumento de realização de garantias processuais.

10.1. Motivação das decisões judiciais, contraditório e ampla defesa. 184

10.2. Inércia jurisdicional e princípio dispositivo. 186

10.3. Poder de ação e pluralidade de demandas 188

10.4. Coisa julgada. 189

10.5. Duplo grau de jurisdição. 190

10.6. Imparcialidade do órgão julgador. 191

11. Requisitos mínimos do dever de motivação.

11.1. Clareza. .192

11.2. Coerência. .195

11.3. Completude. 196

11.3.1. Completude fática.... 198

11.3.2. Completude jurídica. .200

11.3.3. Ainda sobre o entendimento de que o juiz não precisa se manifestar a respeito de todas as alegações das partes: críticas..... .202

11.3.4. A completude da motivação e as decisões sujeitas a recursos....... 205

11.3.5. A motivação implícita. 207

11.4. A motivação per relationem e a motivação aliunde. .208

12. Decisões imotivadas, decisões mal motivadas e suas consequências. 210 
12.1. As decisões judiciais e os planos da existência, validade e eficácia: considerações iniciais

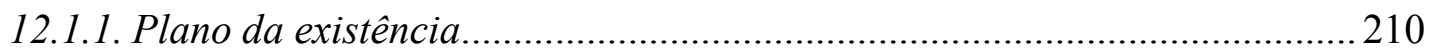

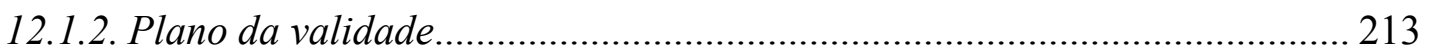

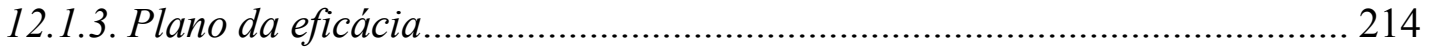

12.1.4. Decisões judiciais inexistentes, nulas e ineficazes.....................................215

12.2. Decisões inexistentes por "falta de motivação" ou motivação incongruente.......217

12.2.1. Inexistência por "falta de motivação"........................................................ 217

12.2.2. Inexistência por incongruência entre a motivação e a causa de pedir....... 218

12.3. Decisões nulas por falta de motivação ou motivação inadequada.......................218

12.4. Meios de ataque à decisão imotivada ou mal motivada................................... 220

CAPÍTULO QUINTO - MOTIVAÇÃO DAS DECISÕES JUDICIAIS E SEGURANÇA JURÍdiCA: A FORMAÇÃo DOS PRECEDENTES E A RATIO DECIDENDI.

13. Motivação das decisões judiciais e segurança jurídica: o precedente judicial.... 222

13.1. A segurança jurídica como fundamento básico do respeito aos precedentes...... 225

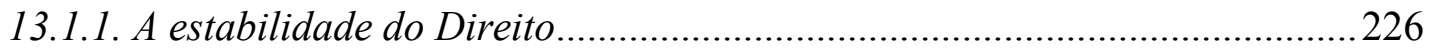

13.1.2. A previsibilidade do Direito: sistematicidade e coerência..........................229

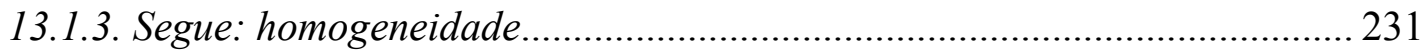

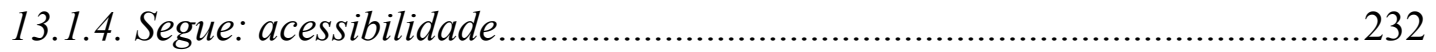

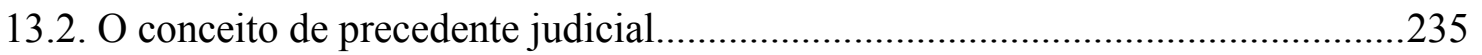

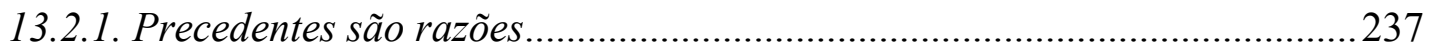

13.2.2. Precedentes não são razões fáticas....................................................... 240

13.2.3. Precedentes são razões jurídicas de uma decisão: o atributo da universalidade

13.2.4. Precedentes são razões jurídicas determinantes ao dispositivo da decisão: a ratio decidendi

13.2.5. A relevância das razões jurídicas da decisão e o conceito de precedente.. 243

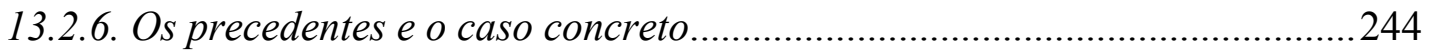

13.2.7. Os precedentes e a motivação implícita..................................................... 245

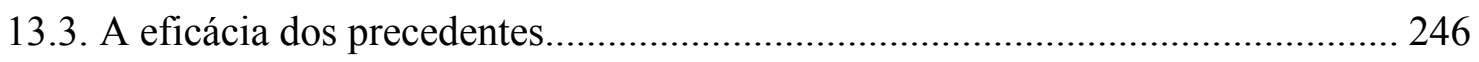

13.3.1. Precedentes obrigatórios: a regra do stare decisis.................................... 246 
13.3.2. Precedentes persuasivos

13.3.3. Precedentes verticais.

13.3.4. Precedentes horizontais.

14. A ratio decidendi e o obiter dictum na motivação das decisões judiciais 257

14.1. A importância da distinção. 258

14.2. Teorias elaboradas para distinguir a ratio decidendi do obiter dictum. 260

14.2.1. O teste de Eugene Wambaugh. 260

14.2.2. A desconsideração da motivação jurídica e os fatos materiais de Arthur Goodhart. .262

14.2.3. A ratio decidendi prescritiva e a ratio decidendi descritiva de Julius Stone. .264

14.2.4. Ratio decidendi como razão jurídica necessária ou suficiente - as propostas de Rupert Cross e de Neil MacCormick. 265

14.2.5. O conceito de Michael Abramowicz e Maxwell Stearns .267

14.2.6. A adequação da ratio de decidendi à realidade brasileira por Luiz Guilherme Marinoni - solução de questões e não de casos. .268

14.2.7. A proposta de Pierluigi Chiassoni - a necessária reconstrução silogística da decisão judicial para a determinação das rationes decidendi. .268

14.2.8. Observações conclusivas..... 269

14.3. O obiter dictum. 271

14.4. A não aplicação de um precedente: a distinção (distinguishing)...... .274

15. A experiência brasileira. .276

15.1. As súmulas. .277

15.1.1. Conceito. 278

15.1.2. As Súmulas e a doutrina de precedentes: os enunciados sumulares são rationes decidendi. 279

15.2. A Súmula vinculante. 280

15.3. Decisões monocráticas amparadas em entendimento jurisprudencial consolidado e a "súmula impeditiva de recursos". 282

15.4. Os "recursos repetitivos" .282

15.5. O efeito vinculante dos acórdãos prolatados em controle concentrado de constitucionalidade. 284

15.5.1. Eficácia vinculante de decisão proferida em ADPF. 285 
15.5.2. A "objetivação" do controle de constitucionalidade difuso e a teoria da transcendência dos motivos determinantes.

\section{CAPÍtULO SEXTO - A MOTIVAÇÃO DAS DECISÕES JUDICIAIS E A PROTEÇÃO DA “CONFIANÇA LEGÍTIMA” DO JURISDICIONADO...............28}

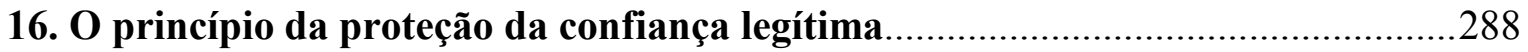

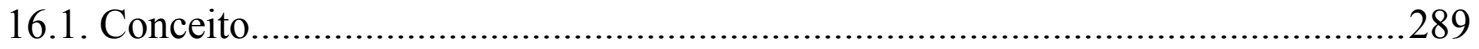

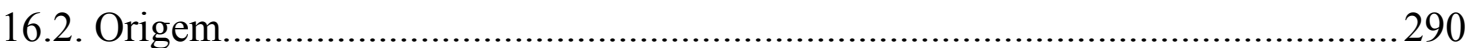

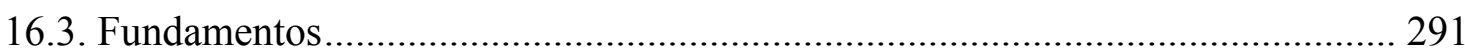

16.3.1. Confiança legítima e segurança jurídica objetiva .....................................292

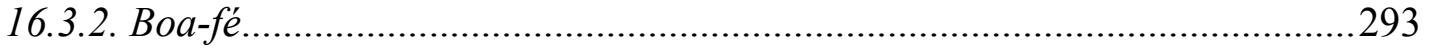

16.4. A eficácia normativa do princípio no Brasil......................................................295

16.5. Pressupostos de aplicação do princípio da confiança...........................................296

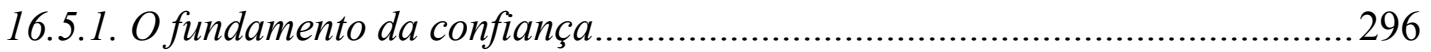

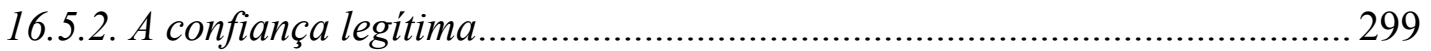

16.5.3. O exercício da confiança ................................................................... 300

16.6. A violação do princípio da confiança (a frustração da confiança)...................... 301

17. A jurisdição e a violação da confiança legítima do jurisdicionado.......................302

17.1. Os precedentes judiciais como fundamento da confiança...................................303

17.1.1. Dois exemplos de violação da confiança do jurisdicionado pela

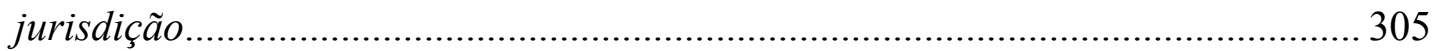

17.2. Sobre a natureza da atividade jurisdicional e a (ir)retroatividade da jurisprudência.

17.3. Mudança jurisprudencial, evolução do Direito e confiança legítima do

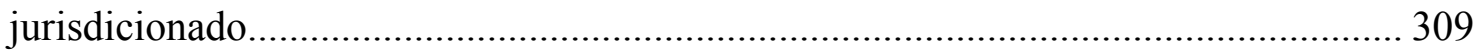

17.4. Requisitos para que os precedentes sirvam como fundamento da confiança... 311

17.4.1. A eficácia do precedente.

17.4.2. Segue: a aparência de legitimidade do precedente.

17.4.3. Segue: baixo grau de modificabilidade do precedente.................................314

17.4.4. Segue: permanência no tempo do precedente............................................. 315

17.4.5. Segue: indução do precedente ..................................................................... 315

17.5. A legitimidade da confiança do jurisdicionado................................................. 316 
17.5.1. Precedentes e jurisprudência......

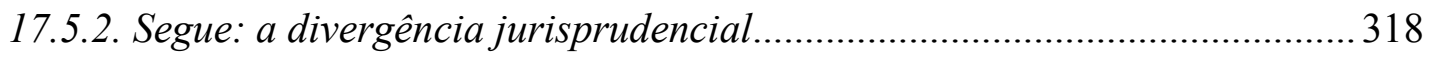

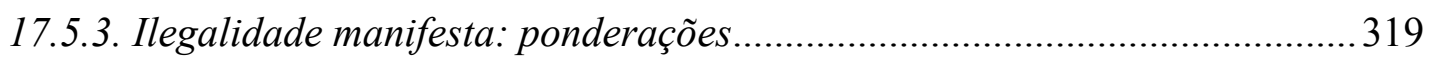

17.5.4. O parâmetro do “advogado bem informado "............................................. 321

17.6. O exercício da confiança legítima do jurisdicionado........................................ 322

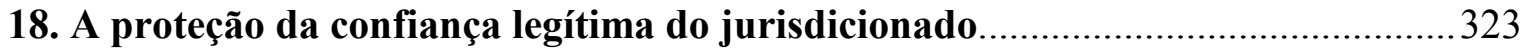

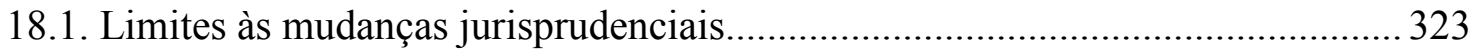

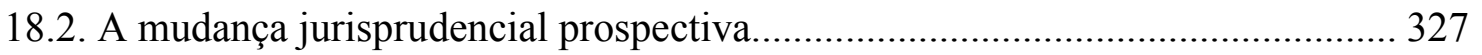

18.3. Duas regras básicas de utilização da técnica de revogação prospectiva de precedentes.

18.3.1. Prevalência dos interesses do particular sobre os do Estado (ou interesse

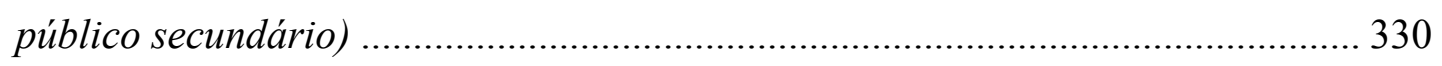

18.3.2. Ponderação entre os interesses dos particulares envolvidos....................... 331

18.4. Críticas formuladas à revogação prospectiva de precedentes - e suas respostas.

18.4.1. Aplicação de um precedente já superado - descumprimento da função

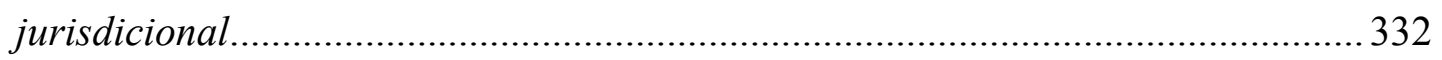

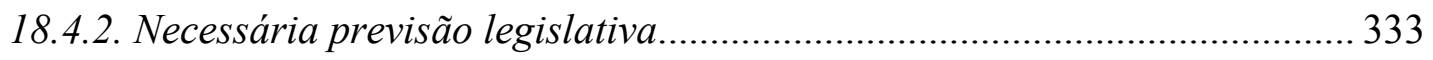

18.4.3. Desestímulo à busca por decisões mais justas........................................... 335

18.4.4. Majoração indevida dos poderes dos juízes................................................ 336

18.5. A responsabilidade do Estado pela violação da confiança legítima do jurisdicionado. 


\section{INTRODUÇÃO}

Muito pouco se escreveu e se escreve no Brasil a respeito da motivação das decisões judiciais. Um ano antes da promulgação da Constituição de 1988, em trabalho que propôs, justamente, a previsão constitucional de obrigatoriedade da motivação, José Rogério Cruz e Tucci observou: "Verifica-se, entretanto, que, diversamente da doutrina alienígena, entre nós, pouca atenção tem-se dado a essa relevantíssima temática". ${ }^{1}$ Alçada à categoria de norma constitucional, a motivação das decisões judiciais continuou a ser pouco tratada, o que foi constatado no ano de 1990 por José Augusto Delgado: “A abordagem do tema referente à obrigatoriedade do Juiz motivar os atos decisórios não tem merecido, entre nós, ao contrário do que acontece na doutrina estrangeira, a devida atenção". ${ }^{2}$ Desde então, apesar de publicadas algumas excelentes obras dedicadas ao instituto, o cenário pouco mudou. ${ }^{3}$

Além disso, proliferam-se decisões judiciais imotivadas ou mal motivadas, amparadas sempre no equivocado entendimento jurisprudencial de que o juiz não precisa manifestar-se a respeito de todas as alegações das partes; basta que apresente as razões de sua decisão, independentemente do que foi alegado e provado no processo, ou mesmo do que determina o Direito. A situação é agravada pela ampla utilização de modelos padrões de decisões que nem sempre servem para dar uma resposta adequada às pretensões formuladas pelas partes e, com espantosa frequência, nem mesmo têm pertinência ao caso concreto.

Ambas as situações são graves, pois a omissão doutrinária contribui para o descaso judicial com a garantia; e o descaso judicial implica uma prestação jurisdicional arbitrária e ilegítima. Com efeito, três constatações demonstram a importância do dever de motivação em qualquer sistema jurídico.

\footnotetext{
${ }^{1}$ TUCCI, José Rogério Cruz e. A Motivação das Decisões Judiciais. p. 5.

${ }^{2}$ DELGADO, José Augusto. A sentença judicial e a constituição federal de 1988. p. 37-40.

${ }^{3}$ Merece destaque a excepcional obra de Antonio Magalhães Gomes Filho, publicada em 2001 sob o título de A Motivação das Decisões Penais.
} 
Em primeiro lugar, o dever de motivação é pressuposto do Estado de Direito, constituindo um necessário instrumento de controle da atividade jurisdicional. É pela motivação que o juiz presta contas do exercício do poder juridicional, demonstrando às partes, aos tribunais que lhe são hierarquicamente superiores e à sociedade de modo geral que aquela era a decisão correta a ser tomada, pois congruente ao que foi narrado e provado pelas partes, e congruente ao Direito produzido democraticamente pelo povo e para o povo.

Em segundo lugar, o dever de motivação é fundamental para a promoção da segurança jurídica. A jurisdição desempenha relevantíssima função de esclarecimento, integração e homogeneização do Direito, dissolvendo antinomias, buscando soluções sistemáticas para eventuais omissões legislativas e definindo a forma pela qual o Direito deve ser interpretado e compreendido.

Em terceiro lugar, o dever de motivação é, muito possivelmente, a mais importante de todas as garantias do devido processo legal. Não só porque a motivação é indispensável ao controle e à legitimação da atividade jurisdicional - e o devido processo legal é instrumento precípuo de controle e legitimação da atividade jurisdicional -, mas também porque a motivação é a última das garantias processuais. Se a inércia jurisidicional é indispensável para conferir imparcialidade ao julgamento, a motivação impede que o pedido seja julgado a partir de uma causa de pedir que não consta da petição inicial (constituindo uma demanda distinta da proposta, portanto); se a coisa julgada é necessária para dar estabilidade a situações jurídicas já consolidadas, promovendo a paz social, a motivação é fundamental para que se saiba quais são os seus limites; e se a observância do contraditório e da ampla defesa são condições essenciais de qualquer processo, transformam-se em garantias vazias se não houver uma resposta judicial racional e expressa a tudo aquilo que as partes alegaram e provaram; e assim por diante.

O dever de motivação adquire ainda mais relevância quando constatados três movimentos relativamente recentes, que se interlaçam com as relações existentes entre motivação, Estado de Direito, segurança jurídica e devido processo legal: (a) crescem os poderes atribuídos ao juiz tanto para a condução do processo como para a interpretação do direito material; (b) o Direito brasileiro vem atribuindo mais valor e eficácia aos precedentes judiciais; e (c) os precedentes judiciais (leia-se, motivações jurídicas de 
decisões judiciais pretéritas) ampliam sua influência na tomada de decisões do jurisdicionado.

Em relação ao primeiro movimento, é bastante comum que os defensores do chamado 'ativismo judicial' (processual ou material) invoquem o contraditório como garantia fundamental à proteção das partes contra o arbítrio; seria o contraditório, portanto, que legitimaria os crescentes poderes dos juízes, seja para guiar o processo, seja para interpretar cláusulas gerais e conceitos indeterminados ou ponderar princípios. Mas não é bem assim. O instrumento legitimador da atividade jurisdicional não é o contraditório, mas a exposição clara, coerente e racional das razões pelas quais a decisão foi tomada. Independentemente do que foi alegado e provado pelas partes no processo, o juiz deve atuar dentro de limites jurídicos rígidos e muito bem estabelecidos. O simples fato de autor e réu debaterem sobre o significado de uma cláusula geral não autoriza o juiz a interpretála de forma contrária ao sistema jurídico, aos precedentes dos tribunais superiores e aos valores da sociedade em que está inserido. A legitimidade da atuação jurisdicional, seja ela ampla ou restrita, vem da demonstração de que os poderes foram exercidos pelo Estadojuiz com racionalidade e de acordo com o Direito. Por isso, quanto maiores os poderes atribuídos ao Estado-juiz, maior têm que ser a profundidade e a completude da motivação das decisões.

Quanto ao segundo movimento, é notório o fato de que o Direito brasileiro vem dando mais valor e eficácia aos precedentes judiciais, seja de maneira formal, com o surgimento das súmulas vinculantes e da cláusula impeditiva de recursos, p.ex., seja de maneira informal, com o crescente respeito dos juízes ao entendimento dominante de um tribunal hierarquicamente superior. Há, ainda, institutos híbridos, voltados para a celeridade processual, mas ligados ao respeito a precedentes, como a resolução liminar do mérito de causas repetitivas - art. 285-A do CPC - e o julgamento de recursos repetitivos pelo Superior Tribunal de Justiça. Na medida em que precedentes são rationes decidendi, quer dizer, razões jurídicas pelas quais uma decisão pretérita foi tomada, a motivação das decisões judiciais precisa ser valorizada e compreendida para que também a teoria dos precedentes possa ser compreendida e corretamente aplicada.

Por fim, o necessário respeito a precedentes majora a função desempenhada pela jurisdição de definir a interpretação que deve ser dada ao Direito, estabelecendo, como consequência, diretrizes de comportamento aos jurisdicionados. A motivação das 
decisões judiciais, portanto, torna-se uma referência de conduta às pessoas, que agirão não de acordo com o que entendem ser juridicamente correto, mas de acordo com o que os tribunais dizem ser juridicamente correto a partir da interpretação que deram ao Direito.

Sendo assim, o objetivo deste trabalho é reafirmar o papel da motivação das decisões judiciais como garantia inerente ao Estado de Direito, demonstrando a sua imprescindibilidade tanto para o controle e a legitimitação da atividade jurisdicional como para a promoção da segurança jurídica e realização do devido processo legal.

\section{$\S^{\circ}$ Delimitação do tema}

O objetivo desta dissertação é delinear o dever de motivação das decisões judiciais como garantia do Estado de Direito, o que implica reconhecê-lo como instrumento de promoção da segurança jurídica e garantia ínsita ao devido processo legal. Sendo assim, não serão estudados institutos processuais intimamente relacionados com a motivação, mas que com ela não se confundem. É o caso, p.ex., da coisa julgada, da vinculação do assistente à justiça da decisão, do contraditório e da ampla defesa, das provas, dos recursos cíveis, incluindo embargos de declaração, da distinção entre error in iudicando e error in procedendo, da preclusão para o juiz etc. A menção que será feita a vários deles ao longo do texto terá sempre como objetivo o desenvolvimento do tema proposto.

Também é importante ressaltar que a motivação será tratada neste trabalho sempre do ponto de vista jurídico. Ainda que o instituto comporte análises psicológicas e sociológicas, importa aqui o que a motivação deve ser e não o que ela eventualmente pode ser ou é na prática forense.

\section{§2 Desenvolvimento da dissertação}

Esta dissertação é dividida em seis capítulos, cada um subdividido em três tópicos.

O Capítulo Primeiro apresenta a fundação de todo o trabalho, estabelecendo as premissas que nortearão as conclusões apresentadas nos Capítulos subsequentes. É nele que serão definidos os conceitos de Estado de Direito, segurança jurídica e devido 
processo legal, expressões largamente utilizadas com os mais diversos significados, e que serão assentadas as concepções do autor a respeito da função do Direito, dos valores que ele busca realizar, das interações entre segurança jurídica e justiça e da função exercida pelo devido processo legal no sistema jurídico brasileiro.

O Capítulo Segundo é voltado especificamente para o posicionamento da motivação como garantia inerente ao Estado de Direito, definindo a sua natureza normativa e o papel por ela desempenhado na legitimação e no controle da atividade jurisdicional. O ponto 5 , que trata do desenvolvimento histórico da motivação, é fundamental para que seja compreendida a importância do instituto e a relação que possui com a liberdade do indivíduo, a racionalidade do poder jurisdicional e a segurança jurídica.

O Capítulo Terceiro dá continuidade ao Capítulo Segundo ao defender uma natureza jurídica, uma estrutura e um conceito de motivação que sejam compatíveis com o ideal do Estado de Direito. Também são apresentados os atributos mínimos de racionalidade da motivação.

O Capítulo Quarto foca em aspectos endoprocessuais da motivação, traçando brevemente algumas das interações existentes com outras garantias do devido processo legal, e apresentando os requisitos mínimos de clareza, coerência e completude da prestação de contas judicial, bem como as consequências jurídicas decorrentes de decisões imotivadas ou mal motivadas.

Encerrado o Capítulo Quarto, o objeto de estudo passa a ser a relação existente entre motivação e segurança jurídica. O Capítulo Quinto busca demonstrar que a motivação é fundamental para promover a segurança jurídica objetiva, identifica a motivação com os precedentes judiciais, distinguindo ratio decidendi e obiter dictum, e aponta sucintamente alguns dos institutos processuais brasileiros voltados à valorização e respeito dos precedentes.

Por fim, o Capítulo Sexto dedica-se a demonstrar que a motivação das decisões judiciais influencia a tomada de decisões do jurisdicionado e, por isso, deve ser encarada como fundamento do exercício de uma confiança legítima que deve ser sempre tutelada. 


\section{$\S^{\circ}$ Nomenclatura adotada: motivação $x$ fundamentação}

Para designar o ato judicial de fornecer razões para justificar a decisão, optou-se neste trabalho pela palavra "motivação", em detrimento da opção legislativa "fundamentação". A escolha possui duas razões. A primeira é de ordem prática. A utilização do termo "motivação" coaduna-se com a terminologia empregada nos países de língua italiana (motivazione), francesa (motivation) e espanhola (motivación); nos países de língua inglesa, embora normalmente refiram-se a reasoned judgments ou giving reasons, também é utilizada, eventualmente, "motivation”. A segunda é de ordem teórica. Embora os termos tenham basicamente o mesmo significado, "fundamentação" transmite a ideia de que motivar uma decisão é simplesmente indicar os seus fundamentos, as razões que a suportam. O dever de motivar, porém, exige mais do que isso. Motivar não é só dizer que a decisão é boa, mas que aquela era a única decisão que poderia ser tomada no processo; ou seja, que a decisão é a melhor que poderia ter sido tomada diante de todos os elementos colocados à disposição do juiz. Sendo assim, o instituto será referido neste trabalho como "motivação". 


\section{CAPÍTULO PRIMEIRO - ESTADO DE DIREITO, SEGURANÇA JURÍDICA E PROCESSO}

A Constituição de 1988, em seu art. $1^{\circ}$, caput, erigiu o Estado de Direito como modelo de Estado em que se constitui a República Federativa do Brasil. O Brasil é, portanto, ao menos em sede constitucional, um Estado de Direito. Mas o que isso significa?

Revestido de um caráter quase mítico, a aceitação do Estado de Direito costuma ser "espontânea, intuitiva, quiçá instintiva". Como escreveu Luc Heuschling, "salvo para cometer uma gafe retórica e a expor-se à execração da opinião pública esclarecida, nenhum autor, e sobretudo nenhum regime - nem mesmo o mais tirânico dir-se-á abertamente contrário ao Estado de Direito". 5 Isso ocorre porque o Estado de Direito é considerado um "sinal de virtude de sociedades civilizadas"6; a expressão máxima da luta contra a arbitrariedade e o subjetivismo.

Desde a sua origem, o Estado de Direito traduz um determinado tipo de Estado: aquele que repudia o despotismo, a tirania, e privilegia, acima de tudo, a razão. ${ }^{7} \mathrm{O}$ Estado de Direito sempre foi, por isso mesmo, o grande símbolo da liberdade individual, ${ }^{8}$ a qual só seria alcançada mediante a contenção do poder estatal e a garantia de segurança aos

\footnotetext{
${ }^{4}$ HEUCHSLING, Luc. Etat de Droit, Rechtsstaat, Rule of Law. p. 1.

${ }^{5}$ Ibidem. p. 1.

${ }^{6}$ MACCORMICK, Neil. Rhetoric and the Rule of Law: a theory of legal reasoning. p. 12. Para Jeremy WALDRON, o Estado de Direito "is one of the most important political ideals of our time" (The concept and the Rule of Law. p. 1.). Piero CALAMANDREI, ao tratar da "jurisdição de Direito", que é basicamente o mesmo que se entende por Estado de Direito, considerou-a "una di quella conquiste decisive della civiltà, che segnano una tappa dell'ascesa umana e non si possono abbandonare senza retrocedere verso la barbarie" (Istituzioni di diritto processuale civile secondo il nuovo Codice. p. 38).

${ }^{7}$ V. CHEVALLIER, Jacques. L'État de Droit. p. 51.

${ }^{8}$ Entendida aqui como a "effective ability to chose between as many options as possible". RAZ, Joseph. The Rule of Law and its virtue. p. 220.
} 
indivíduos; segurança que não poderia ser garantida senão pelo Direito, expoente da razão. ${ }^{9}$

A limitação do Estado por uma "moldura definida pelo Direito" garante "significativa segurança para a independência e dignidade de cada cidadão. Onde o Direito prevalece, você sabe onde você está, e o que lhe é permitido fazer (...)". ${ }^{10}$ Além disso, também se sabe aonde o Estado pode ir, uma vez que seu âmbito de atuação fica devidamente delimitado pelo ordenamento jurídico.

Exatamente nesse sentido, o processo, especialmente o judicial, assume papel de destaque ao traçar uma "metodologia para o exercício do poder". ${ }^{11}$ É pelo processo, seja ele judicial, administrativo, legislativo, que se "criam condições para alcançar uma solução apoiada numa verdade apta a ser compartilhada pela sociedade". ${ }^{12}$ A adoção de um procedimento preestabelecido, dotado de certas garantias, como a do contraditório e da motivação das decisões, é não só fundamental para delinear o exercício da atividade jurisdicional, mas também legitima a interferência do Estado na esfera particular.

Esses três temas, Estado de Direito (1), segurança jurídica (2) e processo (3) serão brevemente tratados a seguir e servirão como premissas ao desenvolvimento das ideias subsequentes.

\footnotetext{
${ }^{9}$ Ao apresentar o conceito de Estado de Direito em sua origem alemã no século XIX, explica Ernst Wolfgang BÖCKENDÖRFE: "el Estado de Derecho es el Estado del derecho racional, esto es, el Estado que realiza los princípios de la razón en y para la vida en común de lós hombres, tal y como estaban formulados en la tradición de la teoria del derecho racional" (Origen y cambio del concepto de Estado de Derecho. p. 1819).

${ }^{10}$ MACCORMICK, Neil. Rhetoric and the Rule of Law.p. 12. No original: "The Rule of Law is a signal virtue of civilized societies. (...) This gives significant security for the independence and dignitiy of each citizen. Where the law prevails, you know where you are, and what you are able to do without getting yourself embroiled in civil litigation or in the criminal justice system".

${ }^{11}$ GOMES FILHO, Antonio Magalhães. A Motivação das Decisões Penais. p. 27.

${ }^{12}$ Ibidem. p. 27.
} 


\section{Estado de Direito e o controle do poder estatal}

A expressão 'Estado de Direito' (Rechtsstaat) foi cunhada na Alemanha, em 1798, por um jurista denominado Johann Wilhelm Petersen, também conhecido sob o pseudônimo de Placidus, que, por Rechts-Staat-Lehrer (teóricos do Estado de Direito), buscava designar os seguidores da escola filosófica de Kant, opondo-os aos Staat-RechtsLehrer (teóricos do Direito do Estado), defensores do Polizeistaat (Estado de Polícia). ${ }^{13}$

Alguns anos mais tarde, em 1809, a expressão Estado de Direito (Rechtsstaat) foi utilizada por Adam Müller para designar o Estado protetor da liberdade individual. ${ }^{14}$ A partir de 1813, com a publicação da obra Die letzen Gründe von Recht, Staat und Strafe (Os Fundamentos Últimos do Direito, do Estado e da Sanção), de Carl Theodor Welcker, o Estado de Direito, ápice da evolução estatal, associa-se ao Estado Moderno, ou 'Estado da Razão'. ${ }^{15}$ Depois disso o termo passa a carregar consigo, como regra, o significado de liberdade do indivíduo frente ao Estado, traduzindo de forma inigualável o liberalismo alemão do século XIX. ${ }^{16}$

O conceito do 'Estado de Direito' difundiu-se pelo resto da Europa por meio do trabalho de tradução das obras alemãs. Os juristas franceses, por exemplo, não utilizaram a expressão até o início do século XX, quando, vencidos na guerra francoprussiana, dedicaram grande atenção aos seus colegas germânicos em razão da crença na superioridade do sistema alemão de formação de elites. ${ }^{17}$ Embora já houvesse na segunda metade do século XIX algumas traduções do termo Rechtsstaat para o francês, sua

${ }^{13}$ Cf. HEUCHSLING, Luc. Etat de Droit, Rechtsstaat, Rule of Law. p. 36-37; CHEVALLIER, Jacques. L'Etat de Droit. p. 16; COSTA, Pietro. O Estado de Direito: uma introdução histórica. p. 116-117. As ideias de Placidus foram expostas na obra Litteratur der Staatlehre, publicada em Estrasburgo em 1798.

${ }^{14}$ Cf. HEUCHSLING, Luc. Etat de Droit, Rechtsstaat, Rule of Law. p. 37.

${ }^{15}$ Cf. Ibidem. p. 37. Para Ernst Böckenförde, Carl Welcker foi, nessa ocasião, o primeiro a utilizar o termo (Origen y cambio del concepto de Estado de Derecho. p. 19). Também nesse sentido, FERREIRA FILHO, Manoel Gonçalves. As origens do Estado de Direito. p. 11.

${ }^{16}$ Cf. HEUCHSLING, Luc. Etat de Droit, Rechtsstaat, Rule of Law. p. 38 e ss. Daí ser legítima a afirmação de que “Il secolo XIX è il secolo dello 'Stato di diritto' o, secondo l'espressione tedesca, del Rechtsstaat". ZAGREBELSKY, Gustavo. Il Diritto Mite. p. 20.

${ }^{17}$ CHEVALLIER, Jacques. État de Droit. p. 24. 
utilização ficava restrita ao contexto germânico. ${ }^{18}$ Apenas a partir da publicação do Manual de Direito Constitucional de Leon Duguit, em 1907, é que o vocábulo 'État de Droit' é apropriado pela doutrina em referência ao próprio Estado francês, consagrando-se na década de 20 com Carré de Malberg e sua distinção entre État de Droit e État Légal. ${ }^{19} 20$

No entanto, antes de ser um 'conceito', o Estado de Direito é a tradução de um ideal. ${ }^{21}$ Um ideal muito anterior ao Estado Moderno ${ }^{22}$, cujas origens podem ser encontradas, com algumas ressalvas, ainda na Grécia antiga, onde se buscava, mediante vários mecanismos, "manter o sistema democrático 'enquanto subordinava-se o princípio da soberania popular ao princípio da soberania das leis"”. ${ }^{23}$ Em Politica, por exemplo, Aristóteles tratou da "monarquia limitada" ou "reino segundo o Direito", que se opõe à "monarquia absoluta", um governo arbitrário e, por isso, contrário à natureza. ${ }^{24}$ Para Aristóteles, "o reino do Direito é preferível ao de qualquer indivíduo" e o governante nada

${ }^{18}$ Ibidem. p. 23. De acordo com Luc Heuschling, a primeira referência de um jurista francês ao Rechtsstaat ocorreu em 1844, com a tradução do tratado de Robert von Mohl chamado Die Polizeiwisenschaft nach den Grundsätzen des Rechtsstaats (Etat de Droit, Rechtsstaat, Rule of Law. p. 325).

${ }^{19}$ MALBERG, Raymond Carré de. Contribution à la Théorie Générale de l'État. t. I. p. 488-494.

${ }^{20}$ CHEVAlLIER, Jacques. État de Droit. p. 23-24. V. também HEUSCHLING, Luc. Etat de Droit, Rechtsstaat, Rule of Law. p. 376 e ss.

${ }^{21}$ Exatamente nesse sentido, Jeremy Waldron. The concept and the Rule of Law. passim; TAMANAHA, Brian Z. On the Rule of Law. p. 8. Em sentido contrário, considerando o Estado de Direito uma ideia exclusivamente alemã, v. BÖCKENFÖRDE, Ernst Wolfgang. Origen y cambio del concepto de Estado de Derecho. p. 18-19. Para uma crítica expressa do entendimento de Böckenförde, v. HEUSCHLING, Luc. Etat de Droit, Rechtsstaat, Rule of Law. p. 40.

${ }^{22}$ Como escreveu Roberto BIN, “Lo Stato di diritto nasce da un sogno, un sogno antico quanto il pensiero politico". Lo Stato di Diritto. p. 7.

${ }^{23}$ TAMANAHA, Brian Z. On the Rule of Law. p. 8, citando, no trecho, OSTWALD, Martin. From Popular Sovereignty to the Sovereignty of Law. p. 497. V. também FERREIRA FILHO, Manoel Gonçalves. As origens do Estado de Direito. p. 11; HEUSCHLING, Luc. Etat de Droit, Rechtsstaat, Rule of Law. p. 50.

${ }^{24}$ ARISTÓTELES. Politics. p. 75 (III, 16). 
deveria ser senão mero guardião e ministro desse Direito. ${ }^{25}$ Em Roma, Cícero condenou o rei que não se curvava à lei, taxando-o de "criatura tola e repugnante". ${ }^{26}$

A necessária submissão do governante às leis preestabelecidas foi particularmente sentida no direito germânico medieval, segundo o qual os indivíduos possuíam um "direito de resistência" aos comandos reais que violassem as leis costumeiras: “o monarca e o 'estado' existiam dentro da lei, para a lei, e como criaturas da lei, orientados em direção do interesse da comunidade". ${ }^{27}$

Mas foi no célebre ano de 1215 que houve a mais significativa emanação do Estado de Direito enquanto ideal de contenção do poder, antes de se poder falar propriamente em 'Estado de Direito' como atributo do Estado Moderno. Foi nesse ano que a Inglaterra fixou a 'pedra fundamental' do Rule of Law com a assinatura da Magna Carta pelo Rei João, limitando seu próprio poder à lei e a certos procedimentos legais que viriam posteriormente a ser chamados, em 1354 , de due process of law. ${ }^{28} \mathrm{O}$ art. 39 é histórico:

"Nenhum homem livre será aprisionado, desapossado, banido ou
exilado ou de qualquer maneira prejudicado, nem nós agiremos
contra ele, exceto mediante um julgamento legal por seus pares ou
pela lei da terra". ${ }^{29}$ Ainda no século XIII, o juiz Henrici de Bracton escreveu seu famoso tratado 'Sobre as leis e costumes da Inglaterra' (De legibus et consuetudinibus Angliae), onde

${ }^{25}$ Ibidem. p. 76 (III, 16): "And the rule of law, it is argued, is preferable to that of any individual. On the same principle, if it be better for certain individuals to govern, they should be made only guardians and ministers of the law".

${ }^{26}$ Cf. TAMANAHA, Brian Z. On the Rule of Law. p. 11-14; v. as considerações de HAYEK, F. A. The Constitution of Liberty. p. 243-246.

${ }^{27}$ TAMANAHA, Brian Z. On the Rule of Law. p. 24. No original: "The monarch and state existed within the law, for the law, and as creatures of the law, oriented toward the interest of the community".

${ }^{28}$ V. Ibidem. p. 25 e ss; SUMMERS, Robert S. A formal theory of the Rule of Law. p. 127-128. Obviamente, não se pode confundir o contexto histórico-político da Inglaterra feudal do século XIII com a concepção moderna de Estado e, principalmente, com o Rule of Law, termo difundido largamente por Albert Venn Dicey ao final do século XIX. A antecipação histórica deste modelo de Estado, porém, fica evidente na autolimitação do Rei à 'law of the land'.

${ }^{29}$ No original: "No free man shall be taken imprisoned or disseised or outlawed or exiled or in any way ruined, nor will we go or send against him, except by the lawful judgement of his peers or by the law of the land". 
lançou eternas lições sobre as relações entre a monarquia e o Direito. Para ele, o rei estava abaixo da lei, pois é exatamente esta que o faz rei $^{30}$ e "nada é mais adequado a um soberano do que viver pelas leis, nem há maior soberania do que governar de acordo com a lei" ${ }^{31}$ No século XV constou de uma sentença judicial inglesa que "A lei é a mais alta herança que o rei possui; porque pela lei o rei e todos os seus súditos são regidos, e se a lei não prevalece, não há rei nem herança". ${ }^{32}$ Em 1610, mesmo ano em que foi julgado o famoso caso "Dr. Bonham",33, a Câmara dos Comuns encaminhou uma petição (Petition of Grievances) ao Rei James I nos seguintes termos: "Dentre tantas outras fontes de felicidade e de liberdade das quais os súditos de Vossa Majestade (...) desfrutaram sob (...) os Reis e Rainhas deste Reino, não há nenhuma que eles tenham apreciado mais caramente e mais preciosamente do que serem guiados e governados por um reino certo das leis (Rule of Law) (...) e não por qualquer forma incerta ou arbitrária de governo". ${ }^{34}$

A partir do século XVI, com o desenvolvimento da noção moderna de Estado, vários autores utilizaram expressões específicas para designar a necessária 'primazia do Direito'. É o caso, por exemplo, do 'droit gouvernement' do absolutista Bodin $^{35}$ e o 'lawful Government' de Locke ${ }^{36}$, talvez o neologismo de língua inglesa que

\footnotetext{
${ }^{30}$ BRACTON, Henrici de. De legibus et consuetudinibus Angliae, v. V. p. 6 : "Ipse auté rex, nom debet esse sub homine, sed sub deo \& sub lege, quia lex facit regem".

${ }^{31}$ Idem. On the Laws and Customs of England, v. III. Cambridge: Harvard University, 1968. p. 305-306, citado por TAMANAHA, Brian Z. On the Rule of Law. p. 26.

32 "La ley est le plus haute inheritance, que le roy ad; car par la ley it même [o rei] e toutes ses sujets son rulés, et si la ley ne fuit, nul roi, et nul inheritance sera", citado por DICEY, Albert Venn. An Introduction to the Study of the Law of the Constitution. p. 184.

33 Pelo caso "Dr. Bonham", a Corte das Common Pleas, presidida por ninguém menos do que Sir Edward Coke, inaugurou o 'controle de constitucionalidade' das leis ao considerar nula uma lei editada pelo Parlamento que atribuía ao Royal College of Physicians a faculdade de aplicar multas em seu próprio benefício. Para Coke, tal lei seria contrária ao Common Law, o qual estaria acima de qualquer outra fonte do Direito. Sobre isso, v. TAMANAHA, Brian Z. On the Rule of Law. p. 57

${ }^{34}$ Documento citado por HEUSCHLING, Luc. Etat de Droit, Rechtsstaat, Rule of Law. p. 171.

35 BODIN, Jean. De la Republique ou Traité Du Gouvernement. p. 108-109: "Une seconde observation importante, est qu'une ville batîe, murée, pleine d'un peuple nombreux, ne sera pas une Cité, si les Loix des Magistrats n'y établissent un droit gouvernement, où elle sera accomplie, c'est-à-dire, qu'elle aura droit de Cité et d'Université, qu'elle fleurira sous les Loix sages des Magistrats éclairés, et elle ne méritera pas le nom d'Etat".
} 
mais tenha se aproximado de seu correspondente germânico. Algum tempo mais tarde, sob a influência do Iluminismo e amparados na defesa irrestrita da liberdade do indivíduo e na contenção do poder público por uma ordem jurídica racional, autores como Locke, Montesquieu, Rousseau e Kant, este último considerado o verdadeiro "pai espiritual” do Rechtsstaat, ${ }^{37}$ lançaram os fundamentos do Estado de Direito como ideal do Estado Moderno. Na Inglaterra do século XVII, Edward Coke construiu o sistema do common law sobre um Direito racional, restringindo os poderes reais mediante a "razão artificial", a qual poderia ser descoberta unicamente por juristas treinados: no caso, os juízes. ${ }^{38}$ No contexto norte-americano, Madison, Hamilton e Jay, autores dos Federalist Papers, foram de suma importância para traçar as diretrizes do Rule of Law no Novo Mundo.

Diante disso, reafirma-se: o Estado de Direito é um ideal de Estado pelo qual se procura conter a tirania daquele que ascende ao poder (qualquer esfera do poder), constrangendo-o a obedecer a limites preestabelecidos pelo Direito. Ainda que cada nação e cada Estado desenvolva instrumentos próprios de controle e de proteção da segurança jurídica, é possível pensar o Estado de Direito de forma relativamente homogênea, traçando suas características essenciais. ${ }^{39}$ Também por esse motivo é necessário desde logo distinguir o Estado de Direito da configuração política, social ou econômica que se dê ao Estado, seja ele liberal, neoliberal, socialista, comunista, regulador, democrático ou autocrático. $^{40}$ Qualquer modelo sócio-político ou econômico de Estado pode ser considerado um Estado de Direito, desde que haja um efetivo controle do poder estatal. ${ }^{41}$

\footnotetext{
${ }^{36}$ LOCKE, John. Two Treatises on Government. p. 354: "By the first of these, a man is naturally free from subjection to any government, though he be born in a place under its jurisdiction; but if he disclaim the lawful government of the country he was born in, he must also quit the right that belonged to him by the laws of it (...)".

${ }^{37}$ V. HEUSCHLING, Luc. État de Droit, Rechtsstaat, Rule of Law. p. 35.

${ }^{38}$ V. POSNER, Richard. The Problems of Jurisprudence. p. 10-11.

${ }^{39}$ No mesmo sentido, COSTA, Guilherme Recena. Superior Tribunal de Justiça e recurso especial. p. 82.

${ }^{40}$ Cf. ZOLO, Danilo. Teoria e crítica do Estado de Direito. p. 6-7: "É opinião difusa que a literatura especializada tem se empenhado, até o momento, de modo escasso, em uma determinação analítica que possa caracterizar o Estado de Direito sob o perfil institucional e normativo, distinguindo-o de noção contíguas com as quais, muitas vezes, é confundido ou deliberadamente identificado: 'Estado legal', 'Estado liberal', 'Estado democrático', Estado constitucional'”.

41 Sobre a não vinculação do Estado de Direito a determinados modelos sócio-políticos de Estado, especialmente a democracia, v. PALOMBELLA, Gianluigi. The Rule of Law as institutional ideal. passim.
} 
1.1. As origens do Estado de Direito moderno: proteção da liberdade, jusnaturalismo e segurança jurídica

A construção da teoria do Estado de Direito moderno tem como grande mote inspirador a proteção do indivíduo contra a arbitrariedade do poder. ${ }^{42}$ Surge em um contexto político permeado de monarquias absolutistas, cujos soberanos eram equiparados a divindades terrenas. $\mathrm{O}$ rei tudo podia, desde que assim quisesse; o governo era regido pela vontade pessoal daquele que ocupava o trono.

A ascensão do homem ao ponto central do estudo científico iluminista desencadeou uma ferrenha crítica a esse sistema tirânico e opressor de governo. Amparados na ideia de que o ser humano possui direitos inerentes à sua própria natureza, atribuídos muitas vezes por Deus, os iluministas concluíram que o indivíduo antecede o Estado e que os governos nada mais são do que construções do homem para a promoção do homem. O Estado, portanto, decorreria de um contrato social com o fim precípuo de promover e garantir os direitos naturais de cada cidadão. ${ }^{43}$

O simples reconhecimento de direitos naturais do indivíduo, porém, era insuficiente para que eles fossem efetivamente respeitados. Mais do que reconhecer os direitos naturais, seria preciso criar mecanismos de controle do poder, de modo que o governante não pudesse violá-los indiscriminadamente. Na Europa continental, a solução encontrada foi submeter o Poder Público ao direito positivo; uma ideia antiga, mas há muito tempo esquecida. A ela ligou-se indissociavelmente a teoria da separação dos poderes de Montesquieu, pois de nada adiantaria submeter o monarca a leis por ele mesmo

\footnotetext{
Merece destaque a seguinte passagem: "However, the rule of law is conceptually independent of democracy, since its rationale is meant to confront power regardless of its shape, any forms of government, regardless of its autocratic or democratic nature" (p. 34-35).

${ }^{42}$ HEUSCHLING, Luc. Etat de Droit, Rechtsstaat, Rule of Law. p. 42: “Au coeur de la théorie du Rechtsstaat se situe la question de l'arbitraire du pouvoir, de le violence potentielle inscrite dans tout rappot de domination, quel qu'il soit, privé ou public".

${ }^{43}$ V. CHEVALLIER, Jacques. L'État de Droit. p. 51.
} 
elaboradas. $\mathrm{Na}$ Inglaterra, submeteu-se o rei ao common law, um sistema jurídico atemporal e fundado única e exclusivamente sobre a razão. ${ }^{44}$

Na medida em que o governante, no absolutismo, era a fonte de todo o poder, não havia como atrelar o direito senão à sua própria pessoa. Apenas depois das revoluções americana e francesa, quando os constituintes puderam construir uma nova ordem jurídica fundada sobre o indivíduo, é que a teoria dos direitos naturais adquiriu "real concretização política". ${ }^{45}$ A Declaração dos Direitos do Homem e do Cidadão de 1789, já no Preâmbulo, traduz com perfeição o pensamento da época: “O Povo Francês, convencido de que o esquecimento e o desprezo dos direitos naturais do Homem são as únicas causas das infelicidades do mundo, resolveu expor numa declaração solene estes direitos sagrados e inalienáveis, a fim de que todos os cidadãos, podendo comparar sem cessar os atos do Governo com o fim de toda instituição social, não se deixem jamais oprimir e aviltar pela tirania (...)".

Esses mesmos ideais podem ser facilmente percebidos em todo o texto da Constituição do Massachusetts, escrita em 1779 e ratificada em $1780 .{ }^{46}$ Logo no primeiro artigo, o diploma atribui ao homem "certos direitos naturais, essenciais e inalienáveis", "referentes à busca e obtenção da segurança e felicidade" 47 . Um pouco à frente, o artigo X dispõe que "Cada indivíduo da sociedade tem o direito de ser por ela protegido em seu desfrute da vida, liberdade e propriedade, de acordo com leis preestabelecidas (...)"48. E o

${ }^{44}$ Cf. POSTEMA, Gerald J. Some roots of our notion of precedent. p. 11-13; HEUSCHLING, Luc. Etat de Droit, Rechtsstaat, Rule of Law. p. 176 e ss.

${ }^{45}$ V. CHEVALLIER, Jacques. L'État de Droit. p. 53.

${ }^{46}$ V. artigos V, VI, VII, VIII e XII, este último com redação muito parecida à do art. 39 da Carta Magna.

47 "Article I. All men are born free and equal, and have certain natural, essential, and unalienable rights; among which may be reckoned the right of enjoying and defending their lives and liberties; that of acquiring, possessing, and protecting property; in fine, that of seeking and obtaining their safety and happiness". A redação desse artigo foi alterada pela emenda CVI: "All people are born free and equal and have certain natural, essential and unalienable rights; among which may be reckoned the right of enjoying and defending their lives and liberties; that of acquiring, possessing and protecting property; in fine, that of seeking and obtaining their safety and happiness. Equality under the law shall not be denied or abridged because of sex, race, color, creed or national origin".

${ }^{48}$ No original, antes de receber várias emendas: "Article X. Each individual of the society has a right to be protected by it in the enjoyment of his life, liberty and property, according to standing laws. He is obliged, consequently, to contribute his share to the expense of this protection; to give his personal service, or an 
clássico artigo XXX determina que o Estado de Massachusetts deve ser regido por "governo de leis e não de homens". 49

Houve nesse período, portanto, uma verdadeira simbiose entre o conteúdo e a forma do Estado. A este caberia a proteção dos direitos naturais do indivíduo, sua razão essencial de ser; mas para isso, imprescindível era a criação de um "governo de leis e não de homens". Esse Estado é que foi chamado por Placidus de 'Estado de Direito', um Estado protetor da liberdade do indivíduo pela eliminação do despotismo e pela promoção da segurança jurídica. ${ }^{50}$

Três são as características básicas dessa fase. Primeiramente, renunciou-se à natureza divina e transcendental do Estado e passou-se a compreendê-lo como uma "comunidade (res publica) a serviço do interesse comum de todos os indivíduos". O Estado deixou de ser um fim em si mesmo para ser encarado sob um prisma eminentemente teleológico: sua única razão de ser era a promoção do indivíduo, fonte primária de sua existência; e para isso precisava ser regido pelo Direito. Em segundo lugar, como decorrência direta da primeira característica, toda a atuação estatal foi limitada pela liberdade e pela segurança do indivíduo. Por fim, a organização e os limites da atuação do Estado deveriam ser regidos pela razão, o que significou o reconhecimento de determinados direitos individuais, como liberdade civil, igualdade jurídica, independência dos juízes etc. Inclui-se também nessa terceira característica a separação dos poderes,

equivalent, when necessary: but no part of the property of any individual can, with justice, be taken from him, or applied to public uses, without his own consent, or that of the representative body of the people. In fine, the people of this commonwealth are not controllable by any other laws than those to which their constitutional representative body have given their consent. And whenever the public exigencies require that the property of any individual should be appropriated to public uses, he shall receive a reasonable compensation therefor".

${ }^{49}$ No original: "Article XXX. In the government of this commonwealth, the legislative department shall never exercise the executive and judicial powers, or either of them: the executive shall never exercise the legislative and judicial powers, or either of them: the judicial shall never exercise the legislative and executive powers, or either of them: to the end it may be a government of laws and not of men".

${ }^{50}$ V. BÖCKENFÖRDE, Ernst Wolfgang. Origen y cambio del concepto de Estado de Derecho. p. 22; HEUSCHLING, Luc. Etat de Droit, Rechtsstaat, Rule of Law. p. 42 e ss. 
embora na Alemanha houvesse certas restrições à teoria de Montesquieu, considerada uma ameaça à coesão estatal. ${ }^{51}$

1.2. A ascensão do positivismo radical e o esvaziamento do conceito do Estado de Direito

A teoria alemã do Estado de Direito sofreu uma profunda transformação no decorrer do século XIX, afastando-se dos ideais revolucionários franceses e da inspiração original de Kant. Se a primeira fase da teoria do Rechtsstaat é caracterizada por sua instrumentalidade, a seguinte privilegiou exclusivamente a forma do Estado. Os direitos naturais perderam espaço para um positivismo radical e a feição teleológica do Estado foi suprimida pelo culto à lei.

O marco de encerramento da primeira fase da história do Rechtsstaat, segundo Luc Heuschling, está no ano de 1848 com o fracasso da revolução burguesa. ${ }^{52}$ Decepcionada e com medo de insurreições do proletariado nascente, a burguesia negligencia a política e volta todas as suas atenções ao cenário econômico. A preocupação liberal adquire uma conotação eminentemente negativa, no sentido de proteger a esfera privada contra o Poder Público. O controle jurisdicional da administração passa a identificar-se paulatinamente com o Rechtsstaat e o juiz assume um papel cada vez mais importante. Trata-se, seguindo ainda as lições de Luc Heuschling, "de um momento nevrálgico na história do Rechtsstaat", substituindo-se a resolução de conflitos mediante instrumentos políticos, pela resolução jurisdicional de conflitos. ${ }^{53}$ Como consequência, o conceito de Estado de Direito afasta-se dos direitos naturais e potencializa sua feição formal, entendido como um modo de atuação estatal. "De conceito jusnaturalista, quer dizer, prescritivo", o Estado de Direito "torna-se pouco a pouco um conceito positivista, quer dizer, descritivo". 54

\footnotetext{
${ }^{51}$ BÖCKENFÖRDE, Ernst Wolfgang. Origen y cambio del concepto de Estado de Derecho. p. 19-20.

${ }^{52}$ Igualmente, COSTA, Pietro. O Estado de Direito: uma introdução histórica. p. 126 e ss.

${ }^{53}$ HEUSCHLING, Luc. État de Droit, Rechtsstaat, Rule of Law. p. 73-74.

${ }^{54}$ Ibidem. p. 78. Coube a Friedrich Stahl [1856] a elaboração de um novo conceito paradigmático, definindoo não como um conteúdo ou um objetivo do Estado, mas como um modo de ação, uma maneira de realizar esses objetivos ( $C f$. BÖCKENFÖRDE, Ernst Wolfgang. Origen y cambio del concepto de Estado de Derecho. p. 24-25; HEUSCHLING, Luc. État de Droit, Rechtsstaat, Rule of Law. p. 74-75). Stahl não
} 
O ápice da formalização - e consequente derrocada - do Estado de Direito foi atingido com Hans Kelsen e sua Teoria Pura do Direito. ${ }^{55}$ Segundo Kelsen, o "princípio metodológico fundamental" de sua Teoria Pura seria "libertar a ciência jurídica de todos os elementos que lhe são estranhos". ${ }^{56}$ Essa esterilidade teórica foi levada também à noção de Estado, figura tida por indissociável do Direito. Concebido o Estado como "ordem de conduta humana" ${ }^{, 57}$, ou ordem de coação relativamente centralizada" ${ }^{\text {, }}$, não haveria como aceitar o dualismo entre Estado e Direito, pois "todo Estado é uma ordem jurídica" e, consequentemente, "o Estado pode ser juridicamente apreendido como sendo o próprio Direito - nada mais, nada menos". 59

Desse modo, o Estado de Kelsen era, sempre, um Estado de Direito. Essa última expressão, para o autor, nada denota senão um "preconceito jusnaturalista", decorrente da suposição de que apenas uma ordem jurídica que contenha determinados atributos preestabelecidos pode ser considerada uma verdadeira ordem jurídica. ${ }^{60}$ Consequentemente, mesmo Estados autocráticos em que inexista algum tipo de segurança

defendia um Estado desprovido de conteúdo. Pelo contrário, ao criticar a teoria do Direito natural e retirar do Estado de Direito seu aspecto substancial, Stahl constrói uma teoria ética, amparada em princípios cristãos (V. Ibidem. p. 75-76). Um dos grandes juristas alemães a recepcionar parcialmente as lições de Stahl foi Rudolf von Gneist. Rejeitando o cunho tido por individualista da anterior concepção de Estado de Direito, pois centrado excessivamente nos direitos naturais, Gneist define-o como "governo segundo as leis", no sentido não de fundamento, mas de limite para a atuação do Executivo (Cf. BÖCKENFÖRDE, Ernst Wolfgang. Origen y cambio del concepto de Estado de Derecho. p. 27).

${ }^{55}$ Hans KELSEN é taxativo: “A Teoria Pura do Direito é uma teoria do Direito positivo - do Direito positivo em geral, não de uma ordem jurídica especial” (Teoria Pura do Direito. p. 1).

${ }^{56}$ Ibidem. p. 1 .

${ }^{57}$ Ibidem. p. 316.

${ }^{58}$ Ibidem. p. 352.

${ }^{59}$ Ibidem. p. 353. Explica Kelsen: "Quando, porém, penetramos a identidade de Estado e Direito, quando compreendemos que o Direito, o Direito positivo, que não deve ser identificado com a Justiça, é precisamente aquela mesma ordem de coerção que o Estado se apresenta como sendo um conhecimento que não se deixe prender a imagens antropomórficas mas penetre, através do véu da personificação, até as normas postas por atos humanos, então é absolutamente impossível justificar o Estado através do Direito" (p. 352).

${ }^{60}$ Ibidem. p. 353. 
jurídica deveriam ser considerados Estados de Direito, na medida em que constituem comunidades jurídicas. ${ }^{61}$

\subsection{O desenvolvimento do Rule of Law na Inglaterra do século XIX}

Apesar das emanações do Estado de Direito verificadas na Inglaterra desde o século XIII, em especial a partir da Revolução Gloriosa (1688), quando o Rule of Law sedimenta-se como base da relação entre indivíduo e Estado, não havia até o final do século XIX uma "teoria jurídica global do Estado que possa ser proposta (segundo o exemplo continental) como o referente do nexo poder-direito". ${ }^{62}$ Nesse sentido, a obra $A n$ Introduction to the Study of the Law of the Constitution, de Albert Venn Dicey, publicada em 1885, teve papel fundamental no novo discurso do Rule of Law, que serviu justamente para representar as relações entre o direito objetivo e o poder. ${ }^{63}$

Inspirado pelas lições de Jeremy Bentham e John Austin, fundadores da escola da "Jurisprudência Analítica" e do "Legal Positivism" inglês, Dicey desenvolveu uma concepção do Rule of Law voltada exclusivamente aos órgãos estatais que estariam,

${ }^{61}$ Ibidem. p. 353: "Também uma ordem coerciva relativamente centralizada que tenha caráter autocrático e, em virtude de sua flexibilidade ilimitada, não ofereça qualquer espécie de segurança jurídica, é uma ordem jurídica e a comunidade por ela constituída - na medida em que se distinga entre ordem e comunidade - é uma comunidade jurídica e, como tal, um Estado. Do ponto de vista de um positivismo jurídico coerente, o Direito, precisamente como o Estado, não pode ser concebido senão como uma ordem coerciva de conduta humana - com o que nada se afirma sobre o seu valor moral ou de Justiça”.

${ }^{62}$ COSTA, Pietro. O Estado de Direito: uma introdução histórica. p. 140. Igualmente, Emilio SANTORO: "A retórica whig e a historiografia concernente aos acontecimentos políticos ingleses dos últimos séculos parecem, portanto, ir igualmente na direção de indicar no rule of law, no domínio do direito, o segredo que permitiu aos 'direitos dos ingleses, antes de emergir e depois, pouco a pouco, de se afirmar como base fundamental da convivência social. Paradoxalmente, porém, até o fim do século XIX, nenhum jurista tinha tentado definir exatamente em que consistia o rule of Law, qual era o núcleo em torno do qual girava o aparelho constitucional da Grã-Bretanha e como tal aparelho conseguira garantir os direitos de liberdade, que não tinha equivalência em nenhum outro sistema constitucional europeu". Rule of Law e 'liberdade dos ingleses': a interpretação de Albert Venn Dicey. p. 214-215.

${ }^{63}$ Explicou E. C. S. WADE na introdução da 10 edição da obra de DICEY: The supremacy of the law of the land was not a novel doctrine in the nineteenth century. Let no one suppose that Dicey invented the rule of law. He did of course put his own interpretations upon the meaning of that rule. (An Introduction to the Study of the Law of the Constitution. p. xcvii). V. HEUSCHLING, Luc. État de Droit, Rechtsstaat, Rule of Law. p. 214. 
segundo seu ponto de vista, abaixo do Parlamento. O Parlamento inglês, para Dicey, era não só exterior, mas superior ao Rule of Law. ${ }^{64}$ Dicey estabeleceu, então, três elementos básicos do Estado de Direito: a) respeito à legalidade, em especial no que se refere à punição dos cidadãos; b) submissão de todos, indistintamente, às leis; c) imprescindibilidade do "judge-made-law". ${ }^{65}$ Essa última e fundamental característica dizia respeito à própria realidade inglesa. Dicey considerava as constituições escritas insuficientes à concreção fática de suas disposições, pois carentes de efetiva garantia; poderiam ser violadas a qualquer momento, sem que houvesse instrumentos hábeis a tornar certo o seu cumprimento. No Rule of Law, a garantia proviria do próprio Judiciário, a quem competiria a concretização das leis emanadas pelo Parlamento. ${ }^{66}$

1.4. A retomada do conteúdo substancial do Estado de Direito após a Segunda Guerra Mundial e o declínio da expressão

A derrota alemã na Primeira Guerra Mundial desencadeou uma revolução político-social nos anos de 1918 e 1919 que levou à elaboração da célebre Constituição de Weimar e consolidou a sucessão de uma monarquia amparada em fundamentos transcendentais por um regime republicano. As ideias democráticas da República de Weimar resgataram o Rechtsstaat sob a forma de um "Estado de Direito Democrático"

\footnotetext{
${ }^{64}$ DICEY, Albert Venn. An Introduction to the Study of the Law of the Constitution. p. 406: "The sovereignty of Parliament and the supremacy of the law of the land - the two principles which pervade the whole of the English constitution - may appear to stand in opposition to each other, or to be at best only counterbalancing forces. But this appearance is delusive; the sovereignty of Parliament as contrasted with other forms of sovereign power, favours the supremacy of the law, whilst the predominance of rigid legality throughout our institutions evokes the exercise, and this increases the authority, of Parliament sovereignty". Nas páginas seguintes o autor desenvolve o seu pensamento sobre as relações entre a supremacia do parlamento e o Estado de Direito (Chapter XIII - Relation between Parliamentary sovereignty and the Rule of Law. p. 406-414). Para uma versão resumida, v. HEUSCHLING, Luc. État de Droit, Rechtsstaat, Rule of Law. p. 213-216.

${ }^{65}$ DICEY, Albert Venn. An Introduction to the Study of the Law of the Constitution. p. 188-203.

${ }^{66}$ Ibidem. p. 195-202. V. TAMANAHA, Brian Z. On the Rule of Law: history, politics, theory. p. 63-65. COSTA, Pietro. O Estado de Direito: uma introdução histórica. p. 145-146.
} 
(Demokratischer Rechtsstaat), provocando um intenso debate doutrinário entre os defensores do 'relativismo ético' e os adeptos de uma 'filosofia de valores'. ${ }^{67}$

Obviamente, tudo isso foi interrompido com a chegada ao poder do Partido Nazista em 1933. As atrocidades cometidas durante a Segunda Guerra Mundial pelo nazismo desencadearam uma significativa decepção no pós-guerra com a democracia, em especial a democracia absoluta, fundada na irrestrita soberania popular. O positivismo foi condenado pela suposta legitimidade dada a leis injustas e violadoras dos mais básicos direitos do ser humano; e a teoria do Estado de Direito passou por uma nova transformação. ${ }^{68}$

A concepção de Estado como mera ordem jurídica não servia ao novo Estado alemão que se erguia, a partir de 1945, da destruição física e moral provocada pela guerra. Era preciso retomar a caminhada em direção a um Estado que promovesse o ser humano, seja ele de que gênero ou raça fosse. Se a simples existência de leis era, comprovadamente, insuficiente para que se alcançasse tal fim, então seria preciso pautar a atuação do Estado por leis justas. Consequentemente, o próprio Estado deveria ser justo, e o Rechtsstaat, sem uma natureza muito bem definida, passou a ser sua máxima representação.

Em 1949, com a promulgação da Constituição alemã, a expressão Rechtsstaat constou expressamente do art. 28, alínea 1, que dispõe: "a ordem constitucional dos Länder deve ser conforme aos princípios do Estado de Direito [Rechtsstaat $]$ republicano, democrático e social no sentido da presente Lei Fundamental". A mesma Constituição previu a inviolabilidade da dignidade do ser humano, atribuindo-lhe direitos fundamentais (art. $1^{\circ}$ ) e garantindo o respeito da ordem constitucional, da lei e do direito pelos três Poderes, incluindo o direito de cada cidadão de resistir à violação da ordem constitucional caso não lhe reste alternativa (art. 20). ${ }^{69}$

\footnotetext{
${ }^{67}$ V. HEUSCHLING, Luc. État de Droit, Rechtsstaat, Rule of Law. p. 109-143; BÖCKENFÖRDE, Ernst Wolfgang. Origen y cambio del concepto de Estado de Derecho. p. 31-33.

${ }^{68}$ V. HEUSCHLING, Luc. État de Droit, Rechtsstaat, Rule of Law. p. 144-145; BÖCKENFÖRDE, Ernst Wolfgang. Origen y cambio del concepto de Estado de Derecho. p. 34 e ss; COSTA, Pietro. O Estado de Direito: uma introdução histórica. p. 184 e ss.

${ }^{69}$ Cf. CHEVALLIER, Jacques. État de Droit. p. 67.
} 
A constitucionalização expressa do Rechtsstaat, contudo, gerou um efeito reverso ao pretendido. Ao invés de erguê-lo a um novo patamar, o que se viu foi a proliferação de concepções variadas e incompatíveis, provocando a inevitável desvalorização da expressão. Poucas eram as conceituações técnicas do instituto, largamente utilizado para defender as mais diversas teses. Difundiu-se a elaboração de listas de regras e princípios, formais e materiais, decorrentes do Rechtsstaat, como se se tratasse de um saco vazio pronto a ser preenchido da maneira como cada um entendesse melhor.

Mas não só na Alemanha o discurso do Estado de Direito entrou em declínio; também na Inglaterra o Rule of Law perdeu força por ser considerado excessivamente vago ${ }^{70}$ na França a expressão État de Droit foi praticamente abandonada ainda na década de $30 ;^{71}$ e nos Estados Unidos o Rule of Law foi duramente atacado pela esquerda radical, especialmente durante os movimentos sociais das décadas de 60 e $70 .^{72}$ Todos eles, porém, reabilitaram-se na década de 80, quando assumiram uma importância jamais vista. $^{73}$

\subsection{Estado de Direito formal e Estado de Direito substancial}

A partir da década de 80, o discurso do Estado de Direito é retomado de maneira efusiva pela doutrina do Direito Público e acaba por expandir-se ao campo da Política, sendo livremente utilizado por políticos como argumento de autoridade e, principalmente, de legitimação. ${ }^{74}$ Além disso, há uma ampla internacionalização do Estado de Direito. Como descreveu Jacques Chevallier, "todo Estado que se respeita deve,

\footnotetext{
${ }^{70}$ Cf. HEUSCHLING, Luc. État de Droit, Rechtsstaat, Rule of Law. p. 263-264.

${ }^{71}$ V. a descrição detalhada dessa derrocada em HEUSCHLING, Luc. État de Droit, Rechtsstaat, Rule of Law. p. 381-382.

${ }^{72}$ Cf. TAMANAHA, Brian Z. On the Rule of Law: history, politics, theory. p. 73 e ss.

${ }^{73}$ Cf. HEUSCHLING, Luc. État de Droit, Rechtsstaat, Rule of Law. p. 154-156.

${ }^{74}$ Cf. CHEVALLIER, Jacques. État de Droit. p. 9. Em 2002, WALDRON, Jeremy. Is the Rule of Law an essentially contested concept (in Florida)? p. 137 observou a impressionante frequência com que o Rule of Law foi invocado durante o debate envolvendo as eleições para Presidente dos Estados Unidos no ano de 2000. V. também seu artigo The concept and the Rule of Law. p. 1.
} 
doravante, apresentar-se sob o aspecto gracioso, vestir as cores brilhantes do Estado de Direito, que se transformou em um verdadeiro standard internacional". 75

Não por acaso, o Tratado da União Europeia [1992] cita a expressão Estado de Direito cinco vezes. Logo no segundo parágrafo do Preâmbulo considera o Estado de Direito um direito inviolável e inalienável da pessoa humana ${ }^{76}$; ainda no Preâmbulo confirma a ligação da União Europeia ao princípio do Estado de Direito ${ }^{77}$; no art. 2, afirma estar a União Europeia fundada sobre o Estado de Direito ${ }^{78}$; no art. 21,1 , dispõe que as ações da União Europeia repousam no Estado de Direito ${ }^{79}$; e no art. 21, 2, b, consta que a União Europeia desenvolve suas atividades internacionais com o intuito de promover e proteger o Estado de Direito ${ }^{80}$. Também a Carta dos Direitos Fundamentais da União Europeia dispõe no Preâmbulo que a União "repousa sobre o princípio da democracia e o princípio do Estado de Direito". ${ }^{81}$ Em 2004, o respeito ao Estado de Direito foi

${ }^{75}$ CHEVALLIER, Jacques. État de Droit. p. 9. No original : "(...) tout État qui se respecte est désormais tenu de se présenter sous l'aspect avenant, de se parer des couleurs chatoyantes, de l'État de droit, qui est devenu un véritable standard international".

76 "S'INSPIRANT des héritages culturels, religieux et humanistes de l'Europe, à partir desquels se sont développées les valeurs universelles que constituent les droits inviolables et inaliénables de la personne humaine, ainsi que la liberté, la démocratie, l'égalité et l'État de droit".

77 "CONFIRMANT leur attachement aux principes de la liberté, de la démocratie et du respect des droits de l'homme et des libertés fondamentales et de l'État de droit".

78 "Article 2. L'Union est fondée sur les valeurs de respect de la dignité humaine, de liberté, de démocratie, d'égalité, de l'État de droit, ainsi que de respect des droits de l'homme, y compris des droits des personnes appartenant à des minorités. Ces valeurs sont communes aux États membres dans une société caractérisée par le pluralisme, la non-discrimination, la tolérance, la justice, la solidarité et l'égalité entre les femmes et les hommes".

79 "Article 21, 1. L'action de l'Union sur la scène internationale repose sur les principes qui ont présidé à sa création, à son développement et à son élargissement et qu'elle vise à promouvoir dans le reste du monde: la démocratie, l'État de droit, l'universalité et l'indivisibilité des droits de l'homme et des libertés fondamentales, le respect de la dignité humaine, les principes d'égalité et de solidarité et le respect des principes de la charte des Nations unies et du droit international".

80 "2. L'Union définit et mène des politiques communes et des actions et oeuvre pour assurer un haut degré de coopération dans tous les domaines des relations internationales afin:

b) de consolider et de soutenir la démocratie, l'État de droit, les droits de l'homme et les principes du droit international". 
considerado "elemento essencial" de um Acordo de Associação firmado entre o Chile e a Comunidade Europeia. ${ }^{82}$

Nessa nova fase, que nada mais é senão o resgate devidamente adaptado da teoria construída após a Segunda Guerra Mundial, o Estado de Direito é comumente compreendido sob dois aspectos, um formal e um material. Em definiç̧ão clássica, Klaus Stern (1984) afirmou: “o Estado de Direito significa que o poder estatal não pode ser exercido senão sobre o fundamento de uma Constituição e de leis conformes, de um ponto de vista formal e material, a esta última, e com o objetivo de garantir a dignidade do homem, a liberdade, a justiça e a segurança jurídica". ${ }^{83}$

Sob o aspecto formal, o Estado de Direito significa um Estado dotado de uma série de mecanismos de controle do Poder Público que inclui, dentre outros, a tripartição dos poderes, a regra da legalidade e a supremacia da Constituição, da qual decorre o controle de constitucionalidade das leis. A análise, aqui, é essencialmente objetiva, no sentido de se estabelecer instrumentos para a garantia da segurança jurídica do indivíduo. Questiona-se a maneira pela qual a lei foi produzida, se são respeitadas as situações jurídicas já consolidadas, como a coisa julgada e o ato jurídico perfeito, se há uma previsibilidade mínima da jurisprudência, se há independência do Poder Judiciário em

\footnotetext{
81 "Consciente de son patrimoine spirituel et moral, l'Union se fonde sur les valeurs indivisibles et universelles de dignité humaine, de liberté, d'égalité et de solidarité; elle repose sur le principe de la démocratie et le principe de l'État de droit. Elle place la personne au coeur de son action en instituant la citoyenneté de l'Union et en créant un espace de liberté, de sécurité et de justice".

${ }^{82}$ Artigo 1. ${ }^{\circ}$ Princípios 1. O respeito dos princípios da democracia e dos direitos humanos fundamentais enunciados na Declaração Universal dos Direitos do Homem das Nações Unidas, assim como do princípio do Estado de direito, presidirá às políticas internas e externas das Partes e constituirá um elemento essencial do presente Acordo. (Resolução da Assembleia da República n. ${ }^{\circ}$ 31-A/2004 Acordo de Associação entre a Comunidade Europeia e os seus Estados Membros, por um lado, e a República do Chile, por outro, bem como os seus anexos, protocolos e notas, assinado em Bruxelas em 18 de Novembro de 2002.)

${ }^{83}$ STERN, Klaus. Das Staatsrecht der Bundesrepublik Deutschland. p. 781, citado por CHEVALLIER, Jacques. État de Droit. p. 68; por CALMES, Sylvia. Du Principe de Protection de la Confiance Légitime... p. 77; e por VALEMBOIS, Anne-Laure. La Constitutionalisation de l'Exigence de Sécurité Juridique en Droit Français. p. 29.
} 
relação aos demais poderes, se a intromissão estatal na esfera particular decorre de um devido processo legal etc. ${ }^{84}$

Tais características, porém, embora indispensáveis, são tidas por insuficientes para que o Estado possa ser, efetivamente, considerado "de Direito". O Estado de Direito não é mais um "'Estado de não importa qual direito', mas de um direito sustentado por um conjunto de valores e princípios". ${ }^{85}$ Isso quer dizer que, sob um ponto de vista substancial, o Estado de Direito precisa defender valores considerados caros à humanidade, o que pode referir-se tanto à proteção dos direitos fundamentais e garantia da segurança jurídica dos indivíduos, ${ }^{86}$ como à existência de normas que garantam o bemestar social ou estabeleçam um determinado modelo econômico ou sócio-político de Estado.

84 TAMANAHA, Brian Z. On the Rule of Law: history, politics, theory. p. 91. De acordo com Brian Tamanaha, as formulações de um Estado de Direito formal podem ser divididas em três grandes grupos, todos presentes no Estado de Direito contemporâneo. No primeiro, chamado de "Rule by law", o Estado de Direito tem o direito como instrumento de ação, ou seja, toda a atuação estatal é pautada por normas jurídicas preestabelecidas. No segundo grupo, denominado de "legalidade formal", a configuração do Estado de Direito se dá pela aptidão do Estado a traçar um sistema jurídico que permita moldar a conduta do indivíduo. Vigora, aqui, acima de tudo, a segurança jurídica; o Estado deve conter leis claras, genéricas, prospectivas, públicas e estáveis, de modo a permitir às pessoas "o planejamento de suas atividades com conhecimento prévio de suas potenciais implicações legais”. Por fim, há o grupo da 'legalidade democrática', que soma a democracia à legalidade formal. A democracia seria um procedimento para a determinação do conteúdo da lei, sem se confundir com a valoração deste conteúdo. É a produção democrática da lei que lhe dá legitimidade. TAMANAHA, Brian Z. On the Rule of Law: history, politics, theory. p. 94. V. p. 91-101.

${ }^{85}$ CHEVALLIER, Jacques. L'État de Droit. p. 87. Igualmente, CANOTILHO, José Joaquim Gomes. Direito Constitucional e Teoria da Constituição. p. 97: “O Estado Constitucional não é e nem deve ser apenas um Estado de direito". V. também DWORKIN, Ronald. A Matter of Principle. p. 11 e ss.

${ }^{86}$ V. CHEVALLIER, Jacques. État de Droit. p. 67-110. No Brasil, cite-se por todos Odete MEDAUAR: “A expressão Estado de direito pode levar a entender que a mera existência de uma Constituição e de um conjunto de normas, de conteúdo qualquer, permite qualificar um Estado como 'de direito'. Na verdade, hoje, a concepção de Estado de direito liga-se a um contexto de valores e à idéia de que o direito não se resume na regra escrita. Seus elementos básicos são os seguintes: sujeição do poder público à lei e ao direito (legalidade); declaração e garantia dos direitos fundamentais; funcionamento de juízos e tribunais protetores dos direitos dos indivíduos; criação e execução do direito como ordenamento destinado à justiça e à paz social" (Direito Administrativo Moderno. p. 27). 


\subsection{As críticas ao Estado de Direito}

Embora revestido de um caráter "místico", o Estado de Direito não está infenso a críticas, especialmente no que concerne à sua concepção substancial. Duas são as mais relevantes: a) o Estado de Direito seria uma expressão inútil e pleonástica; b) o Estado de Direito seria uma expressão meramente retórica, além de conter, em sua essência, elementos de Direito natural. ${ }^{87}$

\subsubsection{Expressão inútil e pleonástica}

A primeira crítica que se faz ao Estado de Direito, classicamente formulada por Hans Kelsen (v. ponto 1.2), diz respeito a uma suposta inutilidade da expressão. Se o Estado de Direito traduz um Estado regido por uma ordem jurídica, então o Estado de Direito nada mais é do que o próprio Estado Moderno. Além de inútil, o termo seria um pleonasmo. Recentemente, com algumas evoluções, esse entendimento recebeu a adesão de Luc Heuschling, que ao tratar do Rechtsstaat afirmou: 'O prefixo 'Recht' é, em 'realidade', superabundante, como se extrai de múltiplas críticas que demonstram, de maneira ora explícita ora implícita, o caráter pleonástico do neologismo criado em 1798 por Placidus. Inútil, ele ameaça ainda confundir a percepção do conceito de 'État', de 'Staat', conceito chave da doutrina jurídica moderna (...)". ${ }^{88}$

\footnotetext{
${ }^{87}$ HEUSCHLING, Luc. État de Droit, Rechtsstaat, Rule of Law. p. 418-431. O autor traz uma terceira crítica referente à suposta concepção contraditória do Direito contida no Estado de Direito, diante do papel do juiz na formação daquele. Essa questão, porém, está ligada à natureza criativa das decisões judiciais; tema que será parcialmente tratado nos Capítulos seguintes deste trabalho.

${ }^{88}$ HEUSCHLING, Luc. État de Droit, Rechtsstaat, Rule of Law. p. 661-662. No original: "Le préfixe 'Recht' est, en 'réalité', surabondant, comme il ressort des multiples critiques mettant en exergue, de façon soit explicite soit implicite, le caractère pléonastique du néologisme créé en 1798 par Placidus. Inutile, il risque en outre de brouiller la perception du concept d'État, de Staat, concept clé de la doctrine juridique moderne que les juristes anglais ont toutefois abandonné au cours du XIXe siècle. L'identification de l'État e de l'État de droit, $d u$ Staat $e d u$ Rechtsstaat, s'impose en toute logique: loin d'être l'apanage de l'école normativiste de Vienne, qui affirme l'identité du droit, de l'État et, partant, de l'État de droit, la célèbre critique de Kelsen a recontré des échos tant chez les représentants des autres écoles positivistes que chez les avocats du jusnaturalisme. Une fois débarassé de cette scorie sémantique, le juriste est mieux à même de cerner la spécificité de l'État parmi les diverses formes de pouvoir politique. Armé d'un outillage théorique plus pertinent, car plus économe, il peut décrypter plus aisément les enjeux théoriques sous-jacents à l'expérience
} 
Dois são os problemas da crítica. O primeiro está na suposição de que o Estado é uma simples organização jurídica, quando a noção de Estado vai além, podendo ser compreendido, muito resumidamente, como "uma nação politicamente organizada", 89 caracterizada pela institucionalização do poder, pela cidadania, pela soberania e pela unidade. ${ }^{90}$ Em síntese, como explica Tercio Sampaio Ferraz Jr., o pressuposto do Estado Moderno "está no reconhecimento do governo como uma unidade de ordem permanente, não obstante as transformações e as mudanças que se operam no seio da sociedade". 91 Aceito o caráter pleonástico do Estado de Direito, então como configurar Estados regidos por governos autoritários, que desrespeitam a ordem jurídica existente? Não são eles Estados? Ou melhor, como explicar a violação do ordenamento jurídico pelo próprio Estado? Tratar-se-ia de uma autoviolação? O segundo problema está na concepção pobre e incorreta de que Estado de Direito nada mais é do que um Estado juridicamente organizado, quando o seu verdadeiro conteúdo é a promoção da liberdade e da segurança do indivíduo.

\subsubsection{Pluralidade de significados: expressão meramente retórica}

A segunda grande crítica que se faz ao Estado de Direito tem como foco sua pluralidade de significados. Ao traduzir não só a forma, mas também a substância do

du III Reich: celui-ci inaugure un déclin tant du droit que de l'État". Para mais detalhes, v. Ibidem. p. 418426.

${ }^{89}$ COELHO, Inocêncio Mártires. Curso de Direito Constitucional. p. 61.

${ }^{90}$ CHEVALLIER, Jacques. L'État Post-Moderne. p. 12: "As características essenciais do modelo estatal são assim a tradução dos valores subjacentes à modernidade: a institucionalização do poder, quer dizer, a inscrição das relações de dominação política em um quadro geral e impessoal; a produção de um novo quadro de submissão, a 'cidadania', concebida como um vínculo exclusivo, incompatível com a existência de submissões paralelas ou concorrentes; o estabelecimento do monopólio de coerção, o Estado sendo, no espaço das 'fronteiras' que delimitam o campo de sua 'soberania', a única fonte do direito e o único habilitado a fazer uso dos meios de coerção; a consagração de um princípio fundamental de unidade, unidade de valores resultante do pertencimento a uma esfera pública colocada como distinta da sociedade, unidade do direito estatal, colocando-se como um todo coerente, uma 'ordem' estruturada, unidade do aparelho encarregado de desempenhar o poder do Estado". (Tradução livre).

${ }^{91}$ FERRAZ JR., Tercio Sampaio. As origens do Estado contemporâneo ou o Leviathan gestor da economia. p. 426. No mesmo sentido, TELLES JÚNIOR, Goffredo. Iniciação na Ciência do Direito. p. 117: "No mundo moderno, o termo Estado designa a nação com um governo institucionalizado. De fato o Estado é a Nação governada por uma instituição estruturada e estável". 
Estado, o Estado de Direito significa, em última análise, um Estado justo. Com isso, o Estado de Direito não mais seria do que uma expressão retórica, utilizada para legitimar o discurso daquele que dela se utiliza, sem ter nenhum tipo de aplicabilidade técnica. Resumindo, o Estado de Direito é tudo aquilo que se quer que ele seja. Por outro lado, ao se exigir a proteção dos "direitos fundamentais" do indivíduo para que um Estado possa ser chamado de Estado de Direito, haveria um inegável retorno à doutrina do Direito natural.

Essa crítica, porém, deve-se muito mais ao abarrotamento conceitual provocado por uma indevida agregação de elementos inconfundíveis do que propriamente a defeitos da teoria do Estado de Direito.

1.7. O 'conteúdo mínimo' do Estado de Direito: proteção da liberdade e da segurança jurídica

Desde a pré-história, a reunião de pessoas em sociedade motiva-se pela autoproteção e pelo desenvolvimento pessoal. O próprio Rousseau salientou esse fato com muita propriedade: “Como os homens não podem criar novas forças, mas só unir e dirigir as que já existem, o meio que têm para se conservar é formar por agregação uma soma de forças (...)" ${ }^{92}$ É natural, portanto, que o Estado seja concebido como uma criação humana voltada justamente para a promoção do ser humano. ${ }^{93}$ Consequentemente, toda a atuação estatal deve pautar-se pelo desenvolvimento do indivíduo, o que inclui, por óbvio, a proteção de determinados direitos reputados essenciais para uma vida digna. ${ }^{94}$ Tal finalidade é ainda mais saliente no Brasil, em que a dignidade da pessoa humana é erigida expressamente pela Constituição como fundamento da República (art. $1^{\circ}$, III).

\footnotetext{
${ }^{92}$ ROUSSEAU, Jean-Jacques. Do Contrato Social. p. 31. O pensamento já havia sido exposto por John Locke: "The only way whereby any one divests himself of his natural liberty, and puts on the bonds of civil society, is by agreeing with other men to join and unite into a community, for their comfortable, safe and peaceable living one amongst another, in a secure enjoyment of their properties, and a greater security against any, that are not of it". LOCKE, John. Two Treatises of Government. p. 269-270.

93 JUSTEN FILHO, Marçal. O Direito das Agências Reguladoras. p. 11.

${ }^{94}$ As ideias aqui expostas não se confundem com a defesa de direitos naturais do homem. O que se afirma é que o Estado é uma criação teleológica, voltada para a promoção do indivíduo. Essa promoção, porém, depende dos valores de determinada sociedade, e variará segundo o tempo e o espaço.
} 
Se o fim precípuo do Estado é a promoção da dignidade da pessoa humana, também o é o do Estado de Direito. Mas isso não quer dizer que Estado e Estado de Direito sejam a mesma coisa. Essa histórica confusão talvez tenha sido o maior erro cometido por grande parte da doutrina que se dedicou ao estudo do Estado de Direito, assimilando-o a um determinado Estado em um determinado momento histórico. Comum é a utilização de Rechtsstaat para referir-se ao Estado alemão ou État de Droit para referir-se ao Estado francês. Mesmo que se considere uma opção metodológica, seria forçoso concluir tratar-se de uma metodologia inútil. O Estado francês, por exemplo, pode ser perfeitamente identificado dessa forma, sem que se recorra a outros tipos de neologismos.

Também não se pode misturar Estado de Direito com Estado 'justo', exatamente o que fazem as 'teorias materiais' ao conceber o Estado de Direito como o Estado que protege a segurança jurídica $e$ os "direitos fundamentais" 95 e bem-estar social $e$ o que mais se entender necessário. ${ }^{96}$ Mais uma vez, a utilização de duas expressões distintas para designar o mesmo fenômeno não se justifica.

Como vem sendo repetido, Estado de Direito é um ideal de Estado, regido pela razão, em que se busca eliminar o arbítrio do poder mediante uma ordem jurídica preestabelecida e dotada de certas garantias. ${ }^{97}$ Em outras palavras, o Estado de Direito é

95 Coloca-se a expressão entre aspas porque o raciocínio leva ao entendimento de que existem direitos 'fundamentais' a serem protegidos constitucionalmente, quando apenas depois de protegidos pela Constituição é que direitos tornam-se 'fundamentais'. A inversão lógica é patente. Um direito só pode ser considerado fundamental quando a própria Constituição lhe atribui tal condição. Não existem "direitos fundamentais" ao ser humano em qualquer tempo ou lugar. Eles dependerão do contexto histórico em que estão inseridos, variando segundo os valores de cada sociedade. Os direitos reputados 'fundamentais' por um dinamarquês médio certamente não serão os mesmos de um paquistanês médio. A exigência contemporânea de respeito a determinados direitos, ainda quando não constitucionalizados, está ligada à obrigatória defesa de direitos humanos, consagrados internacionalmente. Mas mesmo aqui há uma inegável positivação internacional de valores caros à sociedade ocidental.

${ }^{96}$ Por todos, v. VALEMBOIS, Anne-Laure. La Constitutionnalisation de l'Exigence... p. 45. "Ainsi, l'État de droit substantiel a pour but 'l'instauration et le maintien d'un ordre juridique qui soit juste'(...)"

${ }^{97}$ Como afirmou Albert Venn DICEY, o Estado de Direito "means, in the first place, the absolute supremacy or predominance of regular law as opposed to the influence of arbitrary power, and excludes the existence of arbitrariness, of prerogative, or even of wide discretionary authority on the part of the government" (An Introduction to the Study of the Law of the Constitution. p. 202). Algumas páginas antes, escreveu: "In this sense de rule of law is contrasted with every system of government based on the exercise by persons in authority of wide, arbitrary, or discretionary powers of constraint" (p. 188). 
uma construção teórica voltada à proteção da segurança jurídica e à liberdade do indivíduo, ${ }^{98}$ de modo a impor limites ao poder estatal para que cada pessoa possa, dentro daquilo que lhe é permitido e garantido pelo ordenamento jurídico, com estabilidade e previsibilidade, desenvolver-se plenamente.

Nesse sentido, o Estado de Direito é um "tipo ideal” ao qual os Estados, e especialmente seus sistemas jurídicos, podem aproximar-se em maior ou menor medida. ${ }^{99}$ Um tipo ideal que contém "condições sistêmicas" que englobam "prescrições de conteúdo formal" e "normas de natureza procedimental". ${ }^{100}$ Nesse Estado exige-se que: o Direito vigente seja um Direito positivado e determinado, rejeitando-se a utilização de conceitos voláteis e metafísicos, como os do Direito natural; as funções estatais sejam separadas entre os três poderes; os atos dos agentes públicos sejam públicos e motivados; as normas sejam dotadas de características como clareza, determinação, generalidade, prospectividade, estabilidade, publicidade; garanta-se amplo acesso a um Poder Judiciário imparcial e dotado dos mecanismos necessários para efetivar o direito vigente; o indivíduo não tenha sua esfera jurídica violada senão mediante um 'devido processo legal' etc. ${ }^{101}$

${ }^{98}$ HENRY, Jean-Pierre. Vers la fin de l'État de Droit? p. 1208: "Par la submission du pouvoir au droit, l'état de droit apparaît donc comme un progrès, comme une étape supérieure dans la recherche de la sécurité des rapports. Par la normalisation de l'exercice du pouvoir, il exclue des rapports politiques, comme des rapports sociaux, les aléas dus à la force ou au hasard. C'est précisément pour cette raison que l'état de droit est en fait consideré comme le fondement essentiel de toute société démocratique".

99 COSTA, Guilherme Recena da. Superior Tribunal de Justiça e Recurso Especial. p. 82. Pensamento compartilhado por RAZ, Joseph. The Rule of Law and its virtue. p. 222: "Conformity to the rule of law is a matter of degree. Complete conformity is impossible (some vagueness is inescapable)"; HAYEK, F. A. The Road to Serfdom. p. 112-113: "Though this ideal can never be perfectly achieved (...), the essential point, that the discretion left to the executive organs wielding coercive power should be reduced as much as possible, is clear enough"; e WALDRON, Jeremy. The concept and the Rule of Law. p. 48: "the requirements associated with the Rule of Law are all matters of degree. They are matters of degree (i) because a system of governance may satisfy the Rule of Law in some areas of governance and not others, or (ii) because (as we noted in Part II of this Essay) the Rule of Law comprises multiple demands and some of them may be satisfied but not others, or (iii) because a particular norm or directive may be more or less clear, more or less stable, more or less well-publicized, and enforced through more or less scrupulous procedures".

${ }^{100}$ COSTA, Guilherme Recena da. Superior Tribunal de Justiça e Recurso Especial. p. 82.

${ }^{101}$ Sobre as características das normas em um Estado de Direito, v. Ibidem. p. 82-83. V. também a clássica exposição de FULLER, Lon L. The Morality of Law. p. 33-94. A doutrina costuma resumir a feição formal do Estado de Direito em uma trilogia: separação dos poderes, hierarquia das normas e acesso à justiça (VALEMBOIS, Anne-Laure. La Constitutionnalisation de l'Exigence de Sécurité Juridique en Droit 
Embora essa concepção de Estado de Direito possa ser considerada "formal", inclusive por seus defensores, ${ }^{102}$ ela não prescinde de conteúdo, ${ }^{103}$ nem, muito menos, de finalidade. ${ }^{104}$ Também não significa, de forma alguma, a rejeição dos direitos humanos ou dos direitos fundamentais previstos nas constituições. Distinguir Estado de Direito de um 'Estado justo' não implica rejeitar a busca por este último, nem contentar-se com um Estado meramente formal.

O que se defende é uma teoria "fina" do Estado de Direito, ${ }^{105}$ isto é, uma teoria que foque as atenções apenas no elemento nuclear do conceito, sem tentar englobar todos os valores perseguidos por um 'Estado justo'. Uma teoria que realmente permita que o Estado de Direito, além de realizar seus próprios propósitos, como paz e ordem sociais,

Français. p. 32). Tais elementos, porém, não conseguem abarcar todas as exigências do Estado de Direito, mesmo se considerados de maneira genérica.

${ }^{102}$ SUMMERS, Robert. S. A formal theory of the Rule of Law. p. 128.

103 A configuração da segurança jurídica como 'conteúdo' do Estado de Direito foi expressamente defendida por CHEVALLIER, Jacques. État de Droit. p. 87-99. Joseph Raz parece seguir a mesma linha ao considerar a observância do Estado de Direito necessária ao respeito da dignidade da pessoa humana, ainda que intimamente vinculada, em sua opinião, à segurança jurídica: "More important than both these considerations is the fact that observance of the rule of law is necessary if the law is to respect human dignity. Respecting human dignity entails treating humans as persons capable of planning and plotting their future. Thus, respecting people's dignity includes respecting their autonomy, their right to control their future". RAZ, Joseph. The Rule of Law and its virtue. p. 221.

${ }^{104}$ SUMMERS, Robert. S. A formal theory of the Rule of Law. p. 169: "Institutionalization of the rule of law is one thing, the values it serves, another. A relatively formal theory of the rule of law characteristically serves certain values". Dentre os valores a que Summers se refere estão: governo legítimo (incluindo os três poderes), paz e ordem domésticas, certeza e previsibilidade das ações estatais e os seus efeitos legais nas relações intersubjetivas, autonomia privada, facilitação do livre-arbítrio e do planejamento, respeito pela dignidade da pessoa humana, equidade no tratamento legal pelo Estado etc. (p. 131).

105 A doutrina do common law costuma distinguir as concepções do Estado de Direito em 'finas' (thin) e 'grossas' (thick). Essas últimas, além das garantias ligadas à segurança jurídica, englobam também valores como democracia, direitos humanos, cidadania etc. V. SAMPFORD, Charles. Retrospectivity and the Rule of Law. p. 49-55. Igualmente, TAMANAHA, Brian Z. On the Rule of Law. p. 91-113. Para Gianluigi PALOMBELLA, as teorias 'finas' estariam excessivamente ligadas ao funcionamento do direito positivo, motivo pelo qual prefere chamar a sua teoria de 'institucional' (The Rule of Law as institutional ideal. passim). 
segurança jurídica, liberdade etc., proteja as demais finalidades substanciais do Estado; ${ }^{106}$ justamente aquilo que dele se espera. ${ }^{107}$

As suas vantagens são muitas: a) politicamente neutra, pode servir a qualquer Estado, sob qualquer governo; b) mais restrita, produz maior congruência na argumentação e crítica jurídicas; c) também por ser mais restrita, permite uma melhor definição dos fins do Estado, tornando mais fácil verificar se estão sendo alcançados ou não; d) mais técnica, não se sujeita com tanta facilidade a utilizações meramente retóricas etc. $^{108}$

A atribuição ao Estado de Direito de todos os valores nobres que devem (ou deveriam) ser defendidos por um Estado justo causa uma "hiper-inflação" conceitual que nada faz senão enfraquecer o próprio instituto, retirando toda a aplicabilidade prática de sua utilização. ${ }^{109}$ A partir do momento em que o Estado de Direito é tudo, então na verdade ele não é nada.

A suposta insuficiência da proteção da liberdade do indivíduo contra o arbítrio como finalidade básica do Estado de Direito parece ainda estar associada a uma tentativa de distanciamento da doutrina contemporânea da teoria positivista clássica do século XIX e começo do século XX. ${ }^{110}$ A autorização dada por Kelsen para que Estados autoritários também fossem considerados Estados de Direito assombra o instituto até hoje.

\footnotetext{
${ }^{106}$ Exatamente neste sentido, MACCORMICK, Neil. Rhetoric and the Rule of Law. p. 16.

107 O Preâmbulo da Declaração Universal dos Direitos do Homem de 1948 é claro ao atribuir função instrumental ao Estado de Direito: "Considerando ser essencial que os direitos humanos sejam protegidos pelo império da lei [na versão inglesa consta a expressão "Rule of Law" e na versão francesa a expressão "régime de droit"], para que o ser humano não seja compelido, como último recurso, à rebelião contra a tirania e a opressão".

${ }^{108}$ Sobre isso, v. SUMMERS, Robert. S. A formal theory of the Rule of Law. p. 129; SAMPFORD, Charles. Retrospectivity and the Rule of Law. p. 52-55.

${ }^{109}$ SUMMERS, Robert. S. A formal theory of the Rule of Law. p. 129. V. também as brilhantes críticas de SAMPFORD, Charles. Retrospectivity and the Rule of Law. p. 52-55.

${ }^{110}$ Em sentido similar escreveu Charles SAMPFORD: “One of the potential reasons for prefering thick theories is the concern that fundamentally inadequate laws will receive the cachet and legitimacy of the word 'law' and be supported by the 'rule of law' values. Only laws that reflect values such as 'democracy' and 'rights' should receive the honour of being called 'laws' and the legitimacy that word generates". A resposta do professor australiano é perfeita: "If law has to meet certain criteria of justice before being called law, it is
} 
Mas se o positivismo clássico pecou em privilegiar os meios (forma) em detrimento dos fins (substância), na crença de que poderia retirar do Direito sua obrigatória natureza teleológica, parte da doutrina contemporânea peca em imaginar, muitas vezes, que os fins justificam os meios. Além disso, esquece que a liberdade e a segurança são, também, fins primários do Estado $e$ do Direito.

Desse modo, o Estado de Direito deve ser concebido como um modelo ideal de Estado em que o poder estatal é rigidamente controlado e previamente definido, e as pessoas podem conduzir suas vidas com segurança, prevendo as consequências futuras de seus atos, acreditando que as situações jurídicas já consolidadas não serão mais alteradas e tendo a certeza de que os seus patrimônios jurídicos não serão violados senão por um devido processo legal. Somente quando conquistada essa segurança jurídica é que os demais valores 'substanciais' do Estado (e também do Direito) poderão ser atingidos (v. 2.1 , abaixo). ${ }^{111}$

\section{A segurança jurídica: atributo e finalidade do Estado de Direito}

Considerando tudo o que vem sendo exposto, parece suficientemente claro que a segurança jurídica é um atributo e uma finalidade do Estado de Direito. Como afirmou Rafael Valim, "há uma notória fundamentação recíproca entre o princípio da segurança jurídica e o Estado de Direito, sendo aquele elemento indispensável deste, ao mesmo tempo em que este é condição necessária daquele". ${ }^{112}$ O Estado de Direito é o Estado em que se assegura a segurança jurídica, embora com ela não se confunda. ${ }^{113}$

harder to criticize it" (Retrospectivity and the Rule of Law. p. 55). V. também a exposição de MANRIQUE, Ricardo García. Autonomy and the Rule of Law. passim.

${ }^{111}$ Nesse sentido, RAZ, Joseph. The Rule of Law and its virtue. p. 224.

${ }^{112}$ VALIM, Rafael. O Princípio da Segurança Jurídica no Direito Administrativo Brasileiro. p. 34. O autor, contudo, adota premissas distintas às do presente trabalho, concebendo o Estado de Direito em duplo sentido, formal e material. Em sua ótima obra, considera traços do Estado de Direito: dignidade da pessoa humana, soberania popular, separação das funções estatais, princípio da igualdade, princípio [rectius: regra] da legalidade, sistema de direitos fundamentais dotados de petrealidade, inafastabilidade do controle jurisdicional e princípio da segurança jurídica (p. 34).

${ }^{113}$ HAYEK, F. A. The Road to Serfdom. p. 112-113: "Within the known rules of the game the individual is free to pursue his personal ends and desires, certain that the powers of government will not be used 
Destarte, a discussão ainda existente no Brasil acerca da natureza constitucional da proteção à segurança jurídica perde o sentido diante do art. $1^{\circ}$, caput, da Constituição da República. Se a República Federativa do Brasil é, constitucionalmente, um Estado de Direito, então a segurança jurídica possui, sim, proteção constitucional. ${ }^{114}$ Esse entendimento vem sendo reiteradamente confirmado pelo Supremo Tribunal Federal, que considera a segurança jurídica um "elemento conceitual do Estado de Direito". 115

A proteção da segurança jurídica importa duas consequências imediatas e de grande relevância. Em primeiro lugar, a segurança jurídica é incompatível com o arbítrio estatal, pois parte do pressuposto de que existe uma ordem jurídica estável, previsível e homogênea, impedindo intromissões inesperadas no patrimônio jurídico do indivíduo; além disso, impõe ao Estado o dever de efetivar os direitos dos cidadãos. Em segundo lugar, a segurança jurídica 'situa' a pessoa no tempo e no espaço, atribuindo-lhe condições de confiar no Estado e nos demais indivíduos, e dando-lhe a certeza de que situações jurídicas consolidadas não serão mais alteradas e que determinados fatos jurídicos desencadearão determinadas consequências jurídicas. Seguindo as lições de Luiz Guilherme Marinoni, "o primeiro aspecto demonstra que se trata de garantia em relação ao comportamento daqueles que podem contestar o direito e têm o dever de aplicá-lo; o

deliberately to frustrate his efforts". Ainda na década de 30, Gustav Radbruch, com o brilhantismo que lhe era peculiar, vinculou expressamente a segurança jurídica ao Estado de Direito: "La sécurité que le droit confère à la personne et à l'individu est appelée la paix et l'ordre. (...) C'est sur ces exigences que se fonde ce qu'en Allemagne on appelait l'Etat de droit et en Angleterre the rule of law". RADBRUCH, Gustav. La sécurité en droit d'après la théorie anglaise. p. 88.

${ }^{114}$ Nesse sentido, ALVARO DE OLIVEIRA, Carlos Alberto. Do Formalismo no Processo Civil. p. 79; MARINONI, Luiz Guilherme. Precedentes Obrigatórios. p. 121-124; COUTO E SILVA, Almiro do. $O$ princípio da segurança jurídica (proteção à confiança) no Direito Público brasileiro (...). p. 11; CARRAZZA, Roque Antonio. Segurança jurídica e eficácia temporal das alterações jurisprudenciais. p. 43; MENDES, Gilmar Ferreira. Direito adquirido, ato jurídico perfeito, coisa julgada e segurança jurídica. p. 531-534; SARLET, Ingo Wolfgang. A eficácia do direito fundamental à segurança jurídica... p. 86. Na doutrina estrangeira, CANOTILHO, José Joaquim Gomes. Direito Constitucional e Teoria da Constituição. p. 257; HAYEK, F. A. The Constitution of LIberty. p. 315-316. Em sentido contrário, TORRES, Heleno Taveira. Direito Constitucional Tributário e Segurança Jurídica. p. 121 e ss.

${ }^{115}$ P.ex., MS 25116, Relator(a): Min. Ayres Britto, Tribunal Pleno, julgado em 08/09/2010, DJe-027. 
segundo quer dizer que ela é indispensável para que o cidadão possa definir o modo de ser das suas atividades". 116

Tradicionalmente, ao menos nos sistemas jurídicos do civil law, a segurança jurídica é pensada a partir da função legislativa, exigindo-se normas jurídicas estáveis, previsíveis e acessíveis. Nessa linha, as garantias da legalidade e da licitude possuem posição de destaque; enquanto a garantia da legalidade exige leis prévias para a adoção de comportamentos pelo Estado, a garantia da licitude atribui ao indivíduo ampla liberdade de fazer ou deixar de fazer tudo aquilo que não for expressamente proibido pelo ordenamento jurídico.

No entanto, a segurança jurídica não se restringe ao mundo das leis e talvez nem sequer seja nele que ela desenvolva-se plenamente.

É sabido que ao juiz não compete simplesmente declarar a lei. Antes de tudo, o juiz interpreta o Direito e, então, extrai a solução do caso concreto. Isso não significa, como será visto adiante, que a jurisprudência desenvolva um papel de criação jurídica, mas sim que: (a) toda produção linguística está sujeita à interpretação de seu destinatário, (b) o Direito é um fenômeno social e, como tal, acompanha as transformações e evoluções da sociedade, levando a interpretações diversas do mesmo texto normativo em diferentes contextos temporais ou espaciais, e (c) o Direito não é formado apenas pelas leis.

Não por acaso, o common law, que tem no stare decisis um meio de promover a segurança jurídica e a igualdade entre os jurisdicionados ${ }^{117}$, não se preocupa tanto com a previsibilidade das leis, mas principalmente com a previsibilidade das decisões

\footnotetext{
${ }^{116}$ MARINONI, Luiz Guilherme. Precedentes Obrigatórios. p. 122-123.

${ }^{117}$ Interessante a explicação de Rupert Cross, amparado nas lições de Goodhart: "The continental judge has no doubt always wanted the law to be certain as much as the English judge. But he felt the need less keenly because of the background of rules provided first by Roman law and codified custom, and later by the codes of the Napoleonic era. These resulted in a large measure of certainty in European law. Roman law was never 'received' in England, and we have never had a code in the sense of a written statement of the entirety of the law. 'English law, if it were to remain fluid and unstable, required a strong cement. This was found in the common-law doctrine of precedent with its essential and peculiar emphasis on rigidity and certainty'”. CROSS, Rupert; HARRIS, J. W. Precedent in English Law. p. 11-12. Para Gustav RADBRUCH, a História demonstra o predomínio da segurança jurídica no sistema inglês (La sécurité en droit d'après la théorie anglaise. p. 89).
} 
judiciais. ${ }^{118}$ Com efeito, "quando há uma crise de colaboração na realização do direito material e os textos normativos encontram diversas interpretações no Judiciário, o que obviamente importa são as decisões judiciais, momento em que a dimensão normativa dos textos encontra expressão, e não o texto normativo abstratamente considerado". ${ }^{119}$

Nos pontos seguintes serão traçadas algumas características básicas da segurança jurídica, retomadas ao longo do trabalho com maior ênfase na motivação das decisões judiciais.

2.1. A trilogia dos objetivos do Direito: segurança jurídica, justiça e progresso social

Costuma-se dizer, corretamente, que o Direito não é um fim em si mesmo, mas um meio para que sejam atingidos determinados fins. Trata-se de um instrumento para a consecução de três objetivos básicos (que também os são do Estado), aos quais se denomina de "trilogia dos objetivos do Direito": segurança jurídica, justiça e progresso social (ou "bem comum", segundo Radbruch). ${ }^{120}$

Cada um desses elementos engloba uma série de valores fundamentais à promoção da pessoa humana. Na segurança jurídica estão inseridos, por exemplo, a eliminação do arbítrio e racionalidade na atuação do Estado, paz e ordem sociais, previsibilidade de condutas e comportamentos etc. ${ }^{121}$; na justiça observam-se, dentre outros, a igualdade e a 'generalidade"122; e o progresso social contém, também a título exemplificativo, a felicidade, a saúde, o bem-estar, a cultura etc. ${ }^{123} 124$

\footnotetext{
${ }^{118}$ V. MARINONI, Luiz Guilherme. Precedentes Obrigatórios. p. 125.

${ }^{119}$ Ibidem. p. 126.

${ }^{120}$ RADBRUCH, Gustav. La securité en droit d'après la théorie anglaise. p. 87; ROUBIER, Paul. Théorie Générale du Droit. p. 318 e ss.; VALEMBOIS, Anne-Laure. La Constitutionnalisation de l'Exigence de Sécurité Juridique... p. 5-6.

${ }^{121}$ V., p.ex., os incisos II, XXXIII, XXXVI, XXXVII, XXXVIII, XXXIX, XL, XLI, XLVI, LIII, LIV, LV, LVI, LX, LXI, LXVIII, LXIX e LXXII do art. $5^{\circ}$ e da Constituição da República, assim como os arts. 37 e 93.

${ }^{122}$ V., p.ex., o art. 5’ caput, da Constituição da República (“Todos são iguais perante a lei”) e incisos I e VI.

${ }^{123}$ V. p.ex., a maior parte dos incisos do art. $5^{\circ}$ da Constituição da República, bem como os arts. $6^{\circ}$ e ss.
} 
É natural que cada corrente jusfilosófica tenda a privilegiar um dos objetivos do Direito. Se a segurança jurídica é o principal objeto de estudo das escolas formalistas, pode-se dizer que a igualdade e o progresso social receberam destaque das escolas idealistas e realistas, respectivamente. ${ }^{125}$ No entanto, não é válido concluir que os três sejam sempre conflitantes ou que haja algum tipo de graduação hierárquica entre eles. ${ }^{126}$ Ao contrário, as relações entre segurança jurídica, justiça e progresso social são complexas e desenvolvem-se sob um regime de interdependência. A difusão de julgamentos por equidade em detrimento das normas jurídicas, p.ex., pode até privilegiar, inicialmente, uma suposta 'justiça do caso concreto' (ou justiça pessoal daquele que está julgando), mas desencadeará, inevitavelmente, um sentimento de insegurança nas pessoas, incapazes de prever as consequências de seus atos. Em um segundo momento, o rompimento da segurança jurídica provocará injustiça, pois situações fáticas idênticas receberão respostas jurisdicionais distintas e os mesmos comportamentos sociais produzirão consequências jurídicas diversas. É preciso, portanto, buscar um equilíbrio. ${ }^{127}$

Por outro lado, embora inexista hierarquia, parece correto aceitar uma ordem lógica para a promoção desses valores; e nessa ordem, a segurança jurídica aparece em primeiro lugar. Não, repita-se, porque ela é mais importante do que a justiça ou o progresso social, mas porque ela é um meio (ou pressuposto) para que eles sejam atingidos. ${ }^{128}$ Em trecho clássico, afirmou Paul Roubier: "Lá onde este valor essencial que é

${ }^{124}$ V. RADBRUCH, Gustav. La securité en droit d'après la théorie anglaise. p. 87; ROUBIER, Paul. Théorie Générale du Droit. p. 318. Igualmente, VALEMBOIS, Anne-Laure. La Constitutionnalisation... p. 6.

${ }^{125}$ ROUBIER, Paul. Théorie Générale du Droit. p. 319.

126 TALAMINI, Eduardo. Coisa Julgada e sua Revisão. p. 67: "Nesse sentido, é possível aludir a um 'pluralismo' axiológico. Reconhece-se a existência de uma multiplicidade de valores igualmente consagrados na ordem jurídica, e se constata a inviabilidade de uma hierarquização prévia, abstrata e absoluta entre todos eles. A segurança está inserida nesse quadro: coexiste com outros valores, eventualmente antagônicos, sem que seja possível estabelecer-lhe uma exata classificação hierárquica, de modo prévio e abstrato".

${ }^{127}$ Nesse sentido, v. a elegante explicação de RADBRUCH, Gustav. La securité en droit d'après la théorie anglaise. p. 87-88. O professor alemão demonstra sucintamente como a potencialização de um dos objetivos do Direito pode desencadear um desequilíbrio com os demais. Especificamente no que diz respeito às atrocidades cometidas pelo Estado Nazista, v. a explicação de ROUBIER, Paul. Théorie Générale du Droit. p. 323 .

128 Essa natureza instrumental da segurança jurídica não a desqualifica como valor-fim do Direito. Justamente por ser um meio, um pressuposto para a obtenção da justiça e do progresso social é que o Direito 
a segurança jurídica desapareceu, não há mais nenhum outro valor que possa subsistir; a própria palavra de progresso torna-se um escárnio, e as piores injustiças multiplicam-se com a desordem. $\mathrm{O}$ direito cede lugar ao que um escritor contemporâneo chamou de 'o conceito do político', quer dizer, às puras considerações de oportunidade. O jurisconsulto não há mais nada a dizer: entra-se em um domínio onde ele não pode avançar, sem ser tomado de pavor". ${ }^{129}$

Com efeito, a segurança jurídica é a 'estrutura' do "edifício legislativo" moderno. É ela que protege os demais direitos e garante a sua efetivação, a sua observância. Somente em um sistema jurídico seguro é possível atingir a igualdade e o progresso social.

\subsection{Segurança jurídica pelo Direito e segurança jurídica do Direito}

Vem sendo difundinda na doutrina moderna a antiga separação da segurança jurídica em segurança jurídica pelo Direito e a segurança jurídica do Direito. ${ }^{130} \mathrm{~A}$ segurança jurídica não estaria voltada apenas à segurança dos homens, mas sobretudo à segurança do sistema jurídico. ${ }^{131}$ Philippe Raimbault, por exemplo, alega que a existência do Direito é insuficiente para satisfazer a necessidade de segurança. Prescrições "portadoras de perigos", como a que permite prisões arbitrárias, podem ser inseridas no

deve ter como finalidade a segurança jurídica do indivíduo. Considerar a segurança jurídica unicamente como meio é imaginar, erroneamente, que segurança jurídica e Direito se confundem. Em sentido contrário, atribuindo à segurança jurídica natureza unicamente instrumental, v. PIAZZON, Thomas. La Sécurité Juridique. p. 179.

${ }^{129}$ ROUBIER, Paul. Théorie Générale du Droit. p. 334. Em sentido semelhante, COUDERT Frederic René. Certainty and Justice... p. 1: "Law is necessary a rule of action, and unless a court decides cases according to some cohesive plan or definite rules, the justice administered is scarcely deserving of the name of law".

${ }^{130}$ Antiga, pois já havia sido defendida por Radbruch ainda em 1936. V. RADBRUCH, Gustav. La securité en droit d'après la théorie anglaise. p. 88-89.

${ }^{131}$ VALEMBOIS, Anne-Laure. La Constitutionnalisation... p. 8; RAIMBAULT, Philippe, Recherche sur la Sécurité Juridique en Droit Administratif Français. p. 9-10; VALIM, Rafael. O Princípio da Segurança Jurídica no Direito Administrativo Brasileiro. p. 45. 
"quadro de regras jurídicas", motivo pelo qual a "segurança do direito se sobrepõe necessariamente à segurança pelo direito". ${ }^{132}$

A distinção é inócua e ilógica, pois parte da premissa de que a segurança pelo Direito está ligada à simples existência de normas jurídicas que regulem a atividade social. Mas se o Direito deve garantir a segurança do indivíduo, então é evidente que deve ser dotado de certas características que o deixem previsível, estável, claro, acessível etc. A estipulação legal de prisões arbitrárias, ainda que inserida no ordenamento jurídico, não será, nunca, compatível com a segurança jurídica, pois violadora do corolário básico da previsibilidade. ${ }^{133}$ Por isso, não há segurança jurídica pelo Direito quando carente a segurança do Direito.

2.3. Ainda sobre as relações entre segurança jurídica e justiça

Não muito diversa, em sua essência, é a concepção de que a segurança jurídica deve conter, assim como o Estado de Direito, uma faceta material vinculada à justiça. Utiliza-se o exemplo do Estado Nazista, em que as minorias teriam condições de prever com grande segurança que seriam discriminadas. ${ }^{134}$ Em relação ao exemplo dado por Philippe Raimbault, poderíamos adaptá-lo para uma lei que autorizasse a tortura do

\footnotetext{
${ }^{132}$ RAIMBAULT, Phillippe. Recherche sur la Sécurité Juridique en Droit Administratif Français. p. 10 : "Cependant, l'existence du droit demeure, en soi, insuffisante pour combler le besoin de sécurité. De fait, des prescriptions porteuses de dangers, commme par exemple des arrestations arbitraires - même si elles ne sont évidemment pas qualifiées comme telles - peuvent êtres prévues dans le cadre de règles juridiques. L'exigence se reporte donc logiquement sur l'ordre juridique lui-même et la sécurité du droit se superpose nécessairement à la sécurité par le droit".

${ }^{133}$ José Afonso da Silva segue a mesma linha de pensamento de Philippe Raimbault ao considerar o regime militar brasileiro um regime de "máxima segurança por meio de uma ordem jurídica excepcional" (SILVA, José Afonso da. Constituição e segurança jurídica. p. 16-17). A ligação, que confunde segurança jurídica com mera positivação jurídica, parece incorreta. A última coisa que existe em um sistema com prisões clandestinas, atos estatais arbitrários e censuras imprevisíveis é segurança jurídica. Servem, aqui, as considerações irreparáveis de F. Hayek sobre o Rule of Law: "The rule of law, of course presupposes complete legality; but this is not enough: if a law gave the government unlimited power to act as it pleased, all its actions would be legal, but it would certainly not be under the rule of law." HAYEK, F. A. The Constitution of Liberty. p. 310.

${ }^{134}$ Exemplo dado por Aleksander Peczenik e citado por ÁVILA, Humberto. Segurança Jurídica. p. 656.
} 
suspeito de um crime preso em flagrante. Deste modo, o suspeito teria a certeza de que seria torturado em caso de prisão em flagrante.

O problema da ideia, mais uma vez, está em confundir conceitos e imaginar que todo e qualquer instrumento voltado à realização de determinado objetivo do Direito deva satisfazer também todos os demais. É evidente que um sistema seguro não será necessariamente justo. Mas também parece evidente que defender a promoção da segurança jurídica não significa abdicar da justiça; pelo contrário, a justiça será a primeira a ser violada em um regime de anarquia jurídica. ${ }^{135}$ Como escreveu Giovanni Conso, "os maiores crimes contra a humanidade foram perpetrados sob a bandeira do chamado direito livre, que, enquanto direito sem certeza alguma, nem mesmo pode ser considerado direito". 136

Embora o caminho a ser trilhado seja em direção à realização de todos os objetivos fundamentais do Direito (i.e, segurança jurídica, justiça e progresso social), é preciso que se saiba exatamente o que significa cada um desses valores, qual é a sua função na sociedade, e qual deles está sendo promovido quando estudado determinado instituto jurídico.

\subsection{O conceito de segurança jurídica}

Por tratar-se de "uma exigência jurídica polissêmica" e teleológica, a conceituação da segurança jurídica é bastante difícil e, para muitos, até mesmo indesejável. ${ }^{137}$ Seria, nas palavras de Sylvia Calmes, um instituto "mais funcional do que conceitual". ${ }^{138}$ Daí ser usual na doutrina a sua definição a partir da compreensão de suas características fundamentais, corolários, ou mesmo finalidades, classicamente organizadas

\footnotetext{
${ }^{135}$ V. ÁVILA, Humberto. Segurança Jurídica. p. 657-658.

${ }^{136}$ CONSO, Giovanni. La certezza del diritto: ieri, oggi, domani. p. 547.

${ }^{137}$ V., por todos, VALEMBOIS, Anne-Laure. La Constitutionnalisation... p. 12.

${ }^{138}$ CALMES, Sylvia. Du Principe de Protection de la Confiance Légitime... p. 156.
} 
sob a forma de um trinômio: acessibilidade, estabilidade e previsibilidade do Direito. ${ }^{139} \mathrm{Ou}$ seja, a segurança jurídica seria a exigência de um Direito acessível, estável e previsível. ${ }^{140}$

No entanto, a partir de uma análise um pouco mais acurada, não é difícil perceber que a acessibilidade do Direito busca, ao fim e ao cabo, promover a previsibilidade jurídica. A exigência de normas públicas, claras, precisas e inteligíveis não significa outra coisa senão a exigência de que as pessoas possam prever as consequências jurídicas de seus atos e conhecer seus direitos, deveres e obrigações; sintetizada com louvor na fórmula "saber para prever". ${ }^{141}$ Por outro lado, a proteção da confiança legítima merece uma análise individualizada, tendo em vista a sua carga eminentemente subjetiva, destoando em grande medida da estabilidade e da previsibilidade da ordem jurídica. ${ }^{142}$

A segurança jurídica pressupõe, portanto, um Direito estável e previsível, bem como exige do Estado que respeite a confiança legítima que lhe é depositada pelo particular. Essas características serão retomadas, apenas naquilo que for estritamente relevante a este trabalho, nos Capítulos Quinto e Sexto.

\section{A jurisdição e o processo no Estado de Direito: o devido processo legal}

Quando Carré de Malberg estudou o Estado de Direito em sua clássica obra Contribution à la Théorie Générale de l’État, grande responsável pela difusão da expressão na França, definiu-o como o Estado submetido a um regime de direito, do qual constam normas que atribuem direitos aos cidadãos e normas que estabelecem previamente

\footnotetext{
${ }^{139}$ Sobre esta classificação, v. PIAZZON, Thomas. La Sécurité Juridique. p. 17-52.

${ }^{140}$ Várias são as maneiras de classificar a segurança jurídica. Thomas PIAZZON, p.ex., opta por dividi-la em segurança jurídica objetiva (aspectos institucional, formal e material) e segurança jurídica subjetiva ( $L a$ Sécurité Juridique. p. 74-91). Philippe RAIMBAULT, por sua vez, prefere tratar a segurança jurídica a partir de duas dimensões distintas: temporal e espacial (Recherche sur la Sécurité Juridique... p. 39-360). Não obstante essas classificações sejam mais completas e precisas do que a aqui adotada, exigiriam um desenvolvimento mais profundo do tema, fugindo aos propósitos deste trabalho.

141 NADEAU, Martin. Perspectives pour un príncipe de sécurité juridique en droit canadien: les pistes du droit européen. p. 516.

${ }^{142}$ Há farta doutrina no sentido de distinguir a confiança legítima da segurança jurídica. V. por todos, com ampla referência bibliográfica, CALMES, Sylvia. Du Principe de Protection de la Confiance Légitime... p. 164 e ss.
} 
os instrumentos e meios que o próprio Estado pode empregar para atingir os seus objetivos. $^{143}$

No entanto, Carré de Malberg não considerava o Estado francês um Estado de Direito. Enquanto o Estado de Direito, para ele, era concebido "no interesse dos cidadãos e com o objetivo de guardá-los e protegê-los da arbitrariedade das autoridades estatais", o Estado francês era simplesmente regido por leis; daí tê-lo chamado de 'Estado legal' (État légal). ${ }^{144}$

O ponto central da diferença entre os regimes, segundo o jurista de Estrasburgo, estava na obrigatoriedade, para a efetiva realização do Estado de Direito, de que os cidadãos estivessem "armados de uma ação judicial que lhes permita atacar os atos estatais que venham a lesar seus direitos individuais". ${ }^{145}$ Embora essa via judicial estivesse aberta aos franceses para ataque de atos jurisdicionais e administrativos, inexistia a possibilidade de ataque aos atos legislativos, descaracterizando o État de Droit. ${ }^{146}$

A preocupação de Carré de Malberg, direcionada essencialmente ao 'controle de constitucionalidade' dos atos normativos do Poder Legislativo, desencadeia lições emblemáticas a respeito da importância do processo para a proteção e realização do direito objetivo e, como consequência, do Estado de Direito. De nada adianta a previsão constitucional e legal de normas se não houver instrumentos hábeis a torná-las efetivas.

O tema também foi abordado, ainda que sob ótica um pouco diversa, pelo 'patrono' do Rule of Law na Inglaterra, Albert Venn Dicey, quando estudou o papel do Judiciário na realização do Estado de Direito. Para Dicey, "qualquer conhecimento da história basta para mostrar que constitucionalistas estrangeiros, embora ocupados com a

\footnotetext{
${ }^{143}$ CARRÉ DE MALBERG, Raymond. Contribution à la Théorie Générale de l'État. p. 489-490. No original: "Par État de droit il faut entendre un État qui, dans ses rapports avec ses sujets et pour la garantie de leur statut individuel, se soumet lui-même à un régime de droit, et cela en tant qu'il enchaîne son action sur eux par des règles, dont les unes déterminent les droits réservés aux citoyens, dont les autres fixent par avance les voies e moyens qui pourront être employés en vue de réaliser les buts étatiques (...)".

${ }^{144}$ Ibidem. p. 490.

${ }^{145}$ Ibidem. p. 491. No original : "Pour que l'État de droit se trouve réalisé, il est, en effet, indispensable que les citoyens soient armés d'une action en justice, qui leur permette d'attaquer les actes étatiques vicieux qui léseraient leur droit individuel".

${ }^{146}$ Ibidem. p. 492-493.
} 
definição dos direitos, deram insuficiente atenção à absoluta necessidade de previsão de remédios adequados para que esses direitos que eles proclamavam pudessem ser aplicados". ${ }^{147}$ Nesse ponto estaria a superioridade do sistema inglês do "judge-made-law" em relação às constituições escritas do civil law: o judge-made-law permitiria a efetivação dos direitos, enquanto as constituições escritas não passariam de documentos formais com pouca efetividade.

Atualmente, doutrina e jurisprudência, mesmo as do civil law, não titubeiam em exaltar o 'acesso à justiça' ${ }^{148}$ como garantia fundamental do indivíduo, consistindo em verdadeiro "princípio estruturante do Estado de direito". ${ }^{149}$ No Brasil, o art. 5 XXXV, da $\mathrm{CR}$, ao traduzir a regra da inafastabilidade do controle jurisdicional, é taxativo: "a lei não excluirá da apreciação do Poder Judiciário lesão ou ameaça a direito”. Além dele, o art. 5, XXXIV, $a$, atribui “direito de petição aos Poderes Públicos em defesa de direitos ou contra ilegalidade ou abuso de poder". ${ }^{150}$

Com efeito, é no plano processual que tanto o direito objetivo como os direitos subjetivos encontram alicerce seguro para sua proteção.

No que importa ao direito objetivo, há algum tempo a doutrina reconhece que "a verdadeira garantia das disposições constitucionais reside precisamente em sua proteção processual". ${ }^{151}$ Daí ser válido dizer que as ferramentas processuais à disposição

\footnotetext{
${ }^{147}$ DICEY, Albert Venn. An Introduction to the Study of the Law of the Constitution. p. 198. No original: "But any knowledge of history suffices to show that foreign constitutionalists have, while occupied in defining rights, given insufficient attention to the absolute necessity for the provision of adequate remedies by which the rights they proclaimed might be enforced"

148 Para Canotilho, “a garantia do acesso aos tribunais significa, fundamentalmente, direito à protecção jurídica através dos tribunais". CANOTILHO, José Joaquim Gomes. Direito Constitucional e Teoria da Constituição. p. 486.

${ }^{149}$ Ibidem. p. 485. V. também SUMMERS, Robert S. A formal theory of the Rule of Law. p. 130.

${ }^{150}$ V. DINAMARCO, Cândido Rangel. Instituições de Direito Processual Civil, v. I. p. 198-200.

${ }^{151}$ FIX-ZAMUDIO, Héctor. Les garanties constitutionnelles des parties dans le procès civil en Amérique Latine. p. 34. Pouco antes, escreveu o professor mexicano: "a doutrina moderna não tardou a perceber que a simples elevação de certos princípios ao nível de normas constitucionais não bastava a garantir a sua eficácia, como a história dolorosa e agitada dos povos latino-americanos há demonstrado várias vezes” (p. 34).
} 
de cada cidadão estão entre os mais poderosos mecanismos de proteção e realização do ordenamento jurídico existentes. $^{152}$

Em relação aos direitos subjetivos, é comum que o processo seja considerado a "garantia das garantias", pois apenas no plano processual é que "certas declarações de princípios ou reconhecimentos de direitos contidos nas constituições e nas leis tornam-se efetivos". ${ }^{153}$ Assim é porque os direitos subjetivos dependem, para sua realização, do pagamento das prestações a que terceiros estão obrigados. Diante da proibição da autotutela, somente o Estado pode compelir o inadimplente a realizar o direito violado ou adotar as medidas sub-rogatórias necessárias para restabelecimento do status quo. Essa situação faz com que o processo seja considerado "a primeira e mais fundamental garantia dos indivíduos naquilo que concerne à proteção de seus direitos"154 e a ação, seu pressuposto, "o mais fundamental de todos os direitos". 155

\subsection{O processo como instrumento de racionalização do poder}

Apesar da correção das ponderações exaradas no ponto anterior, é importante notar que, tecnicamente, não é ao processo em si, ao menos não em sentido estrito (procedimento em contraditório), que compete proteger e efetivar o ordenamento jurídico e os direitos subjetivos. Tais funções são, na realidade, inerentes à jurisdição enquanto poder, atividade e função do Estado; ou mesmo do processo, desde que entendido como "realidade fenomenológica'. Em sentido estrito, o processo é mero instrumento de atuação jurisdicional, um "método de trabalho". ${ }^{156}$ Quando se fala em processo como

\footnotetext{
${ }^{152}$ Tamanha é a importância do processo para a efetivação do direito objetivo que ninguém menos do que CHIOVENDA definiu processo como um complexo de atos jurídicos sucessivos coordenados com a finalidade de atuar a lei (Del sistema negli studi del processo civile. p. 230). No original: "Quando parliamo di processo giudiziario, intediamo un complesso d'atti giuridici successivi coordinati allo scopo dell'attuazione della legge". Para PONTES DE MIRANDA, "o fim precípuo do processo é a realização do direito objetivo" (Comentários ao Código de Processo Civil, t. I. p. 225).

153 VESCOVI, Enrique; FERREIRA, Eduardo Vaz. Les garanties constitutionnelles des parties dans le procès civil en Amérique Latine. p. 106-107.

${ }^{154}$ Ibidem. p. 106-107.

${ }^{155}$ MARINONI, Luiz Guilherme. Teoria Geral do Processo. p. 205.

${ }^{156}$ DINAMARCO, Cândido Rangel. Instituições de Direito Processual Civil, v. II. p. 23-25; BEDAQUE, José Roberto dos Santos. Efetividade do Processo e Técnica Processual. p. 36.
} 
"garantia das garantias" ou meio de realização do direito objetivo e dos direitos subjetivos, está-se referindo ao processo de forma ampla, no sentido de plano processual; contrapondo-se, então, ao plano material. ${ }^{157}$

Isso não significa que o processo, estritamente considerado, não exerça uma função primordial no Estado de Direito. Pelo contrário. A construção do ideal do Estado de Direito foi historicamente acompanhada da preocupação com que o patrimônio jurídico dos indivíduos não fosse lesado senão mediante uma decisão proferida ao final de um processo legalmente preestabelecido, como demonstra o já mencionado art. 39 da Carta Magna, seja em sua versão original, seja, principalmente, nas alterações que nele foram feitas no século XIV. ${ }^{158}$ Várias das Constituições dos Estados norte-americanos seguiram a mesma linha no século XVIII (p.ex., Maryland, Pensilvânia e Massachusetts) ${ }^{159}$, tendo a Constituição dos Estados Unidos previsto expressamente o due process of law nas Emendas Quinta $(1791)^{160}$ e Décima Quarta $(1868)^{161}$. Na Alemanha do pós-Segunda Grande Guerra, a inclusão de garantias fundamentais do processo na constituição de 1949 era tida como medida indispensável após o desrespeito de princípios constitucionais pelo

\footnotetext{
157 Cândido DINAMARCO aponta três acepções com que comumente é utilizado o termo 'processo': a) sistema de normas coordenadas por uma ciência específica; b) modelo ou método de trabalho imposto por tais normas; c) realidade fenomenológica. (Instituições de Direito Processual Civil, v. II. p. 23-25). O que aqui se chama de processo civil em sentido estrito é basicamente o mesmo que a segundo acepção, modelo imposto por normas positivas; e o que se chama de processo civil em sentindo amplo confunde-se com a terceira acepção do termo, "realidade fenomenológica".

${ }^{158}$ Essa é a redação que lhe foi dada em 1354: "No man of what state or condition he be, shall be put out of his lands or tenements nor taken, nor disinherited, nor put to death, without he be brought to answer by due process of law."

${ }^{159}$ Cf. COUTURE, Eduardo. Las garantias constitucionales del proceso civil. p. 38.

${ }^{160}$ Quinta emenda: "No person shall be held to answer for a capital, or otherwise infamous crime, unless on a presentment or indictment of a Grand Jury, except in cases arising in the land or naval forces, or in the Militia, when in actual service in time of War or public danger; nor shall any person be subject for the same offense to be twice put in jeopardy of life or limb; nor shall be compelled in any criminal case to be a witness against himself, nor be deprived of life, liberty, or property, without due process of law; nor shall private property be taken for public use, without just compensation".

161 Décima quarta emenda: "No State shall make or enforce any law which shall abridge the privileges or immunities of citizens of the United States; nor shall any State deprive any person of life, liberty, or property, without due process of law; nor deny to any person within its jurisdiction the equal protection of the laws".
} 
regime nazista. ${ }^{162}$ A Constituição brasileira de 1988 dispõe, prudentemente, que "ninguém será privado da liberdade ou de seus bens sem o devido processo legal” (art. $5^{\circ}$, LIV). Além disso, há vários outros dispositivos que garantem de forma explícita faculdades e garantias processuais, como o contraditório, a ampla defesa (art. $\left.5^{\circ}, \mathrm{LV}\right)$ e a motivação das decisões judiciais (art. 93, IX).

Essa ligação entre processo e Estado de Direito decorre do escopo do processo relativo à imposição de uma disciplina ao correto exercício do poder. ${ }^{163}$ Seguindo as lições de Cândido Dinamarco, o Estado não dispensa o poder para alcançar os seus fins; “e, precisando exercer o poder, precisa também o Estado-de-direito estabelecer as regras pertinentes, seja para endereçar com isso a conduta dos seus numerosos agentes (no caso, os juízes), seja para ditar condições limites e formas do exercício do poder". ${ }^{164}{ }^{165}$ No âmbito jurisdicional, é o processo que serve a disciplinar o poder estatal de decidir imperativamente e impor decisões ${ }^{166}$ de acordo com as normas legais e a participação dos

162 "Le non-respect et la destruction des principes et garanties constitutionnels par le régime nazi furent le motif principal d'inclure directement dans la loi fondamentale de la Républiche fédérale de l'Allemagne du 23 mai 1949 (la constitution - GG) non seulement les droits fondamentaux traditionnels (par exemple: la liberté de la personne, la liberté du culte), mais aussi quelques principes fondamentaux de la procédure (par exemple, le droit d'être entendu par un tribunal) et les principes concernant l'indépendance des tribunaux". BAUR, Fritz. Les garanties fondamentales des parties dans le procès civil en Repúblique Fédérale d'Allemagne. p. 3.

163 GOMES FILHO, Antonio Magalhães. A Motivação das Decisões Penais. p. 27: “A função básica do processo é impor uma disciplina que constitui a principal garantia para o correto exercício do poder". No mesmo sentido, ALVARO DE OLIVEIRA, Carlos Alberto. Do Formalismo no Processo Civil. p. 67.

164 DINAMARCO, Cândido Rangel. A Instrumentalidade do Processo. p. 93. Interessante notar as semelhanças entre o trecho transcrito e o conceito de Rule of Law de Robert SUMMERS: "The ideal of the rule of law consists of the authorized governance of at least basic social relations between citizens and between citizens and their government so far as feasible through published formal rules congruently interpreted and applied, with the officialdom itself subject to rules defining the manner and limits of their activity, and with sanctions or other redress against citizens and officials for departures from rules being imposed only by impartial and independent courts or by similar tribunals, after due notice and opportunity for hearing" (A formal theory of the Rule of Law. p. 129).

${ }^{165}$ Seria essa disciplina do poder o fator que, segundo o autor, tem o condão de reunir em uma mesma teoria geral todas as espécies de processo (civil, penal, administrativo etc.). DINAMARCO, Cândido Rangel. $A$ Instrumentalidade do Processo. p. 95.

${ }^{166} C f$. CINTRA, Antônio Carlos de Araújo; GRINOVER, Ada Pelllegrini; DINAMARCO, Cândido Rangel. Teoria Geral do Processo. p. 129. 
envolvidos em contraditório. ${ }^{167}$ No âmbito administrativo, também o processo tem a função de proteger os administrados contra a ingerência indevida do Estado em suas esferas jurídicas. ${ }^{168}$ Até mesmo no âmbito legislativo existem procedimentos que devem ser respeitados, "com a marca da legalidade e participação dos interessados, entendendo-se que ao legiferar a maioria exerce o poder estatal". ${ }^{169}$

De fato, a atuação do Estado por meio de um procedimento desenvolvido em contraditório ${ }^{170}$ impõe o respeito de certas garantias e faculdades atribuídas aos interessados, reduzindo o arbítrio e legitimando o resultado ao final obtido. ${ }^{171}$ Mais especificamente no que diz respeito à jurisdição, que é o que interessa a esse trabalho, quase todas as garantias processuais vinculam-se a essa relação processo/poder. Inércia da jurisdição, juiz natural, juiz independente e imparcial, publicidade dos atos processuais, contraditório e ampla defesa, motivação das decisões judiciais, são todas garantias voltadas à redução do arbítrio e promoção da racionalidade no exercício do poder jurisdicional.

\subsection{Processo justo e devido processo legal}

Partindo da premissa de que o processo é um instrumento de racionalização do poder e contenção do arbítrio, ele deve proporcionar aos participantes garantias e faculdades essenciais ao seu bom desenvolvimento, dentre as quais estão aquelas mencionadas no ponto anterior. A esse 'ideal' de processo convencionou-se chamar de

\footnotetext{
${ }^{167}$ DINAMARCO, Cândido Rangel. A Instrumentalidade do Processo. p. 82.

168 Art. $1^{\circ}$ da lei 9.784/99: "Esta Lei estabelece normas básicas sobre o processo administrativo no âmbito da Administração Federal direta e indireta, visando, em especial, à proteção dos direitos dos administrados e ao melhor cumprimento dos fins da Administração".

${ }^{169}$ DINAMARCO, Cândido Rangel. A Instrumentalidade do Processo. p. 85.

${ }^{170}$ FAZZALARI, Elio. Istituzioni di Diritto Processuale. p. 82 e ss.

${ }^{171}$ Ao tratar do formalismo processual e distinguir o formalismo-valorativo do formalismo excessivo, Carlos Alberto ALVARO DE OLIVEIRA foi enfático: “O formalismo processual contém, portanto, a própria idéia de processo como organização da desordem, emprestando previsibilidade a todo o procedimento. Se o processo não obedecesse a uma ordem determinada, cada ato devendo ser praticado a seu devido tempo e lugar, fácil entender que o litígio desembocaria numa disputa desordenada, sem limites ou garantias para as partes, prevalecendo ou podendo prevalecer a arbitrariedade e a parcialidade do órgão judicial ou a chicana do adversário". O formalismo-valorativo no confronto com o formalismo excessivo. p. 367-368.
} 
'processo justo' (giusto processo, para os italianos) ou 'devido processo legal' (due process of law), expressão recepcionada no direito brasileiro.

O devido processo legal, e o mesmo pode ser dito do 'processo justo', é um "postulado fundamental do processo", uma "norma-mãe"172 que impõe ao legislador a normatização e ao juiz a observância de garantias e faculdades aos interessados, de modo que possam participar adequadamente de um procedimento preestabelecido e, portanto, previsível, com o intuito de influir no convencimento de um julgador imparcial. ${ }^{173}$ Dito de outro modo, o devido processo legal, ou justo processo, é o regime processual ideal para a efetiva disciplina do poder do Estado e para a obtenção de uma sentença justa (juridicamente correta), racional e legítima. ${ }^{174}$ Daí ter escrito Eduardo Couture que a "la garantía del debido proceso es una garantía vinculada a la historia misma de la libertad civil". 175

A supramencionada divisão de funções entre legislador e julgador é fundamental para a efetiva realização do devido processo. O Direito Processual é um ramo do Direito Público e, como tal, deve ser regido pela regra da legalidade. Somente com uma 'reserva legal' para a normatização do processo é que se pode proporcionar previsibilidade

\footnotetext{
${ }^{172}$ DIDIER JR., Fredie. Curso de Direito Processual Civil, v. I. p. 27.

${ }^{173}$ Cf. DINAMARCO, Cândido Rangel. Instituições de Direito Processual Civil, v. II. p. 30.

${ }^{174}$ BOVE, Mauro. Art. 111 cost. e 'giusto processo civile'. p. 490-491: "Del resto è questo il senso primo della clausola del due process of law contenuta nel V Emendamento della Costituzione Nordamericana, nella quale si afferma che nessuno può essere privato della vita, della libertà e della proprietà senza un " dovuto " (giusto) processo. Considerando, fra l'altro, che tale clausola è ritenuta operante nell'ambito di ogni genere di procedimento, quindi non solo giurisdizionale, ma anche amministrativo, è evidente che con essa si è voluto innanzitutto affermare un principio di legalità in riferimento ad un'attività di potere che incide nei diritti fondamentali della persona, ossia si è voluto affermare per prima cosa che la garanzia in sè a fronte del potere è la disciplina del potere, ovvero la sua procedimentalizzazione, disciplina che, poi, inoltre deve necessariamente caratterizzarsi per il rispetto di alcuni valori imprescindibili"'.

${ }^{175}$ COUTURE. Eduardo, J. Inconstitucionalidad por privación de la garantía del debido proceso. p. 135. No mesmo sentido, TROCKER, Nicolò. Il nuovo articolo 111 della costituzione e il 'giusto processo' in materia civile: profili generali. p. 386: "Sarebbe riduttivo ed errato identificare nella realtà costituzionale nazionale gli indispensabili punti di riferimento e le ipotesi di lavoro per l'analisi della garanzia del giusto processo. La garanzia in parola affonda le sue radici in una realtà giuridico-politica che non è soltanto costituzionale e nazionale, ma è anche soprannazionale, ed internazionale, traendo origine - al pari di quanto è accaduto con le principali costituzioni democratiche promulgate dopo il secondo conflitto mondiale - dalla reazione istituzionale degli Stati nei confronti degli abusi e delle violazioni del periodo totalitario".
} 
à atividade desenvolvida pelo Estado. ${ }^{176}$ Nesse sentido, o art. 111 da Constituição italiana, ${ }^{177}$ ao atrelar o 'giusto processo' àquele 'regolato dalla legge', é exemplar. ${ }^{178}$

Por fim, é preciso distinguir mais uma vez o processo como instrumento de atuação jurisdicional e o processo como realidade fenomenológica. A máxima de Chiovenda de que o "processo deve dar a quem tem direito tudo aquilo a que tem direito" é válida desde que se considere o processo na segunda acepção. O processo justo e o devido processo legal, por outro lado, são postulados do processo enquanto procedimento em contraditório. Nenhuma das expressões traduz, nem deve traduzir, a necessária 'justiça' do resultado da atuação jurisdicional. ${ }^{179} \mathrm{O}$ papel de tais postulados não é 'fazer justiça', mas, pelo respeito de garantias e faculdades consideradas essenciais em dado momento histórico, ${ }^{180}$ permitir que seja feita justiça de maneira rápida, efetiva e legítima. ${ }^{181}$ Há casos em que a observância plena do devido processo legal pode não ser suficiente a proporcionar uma sentença justa; mas em todas as hipóteses que o princípio do devido processo legal for desrespeitado, a sentença ao final produzida será inevitavelmente ilegítima. $^{182}$

\footnotetext{
${ }^{176}$ Por óbvio, isso não implica aceitar o engessamento ou a absoluta rigidez do processo. Legalidade não se confunde com formalismo descabeçado. Do mesmo modo que a forma deve ser respeitada para que atinja sua finalidade, atribuindo previsibilidade e racionalidade ao processo, deve ser dispensada quando desnecessária ao atendimento da finalidade do ato (instrumentalidade das formas).

${ }^{177}$ Art. 111. La giurisdizione si attua mediante il giusto processo regolato dalla legge.

${ }^{178}$ V. CHIARLONI, Sergio. Il nuovo art. 111 cost. e il processo civile. p. 1.016; BOVE, Mauro. Art. 111 cost. e 'giusto processo civile'. p. 495-496. Sobre o art. 18 da Constituição do Uruguai, v. VESCOVI, Enrique; VAZ-FERREIRA, Eduardo. Les garanties fondamentales des parties dans la procédure civile en Amérique Latine. p. 116. Note-se que, no Brasil, o art. 1.109 do Código de Processo deixa claro, ainda que indiretamente, que o processo judicial deve ser regido pela regra da legalidade.

${ }^{179}$ Em sentido contrário, com ampla referência bibliográfica, v. POLI, Roberto. Giusto processo e oggetto del giudizio di appello. p. 51 e ss.

${ }^{180}$ Sobre o relativismo histórico do giusto processo, v. BOVE, Mauro. Art. 111 cost. e 'giusto processo civile'. p. 493.

${ }^{181}$ Sobre a relação entre efetividade do processo e devido processo legal, v. TROCKER, Nicolò. Il nuovo articolo 111 della costituzione e il 'giusto processo' in materia civile: profili generali. p. 406-409.

${ }^{182}$ Ao travar elegantíssima discussão com Taruffo sobre o papel da verdade no processo, escreveu Bruno Cavallone: 'La decisione distillata nella solitudine e nel segreto del suo 'laboratorio' da un giudice che ha disapplicato le forme del procedimento (rispettate invece scrupulosamente da Bridoye, convinto che forma
} 


\section{CAPÍTULO SEGUNDO - O DEVER DE MOTIVAR AS DECISÕES JUDICIAIS COMO GARANTIA INERENTE A UM ESTADO DE DIREITO}

O Capítulo anterior foi dedicado à fixação de premissas essenciais a este trabalho. Em síntese, defendeu-se uma concepção "limpa" do Estado de Direito, entendido como um ideal de Estado voltado ao controle do arbítrio do Poder Público e à racionalização dos atos estatais; demonstrou-se brevemente a relação de interdependência entre o Estado de Direito e a segurança jurídica; explicou-se que a mera positivação de direitos e garantias do indivíduo, seja em lei, seja em uma Constituição, é inútil se não estiver acompanhada de instrumentos processuais que efetivamente realizem e protejam esses direitos e garantias; e, por fim, afirmou-se que a legitimidade da atividade jurisdicional depende da observância de um "devido processo legal", o qual não só estabelece uma metodologia ao exercício do poder, dando ordem e previsibilidade à atividade do Estado, como protege garantias e faculdades reputadas essenciais aos sujeitos processuais.

Cumpre agora tratar do dever de motivar as decisões judiciais como uma regra constitucional (4), decorrente de um importante desenvolvimento histórico (5), que, ao controlar a atividade judicial, desponta como garantia inerente ao Estado de Direito e, talvez, como a mais importante das garantias inseridas no devido processo legal (6).

\section{O dever de motivar as decisões judiciais}

Dispõe o art. 93, IX, da Constituição da República: “todos os julgamentos dos órgãos do Poder Judiciário serão públicos, e fundamentadas todas as decisões, sob pena de nulidade (...)". No mesmo sentido dispõe o art. 458, II, do Código de Processo Civil: "São requisitos essenciais da sentença: (...) II - os fundamentos, em que o juiz analisará as questões de fato e de direito".

mutata mutatur substantia) potrà anche essere 'veritiera' secondo rigorosi parametri epistemologici, ma sarà inevitabilmente ingiusta” CAVALLONE, Bruno. In difesa della veriphobia... p. 12. 
A motivação (ou fundamentação) das decisões judiciais é, portanto, um dever constitucional e legal imposto a todos os magistrados, de modo que, ou o ato jurisdicional com conteúdo efetivamente decisório é motivado (excluindo-se, consequentemente, os despachos - art. 162, III, do Código de Processo Civil), ou é nulo.

Existem várias razões que justificam a natureza constitucional do dever de motivação. Dentre elas podem ser citadas: (a) racionalização da atividade jurisdicional; (b) controle da juridicidade da decisão; (c) legitimação do exercício do poder jurisdicional; (d) proteção do devido processo legal e promoção de várias de suas garantias; (e) melhora da qualidade das decisões ao forçar o efetivo exame da causa e aumentar o tempo de meditação sobre ela; (f) redução do número de recursos; e (g) promoção da segurança jurídica ao definir a interpretação dos dispositivos normativos e tornar possível a homogeneização jurisprudencial pelos Tribunais Superiores. ${ }^{183} \mathrm{Ou}$ seja, são muitos os benefícios decorrentes do dever de motivação às partes, ao sistema judiciário e à sociedade como um todo.

\subsection{Conceito}

Nem sempre a doutrina de Direito Processual preocupa-se em definir o significado de um dever de motivação, ou mesmo definir em que consiste motivar uma decisão judicial. Isso pode ser explicado, em boa parte, pelo fato de que a motivação das decisões judiciais é uma garantia que se liga "ao próprio desenvolvimento do Estado moderno e de seu aparelho judiciário, às relações entre o indivíduo e a autoridade, ao modo de estruturar-se o processo em determinado momento histórico e cultural e, inclusive, ao tipo de responsabilidade do juiz diante da sociedade". ${ }^{184}$ Além disso, o conceito da motivação das decisões judiciais está vinculado às interações entre direito e processo e à própria natureza da função jurisdicional. Logo, conceituar a motivação das decisões judiciais implica posicionar-se também sobre essas árduas questões.

Em 1987, José Rogério Cruz e Tucci classificou os conceitos doutrinários de motivação das decisões judiciais em quatro categorias: (a) motivação como exposição

\footnotetext{
${ }^{183}$ Algumas dessas razões foram apontados por LEGROS, Robert. Considerations sur les motifs. p. 7.

${ }^{184}$ GOMES FILHO, Antonio Magalhães. A Motivação das Decisões Penais. p. 51-52.
} 
histórica, (b) motivação como instrumento de comunicação e fonte de indícios, (c) motivação como discurso judicial e (d) motivação como atividade crítico-intelectual. ${ }^{185}$

Mais genericamente, essas quatro categorias revelam duas formas distintas de compreender a motivação das decisões judiciais. De um lado, a motivação pode ser concebida como uma reprodução fiel do raciocínio desenvolvido pelo magistrado para decidir: a exposição de seu iter lógico-jurídico (categorias 'a' e 'd'). De outro, a motivação seria a representação de um raciocínio "justificativo", o qual não se confundiria com o raciocínio "decisório" previamente desenvolvido pelo magistrado (categorias 'b' e 'c'). Para os adeptos dessa segunda concepção, seriam desenvolvidos, sempre, dois tipos de raciocínio judicial: o decisório e o justificativo. O primeiro seria formado pelos verdadeiros motivos pelos quais a decisão foi tomada; e o segundo, apresentado na motivação, traria uma argumentação justificativa da decisão previamente tomada. ${ }^{186}$

Ambas as concepções serão mais bem tratadas no Capítulo seguinte. Por ora, pode-se dizer que, sob um ponto de vista analítico, motivar uma decisão judicial significa expor de maneira ordenada, lógica, clara e coerente as razões pelas quais se decide de determinada maneira. Sob um ponto de vista teleológico, trata-se da necessária justificação formal do exercício do poder jurisdicional, explicitando-se racionalmente às partes, aos órgãos ad quem e a qualquer outra pessoa da sociedade que tenha interesse naquele julgamento por que a decisão tomada foi aquela, e não outra.

\subsection{A natureza normativa do dever de motivação}

O dever de motivação é, antes de tudo, uma garantia jurídica. Isso significa que, de um lado, trata-se de uma autolimitação imposta pelo Estado ao seu poder jurisdicional, obrigando-se a justificar formalmente a sua atuação e a eventual ingerência na esfera jurídico-patrimonial do indivíduo (dimensão subjetiva das garantias). De outro, é um instrumento técnico e institucional que protege os direitos e faculdades do indivíduo do

\footnotetext{
185 TUCCI, José Rogério Cruz e. A Motivação da Sentença no Processo Civil. p. 11-12.

${ }^{186}$ CHIASSONI, Pierluigi. La Giurisprudenza Civile. p. 56-57.
} 
arbítrio e da antijuridicidade (dimensão objetiva das garantias). ${ }^{187}$ Mais especificamente, realiza o direito de todo indivíduo de conhecer as razões pelas quais sua pretensão foi insatisfeita (autor) ou pelas quais a pretensão da outra parte foi satisfeita (réu).

Além de garantia, o dever de motivar as decisões judiciais é uma regra jurídica constitucional e processual, contida no devido processo legal e dele garantidora, que impõe a todo aquele que exerce o poder jurisdicional o dever de expor as razões de suas decisões, justificando-as formalmente. No entanto, diante da difundida concepção de que o dever de motivação é um princípio, ${ }^{188}$ dedicam-se os pontos seguintes para tratar do tema com mais acuidade.

\subsubsection{A obrigatória motivação das decisões judiciais é uma 'regra' jurídica}

Há décadas a doutrina do Direito Constitucional e da Filosofia do Direito discutem critérios para distinguir 'regras' de 'princípios'. Obviamente, não se pretende aqui aprofundar no tema, nem dar uma solução final à questão. É possível, porém, perceber que, independentemente do critério utilizado para distinguir as normas jurídicas, a obrigatória motivação das decisões judiciais é, sempre, uma regra jurídica.

Humberto Ávila agrupou os critérios para diferenciar regras e princípios em três grupos: ${ }^{189}$ (a) critério do "caráter hipotético-condicional", (b) critério do "modo final de aplicação" e (c) critério do "conflito normativo". ${ }^{190}$ A eles podem ser somados o (d)

\footnotetext{
${ }^{187}$ Cf. SANTOS, Tomás-Javier Aliste. La Motivación de las Resoluciones Judiciales. p. 138. Ver também GOMES FILHO, Antonio Magalhães. A Motivação das Decisões Penais. p. 82; TARUFFO, Michele. Il significato costituzionale dell'obbligo di motivazione. p. 47.

188 P.ex., NERY JR, Nelson. Princípios do Processo na Constituição Federal. p. 288 e ss: DIDIER JR., Fredie; BRAGA, Paula Sarno; OLIVEIRA, Rafael. Curso de Direito Processual Civil, v. 2. p. 227 e ss; SANTOS, Tomás-Javier Aliste. La Motivación de las Resoluciones Judiciales. passim; CARVALHO, Milton Paulo de. Os princípios e um novo código de processo civil. p. 205-206.

${ }^{189}$ Há outros de menor importância, como o critério da generalidade, que propõe a classificação de normas mais genéricas como princípios e normas mais específicas como regras. Para maiores detalhes, v. ALEXY, Robert. Teoria dos Direitos Fundamentais. p. 87-89.

${ }^{190}$ ÁVILA, Humberto B. Teoria dos Princípios. p. 35-64.
} 
critério da "fundamentalidade da norma"; ${ }^{191}$ e os (e) critérios decorrentes da "pluralidade normativa do dispositivo", propostos pelo autor.

(a) Segundo o critério do "caráter hipotético-condicional", os princípios são diretrizes para a solução de um caso concreto e as regras são normas que preveem uma hipótese e dela extraem a consequência, o que determinaria previamente a decisão judicial. ${ }^{192}$ Quando o art. 93, IX, determina que "todos os julgamentos dos órgãos do Poder Judiciário serão públicos e fundamentadas todas as decisões, sob pena de nulidade", é evidente que a motivação é uma consequência necessária da hipótese "julgamento". ${ }^{193}$ Isto é, "se houver julgamento pelo Judiciário, então ele deve ser motivado". Não se estabelece aqui nenhuma diretriz para que se descubra a solução do caso concreto. Pelo contrário, o dispositivo traz um comando perfeitamente acabado: ‘todo julgamento deve ser motivado'.

(b) e (c) O critério do "modo final de aplicação" considera que regras são pautadas unicamente pelo critério da validade. Ou elas são válidas e então aplicadas em sua integralidade ou não são válidas e então não são de modo algum aplicadas; daí falar Ronald Dworkin em aplicação "tudo ou nada". Já os princípios estariam sujeitos a ponderação com outros princípios segundo um critério de peso, podendo ceder em determinados casos à incidência de outros princípios naquele momento mais relevantes ou que tragam soluções mais adequadas. ${ }^{194}$ Robert Alexy avançou na concepção ao definir

\footnotetext{
${ }^{191}$ Expressão utilizada por HACHEM, Daniel Wunder. Princípio Constitucional da Supremacia do Interesse Público. p. 137 e ss.

${ }^{192}$ V. ÁVILA, Humberto B. Teoria dos Princípios. p. 40-43. O problema deste critério está na rejeição de que princípios também prevejam mandamentos a partir de situações hipotéticas. Tanto os princípios como as regras são normas jurídicas com "juízos concretos de dever-ser” (ALEXY, Robert. Teoria dos Direitos Fundamentais. p. 87). Utilizando o contraditório como exemplo, a hipótese "exercício da atividade jurisdicional" gera o mandamento "obrigatória participação das partes". Além disso, é possível que o mesmo dispositivo legal atue ora como princípio, ora como regra, o que ocorre com o próprio contraditório. $\mathrm{V}$., com exemplos, ÁVILA, Humberto B. Teoria dos Princípios. p. 41-42. O autor apresenta outras críticas ao critério, sempre fundadas na concepção de que as normas são produzidas apenas depois da interpretação dos dispositivos legais; ideia com a qual não se concorda.

${ }^{193}$ O mesmo vale para o art. 458, II, do CPC.

${ }^{194}$ V. DWORKIN, Ronald. Taking Rights Seriously. p. 22-28: "The difference between legal principles and legal rules is a logical distintion. Both sets of standards point to particular decisions about legal obligation in particular circumstances, but they differ in the character of the direction they give. Rules are applicable in an all-or-nothing fashion. If the facts a rule stipulates are given, then either the rule is valid, in which case
} 
princípios como "mandamentos de otimização" realizáveis de acordo com aquilo que é fática e juridicamente possível, mantendo o conceito de regras como "normas que são sempre ou satisfeitas ou não satisfeitas". ${ }^{195}$ Em síntese, os princípios "não contêm um mandamento definitivo, mas apenas prima facie", e as regras "exigem que seja feito exatamente aquilo que elas ordenam". ${ }^{196}$

O critério do "conflito normativo" é um mero desdobramento do "modo final de aplicação". Defende que o conflito entre regras é feito em um ambiente externo do ordenamento jurídico, pois uma das regras terá que ser sempre invalidada em benefício da outra. ${ }^{197}$ Já o conflito entre princípios ocorre no interior da ordem jurídica, aplicando-se o postulado da ponderação. O princípio não precisa ser invalidado e nem deve ser prevista para ele uma cláusula de exceção: os seus pesos simplesmente variam segundo o caso concreto. ${ }^{198}$

Analisada a motivação à luz de ambos os critérios, mais uma vez fica evidente que o art. 93, IX, da CR e o art. 458, II, do CPC trazem comandos acabados, definitivos: 'todo julgamento deve ser motivado'. A norma não contém nenhum mandamento de otimização, nem comporta análise sobre a possibilidade fática e jurídica de sua concretização. Qualquer conflito com a regra constitucional imporá a invalidade ou a não aplicação da norma conflitante.

(d) O critério da "fundamentalidade da norma", bastante difundido no Brasil, atribui a condição de princípio às normas consideradas fundamentais para o sistema, enquanto as regras são normas instrumentais à concretização destes princípios. ${ }^{199}$ Embora trate-se de uma classificação pouco técnica e relativamente arbitrária, já que pautada em grande parte pela opinião pessoal daquele que analisa a norma, ainda assim

the answer it supplies must be accepted, or it is not, in which case it contributes nothing to the decision" (p. 24).

195 ALEXY, Robert. Teoria dos Direitos Fundamentais. p. 90-91.

${ }^{196}$ ALEXY, Robert. Teoria dos Direitos Fundamentais. p. 104.

${ }^{197}$ Ibidem. p. 92-93.

${ }^{198}$ Ibidem. p. 93-94.

199 Para mais detalhes, com amplas referências bibliográficas, v. SILVA, Virgílio Afonso da. Princípios e regras - mitos e equívocos acerca de uma distinção. p. 612 e ss.; HACHEM, Daniel Wunder. Princípio Constitucional da Supremacia do Interesse Público. p. 136-140. 
seria imperioso classificar o dever de motivação como regra jurídica. ${ }^{200}$ Isso porque a obrigatória motivação não é um elemento nuclear do sistema jurídico, mas concretização de três desses elementos fundamentais, que são o Estado de Direito, a segurança jurídica e o devido processo legal. A motivação das decisões judiciais, por esse modo de compreender as coisas, seria uma típica norma instrumental para a realização do Estado de Direito, da segurança jurídica e do devido processo legal, garantindo a redução do arbítrio judicial, difundindo a maneira como o Direito deve ser interpretado e concretizando outros valores processuais fundamentais, como o do contraditório e da inércia da jurisdição.

(e) Por fim, cabe mencionar os critérios propostos por Humberto Ávila, que são: critério da "natureza do comportamento prescrito", critério da "natureza da justificação exigida" e critério da "medida de contribuição para a decisão". O pensamento do autor gravita, em boa medida, em torno da premissa de que as normas são construídas pelo intérprete a partir dos dispositivos legais. ${ }^{201}$ Com isso, conclui que um mesmo dispositivo pode originar ora princípios (dimensão finalística), ora regras (dimensão comportamental) e ora postulados (dimensão metódica). ${ }^{202}$

(e.1) Para o primeiro dos critérios (natureza do comportamento prescrito), as regras são normas imediatamente descritivas que fixam obrigações, faculdades e proibições pela descrição de determinada conduta. Os princípios são normas imediatamente finalísticas, pois definem estados de coisas que dependem da adoção de certos comportamentos. Dito de outro modo, os princípios determinam a realização de um fim juridicamente relevante e as regras preveem comportamentos. ${ }^{203}$

(e.2) $\mathrm{O}$ segundo dos critérios (natureza da justificação exigida) refuta a diferenciação entre as espécies normativas a partir do seu modo de aplicação, valendo-se do "modo de justificação necessário à sua aplicação". As regras permitem que o seu aplicador limite-se a demonstrar a "correspondência da construção factual à descrição normativa e à finalidade que lhe dá suporte", o que implica um reduzido ônus

\footnotetext{
${ }^{200} \mathrm{Em}$ sentido contrário, atribuindo condição de princípio à motivação das decisões judiciais por considerá-la direito fundamental a ser observado em qualquer processo, NERY JÚNIOR, Nelson. Princípios do Processo na Constituição Federal. p. 34-35 e 288 e ss.

${ }^{201}$ ÁVILA, Humberto B. Teoria dos Princípios. p. 68.

${ }^{202}$ Ibidem. p. 69.

${ }^{203}$ Ibidem. p. 71-72.
} 
argumentativo. Já para a aplicação dos princípios, deve-se "argumentar de modo a fundamentar uma avaliação de correlação entre os efeitos da conduta a ser adotada e a realização gradual do estado de coisas exigido". Seguindo o raciocínio, as regras possuem caráter primariamente retrospectivo, pois descrevem um contexto fático predeterminado, e os princípios possuem caráter primariamente prospectivo, uma vez que impõem a construção do estado de coisas previsto. ${ }^{204}$

(e.3) O terceiro dos critérios (medida de contribuição para a decisão) separa as normas "preliminarmente decisivas e abarcantes" (regras) das normas "preliminarmente complementares e parciais" (princípios). Isso significa que as regras visam a produzir uma solução específica para o caso concreto, enquanto os princípios somente "contribuem" para a tomada de decisão. ${ }^{205}$

Considerando todo o exposto, o autor define: "As regras são normas imediatamente descritivas, primariamente retrospectivas e com pretensão de decidibilidade e abrangência, para cuja aplicação se exige a avaliação da correspondência, sempre centrada na finalidade que lhes dá suporte ou nos princípios que lhes são axiologicamente sobrejacentes, entre a construção conceitual da descrição normativa e a construção conceitual dos fatos" e "Os princípios são normas imediatamente finalísticas, primariamente prospectivas e com pretensão de complementaridade e de parcialidade, para cuja aplicação se demanda uma avaliação da correlação entre o estado de coisas a ser promovido e os efeitos decorrentes da conduta havida como necessária à sua promoção". ${ }^{206}$ Adotando-se os critérios acima descritos, o dever de motivação é, indiscutivelmente, uma regra, pois: (e.1) é uma norma descritiva (descreve o comportamento a ser adotado pelo magistrado), (e.2) retrospectiva (prevê um dever específico a partir de certa conduta - "motivação em caso de julgamento"), (e.3) cuja aplicação depende unicamente da correspondência da conduta prevista (julgamento) à construção normativa (obrigatória motivação). Nada tem, portanto, da feição finalística e prospectiva dos princípios.

\footnotetext{
${ }^{204}$ Ibidem. p. 73-76.

${ }^{205}$ Ibidem. p. 76-78.

${ }^{206}$ Ibidem. p. 78-79.
} 
4.2.2. A importância de se conceber o dever de motivação como regra, e não como princípio

O dever imposto aos juízes de motivar suas decisões é uma regra jurídica, independentemente dos critérios utilizados para distinguir regras de princípios. Uma singela e breve análise lógico-conceitual, como a que foi feita acima, afasta quaisquer dúvidas a respeito dessa conclusão.

A discussão, porém, não tem feição meramente teórico-científica, o que já bastaria para legitimá-la e dar-lhe grande importância. A classificação do dever de motivação como regra ou princípio gera relevantes consequências práticas em relação a um eventual conflito entre normas jurídicas.

Afirmou-se anteriormente que tanto Dworkin como Alexy defendem que as regras não podem conviver com conflitos normativos, pois elas ou são válidas ou são inválidas; havendo conflito, uma das regras deve ser invalidada. No caso dos princípios, seus pesos variam segundo o caso concreto: essa é a concepção predominante no Brasil, inclusive por aqueles que adotam o critério da "fundamentalidade da norma"; 207 embora considerem muito mais grave a violação de um princípio do que a violação de uma regra. $^{208}$

Com efeito, a violação da obrigatória motivação das decisões judiciais não é apenas o desrespeito a uma regra constitucional. Mais do que isso, significa desrespeito ao ideal do Estado de Direito, conceito estrutural de toda a República Federativa do Brasil. No entanto, aceita a natureza principiológica do dever de motivação, sua aplicação passa a ser flutuante, variável segundo o caso concreto. Mesmo se entendido que a violação de um princípio é mais grave do que a violação de uma regra, a sua ponderação com outros princípios poderia levar alguém a crer que o caso concreto permitiria o seu afastamento. E considerando o frenesi que permeia a nossa sociedade atual em busca de um processo

\footnotetext{
${ }^{207}$ Sobre a impropriedade de se realizar este 'sincretismo teórico', v. NERY JÚNIOR, Nelson. Princípios do Processo na Constituição Federal. p. 34-35; SILVA, Virgílio Afonso da. Princípios e regras - mitos e equívocos acerca de uma distinção. p. 612 e ss.

${ }^{208}$ V., por todos, BANDEIRA DE MELLO, Celso Antônio. Curso de Direito Administrativo. p. 53: "violar um princípio é muito mais grave que transgredir uma norma. A desatenção ao princípio implica ofensa não apenas a um específico mandamento obrigatório, mas a todo o sistema de comandos".
} 
célere, ${ }^{209}$ o qual demanda dos juízes produção de decisões em massa, independentemente da qualidade de tais decisões, não espantaria se o "princípio" da motivação das decisões judiciais fosse ponderado com uma equivocada interpretação do princípio da efetividade processual. Aliás, não seria muito diferente do que os tribunais brasileiros vêm fazendo quando sustentam que o juiz não precisa se manifestar sobre todas as alegações das partes, aceitando a livre escolha (quando feita) dos argumentos que serão levados em consideração para o julgamento.

Como regra que é, o dever de motivar as decisões judiciais adquire feições de um comando constitucional pronto, perfeito, acabado; consequentemente, imponderável. Qualquer regra que venha a excepcioná-lo será inválida, pois inconstitucional. E nenhum caso concreto poderá afastar a sua incidência para dar prevalência a outros valores supostamente mais importantes. A classificação do dever de motivação segundo a sua real natureza acaba por dar-lhe mais força e maior proteção, exatamente o que pretendem aqueles que o têm como princípio.

Não custa lembrar que, a despeito do preconceito 'pós-positivista' largamente difundido, regras também possuem conteúdo axiológico, também protegem valores essenciais à sociedade e ao Direito e também contribuem para a realização da justiça. A regra da obrigatória motivação das decisões judiciais é exemplo cabal disso. ${ }^{210}$

\footnotetext{
${ }^{209}$ Não se discute, de forma alguma, a importância do tempo para a consecução de um processo efetivo. A demora na prestação jurisdicional é, em si mesma, fonte de injustiça. O que se critica, aqui, é a promoção de um processo rápido por si só. Como já afirmei em outra ocasião, "Antes de tudo, aquele que tem razão prefere receber uma sentença favorável atrasada a receber uma sentença rápida, mas desfavorável e, portanto, muito mais injusta" (RAMINA DE LUCCA, Rodrigo. Resolução liminar do mérito. p. 116). O escopo fundamental da jurisdição não é apenas pôr fim a conflitos. O escopo principal da jurisdição é pacificar a sociedade com justiça, realizando corretamente a ordem jurídica. A busca por um processo célere não pode significar abdicação da qualidade das decisões judiciais e do respeito irrestrito às garantias e faculdades processuais, desde que legitimamente exercidas.

${ }^{210}$ Nesse sentido, ÁVILA, Humberto B. Teoria dos Principios. p. 114: "as regras não devem ser obedecidas somente por serem regras e serem editadas por uma autoridade. Elas devem ser obedecidas, de um lado, porque sua obediência é moralmente boa e, de outro, porque produz efeitos relativos a valores prestigiados pelo próprio ordenamento jurídico, como segurança, paz e igualdade. Ao contrário do que a atual exaltação dos princípios poderia fazer pensar, as regras não são normas de segunda categoria. Bem ao contrário, elas desempenham uma função importantíssima de solução previsível, eficiente e geralmente equânime de solução de conflitos sociais"; v. também RAMOS, Elival da Silva. Ativismo Judicial. p. 91.
} 


\subsubsection{A imponderabilidade do dever de motivação}

Poder-se-ia objetar que as regras são igualmente passíveis de ponderação, tal qual defendido, acertadamente, por Humberto Ávila. ${ }^{211}$ Desse modo, as razões acima apresentadas em defesa da classificação correta do dever de motivação ficariam prejudicadas.

Acontece que as regras, embora não sejam absolutas, contêm comandos definitivos e devem, em qualquer situação normal, ser respeitadas. A sua superação pela ponderação com outras normas jurídicas é extraordinária e depende de condições muito bem estabelecidas, das quais destaca-se, em primeiro lugar, o incondicional respeito à segurança jurídica. ${ }^{212}$ Considerando que a motivação das decisões judiciais é uma garantia indissociável da segurança jurídica, sua superação fica vetada em qualquer hipótese. Além disso, toda e qualquer ponderação de norma jurídica, especialmente das regras, deve ser adequadamente motivada pelo magistrado. ${ }^{213}$ Ainda que o dever de motivação pudesse ser ponderado, o magistrado ficaria compelido a explicar em sua decisão por que não iria motivar a decisão - um paradoxo insuperável.

\section{A consolidação do dever de motivação como garantia fundamental após a Revolução Francesa e panorama contemporâneo}

O dever de motivação das decisões judiciais recebeu pouca atenção ao longo da História do Direito. Por séculos prevaleceu o entendimento de que as decisões judiciais eram manifestações puras de autoridade e de poder, sendo inconcebível exigir do

\footnotetext{
211 ÁVILA, Humberto B. Teoria dos Princípios. p. 44-51 e 114-120. Humberto Ávila aceita a ponderação de regras, desde que a sua inobservância não viole a segurança jurídica ou cause prejuízo à outra parte. Um exemplo de ponderação de regra processual é a que impõe a intervenção do Ministério Público em processos que envolvam interesses de incapazes, sob pena de nulidade (art. 82, I, e 84 do CPC). Caso a sentença seja favorável ao incapaz, não se decreta a nulidade do processo, tendo em vista a ausência de prejuízo a qualquer das partes ou violação da segurança jurídica.

${ }^{212}$ V. Ibidem. p. 115-119: "Sendo assim, a resistência à superação será muito pequena naqueles casos em que o alargamento ou a restrição da hipótese da regra em razão de sua finalidade forem indiferentes ao valor segurança jurídica. E será tanto maior quanto mais a superação comprometer a realização do valor segurança juíridica" (p. 118).

${ }^{213}$ V. Ibidem. p. 120: “a superação de uma regra deverá ter uma fundamentação condizente: é preciso exteriorizar, de modo racional e transparente, as razões que permitem a superação”.
} 
seu prolator algum tipo de justificação. Chega a ser compreensível, deste modo, que os glosadores medievais tenham recomendado aos juízes, como prudência, que proferissem sentenças imotivadas, pois assim ficariam resguardadas de eventuais defeitos. Nem mesmo os filósofos do iluminismo pré-revolucionário, salvo raras exceções, preocuparam-se com o tema; imaginavam que a solução para a contenção do arbítrio do Poder Judiciário estaria na sua sujeição a leis claras e completas.

A evolução histórica do dever de motivação foi completamente disforme; ele surgia e desaparecia dos ordenamentos jurídicos europeus de acordo com as vicissitudes e as necessidades de cada época. O exemplo do absolutismo é esclarecedor. Inicialmente causou a derrocada da motivação ao privilegiar o misticismo da atividade 'estatal' mediante o sigilo das razões das decisões. Posteriormente resgatou a sua obrigatoriedade para garantir a supremacia do poder do soberano pelo controle da efetiva aplicação do direito dele emanado.

Além de (a) permitir o controle da atividade judicial por um governo totalitário, a motivação das decisões judiciais sobreviveu, até a Revolução Francesa, em razão de outras duas funções básicas por ela desempenhadas: (b) formação de uma jurisprudência interna dos tribunais, de modo que pudessem lembrar como decidiram casos análogos; (c) racionalização da atividade judiciária, reduzindo-se o número de recursos e facilitando o trabalho do órgão ad quem.

Após a Revolução Francesa, a função de controle da atividade judicial foi potencializada à luz da concepção liberal que permeou aquele momento histórico. Os juízes, ao exercerem um poder decorrente do próprio povo e aplicar um direito produzido pelo povo e para o povo, deveriam dar satisfação de sua atividade pela exposição das razões que o levaram a decidir de determinada maneira.

A paulatina consolidação dos ideais inerentes ao Estado de Direito também proporcionou a consolidação da motivação das decisões judiciais como instrumento de controle da atividade judicial. Como será tratado adiante, a grande maioria das constituições que preveem expressamente o dever de motivação foram promulgadas logo após a queda de regimes totalitários. 
5.1. Controvérsia sobre a motivação das decisões judiciais no Direito Romano e seu suposto papel de controle da atividade judicial em relação à aplicação das leis imperiais

Não há consenso entre os historiadores a respeito da existência, ou não, de decisões judiciais motivadas no Direito Romano. ${ }^{214}$ No século XVII, ao comentar a prática então existente de proferir decisões que "contêm simplesmente aquilo que é ordenado, sem algum raciocínio, seja no [âmbito] civil ou criminal”, Roche Flavin afirmou, citando Ulpiano, que "antigamente os juízes faziam inferir em seus julgamentos, sentenças e decisões, a causa ou motivo da condenação ou absolvição". ${ }^{215}$

Para Tony Sauvel, que escreveu um dos mais importantes trabalhos sobre a história do julgamento motivado, ainda que inteiramente dedicado ao Direito francês, a motivação das decisões não era uma prática compatível com o Direito Romano. Depois de refutar as considerações de Roche Flavin, o qual teria "forçado o sentido das palavras", 216 Sauvel explica que a primeira fase do processo romano (ações de lei) consistia unicamente na afirmação solene de um direito por aquele que se pretendia o seu titular; desse modo, não haveria espaço para algum tipo de decisão motivada. ${ }^{217}$ Mais tarde, já no período formular, o pretor elaborava fórmulas às partes que continham a exposição dos fatos, as

\footnotetext{
${ }^{214}$ Controvérsia explicada em parte pela escassez de informações, o que acarreta uma abordagem do tema, muitas vezes, pautada mais em "digressões teóricas" do que nas fontes romanas. $C f$. VILLAR, Alfonso Murillo. La motivación de la sentencia en el proceso civil romano. p. 15.

${ }^{215}$ ROCHE FLAVIN, Bernard de la. Treize Liures des Parlements de Frances. p. 1.084. No original: "Anciennement les Iuges fouloyent inferer en leurs ingements, fentences, \& Arrefts, la caufe ou motif de la condamnation ou abfolution : ce qui fe collige, parce que dit Vlpian en la loy, quod ait Pretor. §.ignominia caufa, en ces mots, Semper enim debet addere cur miles emittatut. D. de his qui not infamia. Mais aujourd'hui cela n'eft en vfage: \& les Arrefts \& iugements ne contiennent que ce, qui eft ordonné fimplement, fans autre raifonnement, foi en civil ou en criminel; la caufe dependant du faict, dilcours, circonftances, \& inerite du procés \& des actes produits".

${ }^{216}$ Com o que concorda expressamente MANCUSO, Fulvio. Exprimere Causam in Sententia. p. 2-3: "La Roche Flavin ha da queste parole arguito la vigenza dell'obbligo di motivare la sentenza nel diritto romano. Egli ha evidentemente dovuto forzare di molto il testo". Segundo os autores, a hipótese tratada por Ulpiano referia-se a um procedimento de natureza administrativa, adotado pela autoridade militar romana, pelo qual era necessário esclarecer se o soldado era devolvido por ferimentos ou por indignidade (v. SAUVEL, Tony. Histoire du jugement motivé. p. 7).

${ }^{217}$ SAUVEL, Tony. Histoire du jugement motivé. p. 7. Para mais detalhes, v. TUCCI, José Rogério Cruz e. $A$ Motivação da Sentença no Processo Civil. p. 25-28; e VILLAR, Alfonso Murillo. La motivación de la sentencia en el proceso civil romano. p. 14 e ss.
} 
demandas de cada uma e, enfim, as soluções possíveis; ao juiz (iudex) simplesmente competia escolher uma dessas soluções a partir da regra si paret condemna, si non paret absolve e, então, proferir sua sententia oralmente. ${ }^{218}$ Também aqui inexistiria algum tipo de raciocínio que permitisse compreender as razões da decisão. ${ }^{219}$

Mas a questão não é tão simples quando analisada a terceira fase do Direito Processual Romano, a do período extraordinário.

Sabe-se que o Imperador Otaviano Augusto, a partir de 27 a.C., deu início a uma significativa reforma na Administração de Roma. ${ }^{220}$ Os magistrados republicanos, outrora compostos por uma classe de cidadãos do povo soberano, foram substituídos por funcionários imperiais, hierarquicamente organizados. A função judicial, antes um privilégio, tornou-se um ofício. ${ }^{221}$

Em 17 a.C., a Lex Julia privatorum promoveu substanciais alterações no sistema processual do ordo iudiciorum privatorum, cujo escopo era, "além de racionalizar o ordenamento processual vigente, tolher do arbítrio do pretor o maior número de causas". 222 O pretor, que antes tinha grande discricionariedade na regulamentação do processo, passou a simplesmente dare iudicium de acordo com a lei. ${ }^{223}$ Essa nova realidade provocou o surgimento de uma série de institutos antes desconhecidos do processo

218 TUCCI, José Rogério Cruz e. A Motivação da Sentença no Processo Civil. p. 30; v. DAWSON, John P. The Oracles of Law. p. 100-107; VILLAR, Alfonso Murillo. La motivación de la sentencia en el proceso civil romano. p. 14 e ss.

${ }^{219}$ Cf. SAUVEL, Tony. Histoire du jugement motivé. p. 7 ; TUCCI, José Rogério Cruz e. A Motivação da Sentença no Processo Civil. p. 28-31. Aceitando a possibilidade de que as sentenças do período formular tenham sido motivadas, com citação de ampla bibliografia, v. SANTOS, Tomás-Javier Aliste. La Motivación de las Resoluciones Judiciales. p. 40-47.

${ }^{220}$ Cf. TUCCI, José Rogério Cruz e; AZEVEDO, Luiz Carlos de. Lições de História do Processo Civil Romano. p. 47-48.

${ }^{221}$ Cf. CALAMANDREI, Piero. La Cassazione Civile, v. I. p. 67; RAGGI, Luigi. Studi sulle Impugnazione Civile nel Processo Romano. p. 21. Inicialmente, a apelação era um recurso dirigido ao próprio Imperador. Em um segundo momento, também a apreciação dos recursos foi delegada a certos funcionários. Daí vem a noção de efeito devolutivo da apelação: devolvia-se ao Imperador a função, previamente delegada a outra pessoa, de julgar a causa. (v. CALAMANDREI, Piero. La Cassazione Civile, v. I. p. 67).

222 TUCCI, José Rogério Cruz. A Motivação da Sentença no Processo Civil. p. 31.

${ }^{223}$ Cf. Ibidem. p. 31, citando Nicola Palazzolo. 
romano, cujo exemplo mais frequente é a appelatio, ${ }^{224}$ ancestral mais remoto da nossa atual apelação, porém cabível apenas contra as sentenças injustas. ${ }^{225}$ Algum tempo depois, sob o Império de Constantino, determinou-se que as sentenças deveriam ser proferidas publicamente e na presença das partes; e em 374 os julgamentos passaram a ser obrigatoriamente escritos. ${ }^{226}$

Considerando esse contexto histórico, não obstante reconheça a lacunosidade das fontes, José Rogério Cruz e Tucci defende que "as sentenças prolatadas na órbita da cognitio extra ordinem eram motivadas". ${ }^{227}$ A conclusão é corroborada por Piero Calamandrei, para quem, embora fossem válidas as sentenças romanas imotivadas, "toda vez que as Fontes justinianas falam de sentença viciada por error in iudicando, trazem exemplos de sentenças motivadas, pois, se uma sentença não fosse motivada, teria sido impossível estudar a natureza e os efeitos do erro". 228

Em sentido oposto, também reconhecendo a falta de registros históricos sobre o assunto, Philippe Godding defende que o juiz romano, mesmo no processo da extra-ordinem do Baixo Império, não era obrigado a motivar suas decisões, seja em relação às questões de direito, seja em relação às questões de fato. Na medida em que o processo era escrito, uma eventual apelação provocaria a provável remessa dos 'autos' para o juiz superior, que poderia conhecer os argumentos de cada uma das partes e deduzir as razões da decisão recorrida. ${ }^{229}$ Muito embora houvesse hipóteses específicas, previstas na

${ }^{224}$ Cf. ORESTANO, Riccardo. L'Appello Civile in Diritto Romano. p. 166 e ss; CALAMANDREI, Piero. La Cassazione Civile, v. I. p. 67; RAGGI, Luigi. Studi sulle Impugnazione Civile nel Processo Romano. p. 21. Orestano chega a dizer que a appellatio não poderia ter surgido senão no novo 'clima' da idade Imperial (p. 167). V., também, as ponderações de LOBO DA COSTA quanto à não correspondência entre appellatio e processo da cognitio extra-ordinem (A Revogação da Sentença. p. 12).

${ }^{225}$ V. CALAMANDREI, Piero. La Cassazione Civile, v. I. p. 74-75; LIEBMAN, Enrico Tullio. Istituti del diritto comune nel processo civile brasiliano. p. 509-510.

${ }^{226}$ TUCCI, José Rogério Cruz. A Motivação da Sentença no Processo Civil. p. 33.

${ }^{227}$ Ibidem. p. 33.

${ }^{228}$ CALAMANDREI, Piero. La teoria dell'error in iudicando nel Diritto italiano intermedio. p. 206.

${ }^{229}$ GODDING,Philippe. Jurisprudence et motivation des sentences, du moyen âge à la fin du $18^{e}$ siècle. $\mathrm{p}$. $46-47$. 
compilação de Justiniano, em que a motivação da decisão era obrigatória, ${ }^{230}$ inexistiria, como também aponta Fulvio Mancuso, um dever geral de motivação das decisões judiciais nas fontes romanas. ${ }^{231}$

A discussão é aprofundada por Alfonso Murillo Villar, que reconhece que “os Imperadores não emitiram um lacônico 'as sentenças serão sempre motivadas", mas entende que, na verdade, teriam ido "mais longe", desenvolvendo "o que se deve entender por motivar as sentenças". ${ }^{232}$ A conclusão decorre do Código do Imperador Valenciano, de 371 - C. 7, 44, 2 -, que ordenou aos juízes, os quais devem "conhecer e falar" (quos cognoscendi et pronuntiandi necessitas teneret), que não redijam subitamente suas sentenças, sem reflexão ou ponderação, na medida em que, depois de lidas às partes, não poderiam mais ser corrigidas ou alteradas. ${ }^{233}$ Segundo Villar, o dispositivo trata do "iter construtivo da sentença", exigindo-se do juiz que "busque a justiça mediante uma resolução deliberada, com o fim de encontrar para cada caso a razão jurídica que faça estável a paz social". ${ }^{234}$ Eventuais dúvidas remanescentes, ainda na linha do raciocínio de Villar, seriam dirimidas pelo Código do Imperador Teodósio, de 382 - C.Th. 4,17,2. Como o juiz deveria examinar tudo o que dizia respeito aos negócios celebrados pelas partes, o prefeito do pretório teria que revisar as sentenças para que algum erro do juiz não acarretasse o reinício do processo. Essa disposição não faria sentido se o juiz simplesmente 'absolvesse' ou 'condenasse' o réu. ${ }^{235}$

\footnotetext{
${ }^{230}$ Ibidem. p. 48-49. Dentre elas estão: a) dever do magistrado de expor as causas pela qual removia um tutor de seu múnus (Dig. 26,10,4 - Decreto igitur debebit causa removendi significari, ut appareat de existimatione); b) para que o réu não pudesse objetar existência de coisa julgada em outro processo, deveria o juiz, diante da necessidade de extinguir um processo que durasse mais de três anos, expor a razão do julgamento de improcedência quando a demora pudesse ser imputada à negligência do advogado (Cod. 3,1,13[11],9); e c) imposição ao juiz da indicação do motivo pelo qual negava seguimento a um recurso de apelação (Dig. 49,5,6). V. MANCUSO, Fulvio. Exprimere Causam in Sententia. p. 4-8.

${ }^{231}$ MANCUSO, Fulvio. Exprimere Causam in Sententia. p. 3: "dalle fonti romanistiche, in verità, non emerge un generale obbligo di motivare".

${ }^{232}$ VILLAR, Alfonso Murillo. La motivación de la sentencia en el proceso civil romano. p. 21.

${ }^{233}$ Ibidem. p. 20.

${ }^{234}$ Ibidem. p. 20-21.

${ }^{235}$ Ibidem. p. 22.
} 
De qualquer forma, caso realmente as sentenças tenham sido motivadas no Direito Romano pós-clássico, o fundamento básico dessa exigência seria verificar se o raciocínio desenvolvido pelo juiz, submetido ao Imperador, estava correto e se a solução adotada aplicava efetivamente as leis imperiais. Isto é, a motivação das decisões judiciais atuaria como instrumento de controle da atividade judicial.

\subsection{A inexistência de motivação das decisões germânicas}

Com a queda do Império Romano, o costume passou a ser a principal fonte do Direito europeu medieval, especialmente nas regiões germânicas, ${ }^{236}$ que na quase totalidade contrapuseram o órgão que definia o conteúdo da sentença mediante um trabalho lógico-mental (Urteilsfinder) e o órgão que, investido de soberania, teria a prerrogativa de proclamar tal conteúdo como sentença (Richter). ${ }^{237}$

No processo franco, talvez o mais representativo dentre todos eles, os julgamentos eram proferidos por uma assembleia judiciária denominada de Mallus. Essa assembleia era presidida por um representante do poder soberano e era composta por um colégio de juízes formado por cidadãos comuns extraídos do povo e de uma assembleia popular. ${ }^{238} \mathrm{O}$ autor não apresentava uma demanda para julgamento, mas formulava uma proposta de sentença que seria apreciada pelo colégio de juízes. A resposta à demanda também se apresentava sob a forma de uma proposta de sentença, contra a qual qualquer membro da assembleia judiciária, incluindo o autor, poderia opor-se. ${ }^{239} \mathrm{O}$ julgamento final era proferido pela assembleia popular de acordo com a "consciência jurídica geral" 240 e, então, declarado solenemente pelo presidente.

\footnotetext{
${ }^{236}$ GODDING,Philippe. Jurisprudence et motivation des sentences, du moyen âge à la fin du $18^{e}$ siècle. $\mathrm{p}$. 38.

${ }^{237}$ Cf. CALAMANDREI, Piero. La Cassazione Civile, v.I. p. 91 e ss, com enfoque no direito franco; e PUGLIESE, Giovanni. Giudicato Civile (storia), 1969. p. 757 e ss, com enfoque no direito longobardo. Para uma análise resumida do processo germânico antigo, v. BESSO, Chiara. La Sentenza Civile Inesistente. p. 36-37.

${ }^{238}$ Cf. CALAMANDREI, Piero. La Cassazione Civile, v. I. p. 91-92.

${ }^{239}$ Cf. Ibidem. p. 93; V. também PUGLIESE, Giovanni. Giudicato Civile (storia). p. 758;

${ }^{240}$ CALAMANDREI, Piero. La Cassazione Civile, v. I. p. 92.
} 
Todo o processo era oral. ${ }^{241}$ Além disso, a assembleia judiciária concentrava em si os poderes legislativo e jurisdicional; a sentença não só julgava a demanda apresentada como elaborava uma norma jurídica para o caso concreto. ${ }^{242}$

No entanto, explica Godding, o papel criativo dos juízes germânicos era inicialmente nulo. De um lado, a prevalência de um sistema de provas irracionais e tarifadas não contribuía para o desenvolvimento do raciocínio jurídico do órgão julgador; de outro, a estabilidade das estruturas sociais e uma economia eminentemente rural faziam com que os problemas apresentados à assembleia judiciária para julgamento fossem sempre os mesmos. ${ }^{243}$

Já no período feudal, ao mesmo tempo em que a perda de uma autoridade central implicou o enfraquecimento da autoridade judiciária e as provas eram, como regra, irracionais, a diversidade de feudos e de senhores feudais difundiu a pluralidade de costumes. $^{244}$ Com o desenvolvimento das cidades e das relações comerciais, novos problemas surgiram para serem resolvidos judicialmente. A partir desse momento, fica muito difícil distinguir a função judicial da função legislativa desenvolvida pelos juízes, que também eram representantes oficiais da comunidade urbana. ${ }^{245}$

De todo modo, muito embora haja registros de sentenças proferidas por juízes longobardos exemplarmente motivadas ainda no século VII, ${ }^{246}$ o conteúdo da sentença era, como regra, "reduzido ao essencial": ${ }^{247}$ quer dizer, ao dispositivo.

\footnotetext{
${ }^{241}$ SAUVEL, Tony. Histoire du jugement motivé. p. 9.

${ }^{242}$ CALAMANDREI, Piero. La Cassazione Civile, v. I. p. 97. Explica o Mestre: "Si consideri anzitutto che, mentre il giudice romano aveva dinanzi a sè, come inderogabile guida, la norma posta da un potere legislativo superiore a lui, l'assemblea giudiziaria germanica riuniva in sè anche il potere legislativo, in quanto non esisteva al disopra di essa una legge scritta posta in precedenza per tutti i possibili casi, ma solo esisteva un diritto consuetudinario vivente nella coscienza giuridica dei singoli membri della consociazione, i quali dovevano, di volta in volta, trovare la norma specifica che faceva al caso concreto".

${ }^{243}$ GODDING, Philippe. Jurisprudence et motivation des sentences, du moyen âge à la fin du $18^{8}$ siècle. p. 39.

${ }^{244}$ Ibidem. p. 39-40.

${ }^{245}$ Ibidem. p. 40.

${ }^{246}$ Cf. TARUFFO, Michele. La Motivazione della Sentenza Civile. p. 320-321.

${ }^{247}$ GODDING, Philippe. Jurisprudence et motivation des sentences, du moyen âge à la fin du $18^{e}$ siècle. p. 41.
} 
5.3. A formação de uma jurisprudência dos tribunais europeus medievais

Entre os séculos VIII e XI há uma generalizada carência de produção jurídico-literária em grande parte da Europa ocidental; fato que levou a doutrina a denominar o período de "séculos mudos" da história do direito". ${ }^{248}$ Como consequência, os juízes viraram guardiões "do costume em uma época em que o escrito, nas jurisdições locais, desapareceu". 249

A importância da atividade judicial para a manutenção do costume, somada à necessidade de atribuir maior sistematicidade ao Direito, disperso em várias fontes normativas, ${ }^{250}$ fez com que algumas regiões da Europa adotassem sistemas de conservação e divulgação da jurisprudência; o que foi facilitado, certamente, pela retomada da utilização do processo escrito a partir do século XII. ${ }^{251}$ Ademais, a abolição dos juízos de Deus pelo IV Concílio de Latrão, em 1215, contribuiu substancialmente para que os juízes começassem a desenvolver um incipiente raciocínio jurídico para tomar decisões. ${ }^{252}$ Logicamente, também se desenvolveu uma rudimentar motivação destas decisões, consistente na indicação de algum elemento que a justificasse. ${ }^{253}$ Falava-se então em exprimere causam.

Ao final do século XII, surgem na França os rotuli, rolos de pergaminho (rôles) que continham a indicação dos julgamentos proferidos por um tribunal. Além deles,

\footnotetext{
${ }^{248}$ TUCCI, José Rogério Cruz e; AZEVEDO, Luiz Carlos de. Lições de História do Processo Civil Lusitano. p. 159, fazendo referência a Gacto Fernández.

${ }^{249}$ GODDING, Philippe. Jurisprudence et motivation des sentences, du moyen âge à la fin du $18^{e}$ siècle. $\mathrm{p}$. 40 .

${ }^{250}$ V. SAUVEL, Tony. Histoire du jugement motivé. p. 15-16; GOMES FILHO, Antonio Magalhães. $A$ Motivação das Decisões Penais. p. 54.

${ }^{251}$ GODDING, Philippe. Jurisprudence et motivation des sentences, du moyen âge à la fin du $18^{e}$ siècle. p. 50 .

${ }^{252}$ GOMES FILHO, Antonio Magalhães. A Motivação das Decisões Penais. p. 53

${ }^{253}$ SAUVEL, Tony. Histoire du jugement motivé. p. 14: "Cependant les motifs du XIII ${ }^{e}$ siècle sont très loin des nôtres. Voir en eux un tout parfait, leur demander un raisonnement qui se suffise à lui-même comme nous les aimons aujourd'hui sont des idées à écarter. Le motif, si fréquent qu'il soit, n'est pas une règle, une exigence de droit. La cour y a recours si elle veut et comme elle veut"; GOMES FILHO, Antonio Magalhães. A Motivação das Decisões Penais. p. 53.
} 
também surgem cadernos em que oficiais públicos (greffiers) faziam anotações referentes às informações contidas nos rôles. Ao final do século XIII, tais cadernos já continham todo o texto das decisões. ${ }^{254}$

Em Echiquier da Normandia, os primeiros rotuli (1207 e 1208) indicavam não só a decisão proferida pelo Tribunal, mas também os seus motivos. A fórmula empregada era "o julgamento é que... porque..." (Judicatum est quod... quia...). ${ }^{255}$ Nos registros do Parlamento de Paris (Corte do Rei) da metade do século XIII era bastante comum que a decisão tomada fosse seguida de suas razões. Como explica Sauvel, "os julgamentos proferidos pela Corte do Rei, desde o momento em que foram redigidos por escrito e segundo aquilo que os registros nos permitem conhecer, foram julgamentos motivados, certamente não em todos os aspectos, mas sempre que a Corte considerava oportuno". 256

Também ao final do século XIII são publicados na Inglaterra os Year Books, cadernos que continham relatórios das decisões proferidas pela Corte dos Common Pleas. ${ }^{257}$ Neles eram com frequência inscritos os fatos alegados e os pedidos formulados pelas partes, a decisão proferida e, principalmente, as razões da decisão, ainda que usualmente curtas e lacônicas. Tais razões serviam basicamente ao próprio tribunal como "anotação oficial da ação tomada". 258

No Direito Ibérico foram utilizadas as famosas fazañas, verdadeiros precedentes judiciais consistentes em "sentenças, casos julgados notáveis e duvidosos, cuja força vinculante decorria da autoridade reconhecida a quem as proferia e aprovava, bem como da exemplaridade do caso". ${ }^{259}$ Tais precedentes eram transmitidos oralmente ou por anotações dos julgamentos feitas pelos próprios juízes. ${ }^{260} \mathrm{Em} \mathrm{1254}$, de modo a unificar as

\footnotetext{
${ }^{254}$ Cf. SAUVEL, Tony. Histoire du jugement motivé. p. 10-11. V. também DAWSON, John P. The Oracles of the Law. p. 290 e ss.

${ }^{255}$ SAUVEL, Tony. Histoire du jugement motivé. p. 11-12.

${ }^{256}$ Ibidem. p. 12-13.

${ }^{257}$ DAWSON, John P. The Oracles of the Law. p. 9-10.

${ }^{258}$ Ibidem. p. 50-51.

${ }^{259}$ TUCCI, José Rogério Cruz e; AZEVEDO, Luiz Carlos de. Lições de História do Processo Civil Lusitano. p. 160 .

${ }^{260}$ Ibidem. p. 160.
} 
fontes normativas, D. Afonso X promulgou o Fuero del Libro, também conhecido como Fuero Real, no qual se impôs expressamente o dever de fundamentar as decisões judiciais. ${ }^{261}$ Alguns anos mais tarde, a regra também foi incluída na lei 5, título 22, das famosas Siete Partidas. ${ }^{262}$

Dentre os glosadores, merecem destaque as considerações impressionantemente atuais de Simone Vicentino, para quem a "credibilidade" e a "confiança" das partes na Justiça seria reforçada pelo juiz que presta contas de sua própria decisão. ${ }^{263}$

5.4. A recomendação de que o juiz, por prudência, não deveria motivar suas decisões

Se os Year Books continuaram a ser publicados na Inglaterra durante os 250 anos seguintes, ${ }^{264} \mathrm{o}$ mesmo não aconteceu nos países continentais.

Como se sabe, a partir do século XI os glosadores de Bolonha fizeram renascer o Direito Romano pelo estudo de um manuscrito do Corpus Juris Civilis que estava localizado em Pisa. Em cerca de cem anos, a doutrina extraída da análise daquele diploma já era difusamente aceita como lei na Itália. ${ }^{265}$

A utilização de leis escritas, mais uma vez, impunha ao juiz que tomasse suas decisões a partir de regras preestabelecidas. Não lhe era facultado criar normas jurídicas ou fundar sua decisão unicamente em precedentes judiciais. A interpretação da lei deveria sempre ser pautada pela intenção do legislador ao redigi-la. Apenas em caso de lacunas é que o Digesto permitia a utilização de costumes, bem como a "solução

\footnotetext{
${ }^{261}$ TUCCI, José Rogério Cruz e. A Motivação da Sentença no Processo Civil. p. 46-47.

${ }^{262}$ Ibidem. p. 47-48.

${ }^{263}$ Cf. MANCUSO, Fulvio. Exprimere Causam in Sententia. p. 220-221.

${ }^{264}$ Cf. DAWSON, John P. The Oracles of the Law. p. 50-51; DAVID, René; JAUFFRET-SPINOSI, Camille. Les Grand Systèmes de Droit Contemporains. p. 240.

${ }^{265}$ Cf. DAWSON, John P. The Oracles of the Law. p. 124-126.
} 
consagrada no tempo por uma jurisprudência constante (rerum perpetue similiter iudicatarum auctoritatem)". ${ }^{266}$

Além disso, a notória omissão das fontes de Justiniano em relação à motivação das decisões judiciais refletiu no pouco interesse dos glosadores em relação ao tema. Segundo Godding, "nenhum título das Institutas, do Código ou do Digesto incita-os a tratar o problema de maneira geral". ${ }^{267}$ Em famosa glosa, Acúrsio explicou que a decisão deveria ser motivada apenas quando o autor se equivocasse na escolha da ação proposta, de modo que o réu não pudesse objetar em novo processo a existência de coisa julgada. ${ }^{268}$

No Direito canônico, a discussão em torno da motivação das decisões judiciais ganhou força a partir da decretal Sicut nobis, do Papa Inocêncio III, de 1199, que dispôs que a validade da sentença não poderia ser questionada por falta de motivação. Atribuiu-se presunção de validade à sentença (e ao procedimento que a originou) proferida pelo juiz competente, pois decorrente da autoridade judiciária. ${ }^{269}$

Justamente porque a sentença não deveria ser obrigatoriamente motivada, prevaleceu o entendimento, tanto entre civilistas como entre canonistas, de que o juiz não só não estava obrigado a motivar suas decisões (salvo nas hipóteses legais), como era prudente que não o fizesse (melius faciet si non exprimat). A exposição dos motivos de uma decisão poderia deixar transparecer alguma nulidade ou alguma desconformidade com o direito material, enquanto decisões imotivadas estariam protegidas de impugnação ou invalidação. ${ }^{270}$ De acordo com o célebre decretalista Hortense, o juiz prudente não motivava suas decisões, pois, se as razões expostas fossem ruins, a decisão seria reformada

\footnotetext{
${ }^{266}$ GODDING, Philippe. Jurisprudence et motivation des sentences, du moyen âge à la fin du $18^{e}$ siècle. p. 43-45.

${ }^{267}$ Ibidem. p. 43.

${ }^{268}$ Cf. GODDING, Philippe. Jurisprudence et motivation des sentences, du moyen âge à la fin du $18^{e}$ siècle. p. 43-45. Igualmente, TUCCI, José Rogério Cruz e. A Motivação da Sentença no Processo Civil. p. 40.

${ }^{269}$ V. TUCCI, José Rogério Cruz e. A Motivação da Sentença no Processo Civil. p. 41; MANCUSO, Fulvio. Exprimere Causam in Sententia. p. 221-222. GODDING, Philippe. Jurisprudence et motivation des sentences, du moyen âge à la fin du $18^{e}$ siècle. p. 47.

${ }^{270}$ MANCUSO, Fulvio. Exprimere Causam in Sententia. p. 221-222.
} 
ou invalidada ainda que pudesse ter sido motivada corretamente (si cautus sit iudex, nullam causam exprimet). ${ }^{271}$

5.5. O declínio da motivação das decisões judiciais no início do absolutismo e seu renascimento no século XVI

Não foi apenas a constatação dos glosadores de que o juiz prudente não deveria motivar suas decisões que provocou o declínio da motivação das decisões judiciais no século XIV. Ainda no século XIII o feudalismo entra em crise e a Coroa paulatinamente recupera o poder central em várias regiões da Europa Ocidental. Na medida em que o rei era fonte de justiça e exercia seus poderes a partir de uma 'legitimação divina', era inconcebível que se lhe exigisse - ou mesmo de seus agentes - algum tipo de justificação dos atos praticados. ${ }^{272}$ Ao final do século XIII, o importante jurisconsulto francês Jacques d'Ableiges defendeu que a Corte do Rei não estava presa a nenhuma lei, sendo-lhe facultado "fazer o contrário quando o quiser, pois é a corte capital do reino e o rei é o imperador de seu reino". ${ }^{273}$ Houve, portanto, como bem salienta Antônio Magalhães Gomes Filho, um retorno à "lógica inerente aos juízos de Deus", ${ }^{274}$ o que se mostrava absolutamente incompatível com a produção de decisões judiciais motivadas. Ademais, o sigilo do procedimento e, mais especificamente, das razões pelas quais a decisão foi tomada aumentavam o misticismo em torno da atividade judicante, o que ampliava não só a liberdade, mas o poder e o prestígio do juiz. O sigilo também impedia que os cidadãos constatassem divergências entre julgamentos de casos idênticos, situação que obviamente afrontaria o senso de justiça daquele que foi lesado. ${ }^{275}$

Mas se o absolutismo tem um papel decisivo no abandono da motivação das decisões judiciais a partir do século XIV, também será por causa dele que alguns tribunais

\footnotetext{
${ }^{271}$ GODDING, Philippe. Jurisprudence et motivation des sentences, du moyen âge à la fin du $18^{e}$ siècle. p. 48; TUCCI, José Rogério Cruz e. A Motivação da Sentença no Processo Civil. p. 41.

${ }^{272}$ GOMES FILHO, Antonio Magalhães. A Motivação das Decisões Penais. p. 55; V. GODDING, Philippe. Jurisprudence et motivation des sentences, du moyen âge à la fin du $18^{e}$ siècle. p. 52.

${ }^{273}$ Cf. SAUVEL, Tony. Histoire du jugement motivé. p. 24.

${ }^{274}$ GOMES FILHO, Antonio Magalhães. A Motivação das Decisões Penais. p. 55.

${ }^{275}$ V. Ibidem. p. 55.
} 
da Europa continental retomarão a prática de motivar as sentenças no século XVI. Assim como supostamente teria acontecido em Roma antiga, a exigência estava ligada à necessidade de controlar a atividade judicial e centralizar os poderes na pessoa do monarca. $^{276}$

Nessa linha merece destaque uma reforma de 14 de maio de 1532 que impôs o dever de motivação das decisões proferidas pela Rota Florentina, dispondo que os juízes deveriam "dar e escrever no rodapé da sentença (...) brevemente os motivos principais que teriam levado àquele julgamento" ou redigir em três dias os motivos da sentença, “alegando-se sempre (...) a lei, a doutrina, as razões indutivas e os motivos de tal juízo". O descumprimento da regra implicava sanções pecuniárias ao magistrado infrator. ${ }^{277} \mathrm{Em}$ 1678, também na Itália, a reforma da Magnífica Rota e Conselho de Justiça impôs o dever de motivação de todas as sentenças proferidas em causas de valor superior a 100 ducados. $^{278}$

Por mais duas razões o dever de motivação se difundiu. ${ }^{279}$ A primeira voltava-se à racionalização da atividade judicial, destacando-se a preocupação com a diminuição de recursos interpostos. Na Rota Romana, p.ex., adotou-se a prática de, antes de proferir uma sentença final imotivada, apresentar às partes um projeto de decisão que continha a parte dispositiva e as rationes dubitandi. Contra essas rationes dubitandi as partes poderiam manifestar-se, gerando uma nova decisão motivada. ${ }^{280}$ A segunda razão

${ }^{276}$ V. TARUFFO, Michele. L'obbligo di motivazione della sentenza civile tra diritto comune e illuminismo. p. 281; v. também GOMES FILHO, Antonio Magalhães. A Motivação das Decisões Penais. p. 55-57.

277 Cf. TARUFFO, Michele. L'obbligo di motivazione della sentenza civile tra diritto comune e illuminismo. p. 279. No original: “A Firenze, l'obbligo di motivazione è imposto alla Ruota Fiorentina (istituita nel 1502), con la riforma del 14 maggio 1532, nel cui capo 12 si prescrive ai giudici di '... dare e scrivere a pié della sentenza ... brevemente e motivi principali, che gli aranno mossi a cosi giudicare ..., o comunque di redigere $i$ motivi entro tre giorni dalla sentenza '... allegandovi sempre ... la legge, e le Doctrine, e le ragioni inductive, e motive di tal suo Iudicio', con la previsione di una sanzione pecuniaria per il giudice che non assolva a tale obbligo".

${ }^{278}$ Cf. Ibidem. p. 280.

${ }^{279}$ V. GODDING, Philippe. Jurisprudence et motivation des sentences, du moyen âge à la fin du $18^{e}$ siècle. p.59-62; igualmente, TARUFFO, Michele. L'obbligo di motivazione della sentenza civile tra diritto comune e illuminismo. p. 279-281.

${ }^{280}$ Cf. TARUFFO, Michele. L'obbligo di motivazione della sentenza civile tra diritto comune e illuminismo. p. 280 . 
consistia em uma autêntica retomada da preocupação com uma jurisprudência linear dos tribunais. Foi o que aconteceu no Piemonte, quando uma constituição de 1615 impôs aos juízes que motivassem as decisões sob requerimento das partes ou por ordens superiores em casos que envolvessem questões de direito importantes ou inéditas. ${ }^{281}$ Também foi o fundamento básico de algumas exigências pontuais observadas nos países germânicos a partir do século XVII. ${ }^{282}$

Em Portugal, o dever de motivar as decisões judiciais veio expressamente previsto pelas Ordenações Manuelinas, promulgadas definitivamente em $1521 .^{283}$ Dando um tratamento à sentença bastante extenso, as Ordenações impunham aos juízes que julgassem secundum allegata et probata, não obstante o rei, "que não reconhece Superior", pudesse julgar "segundo sua consciência" (Ord. Man. 3.50.par.). Um pouco adiante (Ord. Man. 3.50.6), as Ordenações reconhecem que "no mais das vezes os Julgadores não declaram nas sentenças definitivas, que nos seus feitos são postas, as causas ou causas em que se fundam a absolver, ou condenar (...)", fato do qual seguir-se-iam "muitos inconvenientes". De modo que as partes pudessem saber o que foi provado ou não provado, do que e como embargar, apelar ou agravar, além de permitir ao órgão ad quem que "sinta melhor os fundamentos" da decisão recorrida, "mandou-se", "por bem de Justiça", que todos os magistrados declarassem "a causa ou causas em que se fundam a condenar, ou absolver, ou a confirmar, ou a revogar, dizendo especificamente o que é que se prova, e por quais causas do feito se fundam a dar suas sentenças". O descumprimento do mandamento gerava uma multa no valor de 20 cruzados, além de uma multa de 10 cruzados em benefício da parte lesada em caso de apelação ou agravo.

Alguns anos mais tarde, as Ordenações Filipinas, com vigência a partir de 1603, igualmente previram a obrigatoriedade da motivação das decisões judiciais. Pouco houve de novidade. ${ }^{284}$ Manteve-se a vinculação do juiz àquilo que foi alegado e provado, e

\footnotetext{
${ }^{281}$ Cf. Ibidem. p. 280.

${ }^{282}$ V. GODDING, Philippe. Jurisprudence et motivation des sentences, du moyen âge à la fin du $18^{e}$ siècle. p. 59-62.

${ }^{283}$ V. TUCCI, José Rogério Cruz e; AZEVEDO, Luiz Carlos de. Lições de História do Processo Civil Lusitano. p. 34.

${ }^{284}$ Com efeito, as Ordenações Filipinas são comumente criticadas por sua "falta de originalidade, mantendose, por determinantes de ordem política, extremamente fiéis à derrogada legislação”. Ibidem. p. 116.
} 
a motivação permaneceu voltada a facultar às partes saber "se lhes convém" recorrer da decisão e permitir ao órgão ad quem entender "melhor os fundamentos" pelos quais o juízo a quo decidiu (Ord. Filip. 3.66.7).

Em qualquer um dos dois diplomas legislativos é clara a vinculação do comando à racionalização da atividade judiciária, facilitando o controle recursal e reduzindo o número de recursos interpostos pelas partes. Embora haja uma grande preocupação com as questões fáticas do processo, no que estão incluídos os fatos que teriam ou não sido provados, nada se coloca em relação às questões de direito.

5.6. A contribuição da Revolução Francesa para o dever de motivar as decisões judiciais

O panorama acima apresentado pouco mudou até final do século XVIII. Há, é verdade, o exemplo louvável da legislação napolitana de 1774 que, "para afastar a maldade e a fraude sob qualquer pretexto, e assegurar na opinião do público a correção e a religiosidade do magistrado", determinou que "toda decisão (...) explique a razão de decidir, ou seja, os motivos sobre os quais a decisão é apoiada". ${ }^{285}$ De acordo com um despacho real do mesmo ano, a medida tinha importância porque os juízes eram "executores das leis e não legisladores" e "o direito deve ser certo e definido, não arbitrário". Além disso, "a verdade e a justiça que o povo conhece e vê nas decisões dos juízes é o decoro dos magistrados". ${ }^{286}$ Mas se o dever de motivação é, como explica Philippe Godding, "relativamente frequente na Itália, existe em Portugal e começa a espalhar-se nos Länder alemães", as demais cortes europeias continuaram a proferir decisões imotivadas. ${ }^{287}$ Tudo isso começa a ser alterado com a Revolução Francesa.

\subsubsection{O período francês pré-revolucionário}

Depois da implementação de uma série de melhorias na administração da Justiça francesa no século XIII, buscando reduzir a insegurança do período feudal e a

\footnotetext{
${ }^{285}$ Dispositivo citado por EVANGELISTA, Stefano. Motivazione della sentenza civile. p. 154.

${ }^{286}$ Cf. Ibidem. p. 154.

${ }^{287}$ GODDING,Philippe. Jurisprudence et motivation des sentences, du moyen âge à la fin du $18^{e}$ siècle. $\mathrm{p}$. 46-65.
} 
“infinita diversidade de jurisdições senhoriais", que incluiu interdição do duelo judiciário, regras para instrução do processo, fixação de honorários advocatícios, limitação da competência eclesiástica, sistematização do direito costumeiro de cada região, além da já mencionada prática de motivar as decisões judiciais com o intuito de criar um direito jurisprudencial, observou-se um significativo retrocesso no século XIV. ${ }^{288}$ Especificamente no que concerne à motivação, as causas de seu abandono já foram reveladas nos pontos anteriores. Houve também situações pontuais. A Corte do Rei ("Parlamento de Paris"), então responsável pela análise dos recursos de apelação, ao manter uma decisão simplesmente declarava que o juízo a quo havia "bem julgado" - o que contribuiu para atrofiar o desenvolvimento da motivação. Por outro lado, a disseminação do conhecimento de quais eram os costumes que regiam a sociedade francesa da época, ${ }^{289}$ muitos tidos por notórios, reduzia a necessidade de expor os motivos das decisões e criar uma jurisprudência. ${ }^{290}$

De qualquer forma, fato é que a motivação verificada no século XIII era produto de uma necessidade pontual, voltada exclusivamente aos interesses dos próprios tribunais. Como escreveu Sauvel, "não era mais do que uma prática”, e, por isso, sua interrupção, consolidada em 1336 pelo Le style de la chambre des enquêtes, não foi difícil. $^{291}$

A discussão em torno da motivação das decisões judiciais só foi retomada ao final do século XVI, quando o Judiciário francês começou a sofrer severas críticas da opinião pública. Além de os processos serem demorados e caros, a magistratura transformara-se em um cargo venal, transmissível mediante contratos de compra e venda ou, como aconteceria com o passar do tempo, por herança. ${ }^{292}$ Os juízes formaram uma

\footnotetext{
${ }^{288}$ Cf. SAUVEL, Tony. Histoire du jugement motivé. p. 18-21.

${ }^{289}$ Inclusive com a codificação dos costumes no norte da França a partir do começo do século XVI. V. DAWSON, John P. The Oracles of the Law. p. 300-301.

${ }^{290}$ Cf. SAUVEL, Tony. Histoire du jugement motivé. p. 21-22.

${ }^{291}$ Ibidem. p. 23 : "Ce n'était qu'un usage".

${ }^{292}$ Ibidem. p. 26-27; DAWSON, John P. The Oracles of the Law. p. 350-362; CAPPELLETTI, Mauro. Repudiating Montesquieu? The expansion and legitimacy of constitutional justice. p. 11
} 
"nova classe social, já fortemente imbuída de sua importância e frequentemente em rivalidade com a nobreza". ${ }^{293}$

Em 1560 foram reunidos os Estados Gerais ${ }^{294}$ e a nobreza, em parte para conter o poder da magistratura, em parte porque consciente da necessidade de criar-se uma jurisprudência homogênea, solicitou ao Rei que os julgamentos fossem, a partir daquele momento, sempre motivados. Alegou-se que, "ao exprimir e declarar os motivos de seus julgamentos contendo os pontos peremptórios da decisão, as causas (...), artigos de costumes e leis pelas quais eles julgarão", os juízes julgariam cada vez melhor, as decisões serviriam "de instrução a todas as causas similares e haveria menos apelações". ${ }^{295}$ O Rei, todavia, declarou sua incompetência para regular a matéria e deixou livre a cada juiz que agisse como bem entendesse.

Em nova reunião dos Estados Gerais, agora em 1614, foi parte da burguesia que requereu ao rei decisões motivadas, ao menos aquelas "dadas sobre a interpretação dos costumes e pontos de direito", sob a justificativa de que "os motivos serviriam eles mesmos como leis". ${ }^{296}$ A solicitação foi ignorada. ${ }^{297}$

Os anos seguintes foram marcados pela deterioração moral do Judiciário francês. O rígido processo seletivo de juízes estabelecido em 1579 a pedido dos Três Estados começou a ser desconsiderado e até mesmo fraudado durante o século XVII; fato que reduziu consideravelmente a qualidade e comprometimento de boa parte dos

${ }^{293}$ SAUVEL, Tony. Histoire du jugement motivé. p. 26. Para mais detalhes, v. a interessantíssima narrativa de DAWSON, John P. The Oracles of the Law. p. 350-362.

${ }^{294}$ As reuniões dos Estados Gerais eram assembleias convocadas pelo Rei para tratar de questões centrais do Estado francês, como declarações de guerra ou políticas fiscais. Eram compostas de representantes do clero, da nobreza e da burguesia.

${ }^{295}$ Cf. SAUVEL, Tony. Histoire du jugement motivé. p. 27-28: "Les cours, disait-on, doivent 'exprimer et déclarer les motifs de leurs jugements contenant les points péremptoires de la décision des causes, soit par titre, témoins ou confessions des parties, articles de coutumes et lois par lesquels ils jugeront. Ce faisant les juges s'étudieront à juger de mieux en mieux et lesdits arrests et jugements serviront d'instruction à tous en semblables causes et il y aura moins d'appellations'".

${ }^{296}$ Cf. Ibidem. p. 28.

297 Importante notar que dez anos antes, em 1604, um decreto real regulamentou a transmissão dos cargos judiciais, fato que impulsionou o clero e a nobreza a atacar ferozmente a venalidade da magistratura na reunião dos Estados Gerais em 1614. A burguesia, por sua vez, ficou dividida, já que boa parte dela havia sido beneficiada com as novas regras. V. DAWSON, John P. The Oracles of the Law. p. 354-355. 
integrantes da magistratura. ${ }^{298}$ Nesse mesmo século foi potencializado o impressionante poder político adquirido pelos tribunais franceses durante o século XVI, culminando com a primeira Fronde (1648-1649), uma guerra civil travada entre os magistrados e a Coroa (Cardeal Mazarin e a Rainha Regente) durante a menoridade de Luis XIV. Uma das consequências do conflito, originado em parte pelo aumento do número de magistrados pela Coroa, o que reduziu o preço do cargo, foi o estabelecimento de medidas que permitiam aos juízes atingir status de nobreza sob determinadas condições. ${ }^{299}$

Com a maioridade de Luis XIV e sua perfeita personificação do absolutismo europeu, o crescente poder da magistratura foi freado $\mathrm{Na}$ medida em que ele e Estado formavam um ente uno e indivisível ( $L$ 'État, c'est moi), os tribunais franceses foram "efetivamente silenciados" durante o seu longo reinado (1661-1715). ${ }^{300}$ Mas o papel ativo dos magistrados foi retomado com maior intensidade logo depois da morte do monarca e o desrespeito, pelo Parlamento de Paris, de suas disposições testamentárias. Em contrapartida à nomeação do Duque de Orléans como único regente, a Corte foi contemplada com o poder de veto sobre a legislação real; prerrogativa posteriormente estendida a outros tribunais. ${ }^{301}$ Sem surpresa nenhuma, o Parlamento de Paris adotou uma postura política extremamente ativa e os conflitos entre Coroa e magistratura tornaram-se constantes nos anos sucessivos. Os juízes transformaram-se na principal frente de oposição ao governo. ${ }^{302}$

Já no final do século, diante de uma grave crise econômica, a Coroa movimentou-se para efetivar relevantes reformas, como majoração dos tributos, reforma administrativa e, principalmente, transferência da competência para registro das normas expedidas pelo Rei para um novo tribunal. Desgostoso, o Parlamento de Paris solicitou a

\footnotetext{
${ }^{298}$ V. DAWSON, John P. The Oracles of the Law. p. 357-358.

${ }^{299}$ V. Ibidem. p. 360.

${ }^{300}$ Ibidem. p. 368. A data indicada como início do reinado (1661) desconsidera o período da Regência (16431661), com a qual totalizaria mais de 72 anos.

${ }^{301}$ Ibidem. p. 368-369.

${ }^{302}$ Ibidem. p. 368-369.
} 
convocação dos Estados Gerais, o que efetivamelnte ocorreu a partir de 5 de maio de 1789. ${ }^{303}$ Iniciou-se então a Revolução Francesa.

\subsubsection{O legado da Revolução Francesa}

Antes da Revolução havia algumas parcas e pontuais manifestações da doutrina em defesa de um dever de motivação, sempre em referência às decisões penais. Em 1766, ao comentar a célebre obra 'Dos Delitos e das Penas' de Beccaria, Voltaire afirmou com grande sapiência: "Enfim, por que em certos países os julgamentos não são jamais motivados? Existe alguma vergonha de apresentar a razão de seu julgamento? (...) Para qualquer lado que se olhe, encontra-se a contrariedade, a dureza, a incerteza, a arbitrariedade". ${ }^{304}$ Vinte anos mais tarde, Condorcet defendeu que o Direito natural "exige que todo homem que emprega contra membros da sociedade a força que por esta the foi confiada preste contas das suas causas determinantes". ${ }^{305}$ As críticas foram parcialmente recepcionadas em 1787, quando o Conselho do Rei, amparado nas lições de Concorcet, cassou uma decisão judicial porque a sua motivação consistia unicamente na fórmula "segundo as circunstâncias resultantes do processo". ${ }^{306}$ No ano seguinte, um ato normativo

\footnotetext{
${ }^{303}$ Ibidem. p. 369-370.

${ }^{304}$ VOLTAIRE. Commentaire sur le Livre Des Délits et des Peines: par un avocat de province. p. 103-104. No original: "Quand on veut pofer les limites entre l'autorité civile \& les ufages eccléfiaftisques, quelles difputes interminables! où font ces limites? qui conciliera les éternelles contradictions du fife \& de la jurisprudence? Enfin pourquoi dans certain pays les arrêts ne font-ils jamais motivés? Y a-t-il quelque honte à rendre raifon de fon jugement? Pourquoi ceux qui jugent au nom du fouverain, ne préfentent-ils pas au nom du fouverain, ne préfentent-il pas au fouverain leus arrêts de mort avant qu'on les exécute? De quelque côté qu'on jette les yeux, on trouve la contrariété, la dureté, l'incertitude, l'arbitraire. Nous cherchons dans ce fiecle à tout perfectionner; cherchons donc à perfectionner les loix dont nos vies \& nos fortunes dépendent".

${ }^{305}$ CONDORCET. Réflexions d'un citoyen non gradué par un procès bien connu. Francfort, 1786, citado por SAUVEL, Tony. Histoire du jugement motivé. p. 39. No original, transcrito por Sauvel: "[o Direito natural] exige que tout homme qui emploie contre des membres de la societé la force qu'elle lui a confiée lui rende compte des causes qui l'y ont déterminé".

${ }^{306}$ Cf. SAUVEL, Tony. Histoire du jugement motivé. p. 41. A fórmula, em francês, era a seguinte: "Pour les cas résultant du procès".
} 
de Luis XVI determinou a enunciação e a qualificação expressa dos crimes e delitos na sentença penal. ${ }^{307}$

Todavia, fato é que o tema foi largamente negligenciado pelos iluministas. Nem mesmo Montesquieu defendeu um dever geral de motivação das decisões judiciais, não obstante tenha se preocupado com a limitação dos poderes da magistratura e com a conservação da jurisprudência dos tribunais para que "se julgue hoje como se julgou ontem". ${ }^{308}$ Uma omissão que pode ser explicada por duas razões principais: (a) aceitação generalizada do pensamento bastante antigo de que a decisão judicial era exercício puro de autoridade e poder, cujo prolator não precisaria justificar; ${ }^{309}$ e (b) crença de que a segurança jurídica poderia ser proporcionada pela excelência na criação de leis claras, simples e uniformes, de modo que o juiz nada mais fizesse senão aplicar o texto legal ao caso concreto. ${ }^{310}$

Entretanto, por causa do papel desempenhado pelos magistrados no ancien regime, uma das primeiras providências tomadas pelos revolucionários foi "subjugar o Judiciário". Aboliu-se a venalidade do cargo, os juízes passaram a ser eleitos por voto popular e exercer a função por mandatos curtos, instituiu-se o júri em todas as causas criminais, difundiram-se a conciliação e a arbitragem, vetou-se expressamente o poder dos tribunais de criar normas legais e impôs-se o dever de motivar as decisões judiciais. ${ }^{311}$

A motivação das decisões judiciais na França surgiu, portanto, como criação essencialmente ideológica e política, ${ }^{312}$ produzida no ambiente ideologicamente liberal da Revolução Francesa. Insurgindo-se contra o ancien regime e contra os abusos da

\footnotetext{
${ }^{307}$ Cf. Ibidem. p. 41; GODDING, Philippe. Jurisprudence et motivation des sentences, du moyen âge à la fin du $18^{e}$ siècle. p. 66 .

${ }^{308}$ MONTESQUIEU. De l'Esprit des Lois, t. I. p. 194. No original: "Le gouvernement monarchique ne comporte pas des lois aussi simples que le despotique. Il y faut des tribunaux. Ces tribunaux donnent des décisions. Elles doivent être conservées; elles doivent êtres apprises, pour que l'on y juge aujourd'hui comme l'on y jugea hier (...)".

${ }^{309}$ Cf. DAWSON, John P. The Oracles of the Law. p. 377.

${ }^{310} \mathrm{~V}$. TARUFFO, Michele. L'obbligo di motivazione della sentenza civile tra diritto comune e illuminismo. p. 259 .

${ }^{311}$ DAWSON, John P. The Oracles of the Law. p. 375-376.

${ }^{312}$ Cf. GODDING,Philippe. Jurisprudence et motivation des sentences, du moyen âge à la fin du $18^{e}$ siècle. p. 66.
} 
magistratura, os revolucionários viram na imposição de tal dever um incomparável instrumento de controle da atividade judicial. ${ }^{313}$ Não é por acaso que, convocados os Estados Gerais em 1789, nobreza, clero e burguesia requereram, pelos cahiers de doléances (registros em que se anotavam solicitações e reclamações da população para serem levadas diretamente ao Rei), a motivação das decisões judiciais, inclusive as civis.

As consequências de toda essa movimentação apareceram pela primeira vez no art. 15, título V, da Lei de 16-24 de agosto de 1790, fruto das discussões iniciadas na Assembleia Constituinte de março sobre a organização judiciária francesa. ${ }^{314}$ De acordo com o dispositivo, as decisões judiciais deveriam conter quatro seções: na primeira seriam indicados os nomes e a qualificação das partes; na segunda seriam "colocadas com precisão" "as questões de fato e de direito que constituem o processo"; na terceira o juiz indicaria quais foram os fatos reconhecidos ou constatados pela instrução e "os motivos que teriam determinado o julgamento"; e por fim constaria o dispositivo da decisão. ${ }^{315}$

O preceito legal recebeu uma redação digna de efusivos elogios. Impôs ao magistrado, de forma absolutamente clara, a estruturação das decisões judiciais em relatório, motivação e dispositivo; e, sinteticamente, conseguiu expressar o que deveria constar em cada uma dessas partes. A sequência lógica que parte da indicação dos fatos e do direito discutidos no processo e é seguida do apontamento de quais fatos foram efetivamente provados e qual é a razão jurídica pela qual se chega ao dispositivo é válida até hoje.

Alguns anos mais tarde, o dever de motivação foi consagrado constitucionalmente em dispositivo que lembra muito o atual art. 93, IX, da Constituição brasileira. Assim dispunha o art. 208 da Constituição do ano III da República (1795): “as sessões dos tribunais são públicas; os juízes deliberam em segredo; os julgamentos são

\footnotetext{
${ }^{313}$ V. TARUFFO, Michele. La Motivazione della Sentenza Civile. p. 326-327.

${ }^{314}$ DAWSON, John P. The Oracles of the Law. p. 375-376.

${ }^{315}$ No original: "La rédaction des jugemens, tant sur l'appel qu'en première instance, contiendra quatre parties distinctes. Dans la première, les noms et les qualités des parties seront énoncés. Dans la seconde, les questions de fait et de droit qui constituent le procès seront posées avec précision. Dans la troisième, le résultat des faits reconnus ou constatés par l'instruction, et les motifs qui auront déterminé le jugement, seront exprimés. La quatrième enfin contiendra le dispositif du jugement".
} 
pronunciados em voz alta; eles são motivados e nele são enunciados os termos da lei aplicável". 316

A diferença entre os preceitos é considerável. Não obstante seja comum dar maior destaque à norma constitucional de 1795, justamente por ser constitucional, a redação de 1790 foi muito mais feliz. A lei ordinária não exigia do magistrado que informasse a "lei" aplicada ao caso concreto, mas "os motivos" jurídicos determinantes ao julgamento decorrentes dos fatos efetivamente provados. Muito embora a expressão tivesse uma eficácia prática nula diante do art. 12 da mesma lei, o qual impunha aos juízes que solicitassem a manifestação do Poder Legislativo sempre que precisassem interpretar as leis, vale notar que a escolha terminológica foi proposital. Em esboço legislativo preliminar de autoria do constituinte Thouret, determinava-se que o juiz indicasse "“o texto da lei’ que governava o caso"; para ele, a motivação seria "o melhor meio de forçar os juízes ao exame da causa". Contudo, levando em consideração a observação do constituinte Chabroux de que as leis eram pouco numerosas e que alguns casos poderiam não ter correspondência expressa na legislação, optou-se por uma expressão mais ampla: "motivos". ${ }^{317}$ Assim, ao contrário do dispositivo constitucional, o referido art. 15 da lei de organização judiciária partia da premissa de que o legislador seria incapaz de prever expressamente todas as situações fáticas passíveis de apreciação pelo Judiciário.

Já sob o Império de Napoleão, o artigo $7^{\circ}$ da Lei de 20 de abril de 1810 dispôs serem nulos os julgamentos imotivados, ${ }^{318}$ pondo fim à orientação medieval de que a falta de motivação não invalidava o ato decisório. A partir daí, a regra foi definitivamente interiorizada na consciência coletiva do povo francês e não voltou a ser questionada. ${ }^{319}$

\footnotetext{
${ }^{316}$ No original: "Les séances des tribunaux sont publiques ; les juges délibèrent en secret ; les jugements sont prononcés à haute voix ; ils sont motivés, et on y énonce les termes de la loi appliquée".

${ }^{317}$ V. SAUVEL, Tony. Histoire du jugement motivé. p. 45-46; DAWSON, John P. The Oracles of the Law. p. 376 .

${ }^{318}$ No original: "Les arrêts qui ne sont pas rendus par le nombre de juges prescrit, ou qui ont été rendus par des juges qui n'ont pas assisté à toutes les audiences de la cause, ou qui n'ont pas été rendus publiquement, ou qui ne contiennent pas les motifs, sont déclarés nuls".

319 Segundo Philippe GODDING, a reforma legislativa "não suprimiu de uma só vez os resquícios das tradições anteriores". Alguns autores eram "pouco favoráveis à motivação, em razão dos riscos de erro que ela poderia comportar". Ainda assim, como ele mesmo assevera, "le principe ne fut plus remis en question". (Jurisprudence et motivation des sentences, du moyen âge à la fin du $18^{e}$ siècle. p. 67). Com efeito, constou
} 
5.7. A influência imediata dos ideais revolucionários na motivação das decisões judiciais no século XIX

A motivação das decisões judiciais, tal qual concebida na França revolucionária, decorreu de um momento histórico permeado de ideais políticos e ideológicos muito bem definidos. Tratou-se de uma criação não apenas do iluminismo, mas de um iluminismo eminentemente liberal que lutava para conter a arbitrariedade do Estado e fazer prevalecer o direito criado pelo povo. Por óbvio, a transposição do instituto para outros sistemas jurídicos com identidade de funções e de natureza não seria tarefa fácil.

No século XIX são raros os exemplos de Constituições europeias que previram expressamente a obrigatoriedade da motivação das decisões judiciais. Uma delas foi a liberal Constituição siciliana de 1812, a qual albergou uma quantidade impressionante de garantias ao indivíduo. Partindo da premissa constitucional francesa de que ao juiz incumbia simplesmente "aplicar as leis aos casos e aos fatos" (Título III, capo I, caput), ${ }^{320}$ dispunha: "As sentenças, tanto no civil como no criminal, para evitar qualquer arbítrio do julgador, deverão ser fundamentadas sobre a lei do novo código; quando essa faltar, deverá ser implorada ao poder legislativo, que reside junto ao Parlamento" (Título III, capo I, § 5). ${ }^{321}$ Também pode ser citada a Constituição belga de 1831, elaborada logo após a Revolução de 1830. Seu art. 97 foi assim redigido: "Todo julgamento é motivado. Ele é pronunciado em audiência pública". ${ }^{322}$ A importação do preceito francês foi tão bem sucedida que a regra possui até hoje a mesma redação (art. 149 da Constituição de 1994). Por fim, vale lembrar o art. 89 da Constituição de Luxemburgo de 1868, com redação

de um julgamento do Conselho de Estado de 12 de dezembro de 1818 que, malgrado a inexistência de dispositivo legal expresso, as suas decisões possuíam as mesmas características das judiciais e, por isso, a motivação era um imperativo de ordem pública. $C f$. SAUVEL, Tony. Histoire du jugement motivé. p. 50.

${ }^{320}$ No original: "La potestà di giudicare sarà nell'applicare le leggi ai casi ed ai fatti, tanto nel civile che nel criminale".

${ }^{321}$ No original: "Le sentenze tanto nel civile che nel criminale, per evitare ogni arbitrio nei giudicanti, dovranno essere ragionate sulla legge del nuovo codice; ove questa manchi, si dovrà implorare il potere legislativo, che risiede presso il Parlamento".

${ }^{322}$ No original: "Art. 97. Tout jugement est motivé. Il est prononcé en audience publique". 
idêntica à da Constituição belga. ${ }^{323} \mathrm{Na}$ América do Sul, há o exemplo da Constituição colombiana de 1886, que vigorou até 1991, e seu artigo 161: “Toda sentencia deberá ser motivada".

Antes delas, quase todas as Repúblicas Jacobinas formadas na Itália durante a campanha napoleônica (1796 a 1799) copiaram de alguma forma o art. 208 da Constituição francesa de 1795. A Constituição de Bolonha (1796), p.ex., exigia "sentenças fundamentadas e pronunciadas em voz alta". ${ }^{324}$ A Constituição de Popolo Ligure (1797), no art. 222, também previa sentenças pronunciadas em voz altas "e motivadas sobre o fato e sobre a lei, e nunca sobre a autoridade ou sobre os exemplos". 325 Dispositivos semelhantes estavam contidos nas Constituições de Cispadana, ${ }^{326}$ Cisalpina, $^{327}$ Roma $^{328}$ e Nápoles. $^{329}$ Entretanto, a previsão constitucional do dever de motivar era uma mera importação do Direito francês, sem respaldo adequado no ambiente iluminista italiano; ${ }^{330}$ além disso, a regra perdeu a sua feição eminentemente liberal durante o Império napoleônico: circunstâncias que fizeram com que ela desaparecesse das diversas

\footnotetext{
${ }^{323}$ No original: "Art. 89. Tout jugement est motivé. Il est prononcé en audience publique".

${ }^{324}$ No original: "Art. 129 - Le sessioni de' Tribunali collegiati sono pubbliche; $i$ Giudici deliberano in segreto; le sentenze sono ragionate e si pronunciano ad alta voce”.

${ }^{325}$ No original: “Art. 222 - Le sessioni de’ tribunali sono pubbliche. I giudici deliberano in segreto. Le sentenze si pronunziano ad alta voce, e sono motivate sul fatto, e sulla legge, e non mai sull'autorità, né su gli esempi."

${ }^{326}$ No original: “Art. 228 - Le sessioni dei tribunali sono pubbliche. I giudici deliberano in segreto. Le sentenze si pronunciano ad alta voce, sono accompagnate da motivi, e vi si enunziano i termini della legge applicata".

${ }^{327}$ No original: “Art. 208 - Le sedute dei tribunali sono pubbliche, i giudici deliberano in segreto: le sentenze sono pronunziate ad alta voce e si enunziano $i$ motivi del giudicato desunti tanto dal fatto che dai termini della legge applicata".

${ }^{328}$ No original: “Art. 207 - Le sedute dei tribunali sono pubbliche: i giudici deliberano in segreto: le sentenze si pronunziano ad alta voce: esse sono motivate, e, vi si enunziano i termini della legge applicata".

${ }^{329}$ No original: “Art. 207 - Le sessioni de’ tribunali sono pubbliche, i giudici deliberano in segreto: $i$ giudicati sono enunciati ad alta voce: vi saranno divisati i motivi ed i termini della legge applicata".

330 TARUFFO, Michele. L'obbligo di motivazione della sentenza civile tra diritto comune e illuminismo. p. 291.
} 
Constituições promulgadas na Itália no início do século XIX, ${ }^{331}$ não obstante tenha permanecido nas legislações ordinárias.

Os ideais franceses foram particularmente sentidos na Espanha do século XIX ao ser apresentado, em 31 de março de 1811, um projeto de decreto nos seguintes termos: "desejando afastar a malícia, a fraude e a arbitrariedade a todo pretexto, e assegurar ao público a exatidão, zelo e escrupulosidade dos magistrados, vem-se decretar que em toda decisão (...) exponham-se as razões, causas e fundamentos em que se apoiam". ${ }^{332}$ Embora não tenha sido aprovado, é importante notar a ruptura ideológica traduzida no referido projeto. Pouco mais de trinta anos antes, em 23 de junho de 1778, o Rei Carlos III havia proibido que os juízes expusessem os motivos de suas decisões, sobre o argumento de que a medida servia para "evitar os prejuízos que resultam com a prática, que observa a Audiência de Mallorca, de motivar suas sentenças, dando lugar a devaneios dos litigantes, consumindo muito tempo na extensão das sentenças (...) e nas custas"; as sentenças deveriam simplesmente "ater-se às palavras decisórias". ${ }^{333} \mathrm{O}$ dever de motivação foi introduzido paulatinamente no Direito espanhol durante o século XIX, embora só tenha adquirido natureza constitucional na segunda metade do século $\mathrm{XX} .{ }^{334}$

Nos países germânicos regidos pelo despotismo esclarecido, como Áustria e Prússia, as consideráveis diferenças ideológicas em relação ao liberalismo francês revolucionário impediam uma exata identificação entre os propósitos do dever de motivar as decisões judiciais. $^{335} \mathrm{Na}$ primeira metade do século XVIII, a prática era consideravelmente difundida em um sistema bastante peculiar. As sentenças eram redigidas com a indicação de suas razões, as quais eram mantidas em segredo das partes. Em caso de recurso, o qual deveria ser interposto sem saber por qual motivo o juiz havia

\footnotetext{
${ }^{331}$ Cf. Ibidem. p. 292.

${ }^{332}$ Citado por SANTOS, Tomás-Javier Aliste. La Motivación de las Resoluciones Judiciales. p.109.

${ }^{333}$ Real Cédula de Carlos III de 23 de junho de 1778, incluída posteriormente na Lei VIII, Tit. XV, Liv. IX da Novíssima Recopilação. Citada por SANTOS, Tomás-Javier Aliste. La Motivación de las Resoluciones Judiciales. p.103.

${ }^{334}$ Sobre o desenvolvimento histórico da motivação das decisões judiciais na Espanha do século XIX, v. SANTOS, Tomás-Javier Aliste. La Motivación de las Resoluciones Judiciales. p. 107-134

${ }^{335}$ V. TARUFFO, Michele. L'obbligo di motivazione della sentenza civile tra diritto comune e illuminismo. p. $276-278$.
} 
julgado, a motivação era disponibilizada somente ao juízo ad quem, permitindo-lhe que aferisse com maior exatidão o acerto ou erro da sentença. ${ }^{336}$

$\mathrm{Na}$ Prússia, o sigilo da motivação das decisões judiciais foi rompido em 1748 sob o governo de Frederico II, um dos maiores expoentes do despotismo esclarecido europeu. A partir da publicação do Project des Codicis Fridericiani Marchici, conhecido como Dienstpragmatik, previu-se um dever geral de motivação das decisões judiciais, agora disponibilizada às partes, desde que por elas requerido. Seus fundamentos são muito claros e bastante distintos do ideal revolucionário: (a) evitar confusões a respeito do verdadeiro significado do dispositivo da sentença; e (b) facilitar o convencimento do juízo ad quem. A falta de publicidade da motivação impossibilitava o exercício do controle externo da atividade judicial, verdadeiro leitmotiv da regra na legislação revolucionária. ${ }^{337}$ Nas palavras de Michele Taruffo, a motivação corresponde, neste contexto, "à finalidade de controle burocrático sobre a administração da justiça, inerente à estrutura centralizada do Estado autoritário". 338

O sistema processual prussiano foi reformado em 1781 pela Allgemeine Gerichtsordnung für die Preussischen Staaten, a qual foi revisada novamente em 1793, quatro anos depois da Revolução Francesa. Muito embora a motivação tenha recebido um tratamento bastante analítico por esse novo diploma legislativo, inclusive com publicação perante as partes e seus advogados, os seus fundamentos continuaram a ser essencialmente voltados à administração do Judiciário.

A regra ainda demorou praticamente um século para consolidar-se em definitivo no Direito germânico. Pouco depois da criação do Império Alemão (1871-1918), promulgou-se um Código de Processo Civil em 1879 (Zivilprozessordnung) pelo qual determinou-se que todos os pronunciamentos judiciais, de qualquer nível hierárquico,

\footnotetext{
${ }^{336}$ Ibidem. p. 272

${ }^{337}$ V. Ibidem. p. 272-275.

338 Ibidem. p. 276. No original: "È chiaro infatti che, mentre la regolamentazione ora esaminata non corrisponde all funzione di controllo democratico che la motivazione può svolgere, risponde invece alle finalità di controllo burocratico sull'amministrazione della giustizia, inerenti alla strutura accentrata dello stato autoritario: l'obbligo di inserire la motivazione ad acta rappresenta, in sostanza, lo strumento con cui il giudice è collocato e vincolato entro tale strutura".
} 
expusessem suas razões. ${ }^{339}$ A discussão envolvendo a motivação girava em torno do papel criativo dos juízes e do estabelecimento de uma jurisprudência dos tribunais.

De todo modo, ainda que a previsão constitucional de um dever de motivação não tenha vingado no século XIX, é possível perceber a influência da criação revolucionária em muitas legislações ordinárias, incluindo a brasileira.

Em 1824, embora vigentes as Ordenações Filipinas no Brasil pósindependência, havia um notório desrespeito pelos juízes à obrigatória exposição de motivos de suas decisões. Por isso, "com o fim de extirpar abusos inveterados no foro" e "por ser conforme ao liberal sistema ora abraçado", o então Ministro Clemente Ferreira França baixou uma Portaria determinando aos juízes que "declarem nas sentenças que proferirem, circunstanciada e especificamente, as razões e fundamentos das mesmas". ${ }^{340}$

Alguns anos mais tarde, o célebre Regulamento n. 737 de 1850 dispôs: “A sentença deve ser clara, sumariando o Juiz o pedido e a contestação com os fundamentos respectivos, motivando com precisão o seu julgado, e declarando sob sua responsabilidade a lei, uso ou estilo em que se funda" (art. 232).

Tanto em uma como na outra norma, a influência dos ideais franceses revolucionários é evidente. Ao atrelar a motivação ao "liberal sistema ora abraçado" e à finalidade de "extirpar abusos inveterados no foro", o Ministro Clemente Ferreira França aproximou-se consideravelmente da concepção de que as sentenças motivadas são decorrência de um sistema "liberal" voltado ao controle da atividade judicial. Já o Regulamento 737 inovou ao exigir, além dos fundamentos fáticos, a indicação do fundamento jurídico em que a sentença se ampara. Há, destarte, uma considerável ruptura com a antiga concepção lusitana de que a motivação era apenas um instrumento de racionalização da atividade judicial voltado a reduzir o número de recursos e permitir uma melhor análise da causa pelo juízo ad quem.

\footnotetext{
${ }^{339}$ Cf. DAWSON, John P. The Oracles of the Law. p. 436.

${ }^{340}$ Cf. TUCCI, José Rogério Cruz e. A Motivação da Sentença no Processo Civil. p. 54.
} 


\subsection{Panorama atual}

Embora o dever de motivação seja largamente difundido nas legislações ordinárias dos países ocidentais, não se pode dizer o mesmo de uma previsão expressa nas Constituições contemporâneas. Países como Alemanha, Estados Unidos, Canadá, Suíça, Uruguai, ${ }^{341}$ Argentina, ${ }^{342}$ Chile e Colômbia não possuem em suas Constituições referências explícitas à motivação das decisões judiciais. Nem mesmo a Constituição francesa de 1958 resgatou o art. 208 da clássica Constituição de 1795.

Por outro lado, é interessantíssimo notar que muitas das Constituições elaboradas no século XX após a queda de regimes ditatoriais preocuparam-se com a regra da motivação. São ótimos exemplos: Constituição mexicana de 1917 (art. 16), ${ }^{343}$ promulgada após a longa guerra civil que sucedeu a Revolução de 1910; Constituição italiana de 1948 (art. 111), ${ }^{344}$ promulgada após a queda do fascismo; Constituição grega de 1975 (arts. 6, 1 e 10,1) 345 , promulgada após a queda do "Regime dos Coronéis"; Constituição espanhola de 1978 (art. 120, 3), ${ }^{346}$ promulgada após a queda do franquismo; Constituição peruana de 1979 (art. 233, 4), ${ }^{347}$ promulgada após a queda da ditadura militar; Constituição portuguesa de 1976, reformada em 1982 (art. 205, 1), ${ }^{348}$ promulgada após a

${ }^{341}$ Curiosamente, a Constituição uruguaia de 1918 previa o dever de motivação em seu artigo $123^{\circ}$ : “La ley designará las instancias que haya de haber en los juicios de la Alta Corte de Justicia; éstos serán públicos y las sentencias definitivas motivadas por la enunciación expresa de la ley aplicada".

${ }^{342}$ No caso da Argentina, o dever de motivação vem expresso nas Constituições provinciais, como a de Buenos Aires (art. 171), Neuquén (art. 238) e Córdoba (arts. 41, 42, 45 e 46).

343 "Nadie puede ser molestado en su persona, familia, domicilio, papeles o posesiones, sino en virtud de mandamiento escrito de la autoridad competente, que funde y motive la causa legal del procedimiento”.

344 “Art. 111. (...) "Tutti i provvedimenti giurisdizionali devono essere motivati”.

${ }^{345}$ Versão em francês : Art. 6, 1. "Nul ne peut être arrêté ou emprisonné qu'en vertu d'un mandat judiciaire motivé qui doit être signifié au moment de l'arrestation ou de la mise en détention (...)". Art. 10, 1. Chacun ou plusieurs agissant en commun ont le droit, en observant les lois de l'État, d'addresser, par voie écrite, des pétitions aux autorités, qui sont tenues d'agir promptement suivant les dispositions en vigueur et de fournir au pétitionnaire une réponse écrite motivée conformément aux dispositions de la loi".

${ }^{346}$ Art. 120, 3: “Las sentencias serán siempre motivadas y se pronunciarán en audiencia pública”.

347 “Artículo 233. Son garantías de la administración de justicia: (...) 4.- La motivación escrita de las resoluciones, en todas las instancias, con mención expresa de la ley aplicable y de los fundamentos en que se sustentan".

348 Art. 205, 1: “As decisões dos tribunais que não sejam de mero expediente são fundamentadas na forma prevista na lei". 
Revolução dos Cravos e a queda do Estado Novo; e a Constituição brasileira de 1988, promulgada após a queda da ditadura militar.

Nessa lista destaca-se a ausência da Alemanha, cuja Constituição de 1949 possui uma grande quantidade de dispositivos em resposta ao regime nazista que sucumbira quatro anos antes. ${ }^{349}$ De qualquer maneira, ainda na década de 50, a Corte Constitucional Federal alemã assentou que "exceções ao dever de motivação são inconciliáveis com o princípio do Estado de Direito; o cidadão tem direito de conhecer os motivos e as razões sobre as quais está fundamentado um ato que venha a incidir sobre sua posição jurídica; somente por tal via terá condições de tutelar adequadamente os próprios direitos". ${ }^{350}$ Ou seja, o dever de motivação possui proteção constitucional implícita.

Além disso, todos os países europeus signatários da Convenção para Proteção dos Direitos Humanos e das Liberdades Fundamentais têm o dever de proferir decisões judiciais motivadas. De acordo com jurisprudência pacífica da Corte Europeia dos Direitos Humanos (CEDH), o dever de motivação está englobado no art. $6^{\circ}, 1$, que trata do "processo justo". ${ }^{351}$ Em recente decisão proferida no caso Taxquet v. Bélgica, que versava sobre a necessidade de motivação de decisões proferidas por júris populares, a Corte afirmou: "para que as exigências de um processo justo sejam respeitadas, o público e, acima de tudo, o acusado devem ser capazes de compreender o veredito que foi dado. Trata-se de uma garantia essencial contra o arbítrio. Porém, como a Corte frequentemente sublinha, a preeminência do direito e a luta contra o arbítrio são os princípios que sustentam a Convenção (...). No domínio da justiça, estes princípios servem a assegurar a

\footnotetext{
${ }^{349}$ V. CAPPELLETTI, Mauro. Repudiating Montesquieu? p. 5-6.

${ }^{350}$ Cf. TROCKER, Nicolò. Processo Civile e Costituzione. p. 461. A decisão foi proferida em 16 de janeiro de 1957 e o trecho citado foi vertido para o italiano, por Trocker, nos seguintes termos: "La stessa Corte costituzionale federale ha cosi avuto modo di ribadire che 'eccezioni all'obbligo di motivazione non sono conciliabili con il principio dello Stato di diritto; il cittadino ha diritto di conoscere i motivi e le ragioni sulle quali si basa un atto che viene ad incidere sulla sua posizione giuridica; solo per tal via sarà in grado di tutelare adeguatamente i propri diritti"'. V. também TARUFFO, Michele. Il significato costituzionale dell'obbligo di motivazione. p. 40. Amparando-se igualmente nas lições de Trocker, v. GOMES FILHO, Antonio Magalhães. A Motivação das Decisões Penais. p. 68.

${ }^{351}$ Além disso, a Convenção estabelece que as decisões da Corte Europeia dos Direitos Humanos devem ser motivadas: “Art. 45 Motivation des arrêts et décisions 1. Les arrêts, ainsi que les décisions déclarant des requêtes recevables ou irrecevables, sont motivés".
} 
confiança da opinião pública em uma justiça objetiva e transparente, um dos fundamentos de toda sociedade democrática". 352

Em países do common law, até há pouco tempo inexistia o dever legal de motivar as decisões judiciais. ${ }^{353}$ Tratava-se de uma longa tradição, em parte explicada pela utilização generalizada do júri popular até a metade do século XIX. ${ }^{354}$ Mas isso não significa que as decisões fossem imotivadas. O próprio sistema do stare decisis dependia da exposição de razões das decisões dos tribunais, especialmente os superiores, na medida em que decisões imotivadas não possuíam eficácia vinculante. ${ }^{355}$ Por isso, era usual referirse à motivação como um dever inerente ao common law (“common law duty"). ${ }^{356}$

No início da década de 70, ao relatar o sistema processual inglês sob a perspectiva das garantias fundamentais das partes, Jolowicz explicou que o litigante poderia até não ter um direito a decisões motivadas, mas as decisões imotivadas eram raras, se é que realmente existiam. Segundo o autor, caso a falta de motivação fosse

\footnotetext{
${ }^{352} \mathrm{Na}$ versão original francesa: "Il ressort de la jurisprudence précitée que la Convention ne requiert pas que les jurés donnent les raisons de leur décision et que l'article 6 ne s'oppose pas à ce qu'un accusé soit jugé par un jury populaire même dans le cas où son verdict n'est pas motivé. Il n'en demeure pas moins que pour que les exigences d'un procès équitable soient respectées, le public et, au premier chef, l'accusé doit être à même de comprendre le verdict qui a été rendu. C'est là une garantie essentielle contre l'arbitraire. Or, comme la Cour l'a déjà souvent souligné, la prééminence du droit et la lutte contre l'arbitraire sont des principes qui sous-tendent la Convention (parmi d'autres, voir, mutatis mutandis, Roche c. Royaume-Uni [GC], $n^{o}$ 32555/96, § 116, CEDH 2005-X). Dans le domaine de la justice, ces principes servent à asseoir la confiance de l'opinion publique dans une justice objective et transparente, l'un des fondements de toute société démocratique (voir Suominen c. Finlande, $n^{o}$ 37801/97, \& 37, $1^{\text {er }}$ juillet 2003 et Tatichvili c. Russie, $n^{o} 1509 / 02$, \& 58, CEDH 2007-III)".

${ }^{353}$ Fato reconhecido expressamente pela Corte de Apelação inglesa (Court of Appeal) no julgamento do caso English v. Emery Reimbold \& Strick Ltd.: "There is a general recognition in the common law jurisdictions that it is desirable for Judges to give reasons for their decisions, although it is not universally accepted that this is a mandatory requirement". (2002) 1 WLR 2409, CA. V. também WATSON, Garry D. Fundamental guarantees of litigants in civil proceedings in Canada. p. 235; e AKEHURST, Michael. Statements of reasons for judicial and administrative decisions. p. 154 e ss.

${ }^{354}$ Cf. TAGGART, Michael. Should Canadian judges be legally required to give reasoned decisions in civil cases? p. 2.

${ }^{355}$ Cf. CROSS, Rupert; HARRIS, J. W. Precedent in English Law. p. 158-161.

${ }^{356}$ Cf. V. HO, H. L. The judicial duty to give reasons. p. 45. O autor aponta a existência de decisões na Inglaterra que, ainda em 1877, já acenavam para um dever de motivação (p. 43, nota 10).
} 
difundida, certamente haveria um clamor geral por uma lei corretiva. ${ }^{357}$ De acordo com Garry Watson, essas considerações aplicavam-se igualmente ao Canadá. ${ }^{358}$

O panorama atual é outro. ${ }^{359}$ Em 1997, ao julgar o caso Coleman v. Dunlop Ltd., o juiz da Corte de Apelação inglesa (Court of Appeal) Lord Justice Henry Brooke reconheceu inexistir um dever legal de motivação, mas salientou que o common law era "algo vivo" e havia evoluído ao ponto de se concluir que o juiz deve dar razões suficientes para esclarecer suas conclusões. ${ }^{360}$ A partir da recepção pelo Direito inglês da Convenção para Proteção dos Direitos Humanos em 2000, a motivação tornou-se um dever supralegal. ${ }^{361}$ Há vários precedentes da Court of Appeal nesse sentido. Em Flannery v. Halifax Estate Agencies Ltd, julgado no ano de 2000, o mesmo Lord Justice Henry Brooke sustentou que o dever de motivação é uma função ligada ao devido processo e à justiça. As partes devem saber com exatidão por que ganharam ou perderam, além de poderem avaliar se a decisão está equivocada, permitindo-lhes que recorram adequadamente. A necessária motivação ainda produziria decisões de melhor qualidade. ${ }^{362}$

${ }^{357}$ JOLOWICZ, J. A. Fundamental guarantees in civil litigation: England. p. 168-169.

${ }^{358}$ WATSON, Garry D. Fundamental guarantees of litigants in civil proceedings in Canada. p. 236: “( ...) Canadian courts almost invariably do give either oral or written reasons for their decisions. Further, I think that it is true to say of Canada, as Mr. Jolowicz has said regarding England, that if the general practice of the courts were to change there would almost certainly be an immediate demand for legislation requiring the courts to give reasons for their decisions. As matters stand at the moment, few member of the legal profession would defend the occasional failure of judges to give reasons for their decisions".

${ }^{359}$ Com exceção dos Estados Unidos da América, cf. SCHAUER, Frederick. Thinking Like a Lawyer. p. 175180. Ao tratar do tema em 1986, John DAWSON informou que em 29 dos 50 Estados havia uma determinação constitucional (15 deles) ou legal (14 deles) para que as cortes mais altas motivassem por escrito todas as suas decisões finais (Oracles of the Law. p. 87).

${ }^{360}$ V. HO, H. L. The judicial duty to give reasons. p. 42-43. O trecho citado da decisão é o seguinte: "It is true that, in relation to matters in thtese courts, there is no statutory duty on the judge to give reasons. It is also true that for a long time it has been contended that the common law imposed no such duty. But the common law is a living thing, and it seems to me that the point has now come where the common law has evolved to the point that the judge, on the trial of the action, must give sufficient reasons to make clear his findings of primary fact and the inferences that he draws from those primary facts and sufficient to resolve the live issues before him, explaining why he has drawn those inferences".

${ }^{361}$ V. o artigo recente de ANDREWS, Neil. Decisões judiciais e o dever de fundamentar: a experiência inglesa. p. 107-108; v. também HO, H. L. The judicial duty to give reasons. p. 46.

362 (2000) 1 WLR 377, CA. No original: “(1) The duty is a function of due process, and therefore of justice. Its rationale has two principal aspects. The first is that fairness surely requires that the parties especially the 
No Canadá, a Corte Suprema decidiu, em 2002, que o juiz havia cometido um "erro de direito" ao deixar de "dar motivos suficientemente inteligíveis". ${ }^{633}$ De acordo com a decisão, "os motivos do julgamento constituem o principal mecanismo pelo qual os juízes prestam contas às partes e à população das decisões que pronunciam"; ademais, não basta prestar a justiça, é preciso que "seja manifesto que a justiça foi prestada". 364

\section{Motivação das decisões judiciais e Estado de Direito}

A análise histórica do dever de motivação das decisões judiciais demonstra o estreito vínculo existente entre a garantia e o grau de desenvolvimento das instituições de determinado Estado e determinada sociedade. Em diversos momentos históricos a motivação foi promovida para atribuir-se mais racionalidade e transparência à atividade estatal; a sua previsão expressa em constituições promulgadas logo após a queda de regimes ditatoriais é exemplo sonoro disso.

No Brasil, já foi mencionado, o dever de motivação possui previsão constitucional expressa. A inserção do dispositivo na Constituição foi medida de indubitável prudência. Não resolveu, é verdade, todas as graves anomalias verificadas com frequência na praxe forense: ${ }^{365}$ decisões imotivadas ou, muitas vezes, parcialmente

losing party should be left in no doubt why they have won or lost. This is especially so since without reasons the losing party will not know (as was said in Ex parte Dave) whether the court has misdirected itself, and thus whether he may have an available appeal on the substance of the case. The second is that a requirement to give reasons concentrates the mind; if it is fulfilled, the resulting decision is much more likely to be soundly based on the evidence than if it is not".

${ }^{363}$ R c. Sheppard, 2002 CSC 26, [2002] 1 R.C.S. 869

${ }^{364}$ No original: "Les motifs de jugement constituent le principal mécanisme par lequel les juges rendent compte aux parties et à la population des décisions qu'ils prononcent. Les tribunaux disent souvent qu'il faut non seulement que justice soit rendue, mais qu'il soit manifeste qu'elle a été rendue, ce à quoi les critiques répondent qu'il est difficile de voir comment il pourrait être manifeste que justice a été rendue si les juges n'exposent pas les motifs de leur actes". V. também os comentários de HO, H. L. The judicial duty to give reasons. p. 48 e ss. sobre o panorama atual na Austrália.

${ }^{365}$ Anomalias que já apontadas pouco antes da promulgação da Constituição por TUCCI, José Rogério Cruz e. A Motivação da Sentença no Processo Civil. p. 153. Segundo o autor, antes de 1988 existiam "inúmeras e inadmissíveis distorções encontradiças na praxe forense de todo o País, dentre as quais, as que admitem como suficiente a motivação aparente ou implícita, ou aquelas que simplesmente adotam as razões expendidas por um dos integrantes do processo". 
motivadas sob a chancela de um inaceitável entendimento jurisprudencial de que 'o juiz não está obrigado a se manifestar sobre todas as alegações das partes'. De todo modo, a previsão constitucional deu nova dignidade à garantia, assentando definitivamente que todas as decisões, independentemente da espécie ou do órgão prolator, devem ser motivadas.

Mas se o art. 93, IX, da Constituição é de extrema importância, a verdadeira dignidade constitucional do dever de motivação decorre de seu inafastável vínculo com o Estado de Direito.

Explicou-se no Capítulo anterior que o Estado de Direito é o Estado da razão; aquele que refuta o subjetivismo e a arbitrariedade da atuação estatal. Considerando que a racionalidade do raciocínio jurídico pressupõe que toda asserção seja acompanhada das suas razões e seja passível de confrontação, ${ }^{366}$ não é preciso muito aprofundamento para concluir que a racionalidade da decisão judicial depende da exposição de seus motivos de maneira clara, coerente e completa.

Isso quer dizer que o Estado de Direito, louvavelmente compreendido como o "Estado que se justifica", não pode agir sobre o patrimônio jurídico do indivíduo sem justificar essa intromissão; ${ }^{367}$ caso contrário, agirá de maneira ilegítima e arbitrária. ${ }^{368} \mathrm{~A}$ justificação dada pelo Estado deve ser material, pois juridicamente fundamentada, e formal, expondo-se e demonstrando-se o fundamento da atuação. ${ }^{369}$

O dever de motivação afasta a concepção enraizada por séculos na consciência coletiva de que as decisões judiciais, por serem manifestações de autoridade e poder, não precisam ser justificadas, e aloca o poder jurisdicional no mesmo plano do

\footnotetext{
${ }^{366}$ Cf. MACCORMICK, Neil. Rhetoric and Rule of Law. p. 17; v. também TARUFFO, Michele. La Prueba de los Hechos. p. 435-438.

${ }^{367}$ BARBOSA MOREIRA, José Carlos. Prueba y motivación de la sentencia. p. 107: "El Estado de Derecho no está autorizado para interferir em nuestra esfera personal sin justificar su interferência”.

${ }^{368}$ Nesse sentido, em conceituação de rara felicidade, o jurista alemão Jürgen BRÜGGEMANN já havia definido o Estado de Direito como rechtsfertigender Staat, isto é, o "Estado que se justifica". Die richterliche Begründungspflicht. Berlim, 1971. p. 161, citado por BARBOSA MOREIRA, José Carlos. A motivação das decisões judiciais como garantia inerente ao Estado de Direito. p. 117.

${ }^{369}$ V. BARBOSA MOREIRA, José Carlos. A motivação das decisões judiciais como garantia inerente ao Estado de Direito. p. 117.
} 
jurisdicionado, impondo-lhe a prestação de contas de seus atos àqueles que compõem a fonte do seu próprio poder. ${ }^{370} \mathrm{O}$ dever de motivação é, portanto, uma garantia inerente ao Estado de Direito. ${ }^{371}$ Um autêntico produto da superação da lógica absolutista de que o indivíduo estava abaixo do rei pela lógica iluminista de que o Estado serve para realizar o indivíduo. ${ }^{372}$ Como diria Calamandrei, "o juiz não se contenta mais em comandar, não se limita mais ao 'sic volo sic iubeo' pronunciado do alto de seu trono, mas desce ao nível do jurisdicionado e, enquanto comanda, procura explicar-lhe a racionalidade daquele comando". 373

Toda decisão jurisdicional imotivada é, invariavelmente, uma decisão ilegítima e arbitrária. Sem a adequada exposição racional das razões que o justificam, o ato decisório adquire feições subjetivistas e torna impossível o controle da atividade do

${ }^{370}$ Cf. AMODIO, Ennio. Motivazione della sentenza penale. p. 188. Também nesse sentido, amparando-se igualmente nas lições de Ennio Amodio, GOMES FILHO, Antonio Magalhães. A Motivação das Decisões Penais. p. 80.

${ }^{371} C f$., dentre outros, DINAMARCO, Cândido Rangel. O dever de motivar e a inteireza da motivação. p. 941: "No estado-de-direito, em que o poder se autolimita e seu exercício só se considera legítimo quando fiel a regras procedimentais adequadas (Niklas Luhmann, Elio Fazzalari), é natural que à liberdade de formar livremente o seu convencimento no processo corresponda, para o juiz, o dever de motivar suas decisões"; BARBOSA MOREIRA, José Carlos. A motivação das decisões judiciais como garantia inerente ao Estado de Direito. p. 123: “A motivação das decisões judiciais, como expressão da 'justificação formal' dos atos emanados do Poder a que compete, por excelência, a tutela da ordem jurídica e dos direitos subjetivos, constitui garantia inerente ao Estado de Direito"; TARUFFO, Michele. Il significato costituzionale dell'obbligo di motivazione. p. 40: "In questo contesto, l'obbligo di motivazione dei provvedimenti giurisdizionale si configura come garanzia e principio generale della giurisdizione nello Stato di Diritto"; e NERY JÚNIOR, Nelson. Princípios do Processo na Constituição Federal. p. 288-289: “A menção expressa da necessidade de motivação das decisões judiciais no texto constitucional não significa que somente se adotada semelhante regra pelo legislador constituinte é que terá validade e eficácia. Muito ao contrário, a motivação das decisões judiciais surge como manifestação do estado de direito, anterior, portanto, à letra da norma constitucional que a refira expressamente".

${ }^{372}$ V. TARUFFO, Michele. Il significato costituzionale dell'obbligo di motivazione. p. 41. Nas palavras de EVANGELISTA, Stefano. Motivazione della sentenza civile. p. 154: "L'introduzione dell'istituto della motivazione rappresenta uno degli ultimi prodotti della tendenza alla 'razionalizzazione del potere,”.

${ }^{373}$ CALAMANDREI, Piero. Processo e democrazia. p. 664. No original: "Il gudice non si contenta più di comandare, non si limita più al 'sic volo, sic iubeo' pronunciato dall'alto del soglio, mas scende al livello del giudicabile e, mentre comanda, cerca di spiegargli la ragionevolezza di quel comando". 
magistrado tanto em relação ao convencimento fático como em relação à interpretação e à aplicação do Direito. ${ }^{374}$

A exigência de motivação, portanto, liga-se à irrefutável necessidade de se demonstrar que a decisão tomada pelo magistrado é legítima e correta, tanto porque decorrente de um devido processo legal, como porque aplicado o Direito material previamente estipulado pelo legislador e conhecido pelas partes, seus advogados e toda a sociedade.

\subsection{A legitimação da atividade jurisdicional}

Embora o Estado de Direito seja o "Estado que se justifica", nem todo ato estatal deve ser formalmente justificado. A exigência de justificação formal dos atos estatais fica mitigada quanto à atividade legiferante exercida pelo Poder Legislativo, o que se explica por sua "legitimação primária". ${ }^{375}$ Os parlamentares são representantes do povo e atuam sob o manto da soberania popular, motivo pelo qual os atos legislativos devem ser justificados apenas materialmente a partir da Constituição. ${ }^{376}$

O mesmo não ocorre em relação aos Poderes Executivo e Judiciário. Enquanto este deve motivar todas as decisões judiciais, a Administração deve motivar os atos que, dentre outras hipóteses, neguem, limitem ou afetem direitos ou interesses, ou imponham ou agravem deveres, encargos ou sanções (art. 50, I e II, da Lei 9.784/99). Assim, a validade de qualquer ato administrativo ou jurisdicional que interfira na esfera jurídica do indivíduo está condicionada à exposição clara e coerente de suas razões. Uma

\footnotetext{
${ }^{374}$ Afirmou LIEBMAN que "A história do processo, nos últimos séculos, pode ser concebida como a história dos esforços feitos por legisladores e juristas no sentido de limitar o âmbito de arbítrio do juiz, e fazer com que as operações que realiza submetam-se aos imperativos da Razão. (...) Um momento bastante importante desse movimento histórico é o que diz respeito à exigência de que o juiz motive a sentença". Do arbitrio à razão: reflexões sobre a motivação da sentença. p. 79. Em sentido muito parecido, IACOVIELLO, Francesco M. La Motivazione della Sentenza Penale e il sua Controllo in Cassazione. p. 2: "Giudicare è un potere terribile. La storia del processo penale è la storia dei tentativi per imbrigliare tale potere. La motivazione è uno di questi tentativi”.

${ }^{375}$ GOMES FILHO, Antonio Magalhães. A Motivação das Decisões Penais. p. 77.

${ }^{376}$ Não custa lembrar que, sob um prisma político e democrático, os membros do Parlamento dependem da contínua justificação formal de seus atos perante os eleitores, especialmente quando pretendem ser reconduzidos a seus cargos.
} 
autêntica justificação do exercício da atividade estatal a partir da demonstração de que, como foi dito logo acima, está amparada no Direito vigente.

Mas a obrigatória motivação dos atos jurisdicionais é ainda mais relevante. Se, como explica Antonio Magalhães Gomes Filho, os atos administrativos são submetidos a um controle hierárquico que, muitas vezes, culmina com a revisão pelo Chefe do Poder Executivo, eleito democraticamente e com mandato temporário, ${ }^{377} \mathrm{o}$ mesmo não pode ser dito das decisões judiciais. A atividade jurisdicional não extrai a sua legitimidade da escolha popular. ${ }^{378} \mathrm{~A}$ atividade jurisdicional extrai a sua legitimidade de seu exercício procedimentalizado, da participação efetiva das partes no processo, e da juridicidade e racionalidade das decisões ao final proferidas. ${ }^{379}$ Racionalidade que depende, sempre, da demonstração de que as decisões estão fundadas nas normas jurídicas que regem a sociedade e nos fatos devidamente provados pelas partes mediante o exercício do contraditório e da ampla defesa. ${ }^{380}$ A motivação das decisões judiciais, destarte, é elemento indispensável para a legitimação da atividade jurisdicional. ${ }^{381}$

6.2. O controle da atividade jurisdicional

Além de legitimar a atividade jurisdicional, a motivação das decisões judiciais desempenha outra função, que talvez seja a mais importante dentre todas as que lhe são inerentes. A motivação das decisões judiciais é o mais poderoso instrumento de controle do exercício da função jurisdicional pelos juízes de que dispõem as partes e a sociedade.

\footnotetext{
${ }^{377}$ GOMES FILHO, Antonio Magalhães. A Motivação das Decisões Penais. p. 79.

${ }^{378}$ V. MARINONI, Luiz Guilherme. Teoria Geral do Processo. p. 407.

${ }^{379}$ Eduardo Cambi fala em duas fontes de legitimação: uma formal, decorrente da sujeição do juiz à lei e outra substancial, "pela qual cabe ao Judiciário assegurar os direitos fundamentais dos cidadãos" (Neoconstitucionalismo e Neoprocessualismo. p. 280). Parece, todavia, que a mera juridicidade (e não legalidade) do provimento jurisdicional bastaria para dar conta de ambas as fontes de legitimação citadas. A juridicidade da decisão supõe conformidade com o ordenamento jurídico brasileiro e, consequentemente, realização dos direitos fundamentais.

${ }^{380}$ V. MARINONI, Luiz Guilherme. Teoria Geral do Processo. p. 104.

${ }^{381}$ Cf. TARUFFO, Michele. Il significato costituzionale dell'obbligo di motivazione. p. 42.
} 
6.2.1. Controle em relação aos fatos: livre convencimento racional e motivado à luz dos autos

Em todo e qualquer processo judicial, o juiz deve conhecer de pontos jurídicos e pontos fáticos. Pode ser que o processo contenha questões (pontos controversos) $)^{382}$ meramente fáticas, questões meramente jurídicas ou questões fáticas e jurídicas; mas todo processo terá pontos fáticos $e$ jurídicos que justificarão materialmente a decisão em um ou em outro sentido.

Especificamente quanto à matéria fática, compete ao magistrado convencerse de maneira relativamente livre a respeito da veracidade de cada alegação a partir das provas produzidas no processo. Esse convencimento reflete a superação parcial do sistema da prova legal no processo civil moderno, ${ }^{383}$ já que, neste, a própria lei gradua, limita, exclui ou determina a prova a ser produzida em cada caso. ${ }^{384}$ Para o sistema do livre convencimento, toda prova pode exercer uma influência distinta no espírito crítico do julgador, dependendo do contexto em que é produzida. ${ }^{385}$ Uma testemunha pode transmitir mais credibilidade do que outra, a confluência de depoimentos testemunhais pode desacreditar um documento, um laudo técnico produzido pelo assistente técnico de uma das partes pode ser mais convincente do que o laudo produzido pelo perito judicial etc.

\footnotetext{
${ }^{382}$ A diferenciação entre ponto e questão tornou-se célebre na obra de Carnelutti. Para o Mestre italiano, a questão é uma "dúvida acerca de uma razão" que fundamenta a pretensão do autor ou a contestação do réu. V. CARNELUTTI, Francesco. Instituciones del proceso civil, v. I. p. 36-37.

${ }^{383}$ Como disse PONTES DE MIRANDA, Comentários ao Código de Processo Civil, t. II. p. 377, "Nunca o homem conseguiu a verdade sem pensar com liberdade e sem partir de fatos e se ater a eles, ainda quando, em ciência, usasse hipóteses de trabalho". Sobre o sistema da prova legal, de forma clara e resumida, v. SANTOS, Moacyr Amaral. Primeiras Linhas de Direito Processual Civil, v. 2. p. 377-378. V. também ALVARO DE OLIVEIRA, Carlos Alberto. Livre apreciação da prova ... passim.

${ }^{384}$ Superação parcial porque ainda há importantes e necessárias hipóteses de prévia tarifação da prova pela lei. É o exemplo do disposto nos arts. 401 e 403 do Código de Processo Civil que, em prol da segurança, restringem a produção de prova exclusivamente testemunhal em relação à existência de contratos com valor superior ao décuplo do salário mínimo vigente, bem como do pagamento ou remissão da dívida. Em sentido um pouco diverso, mas chegando às mesmas conclusões, Flávio YARSHELL considera que o dispositivo citado limita os meios de prova à disposição das partes. V. Antecipação da Prova sem o Requisito da Urgência... p. 85.

${ }^{385}$ Cf. DINAMARCO, Cândido Rangel. Instituições de Direito Processual Civil, v. III. p. 101-104.
} 
Mas se o sistema do livre convencimento é um inegável avanço em comparação com o sistema da prova tarifada, certo é que a sua adoção irrestrita atribuiria poderes desmedidos aos magistrados. O livre convencimento puro e simples, também chamado de sistema do convencimento íntimo, não consegue controlar a atividade jurisdicional, legitimando julgamentos decorrentes de um convencimento fático arbitrário e irresponsável. ${ }^{386}$ Sem saber quais fatos serão aceitos como verdadeiros pelo magistrado e por quê, toda a atividade probatória das partes no processo torna-se irrelevante ou, ao menos, dependente da boa vontade do julgador. Ademais, a própria realização dos direitos (subjetivos e objetivo) fica prejudicada, uma vez que a negativa de fatos cabalmente provados impediria a incidência da norma vigente. Com exceção do instituto do júri popular, cuja legitimação vem da oportunização de um julgamento por pares extraídos do povo, ${ }^{387}$ o sistema do livre convencimento íntimo, como bem explica Cândido Dinamarco, gera "extrema insegurança" e é, por isso, "inimigo do Estado-de-direito". ${ }^{388}$

Do convencimento judicial, para ser condizente com os valores inerentes ao Estado de Direito, exige-se que seja: (a) racional, (b) fundado exclusivamente nos elementos constantes dos autos do processo e (c) motivado (art. 131 do CPC). Daí falar-se em "livre convencimento racional e motivado à luz dos autos". 389

(a) A racionalidade do convencimento judicial é uma exigência do ideal do Estado de Direito, característica que deve obrigatoriamente revestir todo ato estatal. Significa que o resultado obtido deve ter sido alcançado pelas "forças do intelecto" e não por "impulsos pessoais e eventualmente passionais do juiz". Assim, as conclusões judiciais

\footnotetext{
${ }^{386}$ Cf. SANTOS, Moacyr Amaral. Primeiras Linhas de Direito Processual Civil, v. 2. p. 378-379.

${ }^{387}$ Explica CALAMANDREI que o instituto do júri é uma construção inspirado nas ideias oitocentistas da soberania popular e, essencialmente, contrário ao totalitarismo. Justamente por isso, foi abolido na Itália fascista. Processo e democrazia. p. 664.

${ }^{388}$ DINAMARCO, Cândido Rangel. Instituições de Direito Processual Civil, v. III. p. 104. Com efeito, o sistema do convencimento íntimo nasceu para mal servir. Em 1793, quando os Revolucionários substituíram o despotismo do ancien régime por uma nova ditadura, alteraram o sistema de convencimento judicial para que o Tribunal Revolucionário pudesse processar e condenar à morte os adversários políticos mais rapidamente. Em pouco mais de um ano foram condenadas à morte 2625 pessoas. V. CAMBI, Eduardo. Neoconstitucionalismo e Neoprocessualismo. p. 324-325.

389 DINAMARCO, Cândido Rangel. Instituições de Direito Processual Civil, v. III. p. 105-107; v. também PONTES DE MIRANDA, Comentários ao Código de Processo Civil, t. II. p. 383-384; SANTOS, Moacyr Amaral. Primeiras Linhas de Direito Processual Civil, v. 2. p. 380-381.
} 
devem ser pautadas por motivos traduzíveis em elementos razoáveis e convincentes a uma "pessoa inteligente e sensível à realidade". 390

(b) Apenas aquilo que é produzido dentro de cada processo pode ser levado em consideração pelo juiz em suas decisões. Essa é medida imprescindível ao respeito de uma grande quantidade de garantias atribuídas às partes, que vão desde o respeito ao contraditório até a observância da inércia jurisdicional e imparcialidade do magistrado. ${ }^{391}$

(c) Por fim, "não basta o juiz estar convencido - deve ele demonstrar as razões de seu convencimento". ${ }^{392}$ De fato, os motivos razoáveis e convincentes que fundam o ato devem ser exteriorizados às partes e à sociedade a fim de racionalizá-lo e torná-lo passível de controle, justificando-se-o formalmente. A motivação é indispensável para a legitimação do convencimento judicial porque serve a demonstrar a sua racionalidade, a sua correção e a sua formação a partir de elementos inscritos unicamente dentro do universo processual. ${ }^{393}$

\subsubsection{Controle em relação ao Direito}

O barão Charles-Louis de Secondat foi um dos muitos beneficiados pela venalidade da magistratura francesa dos séculos XVII e XVIII. Descendente de uma antiga e importante família de magistrados, aos 27 anos (1716) recebeu o nome Montesquieu e o cargo de 'président à mortier' do Parlamento de Bordeaux como herança de seu tio. ${ }^{394}$ Montesquieu conhecia profundamente o Judiciário francês e sabia que a concentração excessiva de poderes nas mãos dos magistrados sempre seria fonte de abusos: fato também demonstrado pela História e pela experiência de outros países europeus da época,

\footnotetext{
${ }^{390}$ DINAMARCO, Cândido Rangel. Instituições de Direito Processual Civil, v. III. p. 106.

${ }^{391}$ V. PONTES DE MIRANDA, Comentários ao Código de Processo Civil, t. II. p. 384-388.

${ }^{392}$ MARINONI, Luiz Guilherme. Teoria Geral do Processo. p. 26.

393 DINAMARCO, Cândido Rangel. Instituições de Direito Processual Civil, v. III. p. 107: "O convencimento do juiz precisa ser motivado, porque sem o dever de motivar as decisões de nada valeriam as exigências de racionalidade e atenção ao que consta dos autos"; v. também GOMES FILHO, Antonio Magalhães. A Motivação das Decisões Penais. p. 145-148.

${ }^{394}$ Cf. CAPPELLETTI, Mauro. Repudiating Montesquieu? p. 11-12; v. também a cronologia da vida do autor disponível em MONTESQUIEU. De l'Esprit des Lois, t. I. p. 72.
} 
reiteradamente citados pelo autor. ${ }^{395}$ A corrupção enraizada, a disputa pelo poder com a Coroa, a arbitrariedade e a precariedade do sistema Judiciário, a má qualidade das decisões judiciais, dentre outros, eram apenas exemplos das consequências decorrentes da atribuição de poderes excessivos a uma pessoa ou a um grupo de pessoas. Estava claro para Montesquieu, portanto, que a efetiva liberdade dos indivíduos dependia da separação entre o poder de julgar e os Poderes Legislativo e Executivo. ${ }^{396}$ Essa é a razão pela qual o filósofo francês defendeu, radicalmente, a retirada de todo o poder político dos magistrados. $^{397}$

Independentemente de eventuais falhas na estrutura original da teoria da separação dos poderes, que acabou menosprezando a importância do Judiciário no controle da atividade do Legislativo - criando aquilo que Carré de Malberg chamou de "Estado Legal" -, o núcleo da ideia ainda é perfeitamente válido: aquele que julga não pode criar o Direito. ${ }^{398}$ Pelo contrário, aquele que julga também está submetido ao Direito; e sua função jurisdicional consiste em justamente dar efetividade às normas jurídicas que regem os

${ }^{395}$ MONTESQUIEU. De l'Esprit des Lois, t. I. p. 327 e ss. Montesquieu cita, dentre outros, os cinco éforos de Esparta, magistrados incumbidos de fiscalizar as atividades do rei que acabaram tornando-se os verdadeiros governantes.

${ }^{396}$ Ibidem. p. 328: "Il n'y a point encore de liberté si la puissance de juger n'est pas séparée de la puissance législative et de l'exécutrice. Si elle était jointe à la puissance législative, le pouvoir sur la vie et la liberté des citoyens serait arbitraire : car le juge serait législateur. Si elle était jointe à la puissance exécutrice, le juge pourrait avoir la force d'un oppresseur".

${ }^{397}$ Cf. MARINONI, Luiz Guilherme. Teoria Geral do Processo. p. 26.

${ }^{398}$ Embora MONTESQUIEU tenha, realmente, relegado o Poder Judiciário a um segundo plano, o tom das críticas desferidas contra a sua teoria, algumas vezes decorrentes de meras reproduções irrefletidas, nem sempre é justo. Quando o autor francês chamou o Poder Judiciário de um "poder nulo", fê-lo porque defendia a temporariedade do exercício da atividade judicial. Assim, "o poder de julgar, tão terrível entre os homens, não estando atrelado nem a um certo estado, nem a uma certa profissão, torna-se, por assim dizer, invisível e nulo. Não se tem um juiz sempre debaixo dos olhos; e teme-se a magistratura, e não os magistrados" (De l'Esprit des Lois, t. I. p. 330. Tradução livre). Além disso, a preocupação em tornar o juiz mero "boca da lei" vem da tentativa de aumentar a segurança jurídica. Para Montesquieu, os julgamentos devem ser apenas “o texto preciso da lei" porque, se as decisões fossem "uma opinião particular do juiz, viver-se-ia na sociedade sem saber precisamente as consequências do que se contrata" (De l'Esprit des Lois, t. I. p. 330). Ou seja, a inaptidão parcial da teoria para atingir seus objetivos não retira a legitimidade dos seus propósitos, nem descaracteriza o inegável avanço que representou à época em que foi formulada e a inestimável contribuição ao desenvolvimento das ciências política e jurídica ocidentais. 
casos concretos que lhe são postos para julgamento, pacificando a sociedade mediante a proteção e a realização da ordem jurídica vigente.

Montesquieu, como outros de seus contemporâneos, não enxergou que um verdadeiro controle da atividade jurisdicional dependia da obrigatoriedade de que todas as decisões judiciais proferidas fossem devidamente motivadas. $\mathrm{O}$ autor francês acreditava nas leis e na capacidade do Poder Legislativo de editar leis tecnicamente perfeitas; crença que a História e o desenvolvimento científico mostraram estar equivocada.

Nesse mesmo erro não incidiram os revolucionários franceses. Preocupados com a efetiva aplicação, pelos juízes, do Direito criado pelo legislador, eles sabiam que o controle da juridicidade da decisão deveria ser realizado posteriormente, pois nada impediria que um juiz ignorasse a lei previamente elaborada ou a aplicasse equivocadamente. As considerações dos constituintes Thouret e Chabroux (ponto 5.6.2) são muito claras nesse sentido.

De fato, não basta apresentar ao juiz um corpo de dispositivos legais e esperar que ele os aplique mecanicamente. Por mais claro que seja um texto, o significado nele contido só pode ser extraído por um processo de interpretação que vai além da letra da lei e atinge o sistema jurídico como um todo. ${ }^{399}$ Os sistemas jurídicos, ensinava Pontes de Miranda, são "sistemas lógicos" que devem ser interpretados para que se revelem as regras jurídicas que dele fazem parte; regras que podem ter sido escritas ou não ter sido escritas, mas que existem da mesma forma neste sistema. ${ }^{400}$

Atualmente parece desnecessário dizer que o controle jurídico de uma decisão judicial vai muito além da mera indicação de um dispositivo legal. Não só porque a norma jurídica não se confunde com o texto normativo, cujo significado varia no tempo e no espaço, ${ }^{401}$ mas também pela sempre crescente complexidade da sociedade, fato que impõe ao legislador a busca de novas técnicas legislativas que impeçam o engessamento da

\footnotetext{
${ }^{399}$ GRAU, Eros Roberto. Ensaio e Discurso sobre a Interpretação/Aplicação do Direito. p. 44.

${ }^{400}$ PONTES DE MIRANDA, Francisco Cavalcanti. Tratado de Direito Privado, t. I. p. IX e XII-XIII.

${ }^{401}$ Lembrando-se que o Direito, depois de criado, não é do legislador, mas da sociedade por ele regida. V. Ibidem. p. XII: a regra jurídica "foi para ser ouvida e lida pelos que hão de observá-la e é para ser lida, hoje, por eles. Nem o que estava na psique dos que a criaram, nem o que está na psique dos que hoje a criam, têm outro valor além do que serve à explicitação do que é que foi ouvido e lido por aquêles a que foi dirigida, ou o é por aquêles a quem hoje se dirige".
} 
sociedade e permitam o julgamento do maior número possível de casos a partir da interpretação de um mesmo texto normativo. O exemplo mais sonoro disso é a ampla utilização de cláusulas gerais e de conceitos indeterminados nos textos normativos mais recentes, cujo significado deve ser extraído da análise das demais normas jurídicas que compõem o sistema jurídico (sobretudo aquelas hierarquicamente superiores). ${ }^{402}$ Por outro lado, o desenvolvimento dos direitos fundamentais e da teoria dos princípios, com reconhecida eficácia normativa, faz com que muitos casos sejam regidos por mais de uma norma jurídica simultaneamente, exigindo-se do magistrado processos cognitivos cada vez mais complexos para a definição da norma aplicável e a consequente tomada de decisão.

É óbvio que nada disso faz supor que o Direito positivado tenha perdido importância ou que tenha deixado de reger a sociedade; conclusão a que só se pode chegar a partir de uma má compreensão do que realmente significa o 'positivismo jurídico'. Os adeptos daquilo que se convencionou chamar "pós-positivismo", termo que supõe a superação do modelo anterior, muitas vezes não percebem que as críticas que desferem corretamente contra características da teoria clássica do Direito, tais quais (a) identificação do Direito com a lei, (b) prevalência absoluta das regras sobre os princípios, (c) formalismo, (d) confusão entre validade e legitimidade da norma, dentre outras, são críticas contra uma determinada maneira de compreender o Direito, mas não contra o positivismo. ${ }^{403}$ A base teórica da moderna Teoria do Direito é exatamente a mesma da Teoria clássica do Direito: superação do jusnaturalismo pela "domesticação das fontes de produção do direito" pelo Estado Moderno, preponderando-se o Direito estatal sobre o Direito não estatal, como o costumeiro ou o divino. ${ }^{404}$ Considerando que a Constituição mesma é um diploma normativo positivado, a defesa de um "Estado Constitucional" em detrimento de um "Estado de Direito legislativo"405 não significa, de forma alguma,

\footnotetext{
${ }^{402}$ V. GÓES, Gisele Santos Fernandes. Existe Discricionariedade Judicial? Discricionariedade X Termos Jurídicos Indeterminados e Cláusulas Gerais. p. 92: “E como manejar na decisão judicial os termos indeterminados e cláusulas gerais? Deve o juiz socorrer-se dos princípios jurídicos no momento da interpretação".

${ }^{403}$ Lembrando-se que a teoria da coerência do ordenamento jurídico, a teoria da completude do ordenamento jurídico e a teoria da interpretação mecanicista do ordenamento jurídico não são indispensáveis à teoria do positivismo jurídico. Cf. BOBBIO, Norberto. Il Positivismo Giuridico. p. 250.

${ }^{404}$ Cf. RAMOS, Elival da Silva. Ativismo Judicial. p. 38-39.

${ }^{405}$ Por todos, ZAGREBELSKY, Gustavo. Il diritto mite. passim, especialmente p. 208 e ss.
} 
rompimento com o positivismo, mas rompimento com o legalismo, algo totalmente diverso. ${ }^{406}$ Tanto os positivistas clássicos como os positivistas modernos buscam as respostas para os casos concretos em um Direito positivo. A diferença é que o positivista moderno tem como referencial primário a Constituição e os direitos fundamentais, sendolhe facultado afastar a incidência de uma lei quando substancialmente contrária ao que preceitua a Constituição. Nenhum deles aceita, como regra, que o juiz negue aplicação a uma norma jurídica válida e legítima para julgar segundo a sua consciência ou segundo o seu senso de justiça pessoal.

Esse é justamente o sentido do atual positivismo, denominado de "positivismo moderado" ou "positivismo renovado". ${ }^{4}$ O Direito prevalece não na forma de um texto legal absolutamente claro e definitivo que deve ser simplesmente aplicado mecanicamente pelo juiz aos fatos concretos. ${ }^{408} \mathrm{O}$ Direito prevalece como um dado objetivo que serve de limite ao exercício do poder jurisdicional pelo magistrado, a quem compete descobrir a norma aplicável ao caso concreto por uma atividade interpretativa que leve em consideração o ordenamento como um todo. ${ }^{409}$ As decisões judiciais, portanto, não devem ser legais $;^{410}$ devem ser jurídicas.

\footnotetext{
${ }^{406}$ Muito embora Eduardo CAMBI defenda a superação do positivismo por um "neopositivismo" (expressão mais adequada, pois remete ao novo positivismo e não a um movimento posterior e substitutivo), acaba reconhecendo que a base teórica é a mesma: "O neopositivismo, como consequência filosófica do neoconstitucionalismo, apresenta-se como uma nova forma de interpretação e de aplicação do direito. Parte das bases do positivismo jurídico, procurando mostrar uma outra forma de compreensão do fenômeno jurídico". Neoconstitucionalismo e Neoprocessualismo. p. 83. Um pouco adiante, o autor rejeita a renúncia ao direito positivo: "O positivismo não pode ser superado por meio da renúncia ao direito positivo ou à positividade do direito. Porém, a positividade do direito não se confunde com o legalismo" (Ibidem. p. 84). Ora, se a positividade do direito não se confunde com o legalismo, e se o legalismo é que deve ser afastado, então não há nenhuma razão para se propor um neopositivismo.

${ }^{407}$ Como explica Norberto BOBBIO, é preciso distinguir a versão extremista da versão moderada do positivismo: "la maggior parte delle critiche fatte dagli antipositivisti valgono infatti solo per la versione estremistica ma non per quella moderata". Il Positivismo Giuridico. p. 248.

${ }^{408}$ RAMOS, Elival da Silva. Ativismo Judicial. p. 137.

${ }^{409}$ Essa é basicamente a opinião de RAMOS, Elival da Silva. Ativismo Judicial. p. 137, salvo pelo fato de que o autor entende que a atividade interpretativa do juiz tem natureza criativa.

${ }^{410} \mathrm{O}$ sentido aqui utilizado faz referência à concepção de que o juiz aplica a 'lei'. Não se confunde, portanto, com a 'regra da legalidade'.
} 
Note-se que mesmo aqueles que defendem a criação do Direito pelo juiz, seja mediante a concretização de uma norma abstrata, seja pela interpretação do texto normativo, seja nos casos de suposta lacuna do ordenamento jurídico, ou ainda pela atribuição de eficácia vinculante aos precedentes, não desconsideram de forma alguma a relevância do Direito positivado, nem refutam a sua imperatividade. As lições de Eros Grau são ótimos exemplos disso: "Todo intérprete, embora jamais esteja submetido ao 'espírito da lei' ou à 'vontade do legislador', estará sempre vinculado pelos textos normativos, em especial - mas não exclusivamente - pelos que veiculam princípios (e faço alusão aqui, também, ao 'texto' do direito pressuposto). (...) A 'abertura' dos textos de direito, embora suficiente para permitir que o direito permaneça ao serviço da realidade, não é absoluta. Qualquer intérprete estará, sempre, permanentemente por eles atado, retido. Do rompimento dessa retenção pelo intérprete autêntico resultará a subversão do texto". 411

Por mais "fluido" que o Direito esteja ou venha a ser, ${ }^{412}$ ainda será necessária uma base dogmática para dar parâmetros à tomada de decisão. Por mais principiológico que o Direito esteja ou venha a ser, ainda será necessário que os princípios estejam positivados no sistema jurídico, mesmo que implicitamente. Ao analisar o célebre art. $1^{\circ}, 2$, do Código Civil suíço de $1907,{ }^{413}$ que em caso de lacuna normativa e consuetudinária autoriza ao juiz que julgue como se legislador fosse, Eduardo Couture foi enfático: "[a fórmula] não significa uma permissão em branco para que o juiz faça e desfaça o que ele quiser, mas que sua sentença deve ser emitida em consideração aos princípios gerais que sustentam o direito vigente". ${ }^{414}$ Princípios gerais, frise-se, extraídos não de um Direito natural e metafísico, mas do próprio sistema jurídico positivo. ${ }^{415}$

\footnotetext{
411 GRAU, Eros Roberto. Ensaio e Discurso sobre a Interpretação/Aplicação do Direito. p. 56. V. também ÁVILA, Humberto. Teoria dos Princípios. p. 34-35.

${ }^{412}$ Utilizando-se a expressão consagrada por Gustavo ZAGREBELSKY na obra Il Diritto Mite.

${ }^{413}$ No original: "A défaut d'une disposition légale applicable, le juge prononce selon le droit coutumier et, à défaut d'une coutume, selon les règles qu'il établirait s'il avait à faire acte de législateur".

${ }^{414}$ COUTURE, Eduardo. Fundamentos del Derecho Procesal Civil. p. 252. Igualmente, CAMBI, Eduardo. Neoconstitucionalismo e Neoprocessualismo. p. 270-271. Em sentido contrário, BRIGUGLIO, Antonio Renato. 'Creatività' della giurisprudenza, mutamento giurisprudenziale e giudizio di rinvio. p. 1369-1373.

${ }^{415}$ Nesse sentido, AARNIO, Aulis. Le rationnel comme raisonnable. p. 107; GRAU, Eros Roberto. Ensaio e Discurso sobre a Interpretação/Aplicação do Direito. p. 48: "Insisto: os princípios gerais de direito não constituem criação jurisprudencial; e não preexistem externamente ao ordenamento. A autoridade judicial, ao
} 
Ou seja, a decisão judicial, criativa ou não, deve partir de uma base preestabelecida e deve conformar-se a ela. Como diria Calamandrei, a distinção entre atividade política e atividade jurídica só é possível quando também distintos os momentos legislativo e jurisdicional do Direito. ${ }^{416}$ A partir do momento em que Política e Direito tornam-se inconfundíveis, então não há mais técnica jurídica, nem é mais necessária a existência de juristas; ${ }^{417}$ a sociedade perde todo e qualquer tipo de referencial e descamba para a insegurança, arbitrariedade, injustiça e opressão.

Por isso, seguindo a excelente disposição do art. 113 do codice di procedura civile italiano, "ao pronunciar sobre a causa o juiz deve seguir as normas de direito, salvo quando lei atribuir-lhe o poder de decidir por equidade". ${ }^{418} \mathrm{E}$ ao exigir-se do magistrado que siga as normas de Direito, há que se exigir dele também a prestação de contas da decisão, demonstrando-se em uma motivação clara, coerente e completa a juridicidade do ato jurisdicional.

Quanto mais fluido for o ordenamento jurídico, repise-se, mais premente é a necessidade de que as decisões sejam bem fundamentadas, afastando-se qualquer dúvida sobre o efetivo respeito da ordem jurídica. Nas palavras de Barbosa Moreira, "a motivação é tanto mais necessária quanto mais forte o teor de discricionariedade da decisão, já que apenas à vista dela se pode saber se o juiz usou bem ou mal a sua liberdade de escolha, e sobretudo se não terá ultrapassado os limites da discrição para cair no arbítrio". 419

tomá-los de modo decisivo para a definição de determinada solução normativa, simplesmente comprova a sua existência no bojo do ordenamento jurídico, do direito que aplica, declarando-os. Eles são, destarte, efetivamente descobertos no interior de determinado ordenamento. E o são - repito-o - justamente porque neste mesmo ordenamento (isto é, no interior dele) já se encontravam, em estado de latência”.

${ }^{416}$ CALAMANDREI, Piero. Il nouvo processo civile e la scienza giuridica. p. 467.

${ }^{417}$ Ibidem. p. 467. CALAMANDREI, em outro trabalho, amparado nas lições de Flavio Lopez de Oñate, lembra que "L'opera chiarificatrice del giurista è essenzialmente (...) lotta contro l'arbitrio". Cf. La certezza del diritto e le responsabilità della dottrina. p. 509.

${ }^{418}$ No original: "Nel pronunciare sulla causa il giudice deve seguire le norme del diritto, salvo che la legge gli attribuisca il potere di decidere secondo equità".

${ }^{419} C f$. BARBOSA MOREIRA, José Carlos. A motivação das decisões judiciais como garantia inerente ao Estado de Direito. p. 116. No mesmo sentido, TARUFFO, Michele. Il significato costituzionale dell'obbligo di motivazione. p. 43: "solo mediante il controllo sulla validità di queste ragioni si può stabilire se la decisione deriva dalla legge o dall'arbitrio del giudice". O autor, com razão, explica que uma "legalità non controllabile equivale in realtà ad una non-legalità" (Ibidem. p. 43); o tema é abordado por Luiz Guilherme 
Para aqueles que acreditam que o Direito é criado pelo juiz ao interpretar o texto normativo ou ao preencher lacunas e definir o sentido de cláusulas gerais e conceitos indeterminados, a motivação legitima esta atividade criativa, racionalizando-a e propiciando a discussão sobre a validade da norma jurídica criada. Para aqueles que, como este autor, refutam a criação jurisdicional do Direito, ou mesmo para quem vê nas decisões judiciais a concretização de normas abstratas (teoria unitária do ordenamento jurídico), a motivação serve a demonstrar que a decisão judicial não usurpa poderes legiferantes que não são seus, legitimando igualmente a atividade jurisdicional pela demonstração da juridicidade da decisão.

\subsubsection{O controle das decisões judiciais pelas partes e pelos tribunais}

Os destinatários primários da motivação são as partes. São elas que inicialmente devem analisar o acerto ou equívoco da decisão proferida, a fim que se resignem quanto ao resultado desfavorável e, dependendo do caso, cumpram o comando jurisdicional ou, se entenderem cabível, interponham os recursos e ações autônomas postos à sua disposição para invalidá-la, reformá-la, esclarecê-la ou integrá-la. ${ }^{420}$ Destarte, são as partes que, constatando defeitos na resposta jurisdicional, como, p.ex., má valoração das provas, má distribuição do ônus da prova, desrespeito a certa norma jurídica, interpretação assistemática de dispositivo legal etc., definem o que pretendem com seus recursos ou ações autônomas.

Interposto o recurso, a função de controle da juridicidade da decisão é remetida ao órgão ad quem, que poderá exercê-la de maneira muito mais concreta ao

MARINONI sob a ótica da efetividade do processo, reconhecendo que a compreensão da lei a partir da Constituição "confere ao juiz maior subjetividade, o que vincula a legitimidade da prestação jurisdicional à explicação da sua correção" (A legitimidade da atuação do juiz a partir do direito fundamental à tutela jurisdicional efetiva. p. 234).

420 A doutrina é bastante cética quanto a essa função de convencimento do acerto da decisão, pois a experiência demonstra o uso indiscriminado de recursos contra sentenças bem ou mal fundamentadas, principalmente por litigantes habituais, que dificultam ao máximo a realização do direito da outra parte para tentar reduzir o número de demandas contra si propostas. No entanto, ainda que em pequena escala, e especificamente para litigantes não habituais, a motivação pode, sim, reduzir o número de recursos quando, por sua concretude ou pelos argumentos utilizados, a parte entender ser baixa a probabilidade de êxito na instância recursal. 
invalidar ou reformar a decisão dentro do próprio processo em que foi proferida. $\mathrm{Na}$ hipótese de embargos de declaração, o controle é realizado pelo próprio juízo que proferiu a decisão, sanando suas omissões ou prestando os esclarecimentos necessários.

Muito embora a História seja pródiga em exemplos de sistemas recursais moldados sobre uma estrutura normativa que dispensava a motivação, é muito difícil conceber um sistema recursal verdadeiramente efetivo sem que os juízes tenham o dever de expor as razões de suas decisões. A interposição de um recurso supõe o apontamento de alguma falha material ou formal específica na decisão ou no processo que a originou. ${ }^{421}$ Sem saber os motivos pelos quais a decisão proferida foi aquela, e não outra, a indicação de tais vícios ficaria prejudicada. Nem as partes seriam capazes de atacar especificamente a decisão, nem o juízo ad quem teria condições de apurar se a decisão está correta ou não. Em síntese, os recursos deixariam de ser um instrumento de revisão para constituírem instrumentos de reanálise da causa, exigindo-se das partes que retomassem toda a argumentação fática e jurídica desenvolvida até então, mas agora em uma nova instância.

Quanto aos recursos voltados ao exercício de atividade nomofilática pelos Tribunais Superiores, como é o caso, no Brasil, do recurso especial e do recurso extraordinário, ficariam inviabilizados na falta de um dever de motivação. ${ }^{422} \mathrm{Na}$ medida em que tais recursos voltam-se unicamente ao controle da aplicação do Direito pelos magistrados, e à consequente uniformização da jurisprudência nacional, dependem do prévio convencimento fático desenvolvido nos juízos inferiores. Tomando certos fatos discutidos no processo como verdadeiros a partir daquilo que constou da motivação das decisões de primeiro e de segundo grau, os Tribunais Superiores podem analisar concretamente como se deu a aplicação do Direito, invalidando ou reformando a decisão atacada. Se as decisões recorridas não fossem motivadas, os Tribunais Superiores não teriam um ponto de partida para a análise da correção jurídica da decisão. Em suma, seriam forçados a rejulgar a causa, extrapolando a função precípua que lhes é atribuída: controlar e homogeneizar a interpretação e aplicação do Direito.

\footnotetext{
${ }^{421}$ V., p.ex., ASSIS, Araken de. Manual dos Recursos. p. 132-133; DIDIER, Fredie; CUNHA, Leonardo José Carneiro da. Curso de Direito Processual Civil, v. 3. p. 98.

${ }^{422}$ V. BARBOSA MOREIRA, José Carlos. A motivação das decisões judiciais como garantia inerente ao Estado de Direito. p. 115.
} 


\subsubsection{O controle das decisões judiciais pela sociedade}

Tendo em vista que, nas democracias, o poder jurisdicional, assim como qualquer outro poder estatal, decorre da soberania popular, o ato de motivar uma decisão configura verdadeira prestação de contas do juiz aos legítimos detentores do poder por ele exercido, ${ }^{423}$ estabelecendo-se uma "relação direta (...) entre administração da justiça e ambiente social". ${ }^{424}$ Destarte, sob um prisma ideal, a motivação das decisões judiciais serve como instrumento de controle popular sobre o exercício da atividade jurisdicional. ${ }^{425}$ Essa era a base do pensamento revolucionário francês.

É importante ter claro que o controle da atividade judicial pela sociedade não remete à criação de um juiz político, influenciado indevidamente pela opinião pública. Muito pelo contrário. $\mathrm{O}$ controle popular exercido sobre a atividade jurisdicional visa a afastar qualquer politização judicial, voltando-se à concreta observância do Direito para a tomada de decisões. Antonio Magalhães Gomes Filho resume com clareza: "O que a motivação deve propiciar, ao invés, é a comunicação entre a atividade judiciária e a opinião pública, ensejando a apreciação geral da sociedade sobre a forma pela qual é aplicado concretamente o direito". ${ }^{426}$

Não sem alguma razão, parte da doutrina é bastante crítica quanto à existência de um efetivo controle popular da atividade jurisdicional. Muitas vezes considerada demagógica, a ideia sofre duas objeções significativas: (a) a motivação destina-se não ao povo, mas aos operadores do Direito, pois são estes que possuem condições de "descodificar" o discurso técnico-jurídico próprio da decisão; (b) na medida em que somente as partes são dotadas de mecanismos de ataque a decisões antijurídicas, o controle popular da atividade jurisdicional seria irrelevante. ${ }^{427}$

\footnotetext{
${ }^{423}$ Pela veemência da exposição, cita-se mais uma vez o trabalho de AMODIO, Ennio. Motivazione della sentenza penale. p. 188.

${ }^{424}$ TARUFFO, Michele. La Motivazione della Sentenza Civile. p. 407.

${ }^{425}$ Cf. CINTRA, Antônio Carlos de Araújo; GRINOVER, Ada Pelllegrini; DINAMARCO, Cândido Rangel. Teoria Geral do Processo. p. 69.

${ }^{426}$ GOMES FILHO, Antonio Magalhães. A Motivação das Decisões Penais. p. 81.

${ }^{427}$ V. SILVA, Blecaute Oliveira. A Garantia Fundamental à Motivação da Decisão Judicial. p. 147-148.
} 
Contudo, se é verdade que apenas os operadores do Direito conseguem compreender o discurso jurídico, também é verdade que a inacessibilidade do Direito por boa parte da população configura uma gravíssima anomalia. Embora obrigatoriamente científico, o Direito não pode ser conhecido e compreendido por uma parcela restrita da população; afinal, o Direito rege toda a sociedade, e não apenas a vida dos juristas. Se ninguém pode violar o Direito por ignorância (v. 13.1.4, abaixo), então é evidente que o Direito deve, ou ao menos deveria, ser passível de compreensão, ainda que relativa, por todas as pessoas. Pessoas, aliás, que supostamente criaram esse Direito mediante representação parlamentar. Desse modo, a inacessibilidade do Direito pela população em geral decorre mais de lamentáveis circunstâncias sociológicas, políticas e culturais do que propriamente jurídicas.

No que diz respeito à segunda crítica, não há como refutá-la. Realmente a população é desprovida de instrumentos de ataque a decisões antijurídicas, o que pode ser explicado em parte pela tradicional concepção privatista do Direito Processual. Até hoje percebe-se uma forte resistência em aproximar o Direito Processual de outros ramos do Direito Público, em especial do Direito Administrativo, com o qual possui muitos pontos em comum. Por isso, a crítica talvez devesse ser redirecionada à falta de algum instrumento que, a exemplo da ação popular ou da ação civil pública, permita ao indivíduo, ou coletividade de indivíduos, buscar a proteção da ordem jurídica, ao menos em algumas hipóteses, contra abusos ou inevitáveis erros cometidos pelo Poder Judiciário.

Independentemente de tudo isso, tem razão Taruffo ao sustentar que o escopo da motivação não é exatamente a efetividade do controle popular, mas a efetiva possibilidade de que esse controle seja realizado. ${ }^{428}$ Isso significa que a motivação deve possibilitar o controle popular da correção da decisão, ainda que esse controle, por características do próprio sistema jurídico, não apresente nenhuma efetividade endoprocessual. Alguém poderia dizer que tal controle popular seria uma ficção. Mas mesmo se assim fosse, tratar-se-ia de uma ficção da qual depende a legitimidade das decisões jurisdicionais.

\footnotetext{
${ }^{428}$ TARUFFO, Michele. La Motivazione della Sentenza Civile. p. 409.
} 


\title{
CAPÍTULO TERCEIRO - AINDA SOBRE AS RELAÇÕES ENTRE MOTIVAÇÃO DAS DECISÕES JUDICIAIS E ESTADO DE DIREITO: NATUREZA, ESTRUTURA E CONCEITO
}

\begin{abstract}
Vem-se afirmando que o dever de motivação é uma garantia constitucional inerente ao Estado de Direito, especialmente desenvolvida após a Revolução Francesa, e voltada ao controle da atividade judicial. Os próximos pontos buscam aprofundar as ideias até agora expostas, defendendo-se a natureza declaratória da motivação (7), bem como a sua necessária estrutura lógico-argumentativa, pautada por rígidas regras de racionalidade (8). Por fim, será retomado o conceito de motivação, de modo a compatibilizá-lo com a sua natureza, a sua estrutura e a concepção que deve ser dada ao Estado de Direito (9).
\end{abstract}

\section{A natureza declaratória da motivação das decisões judiciais}

Desde que o Direito Processual brotou como ciência autônoma do Direito Material a partir da célebre polêmica entre Windscheid e Muther nos anos de 1856 e 1857, e consolidou-se com a obra de Oskar von Bülow em 1868, discute-se o modo pelo qual ambos relacionam-se e qual é a verdadeira natureza da jurisdição. Embora a polêmica entre Windscheid e Muther tenha focado suas atenções na natureza da actio romana, acabou abrindo espaço para que os juristas percebessem que o Direito é composto por dois planos distintos, o material e o processual. ${ }^{429}$ Todo o desenvolvimento doutrinário subsequente sobre o conceito de ação, que também acarretou o desenvolvimento da ciência processual, esteve em grande parte ligado às relações entre direito material e processo. ${ }^{430}$

A grande questão que sempre se colocou é: o direito material nasce no processo, mediante uma decisão judicial, ou preexiste a ela, competindo à decisão judicial meramente declarar este direito? Em outras palavras, a jurisdição tem natureza constitutiva (criativa do direito) ou declaratória (recognitiva de um direito preexistente) $?^{431}$

\footnotetext{
${ }^{429}$ V. FAZZALARI, Elio. Note in Tema di Diritto e Processo. p. 9-18.

${ }^{430}$ Cf. ALVARO DE OLIVEIRA, Carlos Alberto. Teoria e Prática da Tutela Jurisdicional. p. 7.

${ }^{431}$ V. DINAMARCO. Cândido Rangel. Direito e processo. p. 69.
} 
Muito embora essa "velha, mas sempre nova disputa"432 acerca da natureza da jurisdição seja comumente encarada sob o prisma genérico da 'decisão judicial', especificamente em relação à parte dispositiva, as suas novas vertentes vinculam-se à motivação. Se os antigos adeptos da teoria unitária do ordenamento jurídico atribuíam à sentença função de individualização da norma jurídica abstrata, criando-se então a norma jurídica do caso concreto, os novos constitutivistas enxergam na decisão judicial um método de criação da própria norma abstrata a ser utilizada para o julgamento do caso concreto. Sob essa nova ótica, ao dispositivo não importa se o comando nele contido decorre de um direito criado ou declarado jurisdicionalmente. A sentença continuará tendo eficácia constitutiva ou condenatória, independentemente da fonte do Direito (a eficácia declaratória das sentenças não é compatível com a criação de direitos pela jurisdição). Para a motivação, porém, o tema apresenta interesse concreto, pois é a ela que incumbe a criação ou a declaração do direito sobre o qual se funda o dispositivo; situação que define a sua própria natureza e o papel por ela desempenhado na tomada de decisões pelo juiz.

7.1. A motivação das decisões judiciais possui natureza declaratória e retrospectiva

Adiantou-se no ponto 6.2.2 do Capítulo anterior que a motivação das decisões judiciais possui natureza declaratória; isto é, sua função não é criar, mas declarar como o Direito regula o caso concreto, retrospectivamente, dando o embasamento jurídico necessário à decisão tomada.

Com efeito, todo provimento jurisdicional com cunho decisório de mérito, seja ele declaratório, constitutivo, desconstitutivo, condenatório ou de improcedência, depende do reconhecimento prévio de uma situação jurídica determinada que decorra dos fatos que foram alegados e provados pelas partes. ${ }^{433}$ No caso da tutela jurisdicional declaratória, o reconhecimento da existência ou inexistência da situação jurídica (ou do fato em caso de discussão sobre a autenticidade de um documento) confunde-se com o

\footnotetext{
${ }^{432}$ Ibidem. p. 67.

${ }^{433}$ Nesse sentido, Idem. Instituições de Direito Processual Civil, v. III. p. 196-198: “Ao afirmar em sentença que uma pretensão é boa, porque apoiada pelos fatos provados e conforme com o direito, ou que ela colide com os fatos ou com a ordem jurídica, o juiz está revelando uma norma que não opera em relação ao processo, mas ao mundo exterior" (p. 197).
} 
próprio escopo da demanda, embora reconhecer não seja o mesmo que declarar. ${ }^{434} \mathrm{Nas}$ demais, esse reconhecimento da existência ou inexistência de uma situação jurídica, que significa como regra a existência ou inexistência de um direito subjetivo (tutelas declaratórias e condenatórias) ou de um direito potestativo (tutelas constitutivas ou desconstitutivas), é pressuposto da decisão tomada. ${ }^{435}$

Imagine-se que o demandante tenha pedido a condenação do réu ao pagamento de determinada quantia em dinheiro que havia sido objeto de um contrato de mútuo. A condenação do réu depende, em qualquer hipótese, do reconhecimento pelo juiz de que o autor possui o direito subjetivo a um crédito exigível e insatisfeito. Igualmente, a procedência do pedido de interrupção das atividades comerciais de um bar vizinho que causa "interferência prejudicial ao sossego" impõe a constatação da existência de um direito ao sossego indevidamente violado pelo exercício anômalo de uma faculdade do réu (art. 1.277 do CC). Utilizando-se outro exemplo já dado anteriormente neste trabalho, a procedência da demanda e a consequente desconstituição da situação jurídica em que se encontra o réu, sócio da sociedade empresária, depende do reconhecimento de um direito potestativo dos autores à sua exclusão (atrelado à confirmação de que a conduta do réu configura falta grave no cumprimento de suas obrigações). Em caso de sentença declaratória negativa, o magistrado deve reconhecer a inexistência de uma situação jurídica determinada (inexistência de um direito, inexistência de um contrato, inexistência de uma sentença etc.).

Exatamente o mesmo raciocínio vale para as sentenças de improcedência. Se o autor pede a condenação do réu por inadimplemento contratual, a constatação de eventual exceção de contrato não cumprido implicará a inexigibilidade do direito subjetivo que ampara a pretensão deduzida em juízo - o que a torna ilegítima. A demonstração pelo

\footnotetext{
${ }^{434} \mathrm{O}$ reconhecimento da existência de uma situação jurídica na motivação da decisão não se confunde com a decisão (dispostivo) que declara a sua existência.

${ }^{435}$ COUTURE, Eduardo J. Fundamentos del Derecho Procesal Civil. p. 258: "En verdad, debe anticiparse que todas las sentencias contienen una declaración del derecho como antecedente lógico de la decisión principal. Também vale citar DINAMARCO, Cândido Rangel. Instituições de Direito Processual Civil, v. I. p. 134: “a sentença não cria direitos, mas revela-os (...) Mesmo quando por sentença fica instituída uma situação jurídica nova (sentenças constitutivas) o direito a essa nova situação preexiste à sentença que a cria (...). O escopo jurídico do processo civil não é a composição da lide, ou seja, a criação ou complementação da regra a prevalecer no caso concreto - mas a atuação da vontade concreta do direito".
} 
réu de que não praticou falta grave no cumprimento das suas obrigações significa reconhecer que os autores não possuem o direito potestativo à expulsão do sócio. A improcedência do pedido de que o bar vizinho deixe de funcionar implica reconhecer que a faculdade de usar o imóvel, decorrente de um direito subjetivo de propriedade, está sendo legitimamente exercida pelo réu, inexistindo violação a algum direito subjetivo do autor. $\mathrm{E}$ para encerrar, a improcedência da demanda que requer a declaração de inexistência de uma obrigação depende do reconhecimento de que esta obrigação efetivamente existe e que o réu possui um direito subjetivo em face do autor. ${ }^{436}$

Em qualquer um desses casos, a decisão funda-se na existência ou na inexistência de uma situação jurídica que atribui, ou não, faculdades, poderes, deveres, obrigações ou direitos a uma das partes. Logo, em toda e qualquer decisão judicial é preciso que a norma aplicável aos fatos, independentemente de sua natureza, seja um dado prévio e determinado. A norma deve preexistir à decisão, pois é isso que justifica a legitimidade ou ilegitimidade da pretensão inicial do autor.

Não se está aqui, por óbvio, defendendo que o juiz simplesmente aplica o texto da lei. O que se está defendendo é que o juiz não cria o direito aplicável ao caso concreto, mas reconhece qual é o direito aplicável ao caso concreto a partir da interpretação da ordem jurídica vigente. Esse direito pode ser caracterizado simplesmente por uma regra, por um princípio positivado, por um costume, pela interpretação sistemática de uma regra ou mesmo por um princípio que, no caso concreto, sobrepôs-se a outro. Em todas essas situações a decisão judicial, expressa no dispositivo, dependerá do reconhecimento, na motivação, da existência de normas jurídicas que atribuem ou não direitos, faculdades, poderes, deveres e obrigações às partes. ${ }^{437}$

\footnotetext{
${ }^{436} \mathrm{O}$ que não significa que a sentença terá força executiva. O reconhecimento da existência de um direito não se confunde com o reconhecimento de que um direito existe e é exigivel. Sobre isso, v. RAMINA DE LUCCA, Inexequibilidade das sentenças declaratórias. p. 108-121.

${ }^{437}$ Nesse sentido, EISENBERG, Melvin Aron. The Nature of the Common Law. p. 140: "The first claim is that courts determine cases on the basis of legal rights and duties, rather than making law in a legislative capacity. This claim is correct. A court does not say, 'We establish this legal duty for the first time today, and we impose liability on you for not performing the duty yesterday'. Rather, a court says, 'You were under a legal duty to do this, and we impose liability on you because you didn' 't'".
} 
O vizinho que tem o seu sossego perturbado indevidamente pode pedir a condenação do réu a uma obrigação de não fazer porque do art. 1.277 do Código Civil extrai-se uma norma neste sentido. O dono do prédio que não tem acesso à via pública pode pedir a condenação do seu vizinho, mediante indenização, a uma obrigação de fazer (dar passagem), porquanto é isso que lhe garante a norma contida no art. 1.285 do Código Civil. O consumidor que sofre cobrança abusiva pode pedir a condenação do réu a pagamento de danos morais, pois é o que está consagrado, dentre outros, nos arts. 42 do Código de Defesa do Consumidor e 927 do Código Civil; e se o CDC inexistisse, o juiz poderia julgar procedente a demanda depois de reconhecer violação pelo fornecedor da dignidade do autor (art. $1^{\mathrm{o}}$, III, da CR).

De uma forma ou de outra, os direitos preexistem à decisão judicial porque as normas que os consagram também preexistem à decisão judicial. O Poder Judiciário, ao menos no plano ideal do dever-ser, não cria o Direito, mas interpreta-o e aplica-o (isto é, garante os efeitos por ele previstos) ao caso concreto de acordo com os valores da sociedade em que está inserido; ${ }^{438}$ o que permite concluir, mais uma vez, que a motivação das decisões judiciais possui natureza retrospectiva e declaratória.

\subsection{Sobre as teorias de que o juiz cria o Direito}

Além da clássica teoria de Oskar von Bülow de que a decisão judicial serve para dar concretude a normas jurídicas abstratas, de modo que o ordenamento jurídico realiza-se unicamente no plano processual, ${ }^{439}$ podem ser citadas outras três teorias, mais

\footnotetext{
438 Cf. TALAMINI, Eduardo. Novos aspectos da jurisdição... p. 99: “O fenômeno jurídico ocorre independentemente do pronunciamento jurisdicional - e cabe ao julgador identificá-lo à luz dos valores reinantes na sociedade".

${ }^{439}$ Cf. DINAMARCO, Cândido Rangel. Direito e processo. p. 70-71. V. também FAZZALARI, Elio. Note in Tema di Diritto e Processo. p. 18-19; ROCCO, Alfredo. La Sentencia Civil e la Interpretación de las Leyes Procesales. p. 197-200. As ideias foram posteriormente desenvolvidas por Hans Kelsen e aceitas, na Itália, por autores como Mortara, Capograssi, Pekelis, Allorio, Satta, Carnelutti e Calamandrei. Para KELSEN, “O juiz não tem simplesmente de descobrir e declarar um direito já de antemão firme e acabado, cuja produção já foi concluída" (Teoria Pura do Direito. p. 264). Na verdade, "A norma individual, que estatui que deve ser dirigida contra um determinado indivíduo uma sanção perfeitamente determinada, só é criada através da decisão judicial. Antes dela, não tinha vigência” (Teoria Pura do Direito. p. 265). Em sentido similar, escreveu CAPOGRASSI que "Il processo è proprio questo far rivivere come presente l'azione passata e
} 
modernas, que atribuem natureza criativa à decisão judicial, especialmente no que diz respeito à motivação. ${ }^{440}$

A primeira dessas teorias parte da distinção entre o texto normativo e a norma que dele se extrai (chamada neste trabalho de teoria interpretativa). ${ }^{441} \mathrm{O}$ texto normativo seria "por si mesmo morto", um "símbolo do ato de vida de outra pessoa" que deveria ser sempre 'chamado à vida' pelo intérprete. ${ }^{442}$ Já a normas seriam "os sentidos construídos a partir da interpretação sistemática de textos normativos". ${ }^{443}$ Desse modo, o texto normativo é o objeto a ser interpretado e a norma é o resultado da interpretação. ${ }^{444}$ Diante da distinção entre dispositivo e norma, conclui-se que toda atividade interpretativa é, também, uma atividade criativa. Não haveria como interpretar sem subjetivar o resultado produzido. Seria o caso, nas palavras de Cappelletti, da diferente interpretação musical dada pelo pianista Arthur Rubinstein ou pelo pianista Vladimir Horowitz: "por mais que o intérprete se esforce por permanecer fiel ao seu 'texto, ele sempre será, por assim dizer,

esaurita, e questo far diventare concreta la legge, che è generale e astratta. Perciò il processo è processo: appunto un procedere per arrivare a questa transformazione (...) di una legge che è generale, e farla diventare concreta. (...) questa transformazione non si opera alla fine con la sentenza, mas si opera in tutti $i$ momenti in cui si risolve quel procedere, e si opera alla fine in modo riassuativo e integrale con la sentenza" (Giudizio processo scienza verità. p. 7). CARNELUTTI chamava de processo o "conjunto de actos dirigidos a la fomación o a la aplicación de lós mandatos jurídicos (...)"; "La voz proceso sirve, pues, para indicar un método para la formación o para la aplicación de lo derecho" (Instituciones del Proceso Civil, v. I. p. 2122). Para um resumo crítico da teoria, v. FAZZALARI, Elio. Note in Tema di Diritto e Processo. p. 19 e ss.

${ }^{440}$ Não se pode confundir a suposta criação do direito na interpretação da norma jurídica (conteúdo da motivação da decisão) com a eficácia constitutiva ou desconstitutiva da tutela jurisdicional (vinculada ao dispositivo da decisão). Evidentemente, a 'declaração' [rectius: decretação] de inconstitucionalidade de uma lei, no controle concentrado, provoca uma alteração da ordem jurídica diante da invalidação, i.e., desconstituição de um ato normativo até então vigente, pois trata-se de um efeito da própria decisão; algo totalmente diverso da criação da norma jurídica como fundamento decisório.

${ }^{441}$ V. ASCARELLI, Tullio. Giurisprudenza costituzionale e teoria dell'interpretazione. p. 351 e ss: "La norma non è 'racchiusa' nel testo sì da poter essere ivi discoperta e l'interpretazione non è 'lo specchio' di quanto racchiuso nel testo; il testo è se mai um seme per quella sempre rinnovata e transitória formulazione della norma che per ogni applicazione compie l'interprete" (p. 356).

${ }^{442}$ CAPPELLETTI, Mauro. Juizes Legisladores? p. 22.

${ }^{443}$ ÁVILA, Humberto. Teoria dos Principios. p. 30.

${ }^{444}$ Ibidem. p. 30; GRAU, Eros Roberto. Ensaio e Discurso sobre a Interpretação/Aplicação do Direito. p. 27. 
forçado a ser livre". ${ }^{445}$ Cappelleti propugna, então, que a natureza da atividade jurisdicional é exatamente a mesma da atividade legislativa: ${ }^{446}$ "O verdadeiro problema é outro, ou seja, o do grau de criatividade e dos modos, limites e aceitabilidade da criação do direito por obra dos tribunais judiciários". ${ }^{4} 7$

A segunda teoria, aqui denominada de "mista", vincula a atividade de criação judicial ao papel integrador desempenhado pela jurisprudência no sistema jurídico. Segundo Hart, "sempre haverá, em qualquer sistema jurídico, casos não regulamentados juridicamente sobre os quais, em certos momentos, o direito não pode fundamentar uma decisão em nenhum sentido". ${ }^{448}$ Nessas hipóteses, o juiz "terá de exercer a sua discricionariedade e criar o direito referente àquele caso, em vez de simplesmente aplicar o direito estabelecido já existente", 449

Por fim, o papel da jurisprudência como fonte do Direito estaria na atribuição de eficácia vinculante aos precedentes (adiante designada teoria da eficácia vinculante dos precedentes). Nas palavras de Marinoni, "quando a norma jurídica fixada pela jurisdição configura precedente obrigatoriamente aplicável a outros casos, há visível aproximação com a norma criada pelo legislador". ${ }^{450}$ Ainda segundo o autor, a característica inerente aos precedentes obrigatórios de orientar a conduta dos cidadãos e dar previsibilidade à atuação jurisdicional seriam próprias de uma norma geral capaz de oferecer ainda mais segurança ao indivíduo do que a norma legislativa. ${ }^{451}$

\footnotetext{
${ }^{445}$ CAPPELLETTI, Mauro. Juizes Legisladores? p. 22.

446 Ibidem. p. 27: "Do ponto de vista substancial, portanto, não é diversa a 'natureza' dos dois processos, o legislativo e o jurisdicional. Ambos constituem processos de criação do direito".

${ }^{447}$ Ibidem. p. 21.

${ }^{448}$ HART, H. L. A. O Conceito de Direito. p. 351.

${ }^{449}$ Ibidem. p. 351. Ao contrário de Cappelletti, Hart não equipara qualitativamente as atividades judicial e legislativa, já que aquela decorreria de um “poder intersticial” (p. 352).

${ }^{450}$ MARINONI, Luiz Guilherme. Precedentes Obrigatórios. p. 94

${ }^{451}$ Ibidem. p. 95
} 


\subsubsection{Teoria interpretativa: críticas}

É bastante comum que os adeptos da teoria de que o juiz cria o Direito oponham o entendimento defendido à concepção do "juiz boca da lei”. No entanto, é preciso desvincular a teoria declaratória das decisões judiciais das concepções jurídicas setecentistas e oitocentistas. Ninguém defenderia, hoje, que o juiz deve simplesmente 'dizer' qual é o Direito sem nenhum processo de interpretação da norma aplicável ao caso concreto. Também parece já largamente aceita a distinção entre texto normativo e norma jurídica. O cerne da questão, portanto, não é saber se há interpretação ou não há interpretação judicial, ou se a norma confunde-se com o texto legal. Importa saber se a interpretação de dispositivos normativos pode ser equiparada a um processo de criação jurídica.

A análise da teoria da natureza constitutiva da interpretação jurídica pode ser iniciada a partir do exemplo dado por Cappelletti que, longe de corroborá-la, ajuda a compreender os seus equívocos. Em sua opinião, a interpretação dos textos normativos é como a interpretação de uma peça musical. Ainda que a partitura seja a mesma, a interpretação dada por um artista nunca será idêntica àquela dada por outro.

Cappelletti equiparou fenômenos completamente distintos. Interpretar um texto significa dar sentido a um conjunto de signos linguísticos dispostos de maneira tal que lhes permita ser corretamente compreendidos. ${ }^{452}$ Interpretar uma peça musical significa executá-la (do mesmo modo que uma interpretação teatral é a execução de uma peça de teatro). Na medida em que a execução musical é uma realização humana, dependerá das habilidades do músico, de sua constituição física, do instrumento musical utilizado e de uma série de outras variáveis. Com efeito, não há nenhuma "interpretação" musical idêntica a outra.

\footnotetext{
${ }^{452}$ Nesse sentido, BOBBIO, Norberto. Il Positivismo Giuridico. p. 220-221: "Ebbene, interpretare significa risalire dal segno (signum) alla cosa significata (designatum), cioè comprendere il significato del segno individuando la cosa da esso indicata". Igualmente, GIANFORMAGGIO, Letizia. L'interpretazione della costituzione. p. 173: “(...) con termine 'interpretazione', ci riferiamo al procedimento (o al risultato del procedimento) di attribuzione di un significato ad un segno". De acordo com o Novo Dicionário Aurélio da Língua Portuguesa, interpretar é "ajuizar a intenção, o sentido de"; "explicar, explanar ou aclarar o sentido de" (p. 959).
} 
No entanto, antes da execução de uma peça musical existe uma importantíssima etapa de interpretação de sinais linguísticos dispostos em uma partitura. Uma interpretação que consiste na tentativa de compreender e dar ao texto o exato significado buscado por seu autor. O processo de execução de uma peça de Chopin por Rubinstein, p.ex., partia da leitura da partitura escrita pelo compositor, passava pelo processo de interpretação mental do que aquilo significava (qual é a nota seguinte? qual é o tempo? qual é a intensidade com a qual a nota deve ser tocada? etc.) e terminava na execução propriamente dita. Ao interpretar a partitura de Chopin, Rubinstein buscava representar aquilo que ele imaginava ser o significado do 'texto' ali impresso.

Para que o exemplo dado por Cappelletti tivesse um mínimo de validade, a execução de uma peça musical deveria ser comparada à redação de uma sentença que julga com fundamento em determinada norma jurídica. Exatamente como o ato de tocar um instrumento musical, a redação conterá a 'impressão digital' de seu autor, utilizando-se termos e construções linguísticas que lhe são característicos. As sentenças de dois juízes que invalidam um ato administrativo impugnado por falta de motivação (art. 50 da Lei 9.784/99) poderão apresentar diferenças substanciais em termos de estrutura, estilo, clareza etc. Ainda assim, tanto o processo de interpretação de um texto normativo como o processo de interpretação de uma peça musical partem de um dado preexistente para que se chegue ao resultado da interpretação: aquilo que o intérprete honestamente acredita ser o significado do objeto.

Nada disso é criação. Criar significa dar existência a algo a partir do nada. Um juiz não decide a partir do nada, do mesmo modo que Rubinstein não interpretava Chopin a partir do nada. Para que qualquer um dos dois pudesse criar, eles teriam que abdicar da interpretação. ${ }^{453}$

\footnotetext{
${ }^{453}$ Distinguindo interpretação e criação, v. FALCÓN Y TELLA, María José. Lições de Teoria Geral do Direito. p. 121: “'De iure', no Dirieto privado, a coisa está bastante clara: a jurisprudência, no Direito espanhol, não é fonte do Direito, nem antes nem depois da reforma do Titulo Preliminar do Código Civil de 1974. As razões são as seguintes. A jurisprudência não cria normas, limita-se a interpretá-las e a aplicá-las, enquanto a fonte, sim, as cria”. V. também NUVOLONE, Pietro. Discrezionalità del giudice e certezza del diritto. p. 588 e ss.
} 
Evidentemente não se está aqui defendendo que só há uma interpretação possível para cada objeto. ${ }^{454}$ A forma de ver o mundo varia de pessoa para pessoa, seguindo os valores, concepções e preconceitos próprios de cada um. Há, consequentemente, várias maneiras de se interpretar o mesmo texto normativo. A motivação de uma decisão administrativa pode ser reputada suficiente ou insuficiente, assim como o significado do texto "os atos administrativos deverão ser motivados, com indicação dos fatos e dos fundamentos jurídicos" (art. 50 da Lei 9.874/99) pode ser mais ou menos amplo segundo aquele que está julgando. Justamente por isso há tribunais encarregados de uniformizar a interpretação jurídica no Brasil (STF, STJ etc.).

Entretanto, é inerente ao processo interpretativo que se busque extrair o significado do objeto interpretado. A postura do intérprete tem que se confundir com a de um investigador: alguém que procura descobrir o significado daquilo que lhe é dado a examinar.

Essas considerações não são muito diferentes do que defende Humberto Ávila. Para o professor gaúcho, o intérprete não pode desprezar os "pontos de partida" atribuídos pelo ordenamento jurídico, inexistindo liberdade ao julgador para "fazer as conexões entre as normas e os fins a cuja realização elas servem”. E continua: “o intérprete deve interpretar os dispositivos constitucionais de modo a explicitar suas versões de significado de acordo com os fins e os valores entremostrados na linguagem constitucional". A isso chama de "atividade de reconstrução". ${ }^{455}$

Ora, se o intérprete deve explicitar sua versão de significado a partir dos fins e valores constitucionais, então ele nada mais faz do que explicitar o que ele acredita ser a norma jurídica aplicável de acordo com um "universo axiológico que não é necessariamente o seu". ${ }^{456}$ Inexistindo liberdade criativa para fugir dos "pontos de

\footnotetext{
454 Embora considerasse criativa a atividade de interpretação, explicou COUTURE, Eduardo J. Interpretación e integración de las leyes procesales. p. 31: “Interpretar es, decíamos, desentrañar un sentido. Pero desentrañar un sentido dentro de un orden normativo de la indole del que acaba de referirse del orden procesal, es no solo extraer la razón del texto, sino también su significación dentro del sistema de principios".

455 ÁVILA, Humberto. Teoria dos Princípios. p. 34-35.

${ }^{456}$ Nas palavras de DINAMARCO, Cândido Rangel. Instituições de Direito Processual Civil, v. I. p. $135-$ 136: "A grande e legítima liberdade que o juiz tem ao julgar é liberdade de remontar aos valores da
} 
partida", inexiste criação judicial do direito. E pouco adianta chamar o fenômeno de "reconstrução", já que reconstruir nada mais é do que construir algo que existia e não existe mais.

A simples inconfundibilidade entre texto e norma não atribui papel criativo à jurisprudência. $\mathrm{O}$ art. $5^{\circ}$, LII, da CR poderia ter recebido as mais diversas redações, e ainda assim existiria uma norma constitucional impedindo a extradição de um estrangeiro por crime político ou de opinião, independentemente de qualquer decisão judicial. ${ }^{457}$ Ao negar a extradição do estrangeiro, o STF não cria uma norma nova, mas reconhece que aquele estrangeiro tem proteção constitucional a partir da interpretação do dispositivo citado. Uma norma que deve, necessariamente, preexistir à decisão.

Chega-se então à segunda grande falha da 'teoria interpretativa'. Se toda norma só é criada depois da interpretação do texto normativo, então não há normas jurídicas até que uma decisão judicial "crie" o seu significado; por conseguinte, o direito só existiria no plano do processo.

A discussão entre os adeptos da teoria unitária (ou monista) e os adeptos da teoria dualista do ordenamento jurídico é, como dito, antiga. Para aqueles, o Direito só se produz depois da decisão judicial que 'cria' a norma jurídica aplicável ao caso, originandose então direitos, obrigações etc. Para estes, a ordem jurídica desenvolve-se em dois planos muito bem definidos: o material e o processual. Todo fato ocorrido no mundo concreto que se encaixe na hipótese fática prevista em uma norma jurídica preexistente produz, desde logo, as consequências jurídicas cominadas (costuma-se falar em sanção, o que não parece ser o mais adequado). Desse modo, "Direitos subjetivos, obrigações e relações jurídicas

sociedade, captá-los e compreendê-los com sensibilidade e com a mais autêntica fidelidade a um universo axiológico que não é necessariamente o seu. Agindo dessa maneira, o juiz coloca-se como válido canal de comunicação entre os valores vigentes na sociedade e os casos concretos em que atua. Isso não é criar normas, mas revelá-las de modo inteligente, sabido que a lei não é a fonte única e exclusiva do direito, mas também os princípios gerais do direito. (...) Valorar os fatos concretos de uma causa mediante a interpretação dos textos de lei à luz dos princípios e dos valores da sociedade não é criar normas antes inexistentes na ordem jurídica como um todo".

${ }^{457}$ Com argumentação similar, embora conclua ao final que "Toda norma é, pois, produto da interpretação de um sinal lingüístico", v. SILVA, Virgílio Afonso da. Princípios e regras - mitos e equívocos acerca de uma distinção. p. 616-617. 
constituem criação imediata da concreta ocorrência dos fatos previstos nas normas: a sentença não os cria nem concorre para a sua criação". ${ }^{458}$

A teoria unitária, muito embora tenha tido ilustres defensores, não resiste à mais superficial das análises, a começar pela ilogicidade do pensamento de que toda a ordem jurídica é um nada que só vem a ser concretizado se e quando uma das partes busca a proteção do Judiciário. ${ }^{459} \mathrm{Um}$ credor não teria direito ao crédito até que o juiz constituísse esse direito em sentença. Como explicar, então, a incidência de juros desde a constituição da mora? A empresa de telefonia que inscrevesse o consumidor indevidamente como inadimplente não teria praticado nenhum ato ilícito até a sentença. Mas o que justificaria condená-la ao pagamento de danos morais ao consumidor no caso em que a inscrição foi cancelada antes de proferida a sentença? Teria o juiz que constituir uma nova situação jurídica retroativamente? Também ficam sem explicação a concessão de tutelas antecipadas (afinal, inexiste direito constituído); as tutelas declaratórias (seriam sempre constitutivas, incluindo o reconhecimento de paternidade); a eficácia do pagamento ou da compensação; a prescrição (em que consistiria?); a decadência (o seu reconhecimento implicaria a recusa do juiz a criar um direito potestativo?); a aquisição originária da propriedade por usucapião etc. etc. etc. ${ }^{460}$

Em síntese, a teoria unitária generalizou indevidamente o patológico desrespeito à ordem jurídica vigente, ${ }^{461}$ fechando os olhos ao que normalmente acontece: o

\footnotetext{
${ }^{458}$ DINAMARCO, Cândido Rangel. Instituições de Direito Processual Civil, v. I. p. 132.

${ }^{459}$ De acordo com FAZZALARI, definir um ordenamento jurídico como unitário ou dualista depende da opção feita no momento de sua construção. Quer dizer, é possível que haja ordenamentos jurídicos unitários e é possível que haja ordenamentos jurídicos dualistas. Entretanto, ao analisar os sistemas jurídicos italiano e romano, Fazzalari não titubeou em concluir que ambos eram dualistas. Cf. Note in Tema di Diritto e Processo. p. 36-50.

${ }^{460}$ Nas palavras de Carlos de Alberto ALVARO DE OLIVEIRA, com fundamento em Antonio Segni, "Para além do direito positivo, a norma vive nos fatos, surge desses e do coração dos homens, e o Estado reconhece essas criações espontâneas fundadas no animus dos socii mais do que na força. Esta age (quando age) apenas para realizar a ação, tal como prevista na lei. E o estabelecimento de um sistema de coações constitui um passo posterior da lei positiva, além do juízo imperativo de valor que constitui o comando jurídico: soma-se a este e dele se distingue (se não se contrapõe). Daí a necessidade de distinguir também os dois ordenamentos: o relativo ao direito processual e o concernente ao direito material" (Teoria e Prática da Tutela Jurisdicional. p. 8).

${ }^{461}$ Neste sentido, DINAMARCO, Cândido Rangel. Instituições de Direito Processual Civil, v. I. p. 133.
} 
Direito é respeitado e as relações jurídicas desenvolvem-se normalmente. Ao preocupar-se excessivamente com o plano processual, a teoria unitária não conseguiu explicar uma enorme quantidade de fenômenos jurídicos que se desenvolvem essencialmente no plano material.

Obviamente, as insuperáveis falhas da teoria unitária não passaram despercebidas aos olhos daqueles que, atualmente, atribuem natureza criativa ao processo interpretativo do Direito. Guilherme Recena Costa, autor de uma das mais claras e completas defesas desse entendimento, afirma textualmente: "Com isso, quero sublinhar que reconhecer o papel criativo dos juízes não implica a adoção de uma teoria unitária do ordenamento jurídico. Os destinatários das normas, na maior parte das vezes, interpretarão e aplicarão eles mesmos os textos legais (ou seguirão as normas formuladas em precedentes por eles conhecidos), sem que se tenha de recorrer a uma decisão autoritativa para tanto". 462

Mas ou a norma existe antes da interpretação do texto pelo juiz ou ela não existe antes da interpretação do texto pelo juiz. Mesmo que se aceite que a norma pode ser criada pelos próprios destinatários, essa criação seria de todo irrelevante, já que despida de qualquer eficácia jurídica. O que os destinatários fariam seria, no máximo, agir em conformidade com uma suposição do Direito que seria constituído, eventual e posteriormente, em juízo; retornando-se invariavelmente à teoria unitária.

Ademais, não haveria sentido falar em precedentes vinculantes, pois a norma criada em outro julgamento não seria exatamente a mesma norma criada pelo novo intérprete. Sendo a interpretação subjetiva, sua natureza criativa imporia a criação de tantas normas quantos fossem os intérpretes - inclusive em um mesmo processo caso houvesse interposição de recursos. Além de aceitar-se obrigatoriamente a existência de 'diversos direitos' relativos a uma mesma situação fática, a aplicação de precedentes implicaria a criação de novas normas, ainda que com conteúdos idênticos às criadas nos casos anteriores.

${ }^{462}$ COSTA, Guilherme Recena. Superior Tribunal de Justiça e Recurso Especial. p. 77. 


\subsubsection{Teoria mista: críticas}

A teoria mista supõe que o Direito contém lacunas: situações fáticas que não são juridicamente reguladas nem a favor do autor, nem a favor do réu, configurando 'casos difíceis' (hard cases). Diante de tais casos difíceis, o juiz deveria criar o direito intersticialmente para que então pudesse decidir o caso concreto que lhe é apresentado.

A teoria foi duramente criticada por Dworkin, pois "ainda quando nenhuma norma positivada disponha sobre o caso, uma das partes deve ter, apesar disso, o direito de vencer". É “dever do juiz", portanto, "mesmo em casos difíceis, descobrir quais são os direitos das partes, e não inventar novos direitos retrospectivamente". 463

Recentemente, Dworkin utilizou o seguinte caso para exemplificar suas ideias. A Sra. Sorenson tomou durante vários anos um medicamento denominado Inventum, o qual era fabricado por onze laboratórios farmacêuticos distintos. Devido a graves efeitos colaterais não divulgados, a Sra. Sorenson adquiriu problemas cardíacos permanentes. Obviamente, ela seria incapaz de provar quais comprimidos e de quais fabricantes teriam causado os efeitos colaterais. Embora não tivesse adquirido comprimidos dos onze laboratórios farmacêuticos, decidiu processá-los todos sobre o argumento de que todos eles seriam responsáveis pelos danos causados segundo a participação de cada um na disponibilização do produto no mercado. O que fazer, então? Julgar procedente a demanda porque quem lucra com um empreendimento deve arcar com os seus custos (adoção da teoria do risco), ou julgar improcedente a demanda porque os laboratórios não podem ser responsabilizados por um dano que não tenha sido comprovadamente causado por eles? ${ }^{464}$

Independentemente da resposta dada, Dworkin explica que seria preciso "identificar os princípios gerais que fundamentam e justificam o direito estabelecido de responsabilidade civil de um fabricante, e depois aplicar esses princípios ao caso"; logo,

\footnotetext{
${ }^{463}$ DWORKIN, Ronald. Taking Rights Seriously. p . 81.

${ }^{464}$ Idem. A Justiça de Toga. p. 12-14 e 203-204.
} 
"Tudo depende da melhor resposta à difícil questão de saber que conjunto de princípios oferece a melhor justificação para essa área do direito como um todo". 465

A crítica de Dworkin está correta. A teoria mista, embora muitas vezes seja adotada por supostamente romper com a concepção de Montesquieu de que o juiz deve simplesmente 'dizer' o direito (se o juiz cria, ele não diz), na verdade possui uma estrutura científica já claramente superada, com sólidas raízes na concepção clássica do Direito. ${ }^{466}$ Hart atribuiu aos juízes poder discricionário de criar o direito para o caso concreto porque acreditava que o Direito resumia-se às regras jurídicas; inexistente uma regra suficientemente clara que estivesse apta a regular o caso concreto, então competiria ao juiz criá-la. Não é por acaso, portanto, que Dworkin rotulou pejorativamente as ideias de Hart de positivistas ${ }^{467}$ e Eugenio Bulygin afirmou que "A discricionariedade judicial é um dos pilares da teoria positivista do direito" $" 468$.

A atribuição de poderes discricionários aos juízes para que decidam os casos difíceis como bem entendem é um atentado à segurança jurídica e ao Estado de Direito. ${ }^{469}$ Por mais difícil que seja o caso concreto, é no sistema jurídico que o juiz deve buscar a solução, e não simplesmente inventar arbitrariamente uma resposta subjetiva. ${ }^{470}$ Utilizando-se o caso da Sra. Sorenson como exemplo, alguns dirão que todos os

${ }^{465}$ Ibidem. p. 204. O apelo feito pelo autor é esclarecedor: "Falem com os juristas e juízes que terão de se haver com a nova Lei dos Direitos Humanos do Reino Unido. Não digam aos juízes que eles devem exercer seu poder discricionário como acharem melhor. Eles querem saber como entender essa lei enquanto direito, como decidir, e a partir de qual fonte, de que modo a liberdade e a igualdade passaram a ser vistas em nossos dias, não apenas como ideais políticos, mas também como direitos jurídicos” (Ibidem. p. 263-264).

${ }^{466}$ HART, H. L. A. O Conceito de Direito. p. 23 e ss.

${ }^{467}$ V., DWORKIN, Ronald. Taking Rights Seriously. p. 81.

${ }^{468}$ BULYGIN, Eugenio. Il Positivismo Giuridico. p. 145-146. No original: "La discrezionalità giudiziale è uno dei pilastri della teoria positivista del diritto, oggeto di frequenti attachi da parte dei suoi avversari".

${ }^{469}$ Cf. NUVOLONE, Pietro. Discrezionalità del giudice e certezza del diritto. p. 586 e ss: "È contrario alla certezza affidare al giudice il compito di legiferare nel caso concreto (...)".

470 Cite-se mais uma vez CALMON DE PASSOS, J. J. O magistrado, protagonista do processo jurisdicional? p. 222: "Daí o imperativo tanto do controle interno como do controle externo do exercício da função jurisdicional. Se inexistirem, tudo será falácia. Nem se poderá falar de democracia, nem se estará falando de algo viável no concreto da vida social, visto como, nos regimes autocráticos, o juiz é uma figura secundária, apenas o chicote do tirano; e nas democracias, se liberado de sua submissão à legalidade (no seu sentido amplo), será, caso tolerado, a prova cabal de que a democracia em que atua é um faz-de-conta ou uma fachada com cara de decente ocultando um covil de sicários". 
fornecedores deverão responder pelos danos que lhe foram causados e outros dirão que ela não poderá buscar a reparação que entende devida sem provar quais deles são os verdadeiros responsáveis pelos danos. Ainda assim, ambos os posicionamentos, para terem um mínimo de legitimidade, devem estar devidamente justificados, formal e materialmente, no Direito. Se o juiz acredita que a Sra. Sorenson não tem direito à reparação, então deve buscar os fundamentos jurídicos que amparem a sua decisão, recorrendo, se for o caso, aos princípios do Direito Civil, aos princípios constitucionais, à analogia etc. Se não conseguir encontrar algum fundamento que justifique sua decisão, então evidentemente não poderá julgar improcedente a demanda. E vice-versa. De uma forma ou de outra, cabe a ele descobrir, a partir das normas expressas e implícitas contidas no sistema jurídico, se a Sra. Sorenson apresenta uma pretensão legítima ou ilegítima, motivando juridicamente a sua decisão. ${ }^{471}$

\subsubsection{Teoria da eficácia vinculante dos precedentes: críticas}

A terceira das teorias estrutura-se sobre a concepção de que a atribuição de força vinculante às decisões judiciais as aproxima das normas legais, pois servem a orientar a conduta dos cidadãos e dar previsibilidade à atuação jurisdicional.

Não há dúvidas de que a obrigatoriedade de respeito a precedentes é extremamente salutar à promoção da segurança jurídica. Como se sabe, a doutrina do stare decisis desenvolveu-se nos países do common law justamente pela preocupação daquele sistema jurídico com a previsibilidade do Direito - indubitavelmente potencializada com o julgamento idêntico de casos idênticos (v. 13.1 e ss., abaixo). Todavia, é de se questionar a validade da confusão entre respeito de precedentes e criação do direito.

Cite-se como exemplo o art. 401 do Código de Processo Civil, o qual dispõe que a prova exclusivamente testemunhal só é admitida para provar a existência de

\footnotetext{
${ }^{471}$ A grande crítica ao pensamento de Dworkin, e foram vários os seus autores, está ligada à concepção de que todo caso possui uma resposta correta. Todavia, aceitar a existência de respostas corretas aos casos concretos não quer dizer que todos os juristas chegarão às mesmas respostas nos casos difíceis, ou que a resposta possa ser provada correta. Quer dizer, sim, que os juízes devem "caçá-las pela razão e pela imaginação" (DWORKIN, Ronald. Law's Empire. p. ix.). A regra de única decisão correta, como muito bem pontuou Teresa Arruda Alvim WAMBIER, é um "pressuposto operativo de funcionamento ou de operabilidade do sistema" (Precedentes e evolução do direito. p. 30).
} 
contratos cujo valor não supere o décuplo do maior salário mínimo vigente no Brasil. $\mathrm{O}$ Superior Tribunal de Justiça já decidiu que não há ofensa ao art. 401 quando a existência de contrato de valor superior a dez salários mínimos é comprovada por depoimento pessoal daquele que a nega, uma vez que prova testemunhal e depoimento pessoal não são a mesma coisa. ${ }^{472}$

A primeira questão que se deve colocar é: o STJ criou uma norma jurídica nova? Não. O Tribunal simplesmente reconheceu (implicitamente) que, nos termos do art. 332 do CPC, todos os meios legais são hábeis para provar os fatos alegados pelas partes, no que está incluído o depoimento pessoal. Na medida em que a confissão faz prova contra o confitente (art. 350 - também aplicado implicitamente) e que depoimento pessoal não é a mesma coisa que prova testemunhal (motivo explicitamente dado), então a confissão do réu em seu depoimento é válida para, por si só, comprovar a existência do contrato celebrado com o autor. Não há nenhum tipo de criação ou inovação jurídica. Há, sim, uma atividade intelectual desenvolvida pelos Ministros que lhes permitiu apreender a solução jurídica prevista pelo Direito brasileiro.

A segunda questão é: se as decisões do STJ tivessem força vinculante, a observância obrigatória do precedente acima citado configuraria uma nova norma jurídica? Mais uma vez a resposta deve ser negativa. Diante de uma situação análoga ao exemplo acima dado, o juízo inferior não aplicará a norma geral definida pelo STJ, mas interpretará o art. 401, assim como os arts. 332 e 350, todos do CPC, exatamente da mesma forma que o STJ. Ou seja, o que vincula não é a decisão como norma geral, mas a compreensão do ordenamento jurídico estabelecida pelo Tribunal superior, a razão dada para decidir (ratio decidendi - v. 13.2 e ss., abaixo). Apontada a violação do art. 401 pelo depoente que confessou a existência de contrato de valor superior a 10 salários mínimos, o juízo inferior deverá rejeitar a alegação não porque o STJ criou uma norma geral, mas porque a interpretação "correta" do art. 401, expressamente definida pelo Tribunal, é a que se limita à vedação de provas testemunhais.

A teoria da eficácia vinculante dos precedentes só possui respaldo lógico se o próprio precedente puder ser considerado uma nova norma jurídica. Quer dizer,

\footnotetext{
${ }^{472}$ REsp 256.115/RO, Rel. Ministro CARLOS FERNANDO MATHIAS (JUIZ FEDERAL CONVOCADO DO TRF $1^{\text {a }}$ REGIÃO), QUARTA TURMA, julgado em 20/11/2008, DJe 09/12/2008
} 
precedentes obrigatórios só se equiparam às normas jurídicas se eles próprios forem novas normas jurídicas que, por sua obrigatoriedade, tornam-se gerais. Mas aí os Tribunais Superiores não exerceriam atividade de homogeneização da jurisprudência, e sim atividade puramente criativa do direito.

\section{A estrutura da motivação das decisões judiciais: o silogismo judicial e a argumentação jurídica}

O art. 458, do Código de Processo Civil dispõe: "São requisitos da sentença: I - o relatório, que conterá os nomes das partes, a suma do pedido e da resposta do réu, bem como o registro das principais ocorrências havidas no andamento do processo; II - os fundamentos, em que o juiz analisará as questões de fato e de direito; III - o dispositivo, em que o juiz resolverá as questões que as partes lhe submeterem.

A estrutura das sentenças está devidamente delineada no CPC, portanto. $\mathrm{O}$ juiz deve relatar tudo que aconteceu de relevante no processo, apresentar os fundamentos fáticos e jurídicos da sua decisão, isto é, motivá-la, e então decidir. Essa mesma estrutura vale para os acórdãos e para as decisões interlocutórias, as quais podem ser motivadas "de modo conciso" (art. 165 do CPC).

Mas qual é a estrutura pela qual devem ser apresentados esses fundamentos fáticos e jurídicos? E de que maneira eles relacionam-se com o dispositivo?

Existem basicamente três modelos estruturais da motivação das decisões judiciais propostos pela doutrina: o lógico-dedutivo, o indutivo e o argumentativo. Dando continuidade aos propósitos deste trabalho, cumpre analisar quais deles compatibilizam-se com os ideais do Estado de Direito e permitem que a motivação das decisões judiciais cumpra adequadamente as suas funções de legitimação e controle da atividade jurisdicional.

\subsection{O modelo lógico-dedutivo}

O método lógico-dedutivo manifesta-se mediante um processo silogístico, caracterizado pela adoção de certas premissas predeterminadas (premissa maior) às quais confrontam-se elementos variáveis (premissa menor) para a extração de uma conclusão. 
Dois são os tipos de silogismo: o teórico e o prático. O silogismo teórico ampara-se em duas proposições apofânticas, isto é, dados que exprimem significados verdadeiros ou falsos. Um exemplo de silogismo teórico é o seguinte: se todos os homens são seres bípedes racionais (proposição 1 - premissa maior), e se José Carlos é um homem (proposição 2 - premissa menor), então José Carlos é um bípede racional (conclusão). Como explica Pierluigi Chiassoni, o grande mérito do silogismo teórico está em que, se as duas proposições são verdadeiras, então a conclusão obtida também é verdadeira. ${ }^{473}$

O silogismo judicial, por sua vez, é espécie do 'silogismo prático', de maneira que uma das suas proposições apofânticas é substituída por uma proposição prescritiva (comando normativo), extraindo-se uma conclusão também prescritiva. A premissa maior é formada pela norma jurídica e a premissa menor é formada pelos fatos relevantes ao caso concreto. Verificada a subsunção dos fatos à norma, o juiz extrai a conclusão, que é a decisão judicial. ${ }^{474}$

Serve como exemplo de um raciocínio judicial silogístico o seguinte. O art. 331 do Código Civil dispõe: "Salvo disposição legal em contrário, não tendo sido ajustada época para o pagamento, pode o credor exigi-lo imediatamente". Verificada a situação hipotética 'não há época ajustada para pagamento de obrigação', então deve o juiz reconhecer a exigibilidade imediata do crédito de titularidade do credor, julgando a demanda proposta segundo a consequência prevista em lei. Se João vende a Pedro um automóvel sem fixar data para o pagamento da quantia devida por Pedro, então os fatos subsumem-se à norma preexistente e o débito tem exigibilidade imediata. A conclusão 'Pedro deve pagar imediatamente' decorre do processo lógico que se extrai da incidência da premissa maior (norma legal) à premissa menor (celebração de contrato de compra e venda sem previsão de data para pagamento) pela seguinte fórmula: se as obrigações, salvo quando for ajustada época para pagamento, são imediatamente exigíveis, e se Pedro assumiu obrigação de pagar sem data ajustada para pagamento, então a obrigação de Pedro é imediatamente exigível.

\footnotetext{
${ }^{473}$ CHIASSONI, Pierluigi. La Giurisprudenza Civile. p. 151-152.

${ }^{474}$ V. CALAMANDREI, Piero. La genesi logica della sentenza civile. passim; especialmente p. 31 e ss.; ROCCO, Alfredo. La sentencia civil. p. 9-10.
} 
Adotando-se a estrutura lógico-dedutiva, a função da motivação consiste em demonstrar que a decisão proferida decorre unicamente da subsunção dos fatos à norma jurídica preestabelecida pelo legislador.

8.2. As críticas ao modelo lógico-dedutivo e o desenvolvimento de modelos 'antiformalistas'

O elevado cientificismo do modelo lógico-dedutivo acarretou o seu amplo acolhimento pelo iluminismo. Se ao juiz competia unicamente aplicar a lei emanada pelo povo soberano, então ele nada mais faria do que aplicar as regras jurídicas aos fatos apresentados, extraindo a conclusão desejada pela lei. Em uma das obras jurídicas mais importantes daquele momento histórico, Beccaria escreveu: "Em cada delito, o juiz deve formular um silogismo perfeito: a premissa maior deve ser a lei geral; a menor, a ação em conformidade ou não com a lei: a consequência, a liberdade ou a pena”. ${ }^{475}$

A adoção de uma concepção extrema e simplista do modelo lógico-dedutivo fez com que os pensadores iluministas acreditassem que toda decisão poderia ser tomada pela realização de um único silogismo judicial. Beccaria é claro: “Quando o juiz for coagido, ou quiser formular mesmo que só dois silogismos, estará aberta a porta à incerteza". ${ }^{476}$

Obviamente, não tardou para que se constatassem os equívocos da teoria. Em primeiro lugar, atestou-se a impossibilidade de que todos os casos concretos fossem julgados mediante um único silogismo judicial. Afinal, a simples dualidade entre os planos material e processual já impõe a adoção de ao menos dois silogismos judiciais: um material e outro processual. Em segundo lugar, a teoria desenvolvida pelos iluministas, e posteriormente pelos positivistas clássicos, não explica como são escolhidas as premissas do silogismo. Utilizando-se o exemplo em que um dos sócios pratica ato ilícito para desviar dinheiro da sociedade, o modelo dedutivo clássico não esclarece como o juiz chegou à conclusão de que os fatos concretos configuram uma "falta grave" passível de exclusão societária, nos termos do art. 1.030 do Código Civil. Isso, bem apontou Letizia

\footnotetext{
${ }^{475}$ BECCARIA, Cesare. Dos Delitos e das Penas. p. 46.

${ }^{476}$ Ibidem. p. 46.
} 
Gianformaggio, elimina o controle democrático das decisões, ${ }^{477}$ pois, muito embora haja um controle formal da aplicação do Direito pelos magistrados, a facilidade de manipulação das premissas torna incerta a validade do provimento judicial. ${ }^{478}$

Os defeitos do modelo lógico-dedutivo, aliados aos nascentes movimentos jurídicos "antiformalistas", dos quais se destacaram o "direito livre" na Europa continental e o "realismo jurídico" nos Estados Unidos, abriram espaço para o desenvolvimento do denominado "modelo indutivo" de raciocínio judicial.

\subsubsection{O modelo indutivo}

O modelo indutivo de raciocínio judicial apoia-se em doutrinas antiformalistas que pretendem substituir a vontade do legislador pela criatividade do juiz e sua suposta aptidão em encontrar o "verdadeiro direito" de cada caso concreto. ${ }^{479}$ Para tanto, utiliza-se, supostamente, o método indutivo de investigação científica, segundo o qual as conclusões seriam obtidas a partir da observação de fenômenos concretos. Como consequência, as peculiaridades da causa posta para julgamento prevaleceriam sobre as normas jurídicas, consideradas elementos meramente referenciais ao convencimento do magistrado. A decisão judicial tomada a partir de um raciocínio indutivo seria, em essência, uma decisão casuística, pautada pela conclusão que mais adequadamente realiza a justiça do caso concreto.

Um dos principais expoentes de um modelo indutivo de raciocínio judicial foi Theodor Viehweg, que resgatou a noção de pensamento tópico. Segundo Viehweg, “A tópica está evidenciada no jus civille, no mos italicus, assim como na civilística contemporânea e presumivelmente também alhures. As tentativas modernas de eliminá-la

\footnotetext{
${ }^{477}$ GIANFORMAGGIO, Letizia. Modelli di ragionamento giuridico. p. 99-100.

478 Robert ALEXY enumera quatro motivos, não exaustivos, pelos quais o silogismo é insuficiente para representar o raciocínio judicial: (1) a linguagem jurídica é imprecisa; (2) existe conflito entre normas; (3) há casos que não se amoldam a nenhuma norma válida existente; e (4) a decisão pode, "em casos especiais", contrariar a literalidade de uma norma (rectius: dispositivo legal). Teoria da Argumentação Jurídica. p. 1920.

479 Cf. GOMES FILHO, Antonio Magalhães. A Motivação das Decisões Penais. p. 120-121; GIANFORMAGGIO, Letizia. Modelli di ragionamento giuridico. p. 98-101.
} 
da Jurisprudência ${ }^{480}$ são reminiscências exitosas só em mínima parte". ${ }^{481}$ Ainda de acordo com o professor alemão, "O aspecto mais importante na análise da tópica constitui a constatação de que se trata de uma técnica do pensamento que está orientada para o problema". ${ }^{482}$ No entanto, a tópica seria incompatível com um sistema dedutivo: "quando se pretende estabelecer um sistema dedutivo (...), a tópica tem que ser abandonada". ${ }^{4} 3$ Para Viehweg, a técnica jurídica seria "uma forma fenomênica de incessante busca do justo" que não pode ter caráter científico, uma vez que não pode ser axiomatizada: “os axiomas em si, como proposições nucleares do direito, continuam, não obstante, logicamente arbitrários". 484

Também vale destacar, entre a doutrina europeia ocidental, o trabalho de François Gény e sua teoria da "libre recherche scientifique" (livre pesquisa científica). Dividida em dois tomos, a obra principal de Gény, Méthode d'Interpretation et Sources en Droit Privé Positif, ataca o positivismo jurídico clássico e sustenta que as fontes formais do Direito são incompletas e insuficientes para a solução dos problemas da vida. ${ }^{485}$ Gény conclui: "Chega-se então, necessariamente, a um momento em que o intérprete, desprovido de todo apoio formal, deve fiar-se em si mesmo para descobrir a decisão que ele não pode recusar"; ${ }^{486}$ uma atividade de criação e de desenvolvimento do Direito, "análoga àquela que incumbe ao próprio legislador", que não poderia ser negada ou desconhecida, ${ }^{487}$ pois fruto de uma "necessidade da natureza". 488 Equiparando o Poder Judiciário ao Poder Executivo, Gény vê a criação judicial do direito como um "poder discricionário" atribuído

\footnotetext{
${ }^{480}$ Com o significado, aqui, de "ciência do Direito".

${ }^{481}$ VIEHWEG, Theodor. Tópica e Jurisprudência. p. 16.

${ }^{482}$ Ibidem. p. 33.

${ }^{483}$ Ibidem. p. 45.

${ }^{484}$ Ibidem. p. 92.

${ }^{485}$ GÉNY, François. Méthode d'Interpretation et Sources en Droit Privé Positif, t. I. passim, esp. p. 28-53, 232-234 e 240-316.

${ }^{486}$ Idem. Méthode d'Interpretation et Sources en Droit Privé Positif, t. II. 75. No original: "Il arrive donc, nécessairement, um moment, où l'interprète, dépourvu de tout appui formel, doit se fier à lui-même, pour découvrir la décision qu'il ne peut refuser (art. 4 C. civ. franç.)".

${ }^{487}$ Ibidem. 77.

${ }^{488}$ Ibidem. 182.
} 
à "autoridade judiciária", ${ }^{489}$ No entanto, esse poder não pode tornar-se arbitrário. ${ }^{490} \mathrm{O}$ juiz deve desprender-se de qualquer influência pessoal na criação do direito, decidindo com base em elementos de "natureza objetiva". Daí o nome da teoria: "pesquisa livre" porque se trata de uma ação própria de uma autoridade positiva; "pesquisa científica" porque seus fundamentos não podem ser outros senão "elementos objetivos que apenas a ciência pode revelar". 491

\subsubsection{A inaptidão do modelo indutivo como modelo de raciocínio judicial}

O modelo indutivo de tomada de decisões não existe. Não existe como correspondente do método indutivo de investigação científica e, consequentemente, não existe como modelo de raciocínio judicial.

No método indutivo de investigação científica, o cientista não toma decisões, mas extrai conclusões da observação e apreensão de fenômenos naturais ou sociais. Quer dizer, o cientista empírico não decide; compreende fatos e chega a verdades gerais a partir da colheita de amostras, confrontação de teses e aplicação de regras de probabilidade. As diferenças em comparação com o raciocínio judicial decisório são gritantes.

Em primeiro lugar, toda decisão é tomada por algum motivo. Sempre. João, p.ex., decide ir ao restaurante $\mathrm{X}$ ou porque é mais barato ou porque o atendimento lhe agrada ou porque está localizado perto de sua casa ou porque a refeição é, em sua opinião, a melhor da cidade. Mas sempre haverá um motivo para que ele tome a decisão de ir ao restaurante X. Exatamente a mesma coisa ocorre em um processo judicial. Qualquer decisão tomada pelo magistrado terá um fundamento determinado, legítimo ou ilegítimo. No Estado de Direito esse fundamento, para ser legítimo, deve ser jurídico; todavia, é possível que a decisão seja antijurídica, arbitrária ou ilegítima, pois fundada em razão antijurídica, arbitrária ou ilegítima. O juiz tanto pode condenar o réu a indenizar o autor porque o autor estava mais bem vestido na audiência de instrução e julgamento, como

\footnotetext{
489 A "autoridade judiciária" seria uma "ramificação claramente especializada" da "autoridade executiva". Ibidem. 183.

${ }^{490}$ Ibidem. 185.

${ }^{491}$ Ibidem. 78.
} 
porque o réu é uma pessoa rica e o autor é uma pessoa pobre; ou ainda porque o réu causou um dano injusto ao autor e, segundo o Direito brasileiro, tal situação enseja a obrigação de reparar o dano. As duas primeiras razões são espúrias, é claro, mas são, indiscutivelmente, razões de uma decisão.

Como foi visto, o modelo lógico-dedutivo, independentemente de sua validade, apresenta uma proposta de tomada de decisão, a qual seria alcançada pelo reconhecimento da incidência de uma norma jurídica democraticamente elaborada a fatos alegados e provados pelas partes. O modelo indutivo, porém, não traz nenhum critério de tomada de decisões ou algum elemento que explique qual é a razão que justifica a decisão por ele tomada e por quê. A suposta prevalência dada pelo empirismo jurídico aos fatos, em detrimento do Direito, é insuficiente para esclarecer, p.ex., por que o réu foi condenado a ressarcir o autor pelos danos causados. ${ }^{492}$

Os adeptos do método indutivo diriam que a essência desse tipo de raciocínio estaria na produção de decisões justas no lugar de decisões meramente jurídicas. Não explicam, contudo, como a prevalência dos fatos narrados pelas partes em detrimento do Direito elaborado pelo legislador contribui para a produção de decisões justas. ${ }^{493}$

Imagine-se o exemplo em que o autor, pessoa pobre que passa por necessidade, sofreu determinado dano material, mas, por ser o réu uma pessoa rica, pede uma indenização três vezes superior à devida. O juiz concorda com a tese, vê na decisão uma possibilidade de distribuição de renda e de solução das dificuldades pelas quais passa

\footnotetext{
${ }^{492}$ Mais ou menos nesse sentido, GIANFORMAGGIO, Letizia. Modelli di ragionamento giuridico. p. 100: "Si sa bene che un'inferenza induttiva va provata, e la prova è data da un element esterno al ragionamento. La conclusione di un’inferenza induttiva viene provata sul fatto, cioè empiricamente: con la verifica o, almeno, con i tentativi di falsificazione. Ma questo procedimento è praticabile solo se la conclusione del ragionamento è una asserzione. La conclusione del ragionamento giuridico, invece, è una norma e di una norma, di cui non si predica la verità o la falsità, non ha alcun senso dire che viene provata sul fatto".

493 Ao tratar da doutrina de Viehweg, Michele TARUFFO concluiu que o pensamento tópico "non si presenta come un modello di giudizio, ma solo come l'indicazione di un procedimento di scelta delle premesse e dei criteri da impiegare nel giudizio" (La Motivazione della Sentenza Civile. p. 172). Em outra passagem explica: "La topica è essenzialmente un procedimento di discussione del problema, ma non un metodo di soluzione del problema stesso" (p. 172, nota 48). Por fim, vale citar o seguinte trecho: "Invero, è difficile non concordare con l'opinione di chi ritiene che la definizione topica del ragionamento giuridico non faccia altro che descrivere un aspetto abbastanza banale dell'attività che il giudice ha sempre svolto, senza nulla aggiungere né a tale attività né alla conoscenza di essa" (p. 175).
} 
o autor (realizando-se a "justiça", portanto), e condena o réu na quantia pedida. Não há dúvidas de que o juiz julgou o caso concreto de maneira casuística e pautada por uma suposta equidade, elementos característicos do 'modelo indutivo' de raciocínio judicial. Também não há dúvidas de que o juiz acredita ter "encontrado o direito mais adequado ao caso". Entretanto, analisado o processo de raciocínio um pouco mais atentamente, percebese que a conclusão não foi extraída unicamente dos fatos, embora eles sejam realmente o elemento central da reflexão judicial. A conclusão foi extraída da aplicação aos fatos de um senso de justiça próprio do magistrado; de normas morais que regem a sua maneira de ver o mundo e avaliar os fatos. Ou seja, a decisão continua sendo tomada pela avaliação de fatos a partir de valores e normas de conduta preestabelecidas. A diferença é que tais normas não foram elaboradas democraticamente e não eram previamente conhecidas pelas partes; são, sim, valores de uma pessoa, muitas vezes diametralmente conflitantes com os valores do resto da sociedade. No fim das contas, o único traço distintivo entre o modelo lógico-dedutivo e o denominado 'modelo indutivo' de raciocínio judicial está na substituição do direito estatal, como premissa maior do silogismo, pelo direito produzido subjetivamente pelo magistrado. ${ }^{494}$

Por isso tem razão Letizia Gianformaggio ao defender que "Quaisquer que sejam as belas palavras e as expressões de nobres ideais com as quais é apresentada, a operação antiformalista, antilegalista e antijuspositivista consistente em forjar um esquema de raciocínio jurídico modelado sobre o raciocínio indutivo das ciências empíricas não há outro profundo significado (...) do que a tentativa de subtração da atividade do juiz a qualquer forma de controle". ${ }^{495} \mathrm{O}$ juiz transforma-se em um novo ídolo, um super-herói

\footnotetext{
494 A associação muitas vezes feita entre o método indutivo e o sistema do common law não se sustenta. Embora o common law, em sua origem, fosse um sistema eminentemente casuístico, as decisões judiciais sempre tiveram balizas muito bem definidas que as dirigissem. Se em um primeiro momento tais balizas eram formadas pelos quase sagrados costumes ingleses, atualmente são formadas pelos precedentes judiciais (principalmente a partir do século XIX) e, de maneira cada vez mais intensa, pelos statutes, quer dizer, as normas positivadas.

495 GIANFORMAGGIO, Letizia. Modelli di ragionamento giuridico. p. 100-101. No original: "Quali che siano le belle parole e le espressioni di nobili ideali con cui la si presenta, l'operazione antiformalistica, antilegalistica ed antigiuspositivistica consistente nel forgiare uno schema di ragionamento giuridico modellato sul ragionamento induttivo delle scienze empiriche, non ha altro profondo significato, ove condotta con rigorosa coerenza (il che, va detto, nella storia della metodologia giuridica è raramente accaduto), che il tentativo di sottrazione dell'attività del giudice ad ogni forma di controllo".
} 
capaz de apreender fielmente a vontade e os interesses dos cidadãos, ${ }^{496}$ ainda que não the seja dado nenhum parâmetro para tanto. O Direito deixa de ser a vontade arbitrária do legislador (aquilo que Carré de Malberg chamou de Estado legal) e consolida-se como a vontade arbitrária dos juízes. ${ }^{497}$ Esse é, seguindo as lições da autora italiana, "o significado das fórmulas: 'os juízes criam direito' e 'os juízes fazem política", 498

De qualquer maneira, a inexistência de um modelo indutivo de raciocínio judicial não significa que o empirismo, corretamente considerado, seja irrelevante à tomada de decisões. O empirismo é fundamental para a construção das máximas de experiência, compreendidas como "as ilações que o juiz extrai da ocorrência de certos fatos para concluir que o outro fato tenha acontecido, com eficácia restrita a cada caso em que julga" ${ }^{499}$ As máximas de experiência são, portanto, "verdades gerais" construídas a partir da observação e conhecimento de como os fatos comumente se passam. ${ }^{500}$ Essa produção indutiva de conhecimento é importantíssima para a tomada de decisões pelo magistrado, sobretudo no que se refere à valoração das provas produzidas e sua aptidão para confirmar os fatos narrados pelas partes. Ainda assim, o raciocínio indutivo permite a construção de uma razão a ser dada para a decisão (a premissa do silogismo), mas é incapaz de fornecer a decisão propriamente dita (a conclusão do silogismo).

\footnotetext{
${ }^{496}$ Ibidem. p. 101.

${ }^{497}$ V. também AARNIO, Aulis. Le rationnel comme raisonnable. p. 9 : "Si la signification du droit à la base des décisions est fortement atténuée ou même niée, la voie est ouverte à l'arbitraire. Il faut se souvenir que la législation - malgré ses défauts - s'est révélée être une méthode efficace et utile pour diriger la conduite des gens en général".

${ }^{498}$ GIANFORMAGGIO, Letizia. Modelli di ragionamento giuridico. p. 101.

${ }^{499}$ DINAMARCO, Cândido Rangel. Instituições de Direito Processual Civil, v. III. p. 121.

${ }^{500}$ Esse é o teor do art. 335 do CPC: "Em falta de normas jurídicas particulares, o juiz aplicará as regras de experiência comum subministradas pela observação do que ordinariamente acontece e ainda as regras da experiência técnica, ressalvado, quanto a esta, o exame pericial".
} 


\subsection{O modelo argumentativo}

Igualmente em resposta ao modelo lógico-dedutivo, mas em sentido consideravelmente diverso do modelo indutivo, desenvolveu-se com grande força o denominado modelo argumentativo (ou retórico) de raciocínio e motivação judiciais. ${ }^{501}$

De um modo geral, esse modelo decorre de duas premissas. A primeira é que não existe uma exata correspondência entre a motivação e a tomada de decisão, a começar pelo fato de que elas se manifestariam em momentos significativamente distintos. ${ }^{502}$ A motivação viria em um momento posterior, constituindo uma atividade justificativa da decisão previamente tomada. A segunda, e mais importante, é que o Direito não é uma ciência puramente lógica, mas sobretudo argumentativa. ${ }^{503}$ Consequentemente, a motivação também não poderia ser um ato puramente lógico, mas retórico, pelo qual o magistrado deveria justificar a decisão tomada a partir de técnicas discursivas. Em outras palavras, a motivação seria um discurso argumentativo. A partir daí, desenvolveram-se as mais variadas teorias, ora dando prevalência à racionalidade do discurso, ora à sua capacidade de persuasão, ora à sua função de legitimação da atividade jurisdicional.

Para Chaïm Perelman, um dos "pais" do modelo argumentativo, motivar um julgamento é o mesmo que justificá-lo, e não "fundamentá-lo de uma maneira impessoal e, por assim dizer, demonstrativa”. Essa justificação consistiria na persuasão de um determinado auditório, previamente conhecido, de que a decisão proferida atende às suas exigências. ${ }^{504}$ A motivação, portanto, seguindo as lições de Perelman, é um ato persuasivo

\footnotetext{
${ }^{501}$ V. SANTOS, Tomás-Javier Aliste. La Motivación de las Resoluciones Judiciales. p. 252-285.

${ }^{502} \mathrm{O}$ fato de Chaïm Perelman não ter feito essa distinção foi alvo de severas críticas por parte de Michele Taruffo. V. TARUFFO, Michele. La Motivazione della Sentenza Civile. p. 198-199.

${ }^{503}$ Cf. MACCORMICK, Neil. Rethoric and the Rule of Law. p. 14.

${ }^{504}$ PERELMAN, Chaïm. La motivation des décisions de justice. p. 425. No original: "Pour conclure, motiver un jugement, c'est le justifier, ce n'est pas le fonder d'une façon impersonelle et pour ainsi dire, démonstrative. C'est persuader un auditoire, qu'il s'agit de connaître, que la décision est conforme à ses exigences". Um dos elementos mais importantes da teoria de Perelman é o denominado "auditório universal", que seria "constituído pela humanidade inteira, ou pelo menos por todos os homens adultos e normais" (Idem; OLBRECHTS-TYTECA, Lucie. Tratado da Argumentação. p. 29-39). A aceitação do argumento por este auditório universal seria o teste último de sua racionalidade: "somente quando o homem às consigo mesmo e o interlocutor do diálogo são considerados encarnação do auditório universal é que adquirem o privilégio filosófico confiado à razão, em virtude do qual a argumentação a eles dirigida foi amiúde assimilada a um discurso lógico" (Ibidem. p. 34).
} 
pelo qual se deve buscar a adesão refletida a um direito que seja obra da razão e da persuasão. Esse direito, tido pelo autor como "democrático", opõe-se ao "direito arbitrário", cuja imposição é incompatível com a motivação das decisões judiciais. ${ }^{505}$

Michele Taruffo, seguido no Brasil por Antonio Magalhães Gomes Filho, ${ }^{506}$ concorda que a motivação seja um discurso retórico, mas não nos mesmos moldes de Perelman. ${ }^{507}$ A natureza retórica da motivação não se presta, para o professor italiano, ao convencimento de interlocutores, mas à justificação da decisão tomada, pautada em argumentos racionalmente válidos e controláveis pelas partes, instâncias superiores e opinião pública. A motivação é, assim, um instrumento voltado ao controle "generalizado" e "difuso" do exercício do poder jurisdicional pelo juiz. ${ }^{508}$

Também adotando a concepção de que a motivação é um discurso retórico, Letizia Gianformaggio afirma que o essencial do raciocínio judicial não é a aplicação dedutiva da norma ao caso concreto, nem a inferência indutiva da norma de uma situação particular, mas a "justificação da assunção de uma ratio ao invés de outra", cujos destinatários são as partes, as instâncias superiores e a opinião pública. ${ }^{509} \mathrm{Com}$ isso, o cerne do raciocínio judicial seria a solução de controvérsias jurídicas pela valoração das razões apresentadas pelas partes. ${ }^{510}$

\footnotetext{
${ }^{505}$ PERELMAN, Chaïm. La motivation des décisions de justice. p. 425. No original: "Le droit autoritaire, celui qui s'impose par le respect et la majesté, n'a guère à motiver. Celui qui se veut démocratique, ouvre de persuasion et de raison, doit chercher, par la motivation, à obtenir une adhésion raisonée".

${ }^{506}$ GOMES, FILHO, Antonio Magalhães. A Motivação das Decisões Penais. p. 122-123.

${ }^{507}$ De acordo com TARUFFO, Perelman não consegue definir o que é uma argumentação racional; pelo contrário, a vinculação da validade da argumentação a um auditório universal faz da "irracionalidade difusa um critério de racionalidade" (La Motivazione della Sentenza Civile. p. 200-201).

${ }^{508}$ TARUFFO, Michele. La Motivazione della Sentenza Civile. p. 407.

${ }^{509}$ GIANFORMAGGIO, Letizia. Modelli di ragionamento giuridico. p. 101. No original: "Secondo questo modello, l'essenziale, lo specificamente giuridico del ragionamento del giudice che motiva un verdetto non è l'applicazione deduttiva della norma al caso particolare, non è l'inferenza induttiva di una norma da un particolare (norma o caso che sia) alla norma generale; ma è la giustificazione della assunzione di un ratio piuttosto che un'altra".

${ }^{510}$ Ibidem. p. 102.
} 


\subsubsection{A teoria standard da argumentação judicial}

A partir da década de 70 desenvolveu-se aquilo que se convencionou denominar de "teoria standard da argumentação judicial", 511 entre cujos representantes estão Neil MacCormick, Robert Alexy, Aulis Aarnio, Jerzy Wróblewski e Aleksander Peczenik.

O ponto de contato entre a teoria dos autores mencionados está no reconhecimento de que o raciocínio judicial tem natureza argumentativa, mas sem abdicar da obrigatória racionalidade e previsibilidade exigidas de todo ato jurisdicional. A teoria standard busca construir uma teoria da argumentação jurídica que não conflite com os valores do Estado de Direito.

Nos pontos seguintes serão tratados, muito brevemente e apenas em relação àquilo que for considerado estritamente relevante a este trabalho, alguns aspectos da teoria dos quatro primeiros autores citados.

8.3.2. A teoria de Jerzy Wróblewski - justificação interna e a justificação externa da motivação

Toda decisão, ensina Wróblewski, é uma escolha entre alternativas possíveis. No caso das decisões judiciais, o traço característico fundamental é que essa escolha deve ser feita com base no direito vigente. ${ }^{512}$ Todavia, a riqueza e o conteúdo das alternativas que se apresentam ao juiz tornam incertas as conclusões obtidas. Justamente por isso, a racionalidade da decisão judicial estaria vinculada à sua justificação. O juiz deve apresentar a decisão tomada como sendo a única decisão que poderia ser tomada naquele caso concreto, identificando as suas premissas e justificando-as como boas e

\footnotetext{
511 V. SANTOS, Tomás-Javier Aliste. La Motivación de las Resoluciones Judiciales. p. 266 e ss; CHIASSONI, Pierluigi. Tecnica dell'Interpretazione Giuridica. p. 13 e ss.

${ }^{512}$ WRÓBLEWSKI, Jerzy. Motivation de la Décision Judiciaire. p. 114.
} 
apropriadas. ${ }^{513}$ Os argumentos judiciais não são qualificados, portanto, em termos de verdade ou falsidade, mas em termos de persuasividade, razoabilidade etc. ${ }^{514}$

Essa distinção entre 'identificação' das premissas e 'justificação' é um aspecto fundamental na doutrina de Wróblewski. Toda decisão judicial deve apresentar ao menos dois tipos de justificação: uma interna e outra externa. A justificação interna é uma justificação eminentemente silogística, em que o juiz demonstra que a conclusão obtida decorre logicamente das premissas, jurídicas e fáticas, adotadas. A justificação interna, porém, não esclarece como são escolhidas essas premissas. A decisão, então, deve ser justificada também externamente, isto é, deve ser apresentada uma argumentação persuasiva a respeito dos elementos utilizados para a composição das premissas jurídicas e fáticas que desencadeiam a conclusão obtida. Em síntese, a decisão judicial é um silogismo, cujas premissas são justificadas argumentativamente. ${ }^{515}$

Para Wróblewski, a decisão é racional do ponto de vista interno quando é consequência das premissas que a fundamentam, e é racional do ponto de vista externo quando justificadas, segundo critérios racionais, as premissas e regras de inferências contidas na motivação. ${ }^{516}$

${ }^{513}$ Idem. Constitución y Teoría General de la Interpretación Jurídica. p. 57. V. também Idem. Motivation de la Décision Judiciaire. p. 116.

${ }^{514}$ Idem. Constitución y Teoría General de la Interpretación Jurídica. p. 58-59.

${ }^{515}$ Essas considerações levam a uma fórmula compacta da decisão final proferida: "de acordo com a norma $\mathrm{N}$, no sentido $\mathrm{S}$, o fato $\mathrm{F}$, que aconteceu no lugar $\mathrm{L}$ e no tempo $\mathrm{T}$, possui as consequências legais $\mathrm{C} 1$..Cn de acordo com as diretivas de escolha das consequências $\mathrm{C} 1 . . \mathrm{Cn}$ e as estimações [valorativas] $\mathrm{VC} 1 . . \mathrm{VCn}$ " (Idem. Motivation de la Décision Judiciaire. p. 120). A fórmula, porém, não esclarece como é feita a interpretação da norma, quer dizer, como se chegou ao "sentido S"; também não esclarece como se adotou a premissa de que o "fato F" aconteceu no "lugar L" e no "tempo T". Uma fórmula mais extensa que também abarque esses elementos seria a seguinte: "de acordo com a norma $\mathrm{N}$, que há o sentido $\mathrm{S}$ de acordo com as diretivas de interpretação DI1...DIn e estimações [valorativas] VI1...VIn, necessárias para a escolha e o emprego destas diretivas, o fato $\mathrm{F}$, cuja ocorrência no lugar $\mathrm{L}$ e no tempo $\mathrm{T}$ foi provada pelos meios de prova admitidos P1...Pn, em conformidade com as diretivas DP1...DP2 e estimações [valorativas] VP1...VP2, possui as consequência legais $\mathrm{C} 1 \ldots \mathrm{Cn}$ em conformidade com as diretivas de escolha das consequências DC1...DCn e estimações [valorativas] VC1...VCn" (Ibidem. p. 121). Sobre o significado dos elementos interpretativos e valorativos, v. Idem. Constitución y Teoría General de la Interpretación Jurídica. p. 57-80.

${ }^{516}$ Idem. Motivation de la Décision Judiciaire. p. 134. 


\subsubsection{A teoria de Neil MacCormick - necessária conciliação entre o Estado de Direito e a argumentação jurídica}

De acordo com MacCormick, é preciso conciliar dois elementos distintos, mas igualmente importantes: o Estado de Direito e o caráter argumentativo do Direito. Embora o Direito seja uma "disciplina argumentativa" que raramente pode ser apresentada com argumentos demonstrativos, o Estado de Direito deve prevalecer, pois só assim haverá condições de promoção da dignidade da pessoa humana. ${ }^{517} \mathrm{E}$ é justamente a adoção de um determinado modelo de argumentação jurídica que permite a conciliação entre eles. Isso quer dizer, no mínimo, que "não pode haver asserções sem razões - tudo o que for afirmado pode vir a ser confrontado e, diante de um confronto, uma razão deve ser oferecida para tudo o que for afirmado, independentemente da afirmação tratar de argumentos jurídicos ou (...) de alguma questão fática”. 518

Uma relevante peculiaridade do raciocínio jurídico, segue MacCormick, é que a argumentação não parte do vazio e tenta estabelecer conclusões razoáveis a priori. As soluções encontradas devem ter fundamentos jurídicos, devem ser apresentadas como soluções decorrentes de normas jurídicas. ${ }^{519}$ Quer dizer, as normas jurídicas devem ser o ponto de partida de qualquer decisão judicial. ${ }^{520}$

MacCormick conclui, então, que o silogismo judicial não só tem espaço, como desempenha um papel importante no raciocínio jurídico. Afinal, aceitar o dedutivismo não significa negar o raciocínio informal, o raciocínio fundado em

\footnotetext{
517 MACCORMICK, Neil. Rhetoric and the Rule of Law. p. 12-17. Explica o autor "I do believe in the argumentative quality of the law, and find it admirable in an open society. (...) But I also believe in the Rule of Law, and think that our life as humans in community with other is greatly enriched by it. Without it, there is no prospect of realizing the dignity of human beings as independent though interdependent participants in public and private activities in a society" (p. 16).

${ }^{518}$ Ibidem. p. 17. No original: "This implies at least that there may not be assertions without reasons whatever is asserted may be challenged, and, upon challenge, a reason must be offered for whatever is asserted, wheter the assertion is of some normative claim or a claim about some state of affairs, some 'matter offact'".

${ }^{519}$ Ibidem. p. 23.

${ }^{520}$ Idem. The motivation of judgements in the common law. p. 193: "To understand today's subject in the round, one has to realise that respect for established rules is the starting point for the decision of any problem (...)". Idem. Rhetoric and the Rule of Law. p. 104.
} 
probabilidades ou mesmo a retórica. ${ }^{521}$ Como o silogismo é incapaz de, por si só, representar a motivação de todas as decisões judiciais, especialmente aquelas proferidas em casos difíceis, ${ }^{522}$ o desafio está, para o professor escocês, em estabelecer quais são os limites que devem ser impostos à argumentação judicial para que o Direito apresente a segurança exigida pelo Estado de Direito. ${ }^{523}$

Quatro são as características que, no seu entendimento, as razões apresentadas na motivação das decisões judiciais devem conter: (a) universalidade; (b) perspectiva de consequências; (c) razoabilidade; e (d) coerência.

(a) Uma motivação universalizada ou universalizável quer dizer que todos os casos idênticos ou análogos ao que foi julgado devem ser passíveis de julgamento de acordo com as mesmas razões apresentadas. ${ }^{524} \mathrm{Ou}$ seja, o julgamento não pode ser pautadado por razões individualizadas para o caso concreto, mas sim por razões universais que sirvam para todas as situações similares. Uma manifestação clara da regra de que "casos iguais devem ser tratados igualmente" (to treat like cases alike).

(b) Universalizadas as razões dadas para a decisão do caso concreto, então deve ser feita a análise e valoração das suas consequências. ${ }^{525}$

(c) A motivação deve ser, ainda, razoável. O sentido da razoabilidade jurídica, defende MacCormick, deve ser o da "razoabilidade prática", distinguindo-a da "capacidade abstrata" de encontrar razões a partir de problemas teóricos. Pessoas razoáveis, explica, possuem o atributo da prudentia, situando-se exatamente entre a cautela excessiva e a indiferença aos riscos. Suas conclusões sempre levam em consideração as provas e os diferentes pontos de vista, convergindo valores e razões para uma conciliação e, em caso de litígio, dando prevalência aos valores mais proeminentes. ${ }^{526}$ Desse modo, a irrazoabilidade "consiste em ignorar algum fator ou fatores relevantes, ou tratar como relevante o que deveria ser ignorado. Alternativamente, pode envolver alguma distorção

\footnotetext{
${ }^{521}$ Ibidem. p. 32 e ss.

${ }^{522}$ Ibidem. p. 237 e ss.

${ }^{523}$ Ibidem. passim, esp. p. 279-280.

${ }^{524}$ Ibidem. p. 78-100.

${ }^{525}$ Ibidem. p. 101-120.

${ }^{526}$ Ibidem. p. 166.
} 
grosseira dos valores relativos de diferentes fatores". ${ }^{527}$ Para MacCormick, a razoabilidade é objetiva, pois afasta interesses subjetivos do julgamento. ${ }^{528}$

(d) Por fim, e complementando a exigência da razoabilidade, a motivação deve ser coerente e consistente. A diferença entre os conceitos, para o professor escocês, é a seguinte. Enquanto consistência é sinônimo de ausência de contradição, a coerência exige mais do que isso: exige sentido. Um texto coerente não é apenas aquele que não é contraditório, mas aquele que efetivamente possui uma razão de ser. Uma norma jurídica que estipula limites de velocidade distintos para os carros de acordo com a cor de sua pintura pode ser consistente (i.e., não contraditória), mas não será coerente, pois falha em servir a valores considerados relevantes. ${ }^{529}$

A coerência da motivação dá-se em dois planos: coerência normativa e coerência narrativa. A coerência normativa refere-se à justificação da decisão judicial com base no sistema jurídico em que está inserida. A coerência narrativa refere-se à justificação das inferências extraídas das provas produzidas e dos fatos adotados como premissas para a decisão. ${ }^{530}$

\subsubsection{A teoria de Robert Alexy - as regras do discurso prático e do discurso jurídico}

A proposta de Robert Alexy é construir uma fundação para a teoria da argumentação jurídica racional. Para tanto, enumera várias regras e formas envolvendo o discurso prático geral e, também, o discurso jurídico. Em relação ao discurso prático, divide-as em: regras fundamentais, regras de razão, regras de ônus argumentativo, formas de argumento, regras de fundamentação e regras de transição. Importam aqui as regras fundamentais e as regras de ônus argumentativo. No que diz respeito ao discurso jurídico, elas são divididas em regras e formas de justificação interna e regras e formas de justificação externa. ${ }^{531}$

\footnotetext{
${ }^{527}$ Ibidem. p. 173.

${ }^{528}$ Ibidem. p. 162-188.

${ }^{529}$ Ibidem. p. 190-191.

${ }^{530}$ Ibidem. p. 189 e ss.

${ }^{531}$ Para uma apresentação sistematizada, v. ALEXY, Robert. Teoria da Argumentação Jurídica. p. 287-293.
} 
As quatro regras "fundamentais" de toda comunicação linguística são: (rf.1) regra lógica: o discurso não pode ser contraditório; (rf.2) regra de sinceridade: toda afirmação deve refletir aquilo que seu autor acredita; (rf.3) regra de coerência: se o falante atribui um predicado $\mathrm{P}$ para um objeto $\mathrm{O}$, deve estar disposto a aplicar esse mesmo predicado $\mathrm{P}$ a todo objeto igual a $\mathrm{O}$ em todos os aspectos relevantes; (rf.4) regra da clareza da comunicação: "diferentes falantes não podem usar a mesma expressão com diferentes significados", a qual é complementada pela exigência de clareza e sentido da fala. ${ }^{532}$

O ônus argumentativo também possui quatro regras, das quais importam aqui as três primeiras: (roa.1) a pretensão de tratar uma pessoa A de maneira diferente de uma pessoa B deve ser justificada; (roa.2) o ataque a uma proposição ou a uma norma que não é objeto da discussão deve ser justificada; (roa.3) se uma pessoa A apresenta um argumento, e seu interlocutor B apresenta contra-argumentos, então a pessoa A deve dar novos argumentos.

As regras da justificação interna das decisões judiciais são: (rji.1) universalismo normativo: toda decisão judicial deve ser fundamentada em pelo menos uma norma universal; (rji.2) obrigatória referência a um caso concreto: a decisão judicial deve decorrer logicamente de ao menos uma norma universal, junto a outras proposições; (rji.3) universalidade das premissas interpretativas: sempre que houver dúvida sobre a qualificação de um fato, deve ser apresentada uma regra que decida a questão; (rji.4) exaustividade das premissas - completude lógica das passagens argumentativas: "são necessárias as etapas de desenvolvimento que permitam formular expressões cuja aplicação ao caso em questão não seja discutível"; (rji.5) máximo detalhamento da argumentação: deve-se articular o maior número possível dessas etapas de desenvolvimento. ${ }^{533}$

E, por fim, as regras de justificação externa das decisões judiciais são: (rje.1) regra da saturação dos argumentos que houver entre os cânones da interpretação: o juiz deve apresentar premissas empíricas ou normativas para o resultado interpretativo obtido; (rje.2) regra de vinculação ao direito vigente: argumentos voltados à interpretação

\footnotetext{
${ }^{532}$ Ibidem. p. 187-190.

${ }^{533}$ Ibidem. p. 220-228. Sobre essas regras, v. CHIASSONI, Pierluigi. Tecnica dell'Interpretazione Giuridca. p. 29-37.
} 
segundo a literalidade da lei ou à vontade do legislador histórico prevalecem sobre os demais argumentos, salvo se a prioridade de outros argumentos possa ser racionalmente justificada; (rje.3) princípio da universalidade: "a determinação do peso de argumentos de diferentes formas deve ocorrer segundo regras de ponderação"; (rje.4) devem ser levados em consideração todos os argumentos que possam ser incluídos entre os cânones de interpretação; (rje.5) todo enunciado dogmático questionado deve ser fundamentado com ao menos um argumento prático geral; (rje.6) "todo enunciado dogmático deve enfrentar uma comprovação sistemática, tanto em sentido estrito como em sentido amplo - controle de consistência (no mesmo sentido dado por MacCormick); (rje.7) exigência de racionalidade: "se são possíveis argumentos dogmáticos, devem ser usados"; (rje.8) princípio da universalidade: sempre que for possível citar um precedente que ampare a decisão obtida, deve-se fazê-lo; (rje.9) o ônus argumentativo é daquele que pretende afastar-se de um precedente - regra oa.1 do ônus argumentativo; (rje.10) as formas especiais de argumentação jurídica (analogia, argumentum a contrario, argumentum a fortiori, argumentum ad absurdum) devem ser saturadas. ${ }^{534}$

\subsubsection{A teoria de Aulis Aarnio - racionalidade e aceitabilidade da motivação}

Seguindo substancialmente as lições de Alexy, Aulis Aarnio, em célebre obra, busca elementos que garantam racionalidade e aceitabilidade à interpretação do Direito e, consequentemente, à motivação das decisões judiciais. ${ }^{535}$

Aarnio parte do pressuposto de que o Direito não é um mero conselho dado ao juiz que pode ou não ser seguido, mas o "fundamento autoritário" das decisões judiciais. ${ }^{536}$ Mesmo em casos difíceis, nos quais seria proferida uma "decisão

\footnotetext{
${ }^{534}$ ALEXY, Robert. Teoria da Argumentação Jurídica. p. 228-278.

${ }^{535}$ AARNIO, Aulis. Le rationnel comme raisonnable. passim. Para Aarnio, "la théorie de l'interprétation en dogmatique juridique équivaut, en partie, à la théorie e la justification du choix d'une interpretation" (p. 62). ${ }^{536}$ Ibidem. p. IX.
} 
discricionária", ${ }^{537}$ o juiz deve agir em conformidade com a ordem jurídica, tratando-se "literalmente de um caso de aplicação do direito". 538

No entanto, as normas jurídicas não são proposições teóricas que simplesmente descrevem a realidade; logo, o Direito nem sempre dá uma resposta completa para os problemas que se apresentam. O Direito precisa ser interpretado e é nessa interpretação que residem as incertezas e indeterminações. ${ }^{539}$

Considerando que o poder não se legitima em si mesmo, as decisões judiciais, atos de autoridade e poder que são, devem ser justificadas. Mas, para que se promova a segurança jurídica, elemento central da teoria do professor finlandês, ${ }^{540}$ a justificação precisa ser racional e aceitável. Em suas palavras, "apenas uma interpretação que tenha sido justificada de maneira apropriada é pertinente do ponto de vista da segurança jurídica". 541

Acolhendo a distinção de Wróblewski entre justificação interna e justificação externa da decisão judicial, Aarnio entende que a racionalidade da motivação está ligada à lógica de seu raciocínio (justificação interna) e ao discurso que justifica as premissas adotadas (justificação externa). Já a aceitabilidade (axiológica) da motivação volta-se ao resultado do raciocínio judicial e à sua correspondência com o sistema de valores da comunidade jurídica. ${ }^{542}$ Em síntese, a racionalidade remete à forma, e a aceitabilidade ao conteúdo da justificação. ${ }^{543}$

\footnotetext{
${ }^{537}$ A decisão seria discricionária tanto quando a norma jurídica autoriza mais de uma interpretação como quando mais de uma norma jurídica regula a fattispecie. Ibidem. p. 3.

${ }^{538}$ Ibidem. p. 3-4. Na tradução francesa: "Quelle que puisse être sa position formelle, le juge est supposé agir conformément à l'ordre juridique. Il s'agit littéralement d'un cas d'application du droit" (p. 4).

${ }^{539}$ Ibidem. p. IX-X.

${ }^{540}$ Ibidem. p. 4 e, esp., 29 e 62.

${ }^{541}$ Ibidem. p. 62. Na tradução francesa: "en effet, seule une interprétation qui a été justifiée de façon appropriée est pertinente du point de vue de la sécurité juridique".

${ }^{542}$ Ibidem. p. 232-233.

${ }^{543}$ Ibidem. p. 234-235.
} 
As condições gerais de Aarnio para um discurso racional são: (a) consistência; (b) efetividade; (c) sinceridade; (d) generalização; (e) suporte; (f) regras procedimentais do ônus da prova; e (g) regras materiais do ônus da prova. ${ }^{544}$

(a) A motivação é consistente quando, dentre outros, não há conflito interno, verifica-se que a justificação interna é lógica, bem como são adotadas a regra do "terceiro excluído" e a regra de transitividade. ${ }^{545}$

(b) A motivação é efetiva quando permite que se chegue a uma conclusão. Para tanto, é preciso que haja um acordo linguístico mínimo entre os interlocutores e as expressões devem ser utilizadas de maneira uniforme.

(c) A motivação é sincera quando afastados argumentos de autoridade e persuasões autoritárias, e pautada por uma autêntica honestidade argumentativa, isto é, as razões apresentadas na motivação devem corresponder àquilo que o juiz realmente pensa ser válido. Além disso, pressupõe um sujeito imparcial que não apresente apenas suas próprias razões como também os argumentos que lhe são contrários.

(d) A motivação é generalizável se as razões apresentadas puderem servir a outros casos similares. A motivação de uma decisão não pode ser pautada por razões que sirvam unicamente ao julgamento daquele caso específico apresentado pelas partes.

(e) As regras de suporte referem-se à necessidade de que cada afirmação seja acompanhada das razões que suportam a afirmação. O objetivo da justificação é atingir a coerência e, então, a aceitabilidade da comunidade jurídica.

(f) e (g) Finalmente, as regras do "ônus da prova"546 implicam que a pessoa que apresenta uma proposição tem o ônus de justificá-la. No contexto "procedimental", a justificação deve limitar-se e ter pertinência à proposição feita. Não é racional, portanto, a motivação judicial que, a pretexto de justificar o dispositivo da decisão, trata de questões

\footnotetext{
${ }^{544}$ Ibidem. p. 239-250.

545 Ibidem. p. 240-241. Segundo a "regra do terceiro excluído", uma proposição ou é verdadeira ou é falsa. Desse modo, "se um elemento X possui a propriedade $\mathrm{P}$, esta propriedade não pode, ao mesmo tempo, fazerlhe falta". Já para a regra da transitividade, aceito o enunciado "se X, então Y" e "se Y, então Z", há que se aceitar o enunciado "se X, então Z".

${ }^{546}$ Embora o autor refira-se a "burden of proof" (traduzido na versão francesa como "charge de la preuve"), talvez a expressão mais adequada fosse "ônus argumentativo".
} 
absolutamente irrelevantes ou, não raro, distintas da que estão sendo discutidas no processo. Outro aspecto do contexto "procedimental" é que o ônus argumentativo (ou "da prova", como chama Aarnio) recai sobre aquele que pretende mudar o status quo. Sendo assim, o juiz possui o ônus de justificar por que não segue a jurisprudência de um tribunal superior, p.ex. Em contrapartida, a resposta à tentativa de mudança do status quo também deve ser justificada. Se uma das partes afirma que, naquele caso, não deve ser seguida a jurisprudência já pacificada, o juiz possui o ônus de justificar o motivo pelo qual a seguirá. No contexto "substancial", destaca-se a necessidade de justificação quando há violação do princípio da isonomia. Aqui, pode-se citar o exemplo da mudança de jurisprudência de um tribunal.

No que diz respeito à aceitabilidade racional, Aarnio desenvolve interessante teoria sobre um "relativismo de valores moderado", ligado ao que ele chama de "forma de vida". ${ }^{547}$ No que importa a este trabalho, o autor defende que mesmo pessoas com valores de base diferentes podem compreender-se mutuamente, uma vez que possuem uma linguagem comum (lembrando-se que o destinatário da motivação seria a “comunidade jurídica").

De acordo com Aarnio, a justificação só é bem sucedida se, e somente se, o seu destinatário, que também aceita os princípios de racionalidade da justificação externa da decisão (acima apresentados), é convencido de que as razões apresentadas podem ser aceitas. Contudo, diante de seu "relativismo de valores moderado", a dogmática jurídica deve buscar interpretações jurídicas que possam assegurar o suporte da maioria dos membros de uma comunidade jurídica que raciocinam racionalmente. ${ }^{548}$ Esse é o significado da aceitabilidade racional: um princípio regulador da dogmática jurídica que dá legitimidade à interpretação judicial e torna palpável a análise das atitudes a partir da exigência da segurança jurídica. ${ }^{549}$

Nessa linha de pensamento, o relativismo moderado de valores e a aceitabilidade racional seriam desdobramentos da democracia. A conclusão da maioria dos membros da sociedade, adeptos dos princípios da racionalidade discursiva, possuiria uma

\footnotetext{
${ }^{547}$ Ibidem. p. 250-269.

${ }^{548}$ Ibidem. p. 276.

${ }^{549}$ Ibidem. p. 276-277.
} 
"pertinência social" superior à das demais conclusões. Essa pertinência social não decorreria de argumentos persuasivos, do exercício do poder ou de uma autoridade formal, mas da "força racional da justificação". 550

Resumindo, a segurança jurídica seria respeitada se: (a) a decisão (ou a interpretação) tem amparo jurídico; (b) o discurso é racional; e (c) a decisão segue o código de valores dominante dos seus destinatários. ${ }^{551}$

8.4. A conjugação entre lógica e argumentação: as teorias de Ricardo Luis Lorenzetti e Pierluigi Chiassoni

Três das críticas geralmente dirigidas à teoria standard da argumentação judicial dizem respeito (a) à sua ênfase excessiva sobre a motivação normativa da decisão, deixando de lado o raciocínio sobre os fatos relevantes ao julgamento, (b) à sua suposta inaptidão para descrever os argumentos judiciais utilizados para justificar a decisão tomada, uma vez que se trata de uma teoria eminentemente prescritiva, e (c) às concepções filosóficas de seus autores a respeito do conhecimento da verdade dos fatos no processo. ${ }^{552}$

Independentemente do acerto ou não das críticas, a contribuição dada pela teoria standard à conscientização de que as decisões judiciais, mesmo se não puderem ser motivadas de maneira absolutamente lógica, ainda assim podem ser racionais, controláveis e amparadas no Direito vigente é inestimável. A teoria standard rompe com a perniciosa concepção de que a legitimidade de uma decisão judicial decorre da simples apresentação de argumentos que a justifique, não importa quais sejam. Na verdade, a legitimidade da decisão judicial decorre de uma motivação jurídica, amparada em argumentos racionalmente válidos e controláveis: um dado indispensável a qualquer teoria da motivação judicial.

A teoria standard tem o grande mérito, portanto, de reconhecer a importância da lógica para que uma decisão seja adequadamente motivada, seja pela

\footnotetext{
${ }^{550}$ Ibidem. p. 277-278.

551 Ibidem. p. 278. Na tradução francesa: "L'attente de sécurité juridique est parfaitement remplie si et seulement si (a) la décision (ou l'interprétation) tombe dans le cadre juridique, (b) le discours se fait de manière rationnelle, et (c) la décision obéit au code de valeurs dominant".

${ }^{552}$ V. SANTOS, Tomás-Javier Aliste. La Motivación de las Resoluciones Judiciales. p. 266-268.
} 
distinção entre justificação interna e justificação externa, seja pela aceitação de que os casos simples são eminentemente decididos pelo método dedutivo. Essa forma de ver as coisas foi particularmente desenvolvida por Ricardo Luis Lorenzetti e Pierluigi Chiassoni, cujas teorias são descritas abaixo.

8.4.1. A teoria de Ricardo Luis Lorenzetti - diferentes modelos para a decisão de casos fáceis e casos dificeis

Em interessantíssima obra, Ricardo Luis Lorenzetti busca conjugar os modelos lógico-dedutivo e argumentativo de raciocínio judicial. O autor identifica três formas de encarar a distinção entre casos fáceis e casos difíceis. Para a primeira, todos os casos são fáceis, de modo que todas as decisões podem ser resolvidas dedutivamente. Para a segunda, todos os casos são difíceis, pois a ordem jurídica atingiu uma indeterminação tão grande que toda decisão judicial tem como fundamento um princípio. Para a terceira, há casos fáceis, que são a regra, e há casos difíceis, que são a exceção. Nessa última hipótese, a maior parte dos casos, que são fáceis, é decidida por um processo silogístico; já os casos difíceis, em que há indeterminação da norma aplicável, problemas de interpretação, dificuldades quanto à prova dos fatos ou dificuldades a respeito da qualificação desses fatos, devem ser resolvidos mediante técnicas argumentativas.

Para Lorenzetti, as duas primeiras posições são insuficientes. A primeira peca pela incompletude, já que há casos que efetivamente não podem ser resolvidos dedutivamente. Quanto à segunda, sua crítica é feroz: "uma vez que se esgote o prazer estético da descrição do sistema aberto e fluido, temos de pensar nas soluções, e dizer que algo é 'flexível' não constitui um guia para quem tem de resolver um caso". Além disso, a aplicação do método dedutivo "constitui a base do funcionamento normal do sistema jurídico, que lhe outorga estabilidade e segurança jurídica". 553

Seguindo Neil MacCormick na terceira corrente, Lorenzetti conclui que há casos fáceis e casos difíceis. Os casos fáceis, a vasta maioria, são aqueles em que a decisão pode ser proferida mediante um raciocínio dedutivo. Já os casos difíceis são resolvidos por princípios, que informam a discricionariedade judicial, e paradigmas, que são "guias

\footnotetext{
${ }^{553}$ LORENZETTI, Ricardo Luis. Teoria da Decisão Judicial. p. 158-159.
} 
políticos que requerem a compatibilização dos modelos no marco da ordem social". ${ }^{554}$ Isso significa que o raciocínio judicial deve desenvolver-se de acordo com os passos sucessivos: (1) primeiro são aplicadas dedutivamente as regras válidas; (2) em seguida o resultado da dedução é controlado de acordo com os precedentes judiciais; (3) se os dois primeiros passos não forem suficientes para alcançar-se a decisão, então se está diante de um caso difícil que deverá ser resolvido por princípios; (4) caso a solução seja definida por paradigmas, esses devem ser explicados e harmonizados. ${ }^{555}$

(1) A primeira etapa em qualquer decisão judicial é tentar deduzir a solução do caso a partir de uma regra jurídica. Esse procedimento é antecedido pela delimitação dos fatos relevantes que tenham sido provados de acordo com as fontes e os meios probatórios; e também pela identificação da norma válida segundo os critérios de hierarquia, especialidade e temporalidade, e determinação de seu sentido pela interpretação. ${ }^{556}$

(2) Encontrada a norma jurídica aplicável ao caso concreto, o juiz deve “olhar para trás" (elemento de consistência), "olhar para cima" (elemento de coerência) e "olhar para frente" (elemento consequencialista). "Olhar para trás" significa conferir a solução por ele dada com os precedentes judiciais envolvendo casos similares. Para Lorenzetti, "quem quiser se apartar de um precedente assume a carga da argumentação justificativa da mudança". "Olhar para cima" é o mesmo que checar a coerência da solução dada ao caso concreto com o resto do sistema jurídico, ou seja, "olhar as regras gerais que dão coerência ao sistema jurídico". Essa coerência, explica o autor, é presumida; aquele que pretende provar o contrário tem o ônus argumentativo. Por fim, "olhar para a frente" é o mesmo que analisar as consequências jurídicas e socioeconômicas que a decisão pode vir a provocar para além do contexto específico do processo em que é proferida. Quando a decisão contiver consequências que impliquem prejuízo institucional, deverão ser adotados mecanismos que garantam à decisão o menor dano possível. ${ }^{557}$

\footnotetext{
${ }^{554}$ Ibidem. p. 159.

${ }^{555}$ Ibidem. p. 157.

${ }^{556}$ Ibidem. p. 159-160.

${ }^{557}$ Ibidem. p. 160-163.
} 
(3) Não sendo possível a solução do caso concreto pelos dois primeiros passos, então o juiz deverá justificar a sua decisão a partir de uma argumentação jurídica racional fundada em princípios. Os critérios lógicos para a tomada da decisão são: (i) identificar uma situação de conflito entre princípios contrapostos; (ii) buscar a alternativa mais econômica, isto é, aquela que menos afeta outros princípios; (iii) verificar se o sistema jurídico não proíbe a ponderação entre certos princípios, ou define previamente uma hierarquia entre eles; (iv) buscar o ponto ótimo de equilíbrio na ponderação; (v) adequar os argumentos aos princípios envolvidos, o que implica: apresentar argumentos razoáveis e racionais para limitar direitos fundamentais; optar sempre pela solução que favoreça a autonomia pessoal e a liberdade; reconhecer direitos fundamentais desde que sejam compatíveis com os bens coletivos. ${ }^{558}$

(4) Enfim, devem ser analisados os paradigmas que regem a decisão. Segundo Lorenzetti, “a regra e o princípio são guias para raciocinar correta e explicitamente", subsumindo o suporte fático a uma regra ou valorando o peso de cada princípio na tomada da decisão, ${ }^{.59}$ mas antes deles vêm os paradigmas, "modelos decisórios" prévios que traçam objetivos a serem alcançados. Ou seja, princípios são standards que devem ser observados, e os paradigmas são standards que devem ser alcançados, tais como: acesso a bens jurídicos primários, proteção dos vulneráveis, proteção dos interesses coletivos, realização do Estado de Direito e análise consequencialista das ações privadas. ${ }^{560}$

A realização dos paradigmas, porém, apresenta três problemas fundamentais: adoção de soluções diversas para o mesmo caso por juízes diferentes; expansão indevida dos paradigmas para contextos aos quais não pertence; e conflitos entre paradigmas. Tudo isso leva à necessária fixação de critérios de correção que limitem a interpretação jurídica subjetiva "para que os cidadãos tenham uma percepção clara de que as decisões se baseiam na igualdade e no Estado de Direito".

Dois são os passos para a utilização dos paradigmas. O primeiro é o da "explicação", o qual implica a exposição do paradigma e do objetivo a ser alcançado. O

\footnotetext{
${ }^{558}$ Ibidem. p. 209-226.

${ }^{559}$ Ibidem. p. 163.

${ }^{560}$ Ibidem. p. 227-228.
} 
segundo é o da "harmonização", momento em que o conflito entre paradigmas deve ser resolvido por uma harmonização que leve em consideração o modelo da democracia deliberativa. Para tanto devem ser utilizadas as seguintes diretrizes: (i) o juiz não pode substituir as decisões das maiorias por suas próprias convicções, competindo-lhe reforçar os mecanismos existentes para que elas se expressem; (ii) identificar os consensos básicos da sociedade; (iii) harmonizar os diferentes paradigmas concorrentes, analisando os benefícios e desvantagens de cada um deles; (iv) ter consciência de que existe um metavalor, que é o pluralismo de valores. A tarefa da Constituição é possibilitar a vida em comum, buscando uma sociedade mais inclusiva, e não estabelecer um projeto de vida determinado; (v) o juiz não precisa moldar um conceito normativo preciso, mas buscar a pacificação social; (vi) devem ser identificados os consensos majoritários e limitados quando violarem direitos fundamentais. ${ }^{561}$

\subsubsection{A teoria de Pierluigi Chiassoni - a reconstrução silogística da argumentação judicial}

Outra teoria que merece destaque é a de Pierluigi Chiassoni, um autêntico defensor do caráter argumentativo da motivação das decisões judiciais.

Adotando a distinção de Wróblewski entre justificação interna e justificação externa, Chiassoni explica que uma sentença judicial é corretamente motivada se, e apenas se, cada uma das decisões nela contida é racional ou racionalmente justificada; e uma decisão é racional se, e apenas se, três condições são satisfeitas. A primeira delas, uma condição de racionalidade formal (condição de justificação interna), exige que a decisão seja justificada dedutivamente, de modo que a conclusão decorra logicamente de suas premissas. As outras duas são condições de racionalidade substancial: a decisão deve ser justificada a partir da correção jurídica das suas premissas normativas (condição de justificação externa normativa), ${ }^{562}$ e a decisão deve ser justificada a partir da correção jurídica de suas premissas fáticas (condição de justificação externa probatória). ${ }^{563}$

\footnotetext{
${ }^{561}$ Ibidem. p. 228-229.

562 Quanto a essa condição de racionalidade, Chiassoni explica que a identificação das normais gerais utilizadas na motivação consiste em "deduzir normas explícitas dos dispositivos”, i.e., traduzir disposições em normas explícitas", levando em consideração opções e operações hermenêuticas que reflitam premissas
} 
Especificamente no que importa a este trabalho, Chiassoni defende que mesmo a justificação externa das decisões judiciais pode ser, ao menos em parte, reconstruída em silogismos judiciais mediante uma "metodologia silogística de análise das sentenças". ${ }^{564}$ De um modo geral, tal metodologia permitiria ao intérprete atestar com clareza: (i) quais são as premissas da decisão; (ii) se a conclusão decorre logicamente das premissas; (iii) se a motivação explícita apresenta "saltos lógicos" ou contém premissas implícitas; e (iv) quais argumentos foram adotados para justificar cada uma das premissas. $^{565}$

Chiassoni apresenta, então, a seguinte proposta de tipologia de silogismos: (a) silogismo normativo; (b) silogismo interpretativo; (c) silogismo de ligação; (d) silogismo classificatório; e (e) silogismo probatório. No entanto, desenvolve apenas os quatro primeiros em sua obra. ${ }^{566}$

(a) Silogismos normativos são aqueles em que a premissa maior e a conclusão constituem enunciados normativos, quer dizer, normas jurídicas que prevejam uma consequência a determinada fattispecie, mas que não configurem regras interpretativas. O silogismo judicial normativo pode atingir vários graus, dependendo do nível de abstração desenvolvido no raciocínio judicial. Será de primeiro grau quando a conclusão obtida exprimir a consequência da norma jurídica a partir de sua subsunção à fattispecie. Será de segundo grau quando a premissa maior for uma norma jurídica mais geral e abstrata, a premissa menor for um enunciado que exprima uma qualificação - uma classe de fatos concretos disciplinados pela premissa maior -, e sua conclusão coincidir com a premissa maior de um silogismo de primeiro grau. E assim por diante.

O exemplo dado por Chiassoni é esclarecedor. De acordo com o art. 1418 do Código Civil italiano, são nulos os contratos contrários a normas imperativas. Diante de

interpretativas do raciocínio justificativo judicial; e deduzir normas implícitas a partir de outras normas explícitas ou implícitas com o auxílio de princípios metodológicos que incluem: analogia, raciocínio $a$ contrario e função produtiva. CHIASSONI, Pierluigi. Tecnica dell'Interpretazione Giuridica. p. 49-50.

${ }^{563}$ Ibidem. p. 13-15.

${ }^{564}$ Idem. La Giurisprudenza Civile. p. 155 e ss.

${ }^{565}$ Ibidem. p. 156.

${ }^{566}$ Ibidem. p. 158. 
uma alegação de nulidade de contrato celebrado no domingo, o juiz poderia desenvolver o seguinte raciocínio.

Silogismo normativo de terceiro grau: se os contratos contrários a normas imperativas são nulos, e se os contratos sacrílegos são contrários a normas imperativas, então os contratos sacrílegos são nulos.

Silogismo de segundo grau: se contratos sacrílegos são nulos, e se os contratos celebrados no domingo são sacrílegos, então os contratos celebrados no domingo são nulos.

Silogismo de primeiro grau: se contratos celebrados no domingo são nulos, e se Maria e Pedro celebraram um contrato no domingo, então o contrato celebrado por Maria e Pedro é nulo.

Ou seja, o caso concreto é resolvido pelo desenvolvimento de um raciocínio lógico que parte de fatos e normas mais abstratos até encontrar a premissa maior do silogismo final de primeiro grau. ${ }^{567}$

(b) Os silogismos interpretativos são, para Chiassoni, aqueles cujas conclusões apresentam um enunciado interpretativo a respeito das fontes do Direito. Esse enunciado pode apresentar uma regra interpretativa, considerações e juízos sobre resultados interpretativos, considerações e juízos sobre a atividade interpretativa, atribuição de significado a enunciados normativos etc.

A motivação do acórdão proferido pelo STJ no REsp 161.906/BA pode ser utilizada como exemplo singelo de silogismo interpretativo: "na relação locatícia, as normas de exegese que informam a interpretação dos termos contratuais são aquelas que mais beneficiam o locatário, sabidamente a parte mais fraca da relação". Transformada em silogismo, a afirmação poderia ser assim colocada: se os contratos devem ser interpretados em favor da parte mais fraca da relação contratual, e se o locatário é a parte mais fraca da relação contratual, então os contratos devem ser interpretados em favor do locatário.

Cite-se outro exemplo. Ao julgar o REsp 256.115/RO, assim decidiu o STJ: "Destarte, estando o aresto recorrido assentado em premissas resultantes da análise do depoimento pessoal do réu, não há de se falar em ofensa ao art. 401 do CPC, que somente

${ }^{567}$ Ibidem. p. 158-160. 
seria aplicável à hipótese vertente acaso fundada as conclusões da Corte a quo exclusivamente na prova testemunhal" ${ }^{568}$ O silogismo interpretativo seria: se depoimento testemunhal não se confunde com depoimento pessoal, e se o art. 401 do Código de Processo Civil veda apenas a prova exclusivamente testemunhal para provar a existência de contratos de valor superior a dez salários mínimos, então o art. 401 não veda a utilização de depoimento pessoal para provar a existência de contratos cujo valor supere dez salários mínimos.

(c) O vínculo entre o silogismo interpretativo e o silogismo normativo é realizado por um silogismo de ligação, cuja conclusão serve como premissa maior de um silogismo normativo. Para Chiassoni, o silogismo de ligação demonstra que mesmo motivações argumentativas podem ser representadas silogisticamente. ${ }^{569}$

Em Agravo em Recurso Especial nº 167.161/MS, o Estado do Mato Grosso do Sul insurgiu-se contra acórdão do Tribunal de Justiça que havia autorizado a execução provisória de sentença proferida em mandado de segurança, sobre o fundamento de que o art. $2^{\circ}$-B da Lei 9.494/97 havia sido violado. A decisão monocrática foi motivada basicamente dessa maneira: "Dispôs o Tribunal de origem que deve ser imediatamente cumprida a decisão proferida em mandado de segurança, quando não se encaixa em nenhuma das hipóteses em que os arts. $7^{\circ}$ e 14 da Lei n. 12.016/2009 proíbem a execução provisória do julgado. (...) Com efeito, não tratou o impetrante de utilizar o recurso como ação de cobrança, nem pretende o pagamento de débitos pretéritos, buscou, em verdade, o direito de averbar o tempo de serviço prestado à empresa pública para fins de contagem de tempo de serviço, o que não se confunde com a liberação de recurso, nem inclusão de folha de pagamento, etc. A ordem concessiva, consistente na citada obrigação de fazer, não encontra resistência no art. $2^{\circ}$-B da Lei n. ${ }^{\circ}$ 9.494/97 - 'A sentença que tenha por objeto a liberação de recurso, inclusão em folha de pagamento, reclassificação, equiparação, concessão de aumento ou extensão de vantagens a servidores da União, dos Estados, do Distrito Federal e dos Municípios, inclusive de suas autarquias e fundações, somente poderá ser executada após seu trânsito em julgado' - uma vez que não trata das restrições

\footnotetext{
${ }^{568}$ REsp 256.115/RO, Rel. Ministro CARLOS FERNANDO MATHIAS (JUIZ FEDERAL CONVOCADO DO TRF $1^{\text {a }}$ REGIÃO), QUARTA TURMA, julgado em 20/11/2008, DJe 09/12/2008

${ }^{569}$ CHIASSONI, Pierluigi.La Giurisprudenza Civile. p. 169-173.
} 
nele contida. Relembre-se que: 'O Superior Tribunal de Justiça firmou entendimento no sentido de que os arts. $2^{\circ}$-B da Lei $9.494 / 97$ e $5^{\circ}$ e $7^{\circ}$ da Lei 4.348/64 devem ser interpretados de forma restritiva, de modo que somente são aplicáveis às hipóteses expressamente previstas por eles' (REsp 507.042/AC, Rel. Ministro ARNALDO ESTEVES LIMA, QUINTA TURMA, julgado em 23/08/2005, DJ 03/10/2005, p. 311)”.

Os silogismos contidos na motivação poderiam ser sinteticamente expressados da maneira que segue:

Conclusão do silogismo interpretativo (a mera alegação de que se trata de um entendimento do Tribunal impede a reformulação do silogismo interpretativo): o art. $2^{\circ}$-B da Lei 9.494/97 deve ser interpretado restritivamente.

Silogismo de ligação: Se o art. $2^{\circ}$-B da Lei 9.494/97 deve ser interpretado restritivamente, e se na redação do dispositivo não existe restrição ao cumprimento provisório de sentenças que imponham obrigação de fazer, então sentenças proferidas em mandado de segurança que imponham obrigação de fazer podem ser cumpridas provisoriamente.

Silogismo normativo: Se sentenças proferidas em mandado de segurança que imponham obrigação de fazer podem ser cumpridas provisoriamente, e se o impetrante obteve uma sentença em mandado de segurança que impôs uma obrigação de fazer ao Estado do Mato Grosso do Sul, então a sentença proferida em benefício do impetrante pode ser cumprida provisoriamente.

(d) Enfim, existem os silogismos de qualificação, que são aqueles cuja conclusão representa um enunciado de qualificação, classificação ou subsunção que serve de premissa menor para um silogismo normativo. Eles podem ser representados por, dentre outros: inclusão de um "indivíduo" (comportamentos, estado de coisas, seres animados ou inanimados etc.) em uma classe mais ampla; inclusão de um "indivíduo" determinado em uma fattispecie abstrata; inclusão de um "indivíduo" determinado em uma classe de "indivíduos" que não constitui uma fattispecie, mas está incluída em uma fattispecie abstrata etc. Como regra, o silogismo de qualificação é coordenado com ao menos um silogismo interpretativo. ${ }^{570}$

${ }^{570}$ Ibidem. p. 173-174 
Um exemplo concreto poderia ser o do julgamento, pelo STJ, do REsp $n^{\circ}$. 616.022/SC. Locatária e locadora celebraram contrato de locação pelo prazo de cento e vinte meses, tendo indicado como termo inicial o dia 15 de novembro de 1988 e termo final o dia 14 de novembro de 1998. A locatária defendia que o prazo genericamente indicado de cento e vinte meses deveria prevalecer, desconsiderando-se o termo final expressamente indicado no contrato. A controvérsia sobre o prazo era determinante para a aferição da tempestividade da ação renovatória proposta pela locatária. A decisão do STJ foi: "De início, consoante entendimento manifestado por esta Corte, a data definida no contrato de locação para seu término prevalece sobre qualquer outra forma de contagem do lapso temporal de vigência do pacto. $\mathrm{Na}$ realidade dos autos, ainda que o dia 14 de novembro de 1998, estabelecido pelas partes como marco ad quem da relação locatícia, não coincida com o interregno de 120 (cento e vinte meses) que fora fixado na avença, sobre este é preponderante, devendo ser utilizado como baliza para aferição da decadência da ação renovatória". O entendimento a que a decisão se refere foi exposto da seguinte maneira no julgamento do REsp 299.031/SP: "Nesse contexto, há de prevalecer a clara e específica estipulação da avença, apta a afastar qualquer outra forma de contagem do prazo $(\ldots) "$

Silogismo interpretativo: se na interpretação das declarações de vontade prevalece a intenção das partes (premissa maior - art. 113 do Código Civil), e se a interpretação da intenção das partes em um instrumento contratual é representada pela cláusula mais específica e que menos dúvida gera, então cláusulas contratuais específicas devem prevalecer sobre cláusulas contratuais genéricas.

Silogismo de qualificação: se cláusulas contratuais específicas devem prevalecer sobre cláusulas contratuais genéricas, e se o contrato celebrado entre o locador “A" e o locatário "B" possui uma cláusula que prevê um prazo contratual genérico de 120 meses, e outra cláusula que prevê um termo inicial específico no dia 15 de novembro de 1988 e um termo final específico no dia 14 novembro de 1998, então a intenção das partes “A" e "B" era que o termo final do contrato fosse o dia 14 de novembro de 1998.

Silogismo normativo de segundo grau: se a ação renovatória deve ser proposta em até 6 meses do termo final do contrato, sob pena de decadência do direito potestativo do locatário à renovação (art. 51, $\S 5^{\circ}$, da Lei 8.245/91), e se o termo final do contrato celebrado entre as partes "A" e "B" era o dia 14 de novembro de 1998 , então o 
locatário "B" deveria ter proposto a ação renovatória até o dia 14 de maio de 1998, sob pena de decadência.

Silogismo normativo de primeiro grau: se o locatário "B" deveria ter proposto a ação renovatória até o dia 14 de maio de 1998, sob pena de decadência, e se o locatário "B" propôs ação renovatória no dia 15 de maio de 1998, então o locatário "B" decaiu de seu direito potestativo de obter a renovação compulsória do contrato de locação com "A".

Além da tipologia de silogismos apresentada, Chiassoni defende que os silogismos existentes em uma decisão judicial podem relacionar-se de quatro maneiras: (A) relações de concatenação lógica; (B) relações de coordenação argumentativa; (C) relações de coordenação praxeológica; e (D) relações de convergência praxeológica. (A) As relações de concatenação lógica podem ser verticais ou horizontais. Nas relações verticais, a conclusão de um silogismo coincide com a premissa maior de outro silogismo. Nas relações horizontais, a conclusão de um silogismo coincide com a premissa menor de outro silogismo. (B) Na coordenação argumentativa, a conclusão de um silogismo corrobora na justificação da conclusão de outro silogismo, mas sem compor uma de suas premissas. (C) $\mathrm{Na}$ coordenação praxeológica, os silogismos não são concatenados, mas a questão resolvida por um deles é prejudicial, sob um aspecto lógico-jurídico ou argumentativo, à questão resolvida pelo outro silogismo. (D) E na convergência praxeológica, os silogismos não são concatenados, mas ambos chegam à mesma conclusão a partir de premissas maiores diferentes. ${ }^{571}$

\subsection{Lógica e argumentação: a estrutura da motivação das decisões judiciais}

Considerando tudo o que foi exposto até o momento, parece razoável concluir que, conquanto insuficiente para, por si só, representar a estrutura da motivação das decisões judiciais, o silogismo judicial não pode ser ignorado ou menosprezado. Como explicou Wróblewski, toda decisão deve ser internamente justificada de maneira eminentemente lógica. O dispositivo tem que decorrer logicamente das premissas estabelecidas pelo juiz, o que significa que o dispositivo tem que estar de acordo com a

\footnotetext{
${ }^{571}$ Ibidem. p. 174-176.
} 
consequência prevista na norma jurídica aplicável ao caso concreto; ou na hipótese de improcedência ou indeferimento do pedido, tem que ser uma consequência lógica da não correspondência entre os fatos alegados e provados pelo autor e a consequência jurídica que lhes pretende atribuir com seu pedido. Sendo assim, toda decisão deve ser, ao menos internamente, um silogismo judicial; ${ }^{572}$ essa é, seguindo o entendimento de Chiassoni, uma exigência de racionalidade formal.

Por outro lado, nem toda decisão precisa ser externamente justificada de forma argumentativa. A tese de que atualmente todas as causas judiciais são difíceis e indeterminadas é falaciosa. Qual é a indeterminação jurídica de uma demanda em que se pede a renovação de um contrato de locação? Ou da demanda em que se pede a condenação do réu à obrigação de fazer prevista em contrato? Ou ainda da demanda voltada à invalidação de uma multa imposta em processo administrativo sem que a autuada tivesse sido intimada para se defender? Nenhum desses casos possui indeterminação jurídica ou depende de aplicação de princípios para ser resolvido. Comprovados os fatos alegados pelo autor, basta que se os subsuma à norma jurídica aplicável e extraia a consequência prevista no ordenamento jurídico. Não comprovados os fatos pelo autor, então o pedido deve ser julgado improcedente. De uma forma ou de outra, Lorenzetti tem razão ao afirmar, repete-se, que o método dedutivo "constitui a base do funcionamento normal do sistema jurídico, que lhe outorga estabilidade e segurança jurídica". 573

Quanto aos casos difíceis, não há como refutar a insuficiência do silogismo judicial e o necessário desenvolvimento de um discurso argumentativo para que a decisão seja adequadamente motivada. Mas isso não implica que a lógica possa ser simplesmente abandonada e o discurso possa ser desenvolvido arbitrariamente. Além das várias regras de racionalidade impostas pela teoria standard da argumentação jurídica, Pierluigi Chiassoni

\footnotetext{
572 Ensina NOJIRI, Sérgio. O Dever de Fundamentar as Decisões Judiciais. p. 79: "De uma maneira genérica, podemos afirmar que [lógica] é o estudo dos métodos e princípios usados para distinguir o raciocínio correto do incorreto. Seu objetivo principal é a descoberta e a fundamentação de procedimentos de conclusão que sejam válidos sem referência a conteúdos materiais".

${ }^{573}$ LORENZETTI, Ricardo Luis. Teoria da Decisão Judicial. p. 158-159. Igualmente, SARTORIUS, Rolf. The justification of the judicial decision. p. 179: “(...) the judge will be faced with a majority of initial commitments which he is not free to revise in the light of systematic considerations. Indeed, most of the judges' initial commitments will be of this sort, for the easy cases constitute the vast majority of cases, and in them the judge is simply not free to revise his obligations".
} 
demonstra com bastante argúcia que é possível reconstruir silogisticamente boa parte da motivação relativa à interpretação dos dispositivos normativos e à qualificação dos fatos. Ademais, a exigência de que a motivação contenha razões universais ou universalizáveis (MacCormick e Alexy - característica da generalização para Aarnio) configura, ao fim e ao cabo, um controle dedutivo da argumentação: x deve ter a consequência y porque para todo $\mathrm{x}$, então $\mathrm{y}$.

No que diz respeito à motivação fática, a conclusão não diverge, sobretudo quando se constata que, especificamente no âmbito civil, ela não possui o mesmo grau de indeterminação da motivação jurídica. Em primeiro lugar, apenas são levados em consideração no processo os fatos alegados e provados pelas partes, restringindo-se consideravelmente o contexto fático; na motivação jurídica, prevalece a regra do iura novit curia, expandindo o contexto jurídico para absolutamente todo o ordenamento. Em segundo lugar, as alegações fáticas são consideradas provadas quando demonstradas de acordo com as fontes e os meios de prova processualmente admissíveis. O Código de Processo Civil contém 112 artigos (332 ao 443) voltados a disciplinar de que maneira são produzidas as provas no processo, inclusive delimitando a força probante de determinadas fontes (como ocorre com os documentos), restringindo meios de prova em certos casos (como ocorre com a restrição da prova exclusivamente testemunhal para contratos superiores ao décuplo do salário mínimo) e autorizando a realização de perícias por profissionais altamente especializados que podem auxiliar o juiz no esclarecimento dos fatos. Em terceiro lugar, eventuais divergências e indeterminações fáticas são resolvidas pela aplicação da regra do ônus da prova, cuja dimensão objetiva é justamente servir de regra de julgamento. Se o juiz entender que os fatos narrados por um das partes não foram suficientemente provados, então tais fatos são considerados inexistentes.

Tudo isso permite que também a motivação fática desenvolva-se eminentemente pela construção de silogismos: se João alega que emprestou dinheiro a José, e se João juntou aos autos o contrato de mútuo celebrado com José, então João efetivamente emprestou dinheiro a José; ou ainda, se José alega que já pagou a obrigação que assumiu com João, e se José apresentou um comprovante de depósito bancário do valor do mútuo em conta de titularidade de João, então José pagou a obrigação que assumiu com João; e finalmente, se João alega que emprestou dinheiro a José, e se João não produziu nenhuma prova de que emprestou dinheiro a José, então, para os fins do 
processo, João não emprestou dinheiro a José. Problematize-se mais um pouco: se João alega que José apropriou-se de dinheiro da sociedade de que são sócios mediante operação irregular no dia $\mathrm{X}$, e se a perícia realizada na contabilidade da sociedade não apurou nenhuma retirada anormal de valores no dia $X$, então José, para os fins do processo, não se apropriou de dinheiro da sociedade no dia X.

$\mathrm{Na}$ verdade, excetuando-se as discussões relativas à produção de prova e cerceamento de defesa, as quais possuem natureza jurídica e não propriamente fática, o grande problema da motivação em relação aos fatos está, salvo melhor juízo, nas recorrentes omissões e incompletudes das decisões judiciais. Não raro as decisões são motivadas com um lacônico "os fatos foram comprovados por farto material probatório" ou algo similar.

Obviamente, existem casos problemáticos, tais como: testemunhas contraditórias, testemunhos que divergem de informações contidas em documentos, impugnação do conteúdo da perícia realizada, confissão que destoa do restante do material probatório etc. Mas em qualquer uma dessas hipóteses o juiz poderá construir silogismos utilizando como premissa maior as máximas de experiência ou estabelecer um discurso argumentativo pautado pelas regras de racionalidade estabelecidas pela teoria standard para justificar a sua escolha por determinada prova ou explicitar como concluiu que a alegação de uma das partes é a verdadeira.

Sendo assim, a motivação das decisões judiciais, para ser condizente com os valores do Estado de Direito, deve conciliar lógica e argumentação jurídica racional. Além de obedecer às regras de racionalidade expostas acima (v. 8.3.1 e ss.), a motivação argumentativa deve, sempre que possível, permitir uma reconstrução silogística que torne possível o controle de suas premissas e a logicidade da conclusão obtida.

\section{A motivação das decisões judiciais: exposição e justificação - o referencial do Estado de Direito}

Afirmou-se anteriormente que, sob um ponto de vista analítico, motivar uma decisão judicial significa expor de maneira racional, ordenada, lógica, clara e coerente as razões pelas quais se decide de determinada maneira e, sob um ponto de vista teleológico, trata-se da necessária justificação formal do exercício do poder jurisdicional, explicitando- 
se racionalmente às partes, aos órgãos ad quem e a qualquer outra pessoa da sociedade que tenha interesse naquele julgamento por que a decisão tomada foi aquela, e não outra.

Considerando tudo o que foi exposto desde então, a conceituação merece um breve aprofundamento.

\subsection{A motivação é uma exposição de razões}

A motivação das decisões judiciais é, acima de tudo, uma exposição de razões. Relatadas as alegações fáticas de ambas as partes, as consequências jurídicas que o autor pretende extrair de tais fatos, os óbices jurídicos ou fáticos que o réu apresenta a tais consequências, e as provas produzidas, o juiz deve expor, repete-se, racional, ordenada, lógica, clara e coerentemente quais são as alegações fáticas relevantes ao processo, e por quê, quais delas foram provadas, e por quê, se a consequência jurídica pretendida pelo autor está correta, e por quê, e se os óbices apresentados pelo réu à consequência jurídica pretendida pelo autor procedem, e por quê.

Desse modo, a motivação deve apresentar, sempre, razões fáticas e jurídicas que fundamentem a decisão, não importa em que sentido seja. A estrutura pela qual têm que ser apresentadas essas razões já foi vista: o juiz deve demonstrar que a decisão é uma consequência lógica da subsunção dos fatos à norma jurídica aplicável; e deve demonstrar como chegou à conclusão de que os fatos realmente ocorreram, e de que a norma jurídica aplicável é realmente aquela. Ou seja, a motivação é uma exposição lógico-argumentativa de razões pelas quais a decisão tomada foi aquela, e não outra.

9.2. A motivação é uma justificação formal do exercício da atividade jurisdicional

Teleologicamente considerada, a motivação serve para justificar a interferência do Estado no patrimônio jurídico do indivíduo. Diz-se teleologicamente porque a motivação não é em si mesma uma justificação. A motivação é uma exposição racional, lógica, coerente e clara de razões fáticas e jurídicas de uma decisão, que tem como escopo e função justificar formalmente um ato estatal de poder.

Destarte, não é qualquer razão que serve para justificar um ato estatal. A motivação não é uma exigência vazia que pode ser atendida com qualquer tipo de 
argumento. A motivação é uma justificação formal de que o ato jurisdicional está fundamentado materialmente no Direito. Por isso, não basta pegar um modelo pronto e abarrotado de excertos doutrinários e citações jurisprudenciais totalmente desvinculados do caso concreto, como sói acontecer, para que a decisão judicial seja considerada "motivada". A motivação da decisão judicial depende da efetiva demonstração de que aquele ato é jurídico porque, considerando os fatos alegados e provados pelas partes, aquela é a consequência prevista ou almejada pela ordem jurídica brasileira.

Essas ponderações, já amplamente colocadas nos pontos anteriores, são fundamentais para que se tenha claro que a motivação legitima, sim, a atividade jurisdicional, mas apenas se o seu conteúdo estiver de acordo com as exigências inerentes ao Estado de Direito.

\subsection{Sobre a dissociação entre a motivação e as razões de decidir}

Motivação e decisão judicial (em sentido estrito - dispositivo) não se confundem. A decisão judicial é uma manifestação do poder jurisdicional de decidir imperativamente uma demanda apresentada ao Estado para que seja satisfeita. A motivação é a prestação de contas dessa manifestação de poder.

No entanto, como foi exposto brevemente no ponto 4.1 deste trabalho, existem duas maneiras de relacionar essa prestação de contas com a decisão judicial. A primeira defende que a motivação deve reproduzir fielmente o iter percorrido pelo juiz para chegar à decisão a respeito da demanda inicial apresentada pelo autor. A segunda defende que não há uma correspondência necessária entre o discurso justificativo do juiz e as verdadeiras razões pelas quais ele tomou a decisão. A motivação seria um discurso produzido a posteriori voltado a justificar a decisão tomada. A esses dois momentos convencionou-se denominar, respectivamente, de contexto da justificação (context of justification) e contexto da descoberta (context of discovery).

Diante desse panorama, as razões expostas pelo juiz são representações fiéis daquelas pelas quais ele decidiu ou foram elaboradas posteriormente em um contexto de justificação?

$\mathrm{Na}$ perspectiva analítica da motivação, a resposta a essa pergunta é juridicamente irrelevante. A partir do momento em que as razões são apresentadas em uma 
decisão judicial, o ato jurídico está praticado e, para todos os efeitos, as razões da decisão são aquelas; corretas ou incorretas, correspondentes à realidade ou não. Sob uma perspectiva analítica, portanto, e é sob essa perspectiva que a motivação é uma exposição de razões, a dissociação entre as verdadeiras razões de uma decisão e as razões formalmente dadas pelo juiz não possui nenhuma repercussão jurídica; salvo, é claro, naquilo que concerne à parcialidade do juízo. Assim como ocorre com os atos administrativos e a notória "teoria dos motivos determinantes", ${ }^{574}$ a motivação formal do ato estatal integra o ato e dele faz parte, independentemente da concreta correspondência com o mundo real. As razões de uma decisão judicial são, para o Direito, aquelas que foram dadas; e é com base nelas que o ato jurisdicional será apreciado e aferido.

O tema, porém, possui particular importância quando analisado sob a perspectiva teleológica da motivação das decisões judiciais. Afinal, se a motivação não representa as razões pelas quais o juiz decidiu, então qual é a sua verdadeira efetividade como instrumento de legitimação e controle do poder jurisdicional?

\subsubsection{A motivação não é a justificação de uma decisão intuititva}

A dissociação entre motivação e razões de decidir recebeu defesa célebre de Piero Calamandrei na fase final de sua vida, alterando sensivelmente as suas opiniões iniciais. ${ }^{575}$ Para o Mestre florentino, a sentença "nasce" antes que o juiz saiba exatamente quais são as razões lógicas que o levaram a decidir daquela maneira. ${ }^{576} \mathrm{O}$ dispositivo da decisão, portanto, é um prius e não um posterius à motivação, constatação que demonstraria a "insuficiência" e a "unilateralidade" da redução da sentença a um esquema

\footnotetext{
${ }^{574}$ Por todos, MEDAUAR, Odete. Direito Administrativo Moderno. p. 137.

$575 \mathrm{O}$ artigo La crisi della motivazione decorre de uma de seis conferências proferidas por Calamandrei na Universidade Nacional do México entre 14 e 28 de fevereiro de 1952, todas publicadas originalmente em 1954 na obra Processo e Democrazia. No artigo/conferência La crisi della motivazione, Calamandrei diverge profundamente das ideias que havia exposto no artigo La genesi logica della sentenza civile, publicado pela primeira vez em 1914 na Rivista Critica di Scienze Sociali.

${ }^{576}$ CALAMANDREI, Piero. La crisi della motivazione. p. 667. Também nesse sentido, v. DINAMARCO, Cândido Rangel. Instituições de Direito Processual Civil, v. III. p. 657-658; JORGE, Mário Helton. Manual Teórico e Prático da Sentença Cível. p. 33. Em sentido contrário, LIEBMAN, Enrico Tullio. Do arbitrio à razão: reflexões sobre a motivação da sentença. p. 80; AMODIO, Ennio. Motivazione della sentenza penale. p. 216-218.
} 
silogístico. ${ }^{577}$ Desse modo, a motivação seria, na maior parte dos casos, um "exame de consciência sucessivo, realizado pelo juiz para persuadir-se de que bem julgou"; uma atividade lógica para "controlar, à luz da razão, a bondade de uma decisão resultante do sentimento". 578

O pensamento de Calamandrei é fundado basicamente em sua larga experiência forense. Utiliza como parâmetro o trabalho do advogado, primeiro juiz de seu cliente, que, posto diante dos fatos narrados, descobre intuitivamente a solução para o caso com um "sentimento quase instintivo de simpatia ou repugnância". Só então começa o "trabalho de pesquisa e controle na legislação e na doutrina". ${ }^{579}$ Segundo Calamandrei, "o jurista não é um manual legislativo", mas é aquele que "sabe como estudar um caso jurídico". 580

No entanto, a tese do Mestre não procede. A motivação não serve para justificar uma decisão intuitiva nem, muito menos, para persuadir o juiz de que bem julgou. E isso fica muito claro quando formuladas algumas perguntas: o sentimento de que determinada solução é correta pode ser considerado uma decisão judicial? A mera suposição prévia de que o autor deve ter seu pedido julgado procedente por A ou por B significa que foi proferida uma decisão judicial? E se a decisão intuitiva violar frontalmente uma norma legal ou contrariar a interpretação pacífica que lhe é dada pela doutrina e jurisprudência? Manterá o juiz a decisão intuitiva apesar de ilegal, apesar de inexistir alguma norma jurídica que lhe dê amparo?

Todas as questões devem ser respondidas negativamente. $\mathrm{O}$ mero "sentimento" de que uma solução é correta não pode ser considerado uma decisão judicial, nem pode prevalecer sobre a constatação de que aquela intuição estava equivocada. Afinal, como o próprio Calamandrei explica, a descoberta intuitiva da solução para o caso concreto deve passar, logo em seguida, por um "trabalho de pesquisa e controle na legislação e na doutrina". Ora, se a decisão intuitiva precisa ser controlada posteriormente, então essa decisão intuitiva é um projeto inicial de decisão e não a decisão em si mesma

\footnotetext{
${ }^{577}$ CALAMANDREI, Piero. La crisi della motivazione. p. 668.

${ }^{578}$ Ibidem. p. 668.

${ }^{579}$ Ibidem. p. 668-669.

${ }^{580}$ Ibidem. p. 669.
} 
considerada. A decisão depende de uma prévia racionalização que confirme o juízo preliminarmente formado pelo julgador. Em outras palavras, a decisão só será efetivamente tomada depois que constatado que o juízo intuitivo do julgador estava correto. Além disso, mesmo que intuitiva, a decisão deve passar por um controle que lhe garanta amparo jurídico, já que aceitar o contrário implicaria abandonar os ideais inerentes ao Estado de Direito e à segurança jurídica. Dessa forma, a decisão ao final proferida não estará fundada no espírito íntimo do julgador, mas no Direito que rege a sociedade. ${ }^{581}$

Por outro lado, é preciso ter em mente que o juiz não é um leigo que jamais estudou Direito e funda todas suas decisões em um ideal próprio de justiça. Calamandrei mesmo assevera que o fundamento da decisão intuitiva é um "senso jurídico" acumulado ao longo dos anos. ${ }^{582} \mathrm{Ou}$ seja, o fundamento dessa 'decisão preliminar' é o conhecimento do que é o Direito, de quais são os valores que estão em sua base e qual é o espírito informativo de determinado sistema jurídico. $\mathrm{Na}$ medida em que, tecnicamente considerada, intuição é o julgamento consciente fundado em um conhecimento estrutural inconsciente, ${ }^{583}$ é até possível aceitar um juízo preliminar intuitivo por parte do juiz. Ainda assim, a intuição estará fundada em um conhecimento prévio do Direito, ainda que inconsciente, e representará um enquadramento dos fatos àquilo que o juiz imagina que seja o Direito: um autêntico silogismo, ainda que provisório e hipotético. ${ }^{584}$ Diante de um

\footnotetext{
581 V. LIEBMAN, Enrico Tullio. Do arbitrio à razão: reflexões sobre a motivação da sentença. p. 80: "Intuição e raciocínio concorrem, em diversas medidas, para formar o juízo e é inútil tentar estabelecer regras e ordens nos elementos e os casos são infinitos. Para o direito é irrelevante conhecer dos mecanismos psicológicos que, às vezes, permitem ao juiz chegar às decisões. O que importa, somente, é saber se a parte dispositiva da sentença e a motivação estão, do ponto de vista jurídico, lógicos e coerentes, de forma a constituírem elementos inseparáveis de um ato unitário, que se interpretam e se iluminam reciprocamente". V. também AMODIO, Ennio. Motivazione della sentenza penale. p. 216-218.

${ }^{582}$ Ibidem. p. 669.

${ }^{583}$ DIENES, Zoltán; SCOTT, Ryan. Measuring unconscious knowledge: distinguishing structural knowledge and judgment knowledge. p. 7: "When structural knowledge is unconscious but judgment knowledge is conscious, the phenomenology is of intuition. Intuition is knowing that a judgment is correct, but not knowing why".

${ }^{584}$ Sobre o conhecimento inconsciente, a Psicologia moderna estuda o processo de tomada de decisões a partir de informações indisponíveis ao consciente do indivíduo: um conhecimento adquirido de forma inconsciente ou transportado do consciente para o inconsciente. O exemplo comumente dado é o da escolha
} 
caso inédito de Direito Processual, o jurista pode até não saber de antemão qual solução é a mais correta, mas será capaz de "intuí-la" a partir do conhecimento de quais são os princípios processuais, para que serve o processo e o que se espera de um devido processo legal.

De qualquer maneira, a tese do julgamento intuitivo só abrange uma hipótese fática, que é a do magistrado que sabe qual é a solução adequada, mas não consegue racionalizá-la de imediato em linguagem jurídica. Tanto isso é verdade que Calamandrei preocupa-se em atribuir ao julgamento intuitivo a condição de regra geral, mas não absoluta. ${ }^{585}$

A preocupação tem razão de ser. Em muitos casos a solução do caso concreto é completamente desconhecida do julgador. Imagine-se que um magistrado tenha sido recentemente removido para uma Vara da Fazenda Pública. Diante de um complexo processo de desapropriação indireta que envolva questões ambientais, p.ex., o magistrado muito provavelmente não saberá como resolvê-lo. Terá que estudar, descobrir como o Direito regula aquela matéria e então extrair a solução adequada para o caso concreto. A conclusão será inequivocamente posterior ao convencimento judicial e à formulação das razões que o levaram a decidir daquela maneira.

Também são muitos os casos em que o jurista terá prévio conhecimento da existência das exatas normas que regulam os fatos que lhe estão sendo narrados. Isso é ainda mais frequente quando a discussão envolve área do conhecimento em que o jurista especializou-se. Um magistrado que atua há anos com processos envolvendo Direito do Consumidor não precisará decidir intuitivamente o caso em que o autor, consumidor, pede condenação do réu, fornecedor, porque este praticou cobrança vexatória. A decisão será inferida de imediato a partir do prévio conhecimento da norma jurídica que rege os fatos que estão sendo narrados. Se questionado por que decidiu em favor do autor no primeiro caso, o magistrado poderá imediatamente responder: porque a dignidade da pessoa humana é fundamento da República Federativa do Brasil (art. 1º, III, da CR) e, consequentemente,

de construções gramaticais sem saber ao certo qual é a regra que impõe aquela construção; algo não muito diferente da tomada de decisões pelo juiz a partir do desconhecimento consciente da norma jurídica aplicável ao caso. V. Ibidem. passim.

${ }^{585}$ CALAMANDREI, Piero. La crisi della motivazione. p. 669. 
é vedada a cobrança vexatória no Direito brasileiro (art. 42 do CDC). Constatada a cobrança vexatória, então houve lesão a um direito subjetivo do autor e sua pretensão é legítima.

9.3.2. Críticas à teoria de que a motivação é uma fonte de indícios - a racionalidade e a aceitabilidade da motivação

Outra defesa célebre envolvendo a dissociação entre as razões de decidir e a motivação das decisões judiciais foi a de Michele Taruffo. O professor italiano enxerga na motivação uma fonte de indícios das verdadeiras razões pela qual a decisão foi tomada, muitas delas, não raro, inconfessáveis. A motivação, portanto, não apresentaria todos os inafastáveis elementos subjetivos que influem no convencimento do juiz, tais como: preconceitos, valores, opiniões e preferências pessoais. ${ }^{586}$

Essa forma de ver as coisas, todavia, acaba generalizando uma situação patológica, que é aquela em que o juiz deixa de julgar segundo o que determina a ordem jurídica para julgar de acordo com os seus impulsos pessoais. Justamente o que o ideal do Estado de Direito tenta evitar.

Não que as decisões judiciais sejam ou devam ser frutos de uma neutralidade judicial. Bem se sabe que neutralidade e imparcialidade são características assaz distintas e, no caso dos juízes, é a imparcialidade que se exige, não a neutralidade. Isso quer dizer que o juiz, ao julgar, não pode apresentar interesse pessoal na causa; mas inevitavelmente valer-se-á de suas concepções da vida para valorar alegações fáticas, provas e o próprio Direito. ${ }^{587}$ No entanto, a decisão judicial é um ato do Estado e não da pessoa-juiz. Consequentemente, ao presentar o Estado e desempenhar uma atividade pública, o magistrado deve abdicar de suas preferências pessoais e buscar decidir segundo aquilo que ele honestamente acredita ser o desejável pela ordem jurídica vigente. Mais do que isso, deve sobrepor os valores da sociedade sobre os seus próprios, abstendo-se de

\footnotetext{
${ }^{586}$ TARUFFO, Michele. La Motivazione della Sentenza Civile. passim, esp. 63-106.

${ }^{587}$ Cf. DINAMARCO, Cândido Rangel. Instituições de Direito Processual Civil, v. I. p. 200-203.
} 
revalorar aquilo que já foi valorado democraticamente. ${ }^{588}$ Dito de outro modo, se determinada norma jurídica é válida (incluindo aqui sua constitucionalidade material), o juiz tem de garantir-lhe a efetividade independentemente de valoração sobre sua justiça ou adequação; função que foi, ou deveria ter sido, desempenhada pelo Poder Legislativo mediante uma democracia representativa. E se há dúvidas sobre o sentido que deve ser emprestado a determinado dispositivo normativo, sua interpretação tem de ser pautada pelos valores da sociedade, ainda que distintos dos da pessoa-juiz. ${ }^{589}$

\subsubsection{A motivação e as razões de decidir - a regra da sinceridade}

Quando criticada a teoria de que a interpretação jurídica tem natureza criativa (v. 7.2.1, acima), explicou-se que a comparação de Cappelletti com a interpretação musical só teria sentido se a relação fosse feita com o ato de motivar a decisão, pois a redação de cada juiz conteria a sua "impressão digital", variando de acordo com as aptidões e habilidades de cada um, estrutura de raciocínio etc. Ainda que as conclusões fáticas e jurídicas de dois juízes sejam as mesmas, a motivação não o será - exatamente como acontece com a execução de uma peça musical.

Dessa simples constatação fica mais do que evidente que a motivação, enquanto ato processual, vem, sim, em um momento posterior à tomada de decisão. A motivação é uma justificação daquilo que foi decidido previamente em um "contexto de descoberta”. Mas será que isso basta para dissociar a motivação das razões de decidir?

Ao traçar as regras da argumentação racional e, consequentemente, as regras de uma motivação racional, Alexy e Aarnio estabeleceram como regra fundamental a sinceridade argumentativa: toda razão apresentada deve refletir aquilo que o seu proponente acredita. Aplicando-se a regra da sinceridade à motivação, então toda razão apresentada pelo juiz para justificar uma decisão deve corresponder à verdadeira razão pela

\footnotetext{
${ }^{588}$ Ibidem. p. 135. Como resumiu o Mestre, “A doutrina processual vem enfatizando que o juiz, embora escravo da lei como tradicionalmente se diz, tem legítima liberdade para interpretar os textos desta e as concretas situações em julgamento, segundo os valores da sociedade”. Ibidem. p. 201.

${ }^{589}$ Trata-se da regra de aceitabilidade imposta por Aulis Aarnio (v. ponto 8.3.5): a decisão segue o código de valores dominante dos seus destinatários. Sob a perspectiva do common law, afirmou EISENBERG, Melvin Aron. The Nature of the Common Law. p. 141: "In establishing common law rules, courts should and do employ policies, and should not and do not employ their personal convictions".
} 
qual o juiz julgou. Desse modo, mesmo existindo uma dissociação entre o "contexto da descoberta" e o "contexto da justificação", a justificação deve refletir exatamente as razões pelas quais a decisão foi tomada. A "simulação" de razões para justificar uma decisão "inconfessável” fere a racionalidade da motivação e, por isso, deve ser inexoravelmente refutada. 


\section{CAPÍTULO QUARTO - DELINEAMENTOS PROCESSUAIS DO DEVER DE MOTIVAÇÃO}

O presente capítulo busca aprofundar a análise das relações entre a motivação e as garantias decorrentes do devido processo legal (10), traçar os requisitos básicos de validade da motivação como ato jurídico-processual (11) e, enfim, apontar as consequências de uma motivação viciada (12).

\section{O dever de motivação como instrumento de realização de garantias processuais}

A legitimidade da atividade jurisdicional depende da observância de um “devido processo legal”, o qual não só estabelece uma metodologia ao exercício do poder, dando ordem e previsibilidade à atividade do Estado, como protege garantias e faculdades reputadas essenciais aos sujeitos processuais (v. 3 e ss., acima). Todavia, sabe-se que a instauração de um processo judicial, por si só, não significa respeito ao direito positivo e aos direitos subjetivos legal e constitucionalmente assegurados. As decisões judiciais também podem ser ilegais ou inconstitucionais; ou mesmo ilegítimas. Ainda que a lei e a constituição erijam um exemplar modelo de devido processo legal, certo é que, inexistentes mecanismos de controle da atividade jurisdicional, não há certeza de que este modelo será realmente observado. De nada adiantam garantias como as do contraditório e da ampla defesa se tudo o que for alegado e provado pelas partes puder ser cabalmente ignorado na decisão judicial. O devido processo legal, portanto, é uma garantia vazia se não for, ela também, garantida.

Nesse sentido, o dever de motivar as decisões judiciais desponta como poderoso instrumento de realização de várias das garantias processuais, incluindo: contraditório e ampla defesa, inércia jurisdicional, princípio dispositivo, poder de ação, coisa julgada, duplo grau de jurisdição e imparcialidade do órgão julgador. 
10.1. Motivação das decisões judiciais, contraditório e ampla defesa

O contraditório e a ampla defesa (art. $5^{\circ}, \mathrm{LV}$, da $\mathrm{CR}$ ) não são sinônimos, mas compõem um binômio indissociável ligado à participação das partes no processo. ${ }^{590} \mathrm{O}$ contraditório impõe que as partes sejam ouvidas a respeito de tudo o que for relevante ao julgamento do mérito do processo, vedando-se qualquer pronunciamento jurisdicional proferido à revelia involuntária de alguma das partes. ${ }^{591}$ Proposta a demanda pelo autor, o réu deve ser chamado ao processo para ser ouvido (art. 213 e ss. do CPC); caso o réu alegue fato novo ou suscite alguma preliminar de mérito, então é o autor que deve ser instado a se manifestar (art. 326 do CPC); e assim sucessivamente. No entanto, além de dar ciência às partes do que acontece no processo e facultar-lhes a manifestação, há que se lhes dar a possibilidade de alegar tudo o que for relevante ao processo e, em seguida, provar a veracidade de suas alegações. Se o contraditório oportuniza a participação, a ampla defesa concretiza essa participação ao atribuir às partes instrumentos concretos para atuar no convencimento judicial. ${ }^{592}$

Tanto o contraditório como a ampla defesa só se justificam se forem dirigidos ao convencimento judicial. De nada adianta permitir à parte que se manifeste no processo e prove suas alegações se não houver um interlocutor aberto e disposto a receber informações e se convencer. Seguindo as preciosas lições de Cintra, Grinover e Dinamarco, "as partes, em relação ao juiz, não têm papel de antagonistas, mas sim de 'colaboradores necessários", pois "somente pela soma da parcialidade das partes (uma representando a tese e a outra, a antítese) o juiz pode corporificar a síntese, em um processo dialético". 593

Pensar em processo dialético supõe, obviamente, que a participação das partes receba como contrapartida necessária uma resposta judicial, seja ela positiva ou

\footnotetext{
${ }^{590}$ É muito comum a inclusão da ampla defesa no contraditório, tratando-o de maneira abrangente. V., p. ex., DINAMARCO, Cândido Rangel. O princípio do contraditório e sua dupla destinação. p. 517 e ss.

${ }^{591}$ V. NERY JUNIOR, Nelson. Princípios do Processo na Constituição Federal. p. 210-211. O autor, porém, acaba por abrir o contraditório para elementos que, ao que parece, não têm nenhuma relação direta com o princípio, como é o caso do poder de ação.

${ }^{592}$ V. NERY JUNIOR, Nelson. Princípios do Processo na Constituição Federal. p. 248-249

${ }^{593}$ CINTRA, Antônio Carlos de Araújo; GRINOVER, Ada Pelllegrini; DINAMARCO, Cândido Rangel. Teoria Geral do Processo. p. 55.
} 
negativa. Afinal, compondo as partes a tese e a antítese, a síntese extraída pelo julgador deve vir suficientemente explicitada para que cada uma delas possa compreender o papel que desempenharam na formação desta decisão. Com grande felicidade, amparado nas lições de Colesanti, Antonio Magalhães Gomes Filho afirmou que "a garantia da motivação representa a última manifestação do contraditório". ${ }^{594}$

Não há violação maior ao contraditório e à ampla defesa do que a decisão que simplesmente ignora a atividade das partes no processo. Se o autor pede a condenação do réu em razão dos fundamentos fáticos $\mathrm{A}, \mathrm{B}$ e $\mathrm{C}$, que, sob seu ponto de vista, implicam as consequências jurídicas $\mathrm{X}$ e $\mathrm{Y}$, então o juiz, para julgar improcedente o pedido, deve impreterivelmente afastar a "veracidade" dos fundamentos A, B e C ou afastar a validade das alegações jurídicas $\mathrm{X} e \mathrm{Y}$. Em sentido inverso, se o réu, em sua contestação, opõe-se à procedência do pedido em razão dos fundamentos, fáticos ou jurídicos, D, E e F, então o juiz, para julgá-lo procedente, não pode tão somente aceitar os fundamentos do autor, mas também deve, impreterivelmente, afastar a validade de todos os fundamentos do réu. Não sendo assim, o contraditório e a ampla defesa não passarão de garantias vazias, verdadeiros engodos legislativos sem nenhum tipo de efetividade.

É injustificável, portanto, o entendimento jurisprudencial que se consolidou no Brasil no sentido de que o juiz não está obrigado a se manifestar sobre todas as alegações das partes. ${ }^{595}$ Um entendimento que, embora pautado pela racionalização da pesada carga de trabalho dos magistrados, permite a livre escolha dos fundamentos que justificam a decisão, independentemente do acerto dos demais. Em suma, a parte deve ser chamada para participar do processo, mas, depois de se manifestar, o juiz pode simplesmente ignorá-la para julgar de acordo com as razões da outra parte.

${ }^{594}$ GOMES FILHO, Antonio Magalhães. A Motivação das Decisões Penais. p. 100. V., igualmente, SILVA, Ovídio A. Baptista da. Fundamentação das sentenças como garantia constitucional. p. 472-473.

${ }^{595}$ P.ex., STJ, AgRg no Ag 1424360/MG, DJe 23/11/2011: "Não ocorre ofensa ao art. 535, II, do CPC se o Tribunal de origem decide, fundamentadamente, as questões essenciais ao julgamento da lide. É cediço que o juiz não fica obrigado a manifestar-se sobre todas as alegações das partes, nem a ater-se aos fundamentos indicados por elas, ou a responder, um a um, a todos os seus argumentos, quando já encontrou motivo suficiente para fundamentar a decisão, o que de fato ocorreu". 
Como bem apontam Marinoni e Arenhart, motivar uma decisão não significa "lembrar as provas e argumentos que servem ao vencedor" ${ }^{596}$ Mais importante do que exaltar as razões pelas quais se julga a favor do vencedor é demonstrar (e nesse sentido justificar) por que as alegações do derrotado não foram acolhidas. ${ }^{597}$ Lembre-se que o principal destinatário da motivação é aquele que recebe uma decisão desfavorável, pois é o seu patrimônio jurídico que está sendo lesado por um ato estatal. ${ }^{598}$ Logo, todas as suas alegações hão de ser expressamente afastadas, ainda que absurdas ou protelatórias. Nesse sentido, são irreparáveis, mais uma vez, as lições de Marinoni e Arenhart: “a motivação é mais importante para o perdedor do que para o vencedor. A motivação importa mais para o perdedor não apenas porque é ele que pode recorrer, mas especialmente porque é o perdedor que pode não se conformar com a decisão, e assim ter a necessidade de buscar conforto e explicação na justificação judicial". 599

Além disso, devem ser adequadamente motivadas todas as decisões que indeferem a produção de prova requerida por uma das partes. Não que todo requerimento probatório deva ser deferido. Como se sabe, apenas são produzidas provas relativas a alegações fáticas determinadas, relevantes, pertinentes e controversas. ${ }^{600}$ Ainda assim, as razões pelas quais o juiz considera a alegação fática a ser provada indeterminada, irrelevante, impertinente ou incontroversa devem ser expostas de forma clara e completa sempre que a prova for indeferida. ${ }^{601}$

10.2. Inércia jurisdicional e princípio dispositivo

Uma das maiores conquistas na história do Direito Processual, seja ele Civil ou Penal, foi impedir que o juiz instaurasse de ofício os processos que iria julgar. O

\footnotetext{
${ }^{596}$ MARINONI, Luiz Guilherme; ARENHART, Sérgio Cruz. Processo de Conhecimento. p. 475.

${ }^{597}$ MARINONI, Luiz Guilherme; ARENHART, Sérgio Cruz. Processo de Conhecimento. p. 476.

598 Tanto isso é verdade que o contraditório é dispensável quando a decisão for favorável à parte que não foi ouvida. São exemplos a resolução liminar do mérito com fundamento no art. 285-A do CPC e a validade e eficácia da sentença favorável a réu revel que não foi citado.

${ }^{599}$ Casos em que a parte deve ser condenada por litigância de má-fé, como disposto nos arts. 17, I, IV, V e VI e 18 do CPC.

${ }^{600}$ DINAMARCO, Cândido Rangel. Instituições de Direito Processual Civil, v. III. p. 58 e ss.

${ }^{601}$ Cf. GOMES FILHO, Antonio Magalhães. A Motivação das Decisões Penais. p. 101-102.
} 
comprometimento psicológico daquele que inicia um processo certamente acabaria com qualquer perspectiva de imparcialidade no julgamento. ${ }^{602}$ Por isso, salvo raras e insignificantes exceções, ${ }^{603}$ a jurisdição é inerte e só age quando provocada. Os limites dessa atuação serão sempre limitados pela pretensão inicial do demandante, deduzida na demanda apresentada para julgamento. ${ }^{604}$

Como se sabe, a resposta à pretensão inicial do demandante é dada no dispositivo da sentença. No entanto, do mesmo modo que o pedido precisa ser qualificado pela causa de pedir para adquirir individualidade, ${ }^{605}$ o dispositivo também precisa ser qualificado pela motivação para que possa correlacionar-se com o pedido individualizado formulado pelo autor. ${ }^{606}$ Todo processo, portanto, tem sua abrangência limitada pelo demandante segundo aquilo que ele pretende e sobre qual fundamento ele pretende. Se o demandante pede a condenação do réu a pagar-lhe indenização (pretensão) decorrente de determinado acidente de trânsito (causa de pedir), não poderá o juiz condená-lo ao pagamento de indenização superior à pleiteada ou condená-lo por outro acidente que não aquele narrado na petição inicial.

Tudo isso significa que a sentença será de procedência ou improcedência pela aceitação ou rejeição da legitimidade da pretensão inicial do autor, levando-se em consideração os fatos que a fundamentam. Como consequência, a decisão proferida deve estar indissociavelmente vinculada à demanda inicial, seja em relação aos fatos, seja em relação aos pedidos, sob pena de configurar um ato não jurisdicional (sentença extra petita

\footnotetext{
${ }^{602} C f$. CINTRA, Antônio Carlos de Araújo; GRINOVER, Ada Pellegrini; DINAMARCO, Cândido Rangel. Teoria Geral do Processo. p. 58.

${ }^{603}$ Como, p.ex., a abertura de inventário de ofício (art. 989 do CPC) e a execução de sentença trabalhista (art. 878 da CLT), se é que essa última hipótese pode ser realmente considerada uma exceção à inércia jurisdicional.

604 A provocação jurisdicional é realizada pelo exercício de um poder atribuído a todo indivíduo de apresentar ao Estado pretensões a serem satisfeitas. Esse poder é a ação, o seu exercício é a demanda e a pretensão do autor posta para julgamento é o mérito do processo. Sobre o tema, v. DINAMARCO, Cândido Rangel. O conceito de mérito em Processo Civil. passim. Para mais detalhes sobre a opinião deste autor, v. RAMINA DE LUCCA, Rodrigo. O mérito do processo e as condições da ação. passim.

${ }^{605}$ Cf. SCHWAB, Karl Heinz. El Objeto Litigioso en el Processo Civil. p. 243; TALAMINI, Eduardo. Coisa Julgada e sua Revisão. p. 79-80.

${ }^{606}$ Cf. WAMBIER, Teresa Arruda Alvim, Nulidades do Processo e da Sentença. p. 299-300.
} 
ou ultra petita) e, como consequência, juridicamente inexistente. ${ }^{607}$ Desse modo, a correlação entre dispositivo e pedido é tão importante quanto a correlação entre motivação e causa de pedir.

10.3. Poder de ação e pluralidade de demandas

Seguindo a mesma linha de raciocínio, afirmou-se que o rompimento da inércia jurisdicional se dá pela demanda, composta por três elementos: partes, causa de pedir e pedido (art. 301, § $2^{\circ}$, do CPC).

Especificamente no que diz respeito à causa de pedir, adota-se no Brasil a teoria da substanciação, segundo a qual a causa de pedir é formada, essencialmente, pelos fatos narrados pelo demandante, independentemente da qualificação jurídica a eles dada. Apenas os fatos narrados vinculam o juízo, prevalecendo a regra do iura novit curia. ${ }^{608}$

Cada causa de pedir configura uma demanda completamente distinta que deve ser apreciada especificamente pelo Poder Judiciário. A pretensão inicial do autor fundada em uma pluralidade de causas de pedir é uma cumulação de demandas (“cumulação de causas"), ${ }^{609}$ apresentando exatamente a mesma natureza jurídicoprocessual de um processo em que há cumulação de pedidos. Se, p.ex., o autor pede a exclusão do réu da sociedade em que são sócios porque o réu teria usurpado poderes de administração e apropriado-se indevidamente de patrimônio da sociedade, cumula na verdade duas demandas distintas no mesmo processo. A cada uma delas, desde que preenchidos os pressupostos processuais, deverá haver uma resposta jurisdicional.

Em termos decisórios, a exclusão de sócio será julgada procedente ou improcedente. A improcedência significa (ao menos deve significar) que a exclusão foi rejeitada tanto pela suposta usurpação de poderes como pela apropriação indevida de patrimônio da sociedade. A procedência, porém, pode decorrer de qualquer uma das

\footnotetext{
${ }^{607}$ V. Ibidem. p. 302 e ss.

${ }^{608}$ V. DINAMARCO, Cândido Rangel. Instituições de Direito Processual Civil, v. II. p. 128: “(...) a invocação dos fundamentos jurídicos na petição inicial não passa de mera proposta ou sugestão endereçada ao juiz, ao qual compete fazer depois os enquadramentos adequados".

${ }^{609}$ Cf. ASSIS, Araken de. Cumulação de Ações. p. 205 e ss.
} 
demandas, ou mesmo de ambas. É a motivação que irá esclarecer qual é o fundamento da decisão.

A motivação, portanto, embora não possua conteúdo decisório em relação ao mérito do processo - decidindo apenas questões incidentais -, desempenha papel fundamental na identificação do julgamento de demandas cumuladas que possuam o mesmo pedido, vinculando o dispositivo a cada uma das demandas formuladas. ${ }^{610} \mathrm{Em}$ caso de improcedência, deve demonstrar por que cada uma das demandas cumuladas não se sustenta. Em caso de procedência, deve explicitar qual das demandas está sendo considerada legítima e qual não considera legítima; e por quê.

\subsection{Coisa julgada}

A delimitação do dispositivo da sentença pela motivação também serve para garantir a correta delimitação da coisa julgada material e adequar a relação entre casos já julgados e novas demandas eventualmente propostas.

Embora haja ainda certa discussão, parece difícil refutar o entendimento de que a coisa julgada é uma qualidade que reveste a sentença de cognição exauriente de mérito, transitada em julgado, "consistente na imutabilidade do conteúdo do comando sentencial". ${ }^{611}$ A coisa julgada, portanto, torna imutável apenas o comando decisório contido no dispositivo da sentença.

Considerando que a motivação não compõe o comando decisório da sentença, ela não é atingida pela coisa julgada, de modo que todas as questões resolvidas incidentalmente para a tomada de decisão final podem ser novamente discutidas em outro processo. $^{612}$

\footnotetext{
${ }^{610}$ Como explica EVANGELISTA, Stefano. Motivazione della sentenza civile. p. 159: "La motivazione, inoltre, agevola l'interpretazione dell'atto e per ciò stesso consente di determinare più esattamente quale sia stato il contenuto della volontà dell'autore dell'atto ed entro quali limiti essa debba ritenersi circoscritta, sì che ne risulta agevolata la più precisa e puntuale esecuzione dell'atto stesso".

${ }^{611}$ TALAMINI, Eduardo. Coisa Julgada e sua Revisão. p. 30.

${ }^{612}$ É diferente o tratamento dado pelo Código de Processo Civil para o assistente que intervém no processo. Nesse caso, o assistente fica vinculado à justiça da decisão, a qual engloba não só o dispositivo, mas sobretudo a motivação da sentença (art. 55 do CPC),
} 
No entanto, como dito, a motivação qualifica o dispositivo e, consequentemente, acaba delimitando objetivamente a coisa julgada. Utilizando-se o mesmo exemplo dado no ponto anterior, imagine-se que João, Maria e José são sócios de uma sociedade empresária administrada exclusivamente por João. Constatado que José agiu clandestinamente como administrador da sociedade para, mediante um ato ilícito que lhe causa prejuízo, obter vantagem em detrimento dos demais sócios, João e Maria pedem a sua exclusão judicial da sociedade. O pedido é um só, mas os fatos que o fundamentam são três, configurando a cumulação de três demandas distintas: exclusão por usurpação de poderes de administração, exclusão por prática dolosa de ato ilícito em nome da sociedade e exclusão pelos danos materiais causados dolosamente à pessoa jurídica. Cada uma dessas demandas poderia ter sido proposta individualmente, mas, por economia, os autores resolveram agrupá-las em um mesmo processo e devem ser inteira e individualmente decididas pelo juiz.

Suponha-se que o pedido de exclusão foi julgado improcedente simplesmente porque, ao longo do processo, descobriu-se que José havia, sim, poderes de administração da sociedade. Nada foi decidido quanto à prática dolosa de ato ilícito em nome da sociedade ou quanto aos danos materiais que lhe foram causados. Toda a motivação foi no sentido de rejeitar a pretensão à exclusão porque José não havia usurpado poderes de administração. Nesse caso, inexiste sentença em relação a duas demandas propostas pelos autores; consequentemente, caso eventualmente a sentença venha a transitar em julgado, também não há obstáculo imposto pela coisa julgada material à repropositura, pelos autores, das demandas não analisadas. Assim é porque a motivação qualifica o dispositivo e determina o que está sendo julgado. Inexistente qualquer referência a fatos que compõem causas de pedir autônomas do pedido, então é evidente que o dispositivo não lhes diz respeito, mas apenas aos fatos que efetivamente foram decididos.

\subsection{Duplo grau de jurisdição}

Muito embora a História seja pródiga em exemplos de sistemas recursais moldados sobre uma estrutura normativa que dispensava a motivação, é muito difícil conceber um sistema recursal verdadeiramente efetivo sem que os juízes tenham o dever de expor as razões de suas decisões. A interposição de um recurso supõe o apontamento de 
alguma falha material ou formal específica na decisão ou no processo que a originou. ${ }^{613}$ Sem saber os motivos pelos quais a decisão proferida foi aquela, e não outra, a indicação de tais vícios ficaria prejudicada. Nem as partes seriam capazes de atacar especificamente a decisão, nem o juízo ad quem teria condições de apurar se a decisão está ou não correta. Em síntese, os recursos deixariam de ser um instrumento de revisão da atividade do juízo $a$ quo para constituírem instrumentos de reanálise da causa, exigindo-se das partes que retomassem toda a argumentação fática e jurídica desenvolvida até então, mas agora em uma nova instância.

Quanto aos recursos voltados ao exercício de atividade nomofilática pelos Tribunais Superiores, como é o caso, no Brasil, do recurso especial e do recurso extraordinário, ficariam inviabilizados na falta de um dever de motivação. ${ }^{614} \mathrm{Na}$ medida em que tais recursos voltam-se unicamente ao controle da aplicação do Direito pelos magistrados, e à consequente uniformização da jurisprudência nacional, dependem do prévio convencimento fático desenvolvido nos juízos inferiores. Tomando certos fatos discutidos no processo como verdadeiros a partir daquilo que constou da motivação da decisão recorrida, os Tribunais Superiores podem analisar concretamente como se deu a aplicação do Direito, invalidando-a ou reformando-a. Contudo, sem que as decisões recorridas sejam motivadas, os Tribunais Superiores não teriam um ponto de partida para a análise da correção jurídica da decisão. Em suma, seriam forçados a rejulgar a causa, extrapolando a função precípua que lhes é atribuída: controlar e homogeneizar a interpretação e aplicação do Direito.

10.6. Imparcialidade do órgão julgador

A motivação promove a imparcialidade do órgão julgador de duas maneiras: desencoraja eventuais desvios, tendo em vista a dificuldade de se justificar racionalmente

\footnotetext{
${ }^{613}$ V., p.ex., BARBOSA MOREIRA, José Carlos. Comentários ao Código de Processo Civil, v. V. p. 331; ASSIS, Araken de. Manual dos Recursos. p. 132-133; DIDIER, Fredie; CUNHA, Leonardo José Carneiro da. Curso de Direito Processual Civil, v. 3. p. 98

${ }^{614}$ V. BARBOSA MOREIRA, José Carlos. A motivação das decisões judiciais como garantia inerente ao Estado de Direito. p. 115.
} 
uma decisão injustificável e serve como indício de que a decisão proferida não foi pautada por uma atuação proba e imparcial.

Com efeito, é indiscutível que a necessidade de apresentar as razões pelas quais uma decisão foi tomada dificulta a atuação parcial do julgador. A motivação de uma decisão favorável a quem não tem razão será, na maioria das vezes, uma motivação irracional, apresentando contradições, omissões graves ou incongruências fáticas e normativas. Consequentemente, a irracionalidade da motivação servirá como indício da improbidade, tornando questionável uma atuação flagrantemente defeituosa.

\section{Requisitos mínimos do dever de motivação}

Indiretamente, o art. 535 do Código de Processo Civil erige três requisitos básicos para que a motivação de uma decisão judicial seja considerada válida, que são: clareza, coerência e completude.

$\mathrm{Na}$ verdade, tais requisitos decorrem da necessária racionalidade da motivação. São requisitos formais de racionalidade que se somam a tantos outros já mencionados, tais quais: congruência narrativa, congruência normativa, congruência axiológica, universalidade, sinceridade etc. (v. 8.3.1 e ss., acima).

Pela importância que detêm no sistema processual brasileiro, os três requisitos legais serão tratados especificamente nos pontos seguintes. ${ }^{615}$

\subsection{Clareza}

A motivação deve ser clara, inteligível. A motivação deve ser passível de compreensão por aquele que a lê, explicitando de forma inequívoca as razões pelas quais a decisão tomada foi aquela e não outra. ${ }^{616}$

Para que tenha clareza, a motivação deve ser, em primeiro lugar, objetiva. A motivação deve focar nos pontos e questões inerentes ao processo, decidindo aquilo que efetivamente deve ser decidido: nem mais nem menos. Essa observação, que poderia ser

\footnotetext{
${ }^{615}$ Para as demais exigências de racionalidade, v. 8.3.1 e ss., acima.

${ }^{616}$ V. TUCCI, José Rogério Cruz e. A Motivação da Sentença no Processo Civil. p. 20.
} 
tida por banal, é de grande relevância. É muito comum que juízes, assim como comumente fazem muitos advogados, sejam tentados a inchar suas decisões com considerações genéricas e citações doutrinárias e jurisprudenciais completamente impertinentes e irrelevantes ao caso concreto. Essa situação é agravada pela usual e perniciosa associação entre decisões prolixas e modelos-padrão utilizados pelo juízo para determinadas espécies de decisões. Muitas vezes, para encobrir uma motivação precária, tais modelos trazem uma série de observações descontextualizadas que nada fazem senão avolumar a decisão e, consequentemente, tornar mais custosa sua compreensão e a localização daquilo que realmente importa. Em outros casos, com resultado idêntico, o excesso é pautado simplesmente pela crença de que decisões extensas serão mais bem recebidas pelas partes e pelos tribunais, demonstrando, supõe-se, um maior zelo no julgamento da demanda. Desse modo, são corriqueiras decisões relativas a pedidos de tutela antecipada que, ao invés de explicitarem por que deferem ou indeferem a antecipação da tutela, gastam infindáveis e enfadonhos parágrafos explicando o que é tutela antecipada, o que significa cada um de seus requisitos e transcrevendo uma porção de excertos doutrinários e jurisprudenciais que nada acrescentam à motivação. Não raro, quando enfim chega o momento de tratar do caso concreto, a motivação é encerrada com um lacônico "no presente caso, não estão preenchidos os requisitos autorizadores da concessão da tutela antecipada" ou algo do gênero. Esse tipo de decisão, além de padecer do vício da omissão (v. 11.3, abaixo), peca também pela falta de clareza, pois dificulta a compreensão das razões que levaram o juiz a decidir daquela maneira.

Com efeito, decisões judiciais não são trabalhos acadêmicos nem exercícios de preciosismo intelectual. Decisões são respostas a demandas (iniciais ou incidentais) apresentadas pelas partes. O juiz deve decidir o que foi pedido, nos termos em que foi pedido, levando sempre em consideração as alegações da parte contrária. Logo, salvo quando realmente pertinentes, são inoportunas longas citações doutrinárias e excessivas citações jurisprudenciais relativas ao mesmo tema.

No entanto, não se deve confundir objetividade com concisão excessiva. Uma decisão objetiva não é o mesmo que uma decisão curta. A decisão é objetiva quando trata dos pontos e questões relevantes ao processo (e toda alegação feita por alguma das partes é relevante ao processo) sem alongar-se demasiadamente, sem perder tempo explicando conceitos jurídicos básicos (como fumus boni iuris ou periculum in mora, 
p.ex.), sem fazer citações desnecessárias etc. A extensão da decisão necessariamente variará de acordo com a complexidade da causa e das questões fáticas e jurídicas envolvidas.

Em segundo lugar, a motivação da decisão deve ser pautada por uma linguagem simples e acessível. Na medida em que a motivação é um ato de prestação de contas do exercício do poder jurisdicional, deve ser passível de compreensão pelas pessoas em geral. Aplicam-se aqui, mutatis mutandi, alguns dos critérios estabelecidos pelo art. 11 da Lei Complementar nº 95/1998 para a elaboração de leis no Brasil, tais como: (a) utilizar as palavras e expressões em seu sentido comum, salvo quando a norma versar sobre assunto técnico; (b) utilizar frases curtas e concisas; (c) construir as orações na ordem direta, evitando-se preciosismo, neologismo e adjetivações dispensáveis; (d) conferir uniformidade ao tempo verbal em todo o texto das normas legais, dando preferência ao tempo presente ou ao futuro simples do presente; (e) expressar ideias repetidas no texto com as mesmas palavras; (f) evitar emprego de expressões e palavras que confiram duplo sentido ao texto; (g) escolher termos que tenham o mesmo significado na maior parte do território nacional, evitando-se o uso de expressões locais ou regionais; (h) usar apenas siglas consagradas pelo uso; i) indicar expressamente o dispositivo objeto de remissão; e (j) reunir sob as categorias de agregação apenas as disposições relacionadas com o objeto da lei. Também devem ser evitadas, a todo custo, palavras e expressões arcaicas ou de rara utilização em território nacional.

Em terceiro lugar, a decisão, naquilo que se referir à fundamentação jurídica, deve ser tecnicamente precisa, ainda que tal característica reduza a sua acessibilidade a boa parte da população. Tratando-se de um ato jurídico, e sendo o Direito uma ciência, a decisão será tanto mais inteligível, ao menos aos operadores do Direito, quanto mais técnica for a utilização dos termos jurídicos nela empregados. $\mathrm{O}$ desconhecimento do Direito pela população (v. 6.2.4, acima) não justifica a sua deterioração científica, nem decisões judiciais atécnicas e imprecisas. Caso a parte não seja capaz de compreender as razões jurídicas da decisão, é função do seu advogado fazer-lhe a tradução adequada. 


\subsection{Coerência}

A motivação deve ser coerente. A coerência aqui representa aquilo que Neil MacCormick chama de "consistência" (v. 8.3.3, acima); quer dizer, a decisão deve ser lógica e coesa. Não pode apresentar nenhum tipo de contradição.

A coerência da motivação pressupõe, antes de tudo, harmonia entre o dispositivo da decisão e as razões que lhe foram dadas. O dispositivo deve ser uma decorrência lógica das premissas indicadas na motivação (v. 8 e ss., acima). Sendo assim, se João pede a condenação de José porque este não lhe pagou obrigação contraída mediante contrato de mútuo, o juiz não poderá julgar procedente o pedido ao mesmo tempo em que afirma, na motivação, ter ficado provado que José já pagou a dívida a João. Haveria uma insuperável contradição entre a decisão condenatória proferida e o reconhecimento de inexistência do suposto débito de José.

Para que a motivação desenvolva-se sobre uma estrutura lógica, deverá ser necessariamente silogística (v. 8 e ss., acima). Isso significa que a decisão terá que indicar quais são os fatos relevantes ao pedido que foram efetivamente provados, e por quê, qual é a norma jurídica que rege o caso concreto e, dependendo do caso, por quê, e, finalmente, explicitar se a pretensão da parte encontra respaldo no ordenamento jurídico. Cada um dos elementos da motivação pode exigir uma justificação externa mais ou menos complexa (v. 8.3.2 e ss., acima), que também será desenvolvida sobre uma estrutura lógicoargumentativa. Como regra, a fixação dos fatos relevantes ao processo que foram provados precederá a determinação da norma jurídica aplicável por lhe ser prejudicial. Afinal, se demonstrada a falsidade das alegações fáticas do autor, não haverá nenhum fato a ser configurado juridicamente. De qualquer forma, a ordem da exposição poderá variar de acordo com as necessidades de cada caso.

Também por uma questão de coerência interna da motivação, questões processuais devem anteceder a análise do mérito. ${ }^{617}$ Logo, antes de julgar o mérito do processo (leia-se, a pretensão inicial do autor), o juiz deverá, p.ex., apreciar eventuais questões preliminares arguidas pelo réu, tais quais a existência de convenção de arbitragem entre as partes, coisa julgada, perempção etc.; no mesmo sentido, um acórdão não poderá

\footnotetext{
${ }^{617}$ V. TUCCI, José Rogério Cruz e. A Motivação da Sentença no Processo Civil. p. 20-21.
} 
analisar o mérito do recurso sem verificar, previamente, se estão preenchidos os pressupostos para o seu conhecimento. Também no mérito certas questões podem, por imperativo lógico, preceder a análise de outras. É o caso, p.ex., da decadência, cujo reconhecimento judicial torna inútil averiguar se o autor possuía ou não o direito potestativo alegado.

Resumindo, o requisito da coerência é um complemento ao requisito da clareza da motivação, ambos atuando em prol da inteligibilidade da decisão.

\subsection{Completude}

A motivação deve ser completa, ou suficientemente motivada. ${ }^{618}$ Tradicionalmente, afirma-se que a decisão é suficientemente motivada quando trata de todas as questões relevantes ao processo. Mas quais são as questões relevantes ao processo? E quem decide o que é e o que não é relevante?

Em linhas gerais, pode-se dizer que uma motivação é completa quando (a) apresenta as razões fáticas e jurídicas que justificam o dispositivo e (b) afasta expressamente todas as alegações fáticas e jurídicas da parte desfavorecida pela decisão. Essas são, em qualquer hipótese, as "questões relevantes ao processo". Caso ambas as partes sejam parcialmente sucumbentes, a decisão deverá afastar todas as alegações fáticas e jurídicas de cada parte relativas àquilo em que foram desfavorecidas. Ou seja, a completude da motivação diz respeito não só à exposição clara, coerente e racional das razões que fundamentam a decisão, mas também, e principalmente, das razões pelas quais não foram acolhidas as alegações e provas produzidas pela parte sucumbente. ${ }^{619}$

Com efeito, o dever de motivação só tem razão de ser se o Estado-juiz for compelido a tratar de todos os pontos e questões surgidos no curso do processo, afastando todas as alegações fáticas e jurídicas feitas pela parte desfavorecida pelo provimento

\footnotetext{
${ }^{618}$ Para WAMBIER, Teresa Arruda Alvim. Omissão Judicial e Embargos de Declaração. p. 101 e ss. e 352, uma motivação completa não é o mesmo que uma motivação suficiente. No entanto, nenhuma motivação é suficiente se não for completa. Sendo assim, as expressões serão utilizadas neste trabalho como sinônimas.

${ }^{619}$ Cf. SILVA, Ovídio A. Baptista da. Fundamentação das sentenças como garantia constitucional. p. 468 473.
} 
jurisdicional. ${ }^{620}$ Lembre-se mais uma vez que a motivação radica na constatação de que o Estado não pode interferir no patrimônio jurídico do particular sem justificar essa interferência (v. 6, acima). Logo, é para a parte desfavorecida que a motivação mais importa, seja porque ela é a destinatária primária da justificação dada pelo Estado para agir em seu desfavor, seja porque ela depende de uma motivação adequada para que possa utilizar plenamente os instrumentos recursais postos à sua disposição. ${ }^{621}$

Motivar uma decisão judicial não significa elencar arbitrariamente os elementos que vão ao encontro do dispositivo (v. 9.1 e ss., acima). Motivar uma decisão judicial é e deve ser uma atividade de absoluta honestidade intelectual, pela qual o Estadojuiz enfrenta aberta e expressamente todas as questões trazidas pelas partes, demonstrando quais delas considerou legítimas e quais delas considerou ilegítimas, de modo a efetivamente prestar jurisdição e valorizar e efetivar a participação das partes no processo. Como ensina Rolf Sartorius, justificar uma decisão não é apenas dizer que existem algumas boas razões para o dispositivo, mas dizer que a decisão representa a melhor solução para as razões disponíveis ao juiz. ${ }^{622}$

\footnotetext{
${ }^{620}$ V. GOMES FILHO, Antonio Magalhães. A Motivação das Decisões Penais. p. 175: “(...) não se pode conceber uma fundamentação em que não estejam justificadas todas as opções adotadas ao longo desse percurso decisório, sob pena de frustrar-se o imperativo constitucional, principalmente se consideradas as funções de garantia que consagra. (...) Em outros termos, devem ser necessariamente objeto de justificação todos os elementos estruturais de cada particular decisão, como a escolha e interpretação da norma, os diversos estágios do procedimento de verificação dos fatos, a qualificação jurídica destes etc., bem como os critérios (jurídicos, hermenêuticos, cognitivos, valorativos) que presidiram as escolhas do juiz em face de cada um desses componentes estruturais do procedimento decisório".

${ }^{621}$ Cite-se mais uma vez contundente decisão da Court of Appeal inglesa: "(1) The duty is a function of due process, and therefore of justice. Its rationale has two principal aspects. The first is that fairness surely requires that the parties especially the losing party should be left in no doubt why they have won or lost. This is especially so since without reasons the losing party will not know (as was said in Ex parte Dave) whether the court has misdirected itself, and thus whether he may have an available appeal on the substance of the case. The second is that a requirement to give reasons concentrates the mind; if it is fulfilled, the resulting decision is much more likely to be soundly based on the evidence than if it is not" (2000) 1 WLR 377, CA.

${ }^{622}$ Cf. SARTORIUS, Rolf. The justification of the judicial decision. p. 178: "But to say of a judicial decision that it is justified is not only to say that there are some good reasons for it; it is to say that on balance, all reasons considered, the decision represents the best resolution of the available reasons. It is to say that the available grounds for decision support the decision made to at least as great a degree as they support any alternative to it". Em sentido idêntico, GOMES FILHO, Antonio Magalhães. A Motivação das Decisões Penais. p. 176-177.
} 
Note-se que mesmo pontos e questões logicamente incompatíveis com as razões dadas pelo juiz devem ser referidos, brevemente, na decisão; ainda que apenas para indicar que o ponto ou questão restou prejudicado. Assim é porque a incompatibilidade pode não ser tão aparente quanto supõe o juiz; e também porque torna a decisão mais transparente às partes e, eventualmente, ao juízo ad quem.

Destarte, a motivação só será completa quando forem levadas em consideração, e expressamente repelidas, absolutamente todas as alegações feitas pela parte vencida, além de indicar expressamente, em caso de acolhimento do pedido formulado, as razões fáticas e jurídicas para tanto. ${ }^{623}$

\subsubsection{Completude fática}

A motivação é completa em relação aos fatos quando expressamente manifesta-se a respeito de todas as circunstâncias fáticas que envolvem o pedido, sejam elas causas de pedir da demanda inicial, fundamentos de um pedido de tutela antecipada ou de produção de determinada prova, razões de defesa etc. Em outras palavras, devem ser definidos quais fatos são 'verdadeiros' para o processo, e por quê, e quais fatos não são 'verdadeiros' para o processo, e por quê. As razões dadas devem ser concretas, e não vagas ou lacônicas. ${ }^{624}$ Como é evidente, as razões dadas para a aceitação de determinados

\footnotetext{
${ }^{623}$ Nesse sentido, CAMARGO, Luiz Henrique Volpe. Motivação dos julgamentos dos Tribunais... p. 199: "Em outras palavras, o acórdão completo é aquele por meio do que o Tribunal enfrenta todos os fundamentos trazidos pela parte para o acolhimento ou rejeição do recurso". De acordo com o Projeto de Lei do Senado no. 166 de 2010, submetido à Câmara dos Deputados, que tem como objeto a adoção de um novo Código de Processo Civil, "não se considera fundamentada a decisão, sentença ou acórdão que não enfrentar todos os argumentos deduzidos no processo capazes de, em tese, infirmar a conclusão adotada pelo julgador" (art. 476, parágrafo único, IV).

${ }^{624} C f$. ALVARO DE OLIVEIRA, Carlos Alberto. Livre apreciação da prova... p. 6-7: "O problema revelase muito mais complexo e mostra-se bem possível que, mesmo com uma autêntica proclamação de princípios, o órgão judicial ao justificar determinada visão dos fatos lance mão de critérios vagos e indefinidos, empregando fórmulas puramente retóricas, despidas de conteúdo, aludindo $\mathrm{p}$ or exemplo à "verdade material", "prova moral", "certeza moral", "prudente apreciação", "íntima convicção". Essas e outras expressões similares representam autênticos sinônimos de arbítrio, subjetivismo e manipulação semântica, por não assegurarem nenhuma racionalidade na valorização da prova, implicar falsa motivação da decisão e ainda impedir o controle da atividade judicial por parte da sociedade, do jurisdicionado e da instância superior".
} 
fatos como verdadeiros devem necessariamente estar vinculadas às provas e alegações produzidas pelas partes, bem como à correta distribuição do ônus da prova entre elas.

Se, p.ex., a sociedade empresária $\mathrm{X}$ impetra mandado de segurança porque (a) foi multada administrativamente sem que fosse intimada para apresentar defesa em processo administrativo; (b) a decisão não foi devidamente motivada; e (c) a multa é desproporcional e desarrazoada, tanto a decisão interlocutória que indefere eventual pedido de liminar, como a sentença que denega a segurança deverão manifestar-se sobre cada um dos fundamentos da demanda. E não basta dizer, p.ex., que a decisão administrativa está motivada. Afirmações lacônicas não servem como razões de uma decisão. É imperioso que sejam indicadas as passagens da decisão administrativa que, segundo o juiz, cumprem o desiderato dos arts. $2^{\circ}$ e 50 da Lei 9.874/99.

Embora isso nem sempre aconteça na prática, a maior parte das questões fáticas relevantes ao processo devem ser resolvidas no despacho saneador (art. 331, §§ $1^{\circ} \mathrm{e}$ $2^{\circ}$ do $\mathrm{CPC}$ ), de modo que não sejam produzidas provas inúteis e irrelevantes na fase instrutória. Esse é o momento em que o juiz deve indicar, diante da manifestação das partes, quais fatos são controversos e relevantes ao julgamento do mérito. Sendo assim, é imperioso que o juiz acolha ou afaste expressamente todas as alegações das partes envolvendo eventuais confissões ou omissões da outra parte acerca de fatos relevantes ao julgamento do mérito; decidindo quais deles são controversos e quais não o são. Feito isso, a sentença não precisará retomar tais questões, devendo apenas fazer referência àquilo que já foi decidido anteriormente. Caso não se tenha o cuidado de sanear corretamente o processo, então a sentença deverá tratá-las com a profundidade necessária.

Tema importante e muitas vezes negligenciado é o da motivação da valoração das provas produzidas pelas partes, sobretudo em audiência. Ao valorar um depoimento testemunhal, ou um depoimento pessoal, é dever do juiz apresentar as impressões que lhe foram deixadas pela prova, indicando expressamente as razões pelas quais determinada testemunha foi mais ou menos crível do que outra, ou por que o depoimento pessoal do autor lhe convenceu de que determinado fato não ocorreu, p.ex. Nesse aspecto, a motivação deve ser minuciosa e bastante esclarecedora. Dois são os motivos. Em primeiro lugar, havendo testemunhas contraditórias, o juiz não pode escolher arbitrariamente a tese de uma das partes; deve explicitar racionalmente como foi convencido de que uma das teses era a "correta". Em segundo lugar, a transcrição de 
depoimentos (art. 169 do CPC), nos casos em que a audiência ainda não é armazenada eletronicamente, elimina quase que integralmente a capacidade do tribunal de revalorar as provas produzidas. Imagine-se que quatro testemunhas depuseram a respeito de um mesmo fato: uma era testemunha do autor e o confirmou; as três testemunhas do réu, por sua vez, negaram a ocorrência do fato. A princípio, a tese do réu deveria prevalecer, pois três pessoas, supostamente imparciais e honestas, suportaram suas alegações. O juiz percebe, porém, que a narrativa da testemunha do autor é muito mais convincente e sincera do que as narrativas das testemunhas dos réus, que estão nitidamente instruídas a fazer determinadas afirmações. Se o juiz não expuser tais impressões em sua sentença, optando por apenas exaltar o depoimento da testemunha do autor e ignorar as testemunhas dos réus, nem as partes nem o tribunal terão condições de compreender o que levou o juiz a dar prevalência a uma testemunha em detrimento de outras três. Inadvertido, o tribunal pode acabar reformando a sentença que, embora correta, omitiu-se quanto a razões fundamentais que justificariam o dispositivo.

\subsubsection{Completude jurídica}

No que diz respeito à motivação jurídica, aplicam-se integralmente as considerações que vêm sendo feitas. As decisões devem necessariamente tratar de todas as alegações jurídicas feitas pela parte vencida e explicitar quais são, e por quê, as razões jurídicas do dispositivo.

A grande peculiaridade da motivação jurídica está na regra do iura novit curia, que significa: "o juiz conhece o Direito". Enquanto o universo fático do processo restringe-se às alegações feitas pelas partes, o Direito deve ser conhecido e aplicado pelo Estado-juiz em sua integralidade. Mesmo que o juiz afaste as alegações jurídicas feitas pela parte, poderá julgar em seu favor a partir de uma configuração jurídica distinta da proposta. Se as alegações fáticas são vinculantes ao juiz, competindo-lhe apenas aceitá-las como provadas ou não provadas, as alegações jurídicas são sugestivas, podendo ser alteradas de ofício.

Suponha-se que José propôs uma demanda pleiteando a anulação de um contrato. Segundo sua narrativa, o contrato teria sido assinado apenas porque o réu teria ameaçado a vida de sua filha. José, porém, configura tais fatos como "erro", e pede a 
anulação do contrato com fundamento no art. 138 do Código Civil. Como já afirmado, o juiz está adstrito aos fatos narrados por José, mas não à configuração jurídica que lhes é dada. Provada a coação, a sentença deverá ser de procedência do pedido de anulação do contrato, utilizando-se como fundamento a norma prevista no art. 151 do Código Civil.

Seguindo a mesma sistemática da motivação fática, o juiz não precisa alongar-se na descaracterização da configuração jurídica dada aos fatos pela parte vencedora. O foco da motivação deve ser, repete-se, na (a) indicação das razões jurídicas que justificam o dispositivo e no (b) afastamento expresso de todas as alegações jurídicas da parte desfavorecida pela decisão.

Outro tema de grande relevância é o que diz respeito à motivação referente à aplicação de conceitos jurídicos indeterminados, cláusulas gerais e ponderação entre princípios. Não raro, as decisões são pautadas por afirmações lacônicas de pouco significado, que em nada esclarecem por que uma razão foi adotada em detrimento de outra. Como não poderia deixar de ser, a motivação deve explicar, concretamente, como e por que interpretou um conceito jurídico indeterminado ou uma cláusula geral, bem como deve explicitar as razões pelas quais um princípio prevaleceu sobre outro. ${ }^{625} \mathrm{Um}$ exemplo recorrente é o do arbitramento de honorários com fundamento no art. $20, \S 4^{\circ}$, do CPC. Várias são as decisões que simplesmente afirmam, quando muito, algo nesse sentido: "Nos termos do art. $20, \S 4^{\circ}$, do CPC, e considerando o grau de zelo do profissional, o tempo exigido para o serviço, o lugar da prestação do serviço, a natureza e a importância da causa, fixo os honorários de sucumbências em X reais". É evidente que a decisão não foi motivada. O julgador deve indicar qual foi o grau de zelo do profissional, quanto tempo durou o serviço, qual foi a complexidade da causa, qual é a sua representatividade

\footnotetext{
${ }^{625}$ Nesse sentido, o Projeto de Lei do Senado n ${ }^{\circ} .166$ de 2010, que foi submetido à Câmara dos Deputados e tem como objeto a implantação de um novo Código de Processo Civil, é de extrema felicidade. Dispõe o seu art. 476, parágrafo único: "Não se considera fundamentada a decisão, sentença ou acórdão que: I - se limita a indicação, à reprodução ou à paráfrase de ato normativo; II - empregue conceitos jurídicos indeterminados sem explicar o motivo concreto de sua incidência no caso; III - invoque motivos que se prestariam a justificar qualquer outra decisão; IV - não enfrentar todos os argumentos deduzidos no processo capazes de, em tese, infirmar a conclusão adotada pelo julgador". Logo em seguida, o art. 477, parágrafo único, é ainda mais contundente: "Fundamentando-se a sentença em regras que contiverem conceitos juridicamente indeterminados, cláusulas gerais ou princípios jurídicos, o juiz deve expor, analiticamente, o sentido em que as normas foram compreendidas".
} 
econômica etc. Se isso não for feito de forma expressa, clara e congruente, a decisão é nula.

11.3.3. Ainda sobre o entendimento de que o juiz não precisa se manifestar a respeito de todas as alegações das partes: críticas

Em sentido diametralmente oposto ao que vem sendo defendido, prevalece largamente no Poder Judiciário brasileiro a concepção de que o juiz não precisa se manifestar a respeito de todas as alegações das partes; basta que apresente as razões de seu convencimento. Dito de outro modo, imagina-se que motivar uma decisão é escolher argumentos que beneficiem a parte vencedora, pouco importando o que foi alegado e produzido pela parte vencida.

Como regra, apenas omissões relativas à análise de pedidos ou requerimentos formulados pelas partes são levadas em consideração pelo Poder Judiciário; i.e., uma decisão só é considerada omissa na parte dispositiva. Nem mesmo para fins de pré-questionamento os tribunais brasileiros têm o costume de dar provimento a embargos de declaração e sanar as patentes omissões dos seus acórdãos. À exceção de recursos especiais interpostos contra tais decisões, ${ }^{626}$ muito dificilmente são providos recursos voltados contra omissões na motivação, sejam eles embargos de declaração, agravos, apelação etc.

Tal postura decorre de uma má compreensão da função do dever de motivação das decisões judiciais e do significado de "questões relevantes ao processo". Há uma crença jurisprudencial generalizada de que é o juiz quem deve escolher quais alegações das partes são dignas de apreciação, filtrando aquilo que não considerar pertinente. Como consequência, a motivação acaba se tornando uma exaltação das razões que fundamentam o dispositivo, ignorando completamente tudo o que foi produzido pela parte sucumbente. A decisão diz por que o vencedor venceu, mas não diz por que o sucumbente perdeu.

\footnotetext{
${ }^{626}$ Sobre o tema, vale conferir o interessante trabalho de CAMARGO, Luiz Henrique Volpe. A motivação dos julgamentos dos Tribunais de $2^{\circ}$ grau na viusão do Superior Tribunal de Justiça: acórdão completo ou fundamentado? passim, esp. p. 217-226.
} 
Trata-se, repete-se, de uma deturpação lógica insustentável. ${ }^{627}$ De um lado, a omissão na motivação fática é tão grave quanto a omissão na parte dispositiva, pois cada causa de pedir não analisada implica uma demanda não julgada. ${ }^{628}$ De outro, omissões relativas a alegações jurídicas e provas produzidas pelas partes são gravíssimas ofensas aos princípios do contraditório e da ampla defesa, além de evidenciarem parcialidade do julgador, o qual deixa de enfrentar elementos que poderiam prejudicar a decisão que resolveu arbitrariamente tomar. ${ }^{629}$

Dois argumentos poderiam ser dados para defender esse "filtro judicial" arbitrário. O primeiro está no volume inegavelmente excessivo de trabalho dos juízes, o que lhes impediria de motivar todas as suas decisões de forma minuciosa. Consequentemente, acabam motivando precariamente suas decisões para conseguir atender às exigências de celeridade impostas pela sociedade em geral e pelos órgãos de controle, como a Corregedoria e o Conselho Nacional de Justiça. A segunda razão está na constatação de que as partes, com lamentável frequência, apresentam uma avalanche de argumentos nitidamente infundados, que nada contribuem ao processo.

Em relação ao primeiro argumento, é indiscutível que a carga de trabalho imposta aos juízes inviabiliza a concomitância de processos céleres e decisões de

${ }^{627}$ Cf. GOMES FILHO, Antonio Magalhães. A Motivação das Decisões Penais. p. 176: “(...) o discurso justificativo dessa mesma decisão não pode ser algo semelhante a um monólogo, em que são apresentados argumentos de autoridade, mas, ao contrário, deve possuir um caráter dialógico capaz de dar conta da real consideração de todos os dados trazidos à discussão da causa pelos interessados no provimento".

${ }^{628}$ V. SILVA, Ana de Lourdes Coutinho. Motivação das Decisões Judiciais. p. 160: “A ausência de apreciação pelo juiz de todos os fatos e fundamentos que justificam o pedido formulado implica uma resposta insuficiente do Poder Judiciário, não sendo dado ao juiz deixar de examinar todas as causas de pedir trazidas pelas partes, elegendo algumas que serão desconsideradas e aquelas que serão objeto de expressa apreciação por parte dele".

${ }^{629}$ Cf. SILVA, Ovídio A. Baptista da. Fundamentação das sentenças como garantia constitucional. p. 471: "Sentenças insuficientemente motivadas ocultam uma parcela de poder arbitrário". Também vale destacar bela passagem de CALMON DE PASSOS: "Destarte, quando se lhe defere poder sem que este poder seja submetido a controles de correção de seu exercício, o julgador se tornará um déspota intolerável, visto como livre e desembaraçado para fazer do direito positivo gato e sapato. Será um tirano que nem mesmo terá a grandeza dos tiranos políticos, vulneráveis em sua visibilidade, mas a pequenez de um tirano solerte que se esconde e se dissimula na decisão que profere, a nível micro, quase anônima pelo reduzido de sua visibilidade, protegido em seus desvios funcionais pelo bonito discurso do imperativo da 'independência' do julgador, como se numa democracia houvesse independência aceitável em face do verdadeiro soberano de todos - os cidadãos” (O magistrado, protagonista do processo jurisdicional? p. 222). 
qualidade. A exigência da sociedade por processos rápidos deve vir acompanhada de investimentos na estrutura do Poder Judiciário, sob pena de deterioração da prestação jurisdicional. Quanto ao segundo argumento, também é certo que a atuação das partes no processo, por meio de seus advogados, é corriqueiramente pautada por aventuras judiciais fundadas em argumentos esdrúxulos e infundados, citações jurisprudenciais descontextualizadas e diversas do caso concreto, distorções doutrinárias etc. Entretanto, nada disso autoriza validar decisões insuficientemente motivadas a partir de uma afirmação ilegal e inconstitucional. Asseverar que os juízes não precisam se manifestar sobre todas as alegações das partes é o mesmo que negar à motivação sua função precípua de controle da atividade judicial, aceitar que demandas formuladas não sejam apreciadas pelos juízes (em caso de omissão quanto a causas de pedir) e tornar inúteis as garantias do contraditório e da ampla defesa.

Se é verdade que há uma sobrecarga de trabalho para os juízes, também é verdade que esse não é um problema resolvível mediante uma prestação jurisdicional falha ou insuficiente. Entre processos rápidos e injustos, e processos demorados, mas justos, certo é que são estes que devem prevalecer. A demora dos processos é causa de injustiça e insegurança jurídica, mas não pode ser solucionada com a geração de mais injustiça e mais insegurança jurídica.

E se é verdade que as partes abusam de suas faculdades processuais, também é verdade que o juiz não pode simplesmente ignorar o que é produzido no processo; situação que imediatamente cederia espaço ao arbítrio. Se as alegações são irrelevantes, então deve o juiz dizê-lo claramente: ${ }^{630}$ “a alegação X feita pelo réu é irrelevante, pois trata do assunto $\mathrm{Y}$, quando na verdade o caso concreto diz respeito à circunstância Z", p.ex. A motivação não precisa ser prolixa nem longa (pelo contrário, deve sempre ser objetiva, cf. exposto no ponto 11.1, acima); basta que haja um efetivo pronunciamento judicial sobre o tema, demonstrando que o juiz leu e refletiu sobre as alegações de ambas as partes e, enfim, está apto para justificar a decisão tomada. No que

\footnotetext{
${ }^{630}$ Nesse sentido, WAMBIER, Teresa Arruda Alvim. Omissão Judicial e Embargos de Declaração. p. 351: “o critério para se saber se uma questão é relevante, e se deve ser referida na decisão, não pode ser exclusivamente o do juiz (ou, pelo menos, não dos juízes de $1^{\mathrm{a}}$ ou de $2^{\mathrm{a}}$ instância). As questões que as partes estimam ser relevantes devem necessariamente ser referidas na decisão, ainda que o Tribunal expressamente observe que, a seu ver, a questão não é relevante".
} 
concerne às alegações evidentemente infundadas, com menos razão ainda podem ser ignoradas pelo magistrado. O Código de Processo Civil é taxativo ao erigi-las como ato de litigância de má-fé, impondo multa à parte infratora (arts. 17 e 18). Ou seja, longe de ignoradas, tais alegações devem ser punidas - sempre com a cautela de não serem cerceadas as garantias do contraditório e da ampla defesa das partes.

As únicas alegações que podem ser omitidas pelo juiz na motivação são as do vencedor; jamais do sucumbente. ${ }^{631} \mathrm{Se}$ o autor formula um pedido a partir de três causas de pedir distintas (três demandas cumuladas, portanto), e o juiz julga que a primeira delas é apta para legitimar o pedido, não precisará analisar as demais. ${ }^{632}$ Mas de nenhuma forma poderá julgar procedente o pedido do autor sem apreciar todas as razões de defesa do réu, sejam fáticas ou jurídicas. Ainda nesse sentido, a sentença só poderá ser reformada pelo tribunal se o acórdão manifestar-se expressamente sobre as três causas de pedir do autor, repelindo-as integralmente; e caso confirmada, todas as razões de apelação do réu deverão ser expressamente afastadas.

\subsubsection{A completude da motivação e as decisões sujeitas a recursos}

A defesa que vem sendo feita da completude da motivação engloba, indistintamente, todas as espécies de decisões judiciais. Essa constatação tem relevo diante da difundida crença de que determinadas decisões não precisam ser motivadas com o mesmo grau de profundidade de outras: especialmente quando sujeitas a recurso com efeito devolutivo amplo, como é o caso da apelação.

Quanto a isso, algumas observações são pertinentes.

1) A atividade desempenhada por juízes de primeiro grau não pode ser desprestigiada dessa forma. Imaginar que uma sentença não precisa tratar de todos os pontos e questões relevantes ao processo (e é relevante tudo o que for alegado e produzido

\footnotetext{
${ }^{631}$ Nas palavras de Adolphe TOUFFAIT e André TUNC, trata-se de "une exigence essentielle de justice: celui qui perd son procès ou qui encourt une condamnation peut légitimement exiger d'en connaître les raisons" (Pour une motivation plus explicite des décisions de justice... p. 488).

632 V. SILVA, Ana de Lourdes Coutinho. Motivação das Decisões Judiciais. p. 160: “Apenas em uma situação estaria o magistrado dispensado de apreciar todas as causas de pedir apresentadas: quando já tiver encontrado fundamento suficiente para acolher o pedido, mas nunca para julgá-lo improcedente (...)”.
} 
pelas partes) porque o tribunal irá reanalisar a questão é o mesmo que reduzir a sentença a uma atividade insignificante e sem sentido, um mero "parecer de luxo" dado por um juiz para facilitar o convencimento do órgão ad quem.

2) Além de desprestigiar a atividade do órgão a quo, tal pensamento também retira toda e qualquer responsabilidade dos juízes de primeiro grau, dando margem a decisões erráticas, irrefletidas e seriamente lesivas às partes e à sociedade (algo que infelizmente já é provocado pelo nosso sistema recursal excessivamente abrangente e exaustivo). Afinal, se a decisão de primeiro grau é só uma etapa provisória e insignificante no curso do processo, então é apenas uma questão de tempo para que o juiz de primeiro grau deixe de se preocupar com as consequências de seus atos.

3) O raciocínio desenvolvido no ponto anterior também serve para desprestigiar os embargos de declaração. Omissões, contradições e obscuridades nas decisões dificilmente seriam sanadas, sempre sobre a crença de que o tribunal poderá revêlas posteriormente.

4) É uma ingênua utopia confiar aos tribunais a correção de decisões omissas, contraditórias e obscuras. Na verdade, a tendência é justamente contrária. Diante do atual movimento doutrinário em prol da valorização das decisões de primeiro grau, há relevante jurisprudência no sentido de que apenas decisões flagrantemente ilegais devem ser revistas, sobretudo em julgamento de agravo de instrumento. ${ }^{633}$ Sendo assim, cria-se um paradoxo insustentável. De um lado, os juízes de primeiro grau passam a atuar de forma descompromissada, uma vez que suas decisões inevitavelmente serão revistas em julgamento de recurso; de outro, mantêm-se decisões ilegais ou incorretas sobre o argumento de que a atividade de primeiro grau deve ser prestigiada. Em resumo, o

${ }^{633}$ P.ex., AGRAVO INTERNO EM AGRAVO. NEGATIVA DE SEGUIMENTO. MANDADO DE SEGURANÇA. NÃO CABIMENTO DE AGRAVO. REPETIÇÃO DA ARGUMENTAÇÃO JÁ APRECIADA. 1. As alterações feitas pela Lei no $9139 / 95$ não alteraram o rito especial e célere do mandado de segurança nem a sua natureza mandamental. $O$ ato que defere ou indefere liminar não comporta a interposição do agravo, a não ser em casos excepcionais, de decisões manifestamente teratológicas, abusivas ou flagrantemente ilegais. Precedentes desta Corte. 2. Matéria já apreciada quando do julgamento do agravo de instrumento. A repetição da argumentação não autoriza a reforma da decisão hostilizada. Precedentes desta Turma. 3. O fato de o entendimento adotado ter sido contrário aos interesses da parte não serve de fundamento à reforma da decisão. (STF. AgReg. no 465270-1. Min. Carlos Velloso. DJ de 05.03.04; TRF/2. $\mathrm{AI}^{\mathrm{o}}$ 20040201001237-1, DJ de 17.05.04). 4. Agravo improvido. (TRF2, AI no. 2007.02.01.014817-8/RJ, D.J. 06/06/2008). 
jurisdicionado não recebe uma prestação jurisdicional minimamente adequada nem dos juízes de primeiro grau nem dos tribunais.

5) Por fim, nenhuma decisão judicial pode ser motivada parcialmente ou apresentar algum tipo de omissão. Decisões omissas são, dependendo da hipótese, inexistentes ou nulas (v. 12 e ss., abaixo) e, em qualquer situação, frutos de arbitrariedade e contrárias ao ideal do Estado de Direito. Se uma sentença de primeiro grau não precisa julgar todas as demandas cumuladas pelo autor, ou não precisa apreciar todas as razões de defesa do réu, então a solução mais adequada e coerente seria acabar com o duplo grau de jurisdição.

\subsubsection{A motivação implícita}

Chama-se de implícita a motivação que, embora não tenha sido expressamente apresentada, decorre logicamente das demais razões dadas para a decisão. Essa dedução lógica deve ser sempre necessária, i.e., deve ser a única conclusão possível das razões que expressamente constam da motivação. ${ }^{634}$ É o caso, p.ex., da decisão que reconhece expressamente a validade de um contrato. Necessariamente, um contrato só será juridicamente válido se for juridicamente existente. Logo, ao reconhecer a validade, a decisão implicitamente reconhece a existência do contrato.

Como regra, motivações implícitas são altamente indesejáveis. Em primeiro lugar, em muitos casos, é tênue a linha que separa a implicitação da omissão. Embora o reconhecimento de validade de um contrato tenha como consequência lógica e necessária a sua existência, a decisão não poderá deixar de se manifestar expressamente sobre eventuais alegações relativas à inexistência do contrato, p.ex. Se João alega que jamais celebrou contrato com José, sendo falsa a assinatura que consta no instrumento contratual junto aos autos, certamente não será suficiente uma manifestação judicial a respeito da validade do contrato. Em segundo lugar, a dedução lógica de uma razão expressa nem sempre é tão evidente quanto supõe o juiz. Quanto mais transparente for a decisão, quanto menos dúvidas for passível de gerar, tanto melhor será a motivação. Por fim, o mero apontamento de que uma razão de decidir decorre lógica e necessariamente de outra razão de decidir, de

\footnotetext{
${ }^{634}$ V. GOMES FILHO, Antonio Magalhães. A Motivação das Decisões Penais. p. 197-198.
} 
forma sucinta, mas clara, certamente não tomará nem tempo nem energia do órgão julgador.

\subsection{A motivação per relationem e a motivação aliunde}

A motivação per relationem e a motivação aliunde são técnicas utilizadas para reduzir o "empenho justificativo" da decisão. ${ }^{635}$ Com frequência configuram, na feliz expressão de Antonio Magalhães Gomes Filho, verdadeiros "artifícios da motivação", voltados a frustrar o dever constitucional de que todas as decisões judiciais sejam motivadas.

Tanto a motivação per relationem como a motivação aliunde são reproduções de razões contidas em outro ato jurídico, que pode ter sido elaborada pelo próprio órgão julgador ou não. Ou seja, o julgador "apropria-se" de razões dadas em outro ato jurídico para motivar a decisão por ele tomada. Em geral, são denominadas indistintamente de "per relationem". A distinção, porém, é benéfica. Enquanto a motivação per relationem utiliza razões de uma decisão do mesmo processo, a motivação aliunde busca razões produzidas em ambiente externo ao processo. ${ }^{636}$ Sendo assim, há motivação per relationem quando, p.ex., o tribunal confirma uma sentença e, para motivar o acórdão, simplesmente transcreve a motivação do juízo a quo ou faz remissão ao seu conteúdo; e há motivação aliunde quando, p.ex., o tribunal utiliza a motivação de acórdão prolatado em outro processo, seja do próprio tribunal, de tribunal de mesmo nível hierárquico ou superior. Ambas são muito utilizadas não só no Brasil como nos mais diversos sistemas judiciários. $^{637}$

Grosso modo, pode-se dizer que a motivação aliunde é, em determinados casos, aceitável e a motivação per relationem é, em qualquer situação, o mesmo que falta de motivação.

\footnotetext{
${ }^{635}$ Ibidem. p. 196-197.

${ }^{636}$ V. TUCCI, José Rogério Cruz e. A Motivação da Sentença Civil. p. 18-19.

${ }^{637}$ V. TARUFFO, Michele. La Motivazione della Sentenza Civile. p. 422-430; EVANGELISTA, Stefano. Motivazione della sentenza civile. p. 165-166; AMODIO, Enio. Motivazione della sentenza penale. p. 230234; SANTOS, Tomás-Javier Aliste. La Motivación de las Resoluciones Judiciales. p. 232.
} 
A motivação aliunde é aceitável desde que, e somente se, a causa (a) verse sobre questão exclusivamente de direito, (b) seja análoga à que foi julgada pela decisão “apropriada" e (c) não contenha nenhuma alegação fática ou jurídica que não esteja contemplada pela decisão "apropriada". Nessa situação, por economia e racionalidade da atividade judicial, é razoável que seja utilizada a motivação de uma decisão pretérita, uma vez que ambas compartilham a mesma ratio decidendi (v. 13 e 14, abaixo). No entanto, e isso é fundamental, cumpre ao julgador deixar cristalina a identidade entre os casos e a aptidão da motivação aliunde para ser utilizada no caso sob julgamento. Também é imprescindivel que o julgador empreste a motivação de um precedente (para o conceito de precedente, v. 13 e ss., abaixo), jamais utilizando como motivação pareceres ou petições. Note-se que os requisitos aqui propostos são os mesmos do estabelecido pelo art. 285-A para o julgamento liminar de causas repetitivas, o qual consagra uma hipótese válida e legítima de motivação aliunde.

No que concerne à motivação per relationem, trata-se de uma severa violação do dever de motivação. ${ }^{638}$ Ainda que o tribunal considere válida e correta a decisão recorrida, não lhe é dado simplesmente transcrevê-la. Pode, é claro, aproveitar trechos relevantes ou de clareza ímpar. Mas é dever do tribunal expor as razões pelas quais a considera válida e correta, justificando a sua manutenção. Lembre-se sempre que um recurso é uma impugnação específica de uma decisão judicial, e não mera reafirmação de alegações expendidas anteriormente. Quando o juízo ad quem apenas transcreve a decisão recorrida - que está junta aos autos e é pública, o que torna o ato ainda mais insensato -, deixa de dar uma resposta às razões apresentadas pelo recorrente para a sua reforma ou invalidação. Ou seja, o acórdão perde a dialeticidade necessária a todo provimento judicial, transformando o recurso em uma faculdade vazia e inútil. Se a motivação de uma decisão recorrida serve como motivação da resposta dada ao recurso, então ou o recurso é inepto,

\footnotetext{
${ }^{638}$ Cf. EVANGELISTA, Stefano. Motivazione della sentenza civile. p. 165: “(...) non assolve all'obbligo della motivazione il giudice che si limiti a richiamare le ragioni addotte in altro provvedimento giurisdizionale: ciò perché tale richiamo non consente di stabilire se il giudice abbia preso in esame e valutate le particolari ragioni addotte dalle parti in ordine alla questione controversa".
} 
pois deixou de trazer razões para a reforma ou invalidação da decisão (sendo caso, então, de não conhecimento), ou a motivação é certamente inadequada. ${ }^{639}$

Ainda menos legítima é a motivação per relationem que empresta razões de parecer do Ministério Público, de pareceres contratados por uma das partes ou mesmo de petições. Com efeito, o julgador poderá citá-los e utilizá-los como parâmetro para a decisão. Mas a motivação é um ato de justificação da atividade jurisdicional. São as razões do Estado-juiz para julgar como julgou. Transcrever razões alheias e abster-se de fazer qualquer observação sobre o caso concreto certamente não atinge os propósitos do dever de motivação.

\section{Decisões imotivadas, decisões mal motivadas e suas consequências}

De acordo com o art. 93, IX, da Constituição da República, toda decisão judicial deve ser motivada, "sob pena de nulidade". Entretanto, se toda decisão mal motivada é nula, a decisão imotivada pode ser nula ou inexistente, dependendo da natureza da omissão judicial.

Considerando as dificuldades sempre presentes envolvendo a distinção entre nulidade e inexistência jurídica, serão estabelecidas algumas premissas nos próximos pontos para, em seguida, tratar das consequências decorrentes de decisões imotivadas ou mal motivadas.

12.1. As decisões judiciais e os planos da existência, validade e eficácia: considerações iniciais

Todo ato jurídico manifesta-se em três planos distintos: existência, validade e eficácia. Sendo assim, um ato pode ser juridicamente existente ou inexistente, válido ou inválido e eficaz ou ineficaz.

\footnotetext{
${ }^{639}$ Nesse sentido, Ibidem. p. 165: “Anche qui è, invece, necessario che la motivazione dimostri come il giudice di appello abbia sottoposto ad adeguato vaglio critico i motivi di gravame e per quali ragioni si pervenuto al convincimento della inidoneità dei medesimi a determinare la riforma della sentenza del giudice a quo".
} 


\subsubsection{Plano da existência}

Nem todo ato material é um ato jurídico. Determinados acontecimentos da vida ou condutas individuais podem não se transformar em ato jurídico, ainda que voltadas a produzir efeitos no mundo do Direito. Já dizia Pontes de Miranda: “Ou algo entrou ou se produziu e, pois, é, no mundo jurídico; ou nêle não entrou, nem se produziu dentro dêle, e, pois, não é’.640

$\mathrm{O}$ ato jurídico, para assim ser considerado, deve conter elementos que lhe são essenciais, que lhe caracterizam e dão-lhe suas características próprias ${ }^{641}$. Parte da doutrina prefere referir-se a preenchimento mínimo do suporte fático da norma. ${ }^{642}$ Pouco importa. Basta que se atente à necessidade de haver o mínimo exigido pela lei para que o ato praticado seja aquilo que pretende ser. Um 'casamento' celebrado por quem não tem poderes para tanto não é um casamento, pois é "elemento essencial" do ato, faz parte do núcleo do suporte fático da norma a celebração por pessoa competente. ${ }^{643}$ Do mesmo modo, um negócio jurídico sem objeto não pode ser um negócio jurídico. ${ }^{644}$ Muitos outros são os exemplos.

A doutrina não é pacífica a respeito da pertinência de se falar em 'ato jurídico inexistente'. Utilizando-se o agrupamento realizado por Eduardo Talamini, quatro são as críticas usuais que se faz à categoria: a) o adjetivo inexistente não pode qualificar um fato; chamar um fato de inexistente significaria falar em ato não-ato; b) juridicamente, ou o fato guarda correspondência com seu suposto normativo ou não guarda. Assim, a nulidade já corresponde à própria inexistência, pois ambas são hipóteses de dissonância entre o fato e o suposto normativo; c) todo ato juridicamente relevante praticado, na medida em que mereça atenção do ordenamento jurídico, deve ser dele desconstituído, o

\footnotetext{
${ }^{640}$ PONTES DE MIRANDA, Francisco Cavalcanti. Tratado de Direito Privado, t. IV. p. 8.

641 COUTURE, Eduardo Juan. Fundamentos.... p. 307; AZEVEDO, Antônio Junqueira de. Negócio Jurídico... p. 26 e ss.

${ }^{642}$ ASCARELLI, Tullio. Inesistenza e nullità. p. 61-65; PONTES DE MIRANDA, Francisco Cavalcanti. Tratado de Direito Privado, t. IV. p. 3 e ss; MELLO, Marcos Bernardes de. Teoria do Fato Jurídico: plano da existência. p. 43 e ss. e 102-103.

${ }^{643}$ Exemplo dado por MELLO, Marcos Bernardes de. Teoria do Fato Jurídico... p. 102-103.

${ }^{644}$ AZEVEDO, Antônio Junqueira de. Negócio Jurídico... p. 31 e ss.
} 
que implicaria sua existência; d) não há como identificar os elementos que implicam a inexistência ou que acarretam a invalidade. ${ }^{645}$

A primeira crítica pode ser facilmente afastada. Quando se fala em ato inexistente, o termo 'inexistente' não está qualificando o substantivo, mas retirando do substantivo a sua natureza. Um 'ato inexistente' significa que o ato praticado que pretende se passar por determinado ato jurídico não é esse ato jurídico. Utilizando o exemplo acima dado, a expressão "casamento inexistente" refere-se ao ato praticado que pretende ser um casamento, mas, por carecer de seus elementos essenciais, não é casamento. O adjetivo inexistente simplifica uma ideia mais complexa, portanto. ${ }^{646}$

A quarta crítica também não se sustenta. A definição dos 'elementos essenciais' do ato jurídico não é tarefa árdua quando se o submete a uma análise teleológica. Toda sentença, p.ex., é um ato decisório. A 'razão de ser' da sentença é decidir. Um ato praticado por um juiz desprovido de decisão não poderá ser sentença; daí por que sentença sem dispositivo é sentença inexistente. ${ }^{647}$ Do mesmo modo, o ato não será sentença quando o agente carecer de investidura jurisdicional; a sentença não só é ato decisório, como é ato decisório jurisdicional. Esse tipo de análise lógico-jurídica pode ser feita com qualquer ato jurídico.

A segunda crítica, feita por, dentre outros, $\operatorname{Satta}^{648}$ e Carnelutti ${ }^{649}$, embora seja mais substanciosa, também deve ser afastada. Se é verdade que atos jurídicos em sentido lato, ou "atos-fatos", estão previstos em normas que se limitam a descrever um ato

\footnotetext{
${ }^{645}$ TALAMINI, Eduardo. Coisa Julgada e sua Revisão. p. 281-284.

646 ARAGÃO, Egas Dirceu Moniz de. Comentários ao Código de Processo Civil, v. II. Rio de Janeiro: Forense, 1974. p. 274: "A inexistência pode assumir dois aspectos distintos: um meramente vocabular, que significa não-ato; outro jurídico, que significa ato existente no mundo dos fatos, mas não existente no mundo do Direito.(...) "No segundo caso, porém, o ato tem toda a aparência de validade em face do Direito e, no entanto, mais do que apenas nulo, é juridicamente inexistente".

${ }^{647}$ Nesse sentido, DINAMARCO, Cândido Rangel. Instituições de Direito Processual Civil, v. III. p. 692 ; BARBOSA MOREIRA, José Carlos. Comentários ao Código de Processo Civil, v. V. p. 101; TALAMINI, Eduardo. Coisa Julgada e sua Revisão. p. 309 e ss.; WAMBIER, Teresa Arruda Alvim. Nulidades do Processo e da Sentença. p. 337 e ss; DIDIER JR., Fredie; BRAGA, Paula Sarno; OLIVEIRA, Rafael. Curso de Direito Processual Civil, v. 2. p. 239.

${ }^{648}$ SATTA, Salvatore. Sull'inesistenza degli atti processuali. p. 337-342.

${ }^{649}$ CARNELUTTI, Francesco. Inesistenza dell'atto giuridico? p. 208-211
} 
humano e a atribuir uma consequência a este comportamento, o mesmo não se pode falar dos atos jurídicos em sentido estrito e dos negócios jurídicos. A diferença entre um pagamento nulo e um pagamento inexistente não chega a ter maior importância, pois o elemento volitivo ou a "dicção prescritiva" do agente é irrelevante. As consequências jurídicas previstas em lei decorrem da prática do ato, e não da vontade do agente. Nos atos jurídicos em sentido estrito e nos negócios jurídicos, por outro lado, diante da necessária 'declaração' do agente voltado a obter os efeitos previstos para aquele ato, a norma passa a ter "dois estágios distintos": a correspondência do ato ao suposto normativo e o respeito às “regras técnicas para a obtenção dos efeitos aos quais a 'declaração' tende”. O primeiro estágio diz respeito à existência e o segundo à validade. ${ }^{650}$

Por fim, a terceira crítica, classicamente formulada por Kelsen, parte de uma premissa absolutamente equivocada. ${ }^{651}$ Ao contrário do que se defende, o ato inexistente não entra no mundo jurídico e, por isso, não precisa ser desconstituído. Poder-se-ia questionar: e se a sentença proferida por quem não é juiz for utilizada para dar início à execução civil (cumprimento de sentença)? Como resposta, coloca-se outra questão: o que será executado? A execução fundada em 'sentença' proferida por quem não é juiz carece de comando jurisdicional, e a execução, como se sabe, apenas se legitima pela necessária imposição coativa do império estatal. Todos os atos expropriatórios que se seguirem estarão amparados na aparência de uma sentença, jamais em uma sentença. Trata-se de situação idêntica à observada em uma execução que se inicia e se prossegue sem nenhum título executivo.

$\mathrm{O}$ ato inexistente não está sujeito à desconstituição, mas à declaração judicial de que aquele ato não é o que pretende ser. Contudo, nem mesmo essa declaração será imprescindível, pois o ato inexistirá com ou sem ela. Sua importância e os inegáveis benefícios dela derivados consistem unicamente na promoção da segurança jurídica, evitando-se que a aparência de um ato leve à prática de novos atos jurídicos. ${ }^{652}$

\footnotetext{
${ }^{650}$ TALAMINI, Eduardo. Coisa Julgada e sua Revisão. p. 286-290.

${ }^{651}$ KELSEN, Hans. Teoria Pura do Direito. p. 306-308.

${ }^{652}$ Como afirmou Carlos Alberto ALVARO DE OLIVEIRA, “A sentença proferida na demanda declaratória não condena. Também não manda, não constitui, nem executa. Importante é que a declaração torne certa uma situação jurídica substancial determinada (...)” (Teoria e Prática da Tutela Jurisdicional. p. 146).
} 


\subsubsection{Plano da validade}

Apenas atos existentes podem ser nulos. ${ }^{653}$ "Não pode ser deficiente o que não existe, o que não é. Para ser deficiente é preciso que exista". ${ }^{654}$ A inexistência não é um vício nem uma nulidade grave, mas um simples fato. Aceito o plano da existência/inexistência dos atos jurídicos, não há como se desvincular dessa constatação, sob risco de incidir em grave "assistemática científica". ${ }^{655}$

Existente o ato jurídico, então há que se verificar se o suporte fático da norma foi corretamente preenchido. Defeituoso o preenchimento deste suporte fático, defeituoso é o ato. Todo ato defeituoso tem que ser desconstituído, isto é, desfeito, retirado do ordenamento jurídico. Até sua nulificação ou anulação (invalidação em sentido amplo $\left.^{656}\right)$, o ato existe e pode produzir efeitos jurídicos. ${ }^{657}$

Nada impede que uma nulidade seja declarada pelo Poder Judiciário. As consequências jurídicas imediatas, porém, serão as mesmas de todas as sentenças declaratórias: excetuada a segurança jurídica, nenhuma! Por isso, ato inválido tem de ser retirado do ordenamento jurídico, tem de ser fulminado por decisão desconstitutiva.

\footnotetext{
${ }^{653}$ AZEVEDO, Antônio Junqueira de. Negócio Jurídico... p. 64.

${ }^{654}$ PONTES DE MIRANDA, Francisco Cavalcanti. Tratado de Direito Privado, t. IV. p. 19.

${ }^{655}$ Contra a qual se insurgiu corretamente CABRAL, Antonio do Passo. Nulidades no Processo Moderno. p. 34-35.

${ }^{656}$ Segundo Fredie DIDIER Jr., "Não se pode baralhar ato defeituoso com ato inválido; ato defeituoso é o que se vê, ato inválido decorre do reconhecimento do defeito pelo magistrado, com a consequente destruição do ato" (Curso de Direito Processual Civil, v. 1. p. 228). Embora correta a ideia, não se concorda com a nomenclatura utilizada. Se ato válido é o ato que preenche corretamente o suporte fático da norma, então o ato que deixa de atender aos requisitos legais é inválido. O próprio autor afirma que o "ato inválido existe portanto pode produzir efeitos" (p. 227). Se o ato inválido existe, quer dizer que não foi retirado do ordenamento jurídico e, então, nada difere do ato simplesmente defeituoso. Talvez o ideal fosse falar em 'nulificação' e 'anulação', passando-se a ideia de transformação do ato em 'nada' jurídico, que é exatamente o que a desconstituição do ato faz.

${ }^{657}$ Cf. PONTES DE MIRANDA, Francisco Cavalcanti. Tratado de Direito Privado, t. V. p. 71; AZEVEDO, Antônio Junqueira de. Negócio Jurídico.... p. 49 e ss.; KOMATSU, Roque. Da Invalidade no Processo Civil. p. 37-41; MELLO, Marcos Bernardes de. Teoria.... p. 104 e ss.
} 


\subsubsection{Plano da eficácia}

Chama-se eficácia a aptidão de um ato jurídico de produzir os efeitos que lhe são previstos. Nem sempre o ato válido produz os efeitos que a lei lhe comina, pois sujeito a condição suspensiva. $\mathrm{O}$ ato também pode ser eficaz em relação a determinadas pessoas ou situações jurídicas e ineficaz em relação a outras: a sentença produz efeitos entre as partes do processo, mas é ineficaz em relação a terceiros, por exemplo.

A invalidade, ao contrário do que às vezes se afirma, não induz à ineficácia do ato. Muitas vezes o ato inválido só deixará de produzir efeitos quando retirado do ordenamento jurídico por decisão judicial. ${ }^{658}$ Assim, a sentença proferida por juiz impedido (inválida, portanto) que confirma a antecipação dos efeitos da tutela (art. 520, VIII, do CPC) produzirá efeitos até que o tribunal a reforme (ou se atribua à apelação efeito suspensivo - art. 558, parágrafo único, do CPC).

Importante notar que apenas atos podem ser inválidos. Efeitos jurídicos simplesmente se produzem ou não se produzem. Não existe eficácia nula ou inválida. ${ }^{659}$

Diante disso, a eficácia ou ineficácia de um ato será simplesmente declarada judicialmente. Nada impede que o terceiro, tomando ciência de uma sentença que lhe causa prejuízo, antecipe-se à violação de seu patrimônio e peça, judicialmente, a declaração de que aquela sentença lhe é ineficaz. Caso não o faça e, iniciada a execução civil, venha a sofrer turbação ou esbulho na posse de seus bens por ato de apreensão judicial, poderá requerer a sua manutenção na posse ou restituição do bem, mas não poderá pleitear a desconstituição da sentença. Os embargos de terceiro conterão, explícita ou implicitamente, o pedido de que seja declarada a ineficácia da decisão em relação a si e, então, que seja determinada a manutenção ou restituição da posse.

\subsubsection{Decisões judiciais inexistentes, nulas e ineficazes}

A importância da distinção entre atos processuais nulos e inexistentes nem sempre é muito clara. Com frequência, defende-se que as consequências de ambas são as

\footnotetext{
${ }^{658} \mathrm{~V}$. nota anterior.

${ }^{659}$ Cf. DIDIER JR., Fredie. Curso..., v. 1, 2007. p. 226.
} 
mesmas. ${ }^{660}$ Realmente, por serem os atos processuais parte de um 'ato-complexo' chamado procedimento, tanto a nulidade como a inexistência de um ato previsto em lei, na maioria das vezes, acarretará a invalidade de todo procedimento (e a ineficácia dos atos que se seguem, como disposto no art. 248 do Código de Processo Civil).

Há atos, por outro lado, que originam o procedimento ou colocam-lhe fim. Para eles, a distinção entre existência e invalidade é de indiscutível importância. ${ }^{661}$ Utilizese como exemplo a demanda, pressuposto de existência de todo processo. Mediante a propositura da demanda é que se rompe a inércia jurisdicional, instaura-se o processo e delimita-se o objeto da atividade jurisdicional. Se não há demanda (inexistência de pedidos, p. ex.), a inércia jurisdicional não é rompida e o Estado (salvo exceções definidas em lei) não é chamado a se pronunciar sobre nenhuma pretensão. Qualquer 'decisão' que venha a ser proferida será feita de ofício, como se nunca houvesse existido um processo (o qual, para fins jurídicos, realmente não existiu).

Igualmente, é fundamental a diferença entre decisões inexistentes e decisões inválidas. Uma decisão inexistente jamais possuirá eficácia jurídica, pois não há comando, nem declaração jurisdicional. No caso da sentença inexistente, esta jamais transitará em julgado, e a inércia jurisdicional poderá ser rompida quantas vezes forem necessárias para que o jurisdicionado obtenha uma resposta à sua demanda. A sentença inválida, por outro lado, apenas o é enquanto não transitada em julgado. Depois disso, todos os vícios são sanados. $^{662}$

Uma decisão judicial só pode ser assim considerada se preenchidos três pressupostos básicos e necessários: ela deve ser proferida em um processo judicial, ela deve ser proferida por agente investido de jurisdição (no caso, o juiz) e ela deve decidir uma pretensão formulada no processo. Sem qualquer um desses elementos, a decisão é juridicamente inexistente: com todas as consequências daí decorrentes.

\footnotetext{
${ }^{660}$ V., por todos, BEDAQUE, José Roberto dos Santos. Efetividade... p. 457-460.

661 Especificamente quanto à importância da inexistência da sentença, v. TALAMINI, Eduardo. Coisa Julgada e sua Revisão. p. 279 e ss.

${ }^{662}$ Para mais detalhes, v. RAMINA DE LUCCA, Rodrigo. Querela nullitatis e réu revel não citado no processo civil brasileiro. p. 123-126.
} 
Decisões juridicamente existentes são válidas ou inválidas. São inválidas decisões sem relatório, sem motivação jurídica e, em alguns casos, sem motivação fática, proferidas em processos nulos etc. Nem toda decisão válida é eficaz e nem toda decisão inválida é ineficaz. Decisões válidas podem não produzir efeitos e decisões inválidas produzirão os efeitos que lhes são inerentes até serem corrigidas mediante embargos de declaração ou desconstituídas em julgamento de recurso.

12.2. Decisões inexistentes por "falta de motivação" ou motivação incongruente

Embora a Constituição da República disponha expressamente que são nulas decisões imotivadas, não é sempre assim. Há casos em que a falta de motivação ou a motivação incongruente implicam a inexistência da decisão.

\subsubsection{Inexistência por "falta de motivação"}

A indicação de mais de uma causa de pedir para o mesmo pedido significa uma cumulação de demandas que devem ser apreciadas específica e individualmente pelo julgador (v. 10.3, acima). Se o pedido $\mathrm{X}$ foi formulado com fundamento nas situações fáticas $\mathrm{A}, \mathrm{B}$ e $\mathrm{C}$, então há três demandas distintas: $\mathrm{A}, \mathrm{B}$ e $\mathrm{C}$. Eventual sentença de improcedência deverá ser de improcedência de todas as demandas cumuladas. Embora haja um único dispositivo em resposta ao pedido $X$, a motivação deve correlacionar-se com as razões pelas quais o autor pediu $\mathrm{X}$, demonstrando que cada uma delas não gera a consequência jurídica $X$. Se a motivação limita-se a repelir a causa de pedir $A$, então apenas a demanda $\mathrm{A}$ foi julgada, inexistindo pronunciamento jurisdicional a respeito das demandas B e C (sentença infra petita). Nesse caso, a sentença não só é nula, como inexistente em relação às demandas não julgadas. ${ }^{663}$

\footnotetext{
${ }^{663}$ V. TALAMINI, Eduardo. Coisa Julgada e sua Revisão. p. 312-315: “A falta de decisum sobre a integralidade do objeto do processo (ausência de pronunciamento sobre uma ou algumas das pretensões postas; exame de apenas parte de uma pretensão etc.) faz com que inexista sentença em relação à pretensão ou parcela de pretensão não decidida. O problema, nesse caso, não é propriamente de nulidade da sentença. Se há ausência de comando jurisdicional acerca de parte do objeto do processo, cabe reconhecer que não existe sentença quanto a essa parcela” (p. 313). E continua: “(...) se a sentença não se pronunciar sobre todas as causas de pedir postas, rejeitando apenas a(s) pretensão(ões) fundada(s) em alguma(s) delas, ela será infra
} 
Note-se que a inexistência da decisão não decorre propriamente da falta de motivação, mas da falta de dispositivo. A omissão judicial a respeito de uma das causas de pedir impede a vinculação do dispositivo a todas as demandas cumuladas do autor. Em outras palavras, a falta de motivação tem como consequência a falta de dispositivo na decisão.

\subsubsection{Inexistência por incongruência entre a motivação e a causa de pedir}

Exatamente a mesma solução deve ser dada à incongruência entre a motivação e a causa de pedir da pretensão do autor (sentenças extra petita e ultra petita). Se a decisão infra petita é inexistente porque não há decisão a respeito de uma pretensão formulada, as sentenças extra petita e ultra petita são inexistentes porque inexistente o próprio processo judicial.

Com efeito, o processo judicial só é instaurado mediante a propositura de uma demanda que rompe a inércia jurisdicional e apresenta uma pretensão para julgamento. A demanda, reitere-se mais uma vez, é individualizada não só pelo pedido (pretensão), mas também pelas partes e causa de pedir. Se o autor pede $\mathrm{X}$ com fundamento nas causas de pedir A e B, então o autor formulou apenas duas demandas: A e B. A inércia jurisdicional foi rompida em relação às demandas $\mathrm{A}$ e $\mathrm{B}$; o processo existe em relação às demandas A e B. Se a sentença julga o pedido a partir de uma suposta causa de pedir C, então a sentença não só deixou de julgar as demandas A e B, como também está julgando uma demanda que não existe. Logo, também inexiste rompimento da inércia jurisdicional e instauração de processo judicial. Qualquer pronunciamento a respeito de uma suposta demanda $\mathrm{C}$ será feito de ofício, sem que haja um processo judicial que lhe dê suporte. Trata-se de um ato juridicamente inexistente. ${ }^{664}$

12.3. Decisões nulas por falta de motivação ou motivação inadequada

petita - e não existirá sentença relativamente às pretensões não examinadas” (p. 314). Em sentido contrário, ARRUDA ALVIM. Sentença 'citra petita' - necessidade de ação rescisória. p. 240-241.

${ }^{664}$ Em sentido um pouco distinto, mas também reconhecendo a inexistência jurídica de sentenças extra petita e ultra petita em certas hipóteses, v. TALAMINI, Eduardo. Coisa Julgada e sua Revisão. p. 350-353. 
Com exceção das duas hipóteses acima mencionadas, a falta de motivação ou a motivação inadequada importam a nulidade da decisão judicial, nos termos do art. 93, IX, da Constituição da República. ${ }^{665}$

A nulidade, portanto, atingirá tanto decisões omissas, obscuras e contraditórias, como decisões cuja motivação não preenche os demais requisitos de racionalidade da justificação judicial, tais quais incongruência narrativa, incongruência normativa, falta de sinceridade argumentativa, falta de universalidade das razões jurídicas apresentadas etc. (v. 8.3.1 e ss.).

Nem sempre é simples distinguir decisões inválidas por defeito na motivação de decisões injustas, especialmente no que diz respeito às incongruências narrativa e normativa. De todo modo, as congruências narrativa e normativa não são critérios valorativos da decisão. Não buscam determinar se a decisão está correta ou incorreta, mas se a motivação está fundada nos autos e no Direito. A congruência narrativa é um atributo de racionalidade pelo qual as assertivas judiciais fáticas devem ter correspondência material. A má valoração de uma prova é um error in iudicando que não afasta a congruência narrativa da motivação, mas a decisão que reconhece o pagamento de uma obrigação que não foi nem mesmo alegado pelo réu inadimplente é incongruente com o que consta do processo, carecendo de racionalidade. No mesmo sentido, a má configuração jurídica do fato ou a interpretação equivocada do Direito são errores in iudicando distintos da decisão que se recusa a aplicar, injustificadamente, uma norma jurídica válida e eficaz. Sendo assim, é error in iudicando, p.ex., a decisão que equivocadamente considera suficientemente motivado um ato administrativo que contém apenas afirmações lacônicas; mas é error in procedendo, p.ex. a decisão que reconhece a falta de motivação do ato administrativo, mas julga improcedente a invalidação pleiteada pelo autor porque acredita que ele deve sofrer, efetivamente, a sanção administrativa. Inexiste, no último caso, qualquer congruência entre as razões apresentadas e o ordenamento jurídico, tratando-se de motivação irracional. ${ }^{666}$ Não sendo caso de aplicação

\footnotetext{
${ }^{665}$ Considerando que a falta de motivação implica a inexistência da decisão, TARUFFO, Michele. $L a$ Motivazione della Sentenza Civile. p. 462-466.

${ }^{666}$ Cf. CALMON DE PASSOS, J. J. O magistrado, protagonista do processo jurisdicional? p. 222: “Daí sempre ter afirmado a meus colegas e alunos que é bem fácil se traçar os limites do dever constitucional de fundamentação dos julgados imposta aos magistrados. Viola-o quem julga sem apoio na prova dos autos, ou
} 
do art. $515, \S 3^{\circ}$ do CPC, a sentença deve ser invalidada e os autos remetidos ao juízo a quo para que uma nova sentença, racionalmente motivada de acordo com os autos e o Direito, seja proferida. ${ }^{667}$

12.4. Meios de ataque à decisão imotivada ou mal motivada

A forma de se insurgir contra uma decisão imotivada varia de acordo com as consequências causadas pela falta de motivação. Decisões inexistentes assim o são independentemente de reconhecimento judicial. A inexistência não deixa de existir pelo decurso do tempo e jamais é sanada pela inércia de qualquer uma das partes. Sob um ponto de vista técnico e lógico, com exceção dos embargos de declaração, não são cabíveis recursos contra decisões inexistentes. O instrumento adequado seria o pedido de correição parcial pela parte interessada, de modo que o juiz fosse compelido a prestar adequadamente a jurisdição. No entanto, considerando o desuso da correição parcial, as incongruências constantemente verificadas no tratamento da inexistência jurídica, e a concepção difundida de que decisões infra, extra e ultra petita são sempre nulas, já está consagrada a utilização de recursos contra decisões inexistentes, atribuindo-se-lhes tratamento idêntico ao que seria dado a decisões nulas: invalidação e reenvio ao juízo $a$ quo para que profira uma nova decisão ou julgamento imediato do mérito, nos termos do art. $515, \S 3^{\circ}$, do CPC . Ao contrário da nulidade, porém, as partes podem ver reconhecida a

aplica o direito aos fatos sem invocar um suporte doutrinário autorizado ou precedentes jurisprudenciais que atenderam à exigência constitucional de sua fundamentação substancial e ainda, se tanto puder, inovar ele próprio, oferecendo conclusão inédita mas alicerçada em cânones da dogmática legitimada como saber jurídico pela comunidade em que atua".

${ }^{667}$ Nesse sentido, já decidiu com clareza o Tribunal de Justiça do Estado do Paraná: APELAÇÃO CÍVEL. AÇÃO DE PRESTAÇÃO DE CONTAS. CONTAS REJEITADAS COM FUNDAMENTO EM SENTENÇA PENAL CONDENATÓRIA NÃO TRANSITADA EM JULGADO. IMPOSSIBILIDADE. PRINCÍPIO DA PRESUNÇÃO DE INOCÊNCIA. NULIDADE DA SENTENÇA. BAIXA DOS AUTOS À VARA DE ORIGEM PARA QUE OUTRA SEJA PROFERIDA. ANÁLISE DO MÉRITO PREJUDICADA. RECURSO CONHECIDO E PROVIDO. (TJPR - 7 ${ }^{\mathrm{a}}$ C.Cível - AC 666651-1 - Foro Central da Comarca da Região Metropolitana de Curitiba - Rel.: D’Artagnan Serpa Sá - Unânime - J. 22.02.2011). A motivação do acórdão é precisa: "Corolário lógico, se o douto magistrado sentenciante entende que as contas devam ser rejeitadas, deve fazê-lo com fundamento no conjunto probatório produzido neste caderno processual e não somente com espeque em condenação penal, cujo acórdão que a confirmou é objeto de Recurso Extraordinário. Prejudicada a análise do mérito, voto no sentido de dar provimento ao recurso, anulando a sentença e determinando a baixa dos autos à vara de origem para que outra sentença seja proferida". 
inexistência da decisão a qualquer momento, incluindo eventual fase de cumprimento de sentença inexistente, p.ex., ou mesmo incidentalmente em outro processo. A inexistência tanto poderá ser declarada expressamente em ação declaratória de inexistência proposta justamente para esse fim, cuja decisão fará coisa julgada, como reconhecida na motivação de decisões proferidas em outros processos, servindo como razão de decidir. Essa última hipótese é bastante relevante. Suponha-se que José interveio como assistente de Pedro em determinado processo. A sentença, porém, foi grosseiramente extra petita. Se João propuser ação contra José, não poderá vincular José à justiça daquela decisão inexistente (art. 55 do $\mathrm{CPC}$ ). Cumprirá ao juiz reconhecer a inexistência da sentença e permitir a rediscussão das questões eventualmente relevantes.

No caso de decisões imotivadas existentes, a consequência será exatamente a mesma da decisão mal motivada: error in procedendo que causa a nulidade da decisão e autoriza a sua invalidação no curso do processo. Os recursos postos à disposição das partes para invalidar a decisão são os mesmos que seriam utilizados para invalidar qualquer outra decisão viciada: agravos, apelação, recurso especial etc. Especificamente no que diz respeito ao recurso especial, compete ao Superior Tribunal de Justiça verificar se a decisão foi suficiente e corretamente motivada, levando em consideração as alegações das partes, o conjunto probatório e o Direito vigente. Analisar a congruência narrativa de uma decisão não implica valoração fática, mas perquirição acerca da sua legalidade, nos termos dos arts. 128 e 131 do Código de Processo Civil ${ }^{668}$.

Diferentemente das decisões inexistentes, as decisões imotivadas existentes e as decisões mal motivadas são nulas enquanto passíveis de impugnação no curso do processo. Destarte, uma decisão interlocutória mal motivada só é nula enquanto não preclusas as faculdades recursais da parte prejudicada, e uma sentença (em sentido amplo) mal motivada é nula enquanto não transitada em julgado. Depois disso, repise-se, todos os vícios são sanados. A falta de motivação ou a motivação irracional, porém, autorizam a rescisão da sentença (em sentido amplo) pelo prazo de dois anos após o trânsito em julgado, nos termos do art. 485, V e VIII, do CPC.

\footnotetext{
${ }^{668}$ Cf. SILVA, Ovídio A. Baptista da. Fundamentação das sentenças como garantia constitucional. p. 480482.
} 


\section{CAPÍTULO QUINTO - MOTIVAÇÃO DAS DECISÕES JUDICIAIS E SEGURANÇA JURÍDICA: A FORMAÇÃO DOS PRECEDENTES E A RATIO DECIDENDI}

Se a motivação das decisões judiciais é uma garantia inerente ao Estado de Direito, e se o Estado de Direito é indissociável da segurança jurídica, então, logicamente, motivação e segurança jurídica desenvolvem uma relação profunda e necessária. A segurança jurídica depende não só da estabilidade e da previsibilidade de normas jurídicas preestabelecidas, mas também, e talvez principalmente, da estabilidade e da previsibilidade da aplicação dessas normas jurídicas ao caso concreto. Neste Capítulo será explicado que o respeito a precedentes judiciais é fundamental para a promoção da segurança jurídica, e que apenas decisões motivadas são capazes de gerar precedentes judiciais (13); tratar-se-á da ratio decidendi, elemento jurídico da motivação que serve como precedente (14); e, enfim, serão traçadas algumas linhas gerais a respeito da experiência brasileira na utilização de precedentes (15).

\section{Motivação das decisões judiciais e segurança jurídica: o precedente judicial}

A necessidade de atribuir sistematicidade e previsibilidade ao Direito durante a primeira metade da Baixa Idade Média fez com que alguns tribunais europeus passassem a conservar e divulgar a própria jurisprudência, concentrando de alguma forma as diversas fontes normativas daquela época (v. ponto 5.3 acima). Por óbvio, apenas decisões motivadas permitiriam a conservação de um entendimento jurisprudencial, pois era a motivação que esclarecia como um determinado caso estava sendo julgado. A jurisprudência servia de referência para o julgamento de casos novos e a motivação das decisões judiciais, ao permitir a criação de precedentes, era indispensável para que isso ocorresse. $^{669}$

Foi justamente nesse momento histórico que começaram a ser delineadas as famílias jurídicas do civil law e do common law. Embora inicialmente o privilégio dado à

\footnotetext{
${ }^{669}$ Segundo DUXBURY, Neil. The Nature and Authority of Precedent. p. 25, "The first and crucial stage in the development of stare decisis was that judgements came to be supported by reasons".
} 
jurisprudência fosse característica também dos países da Europa continental, sobretudo na França com seus rotuli, na Espanha com suas fazañas, o resgate do Direito Romano pelos glosadores de Bolonha alterou radicalmente o percurso de desenvolvimento do Direito europeu. A supremacia das leis formais, somada a outros fatores já mencionados (v. ponto 5, acima), como o desenvolvimento do absolutismo, levou à desestruturação da utilização de precedentes judiciais como fundamento de novas decisões. Essas transformações não atingiram a Inglaterra, que, alheia aos acontecimentos continentais, ${ }^{670}$ deu continuidade à publicação de seus Year Books e à crescente prevalência da jurisprudência, a ponto de, no século XVII, Edward Coke colocar a "razão artificial”, a ser descoberta unicamente pelos juízes, acima até mesmo dos poderes do rei. ${ }^{671}$

É de se notar, portanto, que civil law e common law adotaram caminhos distintos para alcançar exatamente o mesmo objetivo: obter segurança jurídica. ${ }^{672}$ Como explicam Cross e Harris, "O juiz continental, sem dúvida, sempre quis, tanto quanto o juiz inglês, que o Direito fosse certo, mas ele sentia essa necessidade menos intensamente por causa do amparo concedido primeiro pelas regras do Direito Romano e dos costumes codificados e depois pelos códigos da Era Napoleônica”. Para que o Direito inglês não ficasse fluido e instável, precisava de uma base consistente, a qual foi encontrada na doutrina dos precedentes e sua característica de "rigidez e certeza". 673 Daí ser perfeitamente válida e pertinente a afirmação de Theodore Benditt no sentido de que "No

\footnotetext{
${ }^{670}$ V. DRUMMOND, Paulo Henrique Dias; CROCETTI, Priscila Soares. Formação histórica, aspectos do desenvolvimento e perspectivas de convergências das tradições de Common Law e de Civil Law. p. 13 e ss.

${ }^{671}$ A seguinte passagem de CROSS, Rupert; HARRIS, J. W. Precedent in English Law. p. 4 é muito clara: "Some branches of our law are almost entirely the product of the decisions of the judges whose reasoned judgements have been reported in various types of law report for close on 700 years".

${ }^{672}$ Sobre isso, v. DRUMMOND, Paulo Henrique Dias; CROCETTI, Priscila Soares. Formação histórica, aspectos do desenvolvimento e perspectivas de convergências das tradições de Common Law e de Civil Law. p. 37: "(...) enquanto no Common Law o desejo de certeza configura argumento em favor da adoção da regra dos precedentes vinculantes, no Civil Law a certeza representa argumento contrário a tal adoção".

${ }^{673}$ CROSS, Rupert; J. W. Harris. Precedent in English Law. p. 11-12. No original: "The continental judge has no doubt always wanted the law to be certain as much as the English judge, but he felt the need less keenly because of the background of rules provided first by Roman law and codified custom, and later by the codes of the Napoleonic era. Roman law was never 'received' in England, and we have never had a code in the sense of a written statement of the entirety of the law. 'English justice, if it were not to remain fluid and unstable, required a strong cement. This was found in the common-law doctrine of precedent with its essential and peculiar emphasis on rigidity and certainty".
} 
final, a exigência de que os juízes sigam precedentes não é mais do que a exigência de que eles sigam regras jurídicas estabelecidas (...)". ${ }^{674}$ Enquanto o civil law extraía tais 'normas' estabelecidas exclusivamente do direito legislado, o common law também buscava 'princípios de direito' contidos na motivação das decisões judiciais. ${ }^{675}$

A motivação das decisões judiciais desenvolveu-se em ambas as famílias jurídicas, portanto, com o mesmo propósito: garantir segurança jurídica. No civil law, a segurança jurídica viria pelo controle da atividade jurisdicional, permitindo verificar se o convencimento fático foi racional e se o direito positivo foi aplicado, seja pela indicação do texto da lei aplicável ao caso concreto, como pretendia o constituinte francês Thouret, seja pela indicação dos motivos da decisão, como entendia mais pertinente o constituinte Chabroux (v. ponto 5.6.2 acima). Se as decisões aplicassem o direito positivo, então haveria, automaticamente, segurança jurídica.

No entanto, até que ponto a motivação é capaz de controlar a atividade judicial, se o juiz é livre para decidir diferentemente casos análogos? Como controlar a imparcialidade do juízo, se toda e qualquer decisão é válida, mesmo que contrária à que foi produzida dias antes pelo próprio juízo? Se o juiz supostamente tem liberdade para interpretar o Direito como bem entende, afastando-se da interpretação dada por um tribunal que lhe é hierarquicamente superior, então qual é o controle que a motivação efetivamente exerce sobre a jurisdição?

Essas questões foram muito bem tratadas por Luiz Guilherme Marinoni, que concluiu que o controle da atividade judicial e a garantia da imparcialidade só podem ser concretizados quando houver homogeneidade nas decisões. ${ }^{676}$ Afinal, "Se o juiz pode

\footnotetext{
${ }^{674}$ BENDITT, Theodore M. The rule of precedent. p. 106. No original: "In the end, the demand that judges follow precedent is no more than the demand that they follow established legal rules, of which the rule of precedent is one".

${ }^{675}$ COUDERT, Fredric René. Certainty and Justice... p. 3: “(...) as a consequence, the common law doctrine of Stare Decisis was gradually evolved by the English law courts as one mode of bringing some sort of coherence in the justice administered by tribunals and in formulating the justice into rules of law". Como explica Pietro NUVOLONE, a segurança juridical pode ser alcançada tanto em ordenamentos jurídicos fundados sobre normas escritas como sobre costumes ou precedentes; o que importa é a validade objetiva da fonte do Direito e a sua previsibilidade (Discrezionalità del giudice e certezza del diritto. p. 586-587).

${ }^{676}$ MARINONI, Luiz Guilherme. Precedentes Obrigatórios. p. 174-176.
} 
atribuir significados distintos à mesma norma, o juiz parcial está livre para decidir como lhe convier, bastando justificar as suas opções arbitrárias". ${ }^{677}$

É diante dessa constatação que a motivação das decisões judiciais não pode ficar restrita à (importantíssima) função que tradicionalmente lhe é atribuída no civil law. A motivação também precisa promover a segurança jurídica, assim como faz no common law, tornando clara a aplicação do Direito pelo Poder Judiciário, e garantindo que essa aplicação será repetida em causas análogas. Somente assim pode-se falar em um sistema jurídico imparcial que aplique o Direito igualmente a todos aqueles que se apresentem como partes em um processo. ${ }^{678}$

Desse modo, há que se dar continuidade à notória aproximação entre o civil law e o common law, que decorre justamente da constatação de que ambos os sistemas podem melhorar com a assimilação de qualidades do outro. A paulatina superação da concepção tradicional de que leis claras são suficientes para garantir julgamentos isonômicos tem colocado em xeque a eficácia meramente persuasiva dos precedentes, atribuindo-lhes maior autoridade e compelindo os juízes inferiores a respeitar o entendimento jurídico consolidado pelos tribunais superiores. Mais do que isso, faz com que os tribunais tratem com mais seriedade os seus próprios julgados, garantindo estabilidade não só legislativa, mas também jurisprudencial.

13.1. A segurança jurídica como fundamento básico do respeito aos precedentes

Há várias razões para que os precedentes sejam seguidos e respeitados. Dentre elas Marinoni cita: o controle do poder do juiz; a promoção da igualdade jurídica dos cidadãos; o desestímulo à litigância; o favorecimento de acordos; a despersonalização da demanda; a racionalização do duplo grau de jurisdição; a contribuição à razoável duração do processo; economia de despesas; e maior eficiência do Poder Judiciário. ${ }^{679} \mathrm{O}$

\footnotetext{
${ }^{677}$ MARINONI, Luiz Guilherme. Precedentes Obrigatórios. p. 175.

${ }^{678}$ Exatamente no mesmo sentido, MACCORMICK, Neil. Rhetoric and the Rule of Law. p. 143: "Connected to this is the idea of an impartial legal system that does the same justice to everyone, regardless of who are the parties to a case and who is judging it".

${ }^{679}$ MARINONI, Luiz Guilherme. Precedentes Obrigatórios. p. 121-190.
} 
fundamento básico do respeito aos precedentes, porém, é a promoção da segurança jurídica, representada pela estabilidade e pela previsibilidade do Direito (v. 2.4, acima).

\subsubsection{A estabilidade do Direito}

Estabilidade é sinônimo de constância, continuidade, manutenção. Nesse sentido, a estabilidade jurídica possui duas implicações imediatas: a primeira é a estabilidade de situações jurídicas já consolidadas, cujos exemplos recorrentes e talvez mais importantes são: direito adquirido, ato jurídico perfeito e coisa julgada; ${ }^{680}$ a segunda, que é a que interessa aqui, é a estabilidade do Direito.

A necessária estabilidade do Direito é uma exigência antiga e fartamente tratada pela doutrina. Tem como fundamento a constatação de que apenas com um conjunto de regras gerais e permanentes é possível que os homens vivam em paz. ${ }^{681}$ Ao apresentar os oito erros mais comuns na criação e manutenção de um ordenamento jurídico, Lon Fuller não deixou escapar a "introdução de frequentes mudanças nas leis que impossibilitem o sujeito de orientar suas ações por elas". ${ }^{62}$ Isso porque "O direito, que extrai seu valor da continuidade, dela extrai também sua legitimidade". ${ }^{683}$

\footnotetext{
${ }^{680} \mathrm{O}$ art. $5^{\circ}$, XXXVI, da Constituição da República não deixa dúvidas: “a lei não prejudicará o direito adquirido, o ato jurídico perfeito e a coisa julgada". Embora o dispositivo restrinja-se à inviolabilidade 'legal', é evidente que tais situações jurídicas são também invioláveis por atos jurisdicionais e administrativos (cf. TALAMINI, Eduardo. Coisa Julgada e sua Revisão. p. 51). Além das três hipóteses acima referidas, há outras situações jurídicas que o ordenamento jurídico protege de modo a garantir a paz social. É o caso, por exemplo, da aquisição de propriedade pela usucapião, atribuindo-se efeitos jurídicos (aquisição originária da propriedade) a uma situação jurídica já consagrada (posse mansa e pacífica prolongada), do tratamento diferenciado conferido à 'posse nova' e à 'posse velha' pelo art. 924 do Código de Processo Civil, e da extinção de direitos e pretensões pelos institutos da decadência e prescrição. No processo civil, a preclusão é importantíssimo instrumento de estabilização das situações jurídicas processuais, tornando definitivos as fases e atos do procedimento, promovendo a progressividade da marcha processual e impedindo que situações já superadas sejam a todo o momento resgatadas e rediscutidas pelas partes ou mesmo pelo juiz. Para mais detalhes, v. ÁVILA, Humberto. Segurança Jurídica. p. 346 e ss.

${ }^{681}$ Cf. RIPERT, Georges. Les Forces Créatrices du Droit. p. 2.

${ }^{682}$ FULLER, Lon L. The Morality of Law. p. 39. No original: "(7) introducing such frequent changes in the rules that the subject cannot orient his actions by them".

${ }^{683}$ RIPERT, Georges. Les Forces Créatrices du Droit. p. 2.
} 
Sem nenhuma dúvida, não há maior causa de insegurança jurídica do que um Direito que se transforma a todo tempo, ${ }^{684}$ pois gera um medo constante nas pessoas de que a norma que pretendem seguir já tenha sido alterada. ${ }^{65}$ A estabilidade, explica Raimbault, "é desde logo um elemento fundamental para que as normas possam afirmar-se no ordenamento jurídico e ser interiorizadas na consciência dos cidadãos" ${ }^{686}$ Por outro lado, bem aponta Joseph Raz, a estabilidade do ordenamento jurídico não serve apenas para a adoção imediata de condutas; mais importante do que isso é a possibilidade de que o indivíduo possa projetar a sua vida em longo prazo, como ocorre com o planejamento tributário das empresas, p.ex. ${ }^{687}$

Evidentemente, as necessárias estabilidade e continuidade do Direito não se confundem com imutabilidade da ordem jurídica. Por ser um fenômeno social, o Direito é e sempre será mutável, adaptável à realidade concreta que regula; caso contrário, ele certamente não desempenhará o papel que lhe é destinado. Como dizia Georges Ripert,

${ }^{684}$ CANOTILHO, José Joaquim Gomes. Direito Constitucional e Teoria da Constituição. p. 259: “A mudança ou alteração frequente das leis (de normas jurídicas) pode perturbar a confiança das pessoas, sobretudo quando as mudanças implicam efeitos negativos na esfera jurídica dessas mesmas pessoas. O princípio do estado de direito, densificado pelos princípios da segurança e da confiança jurídica, implica, por um lado, na qualidade de elemento objectivo da ordem jurídica, a durabilidade e permanência da própria ordem jurídica, da paz jurídico-social e das situações jurídicas; por outro lado, como dimensão garantística jurídico-subjetiva dos cidadãos, legítima a confiança na permanência das respectivas situações jurídicas”.

${ }^{685}$ RAZ, Joseph. The Rule of Law and its virtue. p. 214.

${ }^{686}$ RAIMBAULT. Phillipe. Recherche sur la Sécurité Juridique en Droit Administratif Français. p. 42. No original: "La stabilité est dès lors un élément fondamental pour que les normes puissent s'affirmer dans l'ordre juridique et être intériorisées dans la conscience des citoyens". Igualmente, RIPERT, Georges. Les Forces Créatrices du Droit. p. 1-4. Defendia o professor francês: "La longue durée des lois en assure l'observation machinale parce que l'habitude crée la soumission volontaire. La règle de droit devient avec le temps règle de vie" (p. 2). Em sentido idêntico, embora tratando de estabilidade constitucional, Joseph RAZ: "Constitutions are meant to provide a framework for the public life of a country, giving it direction and shape. For this to be achieved, widespread knowledge of the constitution has to be secured. This requires knowledge of the text but of its significance - that is, knowledge of the constitutional practices in the country. Until people absorb and adjust it, a radical constitutional change upsets these practices. It has ramifications regarding different aspects of public life, and there is bound to be a temporary uncertainty regarding the way the reform or change will affect various aspects of constitutional practice. The uncertainty affects people's ability to function. It is made worse if it generates fear of continuous change, leading to a sense of dislocation and loss of orientation" (Between authority and Interpretation. p. 350-351).

${ }^{687}$ RAZ, Joseph. The Rule of Law and its virtue. p. 214-215. 
adaptar as normas antigas a situações novas é uma feliz forma de conservação. ${ }^{68}$ Por isso, a exigência da continuidade do Direito, considerando-se todas as suas fontes, está voltada justamente ao seu progresso, que deve ser sereno e ponderado, sempre compatível com as transformações ocorridas no meio em que ele está inserido. ${ }^{689}$ Veda-se não a alteração do Direito, mas sua alteração abrupta e excessivamente constante. ${ }^{690}$

Tudo o que foi dito aplica-se igualmente à jurisprudência, considerada aqui uma "fonte hermenêutica" do Direito. De nada adianta exigir estabilidade legislativa se a todo instante as leis recebem uma nova interpretação jurisprudencial. Exigir estabilidade do Direito também implica exigir estabilidade na interpretação e aplicação desse Direito. ${ }^{691}$ A jurisprudência não pode mudar por mudar; ${ }^{692}$ ela deve evoluir; e deve evoluir de forma contínua, serena e ponderada. A constante alteração da jurisprudência é ainda mais danosa do que a mudança contínua da legislação, pois a mudança jurisprudencial age, como regra, retroativamente, produzindo efeitos em relação a fatos pretéritos e surpreendendo negativamente os cidadãos (v. 18 e ss., abaixo).

O respeito aos precedentes proporciona estabilidade na interpretação do Direito ao tornar a jurisprudência sólida e concreta, diante da qual o indivíduo passa a ter

\footnotetext{
${ }^{688}$ RIPERT, Georges. Les Forces Créatrices du Droit. p. 5.

${ }^{689}$ Lições expostas por Aristóteles há mais de dois mil anos: "Ainda quando as leis houverem sido escritas, elas não devem permanecer inalteradas. (...) Desse modo nós inferimos que em certas ocasiões e em certos casos as leis devem ser alteradas; mas quando nós olhamos para a questão sob outro ponto de vista, grande cautela é exigida. Por ser danoso o hábito de mudar ligeiramente as leis, alguns erros do legislador devem ser tolerados quando a mudança trouxer poucas vantagens; o cidadão ganhará menos com a alteração do que perderá com o hábito da desobediência”. Politics. p. 37.

${ }^{690}$ Escreveu com muita propriedade RIPERT, Georges. Les Forces Créatrices du Droit. p. 4: "Quand je dis que la notion de droit est une notion statique, je n'entends pas par là que les règles n'aient pas changé et ne changeront pas, mais je veux affirmer qu'il est dans leur nature de durer e non de changer".

${ }^{691}$ Exatamente nesse sentido, NUVOLONE, Pietro. Discrezionalità del giudice e certezza del diritto. p. 589590.

${ }^{692}$ Perfeita é a crítica de MARINONI, Luiz Guilherme. Precedentes Obrigatórios. p. 131: "Não há como ter estabilidade quando os juízes e tribunais ordinários não se veem como peças de um sistema, mas se enxergam como entes dotados de autonomia para decidir o que bem quiserem. A estabilidade das decisões, portanto, pressupõe uma visão e uma compreensão da globalidade do sistema de produção de decisões, o que, lamentavelmente, não ocorre no Brasil, onde ainda se pensa que o juiz tem poder para realizar a sua 'justiça' e não para colaborar com o exercício do dever estatal de prestar a adequada tutela jurisdicional, para o que é imprescindível a estabilidade das decisões".
} 
condições de saber como deve compreender os dispositivos legais e pode moldar a sua vida confiando que o entendimento jurídico em que pautou suas condutas não será abruptamente mudado ou ignorado. Respeitar precedentes implica respeitar o passado, respeitar aquilo que já foi feito pelos tribunais, atribuindo indiscutível estabilidade à ordem jurídica.

\subsubsection{A previsibilidade do Direito: sistematicidade e coerência}

O segundo corolário básico da segurança jurídica é a previsibilidade, entendida como a possibilidade de que cada pessoa preveja as consequências jurídicas dos atos por ela praticados, preveja os atos que serão praticados pelo Estado e conheça seus direitos, poderes, faculdades, deveres e obrigações. A previsibilidade volta suas atenções prospectivamente, de modo que o indivíduo saiba como agir no presente para que atinja o resultado almejado no futuro. Para isso, o Direito deve ser sistemático, homogêneo e acessível.

Em sua clássica obra, Claus-Wilhelm Canaris extrai duas características básicas de todo sistema: ordenação e unidade ${ }^{693}$; ideias que "radicam (...) na própria ideia de Direito". ${ }^{694}$ Segundo Canaris, "O papel do conceito de sistema é (...) o de traduzir e realizar a adequação valorativa e a unidade interior da ordem jurídica" ${ }^{695}$ Em um segundo momento, deve-se apurar quais são os princípios gerais da ordem jurídica, ou sua "ratio iuris determinante". ${ }^{696}$ Seguindo a mesma linha, amparado na doutrina francesa atual, Philippe Raimbault defende que a sistematização do Direito está relacionada a três características: a) reunião de um conjunto de elementos; b) existência de relações específicas entre estes elementos e não uma simples justaposição; c) unidade interna, estrutura, coesão entre os elementos, exigindo-se compatibilidade, não-contradição e

\footnotetext{
${ }^{693}$ CANARIS, Claus-Wilhelm. Pensamento Sistemático e Conceito de Sistema na Ciência do Direito. p. 12 e ss.

${ }^{694}$ Ibidem. p. 18.

${ }^{695}$ Ibidem. p. 23.

${ }^{696}$ Ibidem. p. 77.
} 
completude. ${ }^{697}$ Esses elementos, explica Tercio Sampaio Ferraz Jr., são tanto normativos como 'não-normativos', consistentes em 'regras que determinam as relações entre os elementos". 698

A sistematicidade do Direito liga-se, portanto, à sua racionalização, buscando unidade, coerência e completude entre o conjunto de normas que formam um ordenamento jurídico. ${ }^{699}$ Trata-se de requisito indispensável à previsibilidade do Direito e, consequentemente, à segurança jurídica. ${ }^{700}$ Ao estabelecer uma hierarquia entre as normas, definir quais são as fontes do Direito, estabelecer critérios para a solução de eventuais antinomias e permitir o preenchimento de lacunas inevitavelmente existentes, dentre outros, a sistematização do Direito aumenta "o grau de certeza das normas"701 e permite ao indivíduo entender com clareza quais são os efeitos da prática de determinado ato.

As decisões judiciais possuem, sabe-se há muito tempo, um papel fundamental na integração dos elementos que compõem o sistema jurídico. Muitas das lacunas e antinomias normativas são supridas pelos juízes mediante a interpretação sistemática dos dispositivos legais, extração de normas implícitas das normas explícitas e raciocínio por analogia. Toda essa atividade, vale sempre lembrar, é desenvolvida na motivação. Consequentemente, ao servir de precedente, a sistematização do ordenamento promovida para o caso concreto, por ser dotada de universalidade (v. 13.2.3, abaixo), aplica-se a todos os casos análogos, suprindo a falha do legislador e garantindo a previsibilidade do Direito.

Cite-se um exemplo. A lei 11.232/2005 incluiu no CPC o art. 475-J, pelo qual o devedor que não cumpre a sentença condenatória em até 15 dias deve pagar uma multa equivalente a $10 \%$ do valor da condenação. Como o dispositivo não estabeleceu o

\footnotetext{
${ }^{697}$ RAIMBAULT, Philippe. Recherche sur la Sécurité Juridique en Droit Administratif Français. p. 167168.

${ }^{698}$ FERRAZ JR., Tercio Sampaio. Introdução ao Estudo do Direito. p. 145.

${ }^{699}$ Sobre as características citadas, v. BOBBIO, Norberto. Teoria do Ordenamento Jurídico. p. 37-170. Lon FULLER considera a contradição entre as leis um dos oito grandes erros na produção legislativa (The Morality of Law. p. 65-70).

${ }^{700}$ Cf. RAIMBAULT, Philippe. Recherche sur la Sécurité Juridique en Droit Administratif Français. p. 168 e ss.

${ }^{701}$ Ibidem. p. 168.
} 
momento em que o prazo de 15 dias começa a ser contado, houve grande controvérsia doutrinária e jurisprudencial: ora o prazo era contado da publicação da sentença; ora o prazo era contado da intimação específica do devedor para pagamento. Depois de pender para a primeira alternativa, o STJ encerrou a controvérsia em 2009, quando assentou que o prazo de 15 dias só seria contado depois que o devedor fosse intimado para pagar. ${ }^{702}$ Independentemente de juízos de valor sobre a decisão e suas razões, fato é que, a partir de uma determinada interpretação sistemática, o STJ sanou uma grave lacuna existente no ordenamento jurídico brasileiro que vinha causando insegurança jurídica. Tendo sido amplamente acolhida como precedente, a decisão foi capaz de encerrar a controvérsia até então existente, promovendo a sistematicidade do Direito. Atualmente o credor sabe a partir de quando pode exigir o pagamento do devedor, e o devedor sabe quando é que deverá cumprir a sentença para que não pague a multa legal. Ambos têm condições de prever as consequências jurídicas de suas ações e omissões.

\subsubsection{Segue: homogeneidade}

A universalidade das normas jurídicas sempre foi considerada um atributo essencial do Direito, pois proporcionaria igualdade entre as pessoas. $O$ art. $5^{\circ}$ da Constituição da República não deixa dúvidas: "Todos são iguais perante a lei, sem distinção de qualquer natureza”.

A igualdade perante a lei é uma exigência de justiça, mas também é pressuposto de segurança jurídica, ${ }^{703}$ sobretudo no que diz respeito à igualdade na aplicação dessa lei. O particular só tem condições de prever as consequências jurídicas de seus atos quando tem a garantia de que o seu comportamento produzirá os mesmos efeitos que o comportamento de qualquer outra pessoa. Não é por acaso, portanto, que a igualdade

\footnotetext{
${ }^{702}$ STJ, AgRg no AgRg no Ag 1056473/RS.

${ }^{703}$ É o que demonstra a seguinte passagem de autoria de Giovanni CONSO: "Sono i cittadini, l'uomo della strada, l'opinione publica a chiedere il maggior grado possibile di certezza: essi vi ravvisano, inconsciamente o consciamente non importa, uno dei fattori essenziali per il ragiungimento di quell' 'eguaglianza di tutti' dinnanzi alla legge che rappresenta l'essenza stessa di una giustizia veramente democratica" (La certezza del diritto: ieri, oggi, domani. p. 547). Também atribuindo à igualdade "na lei e perante a lei” natureza 'assecuratória', BARROSO, Luís Roberto. Em algum lugar do passado: segurança jurídica, direito intertemporal e o novo Código Civil. p. 140
} 
na aplicação do Direito é um "princípio básico" do sistema jurídico inglês, geralmente sintetizado em frases como 'treating like cases alike' (tratar igualmente casos iguais) ou 'like cases should be decided alike' (casos iguais devem ser decididos igualmente). ${ }^{704} \mathrm{O}$ respeito à regra do stare decisis (siga aquilo que foi previamente decidido) decorre dos "benefícios que ela traz", destacando-se a consistência e a eficiência nos julgamentos e, é claro, a promoção da segurança jurídica. ${ }^{705}$

Com efeito, a igualdade da aplicação do Direito pressupõe homogeneidade e consistência na interpretação das normas jurídicas. ${ }^{706}$ Isso conduz de maneira natural à previsibilidade das decisões judiciais e, como consequência, à previsibilidade do Direito. Se cada juiz sentir-se livre para interpretar as normas jurídicas da maneira como bem entende, será impossível ao indivíduo prever qual é a norma jurídica e, principalmente, qual é o sentido da norma jurídica aplicável ao caso concreto. Não que se possa dizer que apenas um desses magistrados esteja interpretando 'corretamente' o Direito; assim como também não se pode dizer que todas as interpretações sejam válidas. Mas é importante que haja uma linha diretiva, ainda que, muitas vezes, essa não seja reputada a mais adequada pela doutrina. Nessa linha de pensamento, a função nomofilática desempenhada pelos Tribunais Superiores, como o Supremo Tribunal Federal e o Superior Tribunal de Justiça, é fundamental para dar simetria ao direito positivo. ${ }^{707}$

\subsubsection{Segue: acessibilidade}

É relativamente universal o adágio de origem romana de que a ninguém é dado desconhecer a lei (nemo censetur legem ignorare ou ignorantia juris non excusat). No Brasil, o art. $3^{\circ}$ da Lei de Introdução ao Código Civil - LICC (agora chamada de Lei de

\footnotetext{
${ }^{704}$ CROSS, Rupert; J. W. Harris. Precedent in English Law. p. 3.

${ }^{705}$ Cf. DUXBURY, Neil. The Nature and Authority of Precedent. p. 35-36.

${ }^{706}$ WAMBAUGH, Eugene. The Study of Cases. p. 97: "Perhaps this enumeration of reasons is unnecessary, for certainly every one perceives without argument that uniformity is essential to law".

707 Sobre a função nomofilática dos Tribunais Superiores, v. o completo estudo de COSTA, Guilherme Recena da. Superior Tribunal de Justiça e o Recurso Especial... p. 98 e ss.
} 
Introdução às Normas do Direito Brasileiro) dispõe que ninguém se escusa de cumprir a lei, alegando que não a conhece. ${ }^{708}$

Não há dúvidas de que a regra gera um dever faticamente impossível de ser atendido, especialmente no Brasil. Nem mesmo de juristas há como se exigir o conhecimento pleno do ordenamento jurídico, tendo em vista a existência de uma imensa quantidade de atos normativos das mais diversas naturezas, constantemente modificados e revogados. Muito mais do que uma regra de conduta, o art. $3^{\circ}$ da LICC e seus correlatos criam uma ficção jurídica que visa a proteger a integridade do ordenamento jurídico, garantindo o seu efetivo respeito. Trata-se, em última análise, de instrumento de proteção da segurança jurídica, na medida em que, em sua ausência, qualquer pessoa que violasse alguma norma jurídica poderia alegar seu desconhecimento, eximindo-se de toda responsabilidade. ${ }^{709}$

Mas se o indivíduo deve conhecer as normas jurídicas que regem sua vida e suas relações sociais, então é preciso que, como contrapartida, tais normas sejam acessiveis, tanto do ponto de vista material como do ponto de vista intelectual, facultandose-lhe o efetivo conhecimento de seu conteúdo e previsibilidade de suas consequências. Como escreveu Jacques Chevallier, "A segurança jurídica implica antes de tudo que o direito existente possa ser conhecido e compreendido". 710

Do ponto de vista material, a acessibilidade corresponde à possibilidade de que cada indivíduo acesse o corpus jurídico, exigindo-se publicidade das normas jurídicas e facilidade em seu acesso. ${ }^{711}$ Quanto a isso, o Tribunal de Justiça da União Europeia fez constar em uma de suas decisões, há mais de trinta anos, que "um princípio fundamental da

\footnotetext{
${ }^{708}$ É idêntico o teor do art. 21 do Código Penal: "O desconhecimento da lei é inescusável”.

709 “L'adage selon lequel nul n'est censé ignorer la loi est par conséquent le prolongement naturel des règles de diffusion $d u$ droit. Cette fiction est elle-même un gage de sécurité juridique objective". PIAZZON, Thomas. La Sécurité Juridique. p. 80.

${ }^{710}$ CHEVALLIER, Jacques. L'État de Droit. p. 97.

${ }^{711}$ PIAZZON, Thomas. La Sécurité Juridique. p. 18.
} 
ordem jurídica comunitária exige que um ato emanado dos poderes públicos não seja oponível aos jurisdicionados antes que se lhes faculte a possibilidade de conhecê-lo". 712

Do ponto de vista intelectual, exigem-se clareza e precisão dos atos normativos, isto é, o sujeito deve ter condições de extrair e compreender o significado da norma, os direitos que lhe são atribuídos, as obrigações e deveres que lhe são impostos, além das consequências em caso de descumprimento de tais deveres e obrigações. ${ }^{713}$

A inteligibilidade das normas jurídicas é tão importante que a Corte Europeia dos Direitos do Homem, em 1979, decidiu: "não se pode considerar uma 'lei' senão a norma enunciada com suficiente precisão para permitir ao cidadão que regule sua conduta". ${ }^{714} \mathrm{Na}$ França é comum que o Conselho Constitucional declare a inconstitucionalidade de leis que violem os "valores constitucionais de inteligibilidade e de acessibilidade". ${ }^{715}$ A Corte de Arbitragem da Bélgica, em decisão de 1993, embora tenha rejeitado a inconstitucionalidade da lei que estava em discussão, assinalou: "De acordo com o princípio fundamental da segurança jurídica, o legislador não pode ameaçar, sem justificativa objetiva e razoável, o interesse que possuem os sujeitos de direito de encontrar-se em condições de prever as consequências jurídicas de seus atos". ${ }^{716}$ A rigidez

712 C.J.C.E., caso 98/78 de 25 de janeiro de 1979, citado por VALEMBOIS, Anne-Laure. La Constitutionnalisation... p. 191

713 "An ambiguous, vague, obscure or imprecise law is likely to mislead or confuse at least some of those who desire to be guided by it". RAZ, Joseph. The Rule of Law and its virtue. p. 214. Igualmente, RAWLS, John. A Theory of Justice. p. 238. "For if, say, statutes are not clear in what they enjoin and forbid, the citizen does not know how he is to behave".

714 CEDH, 26 de abril de 1979, citada por RAIMBAULT, Philippe. Recherche sur la Sécurité Juridique en Droit Administratif Français. p. 146.

${ }^{715}$ Cite-se, a título de exemplo, a decisão no. 2005-512, de 21 de abril de 2005: “Considérant qu'il incombe au législateur d'exercer pleinement la compétence que lui confie la Constitution et, en particulier, son article 34 ; qu'à cet égard, le principe de clarté de la loi, qui découle du même article de la Constitution, et l'objectif de valeur constitutionnelle d'intelligibilité et d'accessibilité de la loi, qui découle des articles 4, 5, 6 et 16 de la Déclaration de 1789, lui imposent d'adopter des dispositions suffisamment précises et des formules non équivoques afin de prémunir les sujets de droit contre une interprétation contraire à la Constitution ou contre le risque d'arbitraire, sans reporter sur des autorités administratives ou juridictionnelles le soin de fixer des règles dont la détermination n'a été confiée par la Constitution qu'à la loi" (Decisão no . 2005-512, de 21 de abril de 2005). V. também a decisão 2005-530, que fala em "complexidade excessiva da lei".

${ }^{716}$ Cour d'Arbitrage belga, Arrêt 10/93, de 11 de fevereiro de 1993, numéro du rôle 364. No original: "Selon le principe fondamental de la sécurité juridique, le législateur ne peut porter atteinte sans justification 
com atos normativos obscuros e imprecisos é recorrente nos demais Tribunais Constitucionais europeus. ${ }^{717}$ No Brasil, o já mencionado art. 11 da Lei Complementar 95/1998 (em cumprimento ao art. 59, parágrafo único, da Constituição) dispõe expressamente que "As disposições normativas serão redigidas com clareza, precisão e ordem lógica”. Para isso, estabelece várias regras de elaboração normativa. ${ }^{718}$

Ou seja, o indivíduo deve ser capaz de efetivamente compreender quais são as normas jurídicas que regem a sua vida. Entretanto, como vem sendo repetitivamente afirmado, isso só é possível se houver uma jurisprudência coerente, homogênea e estável. Conhecer o Direito pressupõe conhecer como o Direito é aplicado pelos tribunais; e só é possível conhecer como o Direito é aplicado pelos tribunais se as suas decisões forem respeitadas, seja pelos juízos inferiores, seja, principalmente, pelos seus próprios membros. Em suma, a jurisprudência deve ter a mesma "acessibilidade intelectual" da legislação. ${ }^{719}$

13.2. O conceito de precedente judicial

Todo precedente judicial é uma decisão judicial. A partir dessa premissa, o conceito de precedente pode ser amplo, restrito ou intermediário.

Adotando-se um conceito amplo, precedentes são decisões pretéritas que decidiram casos análogos ao que está sendo julgado ou discutido. Toda decisão judicial é um precedente judicial, desde que possa ser utilizada como parâmetro ao julgamento de um caso concreto análogo. ${ }^{720}$

objective et raisonnable à l'intérêt que possèdent les sujets de droit à se trouver en mesure de prévoir les conséquences juridiques de leurs actes".

717 V., com análise ampla dos diversos Tribunais europeus, VALEMBOIS, Anne-Laure. La Constitutionnalisation... p. 191-197 ; v. também CHEVALLIER, Jacques. L'État de Droit. p. 97 e VALIM, Rafael. O Princípio da Segurança Jurídica no Direito Administrativo Brasileiro. p. 104.

${ }^{718}$ V. Capítulo Quarto, 11.1, acima.

${ }^{719}$ Nesse sentido, v. PIAZZON, Thomas. Sécurité Juridique. p. 410.

${ }^{720}$ Cf. TUCCI, José Rogério Cruz e. Precedente Judicial como Fonte do Direito. p. 11: “Assim, o núcleo de cada um destes pronunciamentos [decisórios] constitui, em princípio, um precedente judicial"; igualmente, SANTOS, Evaristo Aragão. Em torno do conceito e da formação do precedente judicial. p. 143: "Toda decisão que tenha esse potencial pode ser considerada, de maneira ampla, como um precedente judicial". 
Para a concepção restrita, nem toda decisão judicial é um precedente. A decisão só seria precedente quando tivesse a "potencialidade de se firmar como paradigma para a orientação dos jurisdicionados e dos magistrados". ${ }^{721}$ A concepção restrita, portanto, limita os precedentes a decisões judiciais proferidas em casos paradigmas. Mas isso ainda não seria suficiente. Além de ser a primeira decisão a interpretar a norma, a decisão deveria, na motivação, tratar de todas as questões essenciais envolvendo a tese de direito que fundamenta o julgamento do caso. De acordo com Marinoni, "o precedente é a primeira decisão que elabora a tese jurídica ou é a decisão que definitivamente a delineia, deixando-a cristalina". ${ }^{722}$

A terceira concepção, a que se denomina aqui de intermediária, considera precedente judicial toda decisão que contenha uma tese jurídica passível de ser seguida em casos posteriores. A diferença em relação à concepção ampla é que o caso precisa conter questões jurídicas relevantes, de modo que a controvérsia não seja unicamente fática. ${ }^{723}$ Sendo assim, o caso concreto em que apenas se discute se um devedor já efetuou ou não o pagamento de uma obrigação não teria condições de se transformar em precedente, uma vez que não há uma proposição jurídica relevante que sirva de parâmetro para casos posteriores.

Especificamente no que se refere à concepção restrita, algumas ponderações mostram-se necessárias. Em primeiro lugar, o termo "precedente" tem o significado de algo que precede, que vem antes. Sob um ponto de vista semântico, precedente judicial não é mais do que uma decisão judicial que precede outra. Em segundo lugar, e na mesma linha de raciocínio do argumento anterior, não há nada que legitime restringir a noção de precedente a decisões que tenham julgado "originalmente" um caso concreto. Em terceiro lugar, e esse ponto é fundamental, precedentes estão intimamente ligados à formação de uma jurisprudência. Não raro, casos concretos idênticos são decididos de maneira distinta por um mesmo tribunal até que um dos posicionamentos enfim prevaleça. Essa prevalência pode dar-se pelo julgamento de um caso paradigma que homogeneíze o entendimento do tribunal, ou um determinado entendimento pode ser paulatinamente abandonado pelo

\footnotetext{
${ }^{721}$ MARINONI, Luiz Guilherme. Precedentes Obrigatórios. p. 215.

${ }^{722}$ Ibidem. p. 216; v também TARUFFO, Michele. Precedente e Giurisprudenza. p. 25.

${ }^{723}$ CROSS, Rupert; HARRIS, J. W. Precedent in English Law. p. 40.
} 
tribunal. De uma forma ou de outra, só se pode afirmar que há jurisprudência formada depois que várias decisões são proferidas no mesmo sentido; ou seja, a jurisprudência é composta por uma pluralidade de precedentes convergentes. ${ }^{724} \mathrm{Se}$ apenas casos paradigmas pudessem formar precedentes, então não haveria como explicar a formação de uma jurisprudência. Por fim, é indiscutível que, ao menos na realidade brasileira, quanto mais recente for uma decisão, mais forte é sua força persuasiva, pois demonstra a atualidade do entendimento. ${ }^{725}$ Pela concepção restrita, essas decisões recentes não seriam precedentes, embora indiscutivelmente utilizadas como tal, seja pelas partes, seja pelo órgão julgador. Sendo assim, adianta-se desde logo, os limites impostos pela concepção restrita dos precedentes judiciais não se justificam.

\subsubsection{Precedentes são razões}

Precedentes são, como dito, decisões judiciais; mas isso é relativamente correto. Precedentes são decisões judiciais desde que consideradas de forma lata. Sob uma análise mais precisa, precedentes são motivações de decisões pretéritas, ${ }^{726}$ o que leva a duas conclusões: precedentes são razões dadas para decidir (ratio decidendi) e precedentes são razões para que seja tomada uma decisão.

Precedentes são razões dadas para decidir porque são as razões jurídicas de uma decisão judicial que se tornam referência para a tomada de novas decisões. $O$ dispositivo da decisão é absolutamente irrelevante nesse particular e o relatório, quando

\footnotetext{
${ }^{724}$ Para uma distinção entre precedente e jurisprudência a partir de um critério quantitativo, v. TARUFFO, Michele. Precedente e Giurisprudenza. p. 12; e SANTOS, Evaristo Aragão. Em torno do conceito e da formação do precedente judicial. p. 143. Taruffo também distingue os institutos por questões qualitativas, mas, nesse aspecto, acaba confundindo jurisprudência com entendimentos jurisprudenciais "sumulados" (Precedente e Giurisprudenza. p. 13-17).

${ }^{725}$ E é o que ocorre também na Inglaterra: CROSS, Rupert; HARRIS, J. W. Precedent in English Law. p. 162.

${ }^{726}$ Nesse sentido, MACCORMICK, Neil. Rhetoric and the Rule of Law. p. 144: "It is in the statement of opinions upon cases by way of justifications of decisions that judges lay down precedents and build up case law (or, perhaps, provide the materials out of which scholars and practitioners can build up an articulate body of case law)".
} 
relevante, apenas serve para que se confira a similitude entre o caso julgado no passado e o novo caso concreto que se apresenta para julgamento. ${ }^{727}$

Cite-se um exemplo. Discutia-se na década de 90 se os contratos de abertura de crédito bancário (conhecidos como “cheque especial”) poderiam ser executados, uma vez que a liquidez das obrigações deles decorrentes dependia da apresentação de extratos produzidos unilateralmente pelos bancos. A discussão foi encerrada em 1998 com o julgamento, pelo STJ, dos Embargos de Divergência no REsp nº 108.259/RS, o qual recebeu a seguinte ementa:

PROCESSUAL CIVIL. EXECUÇÃO. CONTRATO DE ABERTURA DE CRÉDITO. INEXISTÊNCIA DE TÍTULO EXECUTIVO. INTELIGÊNCIA DOS ARTS. 585, II, E 586 DO CPC.

Mesmo subscrito por quem é indicado em débito e assinado por duas testemunhas, o contrato de abertura de crédito não é título executivo, ainda que a execução seja instruída com extrato e que os lançamentos fiquem devidamente esclarecidos, com explicitação dos cálculos, dos índices e dos critérios adotados para a definição do débito, pois esses são documentos unilaterais de cuja formação não participou o eventual devedor.

Embargos de divergência, por unanimidade, conhecidos, mas, por maioria, rejeitados.

(EREsp 108259/RS, Rel. Ministro SÁLVIO DE FIGUEIREDO TEIXEIRA, Rel. p/ Acórdão Ministro CESAR ASFOR ROCHA, SEGUNDA SEÇÃO, julgado em 09/12/1998, DJ 20/09/1999, p. 35)

A ementa permite extrair duas partes muito bem definidas do acórdão. Há um dispositivo, consistente na rejeição, por maioria, dos embargos de divergência opostos pelo banco; e há uma razão jurídica para que o dispositivo seja esse e não outro: o contrato de abertura de crédito não é título executivo porque a liquidez de sua obrigação depende de extratos de cuja formação não participa o eventual devedor.

\footnotetext{
${ }^{727}$ Cf. MARINONI, Luiz Guilherme. Precedentes Obrigatórios. p. 259: "O verdadeiro valor do precedenteseja qual for ele - não está na parte dispositiva da decisão, mas na essência das razões apresentadas para justificá-la" (itálico no original).
} 
Agora imagine-se que, uma semana depois de publicado o acórdão, um juiz de primeiro grau deparou-se com uma exceção de pré-executividade apresentada em uma execução de contrato de abertura de crédito bancário cuja obrigação não foi paga pelo executado. Assim como no caso julgado pelo STJ, a liquidez da obrigação do devedor dependia da apresentação, pelo banco, de extratos bancários com todo o histórico de utilização de crédito e inadimplemento. Sem titubear, o juiz utilizou o julgamento do STJ como precedente e acolheu a exceção de pré-executividade. A questão é: qual parte da decisão foi utilizada como precedente? O dispositivo que rejeitou os embargos de divergência, o relatório de tudo o que aconteceu no processo ou a asserção jurídica de que o contrato de abertura de crédito não é título executivo porque a liquidez de sua obrigação depende de extratos de cuja formação não participa o eventual devedor?

Ora, é mais do que evidente que o juiz de primeiro grau, quando cita o acórdão do STJ para fundamentar a sua decisão, "empresta" a razão pela qual o tribunal decidiu. O acórdão do STJ é um precedente não enquanto decisão que rejeita os embargos de divergência; ele é um precedente enquanto razão para a rejeição dos embargos.

Note-se que o dispositivo do acórdão é irrelevante para que a decisão sirva como precedente para casos futuros. Ninguém alegará que o STJ rejeitou os embargos de divergência do banco e, por isso, o juiz de primeiro grau deve, p.ex., acolher a exceção de pré-executividade do executado. Também é irrelevante quais foram as provas produzidas pelas partes, em que sentido decidiram os juízos de instância inferior e tudo mais o que aconteceu no processo. Aquilo que realmente importa do acórdão para novos casos que apresentem discussões análogas é a razão pela qual os embargos de divergência foram rejeitados pelo STJ. Daí ser válida a afirmação de que o precedente judicial é uma razão de decidir.

Além disso, quando o juiz acolhe a exceção de pré-executividade com fundamento em um precedente, esse precedente acaba sendo uma razão para que a decisão seja tomada. O juiz que acolheu a exceção de pré-executividade poderia tê-lo feito mesmo sem concordar com as alegações do executado, mas porque esse é o entendimento de um tribunal superior. Ou ainda que concordasse com o executado, a existência de um 
precedente passou a ser uma razão a mais para que a decisão tomada fosse aquela. Por isso os precedentes são, igualmente, razões para que seja tomada uma decisão. ${ }^{728}$

\subsubsection{Precedentes não são razões fáticas}

O precedente judicial é uma razão de decidir, mas não são todas as razões de uma decisão que compõem um precedente.

Transforme-se a decisão dos Embargos de Divergência no REsp $n^{\circ}$. 108.259/RS em um silogismo judicial (justificação interna): (a) se o contrato de abertura de crédito, na medida em que a liquidez da obrigação nele contida depende de documentos de cuja formação não participa o eventual devedor, não é título executivo, e se (b) o banco está executando um contrato de abertura de crédito acompanhado de extratos produzidos sem a participação do devedor, então (c) o contrato de abertura de crédito executado pelo banco não é um título executivo.

Há claramente uma razão jurídica (a), que é a premissa maior do silogismo; uma razão fática (b), que é a premissa menor do silogismo; e uma conclusão da subsunção dos fatos à norma (c) que justifica o dispositivo do acórdão. A partir dessa conclusão deve ser formado um silogismo processual para a obtenção da decisão final: a rejeição dos embargos de divergência.

Afirma-se que o precedente é uma razão, mas no silogismo formado há duas razões. Há uma razão jurídica e há uma razão fática para a conclusão do silogismo material. Retomando a posição do juiz que pretende utilizar o acórdão do STJ como precedente, o acolhimento da exceção de pré-executividade do devedor terá como fundamento que: (a) todo contrato de abertura de crédito cuja obrigação só possa ser liquidada a partir da produção unilateral de documentos pelo credor não é um título executivo; e que (b) o banco executou um contrato de abertura de crédito acompanhado de

\footnotetext{
${ }^{728}$ DUXBURY, Neil. The Nature and Authority of Precedent. p. 51-52: “(...) although, by the seventeenth century, precedents were not legal authorities, they were nevertheless important because lawyers and judges would often consider them to exemplify proper legal reasoning". (...) "Precedents, then, became the dominant form of authority used in legal argument because they came to be seen as offering reasons for particular rules and doctrines" (p. 51-52). V. também TARUFFO, Michele. Precedente e Giurisprudenza. p. 9.
} 
documentos por ele produzidos unilateralmente. Deixando de lado a hipótese "a", cuja preferência já foi manifestada acima, seria possível ao juiz acolher a exceção de préexecutividade porque, "como já decidiu o STJ, (b) o banco X, no caso tal, executou um contrato de abertura de crédito acompanhado de documentos por ele produzidos unilateralmente"?

É evidente que não. E a explicação é simples: falta-lhe universalidade (ou generalidade). ${ }^{729}$ As razões fáticas de uma decisão são elementos particulares de cada caso concreto. Não é possível utilizá-las como precedentes porque não é possível transpô-los a novos casos que surgem. ${ }^{730}$ Apenas razões universais ou universalizáveis têm aptidão para fundamentar novas decisões; e as razões fáticas não são, em nenhuma hipótese, universais ou universalizáveis.

\subsubsection{Precedentes são razões jurídicas de uma decisão: o atributo da universalidade}

Tradicionalmente, precedentes são conceituados pela doutrina do common law como "princípios de direito" utilizados pelo juiz para fundamentar a decisão. ${ }^{731}$ Muito embora essa concepção seja bem recepcionada no civil law, ${ }^{732}$ parece mais adequado à nossa realidade traduzir a expressão "princípios de direito" para "razões jurídicas" que fundamentam a decisão. ${ }^{733}$

\footnotetext{
${ }^{729}$ De maneira irreparável, Neil MACCORMICK distingue a universalidade da generalidade. Enquanto a universalidade é antônimo de particularidade, tratando-se de "propriedades lógicas" a generalidade é antônimo de especificidade, ambas propriedades quantitativas. Normas jurídicas e precedentes são normas universais, mais ou menos gerais (p.ex., princípio x regras), que justificam decisões particulares. V. Rhetoric and the Rule of Law. p. 94-95. De qualquer forma, as expresses são utilizadas, como regra, indistintamente pela doutrina.

${ }^{730}$ Com clareza, CROSS, Rupert; HARRIS, J. W. Precedent in English Law. p. 169: "Decisions on questions of fact do not constitute a precedent, for every case is considered to be unique. In order to constitute a precedent, a decision must concern a point of law".

${ }^{731}$ V., por todos, MONTROSE, J. L. Ratio decidendi and the house of lords. p. 124-125.

${ }^{732}$ P. ex., COMOGLIO, Luigi Paolo; CARNEVALE, Valentina. Il ruolo della giurisprudenza... p. 10501051.

${ }^{733}$ TARUFFO, Michele. Precedente e Giurisprudenza. p. 20 refere-se a "regola di diritto che è stata posta a diretto fondamento della decisione sui fatti specifici del caso".
} 
A restrição dos precedentes às razões jurídicas das decisões judiciais explica-se, tal qual exposto, pela universalidade que lhes é ínsita. ${ }^{734}$ Uma razão jurídica vale não só para o caso concreto que está sendo julgado, mas para todos os casos análogos a ele. ${ }^{735}$ Trata-se de mero desdobramento da inafastável universalidade do Direito, exigência de justiça (isonomia) e de segurança jurídica (estabilidade e previsibilidade). Se o caso A foi julgado da maneira $J$ por causa da razão jurídica $R$, então o caso $B$, análogo a A, também deve ser julgado de acordo com a razão jurídica $R$.

Exatamente o mesmo aplica-se à qualificação jurídica dos fatos. Imagine-se que no exemplo que vem sendo dado até o momento o banco alegou, em resposta à exceção de pré-executividade formulada em primeiro grau, que os extratos que acompanham o contrato de crédito foram todos assinados pelo devedor, configurando, então, a anuência às informações nele contidas. Com isso, o contrato teria eficácia executiva, uma vez que instruído por documentos de cuja formação o devedor participou. A questão então passa a ser: a anuência do devedor às informações contidas nos extratos basta para que seja preenchida a exigência de participação do devedor na formação do título executivo? A resposta a essa pergunta serve como precedente?

Sim, a resposta a essa pergunta serve como precedente, pois a razão dada também será universal ou universalizável, tendo plenas condições de servir de parâmetro para julgamentos futuros. Ou seja, "sempre que o devedor anuir às informações contidas nos extratos, então estará configurada a sua participação na formação do título executivo". Ou, em sentido contrário, "ainda que o devedor anua às informações contidas nos extratos, isso não basta para que esteja configurada a sua participação na formação do título executivo". Em qualquer uma das hipóteses, a motivação da decisão poderá ser utilizada como referência por outras decisões proferidas em casos similares: "como decidiu o

\footnotetext{
734 Também associando os precedentes à universalidade (ou generalidade), v., dentre muitos outros, MACCORMICK, Neil. Rhetoric and the Rule of Law. passim, esp. 149-153; Idem. Why cases have rationes and what these are. p. 162-165; TARUFFO, Michele. Precedente e Giurisprudenza. p. 10; TUCCI, José Rogério Cruz e. Precedente Judicial como Fonte do Direito. p. 175-176; DAVID, René; JAUFFRETSPINOSI, Camille. Les Grands Systèmes de Droit Contemporains. p. 283; SCHAUER, Frederick. Thinking like a Lawyer. p. 176 e ss; EISENBERG, Melvin Aron. The Nature of the Common Law. p. 8-9; CHIASSONI, Pierluigi. La Giurisprudenza Civile. p. 210.

${ }^{735}$ WAMBAUGH, Eugene. The Study of a Case. p. 15 já dizia: “ (...) the court must pass upon each case precisely as it would pass upon a similar case, that is to say, in accordance with a general rule".
} 
Tribunal 'tal', sempre que o devedor anuir às informações contidas nos extratos, então estará configurada a sua participação na formação do título executivo"; ou "como decidiu o Tribunal 'tal', ainda que o devedor anua às informações contidas nos extratos, isso não basta para que esteja configurada a sua participação na formação do título executivo".

13.2.4. Precedentes são razões jurídicas determinantes ao dispositivo da decisão: a ratio decidendi

Não obstante os precedentes sejam compostos por razões jurídicas, nem todas as razões jurídicas apresentadas para justificar uma decisão podem ser utilizadas como precedente. Trata-se da célebre distinção entre ratio decidendi e obter dictum. Apenas as razões que efetivamente sejam determinantes ao julgamento do processo, i.e., as razões que justificam a decisão, podem servir de referência para o julgamento de casos análogos. Sobre essa distinção será dedicado todo o ponto 14 deste Capítulo.

\subsubsection{A relevância das razões jurídicas da decisão e o conceito de precedente}

Ao definir que os precedentes judiciais são razões jurídicas determinantes de uma decisão que servem de parâmetro para a tomada de novas decisões em casos análogos, adotou-se, sem reparos, tanto a concepção intermediária como a concepção ampla dos precedentes. Mas a concepção intermediária, lembre-se, não atribui a natureza de precedente às decisões judiciais que contenham uma premissa maior pacífica, ao passo que a concepção ampla considera precedente judicial toda decisão que sirva de parâmetro para um julgamento posterior.

Com efeito, nem toda decisão judicial pode servir de precedente. A não comprovação dos fatos narrados pelo autor implica a improcedência do pedido sem que se estabeleça, necessariamente, uma premissa maior a ser seguida em casos análogos. ${ }^{736}$

Por outro lado, a restrição imposta pela concepção intermediária a razões jurídicas controversas não procede por duas razões. Em primeiro lugar, por mais pacífica

\footnotetext{
${ }^{736}$ Há, obviamente, uma premissa maior ao julgamento de improcedência da demanda. Essa premissa, porém, está voltada ao silogismo processual que segue o silogismo material, sendo irrelevante para fins de precedente.
} 
que seja a premissa maior da decisão judicial, nada impede que uma decisão seja utilizada para dar ainda mais força a uma asserção jurídica. Lembrando-se o percurso proposto por Ricardo Lorenzetti para o raciocínio judicial, a subsunção dos fatos à norma deve sempre passar por um controle jurisprudencial, de modo a verificar-se se a interpretação dada pelos tribunais ao dispositivo normativo é idêntica à que já lhe foi anteriormente dada (v. 8.4.1, acima). Também nesse sentido, Alexy considera requisito de racionalidade que, sempre que possível, a motivação da decisão apresente um precedente judicial que a corrobore (v. 8.3.4, acima). Em segundo lugar, ainda que não haja controvérsia jurídica no processo, o juiz terá de motivar juridicamente a sua decisão; e essa motivação, aparentemente de menor importância, pode servir como precedente para decisões futuras. Utilizando o art. 1.030 do Código Civil como exemplo, as partes podem discutir apenas se o sócio-réu apropriou-se ou não de dinheiro da sociedade. Provada a apropriação, então estaria configurada a hipótese normativa da "falta grave". Mas "falta grave" é um conceito indeterminado, cuja interpretação pode variar de pessoa para pessoa. Nada impede que outro réu, em outro processo, afirme que a apropriação de dinheiro da sociedade não configura uma falta grave passível de exclusão societária. A primeira decisão, para a qual a questão de direito não era controversa, certamente servirá de precedente para esse novo caso concreto que se apresenta para julgamento.

Sendo assim, são precedentes judiciais todas as decisões judiciais que apresentem razões jurídicas que justifiquem a conclusão ao final obtida.

\subsubsection{Os precedentes e o caso concreto}

Restringir os precedentes às razões jurídicas de uma decisão não significa que o caso concreto seja irrelevante à sua formação e à sua utilização. Na medida em que os precedentes servem justamente para dar homogeneidade ao tratamento de casos análogos, seria insensato ignorar que os fatos devem ser conhecidos para que se compreenda a extensão e o significado das razões jurídicas apresentadas. Exatamente da mesma forma que a motivação qualifica o dispositivo e esclarece quais são os limites da coisa julgada, e a causa de pedir qualifica os pedidos, delimita a demanda e dá contornos bem definidos ao mérito do processo, o caso concreto também contextualiza o precedente e estabelece como e em que casos ele pode ser utilizado como fundamento de uma decisão. Todavia, assim como a motivação não faz coisa julgada e a causa de pedir não se confunde 
com o mérito do processo, os fatos não compõem o precedente. Em síntese, o precedente é formado apenas pelas razões jurídicas determinantes à tomada da decisão, mas deve sempre ser compreendido à luz do contexto fático em que foi formado.

\subsubsection{Os precedentes e a motivação implícita}

Persistiu por muitos séculos no Direito inglês a concepção de que apenas “princípios de direito" expressamente expostos em uma decisão judicial poderiam servir de precedente. Em sentido contrário, Rupert Cross e J. W. Harris entendem ser possível que decisões imotivadas sejam utilizadas como precedentes, ainda que com autoridade muito fraca. A afirmação dos professores ingleses leva em consideração decisões antigas das cortes inglesas em que se fazia um relatório do processo e, então, decidia-se simplesmente: "julgamento em favor do autor" ${ }^{737}$ Destarte, o que na verdade Cross e Harris defendem é a possibilidade de que algumas decisões contenham uma motivação implícita da qual seja possível extrair a ratio decidendi. ${ }^{738}$

Com efeito, é possível que uma decisão contenha uma ratio implícita, facilmente apreensível, que sirva de precedente para novos casos. Ignorando o teor do acórdão prolatado pelo STJ nos Embargos de Divergência no REsp nº. 108.259/RS e utilizando apenas a ementa já citada, percebe-se que a ratio do acórdão é: "Mesmo subscrito por quem é indicado em débito e assinado por duas testemunhas, o contrato de abertura de crédito não é título executivo, ainda que a execução seja instruída com extrato e que os lançamentos fiquem devidamente esclarecidos, com explicitação dos cálculos, dos índices e dos critérios adotados para a definição do débito, pois esses são documentos unilaterais de cuja formação não participou o eventual devedor”. Não consta desse trecho que a eficácia executiva de qualquer título executivo, como regra, está condicionada à participação do devedor em sua formação. Mas quando o STJ aduz que "esses são documentos unilaterais de cuja formação não participou o eventual devedor”, fica implícita

\footnotetext{
${ }^{737}$ CROSS, Rupert; HARRIS, J. W. Precedent in English Law. p. 47

${ }^{738}$ Ibidem. p. 47. Isso fica muito claro na seguinte passagem: "It would be a mistake to assume that such decisions necessarily lack a ratio decidendi which enables them to be cited as a precedent, for a proposition of law on which they must have been based may be inferred with more or less confidence from the facts coupled with the conclusion".
} 
tal razão jurídica. Se essa razão é ou não a ratio decidendi do acórdão não importa por ora. Mas supondo que o seja, então o acórdão poderia ser utilizado como precedente para execuções de quaisquer contratos que contenham obrigações cuja liquidez dependa de atos unilaterais do credor.

\subsection{A eficácia dos precedentes}

As consequências decorrentes da existência de um precedente para um novo caso que se apresenta para julgamento variam de acordo com a eficácia que lhe é atribuída e de acordo com a posição hierárquica do juízo que o produziu em relação ao juízo que julgará o caso análogo. O precedente pode ser, desse modo, obrigatório ou persuasivo, e ter eficácia vertical ou horizontal.

\subsubsection{Precedentes obrigatórios: a regra do stare decisis}

Os precedentes são obrigatórios quando dotados de eficácia vinculante. Isso significa que, existindo um precedente ao caso que está sendo julgado, ele deve ser seguido, decidindo-se o novo caso da mesma maneira que fora decidido o caso anterior. Pouco importa, portanto, se o novo julgador concorda com as razões apresentadas no caso anterior ou não. Ele segue o precedente porque deve segui-lo. ${ }^{739} \mathrm{O}$ precedente apenas pode ser afastado quando não for aplicável ao novo caso por causa de significativas distinções entre os contextos fáticos de cada processo.

O respeito obrigatório aos precedentes é uma característica própria do common law e da adoção da regra do stare decisis, cujo significado resumido é "siga aquilo que foi decidido anteriormente" ("keep to what has been decided previously"). ${ }^{740}$ Trata-se de uma "prática judiciária" observada com tão "alto grau de uniformidade" que o seu desrespeito é muito raro. ${ }^{741}$ No entanto, ao contrário do que frequentemente se imagina, o common law não é indissociável da regra do stare decisis. Sua adoção, como já mencionado, foi resultado de uma evolução histórica pautada pela necessidade de conferir

\footnotetext{
${ }^{739}$ V. SCHAUER, Frederick. Thinking like a Lawyer. p. 41

${ }^{740}$ CROSS, Rupert; J. W. Harris. Precedent in English Law. p. 3.

${ }^{741}$ Ibidem. p. 98-99.
} 
estabilidade e previsibilidade ao Direito inglês, mas que só adquiriu eficácia vinculante a partir do século XIX. ${ }^{742}$

Com efeito, o common law nasceu e desenvolveu-se como um Direito costumeiro, composto por normas jurídicas não positivadas que regiam invariavelmente o reino inglês desde os tempos mais remotos. Os juízes eram considerados "oráculos vivos" de um direito atemporal e, sobretudo, racional. ${ }^{743} \mathrm{Na}$ metade do século XIX, o Barão James Parke, membro da House of Lords, afirmou que a função do juiz era unicamente expor "o direito não escrito ou comum a partir das decisões de nossos predecessores e de nossas cortes existentes, a partir de doutrinadores de reconhecida autoridade, e sobre os princípios a serem deles claramente deduzidos por sólida razão e justa inferência", 744

Ainda que os precedentes fossem, já nessa época, largamente observados e seguidos, a natureza declaratória da função jurisdicional ${ }^{745}$ afastava a sua irrestrita obrigatoriedade. Os precedentes deveriam ser seguidos desde que não fossem absurdos e injustos, hipótese em que teriam de ser desconsiderados por não terem conseguido apreender efetivamente qual era o direito.

A partir do século XIX, a doutrina declaratória foi severamente criticada pelos novos positivistas ingleses, como John Austin, que a chamou de "ficção infantil" e Jeremy Bentham, que a comparou ao método adotado para treinamento de bichos de estimação ("Dog $l a w "){ }^{746}$ Para eles, o direito não era descoberto pelos juízes, mas

\footnotetext{
${ }^{742}$ V. DAWSON, John P. Oracles of the Law. p. 80 e ss.

${ }^{743}$ Para Edward Coke, um dos juristas mais importantes na formação do common law, "Reason is the life of the law", de modo que "nay Common Law itself is nothing else but Reason". V. POSTEMA, Gerald J. Some roots of our notion of precedent. p. 11.

${ }^{744} 4$ HLC 1, 124 (1853), citada por WESLEY-SMITH, Peter. Theories of adjudication and the status of stare decisis. p. 74. Na transcrição do autor: "'It is the province of the judge' stated Parke B in Egerton v. Brownlow, 'to expound the law only; ... the unwritten or common law from the decisions of our predecessors and of our existing courts, from text-writers of acknowledged authority, and upon the principles to be clearly deduced from them by sound reason and just inference".

${ }^{745}$ V. WESLEY-SMITH, Peter. Theories of adjudication and the status of stare decisis. p. 73; POSNER, Richard. A. The Problems of Jurisprudence. p. 12.

${ }^{746}$ V. WESLEY-SMITH, Peter. Theories of adjudication and the status of stare decisis. p. 74; SHAPIRO, Scott J. Legality. p. 397. Para Bentham, a teoria declaratória equiparava-se ao "Dog law" porque não se diz a cachorros o que pode ou não pode ser feito previamente; espera-se que eles façam algo reprovável para então puni-los. Do mesmo modo, a teoria declaratória não explicitaria anteriormente às pessoas aquilo que podem
} 
consistia em criação decorrente do law-making authority. Ou seja, os juízes exerciam verdadeira atividade legiferante. A doutrina foi posteriormente desenvolvida por Oliver Wendell Holmes Jr. e Benjamin Cardozo, nos Estados Unidos, e Lord Radcliffe e Lord Reid, na Grã-Bretanha, que também não pouparam críticas contundentes à teoria declaratória. De acordo com o Justice Holmes, o common law não é uma "onipresença contemplativa no céu", mas a "voz articulada de soberania ou quase-soberania que possa ser identificada". ${ }^{747}$

O declínio da teoria declaratória e a ascensão da teoria constitutiva teve consequências profundas no common law, incluindo o desenvolvimento da eficácia vinculante dos precedentes. $\mathrm{Na}$ medida em que o direito não estava mais em um plano ideal e abstrato pronto para ser descoberto, mas era criado pelas decisões judiciais, então as novas decisões que não se atinham às anteriores eram decisões ilícitas. Como explica Peter Wesley-Smith, "nenhuma corte superior é infalível quando 'declara' o direito, mas uma corte superior pode ter maior autoridade que uma corte inferior para 'fazer' o direito". 748

Ou seja, no mesmo momento histórico em que os países da Europa continental rompiam com o jusnaturalismo e passavam a adotar um Direito positivo codificado, também a doutrina inglesa rompia com a teoria clássica jusnaturalista do common law e atribuía às decisões judiciais eficácia semelhante à das leis. ${ }^{749}$

Os Estados Unidos, obviamente, também seguem a regra do stare decisis, sendo obrigatório o respeito dos precedentes dos juízos superiores pelos juízos inferiores. Por diversas razões, contudo, a eficácia vinculante que atribuem aos precedentes é

fazer ou deixar de fazer; os juízes simplesmente esperariam por uma atitude considerada reprovável e, então, aplicariam a sanção ( $C f$. Ibidem. p. 397).

747 Southern Pacific Co. v. Jensen - 244 U.S. 222 (1917). No original: "The common law is not a brooding omnipresence in the sky, but the articulate voice of some sovereign or quasi-sovereign that can be identified (...)".

748 WESLEY-SMITH, Peter. Theories of adjudication and the status of stare decisis. p. 81. No original: "When a judge is recognized, however, as able to make law, the notion of vertical stare decisis - of a court being bound by decisions of courts above it in the hierarchy - is perfectly rational. No superior court is infallible when it 'declares' law, but a superior court can have greater authority than a lower court do 'make' law'.

749 Nesse sentido, DAVID, René; JAUFFRET- SPINOSI, Camille. Les Grands Systèmes de Droit Contemporains. p. 282. 
consideravelmente mais branda do que na Inglaterra. Uma dessas razões foi o tardio acolhimento do common law no país. Lembre-se que, na segunda metade do século XVIII, os Estados Unidos, fortemente imbuídos dos ideais liberais iluministas e em guerra contra a Inglaterra, sofriam considerável influência francesa. A elaboração de uma Constituição federal escrita em 1787, e de diversas constituições estaduais nos anos seguintes, e um início de codificação no início do século XIX, incluindo a criação de um código civil no então território de Nova Orleans (posteriormente Estado da Louisiana) em 1808, levavam a crer que o civil law prevaleceria nos Estados Unidos. Foi apenas na metade do século XIX, em boa parte pelo forte vínculo ainda existente com a Inglaterra, que o common law acabou "triunfando". ${ }^{750}$ Também merece destaque a estrutura federalista estadunidense, que limita a eficácia vinculante dos precedentes entre órgãos federais e entre órgãos de um mesmo Estado.

Entre os países do civil law, embora tradicionalmente os precedentes tenham eficácia meramente persuasiva, a regra do stare decisis começa a ser gradualmente recepcionada. Especificamente no que diz respeito ao Brasil, duas hipóteses chamam a atenção: as súmulas vinculantes e a eficácia vinculante das decisões proferidas em controle concentrado de constitucionalidade pelo Supremo Tribunal Federal.

\subsubsection{Precedentes persuasivos}

Os precedentes são meramente persuasivos quando a sua observância em decisões posteriores não é obrigatória. O precedente torna-se apenas um argumento para que a decisão seja no mesmo sentido, mas pode ser descartado pelo julgador que com ele não concorde. Trata-se da eficácia que comumente lhes é atribuída nos países de tradição romano-germânica.

A crença de que precedentes decorrentes de tribunais hierarquicamente superiores não podem ter eficácia vinculante está intimamente ligada a duas concepções equivocadas. A primeira é a suposição de que o respeito obrigatório a precedentes implica atribuir poderes legiferantes ao juiz; e se os juízes não podem criar o Direito, então as suas decisões não podem vincular o julgamento de casos futuros. A segunda é a crença de que o

\footnotetext{
${ }^{750}$ Cf. Ibidem. p. 304-306.
} 
livre convencimento do juiz confunde-se com uma suposta liberdade de aplicação do Direito.

Em primeiro lugar, a eficácia vinculante de um precedente não conduz à conclusão de que o precedente é uma nova norma jurídica. Esse assunto já foi abordado (v. 7.3.2, acima), mas vale a pena retomá-lo brevemente. Precedentes, embora sejam razões jurídicas de uma decisão, não são necessariamente novas normas jurídicas. Se em dado ordenamento jurídico os juízes podem criar o Direito, então os precedentes poderão, sim, ser normas jurídicas criadas judicialmente. Mas se a criação judicial do Direito for rejeitada, o que parece ser o caso no Brasil, então os precedentes nada mais são do que normas jurídicas já existentes aplicadas a situações fáticas concretas. Em qualquer uma das hipóteses, os precedentes podem ser vinculantes ou persuasivos. Um tribunal pode ter o poder de criar uma nova norma jurídica ao caso concreto e, mesmo assim, sua decisão não ser vinculante a casos análogos. Por outro lado, nada impede que a criação jurídica seja vedada a um determinado tribunal, mas atribua-se eficácia vinculante à interpretação por ele dada a um dispositivo legal. Muitos diriam que o STJ agiu criativamente ao rejeitar a eficácia executiva de contratos bancários de abertura de crédito (v. 13.2.1, acima). Outros, como este autor, entendem que o STJ simplesmente aplicou normas implícitas referentes à execução de título executivo extrajudicial; afinal, o núcleo de tais títulos sempre foi, desde a sua origem no Direito Comum, o reconhecimento do próprio devedor da existência de um débito. De uma forma ou de outra, a decisão poderia vincular os julgamentos posteriores ou não; o que demonstra que a obrigatoriedade dos precedentes não tem absolutamente nenhuma relação com a natureza criativa das decisões judiciais. ${ }^{751}$

Em segundo lugar, o livre convencimento judicial é fático, e não jurídico. ${ }^{752}$ Os juízes não podem aplicar o Direito como bem entendem, pois o Direito não lhes

\footnotetext{
${ }^{751}$ Embora Luiz Guilherme MARINONI considere que atribuir eficácia vinculante a um precedente é o mesmo que equipará-lo à lei, tece afirmação, em outro trecho de sua obra, que vale ser citada aqui: “(...) é importante deixar claro que a circunstância de o precedente, no direito brasileiro, ter natureza interpretativa não lhe retira a dignidade e a importância operacional, bem como a sua notável relevância em face da igualdade, da segurança jurídica, da previsibilidade e da otimização da administração justiça". Precedentes Obrigatórios. p. 256.

752 O art. 131 do CPC não deixa dúvidas: "O juiz apreciará livremente a prova, atendendo aos fatos e circunstâncias constantes dos autos, ainda que não alegados pelas partes; mas deverá indicar, na sentença, os
} 
pertence. O Direito é feito pela sociedade e para a sociedade, de modo que sua interpretação deve ser pautada pelos valores da sociedade e não pelos valores pessoais do julgador (v. 7.1, acima). Se um tribunal superior, cuja existência está voltada justamente para controlar a interpretação e aplicação do Direito no território nacional, dá uma determinada interpretação a um dispositivo legal, seria mais do que lógico que os juízos inferiores, cuja atividade é controlada por tais tribunais, respeitassem-na e adotassem-na.

O livre convencimento jurídico dos juízes só teria sentido em um ordenamento jurídico em que as decisões judiciais fossem imediatamente eficazes e definitivas. A realidade dos países do civil law, porém, é bastante diversa. Ao mesmo tempo em que se exalta a liberdade de interpretação do Direito por cada magistrado, como se isso fosse uma demonstração de liberdade do Poder Judiciário (não é!), ${ }^{753}$ as decisões são submetidas a uma estrutura recursal abrangente e, muitas vezes, exaustiva; e com um intuito claro: controlar a correta aplicação do Direito pelos juízos inferiores. Na França pós-revolucionária, por exemplo, além da instalação de um órgão legislativo voltado a dar aos juízes uma "interpretação autorizada" em caso de obscuridade ou omissão nas leis, ou de conflitos entre normas, instalou-se também um Tribunal de Cassação, desvinculado do Poder Judiciário, que serviria como "válvula de escape" em caso de usurpação dos poderes legiferantes pelos magistrados. ${ }^{754}$

motivos que Ihe formaram o convencimento". Apreciar "livremente a prova" é bastante diferente de "apreciar livremente o Direito'.

${ }^{753}$ Seguindo integralmente MARINONI, Luiz Guilherme. Precedentes Obrigatórios. p. 64-65: "Supôs-se que os juízes não devem qualquer respeito às decisões passadas (...) Trata-se de grosseiro mal entendido, decorrente da falta de compreensão de que a decisão é o resultado de um sistema e não algo construído de forma individualizada por um sujeito que pode fazer valer a sua vontade sobre todos os que o rodeiam, e, assim, sobre o próprio sistema de que faz parte. Imaginar que o juiz tem o direito de julgar sem se submeter às suas próprias decisões e às dos tribunais superiores é não enxergar que o magistrado é uma peça no sistema de distribuição de justiça, e, mais do que isso, que este sistema não serve a ele, porém ao povo".

${ }^{754}$ V. Ibidem. p. 131-132. Sobre o surgimento do Tribunal de Cassação e seu desenvolvimento, v. CALAMANDREI, Piero. La Cassazione Civile, v. I. p. 377 e ss. Embora as críticas a essa concepção sejam recorrentes nos dias de hoje, é preciso levar em consideração o contexto histórico em que foi desenvolvida. É elucidativa a explicação de CALAMANDREI: “(...) il regime monarchico lasciava alla Rivoluzione un'eredità di odio contro tutto l'ordinamento giudiziario ed in ispecie contro le Corti sovrane, ed una comune aspirazione a una radicale riforma dell'ordinamento giudiziario sotto un'unica legge. La necessità di riordinare e, sopra tutto, di unificare l'amministrazione della giustitizia era profondamente ed urgentemente sentita dalle classi borghesi e popolari, che, nella incertezza e nella molteplicità delle norme 
Dito de outro modo, os juízes pretensamente podem aplicar o Direito como bem entendem, mas se submetem a um controle hierárquico em relação à maneira como aplicaram o Direito; e se não o aplicarem como reputam adequado os tribunais, sua decisão será invalidada ou reformada por uma nova decisão. Com isso, ao mesmo tempo em que o civil law erige um sistema recursal voltado ao controle da atuação dos juízes hierarquicamente inferiores, permite aos juízes que, pela inexistência de eficácia vinculante dos precedentes, profiram livremente decisões consideradas antijurídicas pelos tribunais que lhes são superiores. Uma situação paradoxal que causa graves distúrbios na estabilidade e na previsibilidade do Direito. ${ }^{755}$ Se cada juiz pode aplicar as normas jurídicas como bem entende, pouco adianta uma legislação exaustiva e completa. A impossibilidade de antever o conteúdo de decisões judiciais gera uma insegurança tão grande quanto a que é proporcionada pela falta de normas que tornem claras as "regras do jogo".

\subsubsection{Precedentes verticais}

Precedentes verticais são aqueles que decorrem de tribunais hierarquicamente superiores ao juízo que pretende aplicá-lo. ${ }^{756}$ Uma decisão do STJ é um precedente vertical em relação a um tribunal de justiça; e a decisão do tribunal de justiça é um precedente vertical em relação a um juízo de primeiro grau.

di diritto, nella instabilità e nella disformità delle interpretazioni, nella intricata complicazione degli organi giurisdizionali, invocavano una sola legge, una giustizia semplice e imparziale, un controllo desinteressato che con un criterio unico mantenesse tutti i giudici entro i limiti del loro potere e vietasse loro di trasgredire, sotto colore di interpretarlo, il diritto obiettivo" (Ibidem. p. 383-384). Ou seja, no caso francês, o respeito a precedentes era incompatível com a cultura da época, pois se a Corte de Cassação existia em razão da desconfiança geral em relação aos juízes, não seria possível construir um sistema sobre a premissa de que as decisões judiciais deveriam ser obrigatoriamente respeitadas em casos análogos. V. MARINONI, Luiz Guilherme. Precedentes Obrigatórios. p. 132-133.

${ }^{755}$ V. MARINONI, Luiz Guilherme. Precedentes Obrigatórios. p. 134-135: "somente uma ingenuidade indesculpável poderia sustentar a ideia de que o duplo grau de jurisdição constitui princípio fundamental de justiça, e até mesmo garantia constitucional, e, ao mesmo tempo, aprovar a tese de que o juiz de primeiro grau deve ter liberdade para decidir de forma contrária ao Superior Tribunal de Justiça e ao Supremo Tribunal Federal".

${ }^{756}$ TARUFFO, Michele. Precedente e Giurisprudenza. p. 26-27. 
Nos países do common law, precedentes verticais são, em regra, vinculantes aos juízos inferiores. Nos países do civil law, os precedentes verticais possuem, como regra, eficácia meramente persuasiva. No entanto, quanto mais verticalizados, i.e., quanto mais alta é a hierarquia do tribunal que o produziu, maior é a probabilidade de que sejam seguidos pelos juízos inferiores. ${ }^{757}$

\subsubsection{Precedentes horizontais}

Precedentes horizontais são aqueles decorrentes do próprio juízo que se depara com um caso análogo para julgamento, ou de um juízo de mesmo nível hierárquico. ${ }^{758}$ Uma decisão do Tribunal de Justiça do Estado do Paraná serve como precedente horizontal ao próprio Tribunal, bem como ao Tribunal de Justiça do Estado de São Paulo ou ao Tribunal Regional Federal da $4^{\mathrm{a}}$ Região, p.ex.

Por algum tempo vigorou no Reino Unido a eficácia absolutamente vinculante dos precedentes. ${ }^{759}$ Diz-se absolutamente vinculante porque os precedentes vinculavam não só os juízos hierarquicamente inferiores, mas vinculavam também os juízos que os produziram. ${ }^{760}$ Entre 1898 e 1966, a House of Lords, então órgão máximo do Poder Judiciário do Reino Unido, considerou absoluto o dever de respeitar os próprios julgados, abstendo-se de reconsiderar suas decisões pretéritas. Na verdade, desde Beamish v. Beamish, julgado em 1861, a House of Lords já vinha atribuindo eficácia absolutamente vinculante aos seus próprios precedentes. Naquela ocasião, não obstante o tribunal tivesse reconhecido que o caso The Queen v. Millis fora erroneamente julgado, entendeu que deveria segui-lo. ${ }^{761}$ Em London Tramways v. London County Council, julgado em 1898, a

\footnotetext{
${ }^{757}$ V. Ibidem. p. 26-27.

${ }^{758}$ Cf. Ibidem. p. 26-27.

${ }^{759}$ Expressão utilizada por MARINONI, Luiz Guilherme. Precedentes Obrigatórios. p. 112 e ss. A doutrina do common law refere-se a "strict rule of binding precedent", cf. GOLDSTEIN, Laurence. Introduction. p. 3. Para um panorama geral sobre o tema, v. DAWSON, John P. The Oracles of the Law. p. 90 e ss.

${ }^{760}$ Note-se que a eficácia absolutamente vinculante dos precedentes não se desenvolveu igualmente em todos os tribunais ingleses. Para um estudo sobre a eficácia vinculante dos precedentes em cada um deles, v. CROSS, Rupert; J. W. Harris. Precedent in English Law. p. 125-158.

761 (1859-61) 9 HLC 274.
} 
questão foi assentada definitivamente. ${ }^{762}$ Em uma esclarecedora passagem, Lord Halsbury afirma: "mas o que é a interferência ocasional no que talvez seja uma justiça abstrata, se comparada com a inconveniência - a desastrosa inconveniência - de ter cada questão sujeita à rediscussão e de tornar as relações da humanidade duvidosas em razão de diferentes decisões, de modo que, na verdade e de fato, não haveria uma real Corte final de apelação". ${ }^{763}$ A partir daí concluiu: "uma decisão dessa Casa, uma vez dada sobre um ponto de direito, é doravante definitiva". ${ }^{764}$

É importante notar que a atribuição de eficácia absolutamente vinculante pela House of Lords aos seus próprios precedentes, longe de constituir medida voltada ao aumento de poder do tribunal, buscava proteger a separação dos poderes e impedir a atividade legiferante dos seus membros. ${ }^{765}$ Com efeito, constou expressamente do julgamento de Beamish v. Beamish que se as decisões proferidas não fossem vinculantes também para os seus membros, então a Corte "estaria arrogando-se a faculdade de alterar o direito, e legislar com autônoma autoridade". ${ }^{766}$

\footnotetext{
762 Sobre o período entre 1861 e 1898 , e os poucos casos em que se refutou a vinculação dos tribunais superiores às próprias decisões, v. EVANS, Jim. Change in the doctrine of precedent during the nineteenth century. p. 58.

${ }^{763}$ [1898] AC 375. No original: "Of course I do not deny that cases of individual hardship may arise, and there may be a current of opinion in the profession that such and such a judgment was erroneous; but what is that occasional interference with what is perhaps abstract justice as compared with the inconvenience - the disastrous inconvenience - of having each question subject to being reargued and the dealings of mankind rendered doubtful by reason of different decisions, so that in truth and in fact there would be no real final Court of Appeal? My Lords, 'interest rei publica' that there should be 'finis litium' at some time, and there could be no 'finis litium' if it were possible to suggest in each case that it might be reargued, because it is 'not an ordinary case', whatever that may mean. Under these circumstances I am of opinion that we ought not to allow this question to be reargued".

764 [1898] AC 375. No original: "My Lords, for my own part I am prepared to say that I adhere in terms to what has been said by Lord Campbell and assented to by Lord Wensleydale, Lord Cranworth, Lord Chelmsford and others, that a decision of this House once given upon a point of law is conclusive upon this House afterwards, and that it is impossible to raise that question again as if it was res integra and could be reargued, and so the House be asked to reverse its own decision".

${ }^{765}$ Exatamente nesse sentido, TUCCI, José Rogério Cruz e. Precedente Judicial como Fonte do Direito. p. 158.

${ }^{766}$ No original: "My Lords, the decision in The Queen v. Millis (...) seemed to me so unsatisfactory (...). If it were competent to me, I would now ask your Lordships to reconsider the doctrine laid down in The Queen $v$. Millis (...). But it is my duty to say that your Lordships are bound by this decision as much as if it had been
} 
A aplicação estrita dos precedentes durou até 1966, quando a House of Lords, reconhecendo o valor dos precedentes para proporcionar segurança aos indivíduos, considerou que uma "aderência muito rígida a um precedente pode levar à injustiça em um caso particular e também restringir indevidamente o desenvolvimento adequado do Direito". Mediante um Practice Statement, ${ }^{767}$ a House of Lords declarou que continuaria atribuindo eficácia vinculante aos seus precedentes, mas poderia "divergir de decisões prévias quando isso lhe parecesse correto". ${ }^{768}$ Ainda assim, até a sua substituição pela Supreme Court of the United Kingdom, em 2009, a House of Lords, utilizou essa faculdade muito raramente, ${ }^{769}$ o que demonstra o alto comprometimento da Corte com a regra do stare decisis. ${ }^{770}$

No Brasil, as mudanças jurisprudenciais são frequentes e, não raro, decisões conflitantes são proferidas em curto espaço de tempo. Dois exemplos podem ser dados. Desde 1992 vigora o enunciado 54 da súmula do STJ no sentido de que "os juros moratórios fluem a partir do evento danoso, em caso de responsabilidade extracontratual”. Independentemente do acerto do entendimento sumulado, fato é que se trata de um preceito bastante antigo e já fortemente interiorizado na consciência dos jurisdicionados. Ao julgar o REsp 903258/RS, porém, tendo como fundamento uma mera divergência de

pronounced nemine dissentiente, and that the rule of law which your Lordships lay down as the ground of your judgment, sitting judicially, as the last and supreme Court of Appeal for this empire, musit be taken for law till altered by an Act of Parliament, agreed to by the Commons and the Crown, as well as by your Lordships. The law laid down as your ratio decidendi, being clearly binding on all inferior tribunals, and on all the rest of the Queen's subjects, if it were not considered as equally binding upon your Lordships, this House would be arrogating to itself the right of altering the law, and legislating by its own separate authority".

${ }^{767}$ Para uma crítica à validade do ato, v. CROSS, Rupert; J. W. Harris. Precedent in English Law. p. 104 e ss. ${ }^{768}$ Practice Statement [1966] 3 All ER 77. No original: "Their Lordships regard the use of precedent as an indispensable foundation upon which to decide what is the law and its application to individual cases. It provides at least some degree of certainty upon which individuals can rely in the conduct of their affairs, as well as a basis for orderly development of legal rules. Their Lordships nevertheless recognize that too rigid adherence to precedent may lead to injustice in a particular case and also unduly restrict the proper development of the law. They propose therefore to modify their present practice and, while treating former decisions of this House as normally, to depart from a previous decision when It appears right to do so".

${ }^{769}$ Cf. CROSS, Rupert; J. W. Harris. Precedent in English Law. p. 135-143; DUXBURY, Neil. The Nature and Authority of Precedent. p. 128.

770 Em um sentido um pouco diverso, ressaltando a possibilidade de "manobra" da doutrina estrita dos precedentes, DAWSON, John P. The Oracles of the Law. p. 94-95. 
opinião jurídica, o STJ, por 4 votos a 1, simplesmente desconsiderou o enunciado 54 e decidiu que os juros moratórios deveriam ser contados a partir do seu arbitramento; isto é, da sentença. ${ }^{771}$

Com todo o respeito, ainda que a composição da Turma fosse relativamente nova, nada justificava a abrupta mudança jurisprudencial; e pior, uma mudança jurisprudencial pautada unicamente em uma concepção jurídica diferente da que vinha sendo manifestada há quase 20 anos pela Corte. Como resultado, a jurisprudência do STJ transformou-se em uma verdadeira confusão. Ora o enunciado era aplicado (EDcl no REsp 1210778/SC), ora era cabalmente ignorado (REsp 888.751/BA).

Em 23 de maio de 2012, apenas seis meses depois, a questão apresentou-se ao STJ na forma de Reclamação. ${ }^{772}$ Por unanimidade, o enunciado $\mathrm{n}^{\mathrm{o}} .54$ foi reafirmado. Absolutamente nenhuma referência foi feita às divergências então existentes na Quarta Turma; e, inexplicavelmente, a aplicação do enunciado foi referendada pelos próprios ministros que dela vinham divergindo. Ainda que a questão, ao que parece, tenha sido reassentada, fato é que houve uma desnecessária turbulência jurisprudencial que não serviu para outra coisa senão causar insegurança jurídica e enfraquecer a aplicação do entendimento sumulado pelos juízos de primeiro e segundo grau. Ademais, nada impede que, a qualquer momento, algum acórdão volte a divergir do entendimento sumulado, criando incerteza e imprevisibilidade nos julgamentos de um tribunal que deveria, justamente, pacificar a aplicação do Direito em território nacional.

O segundo exemplo é o seguinte. Em 14 de setembro de 2010, o STJ decidiu que não poderiam ser cobrados juros moratórios do consumidor durante a construção do imóvel, pois nesse período não haveria capital da construtora mutuado ao promitente comprador. ${ }^{773}$ Essa decisão tornou-se um importante precedente e foi várias vezes reiterada pelo tribunal em julgamentos posteriores (p. ex., AgRG no Ag 1.014.027/RJ e AgRg no AI no. 1.402.399/RJ). Quando as construtoras já estavam

\footnotetext{
${ }^{771}$ REsp 903.258/RS, Rel. Ministra MARIA ISABEL GALLOTTI, QUARTA TURMA, julgado em 21/06/2011, DJe 17/11/2011.

${ }^{772}$ Rcl 3.893/RJ, Rel. Ministro LUIS FELIPE SALOMÃO, SEGUNDA SEÇÃO, julgado em 23/05/2012, DJe 01/06/2012

${ }^{773}$ REsp 670117/PB, Rel. Ministro LUIS FELIPE SALOMÃO, QUARTA TURMA, julgado em 14/09/2010, DJe 23/09/2010.
} 
adaptando-se ao entendimento jurisprudencial, a $2^{\text {a }}$ Seção do STJ decidiu, em junho de 2012, por 6 votos a 3, desconsiderar tudo o que fora produzido nos dois anos anteriores e mudou radicalmente a interpretação jurídica até então prevalecente. ${ }^{774} \mathrm{Um}$ patente descomprometimento com os atos praticados pelo próprio Superior Tribunal de Justiça e, principalmente, com a função nomofilática que lhe é inerente.

\section{A ratio decidendi e o obiter dictum na motivação das decisões judiciais}

Embora haja, ainda, graves distorções na prática forense em relação ao respeito de precedentes de tribunais superiores, ou do próprio tribunal que o produziu, fato é que a regra do stare decisis começa a ser desenvolvida no Brasil, um país de tradição romano-germânica. Desse modo, é preciso que também sejam compreendidos alguns institutos fundamentais para a aplicação dos precedentes, em especial no que se refere à distinção entre ratio decidendi e obiter dictum. ${ }^{775}$

Em apertada síntese, a ratio decidendi é a efetiva razão jurídica pela qual o magistrado decide; e o obiter dictum, que significa "o que é dito de passagem", ${ }^{776}$ é composto por considerações acessórias, por vezes supérfluas, por vezes relevantes, mas que não representam a razão jurídica pela qual os fatos alegados e provados desencadearam a consequência jurídica acolhida pelo magistrado.

No common law, apenas a ratio decidendi possui eficácia vinculante, embora o obiter dictum possa, em alguns casos, apresentar eficácia persuasiva. ${ }^{777}$

\footnotetext{
${ }^{774}$ EREsp 670.117/PB, Rel. p/ Acórdão Ministro ANTONIO CARLOS FERREIRA, SEGUNDA SEÇÃO, julgado em 13/06/2012, DJe 26/11/2012.

775 De acordo com Eugene WAMBAUGH, a definição da ratio decidendi (proposição jurídica pela qual a decisão é vinculante) é uma das investigações mais importantes que devem ser feitas em relação aos precedentes (v. The Study of Cases. p. 8).

${ }^{776}$ Cf. SILVA, Ana de Lourdes Coutinho. Motivação das Decisões Judiciais. p. 196.

${ }^{777}$ Em 1673, escreveu Vaughan CJ: “An opinion given in court, if not necessary to the judgement given of Record, but that it might have been as well given if no such, or a contrary had been broach'd, is no judicial opinion; but mere gratis dictum”. V. CROSS, Rupert; HARRIS. J. W. Precedent in English Law. p. 41).
} 
14.1. A importância da distinção

A distinção entre ratio decidendi e obiter dictum é extremamente polêmica e debatida entre a doutrina e a jurisprudência do common law. Representa, para a teoria geral dos precedentes, algo similar ao que, no Brasil e na Itália, a teoria da ação representa para a teoria geral do processo.

A importância da distinção é evidente: controlar o poder judicial ao impedir que se tornem vinculantes razões jurídicas dissociadas do caso concreto que está sendo julgado.

É notório que a essência da aplicação de precedentes está no julgamento idêntico de casos análogos. Quando se busca um precedente para o julgamento de um caso concreto, busca-se uma decisão judicial que tenha decidido um caso análogo, e não um mero pronunciamento de um tribunal sobre a interpretação que deve ser dada ao Direito. Se tudo aquilo que consta na motivação da decisão judicial tiver aptidão para vincular os julgamentos posteriores, então está aberta a possibilidade para que o juiz não só apresente razões pelas quais está julgando o caso em si, mas que também busque criar "precedentes" para casos completamente diversos. O juiz teria condições de manifestar-se sobre tudo aquilo que tivesse vontade, não importa qual fosse a situação fática ou a pertinência das considerações apresentadas no julgamento. Apenas a ratio decidendi pode servir como precedente porque apenas a ratio decidendi compõe a efetiva motivação da decisão judicial. Limitar a eficácia dos precedentes à ratio decidendi significa limitar a eficácia dos precedentes às razões jurídicas da decisão tomada, produzidas em um ambiente democrático pautado pelo devido processo legal e, mais especificamente, pelo contraditório e pela ampla defesa. Não fosse assim, um tribunal poderia criar um precedente em relação à interpretação de uma lei tributária no julgamento de um conflito entre vizinhos. ${ }^{778}$

\footnotetext{
${ }^{778}$ Sobre isso, escreveu Eugene WAMBAUGH ainda em 1894: "The first key to the discovery of the doctrine of a case is found in the principle that the court making the decision is under the duty to decide the very case presented and has no authority to decide any other. No court can refuse to decide an actual case over which it has jurisdiction; and no court can decide a wholly imaginary case. Nor can a court decide a case partly imaginary" (The Study of Cases. p. 8). Adiante continua: "The reason why a dictum is not authority of the highest grade is the restrictive principle heretofore pointed out, the principle that the court need not and
} 
Essa situação é particularmente agravada pelo fato de que, no Brasil, os julgamentos nos tribunais são colegiados, mas o acórdão, quando unânime, é relatado por apenas um dos julgadores (embora nos tribunais superiores exista a possibilidade de declaração de voto pelos demais ministros). Não obstante tenha que haver concordância entre os julgadores quanto aos fatos relevantes ao processo e à consequência jurídica decorrente de tais fatos, que é o que irá moldar o dispositivo, o acórdão independe da confluência das razões jurídicas dadas por cada magistrado. Um desembargador pode discordar, p.ex., da premissa maior erigida pelo relator, mas concordar que, diante dos fatos (aceitos por ambos), o recurso deve ser provido. Se não houver distinção entre ratio decidendi e obiter dictum, então é possível que não só razões jurídicas completamente dissociadas do caso concreto virem precedentes, mas também seriam precedentes razões jurídicas dissociadas do caso concreto que não são nem mesmo aceitas por todos os julgadores que acordaram no resultado.

Vale citar um interessante exemplo. No julgamento do REsp $n^{\circ} .813 .430 / \mathrm{SC}$ pelo STJ, constou da ementa do acórdão que o sócio "interessado na expulsão de outro deverá instaurar o contencioso em face deste, dos sócios remanescentes e da pessoa jurídica à qual se ligavam". ${ }^{779}$ Haveria, portanto, um litisconsórcio necessário entre o sócio a ser excluído, os sócios remanescentes e a pessoa jurídica. Ocorre que, enquanto o Min. Relator fez referência expressa à necessidade de que os sócios remanescentes façam parte do polo passivo do processo, os demais ministros declararam voto e apenas manifestaramse quanto à necessidade de que a sociedade fosse citada; não fizeram nenhuma referência à citação dos sócios remanescentes. Todos concordaram que a sociedade deveria integrar o polo passivo, mas não houve nenhuma manifestação da maioria do colegiado quanto aos sócios remanescentes. Logo, se é indubitável que o recurso foi unanimemente rejeitado porque a sociedade deveria ter sido citada como litisconsorte necessária do sócio a ser excluído (ratio decidendi), o mesmo não pode ser dito acerca da presença dos demais sócios no polo passivo do processo.

must not do more than the case at bar demands, and hence cannot pass authoritatively upon any case but that" (p. 13-14).

${ }^{779}$ REsp 813430/SC, Rel. Ministro MASSAMI UYEDA, QUARTA TURMA, julgado em 19/06/2007, DJ 20/08/2007, p. 288. 
Esse caso demonstra exemplificativamente que a motivação apresentada no acórdão nem sempre reflete, necessariamente, a opinião de todos os magistrados que o compõem. Pode até ser que os demais ministros tenham concordado com o relator acerca da necessidade de citação dos sócios remanescentes, mas também é perfeitamente plausível que ou os demais ministros não concordavam com aquela razão jurídica, ou não refletiram sobre o assunto, uma vez que o caso poderia ser julgado unicamente pela falta de citação da sociedade, ponto com o qual estavam todos de acordo. De uma forma ou de outra, existe sempre a possibilidade de que o relator trate, na motivação do acórdão, de temas que, por serem considerados irrelevantes pelos demais julgadores, não sejam devidamente debatidos. A distinção entre ratio decidendi e obiter dictum reduz, em parte, os riscos de que tais manifestações unilaterais transformem-se em precedentes.

\subsection{Teorias elaboradas para distinguir a ratio decidendi do obiter dictum}

Há alguns séculos a doutrina do common law vem elaborando teorias variadas para que a ratio decidendi possa ser devidamente identificada e diferenciada do obiter dictum. O tema é tão polêmico que, em 1950, um célebre juiz da Court of Appeal inglesa, Lord Asquith, ironicamente afirmou: "A regra é bastante simples. Se você concorda com o sujeito, você diz que é parte da ratio; se você não concorda, você diz que é obiter dictum, com a implicação de que ele é um idiota congênito". ${ }^{780}$

Adiante serão apresentadas algumas das principais teorias elaboradas para distinguir os conceitos.

\subsubsection{O teste de Eugene Wambaugh}

Em 1892, Eugene Wambaugh publicou a clássica obra Study of Cases, onde defendeu que a ratio decidendi era uma "regra geral sem a qual o caso deveria ter sido decidido de outra maneira". ${ }^{781}$ Segundo Wambaugh, a proposição jurídica ("proposition of

\footnotetext{
${ }^{780}$ Cf. CROSS, Rupert; HARRIS, J. W. Precedent in English Law. p. 50. Na transcrição dos autores: "The rule is quite simple, if you agree with the other bloke you say it is part of the ratio; if you don't you say it is obiter dictum, with the implication that he is a congenital idiot".

${ }^{781}$ WAMBAUGH, Eugene. The Study of Cases. p. 18.
} 
law") que vincula os casos posteriores é aquela que afasta todas as circunstâncias que não sejam essenciais e declara uma regra para aquelas que o sejam. ${ }^{782}$

Além de obedecer a quatro regras básicas, ${ }^{783}$ a determinação da ratio decidendi, propôs Wambaugh, deveria passar pelo seguinte teste. O primeiro passo é escolher a proposição jurídica que se supõe ser a ratio decidendi. Em seguida insere-se uma palavra que altere o significado da proposição. Confrontada a nova proposição com a decisão, deve-se perquirir se o resultado alcançado pelo órgão julgador seria o mesmo se a nova proposição alterada tivesse sido utilizada como fundamento da decisão. Caso a decisão continue sendo a mesma, então, por melhor que a proposição original seja, ela não serve como precedente para novos julgamentos. Contudo, se o resultado da decisão alterarse com a mudança da proposição jurídica, então ela é a ratio decidendi e pode servir de precedente. $^{784}$

O problema do teste proposto por Wambaugh é que a decisão pode estar fundada em mais de uma proposição jurídica que configure uma efetiva ratio decidendi. ${ }^{785}$ Isso ocorre, frequentemente, em cumulação de causas de pedir. Se, p.ex., o autor pede judicialmente a resolução de um contrato porque o réu teria violado uma cláusula contratual e, além disso, teria deixado de pagar uma de suas prestações obrigacionais, o juiz poderá julgar a demanda procedente por qualquer uma das alegações do autor, ou por ambas. Aceita a resolução do contrato por causa de ambas as infrações contratuais, então o teste de Wambaugh não seria suficiente para apurar qual é a ratio decidendi da sentença. Por outro lado, mais de um fundamento jurídico para o dispositivo pode ser apresentado em relação a uma mesma causa de pedir.

Obviamente, Wambaugh não ignorava essas duas situações. Na verdade, a ligação feita pelo antigo professor de Harvard entre a ratio decidendi e uma proposição jurídica que efetivamente sirva como fundamento da decisão é recorrente em sua obra. Em

\footnotetext{
${ }^{782}$ Ibidem. p. 15.

${ }^{783}$ São eles: (1) o tribunal deve decidir apenas o caso que lhe é apresentado; (2) o tribunal deve decidir o caso concreto a partir de uma regra geral; (3) a ratio decidendi não se confunde com as palavras utilizadas pelo tribunal; (4) proposições jurídicas que não foram cogitadas pelos julgadores não podem formar precedentes. V. Ibidem. p. 8-27.

${ }^{784}$ Ibidem. p. 17.

${ }^{785}$ V. CROSS, Rupert; HARRIS, J. W. Precedent in English Law. p. 53-57.
} 
primeiro lugar, Wambaugh defende que, encontrada uma solução jurídica para o caso, o julgador não deve prosseguir analisando as demais, de modo que uma decisão não deveria conter mais de uma ratio decidendi para uma mesma causa de pedir. ${ }^{786}$ Por outro lado, Wambaugh considera que a força de uma decisão como precedente é consideravelmente reduzida quando possui vários fundamentos independentes. ${ }^{787}$

\subsubsection{A desconsideração da motivação jurídica e os fatos materiais de Arthur Goodhart}

Em 1930, Arthur Goodhart publicou um polêmico artigo intitulado Determining the Ratio Decidendi of a Case. O professor estadunidense pretendia afastar-se da teoria "clássica" dos precedentes, rejeitando a própria expressão ratio decidendi, ${ }^{788} \mathrm{e}$ propondo cinco regras para a descoberta do "princípio do caso" contido na decisão que serviria como precedente para o julgamento de novos casos análogos: (1) o "princípio do caso" não se encontra na motivação da decisão; ${ }^{789}$ (2) o "princípio do caso" não se

\footnotetext{
786 WAMBAUGH, Eugene. The Study of Cases. p. 9-10: "and when the court has found one reason that clearly indicates what the court must do, it is not the duty of the court to search for still another reason upon which to base the decision; for to do this would be to waste strength".

${ }^{787}$ Ibidem. p. 34: "the value of the case is diminished if the decision of the appellate court is capable of being supported entirely upon any one of several independent points, and if the precise point upon is not announced'.

${ }^{788}$ GOODHART, Arthur. Determining the ratio decidendi of a case. p. 162: "The initial difficulty with which we are faced is the phrase 'ratio decidendi' itself. With the possible exception of the legal term 'malice', it is the most misleading expression in English law, for the reason which the judge gives for his decision is never the binding part of the precedent".

${ }^{789}$ Note-se que Goodhart havia publicado um artigo, dois anos antes, adotando inteiramente a teoria clássica e procurando a ratio decidendi exatamente na motivação da decisão. Para Marinoni, a mudança de pensamento de Goodhart foi influenciada por uma crítica sofrida, no mesmo ano, por Joseph Francis (v. Precedentes Obrigatórios. p. 225, notas 13 e 15). Com efeito, o trabalho de Francis, cujo objetivo era justamente criticar algumas das ideias de Goodhart, abordou as relações entre a ratio decidendi e os fatos levados em consideração pelo juiz para proferir a decisão: "Without impliedly approving the theories which Mr. Goodhart criticizes, it is submitted that he is here continuing the error of assuming that a court must discuss a point or in some other manner clearly indicate that it had the point in mind before that point can be considered part of the doctrine of the case. (...) There are gaps in judicial decisions just as there are gaps in statutes. When later judges or critics find facts or implications of facts overlooked in a prior decision, if these are important enough to have changed the decision had they occurred to the court, then the case is not to be decisive of those facts; if on the other hand, these facts, though material, would not have altered the decision,
} 
encontra na regra jurídica contida na motivação; (3) o "princípio do caso" não é necessariamente encontrado pela análise de todos os fatos relevantes (e provados) e da decisão judicial; (4) o "princípio do caso" é encontrado quando levados em consideração os fatos tratados pelo juiz como "materiais" e a decisão proferida a partir deles; (5) para encontrar o "princípio do caso", é preciso estabelecer quais fatos foram considerados “imateriais" pelo juiz, pois o "princípio" pode ser determinado também por exclusão. ${ }^{790}$

De acordo com Goodhart, mesmo decisões fundadas em razões equivocadas poderiam tornar-se precedentes: "uma má razão pode, às vezes, fazer bom direito". Contrariando a quarta regra básica de Wambaugh (proposições jurídicas que não foram cogitadas pelos julgadores não podem formar precedentes), Goodhart afirma que casos pautados por premissas incorretas foram capazes de criar novos "princípios" que os próprios julgadores desconheciam. ${ }^{791}$ Por isso, a ratio decidendi (ou "princípio do caso") não seria encontrada na motivação da decisão, a qual "pode ser inteiramente ignorada", 792 mas no confronto entre a decisão judicial e os fatos reputados "materiais" pelo juiz, isto é, fundamentais à tomada da decisão, ${ }^{793}$ a partir daí seria possível encontrar o "princípio do caso" que serviria de precedente para casos futuros.

A teoria de Goodhart recebeu severas críticas, em especial de Alfred Simpson e J. Montrose. Para Simpson, a teoria de Goodhart, no que é essencial, em nada difere da concepção clássica da ratio decidendi. Em primeiro lugar, a análise da ratio decidendi continua vinculada a um pronunciamento judicial; apenas houve a transferência da análise das razões jurídicas (premissa maior) para a análise das razões fáticas (premissa menor). Em segundo lugar, a ratio decidendi continua sendo o vínculo existente entre os "fatos materiais" e a conclusão judicial. ${ }^{794}$ Montrose, em sentido contrário, afirmou existir uma grande diferença entre uma teoria (clássica) que afirma que o raciocínio judicial é

then the case is decisive of those facts". V. FRANCIS, Joseph. Three cases on possession - some further observations. p. 17.

790 Os princípios foram enumerados pelo próprio autor: GOODHART, Arthur. Determining the ratio decidendi of a case. p. 182.

${ }^{791}$ Ibidem. p. 163.

792 Ibidem. p. 168.

${ }^{793}$ O autor erigiu dez regras para a determinação dos fatos "materiais" do processo. V. Ibidem. p. 182-183.

${ }^{794}$ V. SIMPSON, A. W. B. The ratio decidendi of a case (1957). p. 414. 
vinculante e outra que diz que tal raciocínio pode ser ignorado. ${ }^{795} \mathrm{De}$ acordo com Montrose, Goodhart filiava-se à concepção doutrinária de que o precedente não é formado pela própria decisão judicial proferida preteritamente, mas é construído pelo juiz que o aplica; ${ }^{796}$ tema que remete à discussão acerca da natureza da interpretação judicial (v. 7.2.1, acima).

Independentemente da discussão gerada entre Simpson e Montrose, ${ }^{797}$ certo é que a teoria de Goodhart falha duplamente. Ela mantém a base estrutural da teoria clássica (isto é, o precedente é o vínculo existente entre os "fatos materiais" e a decisão proferida), ${ }^{798}$ mas perde o elemento fundamental da teoria dos precedentes, que é justamente perpetuar a interpretação e aplicação do Direito ao longo do tempo. Ao mesmo tempo em que Goodhart vincula as decisões judiciais às que foram proferidas no passado, tratando-se, em última análise, de uma mera proposta de como encontrar precedentes implícitos, ele as torna substancialmente irrelevantes, pois permite que o juiz ignore aquilo que era mais importante - a razão pela qual aqueles fatos desencadearam determinada consequência jurídica - para criar arbitrariamente novas razões reputadas mais adequadas. Dito de outro modo, o juiz teria de analisar uma decisão pretérita para que então inventasse a ratio decidendi que entendesse conveniente.

\subsubsection{A ratio decidendi prescritiva e a ratio decidendi descritiva de Julius Stone}

Em boa parte manifestando-se sobre a proposta de Arthur Goodhart, Julius Stone defendeu a separação da ratio decidendi em dois tipos. A primeira, a que chamou de "descritiva", é aquela que descreve o processo de raciocínio pelo qual uma decisão foi

\footnotetext{
${ }^{795}$ MONTROSE. The ratio decidendi of a case. p. 594.

${ }^{796}$ Ibidem. p. 593: "Goodhart's theory, as indeed I indicated, and Stone points out, is but one of the class of theories which assert that the rule of law for which a case is of binding authority is not one which is pronounced, explicitly or implicitly, by the judge in the precedent case, but which is constructed by later judges".

${ }^{797}$ Por ele respondida em GOODHART, Arthur L. The ratio decidendi of a case. p. 117-124 (1959).

798 SIMPSON, A. W. B. The ratio decidendi of a case (1958). p. 160: “(...) Professor Goodhart's argument as to the determination of the ratio decidendi contains an internal contradiction in that, having said that the rule stated by the judge may be ignored, he then goes on to propound a theory of his own whose basic assumption is that the judge's opinion as what facts are material must be accepted".
} 
tomada. Trata-se de uma mera "explicação do raciocínio da corte para chegar à sua conclusão". A segunda, denominada de "prescritiva", busca "identificar e delimitar $o$ raciocínio a que um juízo posterior está obrigado a seguir”. Nessa segunda acepção, a ratio não deve ser explicada, mas "escolhida". 799

De acordo com Stone, a relação entre a ratio decidendi descritiva e a ratio decidendi prescritiva é, ao menos, de parcial coincidência. O grau dessa coincidência depende do método utilizado para obtenção da ratio prescritiva. Se ela der ênfase à "proposição jurídica enunciada" pelo tribunal, então deveria necessariamente confundir-se com a descritiva ou, ao menos, estar por ela englobada. Se aceita a proposta de Goodhart, p.ex., a ratio prescritiva poderia divergir da ratio descritiva. ${ }^{800}$

A distinção defendida por Stone está relacionada ao papel do juiz que aplica o precedente em um novo caso para a sua delimitação e conformação. Para Stone, são as inevitáveis escolhas feitas na aplicação do precedente que permitem a evolução do common law, de modo que a regra do stare decisis possa conviver com um "perpétuo processo de mudança" do Direito. São tais escolhas que permitem à atividade jurisdicional produzir, controlar e guiar um novo direito. Mas não em um sentido arbitrário ou que se confunda com a atividade exercida pelo Poder Legislativo. O sentido de criação jurídica pelos juízes, defende Stone, é o de escolhas entre decisões alternativas apresentadas autoritariamente ao juiz pelo próprio Direito. ${ }^{801}$

14.2.4. Ratio decidendi como razão jurídica necessária ou suficiente - as propostas de Rupert Cross e de Neil MacCormick

Para Rupert Cross, “A ratio decidendi de um caso é qualquer norma jurídica (rule of law) expressa ou implicitamente tratada pelo juiz como passo necessário à obtenção da sua conclusão, tendo em vista a linha de raciocínio por ele adotada". ${ }^{802}$ Trata-

\footnotetext{
${ }^{799}$ STONE, Julius. The ratio of the ratio decidendi. p. 600-601

${ }^{800}$ Ibidem. p. $600-601$

${ }^{801}$ Ibidem. p. 615-617.

${ }^{802}$ CROSS, Rupert; HARRIS, J. W. Precedent in English Law. p. 72: “The ratio decidendi of a case is any rule of law expressly or impliedly treated by the judge as a necessary step in reaching his conclusion, having regard to the line of reasoning adopted by him, or a necessary part of his direction to the jury".
} 
se, sem dúvida, de um resgate aprimorado do conceito de Wambaugh, ${ }^{803}$ aceitando-se não só rationes implícitas, mas também a possibilidade de que haja mais de uma ratio decidendi em uma mesma decisão.

Neil MacCormick, por sua vez, considera o conceito de Cross muito amplo, optando por restringi-lo à razão jurídica suficiente à decisão tomada. ${ }^{804}$ Ademais, refuta que a ratio decidendi seja uma "norma jurídica", ${ }^{805}$ preferindo a expressão "ruling": "Uma ratio decidendi é uma 'razão' (ruling) expressa ou implicitamente dada pelo juiz que seja suficiente para decidir uma questão jurídica discutida pelas partes, sendo um ponto sobre o qual uma 'razão' (ruling) era necessária para a justificação (ou uma de suas justificações alternativas) da decisão tomada no caso". ${ }^{806}$

Especificamente quanto à distinção entre ruling (traduzida aqui como razão) e rule of law, Cross reconhece que a norma jurídica não pode constituir uma ratio decidendi. No entanto, vale lembrar que Cross não aceita que manifestações sobre pontos jurídicos incontroversos tornem-se precedentes. Por isso, a rule of law só seria precedente enquanto norma jurídica interpretada judicialmente, o que, na prática, seria o mesmo que a ruling de MacCormick. ${ }^{807}$

Também vale ressaltar que MacCormick não inclui no conceito de ratio decidendi a justificação da própria ratio. Com isso, são obiter dicta todas as considerações voltadas à demonstração de que a ratio da decisão é a mais adequada à solução do caso concreto. $^{808}$

\footnotetext{
${ }^{803}$ Cf. DUXBURY, Neil. The Nature and the Authority of Precedent. p. 77.

${ }^{804}$ V. MACCORMICK, Neil. Rhetoric and the Rule of Law. p. 157-160.

${ }^{805}$ Crítica também feita por DUXBURY, Neil. The Nature and the Authority of Precedent. p. 77-78.

${ }^{806}$ MACCORMICK, Neil. Rhetoric and the Rule of Law. p. 153: "A ratio decidendi is a ruling expressly or impliedly given by a judge which is sufficient to settle a point of law put in issue by the parties' arguments in a case, being a point on which a ruling was necessary to his/her justification (or one of his/her alternative justifications) of the decision in the case". No Brasil, v. TUCCI, José Rogério Cruz e. Precedente Judicial como Fonte do Direito. p. 175: "A ratio decidendi, como já observado, é a essência da tese jurídica suficiente para decidir o caso concreto".

${ }^{807}$ V. CROSS, Rupert; HARRIS, J. W. Precedent in English Law. p. 72: "In practice, in the present context 'rule' and 'ruling' are used interchangeably".

${ }^{808}$ MACCORMICK, Neil. Rhetoric and the Rule of Law. p. 153.
} 


\subsubsection{O conceito de Michael Abramowicz e Maxwell Stearns}

Entre a doutrina estadunidense, Michael Abramowicz e Maxwell Stearns apresentaram, em 2005, o seguinte conceito de ratio decidendi (ou holding): ${ }^{809}$ "Uma ratio decidendi (holding) consiste naquelas proposições que, ao longo do caminho decisório escolhido, ou caminhos de raciocínio, (1) são realmente decididas, (2) estão fundadas sobre os fatos da causa, e (3) levam ao julgamento. Se não for ratio decidendi (holding), uma proposição estabelecida em um caso é considerada dicta". 810

O conceito apresenta, portanto, cinco elementos fundamentais: (a) a ratio decidendi é uma proposição; (b) essa proposição pertence a um caminho decisório adotado pelo juiz; (c) a proposição tem que ter sido efetivamente decidida; (d) a proposição tem que estar fundada sobre os fatos relevantes ao processo; (e) a proposição tem que levar à decisão.

De acordo com Abramowicz e Stearns, um juiz pode adotar diversos caminhos diferentes para chegar a uma decisão sobre o caso que lhe é apresentado. ${ }^{811}$ Esse caminho nem sempre é linear. Ele pode ser obrigado a ir para trás ou para os lados, para que então possa ir para frente. As proposições apresentadas nesse percurso devem ser consideradas rationes decidendi. A diferença entre elas e os obiter dicta está justamente na localização destes em caminhos de raciocínio ou caminhos decisórios que não decorrem dos fatos relevantes ao processo ou que não levam a lugar algum. ${ }^{812}$

Em relação à obrigatoriedade de que as proposições tenham sido efetivamente decididas, os autores não excluem a possibilidade de que haja rationes decidendi implícitas na decisão. "Efetivamente decidido", explicam, não é o mesmo que

\footnotetext{
${ }^{809}$ Embora já se tenha tentado distinguir ratio decidendi e holding, as expressões, em última análise, têm o mesmo significado. Enquanto a primeira prevalece no Reino Unido, a segunda é utilizada nos Estados Unidos.

810 ABRAMOWICZ, Michael; STEARNS Maxwell. Defining dicta. p. 113: "A holding consists of those propositions along the chosen decisional path or paths of reasoning that (1) are actually decided, (2) are based upon the facts of the case, and (3) lead to the judgment. If not a holding, a proposition stated in a case counts as dicta".

${ }^{811}$ Ibidem p. 115: "If judges cannot choose among paths, there will be virtually no holdings in cases of even modest complexity (...)".

${ }^{812}$ Ibidem. p. 114.
} 
"expressamente estabelecido"; mas também não significa que podem ser atribuídas proposições à decisão que não constam do caminho decisório adotado. ${ }^{813}$

14.2.6. A adequação da ratio de decidendi à realidade brasileira por Luiz Guilherme Marinoni - solução de questões e não de casos

Depois de realizar um profundo estudo sobre a ratio decidendi no common law, Luiz Guilherme Marinoni defende, corretamente, a sua aplicação adaptada à realidade brasileira. De acordo com o processualista, o common law é voltado à solução de casos; é um case law. Essa característica, porém, não se reproduz no Brasil. Como regra, a formação de precedentes no Direito brasileiro, seja por recurso especial, seja por recurso extraordinário, seja ainda, principalmente, pelo controle concentrado de constitucionalidade, é pautada pela discussão de questões de direito. Sendo assim, a análise da ratio decidendi não pode partir da premissa, tal qual ocorre no common law, de que a ratio é a razão pela qual um caso está sendo julgado. A ratio tem que ser a razão pela qual uma questão jurídica está sendo solucionada. ${ }^{814} \mathrm{Se}$, p.ex., são cumuladas várias causas de pedir em uma ação rescisória, e apenas uma delas é acolhida, as razões jurídicas dadas para a rejeição das demais devem ter, para Marinoni, força de precedente. ${ }^{815}$

14.2.7. A proposta de Pierluigi Chiassoni - a necessária reconstrução silogística da decisão judicial para a determinação das rationes decidendi

Em interessantíssima proposta, valendo-se da reestruturação das sentenças em silogismos judiciais, (v. 8.4.2, acima), Pierluigi Chiassoni defende que a ratio decidendi é a premissa maior de um silogismo normativo, de um silogismo interpretativo, de um silogismo classificatório ou de um silogismo de ligação contidos na decisão judicial. Dependendo da posição em que se encontra, a ratio decidendi pode ser "próxima", "remota", ou "intermediária".

\footnotetext{
${ }^{813}$ Ibidem. p. 119.

${ }^{814}$ MARINONI, Luiz Guilheme. Precedentes Obrigatórios. p. 253 e ss.

${ }^{815}$ Ibidem. p. 246.
} 
A ratio decidendi "próxima" seria o enunciado que constitui a premissa maior de um silogismo judicial de primeiro grau. A ratio decidendi "remota" seria o enunciado que constitui a premissa maior do silogismo judicial de grau mais elevado contido na decisão; tais rationes seriam razões jurídicas bastante amplas ou claramente extraíveis da decisão como premissas implícitas. E, finalmente, as rationes decidendi "intermediárias" seriam aquelas que estariam entre a ratio decidendi próxima e a ratio decidendi remota. ${ }^{816}$

Chiassoni estabelece, então, um modelo metodológico de apreensão do precedente. Em primeiro lugar, deve ser feita uma análise linguística da decisão, de modo a identificar e compreender os enunciados judiciais nela contidos, que incluem: enunciados sobre atos de produção normativa (promulgação ou ab-rogação de disposições legais, p.ex.); enunciados normativos; enunciados interpretativos; enunciados qualificatórios; enunciados sobre os fatos e as provas; enunciados relativos à argumentação jurídica das partes; enunciados decisórios etc. Em segundo lugar, a decisão deve ser reconstruída silogisticamente, como já exposto, distinguindo as diversas rationes decidendi, os obiter utiliter dicta e os obiter inutiliter dicta (v. 14.3, abaixo). Em terceiro e último lugar, deve ser efetuada a "maximização" (massimazione) da decisão. Essa etapa, importantíssima na utilização dos precedentes, trata-se de uma operação pela qual, a partir dos elementos recolhidos nas duas etapas anteriores, obtêm-se os enunciados da decisão que contenham preceitos jurídicos universais que podem servir de precedentes para novos julgamentos. ${ }^{817}$

\subsubsection{Observações conclusivas}

A distinção entre ratio decidendi e obiter dictum, como bem explicou Pierluigi Chiassoni, não é um elemento do mundo sensível que deva ser bem compreendido ou devidamente apreendido pelos juristas. Todas as teorias voltadas ao tema

\footnotetext{
${ }^{816}$ CHIASSONI, Pierluigi. La Giurisprudenza Civile. p. 176-178.

${ }^{817}$ Ibidem. p. 203-210.
} 
foram teorias prescritivas que buscaram estabelecer regras para encontrar a "melhor" ratio decidendi. ${ }^{818}$

É evidente que nem tudo pode ser ratio decidendi. Apenas razões jurídicas podem vincular tribunais inferiores (ou o próprio tribunal) porque apenas razões jurídicas são universais ou universalizáveis. Até mesmo Goodhart, que privilegiou exageradamente os aspectos fáticos do processo, não conseguiu desvincular os precedentes da ligação entre os fatos e a decisão. Por outro lado, é indiscutível que os fatos relevantes ao processo são fundamentais à compreensão e delimitação da ratio decidendi. A razão jurídica é universal ou universalizável, mas assim o é para fatos idênticos ou análogos ao que foi julgado originalmente.

Por isso, parece bastante adequada a proposta de Chiassoni de erigir como ratio decidendi as premissas maiores dos silogismos judiciais contidos na decisão, desde que tais silogismos voltem-se ao dispositivo. ${ }^{819}$ Essa forma de ver as coisas acaba conciliando várias das propostas conceituais apresentadas.

Em primeiro lugar, reconhece que a ratio decidendi é uma razão jurídica, mas não abdica da sua interação com os fatos e com o dispositivo. Afinal, a premissa maior do silogismo inevitavelmente contém uma situação fática abstrata (fattispecie à qual a premissa menor amolda-se) e uma consequência jurídica prevista para tal situação. A identificação da premissa maior do silogismo leva à automática identificação dos fatos reputados "materiais" pelo magistrado.

Em segundo lugar, a premissa maior dos silogismos contidos na decisão pode configurar tanto uma proposição jurídica necessária (Cross) como suficiente (MacCormick) ao julgamento. De qualquer forma, seria mais adequado falar em razão jurídica (ou razões jurídicas) "determinante” ao dispositivo, expressão que não amplia nem restringe demasiadamente o conceito.

\footnotetext{
${ }^{818}$ Ibidem. p. 147: "Rationes decidendi e obiter dicta non sono oggetti del mondo sensibile. Né ha senso interrogarsi su quale sia il vero significato - o il vero concetto - di 'ratio decidendi' e di 'obiter dictum' (...). Pertanto, i discordi que pretendono di definire il vero concetto di ratio decidendi e di obiter dictum sono solo apparentemente dei discosi conoscitivi; si tratta in realtà, di discorsi in funzione prescrittiva" (p. 147).

${ }^{819}$ Em sentido contrário, CROSS, Rupert; HARRIS, J. W. Precedent in English Law. p. 76: (...) it seems that it will always be possible to point to cases in which a dictum could logically have been treated as the major premiss of a syllogism of which the selected facts are the minor premiss and the decision is the conclusion".
} 
Em terceiro lugar, a compreensão das rationes decidendi como premissas maiores dos silogismos contidos na decisão permite que o precedente esteja relacionado, como defende Marinoni, à solução de questões jurídicas, e não de causas. Isso porque tanto constitui ratio decidendi a premissa maior de um silogismo normativo de primeiro grau, como a premissa maior de um silogismo interpretativo que o antecede logicamente.

Em quarto lugar, como o intérprete deve buscar as premissas maiores contidas explícita ou implicitamente na decisão precedente, a teoria propõe-se a alcançar a maior semelhança possível entre a ratio decidendi prescritiva e a ratio decidendi descritiva.

Em quinto e último lugar, não só há um respeito integral aos cinco elementos fundamentais do conceito de Abramowicz e Stearns, como torna mais clara e mais palpável a noção de "caminho decisório". A interação entre os silogismos, que tem como ápice um silogismo normativo de primeiro grau, é exatamente o "caminho decisório" escolhido pelo magistrado.

\subsection{O obiter dictum}

De um modo geral, obiter dictum é tudo aquilo que não é ratio decidendi. Chiassoni, amparado em Gorla e Galgano, distingue os obiter dicta úteis dos obiter dicta inúteis. Úteis seriam as considerações que, embora não constituam a premissa maior de um silogismo normativo, interpretativo, qualificatório ou de ligação que fundamentem o conteúdo da decisão, fazem "parte de uma argumentação jurídico-retórica acessória, formulada para reforçar ulteriormente uma premissa qualquer de um silogismo judicial". Inúteis seriam aqueles que, além de não constituírem premissa maior de um dos silogismos indicados, não fazem nem mesmo parte de uma argumentação jurídico-retórica acessória. $^{820}$

Ainda que o obiter dictum não possa ter a mesma eficácia de uma ratio decidendi, não raro são invocados, e aceitos, como argumentos persuasivos. ${ }^{821}$ Vários

\footnotetext{
${ }^{820}$ CHIASSONI, Pierluigi. La Giurisprudenza Civile. p. 184-185. Distinguindo, igualmente, os obiter dicta de acordo com a "relevância", v. CROSS, Rupert; HARRIS, J. W. Precedent in English Law. p. 76.

${ }^{821}$ V. TUCCI, José Rogério Cruz e. Precedente Judicial como Fonte do Direito. p. 177.
} 
fatores influenciam na maior ou menor eficácia persuasiva dos dicta. Um deles é o juízo prolator. Um dictum do STF certamente terá muito mais relevância do que a mesma consideração feita por um Tribunal Regional Federal; e pode ser até mesmo mais persuasivo para um tribunal do que uma ratio decidendi de outro tribunal de mesmo nível hierárquico. Outro fator relevante é o contexto em que o dictum está inserido. Se há controvérsia jurisprudencial sobre um tema, certamente um dictum a ele relativo terá menos força do que um dictum que trata de questão inédita. Por fim, ainda pode ser mencionada a diferença entre um dictum unanimemente acordado por todos os julgadores e um dictum contido no voto de um dos magistrados, mas não referendado expressamente pelos demais.

Um ótimo exemplo de obiter dictum é o que consta de acórdão do STJ assim ementado: ${ }^{822}$

PROCESSO CIVIL. CUMPRIMENTO DE SENTENÇA. NOVA SISTEMÁTICA IMPOSTA PELA LEI No 11.232/05. ART. 475-J DO CPC. DEPÓSITO DO VALOR EM EXECUÇÃO DENTRO DO PRAZO LEGAL. JUNTADA DO RESPECTIVO COMPROVANTE APÓS O DECURSO DO PRAZO. MULTA DE 10\%. NÃO INCIDÊNCIA.

- O espírito condutor das alterações impostas pela Lei $\mathrm{n}^{\circ}$ 11.232/05, em especial a multa de $10 \%$ prevista no art. 475-J do CPC, é impulsionar o devedor a cumprir voluntariamente o título executivo judicial. A redação do referido dispositivo legal é clara, privilegiando o pagamento espontâneo, nada dispondo acerca da respectiva comprovação no processo.

- Eventual omissão em trazer aos autos o demonstrativo do depósito judicial ou do pagamento feito ao credor dentro do prazo legal, não impõe ao devedor o ônus do art. 475-J do CPC. A quitação voluntária do débito, por si só, afasta a incidência da penalidade.

- Isso não significa que tal inércia não seja passível de punição; apenas não sujeita o devedor à multa do art. 475-J do CPC. Contudo, conforme o caso, pode o devedor ser condenado a arcar com as despesas decorrentes

${ }^{822}$ REsp 1047510/RS, Rel. Ministra NANCY ANDRIGHI, TERCEIRA TURMA, julgado em 17/11/2009, DJe 02/12/2009 
de eventual movimentação desnecessária da máquina do Judiciário, conforme prevê o art. 29 do CPC; ou até mesmo ser considerado litigante de má-fé, por opor resistência injustificada ao andamento do processo, nos termos do art. 17, IV, do CPC.

Recurso especial a que se dá provimento.

Percebe-se claramente que a controvérsia girava em torno da seguinte questão: a não comprovação do cumprimento da sentença no prazo legal faz incidir ao devedor a multa de $10 \%$ prevista no art. 475-J do Código de Processo Civil? A resposta dada pelo acórdão é clara: "Eventual omissão em trazer aos autos o demonstrativo do depósito judicial ou do pagamento feito ao credor dentro do prazo legal, não impõe ao devedor o ônus do art. 475-J do CPC. A quitação voluntária do débito, por si só, afasta a incidência da penalidade". Essa é a ratio decidendi do acórdão.

Contudo, há outras duas passagens indicadas na ementa. A primeira é uma assertiva relacionada à interpretação do art. 475-J, determinante à conclusão obtida em seguida e que serviu de fundamento para o julgamento. Adotando-se o modelo de ratio decidendi acima defendido (premissa maior de um silogismo normativo, interpretativo, qualificatório ou de ligação voltado ao dispositivo), então também essa razão jurídica interpretativa deve ter força de precedente (está no caminho adotado pelo Tribunal para chegar à conclusão, como diriam Abramowicz e Stearns).

A segunda passagem, por sua vez, traz uma situação hipotética ("conforme o caso"), relativa à possibilidade de que o devedor que não comprova o cumprimento da sentença no prazo legal venha a ser condenado por litigância de má-fé. Pelo simples fato de ser hipotética, já se percebe com clareza que referida assertiva não é uma ratio decidendi. ${ }^{823}$ Além disso, a assertiva é irrelevante ao julgamento do recurso. O que importava era saber se o devedor deveria pagar a multa do art. 475-J ou não. Ao abstratamente cogitar a condenação do devedor por litigância de má-fé, o acórdão não trouxe elementos para o julgamento do recurso; apenas fez uma observação "de passagem". Sendo assim, as considerações finais feitas no acórdão são um exemplo perfeito de obiter inutiliter dictum.

\footnotetext{
${ }^{823}$ Nesse sentido, ABRAMOWICZ, Michael; STEARNS Maxwell. Defining dicta. p. 123.
} 
No entanto, trata-se de uma manifestação unânime do STJ, sem declaração de voto, sobre um tema pouquíssimo debatido. Ainda que em um sistema de respeito aos precedentes tal proposição não possa (ou pelo menos não deva) ter força vinculante, não se pode dizer que se trata de passagem inapropriada ou indesejável. É um obiter dictum “inútil”, mas que configura um profícuo ato de transparência e responsabilidade, pelo qual o STJ informa como serão decididos fatos análogos caso apresentem-se com outra roupagem (litigância de má-fé) e estejam vinculados a outro pedido (condenação à multa prevista no art. 17 do CPC). O devedor passa a ter ciência de sua responsabilidade de comprovar o cumprimento da sentença no prazo legal e, em caso de desrespeito, o credor sabe o que pode exigir da outra parte.

14.4. A não aplicação de um precedente: a distinção (distinguishing)

Costuma-se dizer que a aplicação de um precedente dá-se antes por analogia do que por interpretação. Se os fatos do caso precedente são análogos ao do caso novo, então ambos devem receber a mesma solução. Isso é relativamente verdadeiro. Realmente a solução deve ser a mesma para ambos os casos, mas isso porque a consequência jurídica prevista para ambas as hipóteses deve ser a mesma. Mais do que proporcionar julgamentos idênticos a casos idênticos, o respeito a precedentes permite um tratamento jurídico idêntico a situações fáticas idênticas (ou análogas). Destarte, precedentes devem, sim, ser interpretados, de modo que se apreenda qual é a ratio decidendi do caso precedente e como essa ratio pode ser aproveitada no novo caso a ser julgado. Em última análise, interpretar e aplicar precedentes em quase nada difere da interpretação e aplicação de normas jurídicas. Em ambos os casos há um parâmetro decisório prévio que será utilizado se a situação concreta amoldar-se à fattispecie. A vantagem do precedente está em proporcionar um parâmetro fático palpável para a compreensão da norma jurídica que se pretende aplicar, e garantir que essa norma seja aplicada da forma mais homogênea possível pelos juízes.

Quando o caso concreto não coincide com a fattispecie de uma norma jurídica, então a consequência prevista pela norma não lhe é aplicável. O mesmo acontece com os precedentes. Se os fatos relevantes do caso precedente não são análogos aos do novo caso, então a ratio utilizada como fundamento daquela decisão não pode ser a ele transportada. No common law, a atividade pela qual distingue-se um caso do outro, 
afastando-se o aproveitamento de uma determinado ratio decidendi, é denominada distinguishing.

Utilizando-se mais uma vez o exemplo do EREsp $\mathrm{n}^{\circ} .108259 / \mathrm{SP}$, a premissa maior "se a liquidez da obrigação contida em um contrato de abertura de crédito bancário depende da produção unilateral de documentos pelo credor, sem a participação do devedor, então o contrato, mesmo subscrito pelo devedor e assinado por duas testemunhas, não é título executivo (rectius: não tem eficácia executiva)" tem força de precedente para todas as hipóteses fáticas em que "a liquidez da obrigação contida em um contrato de crédito bancário depende da produção unilateral de documentos pelo credor, sem a participação do devedor".

Imagine-se agora que o credor executa um contrato de distribuição cuja multa pelo inadimplemento da outra parte é calculada de acordo com o valor do produto distribuído pelo credor no dia em que o devedor for constituído em mora. Trata-se de uma indiscutível situação em que o contrato contém uma obrigação cuja liquidez depende da produção unilateral de documentos pelo credor. No entanto, é um contrato de distribuição, e não de abertura de crédito bancário. O precedente do STJ pode ser aplicado a esse novo caso? E na hipótese anteriormente citada, em que o banco executa um contrato de abertura de crédito cuja obrigação foi devidamente liquidada por extratos bancários assinados e anuídos expressamente pelo devedor? A ratio decidendi do EREsp n ${ }^{\circ}$. 108259/SP vale como precedente?

A resposta a cada uma dessas questões é justamente o que se busca com o distinguishing. E para isso, é preciso compreender adequadamente a decisão do STJ; é preciso interpretá-la. Constatando-se que a modalidade contratual é irrelevante para a formação da premissa maior da decisão, então o precedente aplica-se irrestritamente a um contrato de distribuição que contenha uma multa ilíquida ou a qualquer outro tipo de contrato que necessite de posterior integração unilateral do devedor para a obtenção de eficácia executiva. Por outro lado, é evidente que a participação do devedor na liquidação da obrigação impede uma analogia com os fatos determinantes ao julgamento do EREsp $\mathrm{n}^{\mathrm{o}}$. 108259/SP. Pode até ser que a eficácia executiva do contrato integrado pelos extratos bancários assinados pelo devedor não seja reconhecida, mas a razão jurídica, a ratio decidendi, terá de ser outra. 
A atividade de distinção de um precedente é vista como uma oportunidade de desenvolvimento do direito pela extensão e limitação dos precedentes. ${ }^{824}$ Todavia, não se pode confundir extensão e limitação de um precedente com a aplicação de rationes decidendi extraídas de silogismos interpretativos, qualificatórios, de ligação ou normativos de grau superior. Uma análise precipitada da aplicação da ratio do EREsp n ${ }^{\circ}$. 108259/SP à execução de um contrato de distribuição, p.ex., poderia levar a crer que ela foi estendida. Mas isso só seria válido se não houvesse na decisão uma ratio decidendi mais ampla, ainda que implícita, segundo a qual carece de eficácia executiva qualquer contrato cuja liquidez da obrigação nele contida dependa de documentos produzidos unilateralmente pelo credor.

\section{A experiência brasileira}

Seria ingênuo imaginar que o Brasil, por ser um país de tradição romanogermânica, desconheça a doutrina dos precedentes. Raciocinar com precedentes é o mesmo que raciocinar de forma lógica: se o caso A1 foi julgado da maneira J, então o caso A2, análogo a A1, também deve ser julgado da maneira J. Além disso, raciocinar com precedentes significa raciocinar a partir de critérios isonômicos: se João e José estão sujeitos às mesmas normas jurídicas, então devem receber a mesma resposta da jurisdição quando estiverem em situações análogas. Por isso, a aplicação de precedentes é inerente ao raciocínio jurídico e à concepção clássica de justiça da cultura ocidental.

Com efeito, o que diferencia o civil law do common law não é a existência de precedentes ou a sua utilização como argumento para influenciar a decisão judicial. Na verdade, todo sistema jurídico que produz decisãos judiciais motivadas produz, também, precedentes. No Brasil, precedentes sempre foram utilizados como elementos argumentativos de persuasão judicial; ainda que sem a tecnicidade e a precisão próprias do common law. A diferença entre uma e outra família é a importância dada aos precedentes e, em certos casos, a eficácia que lhes é atribuída.

Nos últimos anos, porém, percebe-se com clareza a crescente valorização dos precedentes em nosso país; uma valorização que deve vir acompanhada também da valorização da motivação das decisões judiciais e de uma melhor compreensão e utilização

\footnotetext{
${ }^{824}$ MARINONI, Luiz Guilherme. Precedentes Obrigatórios. p. 330-335.
} 
das rationes decidendi. Adiante serão brevemente apontados alguns dos principais institutos do Direito Processual Civil que apontam nesse sentido.

\subsection{As Súmulas}

As Súmulas certamente são o melhor exemplo de interação do Direito brasileiro com a doutrina dos precedentes judiciais.

Até a década de 60, o Supremo Tribunal Federal enfrentava o grave problema do difícil acesso a suas decisões. Os acórdãos eram publicados no Diário da Justiça sem qualquer tipo de índice ou sistematização. A busca por um precedente do Tribunal exigia o exame de cada acórdão publicado em cada um dos volumes do Diário da Justiça para que fosse possível encontrar alguma decisão eventualmente útil. Embora algumas decisões mais relevantes fossem publicadas na Revista Trimestral de Jurisprudência do STF, havia um atraso médio de três anos entre a data do julgamento e a sua divulgação; consequentemente, não raro considerava-se atual uma jurisprudência já defasada. Essa dificuldade de acesso à jurisprudência do STF era prejudicial não só para os jurisdicionados, mas também para o próprio Tribunal, cujos ministros nem sempre recordavam com precisão do que havia sido decidido anteriormente. Além disso, o desconhecimento das decisões do Tribunal gerava uma inconsistência nos julgamentos, sempre variáveis e dependentes da específica composição da Turma ou do Plenário em cada dia. $^{825}$

A primeira solução dada para o problema foi publicar, além do dispositivo, ementas dos acórdãos, pelas quais era apresentado um resumo do que se discutia no processo (fatos relevantes) e da motivação da decisão (ratio decidendi). A medida, como explicou o Ministro Victor Nunes Leal, "embora por um processo de consulta ainda bastante penoso para os advogados", permitia-lhes "conhecer, com o intervalo de mês e meio, através das ementas, como o Supremo Tribunal está decidindo tais ou quais questões". ${ }^{826}$ Outras providências foram tomadas em seguida para facilitar o acesso às decisões do Supremo, como a publicação semanal, a partir de novembro de 1962, de um

\footnotetext{
${ }^{825}$ Cf. LEAL, Victor Nunes. A renovação de métodos do Supremo Tribunal e a súmula de sua jurisprudência dominante. p. $45-46$ e 49.

${ }^{826}$ Ibidem. p. 46-47.
} 
suplemento de jurisprudência no Diário da Justiça precedido de índice - o qual foi sucessivamente melhorado ao longo do tempo. ${ }^{827}$

Quanto à inconsistência dos julgamentos, a solução estava em prestigiar a jurisprudência do STF, o que também resolveria o problema do excessivo número de recursos a serem julgados. Em passagem extremamente lúcida, afirmou o Ministro Victor Nunes Leal: "Impunha-se, portanto, uma providência que, em regra, fizesse prevalecer a jurisprudência predominante do Supremo Tribunal, mesmo nos casos em que a maioria ocasional em uma ou outra sessão do julgamento pudesse pensar de modo contrário. Com essa medida, se garantiria a coerência do Tribunal considerado como instituição permanente, e não apenas como soma eventual das opiniões dos Ministros". ${ }^{828}$ Nasce então, em 30 de agosto de 1963, a Súmula da Jurisprudência Predominante do Supremo Tribunal, posteriormente implantada nos demais tribunais brasileiros. ${ }^{829}$

\subsubsection{Conceito}

Como se sabe, súmula é um resumo, uma resenha, um relatório. A Súmula da Jurisprudência Predominante é um resumo da jurisprudência do Tribunal, onde são incluídos enunciados que apresentam o entendimento consolidado sobre determinada questão jurídica. Em síntese, trata-se de um compêndio de rationes decidendi resumidas e estruturadas administrativamente pelo próprio tribunal que as produziu. Citando mais uma vez o seu idealizador, o Ministro Victor Nunes Leal, a Súmula "Não é uma interpretação obrigatória para os outros tribunais, mas é um método de divulgação oficial da nossa jurisprudência, de consulta e manuseio extremamente fáceis, permitindo aos interessados conhecer, de imediato, sobre as questões compendiadas na Súmula, qual é o pensamento atualmente dominante no Supremo Tribunal". 830

\footnotetext{
${ }^{827}$ Ibidem. p. 47.

${ }^{828}$ Ibidem. p. 49-50.

${ }^{829}$ No Tribunal de Justiça do Estado do Paraná, p.ex., o primeiro enunciado sumular data de 20 de junho de 1977.

${ }^{830}$ LEAL, Victor Nunes. A renovação de métodos do Supremo Tribunal e a súmula de sua jurisprudência dominante. p. 51.
} 
15.1.2. As Súmulas e a doutrina de precedentes: os enunciados sumulares são rationes decidendi

A Súmula é considerada um meio-termo entre os assentos da Casa de Suplicação lusitana e os prejulgados então existentes na vigência do CPC de 1939 (art. 861). ${ }^{831}$ No entanto, nenhum dos dois compartilha da estrutura precedental básica das Súmulas.

Antes de constituírem precedentes, os assentos eram atos de autoridade voltados à uniformização jurisprudencial. $\mathrm{O}$ objetivo era similar ao do julgamento com base em precedentes, mas a partir de uma estrutura significativamente diversa. Os assentos eram produzidos pelo Regedor, antes de proferida a decisão, diante das "dúvidas" dos desembargadores a respeito "do entendimento" de "alguma Ordenação" (Ord. Man., 5, 58, $\S 1$ e Ord. Fil., 1, 5, §5). Assentado o entendimento duvidoso, então a sentença deveria ser necessariamente proferida de acordo com a interpretação dada à legislação. Essa "consulta legislativa" obrigatória, muito parecida com a que foi instituída na França pósrevolucionária, manteve-se inalterada sob a vigência da Lei da Boa Razão de 1769, tornando-se imperiosa a criação de um “Assento, que firme a genuína intelligencia da Lei antes que se julgue o direito das partes". ${ }^{832}$ Os assentos, portanto, não eram precedentes, mas manifestações originais e exteriores a um processo judicial. Exatamente o mesmo pode ser dito do art. 861 do CPC de 1939, segundo o qual a Câmara ou turma julgadora de um tribunal manifestava-se previamente sobre a interpretação de uma norma jurídica a requerimento de qualquer de seus juízes, independentemente da vinculação a um processo judicial. ${ }^{833}$ Também lá a manifestação carecia de natureza verdadeiramente jurisdicional, tratando-se de um "prejulgado".

Os enunciados sumulares, por outro lado, não são manifestações prévias sobre questões que possam vir a surgir, mas rationes decidendi organizadas e sintetizadas, extraídas de acórdãos do próprio tribunal. As Súmulas, ao contrário dos assentos e dos

\footnotetext{
${ }^{831}$ Ibidem. p. 49-51; Idem. Passado e futuro da súmula do STF. p. 289-291.

${ }^{832}$ Trecho transcrito por TUCCI, José Rogério Cruz e. Precedente Judicial como Fonte do Direito. p. 143.

833 “Art 861. A requerimento de qualquer de seus juizes, a Câmara, ou turma julgadora, poderá promover o pronunciamento prévio das Câmaras reunidas sobre a interpretação de qualquer norma jurídica, se reconhecer que sobre ela ocorre, ou poderá ocorrer, divergência de interpretação entre Câmaras ou turmas”.
} 
prejulgados, não inovam na interpretação do Direito, nem trazem nenhum elemento novo à jurisprudência. São, apenas, a consolidação e a divulgação reforçada de precedentes já existentes. Quando se lê, p.ex., no enunciado 485 da Súmula do STJ que "A Lei de Arbitragem aplica-se aos contratos que contenham cláusula arbitral, ainda que celebrados antes da sua edição", o que se tem, na verdade, é a consolidação de uma ratio decidendi que já vinha sendo exposta em reiterados julgados (REsp 712.566/RJ, REsp 791.260/RS, REsp 934.771/SP etc). Em outras palavras, uma razão jurídica utilizada como fundamento de decisões pretéritas.

O próprio Ministro Victor Nunes Leal já apontou com propriedade a natureza da atividade sumular: "um método de trabalho, um instrumento de autodisciplina do Supremo Tribunal, um elemento de racionalização da atividade judiciária, que simplifica a citação de precedentes, elimina afanosas pesquisas e dispensa referência especial (...)". ${ }^{834}$ Nesse sentido, as Súmulas são muito mais parecidas com o rotuli franceses ou os Year Books ingleses (v. 5.3, acima) do que com os assentos lusitanos. As razões da instituição dos três, aliás, são surpreendentemente similares: divulgação da jurisprudência, indicação aos próprios julgadores de como casos análogos foram decididos e promoção de julgamentos coerentes e consistentes.

Desse modo, não obstante decorra de um "procedimento administrativo" 835 e tenha natureza efetivamente administrativa, a Súmula de um tribunal promove a doutrina dos precedentes e aproxima-se do common law ao identificar rationes decidendi e estimular a sua replicação em casos futuros.

15.2. A Súmula vinculante

Na essência, a Súmula vinculante, prevista no art. 103-A da Constituição da República, ${ }^{836}$ em nada distingue das Súmulas "normais". Continua sendo um "resumo" da

\footnotetext{
${ }^{834}$ LEAL, Victor Nunes. A súmula do Supremo Tribunal e o Restatement of the Law dos norte-americanos. p. 63.

${ }^{835}$ Cf. TALAMINI, Eduardo. Novos Aspectos da Jurisdição Constitucional Brasileira. p. 116.

836 “Art. 103-A. O Supremo Tribunal Federal poderá, de ofício ou por provocação, mediante decisão de dois terços dos seus membros, após reiteradas decisões sobre matéria constitucional, aprovar súmula que, a partir de sua publicação na imprensa oficial, terá efeito vinculante em relação aos demais órgãos do Poder
} 
jurisprudência do STF, em que são inseridas compilações de reiteradas rationes decidendi. O que diferencia a Súmula vinculante das demais é justamente a eficácia vinculante que atribui às rationes decidendi nela inseridas; além, é claro, do procedimento administrativo exigido para a aprovação de seus enunciados.

Muito se discutiu sobre a constitucionalidade da Súmula vinculante quando da edição da Emenda Constitucional $n^{\circ}$. 45. Imaginava-se que a concessão de efeito vinculante à jurisprudência pacífica do STF implicaria violação da separação entre os Poderes pelo exercício de atividade legiferante pelo STF e atentado ao suposto (e inexistente!) livre convencimento jurídico dos juízes hierarquicamente inferiores.

Ambas as críticas já foram devidamente afastadas nos pontos anteriores. A obrigatoriedade dos precedentes do STF, além de não se confundir com a criação de normas jurídicas, ${ }^{837}$ é (ou deveria ser) uma consequência natural da função exercida pelo Tribunal no sistema judiciário brasileiro. É insensato dar ao Supremo a função de homogeneizar a interpretação da Constituição e, ao mesmo tempo, permitir que um juiz substituto de uma comarca de entrância inicial tenha a faculdade de ignorar as suas decisões. A Súmula vinculante, portanto, vem tardiamente resolver parte do problema gerado pela inconsistência da jurisprudência.

É interessante notar que muito se exaltou a Súmula vinculante como solução para a morosidade da Justiça, mas nem sempre ficou claro que a diminuição do número de processos e de recursos era uma consequência natural da segurança jurídica promovida pelo instituto. A partir do momento em que o Supremo firma um entendimento obrigatório para todos os demais juízos, é evidente que as partes se sentirão desestimuladas a contrariá-lo ou a ingressar em uma aventura judicial na esperança de ver o seu caso julgado diferentemente dos demais.

\footnotetext{
Judiciário e à administração pública direta e indireta, nas esferas federal, estadual e municipal, bem como proceder à sua revisão ou cancelamento, na forma estabelecida em lei”.

${ }^{837}$ Isso está muito claro no $\S 1^{\circ}$ do art. 103-A da CR: "A súmula terá por objetivo a validade, a interpretação e a eficácia de normas determinadas, acerca das quais haja controvérsia atual entre órgãos judiciários ou entre esses e a administração pública que acarrete grave insegurança jurídica e relevante multiplicação de processos sobre questão idêntica".
} 
15.3. Decisões monocráticas amparadas em entendimento jurisprudencial consolidado e a "súmula impeditiva de recursos"

De acordo com o art. 557 do CPC, o relator poderá negar seguimento a recurso que esteja em confronto com súmula ou com jurisprudência dominante do respectivo tribunal, do Supremo Tribunal Federal, ou de Tribunal Superior. Em situação inversa, o relator também poderá dar provimento monocrático ao recurso interposto contra decisão que contraria súmula ou jurisprudência dominante do Supremo Tribunal Federal, ou de Tribunal Superior (art. 557, $\S 1^{\circ}$-A, do CPC).

Ambos os dispositivos consagram e dão eficácia à jurisprudência dos tribunais, evitando a propagação de decisões que contrariam um entendimento jurídico prevalecente. Note-se que os dispositivos não se referem a jurisprudência pacífica, mas a “jurisprudência dominante", dando margem para decisões monocráticas amparadas em jurisprudência controvertida.

A promoção da jurisprudência dos Tribunais Excepcionais foi intensificada em 2006 pela inclusão no Código de Processo Civil do art. 518, §1 $1^{\circ}$. “O juiz não receberá o recurso de apelação quando a sentença estiver em conformidade com súmula do Superior Tribunal de Justiça ou do Supremo Tribunal Federal”. Isso significa que as súmulas do STJ e do STF, mais do que permitir decisões monocráticas dos tribunais, impedem a própria interposição de recursos de apelação que as contrariem.

Além disso, em 2010, a Lei 12.322 alterou a redação do art. 544 do CPC e incluiu o inciso II ao $\S 4^{\circ}$. Como consequência, interposto agravo contra decisão que não admitiu recurso extraordinário ou recurso especial, o relator poderá, se o acórdão recorrido estiver em confronto com súmula ou jurisprudência dominante no tribunal (art. 544, $\AA^{\circ}$, II, ' $b$ ' e 'c'), tanto negar seguimento como dar provimento desde logo ao recurso especial ou extraordinário.

\subsection{Os "recursos repetitivos"}

Outro instituto moderno que possui íntima relação com a doutrina dos precedentes é o dos "recursos repetitivos", regulado pelo art. 543-C do CPC, o qual foi incluído pela Lei 11.672/2008. Pela sistemática dos "recursos repetitivos", "quando houver multiplicidade de recursos [especiais] com fundamento em idêntica questão de direito" 
(caput), “caberá ao presidente do tribunal de origem admitir um ou mais recursos representativos da controvérsia, os quais serão encaminhados ao Superior Tribunal de Justiça, ficando suspensos os demais" $\left(\S 1^{\circ}\right)$. Fixada a ratio decidendi pelo STJ, duas são as alternativas: ou (a) o acórdão recorrido coincide com a jurisprudência firmada; ou (b) o acórdão recorrido diverge da jurisprudência firmada. Se o acórdão coincidir com o entendimento do STJ (a), então o recurso especial tem seguimento denegado ( $\left(7^{\circ}, \mathrm{I}\right)$. Se o acórdão divergir do entendimento do STJ (b), então a apelação será reapreciada pelo juízo a quo, o qual poderá retratar-se $\left(\S 7^{\circ}, \mathrm{II}\right) .{ }^{838}$

Procedimento muito semelhante já havia sido estabelecido pela Lei 11.418/2006 para a apreciação de repercussão geral de recurso extraordinário (art. 543-B do CPC). Também aqui são escolhidos recursos representativos da controvérsia constitucional, suspendendo-se os demais na origem. Firmado um posicionamento pelo STF, ou os recursos sobrestados não são admitidos (caso inexista repercussão geral), ou abre-se ao juízo a quo a possibilidade de retratação $\left(\S \S 2^{\circ}\right.$ e $\left.3^{\circ}\right)$. Se o acórdão divergente for mantido, e o recurso extraordinário admitido, o STF poderá cassá-lo ou reformá-lo liminarmente $\left(\S^{\circ}\right)$.

Note-se que em nenhuma das hipóteses os tribunais devem seguir, obrigatoriamente, a jurisprudência do STJ e do STF. Os precedentes gerados em julgamento de recursos repetitivos são, assim como as súmulas impeditivas de recursos, vinculantes apenas às partes, e não aos tribunais inferiores. Ainda assim, a imposição de uma reanálise da decisão divergente pelo tribunal de origem é representativa, pois rompe com a suposta liberdade absoluta de livre convencimento dos juízes. Os "recursos

\footnotetext{
${ }^{838}$ A redação do art. 543-C, $7^{\circ}$, II, do CPC é falha, pois dispõe que "os recursos especiais sobrestados na origem" $\left(\S 7^{\circ}\right)$ "serão novamente examinados pelo tribunal de origem" ( $\$ 7^{\circ}$, II). Ora, é evidente que o recurso especial não pode ser "novamente examinado" pelo tribunal de origem, seja porque ele não foi examinado anteriormente, seja porque não compete ao tribunal de origem julgar recursos especiais. $\mathrm{O}$ que o dispositivo quer dizer é que a apelação deverá ser reapreciada, podendo o juízo a quo retratar-se e, então, adotar a mesma ratio decidendi do STJ. Nesse sentido, o Regimento Interno do TJPR é muito mais preciso: “Art. 109. Publicado o acórdão dos Tribunais Superiores, com o julgamento de mérito da questão controvertida, os recursos sobrestados serão conclusos ao $1^{\circ}$ Vice-Presidente para: (...) II. submeter os autos ao órgão julgador competente para juízo de retratação quando constatada a divergência entre o acórdão recorrido e a orientação do respectivo Tribunal Superior". V. CAMARGO, Luiz Henrique Volpe. A força dos precedentes no moderno Processo Civil brasileiro. p. 611.
} 
repetitivos" certamente contribuem para a conscientização de que os precedentes dos tribunais superiores devem ser conhecidos e respeitados pelos juízos inferiores.

15.5. O efeito vinculante dos acórdãos prolatados em controle concentrado de constitucionalidade

As decisões definitivas de mérito proferidas pelo STF em ações diretas de inconstitucionalidade e ações declaratórias de constitucionalidade possuem, como disposto no art. $102, \S 2^{\circ}$, da CR, eficácia erga omnes e efeito vinculante a todos os órgãos do Poder Judiciário e da Administração direta e indireta. Exatamente o mesmo pode ser extraído do art. 28, parágrafo único, da Lei 9.868/99.

Enquanto a eficácia erga omnes de tais decisões está relacionada aos efeitos produzidos pelo dispositivo, de modo que não se restrinjam apenas às partes do processo, a eficácia vinculante está relacionada, como já foi várias vezes repetido neste Capítulo, à motivação da decisão. ${ }^{839}$

Nem sempre a distinção entre eficácia erga omnes e efeito vinculante é clara, não obstante seja de grande importância. Se o Supremo declarar a constitucionalidade de uma lei estadual, p.ex., essa decisão produz efeitos de forma irrestrita, de modo que a sua constitucionalidade não poderá ser rediscutida em novos processos. Esse é um desdobramento da eficácia erga omnes da decisão. No entanto, também a ratio decidendi da decisão produz efeitos vinculantes aos demais órgãos do Judiciário. ${ }^{840}$ Se a mesma discussão for travada envolvendo uma lei análoga de outro Estado da Federação, então as razões dadas pelo Supremo na decisão paradigma deverão ser seguidas pelos juízos inferiores. Perceba-se que na segunda hipótese a eficácia erga omnes do acórdão não se aplica a leis distintas daquela que foi declarada constitucional; o que importa aqui é justamente o efeito vinculante da motivação.

Também não se pode confundir a eficácia desconstitutiva da decisão do STF que invalida uma lei inconstitucional, a qual deixa de existir no ordenamento jurídico, com o efeito vinculante que lhe é constitucionalmente atribuído. A "declaração" (rectius:

\footnotetext{
${ }^{839}$ V. MENDES, Gilmar Ferreira et alii. Curso de Direito Constitucional. p. 1325 e ss.

${ }^{840}$ V. Ibidem. p. 1337.
} 
decretação) de inconstitucionalidade de uma lei, ao menos no controle concentrado de constitucionalidade, implica a sua eliminação do ordenamento jurídico. Logo, o desrespeito de tal decisão por um juiz de primeiro grau tem duas consequências: (a) ele aplica uma lei que não existe mais; e (b) ele contraria o dispositivo da decisão do Supremo,

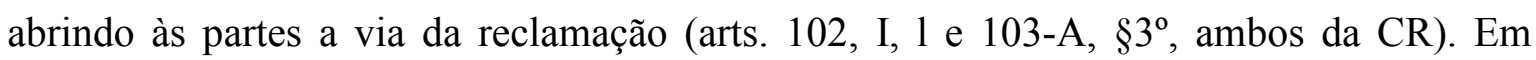
qualquer hipótese, a decisão dissidente fere a eficácia erga omnes que é atribuída à decisão desconstitutiva. Por outro lado, o efeito vinculante da decisão do Supremo permite que as razões dadas para que a lei fosse considerada inconstitucional também sejam, obrigatoriamente, usadas em processos que venham discutir questões jurídicas análogas. É o caso, repete-se, da lei estadual de outro Estado da Federação que padece da mesma inconstitucionalidade; ou, tratando-se da Administração Pública, fica vedada a elaboração de novo ato administrativo normativo que incida no mesmo tipo de inconstitucionalidade.

Em resumo, "a eficácia da decisão do Tribunal transcende o caso singular, de modo que os princípios dimanados da parte dispositiva e dos fundamentos determinantes sobre a interpretação da Constituição devem ser observados por todos os tribunais e autoridades nos casos futuros", 841

\subsubsection{Eficácia vinculante de decisão proferida em $A D P F$}

Em sentido idêntico ao que foi exposto no ponto anterior, o art. $10, \S 3^{\circ}$, da Lei 9.882/99 atribui eficácia erga omnes e efeito vinculante também às decisões proferidas pelo Supremo em Arguição de Descumprimento de Preceito Fundamental.

15.5.2. A "objetivação" do controle de constitucionalidade difuso e a teoria da transcendência dos motivos determinantes

Vem-se difundindo nos últimos anos a tese de que os "motivos determinantes" de decisões proferidas em julgamento de recursos extraordinários teriam, igualmente, efeito vinculante. Apesar do disposto no art. 52, X, da CR, a tese parte do pressuposto de que a objetivação dos recursos extraordinários aproximou o controle difuso

${ }^{841}$ Ibidem. p. 1334. 
de constitucionalidade do controle concentrado. ${ }^{842}$ Desse modo, o sentido do art. $52, \mathrm{X}$, da CR teria sofrido mutação: o Senado não eliminaria mais a lei ou ato normativo inconstitucionais do ordenamento jurídico, mas apenas daria publicidade à decisão do Supremo. ${ }^{843}$

Independentemente do acerto da tese, ${ }^{844}$ trata-se de mais um movimento no sentido de conferir eficácia vinculante às decisões do Supremo, aumentando a importância da doutrina dos precedentes e da motivação das decisões judiciais no Brasil.

15.6. Resolução liminar de causas repetitivas: o art. 285-A do CPC

Por fim, vale ser citado o instituto da resolução liminar de causas repetitivas, previsto no art. 285-A do CPC, que foi introduzido pela Lei 11.277/2006. A redação do dispositivo é a seguinte: “Quando a matéria controvertida for unicamente de direito e no juízo já houver sido proferida sentença de total improcedência em outros casos idênticos, poderá ser dispensada a citação e proferida sentença, reproduzindo-se o teor da anteriormente prolatada".

Extrai-se do dispositivo, portanto, que, tratando-se de processo que envolva questão jurídica já julgada no juízo, poderá o magistrado dispensar a citação do réu e reproduzir a sentença anterior, julgando ambos os casos de maneira idêntica; desde, é claro, que a sentença seja de improcedência, favorecendo o próprio réu não citado.

Com a peculiaridade de atribuir eficácia a precedentes horizontais, a estrutura básica de aplicação do art. 285-A do CPC é exatamente a mesma da doutrina dos precedentes. Aproveita-se a ratio decidendi ("matéria controvertida for unicamente de direito") utilizada para decidir um caso pretérito no julgamento de um caso análogo e posterior (“casos idênticos").

O objetivo principal da referida norma processual não é a segurança jurídica, mas a celeridade processual. Utilizam-se precedentes para reduzir o número de

\footnotetext{
${ }^{842}$ V. DIDIDER JR., Fredie; CUNHA, Leonardo José Carneiro da. Curso de Direito Processual Civil, v. 3. p. 274 e ss.

${ }^{843}$ V. MENDES, Gilmar Ferreira et alii. Curso de Direito Constitucional. p. 1133 e ss.

${ }^{844}$ Em sentido crítico, v. TALAMINI, Eduardo. Novos Aspectos da Jurisdição Constitucional Brasileira. p. 238 e ss.
} 
atos processuais (e cartoriais) e dispensar uma desnecessária análise pormenorizada e específica de um caso cuja ratio decidendi já está bem definida. Ainda assim, o instituto promove a segurança jurídica ao proporcionar julgamento idêntico a casos idênticos. 


\section{CAPÍTULO SEXTO - A MOTIVAÇÃO DAS DECISÕES JUDICIAIS E A PROTEÇÃO DA CONFIANÇA LEGÍTIMA DO JURISDICIONADO}

Tratou-se no Capítulo Quinto da função de promoção da segurança jurídica objetiva exercida pela motivação. Mas a motivação, consubstanciada em precedentes e jurisprudência, também interfere na segurança jurídica subjetiva, ou simplesmente “confiança legítima” do jurisdicionado. Ao motivar uma decisão, o Estado-juiz apresenta ao jurisdicionado uma determinada maneira de compreender e aplicar o Direito, criandolhe, em muitos casos, expectativas legítimas que devem ser protegidas. Neste Capítulo serão apresentadas noções gerais do princípio da proteção da confiança legítima (16), para então defender que também a jurisprudência gera confiança no jurisdicionado digna de proteção (17). Por fim, o último ponto abordará algumas técnicas de preservação da confiança legitimamente depositada pelo particular na jurisdição (18).

\section{O princípio da proteção da confiança legítima}

É fato que o Estado, ao proibir a autotutela e assumir para si a função jurisdicional, deve, como contrapartida, prestá-la efetiva e tempestivamente aos cidadãos, realizando os direitos subjetivos e protegendo o Direito adequadamente. Esse mesmo raciocínio vale, de forma mais ampla, às relações entre Estado e indivíduo. A partir do momento em que o Estado assumiu para si o papel de regular a sociedade, determinar a produção do Direito, e aplicar esse Direito, então deve, como contrapartida, fazê-lo de forma efetiva, clara, segura, íntegra e leal.

Todo o funcionamento estatal é fundado sobre o respeito e a observância do Direito. O legislador deve elaborar normas materialmente justificadas na Constituição, respeitando-se sempre o direito adquirido, o ato jurídico perfeito e a coisa julgada; o administrador deve praticar atos obrigatoriamente constitucionais e legais, pautando-se pelos princípios da legalidade, impessoalidade, moralidade, publicidade e eficiência (art. 37 da $\mathrm{CF}$ ); e a probabilidade de que isso ocorra é, supõe-se, tão grande que seus atos administrativos são presumidamente legítimos; e o juiz deve fazer com que esse Direito 
seja respeitado, seja pelo Estado, seja pelos particulares, realizando os direitos subjetivos das pessoas.

Ora, se o Estado age (ou ao menos deve agir) pelo Direito e para o Direito, e se os atos estatais são presumidamente legítimos, então o indivíduo deve ter condições de confiar no Estado; ${ }^{845}$ de confiar em seus atos; de confiar em seu Direito; e de confiar na maneira pela qual esse Direito é aplicado. Acima de tudo, o indivíduo deve poder confiar naquilo que o Estado lhe apresenta como sendo correto e jurídico; e quando confia, confia de maneira legítima. Nas palavras de Sylvia Calmes, o "indivíduo deve poder evoluir em um ambiente jurídico estável e previsível, no qual ele possa confiar". ${ }^{846}$ A necessária proteção dessa confiança do indivíduo no Estado é representada pelo "princípio da proteção da confiança legítima". ${ }^{847}$

\subsection{Conceito}

A confiança legítima não se confunde com a estabilidade das situações jurídicas e não configura direito adquirido ou vedação à retroatividade dos atos normativos; possui, na verdade, maior abrangência do que a simples irretroatividade normativa, ainda que ambas visem à promoção da estabilidade do Direito. ${ }^{848}$ A confiança legítima protege expectativas jurídicas concretas (e não direitos adquiridos), criadas por um comportamento do Estado, que venham a ser frustradas posteriormente pela revogação ou invalidação daquele comportamento ou desfeitas por um novo comportamento estatal contraditório ou incompatível com o anterior. Almiro do Couto e Silva ensina que o princípio “(a) impõe ao Estado limitações na liberdade de alterar sua conduta e de modificar atos que produziram vantagens para os destinatários, mesmo quando ilegais, ou

\footnotetext{
${ }^{845}$ V. VALIM, Rafael. O Princípio da Segurança Jurídica no Direito Administrativo Brasileiro. p. 111: "neste contexto, não só o administrado pode como deve confiar na ação do Estado".

${ }^{846}$ CALMES, Sylvia. Du Príncipe de Protection de la Confiance Légitime... p. 31. No original: "Le principe étudié signifie que l'individu doit pouvoir évoluer dans un milieu juridique stable et prévisible, dans lequel il peut avoir confiance".

847 Também denominado de principe de protection de la confiance legitime (francês); principio dell'affidamento incolpevole (italiano); principle of protection of legitimate expectations (inglês); principio de la confianza legítima (espanhol); Vertrauensschutzprinzip (alemão).

${ }^{848}$ Cf. VALEMBOIS, Anne-Laure. La Constitutionnalisation... p. 232.
} 
(b) atribui-lhe consequências patrimoniais por essas alterações, sempre em virtude da crença gerada nos beneficiários, nos administrados ou na sociedade em geral de que aqueles atos eram legítimos, tudo fazendo razoavelmente supor que seriam mantidos". ${ }^{849}$

\title{
16.2. Origem
}

Embora traços do princípio da proteção da confiança legítima possam ser encontrados já ao final do século XIX na doutrina de E. Levy, a sua origem remonta à década de 20, quando a doutrina alemã começou a tratar do tema e a jurisprudência administrativa francesa consagrou expressamente a vedação a mudanças bruscas de comportamento do Estado. ${ }^{850} \mathrm{~A}$ importante aplicação do princípio pela jurisprudência suíça na década de 30 faz com que, não raro, considere-se ter sido esse o momento de seu surgimento. ${ }^{851}$ De todo modo, foi após a Segunda Guerra Mundial que a proteção da confiança legítima desenvolveu-se com vigor, tanto na Suíça como, principalmente, na Alemanha ocidental. ${ }^{852}$ Também foi a partir da década de 50 que a confiança legítima começou a ser protegida pelo Tribunal de Justiça da União Europeia (então Tribunal de Justiça das Comunidades Europeias). Ao julgar o caso Algera e outros contra Assembleia Comum da Comunidade Europeia do Carbono e do Aço, em 1957, o Tribunal fez constar na decisão:

\begin{abstract}
"Um estudo de direito comparado demonstra que nos seis Estadosmembros um ato administrativo que confira direitos subjetivos ao interessado não pode, em princípio, ser revogado, se se trata de um ato legal; neste caso, tendo sido adquirido o direito subjetivo, a necessidade
\end{abstract}

\footnotetext{
849 COUTO E SILVA, Almiro do. O princípio da segurança jurídica (proteção à confiança) no Direito Público brasileiro... p. 4-5.

${ }^{850}$ Cf. CALMES, Sylvia. Du Príncipe de Protection de la Confiance Légitime... p. 9-11

${ }^{851}$ P. ex., CHEVALLIER, Jacques. L'État de Droit. p. 98.

${ }^{852}$ V. CALMES, Sylvia. Du Príncipe de Protection de la Confiance Légitime... p. 9 e ss. ; SCHNEIDER, Jens-Peter. Seguridad jurídica y protección de la confianza... p. 249-250; COUTO E SILVA, Almiro do. $O$ princípio da segurança jurídica (proteção à confiança) no Direito Público brasileiro... p. 7-8.
} 
de proteger a confiança na estabilidade da situação criada prevalece sobre o interesse da administração de rever sua decisão". ${ }^{853}$

O princípio da confiança encontrou terreno fértil para se consolidar no Estado Social, uma vez que o próprio destino do indivíduo passou a depender da constância e retidão do comportamento estatal. ${ }^{854}$ Atualmente, por influência germânica, o princípio está largamente difundido na União Europeia, sendo aplicado não só pelo Tribunal de Justiça, ${ }^{855}$ mas sobretudo pela Corte Europeia dos Direitos Humanos. ${ }^{856}$

\subsection{Fundamentos}

O princípio da confiança legítima é muitas vezes considerado uma exigência de justiça e de equidade associada à dimensão material do Estado de Direito. ${ }^{857}$ Não

${ }^{853}$ TJUE C-3/57. Na versão francesa: "Une étude de droit comparé fait ressortir que dans les six États membres un acte administratif conférant des droits subjectifs à l'intéressé ne peut eu principe pas être retiré, s'il s'agit d'un acte légal; dans ce cas, le droit subjectifétant acquis, la nécessité de sauvegarder la confiance dans la stabilité de la situation ainsi créée l'emporte sur l'intérêt de l'administration qui voudrait revenir sur sa décision. Cela vaut notamment pour la nomination d'un fonctionnaire".

${ }^{854}$ Cf. CALMES, Sylvia. Du Príncipe de Protection de la Confiance Légitime... p. 7-8 ; igualmente, COUTO E SILVA, Almiro do. O princípio da segurança jurídica (proteção à confiança) no Direito Público brasileiro... p. 6.

${ }^{855}$ De acordo com Thomas PIAZZON, a segurança jurídica e a confiança legítima são mencionadas em cerca de 10\% das decisões do Tribunal. V. La Securité Juridique. p. 370.

${ }^{856}$ P.ex., CEDH, Broniowski x Polônia, Pedido no . 31443/96, j. em 22 de junho de 2004. Na versão francesa: "Le principe de l'Etat de droit, qui sous-tend la Convention, ainsi que le principe de légalité consacré par l'article 1 du Protocole $n^{o} 1$ exigent des Etats non seulement qu'ils respectent et appliquent, de manière prévisible et cohérente, les lois qu'ils ont adoptées, mais aussi, corrélativement à cette obligation, qu'ils garantissent les conditions légales et pratiques de leur mise en cuvre (paragraphe 147 ci-dessus). Dans le cadre de la présente affaire, il incombait aux autorités polonaises de supprimer l'incompatibilité existante entre la lettre de la loi et la pratique adoptée par l'Etat qui faisait obstacle à l'exercice effectif du droit patrimonial du requérant. Ces principes exigeaient également de l'Etat polonais l'accomplissement en temps utile, de façon correcte et avec cohérence, des promesses législatives qu'il avait formulées quant au règlement des demandes concernant des biens situés au-delà du Boug. Il s'agissait d'une cause générale et importante d'intérêt public (paragraphe 150 ci-dessus). Comme la Cour constitutionnelle polonaise l'a souligné à juste titre (paragraphe 82 ci-dessus), la nécessité de maintenir la confiance légitime des citoyens en l'Etat et en ses lois, inhérente à l'Etat de droit, exigeait que les autorités éliminent de l'ordre juridique les dispositions entraînant des dysfonctionnements et corrigent les pratiques contraires à la loi".

${ }^{857}$ Nesse sentido, VALEMBOIS, Anne-Laure. La Constitutionnalisation de l'Exigence de Sécurité Judirique en Droit Français. p. 59-62. 
obstante já se tenha afastado a validade de um "Estado de Direito material", certo é que a violação da confiança legítima afronta o senso comum de justiça, impondo ao particular um dano pela falta de retidão do Estado. De todo modo, é possível encontrar fundamentos mais técnicos e mais sólidos para a confiança legítima, vinculando-a à segurança jurídica e à boa-fé.

\subsubsection{Confiança legítima e segurança jurídica objetiva}

O primeiro e mais importante fundamento da proteção da confiança legítima é a segurança jurídica. ${ }^{858}$ De um lado, a proteção da confiança está ligada à preservação de situações jurídicas subjetivas já consolidadas; de outro, impede que expectativas legitimamente criadas sejam frustradas, garantindo previsibilidade ao comportamento do particular.

Entretanto, há uma significativa diferença entre a confiança legítima e a segurança jurídica dita objetiva. ${ }^{859}$ Enquanto a segurança jurídica objetiva volta-se a todo o Direito, protegendo interesses coletivos e podendo beneficiar ou prejudicar o indivíduo em uma determinada situação específica, a segurança jurídica subjetiva, ou princípio da confiança legítima, preocupa-se em evitar justamente o agravamento da situação jurídica do indivíduo no caso concreto: "Nessa lógica, a teoria da proteção da confiança legítima exige que apenas o interesse da pessoa privada à fiabilidade das situações seja levado em consideração". 860

Ou seja, a segurança jurídica objetiva tem como escopo a garantia de estabilidade e previsibilidade da ordem jurídica, pouco importando se essa estabilidade e previsibilidade causam algum dano específico a determinada pessoa. O que importa é a existência de um Direito estável e previsível que sirva de ambiente seguro para o

\footnotetext{
${ }^{858}$ V. NERY JUNIOR, Nelson. Boa-fé objetiva e segurança jurídica - eficácia da decisão judicial que altera jurisprudência anterior do mesmo tribunal superior. p. 88 e ss e 104.

${ }^{859}$ Para uma distinção clara e didática entre os institutos, v. COUTO E SILVA, Almiro do. O princípio da segurança jurídica (proteção à confiança) no Direito Público brasileiro... p. 3 e ss.

${ }^{860}$ CALMES, Sylvia. Du Principe de Protection de la Confiance Légitime... p. 167. No original: "Dans cette logique, la théorie de la protection de la confiance légitime exige seul l'intérêt de la personne privée à la fiabilité des situations soit pris en considération". V. também CANOTILHO, José Joaquim Gomes. Direito Constitucional e Teoria da Constituição. p. 257 e ss; ÁVILA, Humberto. Segurança Jurídica. p. 362-363.
} 
desenvolvimento do indivíduo, viabilizando a promoção da justiça e do progresso social. No caso da confiança legítima, o que importa é violação subjetiva da segurança jurídica; a criação de uma expectativa no particular em razão de um "pré-comportamento" do Estado, e sua posterior e indevida frustração.

\title{
16.3.2. Boa-fé
}

O segundo fundamento da confiança (cum fides) legítima é o princípio geral da boa-fé (bona fides). ${ }^{861}$ De um lado, exige-se boa-fé objetiva do Estado, impondo-lhe "consideração com os legítimos interesses do alter, correção, informação, veracidade, lealdade e manutenção de promessas feitas" etc. ${ }^{862}$ de outro, protege-se a boa-fé subjetiva do indivíduo que adotou uma determinada conduta porque confiou no Estado e acreditou que o comportamento por ele adotado deveria ser seguido e respeitado.

Em louvável e já antiga decisão, o STJ aplicou perfeitamente o princípio da confiança a partir da necessária boa-fé do Estado:

\author{
MEMORANDO DE ENTENDIMENTO. BOA-FE. SUSPENSÃO DO \\ PROCESSO. \\ O COMPROMISSO PÚBLICO ASSUMIDO PELO MINISTRO DA \\ FAZENDA, ATRAVÉS DE 'MEMORANDO DE ENTENDIMENTO', \\ PARA SUSPENSÃO DA EXECUÇÃO JUDICIAL DE DIVIDA \\ BANCARIA DE DEVEDOR QUE SE APRESENTASSE PARA \\ ACERTO DE CONTAS, GERA NO MUTUARIO A JUSTA \\ EXPECTATIVA DE QUE ESSA SUSPENSÃO OCORRERA, \\ PREENCHIDA A CONDIÇÃO.
}

\footnotetext{
861 Cf. MARTINS-COSTA, Judith. A proteção da legítima confiança nas relações obrigacionais entre a Administração e os particulares. p. 236. V. também PEREZ, Jesus Gonzales. El Principio General de la Buena Fe em el Derecho Administrativo. p. 52 e ss.; NERY JUNIOR, Nelson. Boa-fé objetiva e segurança jurídica - eficácia da decisão judicial que altera jurisprudência anterior do mesmo tribunal superior. p. 85 e ss.; COUTO E SILVA, Almiro do. O princípio da segurança jurídica (proteção à confiança) no Direito Público brasileiro... p. 2-3; DERZI, Misabel Abreu Machado. A imprevisibilidade da jurisprudência e os efeitos... p. 193.

862 MARTINS-COSTA, Judith. A proteção da legítima confiança nas relações obrigacionais entre a Administração e os particulares. p. 237. V. também PEREZ, Jesus Gonzales. El Principio General de la Buena Fe em el Derecho Administrativo. p. 48 e ss.
} 
DIREITO DE OBTER A SUSPENSÃO FUNDADO NO PRINCIPIO DA BOA-FE OBJETIVA, QUE PRIVILEGIA O RESPEITO A LEALDADE.

DEFERIMENTO DA LIMINAR, QUE GARANTIU A SUSPENSÃO PLEITEADA. RECURSO IMPROVIDO. ${ }^{863}$

A fundamentação do acórdão é extremamente clara e precisa, motivo pelo qual se pede licença para transcrevê-la quase integralmente:

“O compromisso público assumido pelo Governo, através de seu Ministro da Fazenda, (...) presume-se tenha sido celebrado para ser cumprido. Se ali ficou estipulado que as execuções de créditos do Banco do Brasil seriam suspensas por noventa dias, desde que o devedor se dispusesse a um acerto de contas, é razoável pensar que esse seria o comportamento futuro do credor, pelo simples respeito à palavra empenhada em documento público, levada ao conhecimento da Nação.

No Direito Civil, desde os estudos de Ihering, admite-se que do comportamento adotado pela parte, antes de celebrado o contrato, pode decorrer efeito obrigacional, gerando a responsabilidade pré-contratual. $\mathrm{O}$ princípio geral da boa-fé veio realçar e deu suporte jurídico a esse entendimento, pois as relações humanas devem pautar-se pelo respeito à lealdade.

O que vale para a autonomia privada, vale ainda mais para a administração pública e para a direção das empresas cujo capital é predominantemente público, nas suas relações com os cidadãos. É inconcebível que um Estado democrático, que aspire a realizar a Justiça, esteja fundado no princípio de que o compromisso público assumido pelos seus governantes não tem valor, não tem significado, não tem eficácia. Especialmente quando a Constituição da República consagra o princípio da moralidade administrativa.

Tenho que o 'Memorando de Entendimento', embora não seja uma lei, nem mesmo possa ser definido como contrato celebrado diretamente

863 RMS 6183/MG, Rel. Ministro RUY ROSADO DE AGUIAR, QUARTA TURMA, julgado em 14/11/1995, DJ 18/12/1995, p. 44573. Para uma análise desse acórdão, v. MARTINS-COSTA, Judith. $A$ proteção da legítima confiança nas relações obrigacionais entre a Administração e os particulares. p. 228 e ss. 
entre as partes interessadas, criou no devedor a justa expectativa de que, comparecendo ao estabelecimento oficial de crédito a fim de fazer o acerto de contas, teria o prazo de suspensão de 90 dias para o encontro de uma solução extrajudicial (...) Não se trata de hipótese legal de suspensão, mas de obrigação publicamente assumida pela parte de que teria aquela conduta, cumprindo ao juiz lhe dar eficácia (...)".

O STJ, portanto, protegeu a "justa expectativa" gerada no administrado em razão da necessária "lealdade" da Administração em cumprir aquilo que prometeu. Uma autêntica demonstração de que o princípio da confiança também pode ser vinculado ao princípio geral da boa-fé.

\subsection{A eficácia normativa do princípio no Brasil}

No Brasil, a proteção da confiança legítima está consagrada em três dispositivos legais bastante conhecidos: o art. 54 da Lei 9.784/99, o art. 27 da Lei 9.868/99 e o art. 11 da Lei 8.882/99. Enquanto o primeiro trata da confiança legítima do particular na Administração, impedindo-a de invalidar, após o período de 5 anos, atos administrativos de que decorram efeitos favoráveis aos seus destinatários, o segundo e o terceiro protegem a confiança legítima também no Legislativo, permitindo ao STF que module os efeitos das decisões prolatadas em ADIn e em ADPF que invalidam uma lei ou um ato normativo inconstitucional para o momento que se considerar adequado.

Os dispositivos são de grande importância, mas não é apenas neles que o princípio da confiança sobrevive no Brasil. De acordo com o art. $5^{\circ}, \S 2^{\circ}$ da Constituição, “Os direitos e garantias expressos nesta Constituição não excluem outros decorrentes do regime e dos princípios por ela adotados, ou dos tratados internacionais em que a República Federativa do Brasil seja parte”. Ora, se o princípio da confiança decorre da segurança jurídica - garantia constitucional e princípio geral do Direito -, e da boa-fé também princípio geral do Direito -, parece fácil concluir que ele igualmente deve ser encarado como garantia constitucional "decorrente do regime e dos princípios por ela 
adotados", podendo ser aplicado sempre que a confiança legítima do particular for indevidamente frustrada por um comportamento contraditório do Estado. ${ }^{864}$

Já há importantes precedentes do STF reconhecendo a aplicação genérica do princípio da confiança no Direito brasileiro. Ao julgar a Ação Cível Originária no $n^{\circ}$ 79, o Supremo decidiu que, "sob pena de ofensa aos princípios constitucionais da segurança jurídica e da proteção à confiança legítima, não podem ser anuladas, meio século depois, por falta de necessária autorização prévia do Legislativo, concessões de domínio de terras públicas, celebradas para fins de colonização, quando esta, sob absoluta boa-fé e convicção de validez dos negócios por parte dos adquirentes e sucessores, se consolidou, ao longo do tempo, com criação de cidades, fixação de famílias, construção de hospitais, estradas, aeroportos, residências, estabelecimentos comerciais, industriais e de serviços etc". 865

16.5. Pressupostos de aplicação do princípio da confiança

A aplicação do princípio da proteção da confiança legítima possui dois pressupostos dedutíveis da seguinte constatação: o indivíduo deve ter (1) confiado legitimamente (2) em um comportamento estatal digno de confiança. Além deles, há casos que exigem a (3) ação ou omissão do particular com fundamento na confiança legítima. Esse último pressuposto, embora não seja sempre aplicável, é especialmente importante no que diz respeito à quebra da confiança do jurisdicionado pela jurisdição.

\subsubsection{O fundamento da confiança}

O primeiro pressuposto para a aplicação do princípio da confiança legítima é a existência de um fundamento para a confiança do indivíduo, um "pré-comportamento" do Estado capaz de gerar a expectativa no particular de que uma dada situação jurídica não

\footnotetext{
${ }^{864}$ Nesse sentido, ÁVILA, Humberto. Segurança Jurídica. p. 362; NERY JUNIOR, Nelson. Boa-fé objetiva e segurança jurídica - eficácia da decisão judicial que altera jurisprudência anterior do mesmo tribunal superior. p. 83 e ss.

${ }^{865}$ ACO 79, Relator(a): Min. CEZAR PELUSO (Presidente), Tribunal Pleno, j. 15/03/2012, p. 28/05/2012. V. também MS 24781, Relator(a): Min. ELLEN GRACIE, Relator(a) p/ Acórdão: Min. GILMAR MENDES, Tribunal Pleno, j. 02/03/2011, p. 09/06/2011.
} 
será modificada. ${ }^{866}$ Esse fundamento pode ser positivo, consistente em uma ação, um ato jurídico geral e abstrato (ex. lei) ou um ato jurídico individual e concreto (ex. ato administrativo, decisão judicial etc.), e pode ser negativo, consistente em uma omissão do Estado (ex. art. 54 da Lei 9.784/99). ${ }^{867}$

Existe bastante controvérsia acerca de quais são esses "précomportamentos" que efetivamente podem gerar uma confiança legítima no indivíduo. Adota-se aqui o mesmo posicionamento de Humberto Ávila: qualquer ato ou omissão estatal pode servir como fundamento da confiança desde que tenha "aptidão para servir de fundamento para o exercício dos direitos de liberdade e de propriedade". ${ }^{868}$ Pouco importa se o fundamento da confiança era uma lei sabidamente inconstitucional ou uma recente mudança jurisprudencial ainda não consolidada em definitivo por determinado tribunal. ${ }^{869}$ O que importa é a aptidão do ato ou omissão estatal de gerar expectativas no indivíduo que por elas pauta sua conduta. Nas palavras de Humberto Ávila, “O essencial não é, portanto, se a base da confiança é ou não regular, definitiva, inequívoca, precisa, positiva ou concludente - como sustenta, em geral, a doutrina. Decisivos passam a ser os efeitos da base relativamente aos direitos e aos princípios fundamentais, até mesmo quando a base da confiança seja irregular, transitória, equívoca, negativa ou includente (...)”. 870

Seguindo ainda as lições do mesmo autor, podem ser adotados vários requisitos, com graus variantes, que sirvam como critérios para a configuração de um fundamento (ou base) de confiança no Estado. ${ }^{871}$ (1) O primeiro deles é o grau de vinculação normativa do fundamento. Quanto maior a sua força normativa, maior é a sua aptidão para gerar confiança no particular. (2) O segundo critério é a aparência de legitimidade do fundamento. Vários fatores influenciam essa aparência, como o sujeito do

\footnotetext{
866 VALEMBOIS, Anne-Laure. La Constitutionnalisation de l'Exigence de Sécurité Juridique en Droit Français. p. 241.

${ }^{867}$ V. Ibidem. p. 241. V. também ÁVILA, Humberto. Segurança Jurídica. p. 367. Assim como Sylvia CALMES (Du Principe de Protection de la Confiance Légitime... p. 301 e ss.), Humberto Ávila refere-se a "base da confiança".

${ }^{868}$ ÁVILA, Humberto. Segurança Jurídica. p. 367.

${ }^{869}$ Em sentido contrário, CALMES, Sylvia. Du Principe de Protection de la Confiance Légitime... p. 341 e SS.

${ }^{870}$ ÁVILA, Humberto. Segurança Jurídica. p. 370.

${ }^{871}$ Ibidem. p. 374-393.
} 
ato (grau hierárquico, p.ex.) e a forma adotada (publicidade, participação popular, ato colegiado ou monocrático etc.). (3) O terceiro critério é o grau de modificabilidade do fundamento, isto é, a pretensão de sua permanência na ordem jurídica. A provisoriedade do fundamento necessariamente gera menos confiança ao particular do que um fundamento definitivo. $^{872}$ (4) O quarto critério é o grau de eficácia no tempo do fundamento. Quanto mais duradouro for, maior é a confiança gerada no indivíduo, que o interioriza em sua consciência e adapta seu comportamento e suas expectativas à perspectiva de que aquilo é verdadeiro. A durabilidade do fundamento também aumenta a sua aparência de legitimidade e reduz a probabilidade de sua modificação. (5) O quinto critério é o grau de realização das finalidades do fundamento. Ainda quando ilegal, ele pode ter atingido o fim para o qual foi previsto, de modo que inexiste prejuízo em sua manutenção. (6) O sexto critério é o grau de indução do fundamento, isto é, a sua aptidão para induzir o particular a agir ou a omitir-se. Como explica Humberto Ávila, há uma verdadeira “deslealdade do Poder Público" quando este incentiva o particular a adotar um determinado comportamento e, em seguida, frustra as expectativas nele geradas. ${ }^{873}$ (7) O sétimo critério é o grau de individualidade do fundamento. Quanto mais individual (p. ex., um contrato administrativo), maior será a confiança depositado no Estado pelo particular. (8) Por fim, o oitavo e último critério é o grau de onerosidade do fundamento. Quanto maior a onerosidade imposta ao particular pelo ato ou omissão do Estado que fundamenta o seu comportamento, tanto maior deve ser a proteção da confiança desse particular no Estado.

Obviamente, o fundamento da confiança não depende da observância de todos os oito requisitos mencionados; mesmo porque nem todos serão sempre aplicáveis ao caso concreto. A relevante satisfação de um requisito pode suplantar a falta de outro. De qualquer maneira, quanto mais requisitos estiverem preenchidos, maior será a fiabilidade do fundamento da confiança.

\footnotetext{
${ }^{872}$ Note-se que o grau de modificabilidade do fundamento não se confunde com a sua vigência a prazo certo, quando existe definitividade, ainda que temporária. V. Ibidem. p. 383.

${ }^{873}$ Ibidem. p. 387.
} 


\subsubsection{A confiança legítima}

A confiança do indivíduo é uma resposta ao comportamento do Estado que lhe cria expectativas e o faz agir ou omitir-se de acordo com as expectativas criadas. $\mathrm{O}$ indivíduo toma uma decisão porque o Estado o induziu, direta ou indiretamente, a assim proceder. Essa confiança gerada pelo Estado deve ser tutelada, desde que esteja pautada pela boa-fé. ${ }^{874} \mathrm{O}$ indivíduo deve confiar leal e verdadeiramente no comportamento do Estado, agindo ou omitindo-se porque tinha uma concreta expectativa de que, ao assim fazer, obteria a consequência jurídica prevista e, de certa forma, prometida pelo Estado.

Além da boa-fé, parte da doutrina condiciona a legitimidade da confiança à imprevisibilidade de sua traição pelo Estado. A modificação deveria ser suficientemente brusca para pegar o particular desprevenido e tornar-lhe impossível uma adaptação progressiva à mudança. ${ }^{875}$ A necessária imprevisibilidade da traição da confiança, porém, gera um círculo vicioso inaceitável. Quanto maior for a violação da confiança pelo Estado, tanto maior será a previsibilidade de sua traição. Quanto mais numerosas forem, p.ex., as mudanças jurisprudenciais, tanto maior será a previsibilidade de suas alterações pelo particular. Consequentemente, a insegurança jurídica provocada pelo próprio Estado tornaria inaplicável a proteção da confiança legítima, pois o particular sempre teria condições de prever a sua traição. De outra sorte, quanto mais estável e previsível for um ordenamento jurídico, menos relevante será a aplicação do princípio da confiança legítima. Uma situação certamente paradoxal!

O princípio da confiança legítima apenas tem razão de ser em um contexto em que as expectativas dos cidadãos são ou podem vir a ser frustradas. E quanto mais frequentemente forem frustradas essas expectativas, maior será a importância do princípio da confiança para a proteção das pessoas.

Por outro lado, nem sempre o particular tem a opção de seguir ou não seguir um comportamento estatal sem que sofra algum tipo de consequência negativa. São

\footnotetext{
${ }^{874}$ V. TORRES, Heleno Taveira. Direito Constitucional Tributário e Segurança Jurídica. p. 211-213; VALEMBOIS, Anne-Laure. La Constitutionnalisation de l'Exigence de Sécurité Juridique en Droit Français. p. 246;

${ }^{875}$ Cf. VALEMBOIS, Anne-Laure. La Constitutionnalisation de l'Exigence de Sécurité Juridique en Droit Français. p. 243. Para mais detalhes, v. CALMES, Sylvia. Du Principe de Protection de la Confiance Légitime... p. 375 e ss.
} 
incontáveis as situações em que uma decisão deve ser tomada entre duas alternativas possíveis, uma com respaldo estatal (um precedente do STJ, um ato administrativo etc.) e outra não. É evidente que se espera do particular a escolha pela opção respaldada pelo Estado, ainda que exista a possibilidade de o fundamento da confiança vir a ser invalidado, revogado ou alterado. E se assim o é, então a simples previsibilidade de mudança da situação não autoriza impor ao particular os danos causados pela confiança que depositou legitimamente no Estado.

O problema da previsibilidade da frustração da confiança diz respeito ao fundamento (ou base) da confiança; quer dizer, ao comportamento estatal que originou a confiança do particular. Por isso é que tal fundamento deve ter aparência de legitimidade, baixo grau de modificabilidade, durabilidade no tempo etc. São essas situações que definem se o comportamento estatal poderia ou não ter sido objeto de confiança pelo particular. E se o fundamento era confiável, então basta a boa-fé para que a confiança seja considerada legítima.

\subsubsection{O exercício da confiança}

Finalmente, há casos em que o particular deve ter agido ou omitido-se com fundamento na confiança depositada no Estado. Dito de outro modo, o particular deve ter adotado um determinado comportamento em razão das expectativas geradas a partir de uma confiança legítima em um "pré-comportamento" estatal. ${ }^{876}$ Trata-se do "exercício da confiança" legítima do particular. ${ }^{877}$

A exigência de um "exercício da confiança" em algumas hipóteses é facilmente explicada. Assim como a segurança jurídica objetiva, o princípio da confiança procura estabilizar situações fáticas ou jurídicas consolidadas. A diferença entre eles, como visto, é que o princípio da confiança tem um foco específico, voltando-se sempre ao individual e ao subjetivo; seu propósito é garantir a estabilidade de situações consolidadas subjetivas. Mas só se pode falar em uma situação consolidada subjetiva se o particular efetivamente tiver adotado um comportamento pautado pela confiança no Estado. Em

\footnotetext{
${ }^{876}$ Em sentido contrário, v. CALMES, Sylvia. Du Principe de Protection de la Confiance Légitime... p. 391 e ss.

${ }^{877}$ Cf. ÁVILA, Humberto. Segurança Jurídica. p. 398.
} 
resumo, o princípio da confiança exige uma "concretização" da confiança do particular no Estado, ${ }^{878}$ de modo que a abstração própria da segurança objetiva transforme-se na concretude inerente ao princípio da confiança.

Note-se que a concretização da confiança nem sempre é necessária, tal qual demonstra a decisão do STJ acima citada (v. 16.3.2, acima). Naquele caso, o alto grau de comprometimento do Estado com uma manifestação formal do Ministro da Fazenda tornou irrelevante a ação ou a omissão do particular. No mesmo sentido, o art. 54 da Lei 9.784/99 protege a confiança do administrado pela mera durabilidade (permanência do tempo) do comportamento omissivo da Administração.

No que importa a este trabalho, que é a confiança legítima do jurisdicionado nos precedentes judiciais, a concretização da confiança será sempre exigida (v. 17.6, abaixo).

16.6. A violação do princípio da confiança (a frustração da confiança)

Configurada a existência de um pré-comportamento do Estado apto a gerar uma confiança legítima (de boa-fé) no particular, então essa confiança deve ser protegida pelo Estado. Toda vez que o Estado frustra a expectativa do particular de obter o resultado previsto por um pré-comportamento contraditório, pratica um ato ilícito que deve ser, de algum modo, reparado. Tal qual ensina Humberto Ávila, o exercício da confiança é um exercício concreto de liberdade do indivíduo; e a violação da confiança pelo Estado configura uma restrição injustificada do "exercício passado da liberdade juridicamente orientada de alguém". 879

A frustração da confiança não é um requisito do princípio da confiança legítima. Pelo contrário. A frustração da confiança é a violação de uma confiança existente e juridicamente protegida. Como regra, o Estado não deveria frustrar, em nenhum momento, a confiança que desperta no indivíduo, abstendo-se de praticar atos contraditórios e sempre buscando regras de transição quando necessária uma mudança comportamental. O art. 54 da Lei 9.784/99, p.ex., protege a confiança legítima do

\footnotetext{
${ }^{878}$ TORRES, Heleno Taveira. Direito Constitucional Tributário e Segurança Jurídica. p. 211.

${ }^{879}$ ÁVILA, Humberto. Segurança Jurídica. p. 399.
} 
particular antes mesmo que haja a sua frustração, proibindo a Administração de, após 5 anos, invalidar atos de que decorram efeitos favoráveis aos seus destinatários.

\section{A jurisdição e a violação da confiança legítima do jurisdicionado}

Se o princípio da confiança possui relevante aceitação jurisprudencial e doutrinária, e, ao menos no Brasil, previsão normativa expressa no que diz respeito à vedação de comportamentos contraditórios do Estado em suas atividades administrativa e legislativa, o mesmo não pode ser dito sobre as relações entre o princípio e a atividade jurisdicional. A cultura jurídica tradicional do civil law, repleta de incongruências e contradições, nem sempre permite enxergar que a atividade jurisdicional, tanto quanto todas as demais atividades do Estado, deve promover a segurança jurídica, pautar-se pela boa-fé objetiva e, consequentemente, comprometer-se com os seus próprio atos; resumindo, que a jurisdição deve contribuir à obtenção de segurança jurídica e ser passível de confiança pelo jurisdicionado.

De um lado, em uma patente confusão entre retroatividade e retrospectividade, imagina-se que a natureza declaratória da atividade jurisdicional tornaria as decisões judiciais naturalmente retroativas. ${ }^{880} \mathrm{~A}$ frustração da confiança em razão de mudanças jurisprudenciais, revogação de precedentes, divergência jurisprudencial etc. não seria mais do que decorrência dessa eficácia retroativa supostamente inerente à atividade jurisdicional. De outro, as mudanças jurisprudenciais são encaradas com complacência, pois consideradas manifestação da evolução do Direito. O jurisdicionado não teria um “direito adquirido" à manutenção da jurisprudência, nem, muito menos, uma expectativa legítima a ser tutelada. ${ }^{881}$

O objetivo deste ponto é demonstrar que os precedentes judiciais são, sim, fundamento de uma legítima confiança do jurisdicionado; uma confiança que deve sempre ser tutelada, principalmente quando a sua traição decorre de mudança jurisprudencial.

\footnotetext{
${ }^{880}$ P.ex., AUBERT, Jean-Luc. Faut-il 'moduler' dans les temps les revirements de jurisprudence?... J'en doute?, passim.

${ }^{881}$ Essa razão foi expressamente apresentada pela Corte de Cassação francesa no julgamento no 249 de 9 de outubro de 2001: "nul ne peut se prévaloir d'um droit acquis à une jurisprudence figée".
} 
17.1. Os precedentes judiciais como fundamento da confiança

Sob a ótica do Estado de Direito, a motivação é um ato estatal de prestação de contas; um ato de demonstração de que a decisão ao final proferida é uma decisão formal e materialmente fundada no Direito vigente. Sob a ótica da segurança jurídica, indissociavelmente vinculada à primeira, a motivação é um ato de esclarecimento, integração e homogeneização do Direito, que, ao apresentar rationes decidendi e formar uma jurisprudência, serve como referência para o julgamento de casos futuros.

Em várias passagens deste trabalho defendeu-se que as decisões judiciais não são, ao menos não no Brasil, fonte do Direito; não o são formalmente (art. $4^{\circ}$ do Decreto-Lei $n^{\circ}$. 4.657/42) e não o são ontologicamente. ${ }^{882}$ Ao contrário do legislador, o juiz não pode alterar a ordem jurídica porque dela discorda ou simplesmente porque pretende aprimorá-la. Ao juiz não compete interpretar e aplicar o Direito de acordo com a sua própria vontade, mas de acordo com o que foi determinado pelo legislador ("lei" em sentido amplo), de acordo com os princípios inerentes ao ordenamento jurídico vigente (princípios gerais do direito), e de acordo com os valores da sociedade em que está inserido (costumes). Obviamente, não existe uma escala de correção objetiva para que isso ocorra. Ainda assim, o objetivo da atividade jurisdicional deve ser o de alcançar a maior simetria possível entre a jurisprudência e as fontes do Direito. Se a lei mudar, se os princípios gerais do Direito mudarem, se os valores da sociedade mudarem, então a jurisprudência também deverá mudar; mas deverá mudar para acompanhar tais leis, princípios e valores. $\mathrm{O}$ caminho não pode ser inverso.

Nada disso desnatura a importância da jurisprudência para a compreensão da ordem jurídica e para a promoção da segurança jurídica. Ainda que a jurisprudência não seja uma fonte autêntica do Direito, certamente trata-se de uma fonte interpretativa do Direito. Como tantas vezes já se disse na doutrina, a jurisprudência é, com todas as ressalvas já feitas nos capítulos anteriores, o "direito vivo" (diritto vivente); ${ }^{883}$ e é esse "direito vivo" que proporciona acessibilidade e inteligibilidade ao Direito, esclarecendo

\footnotetext{
${ }^{882}$ Os vários desvios existentes na prática forense não alteram a função destinada à jurisprudência no modelo de Estado de Direito adotado constitucionalmente pela República Federativa do Brasil.

${ }^{883}$ A expressão remete à clássica defesa de Tullio ASCARELLI (v. Giurisprudenza costituzionale e teoria dell'interpretazione. p. 351 e ss.) da natureza constitutiva da interpretação do texto legal; mas serve, de qualquer maneira, para designar o Direito interpretado e aplicado pelos tribunais.
} 
como uma determinada expressão deve ser compreendida, quais são os efeitos jurídicos da prática de determinado ato, até que ponto uma norma pode ser aplicada por analogia, como é resolvida uma antinomia legislativa etc. É exatamente por isso que a jurisprudência deve ser estável, coerente e homogênea (v. 13 e ss., acima). Não basta às pessoas conhecer as leis; elas precisam conhecer a aplicação dessas leis aos casos concretos. ${ }^{884}$

Corrobora essa constatação o fato de que a jurisdição é a responsável pela realização e proteção do Direito (v. 3 e ss., acima). Em muitos casos, pouco importa qual é, para o jurisdicionado e seus advogados, a melhor interpretação de um dispositivo legal ou qual é o seu verdadeiro significado dentro do sistema. Por mais convencido que o jurisdicionado esteja a respeito de quais deveriam ser as consequências jurídicas de seu comportamento, o que realmente importa é a interpretação jurídica dada pelos tribunais, pois é ela que prevalecerá caso o jurisdicionado venha a ser autor ou réu em um processo judicial. ${ }^{885}$

De forma bastante consciente, o STF assim se manifestou no julgamento do MS 26603/DF: “Os precedentes firmados pelo Supremo Tribunal Federal desempenham múltiplas e relevantes funções no sistema jurídico, pois lhes cabe conferir previsibilidade às futuras decisões judiciais nas matérias por eles abrangidas, atribuir estabilidade às relações jurídicas constituídas sob a sua égide e em decorrência deles, gerar certeza quanto à validade dos efeitos decorrentes de atos praticados de acordo com esses mesmos precedentes e preservar, assim, em respeito à ética do Direito, a confiança dos cidadãos nas ações do Estado". 886

\footnotetext{
${ }^{884}$ Em curto e brilhante artigo, FRISON-ROCHE, Marie-Anne La théorie de l'action comme principe de l'application dans le temps des jurisprudences. p. 312 resumiu: "l'action des personnes et la prise de risque corrélée fournissent la richesse de l'ensemble et se déploient d'autant mieux que les règles juridiques sont sans surprise, règles juridiques dont le contour doit être donné par la perception qu'elles en ont, c'est-à-dire incluant l'interprétation jurisprudentielle".

${ }^{885}$ Uma interpretação jurídica conservada, divulgada e muitas vezes sumulada, para o conhecimento dos jurisdicionados, pelo próprio Estado. Com bem aponta Eduardo TALAMINI, a preservação dos efeitos produzidos por uma jurisprudência superada é "uma consequência, uma contrapartida necessária, da intensificação do valor, da autoridade, da jurisprudência (...)" (Novos aspectos da jurisdição constitucional brasileira... p. 216).

${ }^{886}$ MS 26603, Relator(a): Min. CELSO DE MELLO, Tribunal Pleno, julgado em 04/10/2007
} 
A jurisdição, portanto, “diz" qual é o Direito ao jurisdicionado; e o jurisdicionado, com a informação recebida, tem condições de moldar a sua vida e prever as consequências jurídicas de seus atos a partir do Direito posto pelo legislador e devidamente interpretado pelo juiz. Lembre-se que a ratio decidendi é uma razão jurídica, uma premissa maior dotada de universalidade. Ao motivar uma decisão, cabe ao juiz demonstrar que o caso foi daquele modo decidido porque aquela era a decisão correta para toda situação fática idêntica ou análoga. Ou seja, a motivação universaliza um caso particular e, ao assim fazer, esclarece como o Direito regula casos idênticos ou análogos. Esse é, sob uma ótica subjetiva, o valor da jurisprudência: informar ao jurisdicionado como o Direito será, no futuro, interpretado e aplicado na hipótese de um caso análogo (incluindo o seu caso) apresentar-se para julgamento. ${ }^{887}$

\subsubsection{Dois exemplos de violação da confiança do jurisdicionado pela jurisdição}

Por várias décadas prevaleceu o entendimento jurisprudencial de que $\mathrm{o}$ prazo para propor ação de nulidade de doação inoficiosa contava-se da morte do doador, quer dizer, da abertura da sucessão. ${ }^{888}$ Afirmava-se que a propositura da demanda antes da morte do doador configuraria disputa sobre herança de pessoa viva, sendo o eventual demandante carecedor de ação. Desse modo, proposta a demanda antes da morte do doador, então o processo muito provavelmente seria extinto sem julgamento de mérito.

A partir da década de 90, a jurisprudência simplesmente mudou. Depois de décadas de processos sendo extintos sobre o fundamento de que era inadmissível a propositura de demanda buscando a invalidação de doação inoficiosa antes da abertura da

\footnotetext{
${ }^{887}$ Nesse sentido, SCHAUER, Frederick. Thinking Like a Lawyer. p. 179: “When a court provides a reason for a decision, therefore, it can be thought of as entering into a social practice not unlike the social practice of promising. We commonly believe that promises create commitments, because it is wrong to lead someone to rely on some proposition and then to turn around and undercut the basis for that reliance. So too with providing reasons. Giving reasons induces reasonable reliance and creates a prima facie commitment on the part of the court to decide subsequent cases in accordance with the reason that it has explicitly given on a previous occasion".

${ }^{888}$ P.ex. STF, RExt 18726, j. 18.06.1951; TJSP, Recurso de Revista n. ${ }^{\circ} 172.044$, j. $1^{\circ}$ de abril de 1970; STF, RExt 94.118/PE, j. 26.11.1982 e p. 25.02.1983; TJSP, AI 13.353-4/5, j. 06/08/1996; TJPR, AC 54.861-4, j. 12.05.1999. O entendimento é manifestado ainda hoje: TJSP, AC 9067876-82.2001.8.26.0000, j. 27.09.2007; TJSP, AC 9036640-20.1998.8.26.0000, j. 04.11.2009
} 
sucessão, o STJ alterou definitivamente a jurisprudência em 1998. Equiparando a doação inoficiosa à venda de ascendente para descendente, e aplicando ao caso o enunciado 494 da súmula do STF, editado quase trinta anos antes (1969), o STJ decidiu que a data inicial do prazo de 20 anos para a propositura da demanda de nulidade era a da prática do ato. ${ }^{889}$ Naquela situação fática, a abertura da sucessão havia ocorrido em 16 de agosto de 1989 e a demanda de nulidade fora proposta em 1991. Na medida em que as doações haviam sido feitas nas décadas de 50 e 60, o STJ deu provimento ao recurso dos herdeiros-donatários e reconheceu a "prescrição da ação" do herdeiro-prejudicado.

Deixada de lado a confusão entre prescrição e decadência, e a confusão entre doação inoficiosa e nulidade de venda de ascendente a descente (objeto do enunciado 494 da súmula do STF, que expressamente distinguiu as categorias nas decisões que o formaram), o resultado do julgamento foi: o herdeiro-beneficiário nunca pôde pedir a nulidade da doação que violou a sua legítima. Se tivesse proposto a demanda dentro do "prazo prescricional”, o processo teria sido extinto por carência de ação. Tendo respeitado a jurisprudência então vigente, e proposto a demanda apenas após a abertura da sucessão do donatário, então o seu "direito prescreveu". Obviamente, vários casos similares repetiram-se em seguida. Herdeiros cujas legítimas foram violadas e que, impossibilitados de propor a demanda à época das doações, viram suas demandas de nulidade julgadas improcedentes sobre o fundamento da "prescrição" vintenária contada da prática do ato pelo donatário. ${ }^{890}$

Na França causou bastante repercussão a responsabilização de um médico, pela Primeira Câmara Civil da Corte de Cassação, por não ter revelado ao seu paciente, em 1974, os "riscos excepcionais" a que ele estava sujeito. O problema é que a jurisprudência francesa só passou a reconhecer tal obrigação em 1998; quer dizer, 24 anos depois da omissão do réu. Ao julgar o caso em 9 de outubro de 2001, a Primeira Câmara Civil afirmou que "a interpretação jurisprudencial de uma mesma norma a um dado momento

\footnotetext{
${ }^{889}$ STJ, REsp 151.935/RS, j. 16.11.1998.

${ }^{890}$ A inversão lógica é tão grande que uma dessas decisões que declarou "prescrita" a demanda de nulidade chegou a sustentar que "no embate entre o interesse particular em ver reconhecida a nulidade do negócio jurídico e o interesse público, consistente na segurança das relações jurídicas, bem como a paz social dela decorrente, à toda evidência, deve prevalecer esta última". Ou seja, a segurança jurídica foi utilizada como fundamento de uma grave violação da segurança jurídica.
} 
não pode ser diferente de acordo com a época dos fatos" e condenou o médico pela violação, em 1974, de uma obrigação que só foi reconhecida como existente em 1998; ou seja, 24 anos mais tarde. ${ }^{891}$

Esses dois singelos mas representativos exemplos, dentre muitos outros que poderiam ser dados, ${ }^{892}$ demonstram sem nenhuma margem para dúvida que a atividade jurisdicional também pode violar a confiança legitimamente depositada no Estado pelo jurisdicionado. $^{893}$

17.2. Sobre a natureza da atividade jurisdicional e a (ir)retroatividade da jurisprudência

O reconhecimento de que a atividade jurisdicional gera uma confiança legítima no jurisdicionado a ser tutelada vincula-se doutrinariamente, com bastante frequência, a uma injustificável dicotomia envolvendo a natureza da atividade jurisdicional. Parte-se do pressuposto de que a recusa em aceitar mudanças jurisprudenciais abruptas depende necessariamente do reconhecimento de que as decisões judiciais criam o Direito e de que a jurisprudência é fonte do Direito.

Essa dicotomia ficou muito clara na França, quando uma comissão de juristas presidida por Nicolas Molfessis apresentou, em março de 2004, um relatório sobre as mudanças de jurisprudência (Rapport sur les revirements de jurisprudence) para o Primeiro Presidente da Corte de Cassação francesa, Guy Canivet. Apesar dos muitos méritos do relatório, a premissa básica era justamente partir de um suposto "princípio de realismo", pelo qual seria imperioso o reconhecimento da jurisprudência como fonte do Direito. ${ }^{894}$ Praticamente toda a discussão desenvolvida posteriormente esteve voltada à compreensão da mudança jurisprudencial sob a ótica da natureza da atividade

${ }^{891}$ Cf. MOLFESSIS, Nicolas (pres.). Rapport sur les revirements de jurisprudence. 1.4.1; BACHELLIER, Xavier; JOBARD-BACHELLIER, Marie-Noëlle. Les revirements de jurisprudence. p. 304-305; MALINVAUD, Philippe. A propos de la rétroactivité des revirements de jurisprudence. p. 312.

${ }^{892}$ No Brasil também ficou bastante conhecida a mudança jurisprudencial envolvendo o crédito-prêmio do IPI. V. FERRAZ JÚNIOR, Tercio Sampaio. Irretroatividade e jurisprudência judicial. p. 30-32; NERY JUNIOR, Nelson. Boa-fé objetiva e segurança jurídica - eficácia da decisão judicial que altera jurisprudência anterior do mesmo tribunal superior. p. 76.

${ }^{893}$ V. RUFFINI, Giuseppe. Mutamenti di giurisprudenza... p. 1390 e ss.

${ }^{894}$ MOLFESSIS, Nicolas (pres.). Rapport sur les revirements de jurisprudence. item 1.4. 
jurisdicional ${ }^{895}$ e independentemente do posicionamento a respeito da modulação de efeitos da mudança jurisprudencial proposta pela comissão, aparentemente um consenso foi formado: a atividade jurisdicional é sempre retroativa. Exatamente o mesmo vem acontecendo na Itália. ${ }^{896}$

Em primeiro lugar, não existe absolutamente nenhuma relação entre a natureza da atividade jurisdicional e o regime jurídico que deve ser dado à mudança jurisprudencial. Não é preciso aceitar a natureza criativa da jurisprudência para defender que a sua mudança frequente é um atentado à segurança jurídica, seja ela objetiva ou subjetiva. Aliás, a lógica deveria ser justamente inversa. Os constitutivistas deveriam aceitar com muito mais tranquilidade as mudanças jurisprudenciais, por constituírem alteração do Direito vigente, do que os declarativistas. É de se espantar que adeptos da teoria declaratória da jurisdição encarem com condescendência as alterações jurisprudenciais por simples opiniões divergentes dos juízes. ${ }^{897}$ Se o Direito é declarado (rectius: reconhecido) pela jurisdição, e efetivamente o é, então parece mais do que evidente que esse Direito não pode variar de acordo com os valores pessoais de cada magistrado. Justamente por ser declarado, o Direito deve ser estável e uniformemente aplicado.

\footnotetext{
895 P.ex., AUBERT, Jean-Luc. Faut-il 'moduler' dans le temps les revirements de jurisprudence?... J'en doute? p. 301 e ss; BACHELLIER, Xavier; JOBARD-BACHELLIER, Marie-Noëlle. Les revirements de jurisprudence. p. 304-310; MALINVAUD, Philippe. A propos de la rétroactivité des revirements de jurisprudence. p. 312-318; MONÉGER, Joël. La maîtrise de l'inévitable revirement de jurisprudence : libres propos et images marines. p. 323-328; SERINET, Yves-Marie. Par elle, avec elle et en elle? La Cour de cassation et l'avenir des revirements de jurisprudence. p. 328-334. Entre a doutrina do common law, v. SAMPFORD, Charles. Retrospectivity and the Rule of Law. p. 168.

${ }^{896}$ V. VERDE, Giovanni. Mutamento di giurisprudenza e affidamento incolpevole... p. 10 e ss; PUNZI, Carmine. Il ruolo della giurisprudenza e i mutamenti d'interpretazione di norme processuali. p. 1353.

${ }^{897}$ De acordo com VERDE, Giovanni. Mutamento di giurisprudenza e affidamento incolpevole... p. 10 e ss, "Il 'diritto vivente' è un fatto storico, di cui si prende e si deve prenderere atto, ma ciò non vale a posizionarlo tra le fonti formali del diritto e, quindi, direbbero $i$ logici, non è un 'significante', ma un 'significato' e, come tale, non può essere assunto a criterio di giudizio vincolante; è una 'realtà' di cui si deve tenere conto, ma dalla quale è lecito discostarsi". Ora, se a jurisprudência é uma realidade que deve ser levada em consideração, como pode ser lícito dela afastar-se?
} 
Em segundo lugar, a atividade jurisdicional só é retroativa em uma hipótese: se ela também for criativa. ${ }^{898}$ A essência da teoria declaratória da jurisdição está na concepção de que a subsunção dos fatos à norma se dá exatamente no momento em que os fatos ocorrem, competindo ao Estado-juiz apenas reconhecer a regulação do caso concreto por determinada norma jurídica e então, tratando-se de sentença constitutiva ou condenatória, concretizar as consequências jurídicas dali decorrentes. Ao voltar-se a um fato pretérito, a jurisdição analisa retrospectivamente esse fato, mas não lhe aplica necessariamente efeitos retroativos. A condenação do devedor, p.ex., nada mais é do que uma ordem prospectiva a ele dirigida para que pague o débito, tendo em vista o reconhecimento retrospectivo de que o direito de crédito do credor não foi satisfeito. Para a teoria declaratória, portanto, a atividade jurisdicional é essencialmente retrospectiva, ${ }^{899}$ mas apenas excepcionalmente retroativa. ${ }^{900}$

De uma forma ou de outra, o simples reconhecimento da jurisdição como uma atividade estatal pública e, ao menos no Brasil, una, ${ }^{901}$ independentemente de ser declaratória ou criativa, retrospectiva ou retroativa, já deveria ser suficiente para rejeitar comportamentos contraditórios entre os diversos juízos e reprovar veementemente a quebra da confiança legítima depositada pelo particular nos precedentes judiciais.

17.3. Mudança jurisprudencial, evolução do Direito e confiança legítima do jurisdicionado

Um segundo problema envolvendo a aplicação do princípio da proteção da confiança legítima ao jurisdicionado está na aceitação banalizada das mudanças jurisprudenciais.

\footnotetext{
${ }^{898}$ Nas palavras de DERZI, Misabel Abreu Machado. A imprevisibilidade da jurisprudência e os efeitos... $\mathrm{p}$. 184: "Ora, uma decisão judicial sempre se dá no presente, em relação a fato pretérito (reconstituído), projetando-se para o futuro. (...) Daí a inafastabilidade da irretroatividade das decisões judiciais, sob pena de destruir a força dos precedentes e de não se conseguir criar a mínima expectativa normativa".

${ }^{899}$ Demandas envolvendo obrigações de não fazer são essencialmente prospectivas, pois voltadas a fatos que ainda não ocorreram, mas potencialmente podem vir a ocorrer no futuro.

${ }^{900}$ Como ocorre, p.ex., na hipótese de invalidação de um contrato nulo, reconhecendo retrospectivamente o defeito e fulminando-o retroativamente da ordem jurídica.

${ }^{901}$ DINAMARCO, Cândido Rangel. Instituições de Direito Processual Civil, v. I. p. 326-328.
} 
Não há dúvidas de que a jurisprudência se altera e deve alterar-se. Costumase dizer que essa alteração é fundamental, pois uma jurisprudência estática seria uma "jurisprudência esclerosada" e "sem vida" ${ }^{902}$ A intensidade da alteração jurisprudencial, como bem aponta Teresa Arruda Alvim Wambier, depende dos princípios basilares de cada área do Direito. Em "ambientes decisionais frouxos", como é o caso de questões envolvendo o Direito de Família, a alteração jurisprudencial é e deve ser mais frequente, acompanhando os valores da sociedade. Por outro lado, as alterações jurisprudenciais devem ser muito restritas em ambientes decisionais mais rígidos, como, p.ex., os que envolvem questões tributárias, administrativas e processuais. ${ }^{903}$

De todo modo, aceitar a alteração jurisprudencial não significa aceitar a sua simples mudança. A jurisprudência não deve e não pode apenas mudar; ela deve evoluir. Deve evoluir para corrigir equívocos que causem prejuízo às pessoas, deve evoluir para adaptar-se aos valores da sociedade ou a mudanças legislativas e deve evoluir para melhorar a sistematização e a aplicação do Direito. A evolução da jurisprudência dificilmente viola a segurança jurídica ou frustra a confiança legítima do jurisdicionado. Se necessária para acompanhar uma alteração legislativa, a evolução da jurisprudência será prospectiva como a lei. Se necessária para melhorar a sistematização e a aplicação do Direito, terá como pressuposto básico a não violação da segurança jurídica e da confiança legítima dos jurisdicionados. Se necessária para acompanhar as transformações sociais, então será necessariamente paulatina e equilibrada, muito provavelmente esperada e almejada pela sociedade. Como escreveu com precisão Teresa Arruda Alvim Wambier, "A sociedade é um organismo vivo, e, como acontece com os organismos vivos, as mudanças pelas quais passa ocorrem lentamente. Não há alterações sociais bruscas. Portanto, já que o direito muda quando precisa adaptar-se, nada justifica que as alterações ocorram da noite para o dia, em situações de normal desenvolvimento". 904

\footnotetext{
902 VERDE, Giovanni. Mutamento di giurisprudenza e affidamento incolpevole... p. 9.

${ }^{903}$ Cf. WAMBIER, Teresa Arruda Alvim. Precedentes e evolução do direito. p. 55-56.

${ }^{904}$ Ibidem. p. 15. Igualmente, DERZI, Misabel Abreu Machado. A imprevisibilidade da jurisprudência e os efeitos... p. 187.
} 
Note-se que mudanças jurisprudenciais por divergência de opinião jurídica dos julgadores são inadmissíveis. ${ }^{905}$ Primeiro porque a jurisdição é, repita-se, una. Tanto o precedente judicial como a decisão dissidente são manifestações de uma mesma jurisdição; logo, manifestações contraditórias de uma mesma fonte de poder. Segundo porque a jurisdição é regida pela impessoalidade. O julgador não é a pessoa do juiz, mas o Estado. ${ }^{906}$ Quando uma decisão é tomada e um precedente formado, é o Estado que se manifesta sobre a questão de direito. ${ }^{907}$ Admitir que os juízes possam 'discordar' de manifestações estatais prévias para que prevaleçam suas 'opiniões' pessoais divergentes significa admitir que as decisões judiciais são atos subjetivos de uma pessoa, e não atos do Estado ou mesmo de uma instituição.

Destarte, uma vez consolidada, a jurisprudência deve ser mantida estável até que haja razões suficientes a justificarem a sua alteração (v. 18.1, abaixo).

17.4. Requisitos para que os precedentes sirvam como fundamento da confiança

No ponto 16.5.1 deste Capítulo foram apresentados alguns requisitos para que um pré-comportamento estatal sirva como fundamento da confiança. Dentre eles, são relevantes no que concerne aos precedentes: (a) eficácia; (b) aparência de legitimidade; (c) baixo grau de modificabilidade; (d) permanência no tempo; e (e) indução.

\footnotetext{
905 Nesse sentido, WAMBIER, Teresa Arruda Alvim. Precedentes e evolução do direito. p. 56: "Situação extremamente diversa é a que ocorre quando a alteração da jurisprudência tem lugar como decorrência de 'mudança de opinião' dos juízes. Esta alteração, via de regra brusca, não significa, em sentido algum, evolução do direito e inviabiliza de modo definitivo a uniformização, já que impossibilita a estabilização. Esta alteração de compreensão do direito decorrente de fatores pessoais é extremamente criticável e nociva $(\ldots)^{\prime \prime}$.

906 Cf. DINAMARCO, Cândido Rangel. Instituições de Direito Processual Civil, v. I. p. 328-331: “O juiz não é sujeito do processo, em nome próprio: ele ocupa o lugar do mais importante dos sujeitos processuais, que é o Estado. Não atua em função de seus interesses, ou de seus escopos pessoais, mas dos escopos que motivam o Estado a assumir a função jurisdicional” (p. 329).

907 V. SCHAUER, Frederick. Thinking Like a Lawyer. p. 177-180: "It is an important consequence of the generality of reasons that a person (or a court) who gives a reason for a decision is typically committed to that reason on future occasions. (...) Thus, when a court gives a reason for its decision, it creates a commitment for that court and an expectation on the part of those who seek to be guided by judicial opinions.
} 


\subsubsection{A eficácia do precedente}

O primeiro critério de valoração a respeito da aptidão de um ato estatal para servir como fundamento da confiança do indivíduo é a sua vinculação normativa. Transpondo-o para a jurisprudência, pode-se falar em eficácia do precedente.

A eficácia do precedente, já foi explicado, remete à sua obrigatoriedade ou à sua persuasividade. Se a obrigatoriedade do precedente torna indiscutível a sua utilização como fundamento da confiança, como é o caso das súmulas vinculantes, p.ex., poder-se-ia questionar se precedentes meramente persuasivos têm aptidão para gerar expectativas legítimas no jurisdicionado.

A resposta a essa questão parece já ter sido dada nos pontos anteriores. Em primeiro lugar, a cultura de desrespeito a precedentes é uma patologia que deve ser extirpada da realidade judiciária brasileira e que de nenhuma maneira compatibiliza-se com os princípios estruturantes do civil law. Impor ao juiz o respeito à lei não significa autorizar o juiz a decidir como bem entende, sobretudo quando este juiz está inserido em uma complexa e exaustiva estrutura recursal que culmina em tribunais voltados especificamente para dar homogeneidade à aplicação do Direito. Sendo assim, mesmo os precedentes ditos "persuasivos" devem ser respeitados horizontal e verticalmente: situação que, por si só, garante-lhes eficácia suficiente para que sirvam de fundamento da confiança. Em segundo lugar, precedentes persuasivos só são conservados, compilados e organizados em súmulas também "persuasivas", largamente divulgadas, para que o jurisdicionado saiba como comportar-se. ${ }^{908}$ Negar eficácia a tais precedentes e súmulas é o mesmo que dizer: o comportamento em desacordo com a jurisprudência muito provavelmente acarretará danos ao jurisdicionado; mas o comportamento de acordo com a jurisprudência não lhe traz nenhuma garantia de indenidade; a única certeza do jurisdicionado é que o seu futuro é incerto e imprevisível. Por fim, resgatando mais uma vez a estrutura recursal brasileira, o desrespeito de precedentes verticais perde um pouco da sua relevância diante da perspectiva do jurisdicionado de que, ao final, mesmo após tempo excessivo, o resultado do processo será como previsto pela jurisprudência do

\footnotetext{
908 V. NERY JUNIOR, Nelson. Boa-fé objetiva e segurança jurídica... p. 90-91: "Nisso reside a boa-fé objetiva do administrado/contribuinte/ jurisdicionado: a conduta que dele se espera é o cumprimento dos comandos emergentes da jurisprudência predominante nos tribunais, notadamente nos superiores".
} 
tribunal de maior nível hierárquico responsável por aquela causa. Mesmo que precedentes possam ser desrespeitados, o jurisdicionado tem condições de fazer com que prevaleça o entendimento do STJ, p.ex., ao interpor recurso especial. O indivíduo, então, comporta-se não com fundamento na eficácia persuasiva ou obrigatória do precedente, mas de acordo com o entendimento de quem julgará, ao final, o seu processo. Por isso, mais importante do que a eficácia do precedente é a sua aparência de legitimidade.

\subsubsection{Segue: a aparência de legitimidade do precedente}

Quanto mais alto o grau hierárquico do sujeito, maior é a aparência de legitimidade do ato por ele praticado. Trazendo essa constatação para a jurisprudência, um precedente do Supremo Tribunal Federal evidentemente transmite muito mais credibilidade do que o precedente de um Tribunal de Justiça. Essa aparência de legitimidade é potencializada, repita-se, pelo fato de que, atendidas as exigências constitucionais (matéria constitucional, pré-questionamento, repercussão geral etc.), quem proferirá a última decisão em um eventual processo de que o jurisdicionado seja parte será o STF, e não o Tribunal de Justiça. Com isso, o sujeito do ato acaba tendo um papel determinante na aferição do fundamento da confiança, pois não é razoável que o jurisdicionado confie (e aqui pode-se falar em uma confiança ilegítima) em um precedente em detrimento de outro que lhe seja hierarquicamente superior.

No já mencionado Relatório Molfessis (v. 17.2, acima), defendeu-se que apenas a Corte de Cassação francesa deveria ter a faculdade de modular os efeitos da mudança jurisprudencial. ${ }^{909}$ Mutatis mutandis, poder-se-ia questionar se o fundamento da confiança do indivíduo na jurisdição não deveria limitar-se aos precedentes dos tribunais superiores.

A resposta deve ser negativa, pois a jurisprudência dos tribunais inferiores também é extremamente relevante para a tomada de decisões pelo jurisdicionado. Ainda que um tribunal superior já tenha consolidado um determinado entendimento, a concretude das alternativas à disposição do particular pode depender da jurisprudência de um tribunal

\footnotetext{
${ }^{909}$ MOLFESSI, Nicolas (pres.) Rapport sur les Revirements de Jurisprudence, item 2.5.3: "Le pouvoir de moduler les effets dans le temps des revirements de jurisprudence doit appartenir exclusivement à la Cour de cassation".
} 
inferior. Cite-se um exemplo hipotético simples. O STF consolidou o entendimento de que não incide IPI sobre a importação de veículo para uso próprio por pessoa física. ${ }^{910}$ Deixada de lado a problemática relativa à admissibilidade do recurso extraordinário, pode-se pensar que, ao fim e ao cabo, mantida a jurisprudência do STF, o importador de veículo para uso próprio não precisará pagar IPI sobre a operação. No entanto, a opção do jurisdicionado em importar o veículo pode estar condicionada ao efetivo não pagamento do IPI, incluindo a dispensa de eventual depósito judicial para que o bem seja desembaraçado. Para isso, é fundamental que a jurisprudência do TRF competente seja idêntica à do STF, pois somente assim o jurisdicionado conseguirá uma decisão favorável imediata contra a inevitável exigência da Receita Federal. Em resumo, a escolha do jurisdicionado em importar um veículo para uso próprio dependerá não só da jurisprudência do STF, mas também da jurisprudência do TRF competente. Caso o TRF simplesmente mude a sua jurisprudência no curso da importação, exigindo do jurisdicionado o recolhimento do tributo (e forçandoo a depositar o valor em juízo), haverá violação da confiança legítima que lhe foi depositada.

\subsubsection{Segue: baixo grau de modificabilidade do precedente}

Além de eficaz e aparentemente legítimo, o precedente será tanto mais confiável quando menor for a probabilidade de que ele venha a ser modificado. Não se deve confundir, porém, grau de modificabilidade do precedente com instabilidade jurisprudencial. A mudança contínua e despropositada da jurisprudência não significa que um precedente não seja confiável. O grau de modificabilidade do precedente está relacionado à sua fragilidade no contexto processual e jurisprudencial em que está inserido. Uma decisão de um Tribunal de Justiça contrária a uma súmula do STJ e sujeita à interposição de recurso especial muito provavelmente será modificada, mas um entendimento jurisprudencial já sumulado, supõe-se, dificilmente será modificado de maneira repentina.

\footnotetext{
910 RE 550170 AgR, Relator(a): Min. RICARDO LEWANDOWSKI, Primeira Turma, julgado em 07/06/2011; RE 255090 AgR, Relator(a): Min. AYRES BRITTO, Segunda Turma, julgado em 24/08/2010 etc.
} 


\subsubsection{Segue: permanência no tempo do precedente}

Quanto mais antigo um entendimento jurisprudencial, maior é a sua interiorização na consciência dos jurisdicionados e da comunidade jurídica, e maior é a sua presunção de estabilidade. ${ }^{911}$

Note-se que a força do precedente está na sua permanência no tempo, e não simplesmente na sua antiguidade. Embora antigo, o precedente deve mostrar-se atual, seja pela sua reiteração periódica pelos tribunais, seja pelo seu difundido respeito pelos jurisdicionados. Utilizando-se o exemplo dado no começo deste ponto (v. 17.1.1, acima), o entendimento jurisprudencial de que o prazo para pleitear a invalidação de doação inoficiosa iniciava-se com a abertura da sucessão era extremamente antigo e reiteradamente vinha sendo reafirmado não só pelos Tribunais de Justiça, mas também pelo STF. Tratava-se, portanto, (ou ao menos deveria tratar-se) de uma jurisprudência altamente confiável.

\subsubsection{Segue: indução do precedente}

Por fim, a jurisprudência deve ser tanto mais confiável quanto maior for o seu poder de induzir o jurisdicionado a adotar um determinado comportamento. Por si só, a jurisprudência já tem um altíssimo poder de indução, mas é evidente que um precedente dissidente de um tribunal de justiça não pode induzir o jurisdicionado a adotar um comportamento contrário a um enunciado da súmula do STJ. Nesse caso, o poder de indução do precedente dissidente é, para fins de proteção da confiança legítima, insignificante.

Atualmente, todas as decisões prolatadas pelo STF em julgamento de recurso extraordinário possuem elevado poder de indução, por força do art. 543-A, $\S 3^{\circ}$, do CPC. Exigida a repercussão geral para a análise do recurso extraordinário pelo Supremo, apenas casos que extrapolam os interesses das partes são objeto de julgamento. Como regra, as atuais decisões do STF são pronunciamentos sobre questões de interesse de uma

\footnotetext{
911 De acordo com Giovanni VERDE, a jurisprudência italiana só considera a mudança jurisprudencial relevante quando o entendimento anterior tivesse prevalecido por um "notável lapso de tempo". Mutamento di giurisprudenza e affidamento incolpevole. p. 16.
} 
comunidade de pessoas que sinalizam "a orientação também para toda uma classe de casos iguais". 912

As súmulas dos tribunais são extremamente indutivas e sempre devem ser consideradas relevantíssimos fundamentos da confiança. Ao sumular um entendimento jurisprudencial, o tribunal sintetiza e torna definitivamente pública uma ratio decidendi para que não só os juízos inferiores sigam-na, mas para que também os jurisdicionados tenham condições de prever as consequências de suas atitudes. O ato de sumular uma ratio decidendi é um ato de comprometimento do tribunal com uma maneira de compreender o Direito; consequentemente, é um ato que inspira confiança no jurisdicionado e o incentiva a comportar-se de acordo com aquela ratio. Soma-se a isso a atribuição de eficácia impeditiva de recursos aos enunciados sumulados (art. 557 do CPC), bem como a possibilidade de que o recurso seja provido monocraticamente quando a decisão recorrida contrariá-los (art. 557, $\S 1^{\circ}$-A, do CPC). Quer dizer, o jurisdicionado sabe que quando se comporta de acordo com um entendimento sumulado, a chance de que esse comportamento seja referendado pelo Poder Judiciário é muito grande.

\subsection{A legitimidade da confiança do jurisdicionado}

A legitimidade da confiança, repete-se, depende única e exclusivamente da boa-fé do indivíduo, sendo irrelevante a previsibilidade de sua violação. O indivíduo deve poder confiar no Estado, seja ele digno de confiança ou não. Essa ampliação é ainda mais relevante se levada em consideração a fluidez da jurisprudência brasileira. A instabilidade jurisprudencial, em boa parte causada pelo corriqueiro e injustificável desrespeito a precedentes, verticais ou horizontais, certamente torna bastante previsível a quebra da confiança depositada pelo jurisdicionado na jurisdição. Aceita a imprevisibilidade como condição para a proteção da confiança, sancionar-se-ia o próprio jurisdicionado por confiar no Estado, ao invés de sancionar o Estado por um comportamento reiteradamente contraditório e descomprometido.

Por outro lado, é inerente à boa-fé a diligência mínima de um homem probo, ${ }^{913}$ pois rejeitar a imprevisibilidade de comportamentos contraditório do Estado não

\footnotetext{
912 ÁVILA, Humberto. Segurança Jurídica. p. 484.
} 
significa aceitar que o jurisdicionado possa agir de forma ingênua e irresponsável. Assim, há confiança legítima quando o fundamento da confiança é dotado de características mínimas que justifiquem a confiança do jurisdicionado. Quanto mais eficaz, aparentemente legítimo, estável, duradouro e indutivo for o precedente, maior deve ser a presunção de boa-fé do jurisdicionado no exercício da sua confiança.

\subsubsection{Precedentes e jurisprudência}

É bastante comum que se atribua aptidão para justificar a confiança legítima do jurisdicionado apenas a uma jurisprudência consolidada. Nessa linha de pensamento, meros precedentes isolados não serviriam como fundamento da confiança e, consequentemente, a confiança neles depositada careceria da diligência mínima de um homem probo.

Esse é um raciocínio que apenas recebe guarida em uma cultura de desrespeito de precedentes, principalmente os horizontais. Como os precedentes não vinculam, e os juízes possuem uma suposta "liberdade de convicção jurídica", então nada impede que um precedente seja ignorado em um julgamento posterior. Consequentemente, os pronunciamentos judiciais anteriores não têm nenhum valor até que sejam insistentemente reiterados por praticamente todos os julgadores de um tribunal; quando então, e apenas então, adquirem alguma credibilidade. Até, obviamente, que novos magistrados tenham "opiniões divergentes".

Partindo da premissa de que a cultura de desrespeito a precedentes é uma anomalia incompatível com o controle da atividade judicial, com a necessária igualdade jurídica, com a segurança jurídica e com a estrutura recursal do civil law, precedentes também devem ser respeitados e também são dignos de confiança; sobretudo quando decorrentes de um tribunal superior, cuja função é justamente harmonizar a aplicação do Direito.

Some-se a isso que o jurisdicionado precisa tomar decisões à medida que elas se mostram necessárias. Imagine-se que uma empresa precisa tomar uma decisão

\footnotetext{
913 A jurisprudência italiana dá grande ênfase à prudência do jurisdicionado para a proteção de sua confiança legítima, $c f$. VERDE, Giovanni. Mutamento di giurisprudenza e affidamento incolpevole. p. 16.
} 
imediata concernente ao recolhimento de tributos entre duas alternativas possíveis, 'a' e 'b'; independentemente da alternativa escolhida, a empresa sofrerá prejuízo caso a outra opção venha a prevalecer jurisprudencialmente (incidência de multas, juros e encargos tributários, suponha-se). A situação é nova e foi julgada pelo STJ apenas uma vez, cujo precedente foi bastante divulgado e já transitou em julgado. De acordo com a opinião da empresa e de seu corpo jurídico, a alternativa juridicamente correta seria a 'a'; o STJ, porém, entendeu que a alternativa ' $b$ ' é que está correta. A empresa, então, segue o entendimento do STJ e opta pela alternativa ' $b$ '. Nesse caso, ela não teria agido de acordo com uma confiança legítima? A conformação de seu comportamento a um precedente do STJ não estava pautada pela boa-fé? Ela teria sido imprudente ao confiar no único precedente do STJ existente sobre o assunto? Deveria ela ter agido em sentido diametralmente oposto a uma ratio decidendi expressamente apresentada pelo STJ?

A legitimidade da confiança na jurisdição não pode ficar vinculada apenas a um entendimento jurisprudencial consolidado. É evidente que não há confiança legítima quando o jurisdicionado segue uma jurisprudência minoritária ou um precedente dissidente. Entretanto, a confiança deve ser analisada de acordo com o caso concreto, privilegiando-se sempre a boa-fé do jurisdicionado para a aferição da sua legitimidade.

\subsubsection{Segue: a divergência jurisprudencial}

Exatamente o mesmo raciocínio desenvolvido no item anterior deve ser aplicado à hipótese de divergência jurisprudencial.

Não custa lembrar mais uma vez que cada juízo brasileiro, seja ele uma vara cível, uma câmara de um tribunal de justiça, uma turma do STJ ou o plenário do STF faz parte de uma mesma e única jurisdição. Quando um Tribunal de Justiça decide de maneira diametralmente oposta a outro, não há uma mera divergência entre órgãos autônomos e independentes. Há uma divergência dentro da própria jurisdição. É o Estado brasileiro, e não "juízes", que decide o caso do João de uma forma e o caso do José de outra. É o Estado brasileiro que ora diz "A" e ora diz "B", tornando absolutamente imprevisível a consequência jurídica das ações e omissões dos jurisdicionados.

A divergência jurisprudencial, portanto, ainda que inevitável, é uma incongruência do sistema que deve ser rapidamente contida e desfeita. Seja "A", seja "B", 
alguma resposta deve ser dada pelo Estado-jurisdição; e deve ser dada de forma taxativa e duradoura.

Dito isso, o jurisdicionado não pode sofrer as consequências da incapacidade do Estado de esclarecer-lhe qual é o Direito. As decisões precisam ser tomadas, e precisam ser tomadas quando se mostram necessárias. A partir do momento em que o jurisdicionado não tem condições de tomar uma decisão porque o Estado é incapaz de lhe dar uma resposta sobre quais são as consequências jurídicas dessa decisão, então o Estado está falhando em seu dever institucional. O indivíduo que de boa-fé confia em um posicionamento jurisprudencial controvertido deve ter essa confiança protegida.

\subsubsection{Ilegalidade manifesta: ponderações}

Outro óbice que geralmente se coloca à proteção da confiança é a ilegalidade (ou inconstitucionalidade) manifesta do seu fundamento. Com isso, precedentes evidentemente "frágeis" não poderiam ser legitimamente confiados pelo jurisdicionado.

Esse raciocínio é, em regra, válido, mas muitas vezes não corresponde à realidade. Há muitos entendimentos jurisprudenciais que se formam, desenvolvem-se e consolidam-se em afronta direta à doutrina, à lei ou mesmo à constituição, e ainda assim são perfeitamente eficazes. ${ }^{914}$ Vários são os exemplos. (1) $\mathrm{O}$ art. 475-J, $\S 1^{\circ}$ do CPC, introduzido pela Lei 11.232/2005, padece de uma grosseira e largamente conhecida inconstitucionalidade formal, mas é tranquilamente aplicado pelos tribunais para legitimar o cumprimento de sentenças declaratórias e, ao menos até a conclusão deste trabalho, não teve sua inconstitucionalidade decretada. (2) O art. 195 do CPC dispõe que "O advogado deve restituir os autos no prazo legal. Não o fazendo, mandará o juiz, de ofício, riscar o que neles houver escrito e desentranhar as alegações e documentos que apresentar". O texto não poderia ser mais claro do que é. O STJ, porém, simplesmente se recusa a aplicar a norma nele prevista, sobre o fundamento de que "Protocolado o recurso dentro do prazo recursal, não há falar em intempestividade pelo simples fato de os autos serem devolvidos

\footnotetext{
914 Lembrando-se as lições de PONTES DE MIRANDA no sentido de que um ato jurídico nulo não é necessariamente ineficaz. Tratado de Direito Privado, t. V. p. 71
} 
em cartório após o transcurso do referido prazo". ${ }^{915} \mathrm{Um}$ "simples fato" a que o legislador, verdadeiro legitimado para legislar, atribuiu expressamente a consequência de desentranhamento do recurso. (3) $\mathrm{O}$ art. 740 do Código Civil dispõe que "O passageiro tem direito a rescindir o contrato de transporte antes de iniciada a viagem, sendo-lhe devida a restituição do valor da passagem, desde que feita a comunicação ao transportador em tempo de ser renegociada". O parágrafo $3^{\circ}$ do mesmo artigo é de clareza solar: "Nas hipóteses previstas neste artigo, o transportador terá direito de reter até cinco por cento da importância a ser restituída ao passageiro, a título de multa compensatória". Reiteradas são as decisões que fecham os olhos à norma ali estatuída e referendam a prática banalizada das companhias aéreas de cobrar multas elevadíssimas dos consumidores que cancelam seus voos.

Quer dizer, a mera ilegalidade ou inconstitucionalidade de um entendimento jurisprudencial não implica necessariamente a sua ineficácia. É evidente que as cobranças abusivas para remarcação de voo são ilegais; mas, infelizmente, é uma ilegalidade acobertada pelo Poder Judiciário. A partir do momento em que uma sequência reiterada de decisões autoriza as companhias aéreas a cobrarem tarifas superiores ao mínimo legal, é de se questionar até que ponto esse comportamento poderá ser sancionado posteriormente pelo Estado caso haja uma mudança jurisprudencial. Se a jurisdição não disse como o Direito realmente regulava tais fatos quando teve a oportunidade, certamente perdeu parte de sua legitimidade para fazê-lo incolumemente em momento subsequente. Se de um lado o consumidor não pode ser prejudicado pelo erro do Estado, também não parece possível que as companhias aéreas sejam prejudicadas por comportarem-se como a jurisdição disse que poderiam comportar-se.

Poder-se-ia argumentar que a manifesta ilegalidade do comportamento das companhias aéreas retiraria toda e qualquer legitimidade da sua confiança. Em princípio, isso é verdade. Mas também é verdade que a manifesta ilegalidade da cobrança abusiva de taxas para remarcação de passagens não foi tão manifestamente ilegal para o Poder Judiciário. E se a jurisdição referenda o comportamento das companhias, a mudança abrupta da jurisprudência configuraria ao menos violação da boa-fé objetiva do Estado. Além disso, a solução para o problema pode parecer simples: basta que as companhias

${ }^{915}$ P.ex., REsp 792.435/RJ, j. 06/09/2007, p. 22/10/2007. 
parem de cobrar tais tarifas abusivas. Essa solução talvez não seja assim tão óbvia se constatado que isso pode diminuir a competitividade da companhia ao reduzir sua margem de lucro em relação às suas concorrentes.

Ou seja, ao invés de buscar parâmetros objetivos de proteção da confiança, parece mais adequado avaliar a integridade do fundamento da confiança e a boa-fé do jurisdicionado ao comportar-se de acordo com determinado precedente. Para isso, vale mencionar a figura do "advogado bem informado" de Eisenberg.

\subsubsection{O parâmetro do "advogado bem informado"}

De acordo com Melvin Eisenberg, o parâmetro a ser adotado para a proteção da confiança legítima é a do "advogado bem informado" (well-informed lawyer). Uma ratio decidendi é confiável quando assim considerada por um "advogado bem informado". ${ }^{916}$ A construção da figura pelo autor norte-americano, porém, traz premissas inerentes a uma segurança jurídica e a uma estabilidade jurisprudencial que não parecem corresponder à realidade brasileira. Por isso, o que importa aqui é a sua essência.

A utilização da figura do "advogado bem informado", devidamente adaptada, tem como implicação imediata a não proteção da confiança legítima pela má compreensão do Direito ou pela negligência do jurisdicionado. A legitimidade da confiança é mais do que a mera probidade de um homem comum, portanto. A legitimidade da confiança tem como pressuposto um conhecimento suficiente do Direito para que o comportamento adotado realmente tenha sido pautado pela existência de um precedente judicial apontando naquele sentido.

Entretanto, se mesmo um "advogado bem informado" é incapaz de aconselhar com relativa segurança o seu cliente a respeito das consequências jurídicas de determinado comportamento, seja por instabilidade jurisprudencial, seja por divergência jurisprudencial, seja ainda por causa de um entendimento jurisprudencial "equivocado", então certamente está-se diante de um caso de confiança legítima a ser tutelada. Em suma, o parâmetro da boa-fé do jurisdicionado não deve ser o de um "homem comum" ou o de um "pai de família", mas o de um "advogado bem informado".

\footnotetext{
${ }^{916}$ V. EISENBERG, Melvin Aron. The Nature of the Common Law. p. 110-111.
} 
17.6. O exercício da confiança legítima do jurisdicionado

Existente uma confiança legitimamente depositada na jurisdição, resta saber se o particular concretizou essa confiança, adotando algum tipo de comportamento a partir das expectativas que the foram geradas pelo Estado. Esse comportamento ativo ou omissivo é que justifica a proteção da confiança, pois, ao contrário dos atos administrativos e legislativos, as decisões judiciais não são endereçadas ao jurisdicionado que teve sua confiança violada. Antes de tudo, as decisões judiciais voltam-se às partes do processo, definindo apenas indiretamente como deve ser o comportamento das demais pessoas.

É claro que essa afirmação não se aplica à edição de enunciados sumulares pelos tribunais, hipótese em que são apresentados parâmetros de comportamento esperados de todos os jurisdicionados, sejam eles partes em processos judiciais ou não. De qualquer forma, tendo em vista uma melhor racionalização do sistema de proteção da confiança, parece razoável limitar a tutela do jurisdicionado que efetivamente sofreu um dano por ter confiado na jurisdição.

Desse modo, nem todo comportamento contraditório da jurisdição viola a confiança legítima do jurisdicionado. O mencionado desrespeito ao enunciado 54 da súmula do STJ pelo próprio STJ, p.ex., ainda que configure uma grave violação da segurança jurídica objetiva, não tem aptidão para frustrar expectativas subjetivas do jurisdicionado, pois ninguém age ou omite-se esperando receber uma compensação por danos morais acrescida de juros desde o evento danoso. ${ }^{917} \mathrm{O}$ autor pode até ter uma expectativa abstrata de receber uma compensação pecuniária mais elevada, mas não foi adotado nenhum comportamento a partir dela que venha a causar-lhe prejuízo. Situação claramente oposta é a do herdeiro que deixa de propor demanda visando à invalidação de doação inoficiosa com fundamento em uma jurisprudência consolidada e, quando finalmente "adquire" interesse processual para tanto, a jurisprudência muda e seu direito passa a ser considerado "prescrito". Ou mesmo a do jurisdicionado que, enquanto pessoa física importa veículo para uso próprio com a expectativa de não ser obrigado a recolher

917 Como explica ÁVILA, Humberto. Segurança Jurídica. p. 482, "Embora toda insegurança jurídica deva envolver alguma frustração, nem toda frustração é caso de insegurança jurídica digna de proteção". 
IPI e, ao buscar a tutela jurisdicional, depara-se com uma decisão diametralmente oposta às que prevaleciam quando resolveu importar o bem, sofrendo um prejuízo indevido.

\section{A proteção da confiança legítima do jurisdicionado}

Estabelecidas as premissas de que (a) o princípio da confiança é uma garantia constitucional decorrente da segurança jurídica subjetiva e da necessária boa-fé objetiva do Estado na sua relação com o particular, e de que (b) os precedentes judiciais também servem de fundamento da confiança, exigindo-se da jurisdição coerência e consistência em sua atuação, há que se tratar agora dos mecanismos existentes para a proteção do jurisdicionado contra a traição de sua confiança.

Em linhas gerais, existem três maneiras pela qual a confiança legítima do jurisdicionado é tutelada: (a) pela abstenção da mudança jurisprudencial ou desrespeito a precedentes já existentes; (b) pela modulação dos efeitos da mudança jurisprudencial; e (c) pela reparação civil do jurisdicionado lesado.

\subsection{Limites às mudanças jurisprudenciais}

O primeiro e mais eficaz instrumento de proteção da confiança legítima é a manutenção e a continuidade da jurisprudência. Isso não significa, ressalte-se novamente, defender uma jurisprudência estática e imutável. O que se pretende é que a jurisprudência pare de mudar e busque apenas evoluir; que se compreenda que a jurisprudência é uma produção do Estado e, como tal, deve ser respeitada. Quanto menos mudanças jurisprudenciais houver, maior será a segurança jurídica objetiva e menor será o risco de que as expectativas dos jurisdicionados venham a ser frustradas. $\mathrm{O}$ jurisdicionado passa a confiar na jurisdição não porque dentre duas alternativas incertas a jurisprudência é a menos incerta delas, mas porque ele sabe que seguir a jurisprudência é uma garantia para obter determinadas consequências jurídicas para determinado comportamento.

Os perigos da mudança de jurisprudência são bastante conhecidos e fartamente tratados no common law. Entre a doutrina norte-americana, Melvin Eisenberg, em excelente obra, apresenta duas diretrizes básicas para que um precedente possa ser revogado: (1) o precedente "substancialmente falha em satisfazer os parâmetros da 
congruência social e consistência sistêmica"; e (2) "os valores que suportam o parâmetro da estabilidade precedental e o princípio do stare decisis - os valores da equidade, proteção da confiança legítima, prevenção da surpresa injusta, replicabilidade e suporte não seriam melhor atendidos pela preservação do precedente que pela sua revogação". ${ }^{918}$ Esse segundo seria o princípio básico da revogação de precedentes.

Dentre a doutrina britânica, J. W. Harris erigiu, em sentido similar, quatro princípios básicos para que um precedente possa ser revogado por uma decisão posterior: (1) chamado por Sampford de "princípio da inexistência de novas razões", um precedente não pode ser revogado quando formado a partir de razões validamente sustentáveis; nesse caso, uma segunda opinião jurisprudencial autorizaria que, posteriormente, fosse dada uma terceira opinião, e assim sucessivamente; (2) a revogação de precedentes (e a mudança jurisprudencial) deve levar em consideração a confiança legítima depositada pelos particulares na decisão anterior; (3) um precedente não pode ser revogado quando o legislador parte da premissa de que ele representava o Direito; (4) não podem ser revistos precedentes quando não estiverem diretamente relacionados ao caso em julgamento. ${ }^{919}$

Ambos os autores, portanto, condicionam a mudança jurisprudencial à inexistência de violação da confiança legítima do jurisdicionado. ${ }^{920}$ Consequentemente,

\footnotetext{
${ }^{918}$ EISENBERG, Melvin Aron. The Nature of the Common Law. p. 104-105. No original: "The first principle that governs overruling is as follows: A doctrine should be overruled if (i) it substantially fails to satisfy the standards of social congruence and systemic consistency, and (ii) the values that underlie the standard of doctrinal stability and the principle of stare decisis - the values of evenhandedness, protecting justified reliance, preventing unfair surprise, replicability, and support - would be no better served by the preservation of a doctrine than by its overruling. Call this the basic overruling principle".

919 Cf. SAMPFORD, Charles. Retrospectivty and the Rule of Law. p. 171. Harris teria flexibilizado tais requisites posteriormente, $c f$. Ibidem. p. 171-172; HODDER, Jack. Departure from 'wrong' precedents by final appellate courts... p. 166-184.

${ }^{920}$ Em sentido diametralmente oposto, v. o voto do Min. Herman Benjamin no REsp 654.446/AL: “A segurança jurídica, portanto, não deve se transformar em eufemismo para acorrentar a jurisprudência a modelos jurídicos arcaicos e ultrapassados, ou para tolher a força criativa das decisões judiciais. São inevitáveis - eu diria salutares - as mudanças de entendimento do STJ, tanto mais se para a jurisprudência, como acima aludido, deseja-se um papel revigorado, em permanente sintonia com o cambiante marco regulatório e as oscilações naturais na assimilação dos valores abrigados pelo ordenamento nacional (...) Isso quer dizer que o princípio da segurança jurídica não garante, nem deve ser pretexto para garantir, a manutenção de determinada jurisprudência, ainda que consolidada, mas que esteja em oposição aos princípios basilares da modernidade, como a dignidade da pessoa humana ou a atribuição à propriedade
} 
sujeitam a mudança jurisprudencial a uma necessidade sistêmica, seja expressamente, como faz Eisenberg, seja indiretamente, como faz Harris ao rejeitar que um precedente seja revogado sem que existam novas razões relevantes para tanto. ${ }^{921}$ Atendidos esses requisitos, a mudança jurisprudencial permite uma salutar evolução do Direito e, em muitos casos, até mesmo colabora com a promoção da segurança jurídica. ${ }^{922}$

Na Inglaterra, a House of Lords, altamente comprometida com seus próprios precedentes, não só acolhia o "princípio da inexistência de novas razões”, como também deixava de revogar precedentes que pudessem violar a confiança dos jurisdicionados, ainda que largamente considerados equivocados. ${ }^{923}$ No mesmo sentido, a High Court australiana dificilmente revoga seus precedentes por mera divergência de opinião. $\mathrm{O}$ "princípio da inexistência de novas razões" é levado bastante a sério e, como regra, busca-se proteger a confiança gerada pela decisão nos jurisdicionados. ${ }^{924}$ Ao se pronunciar sobre o problema da mudança jurisprudencial em 16 de dezembro de 1981, o Tribunal Constitucional Federal da Alemanha afirmou que deve ser ponderado o interesse público na aplicação mais correta possível do Direito com o interesse dos jurisdicionados na permanência da jurisprudência firmada. ${ }^{925}$ Em decisões seguintes, o Tribunal reiterou que os juízes devem

privada de funções(na forma de deveres) em favor da comunidade e das gerações futuras. A evolução do entendimento pretoriano é ínsito à evolução sócio-cultural em que se insere, sendo tão desejável como inevitável. (...) Numa palavra, se é dever do Judiciário traduzir da melhor forma possível a aplicação da legislação, sem preocupação com o status dos precedentes afetados (...)”.

921 Para HODDER, Jack. Departure from 'wrong' precedents by final appellate courts... p. 184, "If the earlier decision suggested for overruling is not obviously wrong, nor clearly bases on materially inadequate information or argument, and not causing self-evident difficulties, it should stand".

922 Cf. EISENBERG, Melvin Aron. The Nature of the Common Law. p. 126. Seguindo as palavras de MONÉGER, Joël. La maîtrise de l'inévitable revirement de jurisprudence. p. 327: "Il faut que l'inévitable revirement soit construit dans le temps: te temps lent des arrêts successifs qui, part touches légères, annoncent le changement; l'instant de l'arrêt qu'il faut rendre est l'aboutissement des années ou des mois de la réflexion, de l'infléxion. Le revirement est connu avant de se produire".

923 Cf. DUXBURY, Neil. The Nature and the Authority of Precedent. p. 128; SAMPFORD, Charles. Retrospectivty and the Rule of Law. p. 177.

${ }^{924}$ V. SAMPFORD, Charles. Retrospectivty and the Rule of Law. p. 173; HARDING, Matthew; MALKIN, Ian. Overruling in the High Court of Australia in common law cases. passim.

925 Cf. VALEMBOIS, Anne-Laure. La Constitutionnalisation de l'Exigence de Sécurité Juridique en Droit Français. p. 231. 
levar em consideração a confiança legítima dos sujeitos de Direito para mudar a jurisprudência. $^{926}$

Resumindo, um precedente não pode ser revogado e, com ainda mais razão, uma jurisprudência não pode ser modificada pela simples divergência de opiniões dos juízes ou pela alteração da formação de um tribunal. ${ }^{927}$ As decisões judiciais são atos do Estado e, como tal, devem ser respeitadas por aqueles que o personificam. ${ }^{928}$

Em passagem bastante realista e ponderada, Marie-Anne Frison-Roche afirmou: "Se a pessoa é racional, ela não espera tanto a satisfação de seus interesses, porque estes podem ser modificáveis ou compartilhados, mas o conhecimento do destino que o Direito lhe reserva, de modo que ela possa agir levando em consideração esse dado". ${ }^{929}$ Em sentido parecido, Cândido Dinamarco já havia defendido que "O importante não é o consenso em torno das decisões estatais, mas a imunização delas contra os ataques dos contrariados; e indispensável, para o cumprimento da função pacificadora exercida

${ }^{926} C f$. VALEMBOIS, Anne-Laure. La Constitutionnalisation de l'Exigence de Sécurité Juridique en Droit Français. p. 231.

${ }^{927}$ Cf. DERZI, Misabel Abreu Machado. A imprevisibilidade da jurisprudência e os efeitos... p. 193: "Nem a mudança da composição do Supremo Tribunal Federal, nem a sincera alteração do entendimento relativo a certa matéria, cláusula ou princípio constitucional, nada justifica o abandono da fundamentação coerente, da segurança e do Estado de Direito. As evoluções da jurisprudência devem operar para os casos futuros, sem nenhuma quebra da confiança".

928 DINAMARCO, Cândido Rangel. Instituições de Direito Processual Civil, v. I. p. 328-331: "O exercício da jurisdição é feito pelo Estado mediante a atuação de agentes específicos, que são os juízes de todos os graus. Eles atuam como se fossem o próprio Estado (...). Tais são os juízes, que corporificam o Estado e o representam no exercício da jurisdição. (...) O juiz não é sujeito do processo, em nome próprio: ele ocupa o lugar do mais importantes dos sujeitos processuais, que é o Estado". Igualmente, PONTES DE MIRANDA, Francisco Cavalcanti. Comentários ao Código de Processo Civil, t. II. p. 338-339: "Enquanto os outros sujeitos da relação jurídica processual têm interesse dependente dos resultados do processo, o juiz não tem interesse próprio, qualquer que seja. O seu interesse é transindividual, identifica-se com a missão social que lhe confiou o Estado: realizar o direito objetivo e pacificar, dirimindo contendas. (...) Toda sua atividade é ordenada no sentido de que, através dele, seja o Estado que exerce o ato. (...) O pedido é feito ao Estado. Esse, pelo seu juiz, responde qual o texto que incidiu, ou qual o texto que não incidiu, ou se não há texto para o caso, ou se o há".

${ }^{929}$ FRISON-ROCHE, Marie-Anne. La théorie de l'action comme principe de l'application dans le temps des jurisprudences. p. 311. No original : "Si la personne est rationnelle, elle n'attend pas tant la satisfaction de ses intérêts, car ceux-ci peuvent être changeants ou partagés, mais de connaître le sort que le droit lui réserve, de sorte qu'elle puisse agir en intégrant cette donnée". 
pelo Estado legislando ou sub specie jurisdictionis, é a eliminação do conflito como tal, por meios que sejam reconhecidamente idôneos". 930

Utilizando o exemplo dado a respeito da invalidação de doação inoficiosa (v. 17.1.1, acima), o momento para propositura da demanda é muito menos importante ao jurisdicionado do que a efetiva determinação desse momento. ${ }^{931}$ Muitos são os casos em mais vale ao jurisdicionado, respeitados limites mínimos de razoabilidade, um posicionamento jurisprudencial equivocado, mas determinado, do que um posicionamento jurisprudencial correto, mas incerto, transitório e indigno de confiança. Configurada tal situação, é preciso verificar se a mudança jurisprudencial não trará mais malefícios do que benefícios à ordem jurídica.

18.2. A mudança jurisprudencial prospectiva

A segunda técnica existente para a proteção da confiança legítima do jurisdicionado é a mudança jurisprudencial prospectiva; isto é, muda-se a jurisprudência, mas conservam-se os efeitos da jurisprudência anterior.

A mudança jurisprudencial prospectiva assemelha-se, com as ressalvas feitas nos Capítulos anteriores, à mudança legislativa. Assim como a lei não pode retroagir para prejudicar direitos adquiridos e atos jurídicos perfeitos, a jurisprudência não pode retroagir para prejudicar expectativas legítimas criadas no jurisdicionado pela própria jurisdição. A mudança é feita para o futuro, de modo que só atinja fatos posteriores à mudança jurisprudencial efetivada.

No julgamento do Mandado de Segurança $n^{\circ}$. 26604/DF, o Supremo Tribunal Federal modulou os efeitos da sua mudança jurisprudencial pelos seguintes e louváveis motivos: "Razões de segurança jurídica, e que se impõem também na evolução jurisprudencial, determinam seja o cuidado novo sobre tema antigo pela jurisdição concebido como forma de certeza e não causa de sobressaltos para os cidadãos. Não tendo havido mudanças na legislação sobre o tema, tem-se reconhecido o direito de o Impetrante

\footnotetext{
${ }^{930}$ DINAMARCO, Cândido Rangel. A Instrumentalidade do Processo. p. 195.

931 Seguindo as palavras de ÁVILA, Humberto. Segurança Jurídica. p. 339: “o cidadão precisa ter condições de saber se a liberdade juridicamente exercida ontem será respeitada hoje, e se a liberdade hoje exercida será respeitada amanhã".
} 
titularizar os mandatos por ele obtidos nas eleições de 2006, mas com modulação dos efeitos dessa decisão para que se produzam eles a partir da data da resposta do Tribunal Superior Eleitoral à Consulta n. 1.398/2007". ${ }^{932}$

A técnica já tinha sido utilizada em outras ocasiões, como no Conflito de Competência $n^{\circ}$. 7204/MG: “como imperativo de política judiciária -- haja vista o significativo número de ações que já tramitaram e ainda tramitam nas instâncias ordinárias, bem como o relevante interesse social em causa --, o Plenário decidiu, por maioria, que o marco temporal da competência da Justiça trabalhista é o advento da EC 45/04. (...) 5. O Supremo Tribunal Federal, guardião-mor da Constituição Republicana, pode e deve, em prol da segurança jurídica, atribuir eficácia prospectiva às suas decisões, com a delimitação precisa dos respectivos efeitos, toda vez que proceder a revisões de jurisprudência definidora de competência ex ratione materiae. O escopo é preservar os jurisdicionados de alterações jurisprudenciais que ocorram sem mudança formal do Magno Texto". ${ }^{933} \mathrm{E}$ também no Inquérito 687: “3. Questão de Ordem suscitada pelo Relator, propondo cancelamento da Súmula 394 e o reconhecimento, no caso, da competência do Juízo de $1^{\text {o }}$ grau para o processo e julgamento de ação penal contra ex-Deputado Federal. Acolhimento de ambas as propostas, por decisão unânime do Plenário. 4. Ressalva, também unânime, de todos os atos praticados e decisões proferidas pelo Supremo Tribunal Federal, com base na Súmula 394, enquanto vigorou". 934

A modulação dos efeitos da mudança jurisprudencial é bastante difundida nos Estados Unidos sob o nome de "revogação prospectiva" de precedentes, ou prospective overruling. Há diversas variações. Na mais comum delas, aplica-se o novo entendimento jurisprudencial ao caso que está sendo julgado e a todos os fatos ocorridos após a mudança jurisprudencial, mas respeitam-se os fatos que lhe são anteriores. Quando a mudança não é aplicável nem mesmo ao caso que está sendo julgado, diz-se que houve uma "revogação prospectiva pura" (pure prospective overruling). Também existe a possibilidade de que o precedente seja revogado a partir de uma data futura fixada pelo tribunal, ao qual se

\footnotetext{
${ }^{932}$ MS 26604, Relator(a): Min. CÁRMEN LÚCIA, Tribunal Pleno, julgado em 04/10/2007.

${ }^{933}$ CC 7204, Relator(a): Min. CARLOS BRITTO, Tribunal Pleno, julgado em 29/06/2005, DJ 09-12-2005.

${ }^{934}$ Inq 687 QO, Relator(a): Min. SYDNEY SANCHES, Tribunal Pleno, julgado em 25/08/1999, DJ 09-112001.
} 
denomina de "revogação prospectivamente prospectiva" (prospective prospective overruling). Essa solução foi dada em 1962 pelo Tribunal de Minnesota ao caso Spanel $v$. Mounds View School District $n^{o}$. 621, ao revogar precedente com efeitos a partir do final da sessão legislativa de Minnesota. Solução distinta foi dada no julgamento de Li v. Yellow Cab Co. A Suprema Corte da Califórnia alterou a sua jurisprudência, mas limitou os efeitos da mudança a todos os casos cujo julgamento ainda não houvesse iniciado, independentemente da data dos fatos. ${ }^{935}$

Outra técnica interessantíssima, complementar à da revogação prospectiva de precedentes, é a "sinalização" (signaling). A sinalização é utilizada quando o precedente perde a congruência social e a consistência sistêmica, mas exerce uma função importante na indução comportamental dos jurisdicionados. O tribunal, então, sinaliza formalmente aos juristas que o precedente não é mais confiável, podendo ser revogado e substituído em julgamentos futuros. Com isso, a jurisprudência anterior é respeitada, porém o tribunal informa aos jurisdicionados que não devem mais confiar naquele entendimento, uma vez que carente de congruência social e consistência sistêmica. ${ }^{936}$ Caso o precedente venha a ser revogado, o Judiciário certamente não poderá ser acusado de ter violado a confiança legítima nele depositada pelos jurisdicionados.

18.3. Duas regras básicas de utilização da técnica de revogação prospectiva de precedentes

Considerando tudo o que vem sendo exposto até o momento, propõem-se duas regras básicas para a revogação prospectiva de precedentes: (a) no confronto entre o particular e o Estado, a confiança legítima do particular sempre deve prevalecer; e (b) no confronto entre particulares, devem ser ponderados os interesses envolvidos.

\footnotetext{
935 Cf. EISENBERG, Melvin Aron. The Nature of the Common Law. p. 127-128.

936 Cf. Ibidem. p. 121-122. Para uma explicação mais aprofundada da técnica da sinalização, v., no Brasil, MARINONI, Luiz Guilherme. Precedentes Obrigatórios. p. 335-343.
} 
18.3.1. Prevalência dos interesses do particular sobre os do Estado (ou interesse público secundário)

É clássica, e extremamente negligenciada, a distinção no Direito Administrativo entre interesses primários e interesses secundários do Estado. Nem todo interesse do Estado é necessariamente de interesse público (primário), pois o Estado "pode ter, tanto quanto as demais pessoas, interesses que lhe são particulares, individuais, e que, tal como os interesses delas, concebidas em suas meras individualidades, se encarnam no Estado enquanto pessoa". 937

Isso significa que nem tudo que traz um ganho ao Estado configura um interesse público propriamente dito (primário); e, frequentemente, são de interesse público situações que interessam unicamente ao particular, de certo modo lesivas ao Estado enquanto pessoa: é o caso, p.ex., do pagamento de indenização justa e prévia para a desapropriação ou da indenização por danos causados em razão de obra realizada pelo Estado. $^{938}$

Tendo isso em mente, e deixando de lado as várias polêmicas que envolvem o interesse público enquanto conceito e enquanto instituto, pode-se dizer que é de interesse público que o Direito seja estável e previsível, que o Estado aja sempre de boa-fé, e que a confiança legítima depositada pelo particular no Estado seja sempre respeitada. Trazendo essas ideias ao Direito Processual, conclui-se que devem ser conferidos efeitos prospectivos a toda mudança jurisprudencial que traga um benefício ao Estado, ou a qualquer pessoa de Direito Público, mas viole a confiança legítima do jurisdicionado.

A razão para que essa regra seja adotada é muito simples. Tratando-se a jurisdição de atividade, poder e função do Estado, é inadmissível que a sua incongruência e a sua contraditoriedade causem prejuízos ao particular em benefício do próprio Estado. Sendo assim, toda e qualquer mudança jurisprudencial que viole a confiança legítima do jurisdicionado e traga benefícios ao Estado na sua relação com o particular, tais quais

\footnotetext{
${ }^{937}$ BANDEIRA DE MELLO, Celso Antônio. Curso de Direito Administrativo. p. 65.

${ }^{938}$ Cf. Ibidem. p. 68-69: "Só mesmo em uma visão muito pedestre ou desassistida do mínimo bom senso é que se poderia imaginar que o princípio da supremacia do interesse público sobre o interesse privado não está a reger nos casos em que sua realização traz consigo a proteção de bens e interesses individuais e que, em tais hipóteses, o que ocorre... é a supremacia inversa, isto é, do interesse privado!”
} 
recolhimento de tributos, sanções administrativas, licitações, contratos administrativos, prazos prescricionais ou decadenciais etc., devem receber efeitos prospectivos.

\subsubsection{Ponderação entre os interesses dos particulares envolvidos}

Se os efeitos da mudança jurisprudencial devem ser sempre modulados em benefício do particular em caso de conflito de interesses com o Estado, a situação é mais delicada quando o conflito de interesses se dá entre particulares. Nessa hipótese, a modulação obedecerá a uma ponderação entre os interesses envolvidos, observando-se uma regra básica: a mudança jurisprudencial sempre será prospectiva quando sua modulação não causar prejuízos significativos aos beneficiários da mudança.

Com efeito, tratando-se de mudança jurisprudencial que causa dano insuportável à parte que confiou legitimamente na jurisdição, e traz poucos benefícios à parte favorecida, então necessariamente deverão ser atribuídos efeitos prospectivos "puros" ao novo entendimento. Serve como exemplo perfeito o já mencionado "prazo prescricional" para invalidação de doação inoficiosa. A mudança jurisprudencial, de um lado, retirou o "acesso à justiça" do herdeiro que se considera prejudicado pela doação; de outro, pouco acrescentou ao herdeiro-donatário, concedendo-lhe apenas um atalho para que obtivesse êxito no processo. A disparidade entre as consequências da mudança jurisprudencial são patentes. A modulação dos efeitos do novo entendimento jurisprudencial não apenas respeitaria a confiança legítima do herdeiro supostamente prejudicado, mas também preservaria o seu poder de ação; além de não causar praticamente nenhum dano ao herdeiro-donatário.

18.4. Críticas formuladas à revogação prospectiva de precedentes - e suas respostas

As críticas endereçadas à revogação prospectiva de precedentes são basicamente as seguintes: (a) ao aplicar um precedente já superado, a jurisdição deixa de atender ao seu mister, qual seja, julgar com justiça o caso que lhe é apresentado; (b) a técnica precisa ser prevista em lei; (c) a revogação prospectiva pura de precedentes desestimula as pessoas a buscarem decisões mais justas e contribuírem para a evolução do Direito; e (d) há uma majoração indevida dos poderes dos juízes. 
18.4.1. Aplicação de um precedente já superado-descumprimento da função jurisdicional

A primeira e mais relevante crítica desferida contra a revogação prospectiva de precedentes está no suposto desvirtuamento da função jurisdicional. Partindo-se da premissa de que a jurisdição deve resolver de forma justa os conflitos que se lhe apresentam para julgamento, a revogação prospectiva de um precedente implicaria decidir casos de forma injusta e contrária ao Direito. A crítica foi muito bem resumida por Charles Sampford: "embora filósofos e juízes reconheçam a importância da confiança, sempre há um forte e simples argumento contrário de que a nova regra é simplesmente uma regra melhor". ${ }^{939}$ De acordo com Xavier Bachellier e Marie-Noëlle Jobard-Bachellier, a revogação prospectiva de precedentes seria uma "denegação de justiça", uma vez que deixaria de ser aplicada ao caso concreto uma norma considerada "apropriada e necessária" pelo tribunal. ${ }^{940} \mathrm{Na}$ High Court australiana, o Justice McHugh afirmou que a aplicação de um precedente revogado significaria aplicar um precedente "injusto ou ineficiente". ${ }^{941}$

Em relação a processos que envolvam conflito de interesses entre particular e Estado, a crítica não tem nenhum fundamento. ${ }^{942}$ Em qualquer hipótese o Estado deve responder pela quebra da confiança legítima do particular, seja porque não foi capaz de elaborar uma norma jurídica suficientemente clara e completa que regulasse taxativamente o caso concreto, seja porque não foi capaz de manter os precedentes que geraram expectativas legítimas no jurisdicionado.

Em relação a processos que envolvam conflitos entre particulares, a crítica traz uma abordagem superficial e imediatista do problema. Realmente, o processo (e a

\footnotetext{
939 SAMPFORD, Charles. Retrospectivity and the Rule of Law. p. 169. No original: "However, although philosophers and judges alike recognize the importance of reliance, there is always a strong, simples, contrary argument that the new rule is simply a better rule".

${ }^{940}$ BACHELLIER, Xavier; JOBARD-BACHELLIER, Marie-Noëlle. Les revirements de jurisprudence. p. 307.

${ }^{941}$ Cf. SAMPFORD, Charles. Retrospectivity and the Rule of Law. p. 169.

${ }^{942}$ No caso dos autores franceses citados ela nem poderia aplicar-se, tendo em vista a separação entre as “jurisdições” administrativa e civil na França.
} 
jurisdição) tem como escopo primário a "atuação da lei". ${ }^{943}$ No entanto, a jurisdição já havia "atuado essa lei" em casos pretéritos, apresentando uma ratio decidendi universal que deveria ser aplicada em todos os casos análogos. Uma ratio decidendi que serviu como fundamento do comportamento adotado pelo particular e que não pode ser simplesmente desprezada porque supostamente encontrada uma ratio mais "apropriada" pelos tribunais. ${ }^{944}$ Se a jurisdição deve "atuar a lei", ela também deve esclarecer, integrar e dissolver as antinomias dessa lei. ${ }^{945}$ Mais do que isso, a jurisdição deve pacificar a sociedade. ${ }^{946}$ Toda vez que a jurisdição encontra precedentes mais "apropriados" dos que os anteriores, ignorando tudo o que foi realizado sob a égide de suas rationes decidendi pretéritas, a jurisdição deixa de esclarecer, integrar e corrigir o Direito; e deixa de pacificar a sociedade.

Além disso, ou o jurisdicionado beneficiado com a mudança não conhecia a jurisprudência, ou a conhecia e mesmo assim resolveu comportar-se contrariamente a ela. Qualquer uma das hipóteses relativiza a "injustiça" de se aplicar a ratio decidendi revogada.

\subsubsection{Necessária previsão legislativa}

Crítica reiteradamente formulada pela doutrina francesa ao mencionado Relatório Molfessis foi a da necessária previsão legislativa para que os efeitos da mudança

\footnotetext{
${ }^{943}$ Cf. CHIOVENDA, Giuseppe. Del sistema negli studi del processo civile. p. 230

944 Segundo SAMPFORD, Charles. Retrospectivity and the Rule of Law. p. 172, "Excessive retrospective judicial law-making is kept in check by the judicial obligation to give and publish reasons (...)”.

${ }^{945}$ Foi exatamente isso o que afirmou a Corte Europeia dos Direitos do Homem no julgamento do caso “Pessino c. France” (req. 40403/02): “31. La Cour a déjà constaté qu'en raison même du principe de généralité des lois, le libellé de celles-ci ne peut présenter une précision absolue. L'une des techniques types de réglementation consiste à recourir à des catégories générales plutôt qu'à des listes exhaustives. Aussi de nombreuses lois se servent-elles par la force des choses de formules plus ou moins floues, afin d'éviter une rigidité excessive et de pouvoir s'adapter aux changements de situation. L'interprétation et l'application de pareils textes dépendent de la pratique (voir, parmi d'autres, Kokkinakis, précité $\$ 40$ et Cantoni, précité §31). La fonction de décision confiée aux juridictions sert précisément à dissiper les doutes qui pourraient subsister quant à l'interprétation des normes, en tenant compte des évolutions de la pratique quotidienne".

${ }^{946}$ V. DINAMARCO, Cândido Rangel. A Instrumentalidade do Processo. p. 193 e ss.
} 
jurisprudencial pudessem ser modulados. ${ }^{947}$ No Brasil, essa tese foi encampada pelo Min. Teori Zavascki no julgamento do REsp $n^{\circ}$. 738.689/PR. O caso tratava da data da extinção do crédito-prêmio de IPI, instituído pelo art. $1^{\text {o }}$ do Decreto-lei $n^{\circ}$. 491/69. Embora entendesse que o benefício fora extinto ao menos desde 1990, o Min. Herman Benjamin propôs a modulação dos efeitos da mudança jurisprudencial para agosto de 2004, protegendo os jurisdicionados que confiaram na jurisprudência anterior do STJ. A proposta foi rejeitada pelo Min. Zavascki por ausência de previsão legislativa:

"Ademais, a modulação dos efeitos das decisões do STF, quando autorizadas, é apenas a que diz respeito a normas declaradas inconstitucionais e limita-se aos efeitos de natureza exclusivamente temporal. Aqui, ao contrário, pretende-se modular os efeitos de decisões judiciais, não sobre a inconstitucionalidade de norma, mas sobre a sua revogação, e não apenas em seus aspectos temporais (= eficácia prospectiva às normas revogadas), mas também em seus aspectos subjetivos (= para beneficiar alguns contribuintes, não a todos) e em seus aspectos materiais (= para abranger apenas alguns atos e negócios, e não a todos). Mais marcadamente ainda se manifesta aqui o caráter evidentemente normativo (= legislativo) da proposta de modulação."

O acórdão acabou com a seguinte ementa:

TRIBUTÁRIO. IPI. CRÉDITO-PRÊMIO. DECRETO-LEI 491/69 (ART. $1^{\circ}$ ). VIGÊNCIA. PRAZO. EXTINÇÃO. "MODULAÇÃO TEMPORAL" DA DECISÃO. IMPOSSIBILIDADE.

1. O crédito-prêmio do IPI, previsto no art. $1^{\circ}$ do DL 491/69, não se aplica às vendas para o exterior realizadas após 04.10 .90 , seja pelo fundamento de que o referido benefício foi extinto em 30.06 .83 (por força do art. $1^{\circ}$ do Decreto-lei 1.658/79, modificado pelo Decreto-lei 1.722/79), seja pelo fundamento de que foi extinto em 04.10.1990, (por força do art. 41 e $\S 1^{\circ}$ do ADCT).

\footnotetext{
947 P.ex., AUBERT, Jean-Luc. Faut-il 'moduler' dans le temps les revirements de jurisprudence?... J'en doute? p. 302; MELLERAY, Fabrice. Réjouissant mais déroutant. p. 322.

948 EREsp 738.689/PR, Rel. Ministro TEORI ALBINO ZAVASCKI, PRIMEIRA SEÇÃO, julgado em $27 / 06 / 2007$
} 
2. Salvo nas hipóteses excepcionais previstas no art. 27 da Lei 9.868/99, é incabível ao Judiciário, sob pena de usurpação da atividade legislativa, promover a "modulação temporal" das suas decisões, para o efeito de dar eficácia prospectiva a preceitos normativos reconhecidamente revogados.

3. Embargos de divergência improvidos.

(EREsp 738.689/PR, Rel. Ministro TEORI ALBINO ZAVASCKI, PRIMEIRA SEÇÃO, julgado em 27/06/2007, DJ 22/10/2007, p. 187)

De forma precisa, o Min. Herman Benjamin retomou o tema no julgamento do REsp 654.446/AL:

"Não se trata exatamente de aplicar por analogia a citada legislação federal aos julgamentos proferidos pelo STJ, mas sim de tomar por empréstimo o fundamento que ensejou sua produção: o Princípio da Segurança Jurídica. Inegável que os valores que levaram o legislador federal a produzir as Leis 9.868 e 9.882, ambas de 1999, vão além do produto legislativo, influindo necessariamente na aplicação do Direito por todos os Tribunais Superiores. Tenho para mim que, também no âmbito do STJ, nas decisões que alterem jurisprudência reiterada, abalando forte e inesperadamente expectativas dos jurisdicionados, devem ter sopesados os limites de seus efeitos no tempo, buscando a integridade do sistema e a valorização da segurança jurídica". ${ }^{949}$

A posição do Min. Benjamin, nesse particular, é irreparável e vai ao encontro do que foi defendido anteriormente neste trabalho (v. 16.4, acima). Corolário da segurança jurídica e da boa-fé, o princípio da confiança legítima deve ser encarado como garantia constitucional, nos termos do art. $5^{\circ}, \S 2^{\circ}$ da CR. A sua aplicação independe de previsão legislativa, portanto.

\subsubsection{Desestímulo à busca por decisões mais justas}

A terceira crítica relevante que se faz tem como foco específico a revogação prospectiva pura de precedentes. Ao deixar de aplicar o novo precedente ao caso em

${ }^{949}$ REsp 654.446/AL, Rel. Ministro HERMAN BENJAMIN, SEGUNDA TURMA, julgado em 04/12/2007, DJe 11/11/2009. 
julgamento, haveria um desestimulo à busca por decisões mais justas, situação que impediria o desenvolvimento da jurisprudência. ${ }^{950}$

A crítica possui diversas falhas. Em primeiro lugar, o Direito deve evoluir primeiramente por alterações legislativas, e não jurisprudenciais. Promover a insegurança jurídica para que o Direito possa evoluir é de uma ilogicidade absurda. Em segundo lugar, a crítica parte do equivocado pressuposto de que os juízes não estão vinculados a precedentes horizontais e verticais, podendo alterá-los sempre que lhes pareça mais "apropriado". Em terceiro lugar, o jurisdicionado não deve ser encorajado a ingressar em aventuras judiciais na esperança de que a jurisprudência seja alterada em seu caso. ${ }^{951} \mathrm{Em}$ quarto lugar, não compete ao jurisdicionado promover a evolução do Direito mediante insurgências contínuas contra a jurisprudência. Esse tipo de comportamento, longe de ser recebido com satisfação, deveria ser severamente coibido pelos juízes.

De qualquer forma, fato é que a revogação prospectiva pura de precedentes é excepcional e somente será aplicada após a realização de uma cautelosa ponderação entre os interesses envolvidos.

\subsubsection{Majoração indevida dos poderes dos juízes}

A quarta crítica que normalmente se faz à revogação prospectiva de precedentes é a suposta majoração indevida dos poderes dos juízes. Nesse sentido, Fabrice Melleray questiona se é possível admitir a dilação sem limites dos poderes dos juízes para então concluir que a técnica parte do questionável pressuposto de que quanto mais estendidos forem os poderes judiciais, maior será a segurança jurídica. ${ }^{952}$

\footnotetext{
${ }^{950}$ BACHELLIER, Xavier; JOBARD-BACHELLIER, Marie-Noëlle. Les revirements de jurisprudence. p. 310 .

951 V. HODDER, Jack. Departure from 'wrong' precedents by final appellate courts... p. 176-177. V. também as precisas lições de DERZI, Misabel Abreu Machado. A imprevisibilidade da jurisprudência e os efeitos... p. 189: “As partes prosseguem assim nos feitos, em regra de longa duração, até a exaustão, pois a passagem do tempo poderá beneficiar uma delas (o risco será recíproco), com uma nova posição jurisprudencial, uma vez que a uniformização do pensamento judicial muitas vezes tem duração precária. $\mathrm{O}$ caráter lotérico da jurisprudência anima a perspectiva de obtenção de vantagens das partes, mas destrói a previsibilidade dos comportamentos, a possibilidade de expectativas normativas confiáveis".
}

${ }^{952}$ MELLERAY, Fabrice. Réjouissant mais déroutant. p. 322. 
De todas as críticas a que a revogação prospectiva de precedentes está sujeita, essa certamente é a mais frágil.

Já foi afirmado (v. 13.3.2, esp., acima) que a falta de vinculação dos juízes a precedentes, sejam eles horizontais ou verticais, torna muito difícil o controle da atividade judicial, pois cria um poder imprevisível e descontrolado, permitindo que cada juiz do país decida como bem entende, sempre sob o escudo do "livre convencimento".

O reconhecimento de que a confiança dos jurisdicionados na jurisdição deve ser tutelada, inclusive mediante a atribuição de efeitos prospectivos às mudanças jurisprudenciais, não cria um "poder” aos juízes. Cria, sim, um “dever-poder” a ser utilizado sempre que necessário. Ao invés de aumentar os poderes dos juízes, o "deverpoder" de modular as mudanças jurisprudenciais limita o suposto "livre convencimento jurídico" e impede que cada caso seja julgado de maneira diferente. Decidir um caso de acordo com uma jurisprudência revogada significa reconhecer que as decisões devem ser tomadas segundo critérios minimamente objetivos, abdicando-se da imposição de opiniões pessoais em detrimento de manifestações pretéritas do Estado-jurisdição.

18.5. A responsabilidade do Estado pela violação da confiança legítima do jurisdicionado

O terceiro instrumento de proteção da confiança legítima é a responsabilização do Estado pelos danos causados em razão da frustração da expectativa gerada no jurisdicionado. A responsabilização do Estado tem lugar quando superadas as outras duas técnicas de proteção da confiança legítima: o precedente foi revogado (ou a jurisprudência alterada) e não foram concedidos efeitos prospectivos à revogação (ou alteração). Trata-se, portanto, da última alternativa para que o jurisdicionado não suporte um dano injusto.

Ao julgar o caso "Pessino c. France", a Corte Europeia dos Direitos Humanos afirmou que o princípio da legalidade (art. $7^{\circ}$ da Convenção Europeia dos Direitos do Homem) ${ }^{953}$ é violado pela falta de uma “interpretação jurisprudencial acessível

\footnotetext{
953 Artigo $7^{\circ}$ - Princípio da legalidade - 1. Ninguém pode ser condenado por uma ação ou uma omissão que, no momento em que foi cometida, não constituía infração, segundo o direito nacional ou internacional. Igualmente não pode ser imposta uma pena mais grave do que a aplicável no momento em que a infração foi cometida.
} 
e razoavelmente previsível". Constatada a alteração abrupta da jurisprudência francesa, a CEDH condenou o Estado Francês a ressarcir ao demandante a multa de 228.673,53 euros que lhe foi imposta judicialmente. ${ }^{954}$

Com efeito, todos os elementos da responsabilidade civil estão preenchidos na hipótese de violação, pelo Estado, da confiança legítima do jurisdicionado. Há um ato ilícito decorrente da violação da boa-fé objetiva pelo Estado ao comportar-se contraditoriamente. Há um dano injusto suportado pelo jurisdicionado (e aqui é fundamental o exercício da confiança de que já se falou mais de uma vez). E há nexo de causalidade entre o dano sofrido pelo jurisdicionado e a violação da boa-fé objetiva pelo Estado. Lembre-se que a responsabilidade do Estado por danos causados ao particular é sempre objetiva, dependendo unicamente da antijuridicidade de seu comportamento. ${ }^{955}$

Destarte, a responsabilização do Estado deve ocorrer sempre que for revogado um precedente que havia servido como fundamento do exercício da confiança legítima de um jurisdicionado.

Retomando o exemplo das taxas abusivas e ilícitas cobradas pelas companhias aéreas para cancelamento ou remarcação de passagens, a mudança

\footnotetext{
954 V. CEDH, req. 40403/02. No original: "Il en résulte que, faute au minimum d'une interprétation jurisprudentielle accessible et raisonnablement prévisible, les exigences de l'article 7 ne sauraient être regardées comme respectées à l'égard d'un accusé. Or le manque de jurisprudence préalable en ce qui concerne l'assimilation entre sursis à exécution du permis et interdiction de construire résulte en l'espèce de l'absence de précédents topiques fournis par le Gouvernement en ce sens. (...) 36. Il résulte ainsi de tout ce qui précède que, même en tant que professionnel qui pouvait s'entourer de conseils de juristes, il était difficile, voire impossible pour le requérant de prévoir le revirement de jurisprudence de la Cour de cassation et donc de savoir qu'au moment où il les a commis, ses actes pouvaient entraîner une sanction pénale (...). 37. Dans ces conditions, la Cour estime qu'en l'espèce il y a eu violation de l'article 7 de la Convention".

955 JUSTEN FILHO, Marçal. Curso de Direito Administrativo. p. 810-811: "O pronto fundamental reside, então, na disciplina jurídica da atividade estatal, para efeito de verificação de juridicidade e de antijuridicidade. (...) É mais apropriado aludir a uma objetivação da culpa. Aquele que é investido de competências estatais tem o dever objetivo de adotar as providências necessárias e adequadas a evitar danos às pessoas e ao patrimônio". V. também BANDEIRA DE MELLO, Celso Antônio. Curso de Direito Administrativo. p. 994-995. De acordo com PEREZ, Jesus Gonzales. El Principio General de la Buena Fe em el Derecho Administrativo. p. 54: "No hace falta que exista dolo. No es necessario que se haya buscado deliberadamente el momento, a fin de evitar las reaciones del administrado. El principio de la buena fe resultará infringido por el simple hecho de no haber tenido em cuenta la lealtad y confianza debida a quien con nosotros se relaciona".
} 
jurisprudencial certamente se impõe e, ponderando-se os interesses envolvidos (violação de direitos dos consumidores $\mathrm{x}$ manutenção de uma situação vantajosa às companhias aéreas), seria impensável a modulação dos seus efeitos. Contudo, como já foi adiantado, não seria razoável que as companhias aéreas tivessem que arcar com os danos decorrentes do período em que o seu comportamento foi referendado pelo Estado-jurisdição. Afinal, com a mudança da jurisprudência, todos os consumidores que pagaram tais taxas, ainda que durante um período em que o próprio Estado dizia serem lícitas, poderiam buscar a sua reparação judicialmente, inclusive com restituição em dobro dos valores pagos. Nesse caso, o Estado deverá responder por metade do valor restituído, já que foi esse o dano efetivo causado pela frustração da confiança nele depositada. 


\section{CONCLUSÃO}

Talvez a mais importante de todas as conclusões deste trabalho seja a de que o Estado brasileiro, ao guiar-se pelo ideal do Estado de Direito, deve proteger e realizar a liberdade e a segurança jurídica, estabelecendo mecanismos rígidos de controle do exercício do poder, seja ele qual for, de modo que as pessoas possam desenvolver-se em um ambiente jurídico estável e previsível. Somente assim é que os demais valores e objetivos do Estado $e$ do Direito poderão ser efetivados. Aceita essa premissa, então é possível compreender o que é e para que serve o dever de motivar as decisões judiciais.

A motivação das decisões judiciais, como foi várias vezes repetido, possui relação íntima com o Estado de Direito, com a segurança jurídica e com o devido processo legal. E não poderia ser diferente. O dever de motivar é uma construção histórica que acompanhou as mais diversas formas de Estado e de concepção do poder. Tradicionalmente negligenciada, justamente por impor limites e exigir racionalidade do exercício do poder jurisdicional, apenas no fértil terreno liberal da Revolução Francesa é que a motivação pôde começar a desenvolver-se plenamente. O dever de motivar as decisões judiciais, portanto, é uma garantia liberal: uma garantia de liberdade, de racionalidade e de previsibilidade conferida ao indivíduo contra a atuação potencialmente arbitrária do Estado-juiz. A motivação controla tanto a racionalidade do convencimento fático do magistrado como a aplicação do Direito produzido democraticamente pelo povo e para o povo. Motivar uma decisão significa demonstrar que a decisão está fundada sobre uma premissa fática devidamente alegada e provada nos autos e sobre uma premissa jurídica correta, pois fruto da aplicação de uma norma jurídica previamente estabelecida e conhecida pelas partes, ainda que tenha sido extraída de uma complexa interpretação do sistema jurídico, dos seus princípios estruturantes e dos valores da sociedade.

Sendo assim, a motivação é indissociável do Estado de Direito, pois não há Estado de Direito onde não se controla o exercício do poder; onde não se presta contas do exercício do poder ao seu verdadeiro titular, que é o povo; onde não se aplicam normas jurídicas claras, inteligíveis, acessíveis e predeterminadas; e onde não se realiza o Direito de forma racional e isonômica. Não por acaso, o dever de motivação é reiteradamente afirmado em Constituições promulgadas logo após a queda de regimes ditatoriais. 
Para ser compatível com o Estado de Direito, a motivação deve ter natureza declaratória e retrospectiva, pois não compete ao juiz criar o direito incidente ao caso concreto. Como se buscou demonstrar no Capítulo Terceiro, ponto 7, nenhuma das teorias que defendem a natureza criativa da motivação das decisões judiciais se sustenta. Em primeiro lugar, interpretar não é o mesmo que criar; logo, os juízes não criam o Direito ao interpretá-lo. Em segundo lugar, o juiz não possui poderes discricionários para criar o direito aplicável ao caso quando a solução não estiver expressa no sistema; devem, sim, extrair a "única solução correta" a partir de uma interpretação sistemática e valorativa da ordem jurídica. Em terceiro lugar, precedentes obrigatórios não são necessariamente normas jurídicas, podendo constituir meros padrões preestabelecidos de intepretação do Direito. Em qualquer hipótese, a motivação deve reconhecer a incidência de uma norma ao caso concreto para que o dispositivo, se for o caso, efetive as respectivas consequências jurídicas.

Além de declaratória e retrospectiva, a motivação, para ser racional, deve apresentar estrutura lógico-argumentativa, sendo internamente justificada por um silogismo judicial, e externamente justificada de maneira congruente com as alegações e provas produzidas no processo e de maneira congruente com o Direito. As razões apresentadas também devem ser universais, sinceras, claras, coerentes e suficientes para dar uma resposta adequada a todas as alegações feitas por aquele que foi desfavorecido pela decisão. A completude da motivação, aliás, é tema de destacada importância. Motivações completas não são aquelas que escolhem argumentos para exaltar o dispositivo. Motivações completas são aquelas que enfrentam todos os argumentos do sucumbente, de modo a demonstrar não só que uma das partes tinha razão, mas também que a outra não a tinha.

No entanto, a função de controle da atividade jurisdicional desempenhada pela motivação é posta em xeque se os juízes puderem decidir de forma errática e contraditória. A motivação controla a atividade jurisdicional desde que se possa aferir a correção ou, ao menos, a razoabilidade jurídica da decisão. Mas esse controle é gravemente prejudicado se não houver homogeneidade nas decisões; se o mesmo juiz puder decidir hoje de maneira diversa do que decidiu ontem e do que decidirá amanhã.

Logo, a segurança jurídica depende tanto da estabilidade e previsibilidade de normas jurídicas preestabelecidas como da estabilidade e previsibilidade da aplicação 
dessas normas ao caso concreto. De nada adiantam leis claras, coerentes, completas e acessíveis se a aplicação dessas leis não for também clara, coerente, completa e acessível. Por isso, se o civil law extrai segurança jurídica de textos escritos elaborados pelo legislador, o common law extrai segurança jurídica, além das leis, da estabilidade e previsibilidade das decisões judiciais. O sistema de precedentes do common law é, portanto, um instrumento de promoção da segurança jurídica de mesma envergadura das normas jurídicas positivadas do civil law.

Como foi insistentemente afirmado, precedentes judiciais são razões jurídicas de decisões pretéritas; ou seja, respeitar precedentes significa respeitar a motivação de decisões judiciais proferidas em casos concretos análogos. Só há precedentes se houver decisões motivadas. Mas nem tudo que é colocado na motivação pode servir de precedente, sob risco de abrir espaço para que sejam criados precedentes de forma arbitrária. Apenas rationes decidendi são precedentes, pois são elas as efetivas razões pelas quais o caso foi julgado.

O conceito de ratio decidendi é extremamente polêmico e debatido entre a doutrina do common law. Trata-se de conceito-base de toda a teoria dos precedentes, motivo pelo qual deve receber copiosa atenção também entre nós. Neste trabalho foi adotada a concepção de Pierluigi Chiassoni, no sentido de que são rationes decidendi as premissas maiores dos silogismos judiciais contidos na motivação da decisão precedente, desde que voltados ao dispositivo.

Por fim, a motivação também deve ser compreendida sob a ótica da segurança jurídica subjetiva, ou princípio da proteção da confiança legítima. O princípio da confiança legítima impõe ao Estado que aja sempre de forma proba e coerente, vedando-se que o particular venha a sofrer danos por ter se comportado de acordo com as diretrizes estabelecidas pelo Estado. No caso das decisões judiciais, a motivação traça um parâmetro de conduta ao particular ao afirmar o sentido e a forma de aplicação de determinada norma jurídica. Com efeito, embora as decisões judiciais não sejam uma fonte autêntica do Direito, são fonte interpretativa do Direito. A jurisdição diz ao jurisdicionado como ele deve interpretar a ordem jurídica e, com essa informação, o jurisdicionado pode moldar sua vida de forma ainda mais segura, estável e previsível. Lembre-se que as razões jurídicas de uma decisão devem ser universais ou universalizáveis. Logo, ao motivar uma decisão, o 
Estado-juiz está dizendo não só como o Direito regula aquele caso concreto, mas como o Direito regula, de forma universal, todos os casos concretos que lhe são análogos.

Sendo assim, não são condizentes com o Estado de Direito, nem com a estrutura sobre a qual está fundado o civil law, mudanças jurisprudenciais abruptas e repentinas que frustrem as expectativas legítimas geradas no jurisdicionado por decisões judiciais precedentes. Desde que respeitadas algumas regras definidas no Capítulo Sexto deste trabalho, as decisões judiciais servem como fundamento de uma confiança legítima do particular na jurisdição. Uma confiança que deve ser sempre tutelada, seja pela vedação de alterações jurisprudenciais injustificadas, seja pela atribuição de efeitos prospectivos à alteração jurisprudencial, seja pela reparação civil do jurisdicionado pelos danos que lhe foram causados pelo Estado-jurisdição. 


\section{REFERÊNCIAS BIBLIOGRÁFICAS}

AARNIO, Aulis. Le Rationnel Comme Raisonnable: la justification en droit. Paris: L.G.D.J., 1992.

ABRAMOWICZ, Michael; STEARNS Maxwell. Defining dicta. Stanford Law Review, 56,2005

AKEHURST, Michael. Statements of reasons for judicial and administrative decisions. The Modern Law Review, 33, 1970.

AlBERTO, Tiago Gagliano Pinto. Poder Judiciário e Argumentação no Atual Estado Democrático de Direito. Rio de Janeiro: LumenJuris, 2012.

ALEXY, Robert. Teoria da Argumentação Jurídica: a teoria do discurso racional como teoria da fundamentação jurídica. 3. ed. Trad. Zilda Hutchinson Schild Silva. Rev. da Trad. Cláudia Toledo. Rio de Janeiro: Forense, 2011.

. Teoria dos Direitos Fundamentais. Trad. Virgílio Afonso da Silva. São Paulo: Malheiros, 2008.

ALVARO DE OLIVEIRA, Carlos Alberto. Livre apreciação da prova: perspectivas atuais. Disponível em: http://www.abdpc.org.br/abdpc/artigos. Acessado em 15 de abril de 2009.

O formalismo-valorativo no confronto com o formalismo excessivo, in Leituras Complementares de Processo Civil. Org. Fredie Didier Jr. 6. ed. Salvador: JusPodivm, 2008.

. Teoria e Prática da Tutela Jurisdicional. Rio de Janeiro: Forense, 2008.

AMODIO, Ennio. L'obbligo costituzionale di motivazione e l'istituto della giuria (a proposito di un recente contributo dottrinale). Rivista di Diritto Processuale, n. 3. Padova: CEDAM, 1970.

. Motivazione della sentenza penale, in Enciclopedia del Diritto, v. XXVII. Milano: Giuffrè, 1977.

AMRANI MEKKI, Soraya. Quelques réflexions procedurales (A propos de la rétroactivité de la jurisprudence). Revue Trimestrielle de Droit Civil, v. 2. Paris: Dalloz, 2005. 
ANDRADE. José Carlos Vieira de. O Dever da Fundamentação Expressa de Actos Administrativos. Coimbra: Almedina, 2003.

ANDREWS, Neil. Decisões judiciais e o dever de fundamentar: a experiência inglesa. Revista de Processo, n. 192. São Paulo: Revista dos Tribunais, fev./2011.

ARAGÃO, Egas Dirceu Moniz de. Comentários ao Código de Processo Civil, v. II. Rio de Janeiro: Forense, 1974.

ARENHART, Sérgio Cruz. A verdade e a prova no processo civil. Disponível em: http://www.abdpc.org.br/abdpc/Artigos.asp?ordem1=artigo. Acessado em 15 de outubro de 2008.

; MARINONI, Luiz Guilherme. Processo de Conhecimento. 7. ed. São Paulo: Revista dos Tribunais, 2008.

; MARINONI, Luiz Guilherme. Prova. São Paulo: Revista dos Tribunais, 2009.

ARISTÓTELES. Politics. Trad. Benjamin Jowett. S.1.: Forgotten Books, 2007. Obra completa disponível em Google Books.

ARRUDA ALVIM. Sentença 'citra petita' - necessidade de ação rescisória. Revista de Processo, n. 14-15. São Paulo: Revista dos Tribunais, 1979.

ASCARELLI, Tullio. Inesistenza e nullità. Rivista di Diritto Processuale, XI. Padova: Cedam, 1956.

. Giurisprudenza costituzionale e teoria dell'interpretazione. Rivista di Diritto Processuale, XII. Padova: CEDAM, 1957.

ASSIS, Araken de. Cumulação de Ações. 4. ed. São Paulo: Revista dos Tribunais, 2002. . Manual dos Recursos. 2. ed. São Paulo: Revista dos Tribunais, 2008.

ATIAS, Christian. Sur les revirements de jurisprudence. Revue Trimestrielle de Droit Civil, v. 2. Paris: Dalloz, 2005.

AUBERT, Jean-Luc. Faut-il 'moduler' dans le temps les revirements de jurisprudence?... J'en doute? Revue Trimestrielle de Droit Civil, v. 2. Paris: Dalloz, 2005.

ÁVILA, Humberto B. Segurança Jurídica. São Paulo: Malheiros, 2011. 
. Teoria dos Princípios: da definição à aplicação dos princípios jurídicos. 11. ed. São Paulo: Malheiros, 2010.

AZEVEDO, Antônio Junqueira de. Negócio Jurídico: existência, validade e eficácia. 4. ed. São Paulo: Saraiva, 2010.

AZEVEDO, Luiz Carlos de; TUCCI, José Rogério Cruz e. Lições de História do Processo Civil Romano. São Paulo: Revista dos Tribunais, 2001.

BACHELLIER, Xavier; JOBARD-BACHELLIER, Marie-Noëlle. Les revirements de jurisprudence. Revue Trimestrielle de Droit Civil, v. 2. Paris: Dalloz, 2005.

BANDEIRA DE MELlO, Celso Antônio. Curso de Direito Administrativo. 25. ed. São Paulo: Malheiros, 2008.

BARBOSA MOREIRA, José Carlos. A Motivação das Decisões Judiciais como Garantia Inerente ao Estado de Direito. Revista Brasileira de Direito Processual, v. 16. Rio de Janeiro: Forense, 1978.

. Comentários ao Código de Processo Civil, v. V. Rio de Janeiro: Forense, 1974.

. Prueba y la motivación de la sentencia, in Temas de Direito Processual : oitava série. São Paulo: Saraiva, 2004.

Reflexões sobre a impacialidade do juiz, in Temas de Direito Processual: sétima série. São Paulo: Saraiva, 2001.

BARROSO, Luís Roberto. Em algum lugar do passado: segurança jurídica, direito interporal e o novo Código Civil, in Constituição e Segurança Jurídica: direito adquirido, ato jurídico perfeito e coisa julgada - estudos em homenagem a José Paulo Sepúlveda Pertence. Coord. Cármen Lúcia Antunes Rocha. Belo Horizonte: Fórum, 2005.

BAUR, Fritz. Les garanties fondamentales des parties dans le procès civil en République Fédérale d'Allemagne, in Les Garanties Fondamentales des Parties dans le Procès Civil. Milano: Giuffrè, 1973.

BECCARIA, Cesare. Dos Delitos e das Penas. São Paulo: Martins Fontes, 1996.

BEDAQUE, José Roberto dos Santos. Efetividade do Processo e Técnica Processual. São Paulo: Malheiros, 2006. 
BENDITT, Theodore M. The rule of precedent, in Precedent in Law. Org. Laurence Goldstein. Oxford: Oxford University, 1991.

BENTHAM, Jeremy. Rationale of Judicial Evidence. Londres: Reynell, 1817. Obra completa disponível em Google Books.

BESSO, Chiara. La Sentenza Civile Inesistente. Torini: G. Giappichelli, 1996.

BIN, Roberto. Lo Stato di Diritto. Bologna: Il Mulino, 2004.

BOBBIO, Norberto. Il Positivismo Giuridico. Torino: G. Giappichelli, 1996.

. Teoria do Ordenamento Jurídico. 10. ed. Trad. Maria Celeste Cordeiro Leite dos Santos. Brasília: Universidade de Brasília, 1999.

BÖCKENFÖRDE, Ernst Wolfgang. Origen y cambio del concepto de Estado de Derecho, in Estudios sobre el Estado de Derecho y la Democracia. Madrid: Trotta, 2000. p. 18-19.

BODIN, Jean. De la Republique ou Traité Du Gouvernement. Paris: Veuve Quillau, 1756. p. 108-109. Edição revista da publicada em 1591. Obra completa disponível em Google Books.

BOVE, Mauro. Art. 111 cost. e 'giusto processo civile'. Rivista di Diritto Processuale. Padova: Cedam, 2002.

BRACTON, Henrici de. De legibus et consuetudinibus Angliae, v. V. Clark: Lawbook Exchange, 2009. p. 6. Obra completa disponível em Google Books.

BRANCO, Paulo Gustavo Gonet; MENDES, Gilmar Ferreira; COELHO, Inocêncio Mártires. Curso de Direito Constitucional. 4. ed. São Paulo: Saraiva, 2009.

BRIGUGLIO, Antonio Renato. 'Creatività' della giurisprudenza, mutamento giurisprudenziale e giudizio di rinvio. Rivista Trimestrale di Diritto e Procedura Civile, 38, 4. Milano: Giuffrè, 1984.

BULYGIN, Eugenio. Il Positivismo Giuridico. Milano: Giuffrè, 2007 Los jueces ¿crean derecho? Isonomía, n. 18. México D.F.: ITAM, 2003.

CABRAL, Antonio do Passo. Nulidades no Processo Moderno. Rio de Janeiro: Forense, 2009. 
CALAMANDREI, Piero. Il nouvo processo civile e la scienza giuridica, in Opere Giuridiche, v. I. Org. Mauro Cappelletti. Napoli: Morano, 1965.

- Istituzioni di diritto processuale civile secondo il nuovo Codice, in Opere Giuridiche, v. IV. Org. Mauro Cappelletti. Napoli: Morano, 1970.

. La Cassazione Civile, v. I, in Opere Giuridiche, v. VI. Org. Mauro Cappelletti. Napoli: Morano, 1976.

. La crisi della motivazione, in Processo e democrazia, in Opere Giuridiche, v. I. Org. Mauro Cappelletti. Napoli: Morano, 1965.

. La genesi logica della sentenza civile, in Opere Giuridiche, v. I. Org. Mauro Cappelletti. Napoli: Morano, 1965.

- La teoria dell'error in iudicando nel Diritto italiano intermedio, in Opere Giuridiche, v. VIII. Org. Mauro Cappelletti. Napoli: Morano, 1979.

CALMES, Sylvia. Du Principe de Protection de la Confiance Legitime en Droits Allemand, Communautaire et Français. Paris: Dalloz, 2001.

CALMON DE PASSOS, José Joaquim. Democracia, participação e processo, in Participação e Processo. Coord. Ada Pellegrini Grinover, Cândido Rangel Dinamarco, Kazuo Watanabe. São Paulo: Revista dos Tribunais, 1988.

. O Magistrado, protagonista do Processo Jurisdicional? In: Os Poderes do Juiz e o

Controle das Decisões Judiciais: estudos em homenagem à Professora Teresa Arruda Alvim Wambier. São Paulo: Revista dos Tribunais, 2008.

CAMARGO, Luiz Henrique Volpe. A força dos precedentes no moderno Processo Civil brasileiro, in Direito Jurisprudencial. Coord. Teresa Arruda Alvim Wambier. São Paulo: Revista dos Tribunais, 2012.

- A motivação dos julgamentos dos Tribunais de $2^{\circ}$ grau na visão do Superior Tribunal de Justiça: acórdão completo ou fundamentado? Revista de Processo, n. 162. São Paulo: Revista dos Tribunais, 2008.

CAMBI, Eduardo. A Prova Civil: admissibilidade e relevância. São Paulo: Revista dos Tribunais, 2006. 
- Neoconstitucionalismo e Neoprocessualismo, in Leituras Complementares de Processo Civil. Org. Fredie Didier Jr. Salvador: JusPodivm, 2008.

CANARIS, Claus-Wilhelm. Pensamento Sistemático e Conceito de Sistema na Ciência do Direito. Lisboa: Fundação Calouste Gulbenkian, 1989.

CANOTILHO, José Joaquim Gomes. Direito Constitucional e Teoria da Constituição. 5. ed. Coimbra, Almedina, 2000.

CAPOGRASSI, Giuseppe. Giudizio processo scienza verità. Rivista di Diritto Processuale, n. V. Padova: CEDAM, 1950.

CAPPELLETTI, Mauro. Juizes Legisladores? Trad. Carlos Alberto Alvaro de Oliveira. Porto Alegre: Sergio Antonio Fabris, 1999.

. Fundamental guarantees of the parties in civil proceedings, in Les Garanties Fondamentales des Parties dans le Procès Civil. Milano: Giuffrè, 1973.

. Repudiating Montesquieu? The expansion and legitimacy of constitutional justice.

Catholic University Law Review, 35. Washington: s.e., 1985-1986.

; VIGORITI, Vincenzo. Fundamental guarantees of the litigants in civil proceedings: Italy, in Les Garanties Fondamentales des Parties dans le Procès Civil. Milano: Giuffrè, 1973.

CARNELUTTI, Francesco. Inesistenza dell'atto giuridico? Rivista di Diritto Processuale, X. Padova: Cedam, 1955.

. Instituciones del Proceso Civil, v. I. Trad. Santiago Sentis Melendo. Buenos Aires:

E.J.E.A., s.d.

CARNEIRO, Athos Gusmão. Sentença mal fundamentada e sentença não fundamentada. Revista de Processo, n. 81. São Paulo: Revista dos Tribunais, 1996.

CARNEVALE, Valentina; COMOGLIO, Luigi Paolo. Il ruolo della giurisprudenza e $i$ metodi di uniformazione del diritto in Italia. Rivista di Diritto Processuale, LIX, 4. Padova: CEDAM, 2004.

CARRATTA, Antonio. Prova e Convincimento del Giudice nel Processo Civile. Rivista di Diritto Processuale Civile. Padova: CEDAM, jan./mar. 2003. 
CARRAZZA, Roque Antonio. Segurança jurídica e eficácia temporal das alterações jurisprudenciais, in Efeitos Ex Nunc e as Decisões do STJ. Org. Roque Antonio Carazza, Tércio Sampaio Ferraz Jr. e Nelson Nery Junior. 2. ed. Barueri: Manole, 2009.

CARVAlHO, Milton Paulo de. Os Princípios e um Novo Código de Processo Civil, in Bases Científicas para um Renovado Direito Processual. Org. Athos Gusmão Carneiro e Petrônio Calmon. 2.ed. Salvador: JusPodivm, 2009.

CAVALlONE, Bruno. In difesa della veriphobia (considerazioni amichevolmente polemiche su un libro recente di Michele Taruffo). Rivista di Diritto Processuale, n. LXV, 1. Milano: CEDAM, 2010.

CHEVALLIER, Jacques. L'Etat de Droit. 5. ed. Paris: Montchestien, 2010. . L'État Post-Moderne. 3. ed. Paris: L.G.D.J, 2008.

CHIARLONI, Sérgio. Sergio. Funzione nomofilattica e valore del precedente, in Direito Jurisprudencial. Coord. Teresa Arruda Alvim Wambier. São Paulo: Revista dos Tribunais, 2012.

. Il nuovo art. 111 cost. e il processo civile. Rivista di Diritto Processuale. Padova: CEDAM, 2000.

CHIASSONI, Pierluigi. La Giurisprudenza Civile: metodi d'interpretazione e tecniche argomentative. Milano: Giuffrè, 1999.

Tecnica dell'Interpretazione Giuridica. Bologna: Il Mulino, 2007.

CHIOVENDA, Giuseppe. Del sistema negli studi del processo civile, in Saggi di Diritto Processuale Civile, v. I. Milano: Giuffrè, 1993.

CINTRA, Antonio Carlos de Araújo; GRINOVER, Ada Pellegrini; DINAMARCO, Cândido Rangel. Teoria Geral do Processo. 13. ed. São Paulo: Malheiros, 1997.

COELHO, Inocêncio Mártires; MENDES, Gilmar Ferreira; BRANCO, Paulo Gustavo Gonet. Curso de Direito Constitucional. 4. ed. São Paulo: Saraiva, 2009.

COMOGLIO, Luigi Paolo. Direzione del processo e responsabilità del giudice, in Studi in Onore di Enrico Tullio Liebman, v.1. Milano: Giuffrè, 1979.

. I modelli di garanzia costituzionale del processo, in Studi in Onore di Vittorio Denti, v.I. Padova: Cedam, 1994. 
COMOGLIO, Luigi Paolo; CARNEVALE, Valentina. Il ruolo della giurisprudenza e $i$ metodi di uniformazione del diritto in Italia. Rivista di Diritto Processuale, LIX. Milano: CEDAM, 2004.

CONSO, Giovanni. La certezza del diritto: ieri, oggi, domani. Rivista di Diritto Processuale, n. 4. Padova: CEDAM, 1970.

COSTA, Guilherme Recena. Superior Tribunal de Justiça e recurso especial: análise da função e reconstrução dogmática. Dissertação de Mestrado. Faculdade de Direito. Universidade de São Paulo, 2011.

COSTA, Pietro. O Estado de Direito: uma introdução histórica, in O Estado de Direito: história, teoria, crítica. Org. Pietro Costa e Danilo Zolo. Trad. Carlo Alberto Dastoli. São Paulo: Martins Fontes, 2006.

COUDERT, Frederic René. Certainty and Justice: studies of the conflict between precedent and progress in the development of the law. New York: D. Appleton and Company, 1913 (reimp. Lexington: Bibliolife, 2011).

COUTO E SILVA, Almiro do. O princípio da segurança jurídica (proteção à confiança) no Direito Público brasileiro e o direito da Administração Pública de anular seus próprios atos administrativos: o prazo decadencial do art. 54 da lei do processo administrativo da União (Lei nº 9.784/99). Revista Eletrônica de Direito do Estado, 2. Salvador, 2005.

COUTURE, Eduardo J. Fundamentos del Derecho Procesal Civil. 4. ed. Montevideo: BdeF, 2010.

. Inconstitucionalidad por privación de la garantía del debido proceso, in Estudios de Derecho Procesal Civil, t. I. 3. ed. Buenos Aires: Depalma, 2003.

- Interpretación e integración de las leyes procesales, in Conferências y Mesa Redonda acerca del Tema Interpretación e Integración de las Leyes Procesales. Mexico: Imprenta Universitaria, 1950.

. Las garantias constitucionales del proceso civil, in Estudios de Derecho Procesal Civil, t. I. 3. ed. Buenos Aires: Depalma, 2003

CROCETTI, Priscila Soares; DRUMMOND, Paulo Henrique Dias. Formação histórica, aspectos do desenvolvimento e perspectivas de convergências das tradições de Common 
Law e de Civil Law, in A Força dos Precedentes. Coord. Luiz Guilherme Marinoni. Salvador: JusPodivm, 2010.

CROSS, Rupert; HARRIS, J. W. Precedent in English Law. Oxford: Clarendon, 2004.

DAVID, René; JAUFFRET- SPINOSI, Camille. Les Grands Systèmes de Droit Contemporains. 11. ed. Paris: Dalloz, 2002.

DAWSON, John P. The Oracles of the Law. New York: William S. Hein, 1986.

DELGADO, José Augusto. A sentença judicial e a constituição federal de 1998. Revista Forense, v. 86, n. 310, p. 37-40, abr./jun. 1990.

DERZI, Misabel Abreu Machado. A imprevisibilidade da jurisprudência e os efeitos das decisões do Supremo Tribunal Federal no Direito Tributário, in O Processo na Constituição. Coord. Ives Gandra da Silva Martins e Eduardo Jobim. São Paulo: Quartier Latin, 2008.

DICEY, Albert Venn. An Introduction to the Study of the Law of the Constitution. 10. ed. [1959]. Reimp. Hong Kong: Macmillan Education, 1987.

DIDIER JR., Fredie. Curso de Direito Processual Civil, v.1. Salvador: JusPodivm, 2007. . CUNHA, Leonardo José Carneiro da. Curso de Direito Processual Civil, v.3. 3. ed. Salvador: JusPodivm, 2007.

; BRAGA, Paula Sarno; OLIVEIRA, Rafael. Curso de Direito Processual Civil, v.2. Salvador: JusPodivm, 2007.

DIENES, Z.; PERNER, J. When knowledge is unconscious because of conscious knowledge and vice versa. Proceedings of the Twenty-third Annual Conference of the Cognitive Science Society 2 1. Edinburgh: Lawrence Erlbaum Associates: Mahwah, 2001.

DINAMARCO, Cândido Rangel. Capitulos de Sentença. 3. ed. São Paulo: Malheiros, 2008 .

. Direito e processo, in Fundamentos do Processo Civil Moderno, v. I. 6. ed. São Paulo: Malheiros, 2010. . Instituições de Direito Processual Civil, v. I. 4. ed. São Paulo: Malheiros, 2004.

_. Instituições de Direito Processual Civil, vv. II e III. 5. ed. São Paulo: Malheiros, 2005. 
. Instrumentalidade do Processo. 12. ed. São Paulo: Malheiros, 2005.

. Nova Era do Processo Civil. 3. ed. São Paulo: Malheiros, 2009.

. O conceito de mérito em Processo Civil. Revista de Processo, n. 34. São Paulo: Revista dos Tribunais, 1984.

. O dever de motivar e a inteireza da motivação, in Fundamentos do Processo Civil Moderno, v. I. 6. ed. São Paulo: Malheiros, 2010.

. O princípio do contraditório e sua dupla destinação, in Fundamentos do Processo Civil Moderno, v. I. 6. ed. São Paulo: Malheiros, 2010.

; CINTRA, Antonio Carlos de Araújo; GRINOVER, Ada Pellegrini. Teoria Geral do Processo. 13. ed. São Paulo: Malheiros, 1997.

DRUMMOND, Paulo Henrique Dias; CROCETTI, Priscila Soares. Formação histórica, aspectos do desenvolvimento e perspectivas de convergências das tradições de Common Law e de Civil Law, in A Força dos Precedentes. Coord. Luiz Guilherme Marinoni. Salvador: JusPodivm, 2010.

DUXBURY, Neil. The Nature and Authority of Precedent. Cambridge: Cambridge University, 2008.

DWORKIN, Ronald. A Justiça de Toga. Trad. Jefferson Luiz Camargo. São Paulo: Martins Fontes, 2010 . A Matter of Principle. Cambridge: Harvard University, 2000. . Law's Empire. Cambridge: Harvard University, 1986. . Taking Rights Seriously. Cambridge: Harvard University, 1978.

EISENBERG, Melvin Aron. The Nature of the Common Law. Cambridge: Harvard University, 1991.

ELY, John Hart. Democracy and Distrust: a theory of judicial review. Cambridge: Harvard University, s.d.

EVANGELISTA, Stefano. Motivazione della sentenza civile, in Enciclopedia del Diritto, v. XXVII. Milano: Giuffrè, 1977. 
EVANS, Jim. Change in the doctrine of precedent during the nineteenth century, in Precedent in Law. Org. Laurence Goldstein. Oxford: Oxford University, 1991.

FALCÓN Y TELlA, María José. Lições de Teoria Geral do Direito. Trad. Claudia de Miranda Avena e Ernani de Paula Contipelli. São Paulo: Revista dos Tribunais, 2011.

FAZZALARI, Elio. Istituzioni di Diritto Processuale. 7. ed. Padova: Cedam, 1994. . Note in Tema di Diritto e Processo. Milano: Giuffrè, 1957.

_. "Processo" e giurisdizione. Rivista di Diritto Processuale Civile. Padova: CEDAM, jan./mar. 1993.

FERRAZ JR., Tercio Sampaio. As origens do Estado contemporâneo ou o Leviathan gestor da economia, in Direito Constitucional. Barueri: Manole, 2007.

. Irretroatividade e jurisprudência judicial, in Efeitos Ex Nunc e as Decisões do STJ.

Coord. Tercio Sampaio Ferraz Júnior, Roque Antonio Carrazza e Nelson Nery Júnior. 2. ed. Barueri: Manole, 2009.

FERREIRA, Eduardo Vaz; VESCOVI, Enrique. Les garanties constitutionnelles des parties dans le procès civil en Amérique Latine, in Les Garanties Fondamentales des Parties dans le Procès Civil. Milano: Giuffrè, 1973.

FERREIRA FILHO, Manoel Gonçalves. As origens do Estado de Direito. Revista de Direito Administrativo, n. 168. Rio de Janeiro: Fundação Getúlio Vargas, 1987.

FIX-ZAMUDIO, Héctor. Les guaranties constitutionnelles des parties dans le Procès Civil en Amérique Latine, in Les Garanties Fondamentales des Parties dans le Procès Civil. Milano: Giuffrè, 1973.

FRANCIS, Joseph. Three cases on possession - some further observations. St. Louis Law Review, 14, 1928-1929.

FRISON-ROCHE, Marie-Anne La théorie de l'action comme principe de l'application dans le temps des jurisprudences. Revue Trimestrielle de Droit Civil, v. 2. Paris: Dalloz, 2005.

GÉNY, François. Méthode d'Interpretation et Sources en Droit Privé Positif: essay critique, t. I e II. Paris : L.J.D.J., 1954.

GERHARDT, Michael J. The Power of Precedent. New York: Oxford University, 2008. 
GIANFORMAGGIO, Letizia. L'interpretazione della costituzione, in Filosofia del Diritto e Ragionamento Giuridico. Torino: G. Giappichelli, 2008. - Modelli di ragionamento giuridico, in Filosofia del Diritto e Ragionamento Giuridico. Torino: G. Giappichelli, 2008.

GODDING, Philippe. Jurisprudence et motivation des sentences, du moyen âge à la fin du $18^{e}$ siècle, in La Motivation des Decisions de Justice. Org. Chaim Perelman e P. Foriers. Bruxelas : Établissements Émile Bruylant, 1978.

GÓES, Gisele Santos Fernandes. Existe Discricionariedade Judicial? Discricionariedade X Termos Jurídicos Indeterminados e Cláusulas Gerais, in Os Poderes do Juiz e o Controle das Decisões Judiciais: estudos em homenagem à Professora Teresa Arruda Alvim Wambier. São Paulo: Revista dos Tribunais, 2008.

GOLDSTEIN, Laurence. Introduction, in Precedent in Law. Oxford: Oxford University, 1991.

GOMES FILHO, Antonio Magalhães. A Motivação das Decisões Penais. São Paulo: Revista dos Tribunais, 2001.

GONÇALVES, Helena de Toledo Coelho. Contraditório e Ampla Defesa. Curitiba: Juruá, 2010.

GOODHART, Arthur. Determining the ratio decidendi of a case. Yale Law Journal, XL, $2,1930$.

. The ratio decidendi of a case. Modern Law Review, 22, 2, 1959.

GORLA, Gino. Sulla via dei 'motivi' delle 'sentenze': lacune e trappole, in Studi in Memoria di Salvatore Satta, v. 1. Padova: CEDAM, 1982.

GRAU, Eros Roberto. Ensaio e Discurso sobre a Interpretação/Aplicação do Direito. 5. ed. São Paulo: Malheiros, 2009.

GRINOVER, Ada Pellegrini; CINTRA, Antonio Carlos de Araújo; DINAMARCO, Cândido Rangel. Teoria Geral do Processo. 13. ed. São Paulo: Malheiros, 1997.

GUIMARÃES, Mário. O Juiz e a Função Jurisdicional. Rio de Janeiro: Forense, 1958.

HACHEM, Daniel Wunder. Princípio Constitucional da Supremacia do Interesse Público. Belo Horizonte: Fórum, 2011. 
HAGER, Barry. The Rule of Law: a lexicon for policy makers. S.1.: Mansfield Center for Pacific Affairs, 2000.

HARDING, Matthew; MALKIN, Ian. Overruling in the High Court of Australia in common law cases. Melbourne University Law Review, 34, 2010.

HARRIS, J. W.; CROSS, Rupert. Precedent in English Law. Oxford: Clarendon, 2004.

HART, H. L. A. O Conceito de Direito. São Paulo: Martins Fontes, 2009

HAYEK, Friedrich. A. von. The Constitution of Liberty: the definitive edition. Ed. Ronald Hamowy. Chicago: The University of Chicago, 2011.

. The Road of Serfdom: text and documents - the definitive edition. Ed. Bruce Caldwell. Chigado: The University of Chicago, 2007.

HENRY, Jean-Pierre. Vers la fin de l'État de Droit? Revue du Droit Public et de la Science Politique en France et à l’Étranger. Paris: L.G.D.J, 1977.

HEUCHSLING, Luc. Etat de Droit, Rechtsstaat, Rule of Law. Paris: Dalloz, 2002.

HITTERS, Juan Carlos. Legitimación democrática del poder judicial y control de constitucionalidad, in Participação e Processo. Coord. Ada Pellegrini Grinover, Cândido Rangel Dinamarco, Kazuo Watanabe. São Paulo: Revista dos Tribunais, 1988.

HO, H. L. The judicial duty to give reasons. Legal Studies, 20, 2000.

HODDER, Jack. Departure from 'wrong' precedents by final appellate courts: disagreeing with Professor Harris. New Zealand Law Review, 2003.

HUSSON, Léon. Les trois dimensions de la motivation judiciaire, in La Motivation des Decisions de Justice. Org. Chaim Perelman e P. Foriers. Bruxelas : Établissements Émile Bruylant, 1978.

IACOVIELlo, Francesco M. La Motivazione della Sentenza Penale e il suo Controllo in Cassazione. Milano: Giuffrè, 1997.

IRTI. Natalino. Dubbio e decisione. Rivista di Diritto Processuale Civile. Padova: CEDAM, jan./mar. 2001.

JAUFFRET- SPINOSI, Camille; DAVID, René. Les Grands Systèmes de Droit Contemporains. 11. ed. Paris: Dalloz, 2002. 
JOBARD-BACHELLIER, Marie-Noëlle; BACHELLIER, Xavier. Les revirements de jurisprudence. Revue Trimestrielle de Droit Civil, v. 2. Paris: Dalloz, 2005.

JOLOWICZ, J. A. Fundamental guarantees in civil litigation: England, in Les Garanties Fondamentales des Parties dans le Procès Civil. Milano: Giuffrè, 1973.

JORGE, Mário Helton. Manual Teórico e Prático da Sentença Cível. 2. ed. Curitiba: J.M., 2012.

JURATOWITCH, Ben. Retroactivity and the Common Law. Portland: Hart, 2008.

JUSTEN FILHO, Marçal. Curso de Direito Administrativo. 2. ed. São Paulo: Saraiva, 2006.

KARAM, Munir. A sentença como fato criador de normas. Revista de Processo, n. 29. São Paulo: Revista dos Tribunais, 1983.

KELSEN, Hans. Teoria Pura do Direito. Trad. João Baptista Machado. São Paulo: Martins Fontes, 2006.

KNIJNIK, Danilo. Os "standards" do convencimento judicial: paradigmas para o seu possivel controle. Disponível em: http://www.abdpc.org.br/abdpc/artigos. Acessado em 22 de outubro de 2009.

KOMATSU, Roque. Da Invalidade no Processo Civil. São Paulo: Revista dos Tribunais, 1991.

LEAL, Victor Nunes. Passado e futuro da Súmula do STF, in Problemas de Direito Público e Outros Problemas, v. 2. Brasília: Ministério da Justiça, 1997.

. A renovação de métodos no Supremo Tribunal e a Súmula de sua jurisprudência predominante, in Problemas de Direito Público e Outros Problemas, v. 2. Brasília: Ministério da Justiça, 1997.

. A Súmula do Supremo Tribunal e o Restatement of the law dos norte-americanos, in Problemas de Direito Público e Outros Problemas, v. 2. Brasília: Ministério da Justiça, 1997.

LEGROS, Robert. Considerations sur les motifs, in La Motivation des Decisions de Justice. Org. Chaim Perelman e P. Foriers. Bruxelas : Établissements Émile Bruylant, 1978. 
LIEBMAN, Enrico Tullio. Do arbitrio à razão: reflexões sobre a motivação da sentença. Trad. Tereza Celina de Arruda Alvim. Revista de Processo, n. 29. São Paulo: Revista dos Tribunais, jan./mar. 1983.

. Istituti del diritto comune nel processo civile brasiliano, in Problemi del Processo Civil. Milano: Morano, 1962.

. Manual de Direito Processual Civil, v. 1. 3. ed. Trad. Cândido Rangel Dinamarco. São Paulo: Malheiros, 2005.

LOBO DA COSTA, Moacyr. A Revogação da Sentença: gênese e genealogia. São Paulo: Ícone, 1995.

LOCKE, John. Two Treatises on Government. Londres: s.e., 1821. p. 354. Obra completa disponível em Google Books.

LORENZETTI, Ricardo Luiz. Teoria da Decisão Judicial: fundamentos de Direito. Trad. Bruno Miragem e Cláudia Lima Marques (rev.). São Paulo: Revista dos Tribunais, 2009.

MACCORMICK, Neil. Can stare decisis be abolished? Juridical Review. S.1.: s.e., 1966.

Rhetoric and the Rule of Law: a theory of legal reasoning. Oxford: Oxford University, 2005.

. The motivation of judgements in the common law, in La Motivation des Decisions de Justice. Org. Chaim Perelman e P. Foriers. Bruxelas : Établissements Émile Bruylant, 1978.

Why cases have rationes and what these are, in Precedent in Law. Org. Laurence Goldstein. Oxford: Oxford University, 1991.

MALBERG, Raymond Carré de. Contribution à la Théorie Générale de l'État. t. I. Paris : Recueil Sirey, 1920.

. Contribution à la Théorie Générale de l’État. t. II. Paris : Recueil Sirey, 1922.

MALINVAUD, Philippe. A propos de la rétroactivité des revirements de jurisprudence. Revue Trimestrielle de Droit Civil, v. 2. Paris: Dalloz, 2005.

MALKIN, Ian; HARDING, Matthew. Overruling in the High Court of Australia in common law cases. Melbourne University Law Review, 34, 2010. 
MANCUSO, Fulvio. Exprimere Causam in Sententia: ricerche sul principio di motivazione della sentenza nell'età del diritto comune classico. Milano: Giuffrè, 1999.

MANCUSO, Rodolfo de Camargo. Divergência Jurisprudencial e Súmula Vinculante. 4. ed. São Paulo: Revista dos Tribunais, 2010.

MARCATO, Antonio Carlos. Crise da Justiça e Influência dos Precedentes Judiciais no Direito Processual Civil Brasileiro, 2008. 265f. Tese (Concurso ao Cargo de Professor Titular). Faculdade de Direito, Universidade de São Paulo, São Paulo

MARINONI, Luiz Guilherme. A legitimidade da atuação do juiz a partir do direito fundamental à tutela jurisdicional efetiva, in Terceira Etapa da Reforma do Código de Processo Civil. Org. Adriano Caldeira e Rodrigo da Cunha Lima Freire. Salvador: JusPodivm, 2007.

. Precedentes Obrigatórios. São Paulo: Revista dos Tribunais, 2010.

. Teoria Geral do Processo. São Paulo: Revista dos Tribunais, 2006.

; ARENHART, Sérgio Cruz. Processo de Conhecimento. 7. ed. São Paulo: Revista dos Tribunais, 2008.

; ARENHART, Sérgio Cruz. Prova. São Paulo: Revista dos Tribunais, 2009.

MARTINS-COSTA, Judith. A proteção da legítima confiança nas relações obrigacionais entre a Administração e os particulares. Revista da Faculdade de Direito da Universidade Federal do Rio Grande do Sul, 22, 2002.

MEDAUAR, Odete. Direito Administrativo Moderno. 12. ed. São Paulo: Revista dos Tribunais, 2008.

MEDINA, José Miguel Garcia; WAMBIER, Luiz Rodrigues; WAMBIER, Teresa Arruda Alvim. Segurança jurídica e irretroatividade da norma processual, in O Processo na Constituição. Coord. Ives Gandra da Silva Martins e Eduardo Jobim. São Paulo: Quartier Latin, 2008.

MELLERAY, Fabrice. Réjouissant mais déroutant. Revue Trimestrielle de Droit Civil, v. 2. Paris: Dalloz, 2005.

MELlO, Marcos Bernardes de. Teoria do Fato Jurídico: plano da existência. 16. ed. São Paulo: Saraiva, 2010. 
MELO, Luiz Pereira de. Requisitos essenciais da sentença. Revista de Processo, n. 11-12. São Paulo: Revista dos Tribunais, 1978.

MENDES, Gilmar Ferreira; COELHO, Inocêncio Mártires; BRANCO, Paulo Gustavo Gonet. Curso de Direito Constitucional. 4. ed. São Paulo: Saraiva, 2009.

MESQUITA, José Ignacio Botelho de. A autoridade da coisa julgada e a imutabilidade da motivação da sentença, in Teses, Estudos e Pareceres de Processo Civil, v. 2. São Paulo: Revista dos Tribunais, 2005.

MOLFESSIS, Nicolas (pres.). Rapport sur les revirements de jurisprudence : remis à Monsieur le Premier Président Guy Canivet, 2004.

MONÉGER, Joël. La maîtrise de l'inévitable revirement de jurisprudence : libres propos et images marines. Revue Trimestrielle de Droit Civil, v. 2. Paris: Dalloz, 2005.

MONICA, Giuseppe della. Contibuto allo Studio della Motivazione. Padova: CEDAM, 2002.

MONTESQUIEU. De l'Esprit des Lois, t. I. Saint-Amand: Gallimard, 2010.

MONTROSE, J. L. Ratio decidendi and the house of lords. The Modern Law Review, 20, $\operatorname{mar} / 1957$.

. The ratio decidendi of a case. The Modern Law Review, 20, mar/1957.

NADEAU, Martin. Perspectives pour un príncipe de sécurité juridique en droit canadien: les pistes du droit européen. Revue de Droit de l'Université de Sherbrooke, n. 40. Québec: Sherbrooke, 2009/2010.

NERY JR., NELSON. Boa-fé objetiva e segurança jurídica - eficácia da decisão judicial que altera jurisprudência anterior do mesmo tribunal superior, in Efeitos Ex Nunc e as Decisões do STJ (Coord. Tércio Sampaio Ferraz Júnior, Roque Antonio Carrazza e Nelson Nery Júnior). 2. ed. Barueri: Manole, 2009.

_. Princípios do Processo na Constituição Federal. 10. ed. São Paulo: Revista do Tribunais, 2010.

NOJIRI, Sérgio. O Dever de Fundamentar as Decisões Judiciais. 2. ed. São Paulo: Revista dos Tribunais, 2000. 
NUVOLONE, Pietro. Discrezionalità del giudice e certezza del diritto, in Studi in Onore di Enrico Tullio Liebman, v.1. Milano: Giuffrè, 1979.

OLBRECHTS-TYTECA, Lucie; PERELMAN, Chaïm. Tratado da Argumentação: a nova retórica. Trad. Maria Ermantina de Almeida Prado Galvão. São Paulo: Martins Fontes, 2005 .

OPPETIT, Bruno. Les garanties fondamentales des parties dans le Procès Civil en Droit français, in Les Garanties Fondamentales des Parties dans le Procès Civil. Milano: Giuffrè, 1973.

ORESTANO, Riccardo. L'Appello Civile in Diritto Romano. 2. ed. Torino: G. Giappichelli, 1966.

PALOMBELLA, Gianluigi. Il Rule of Law: argomenti di una teoria (giuridica) istituzionale. Sociologia del Diritto, n. 1. Milano: Franco Angeli, 2009.

. The Rule of Law as institutional ideal. Comparative Sociology, n. 9. Amsterdam: Brill, 2010.

. The Rule of Law, democracy, and international law: learning from the US Experience. Ratio Juris, v. 20, n. 4. Oxford: Blackwell, dez. 2007.

PERELMAN, Chaïm. La motivation des décisions de justice, essai de synthèse, in La Motivation des Decisions de Justice. Org. Chaim Perelman e P. Foriers. Bruxelas : Établissements Émile Bruylant, 1978.

; OLBRECHTS-TYTECA, Lucie. Tratado da Argumentação: a nova retórica. Trad. Maria Ermantina de Almeida Prado Galvão. São Paulo: Martins Fontes, 2005.

PEREZ, Jesus Gonzalez. El Principio General de la Buena Fe en el Derecho Administrativo. 2. Ed. Madrid: Civitas, 1983.

PIAZZON, Thomas. La Securité Juridique. Paris: Defrénois, 2009.

POLI, Roberto. Giusto processo e oggetto del giudizio di appello. Rivista di Diritto Processuale, n. LXV, 1. Milano: CEDAM, 2010.

PONTES DE MIRANDA, Francisco Cavalcanti. Comentários ao Código de Processo Civil, tt. I e II. Rio de Janeiro: Forense, 1973. 
PONTES DE MIRANDA, Francisco Cavalcanti. Comentários ao Código de Processo Civil, t. VI. Rio de Janeiro: Forense, 1975.

. Tratado de Direito Privado, tt. I, IV e V. 4. ed. São Paulo: Revista dos Tribunais, 1983.

PORTANOVA, Rui. Motivações Ideológicas da Sentença. 3. ed. Porto Alegre: Livraria do Advogado, 1997.

POSNER, Richard A. How Judges Think. Cambridge: Harvard University, 2008. . Law, Pragmatism and Democracy. Cambridge: Harvard University, 2003. . The Problems of Jurisprudence. Cambridge: Harvard University, 1993.

POSTEMA, Gerald J. Some roots of our notion of precedent, in Precedent in Law. Org. Laurence Goldstein. Oxford: Oxford University, 1991.

PUNZI, Carmine. Il ruolo della giurisprudenza e i mutamenti d'interpretazione di norme processuali. Rivista di Diritto Processual, LXVI, 6. Milano: CEDAM, 2011.

RADBRUCH, Gustav. La securité en droit d'après la théorie anglaise. Archives de Philosophie du Droit e de Sociologie Juridique, n. 3-4. Paris: Sirey, 1936.

RAGGI, Luigi. Studi sulle Impugnazioni Civili nel Processo Romano, v. I. Milano: Giuffrè, 1961.

RAIMBAULT, Philippe. Recherche sur la Sécurité Juridique en Droit Administratif Français. Paris : L.G.D.J, 2009.

RAMINA DE LUCCA, Rodrigo. Inexequibilidade das sentenças declaratórias. Revista Dialética de Direito Processual, 92. São Paulo: Dialética, 2010.

. O mérito do processo e as condições da ação. Revista de Processo, 188. São Paulo: Revista dos Tribunais, 2010.

. Resolução liminar do mérito. Revista Dialética de Direito Processual, 78. São Paulo: Dialética, 2009.

. Querela nullitatis e réu revel não citado no processo civil brasileiro. Revista de Processo, 202. São Paulo: Revista dos Tribunais, 2011. 
RAMOS, Elival da Silva. Ativismo Judicial: parâmetros dogmáticos. São Paulo: Saraiva, 2010 .

RAWLS, John. A Theory of Justice. New Delhi: Universal, 2011.

RAZ, Joseph. Between Authority and Interpretation: on the theory of law and practical reason. New York: Oxford, 2009.

. The Rule of Law and its virtue, in The Authority of Law: essays on law and morality. New York: Oxford University, 2002.

REGO, Hermenegildo de Souza. Os motivos da sentença e a coisa julgada (em especial, os arts. 810 e 817 do $C P C$ ). Revista de Processo, n. 35. São Paulo: Revista dos Tribunais, 1984.

RIPERT, Georges. Les Forces Créatrices du Droit. Paris: L.G.D.J., 1955.

ROCCO, Alfredo. La sentencia civil. México - Distrito Federal: Tribunal Superior de Justicia del Distrito Federal - MEX, 2003.

ROCHE-FLAVIN. Bernard de la. Treize Liures des Parlements de Frances. Genève: s.e., 1621. Obra completa disponível em Google Books.

ROUBIER, Paul. Théorie Générale du Droit. 2. ed. Paris: Sirey, 1951.

ROUSSEAU, Jean-Jacques. Do Contrato Social. São Paulo: Martin Claret, 2003.

RUFFINI, Giuseppe. Mutamenti di giurisprudenza nell'interpretazione delle norme processuali e 'giusto processo'. Rivista di Diritto Processual, LXVI, 6. Milano: CEDAM, 2011.

SAMPFORD, Charles. Retrospectivity and the Rule of Law. Oxford: Oxford University, 2006.

SANTORO, Emilio. Rule of Law e 'liberdade dos ingleses': a interpretação de Albert Venn Dicey, in O Estado de Direito: história, teoria, crítica. Org. Pietro Costa e Danilo Zolo. Trad. Carlo Alberto Dastoli. São Paulo: Martins Fontes, 2006.

SANTOS, Evaristo Aragão. Em torno do conceito e da formação do precedente judicial, in Direito Jurisprudencial. Coord. Teresa Arruda Alvim Wambier. São Paulo: Revista dos Tribunais, 2012. 
SANTOS, Moacyr Amaral. Primeiras Linhas de Direito Processual Civil, v. 2. 19. ed. São Paulo: Saraiva, 1998.

SANTOS, Tomás-Javier Aliste. La Motivación de las Resoluciones Judiciales. Madrid: Marcial Pons, 2011.

SARLET, Ingo Wolfgang. A eficácia do direito fundamental à segurança jurídica: dignidade da pessoa humana, direitos fundamentais e proibição do retrocesso social no Direito Constitucional brasileiro, in Constituição e Segurança Jurídica: direito adquirido, ato jurídico perfeito e coisa julgada - estudos em homenagem a José Paulo Sepúlveda Pertence. Coord. Cármen Lúcia Antunes Rocha. Belo Horizonte: Fórum, 2005.

SARTORIUS, Rolf. The justification of the judicial decision. Ethics, 78, 3, 1968.

SAUVEL, Tony. Histoire du jugement motive. Revue du Droit Public et de la Science Politique en France et à l'Étranger, 61. Paris: Librairie Générale de Droit et de Jurisprudence, 1955.

SATTA, Salvatore. Sull'inesistenza degli atti processuali. Rivista Trimestrale di Diritto e Procedura Civile. Milano: Giuffrè, 1956.

SCHAUER, Frederick. Thinking Like a Lawyer: a new introduction to legal reasoning. Cambridge: Harvard University, 2009.

SCHWAB, Karl Heinz. El Objeto Litigioso en el Processo Civil. Trad. Tomas A. Banzhaf. Buenos Aires: Ediciones Juridicas Europa-America, 1968.

SERINET, Yves-Marie. Par elle, avec elle et en elle? La Cour de cassation et l'avenir des revirements de jurisprudence. Revue Trimestrielle de Droit Civil, v. 2. Paris: Dalloz, 2005.

SCHNEIDER, Jens-Peter. Seguridad jurídica y protección de la confianza en el Derecho constitucional y administrativo alemán. Documentación Administrativa (DA), 263-264, 2002

SHAPIRO, David L. In defense of judicial candor. Harvard Law Review, 100, 1986-1987. SHAPIRO, Scott J. Legality. Cambridge: Harvard University, 2011.

SICA, Heitor Vitor Mendonça. O Direito de Defesa no Processo Civil Brasileiro: um estudo sobre a posição do réu. São Paulo: Atlas, 2011. 
SILANCE, L. La motivation des jugements et la cohérence du droit, in La Motivation des Decisions de Justice. Org. Chaim Perelman e P. Foriers. Bruxelas : Établissements Émile Bruylant, 1978.

SILVA, Ana de Lourdes Coutinha. Motivação das Decisões Judiciais. São Paulo: Atlas, 2012.

SILVA, Blecaute Oliveira. A Garantia Fundamental à Motivação da Decisão Judicial. Salvador: JusPodivm, 2007.

SILVA, José Afonso da. Curso de Direito Constitucional Positivo. 15. ed. São Paulo: Malheiros, 1998.

SILVA, Ovídio Baptista da. Constituição e segurança jurídica, in Constituição e Segurança Jurídica: direito adquirido, ato jurídico perfeito e coisa julgada - estudos em homenagem a José Paulo Sepúlveda Pertence. Coord. Cármen Lúcia Antunes Rocha. Belo Horizonte: Fórum, 2005.

- Democracia moderna e processo civil, in Participação e Processo. Coord. Ada Pellegrini Grinover, Cândido Rangel Dinamarco, Kazuo Watanabe. São Paulo: Revista dos Tribunais, 1988.

Fundamentação das sentenças como garantia constitucional, in O Processo na Constituição. Coord. Ives Gandra da Silva Martins e Eduardo Jobim. São Paulo: Quartier Latin, 2008.

. Limites objetivos da coisa julgada no direito brasileiro atual. Revista de Processo, n. 14-15. São Paulo: Revista dos Tribunais, 1979.

SILVA, Virgílio Afonso da. Princípios e regras - mitos e equívocos acerca de uma distinção. Revista Latino-Americana de Estudos Constitucionais, 1, 2003.

SIMPSON, A. W. B. The ratio decidendi of a case. The Modern Law Review, 20, jul/1957.

. The ratio decidendi of a case. The Modern Law Review, 21, mar/1958.

. The ratio decidendi of a case. The Modern Law Review, 22, set/1959.

SLAIB FILHO, Nagib. Sentença Cível (fundamentos e técnica). 5. ed. Rio de Janeiro: Forense, 1998. 
SOMERHAUSEN, Marc. La motivation et la mission normative du juge, in La Motivation des Decisions de Justice. Org. Chaim Perelman e P. Foriers. Bruxelas : Établissements Émile Bruylant, 1978.

SUMMERS, Robert. S. A formal theory of the Rule of Law. Ratio Juris, n. 6. Oxford: Blackwell, 1993.

STAHL, Friedrich Julius. Storia della Filosofia del Diritto. Trad. Pietro Torre. Torino: Tip. G. Favale e Compagnia, 1853.

STEARNS Maxwell; ABRAMOWICZ, Michael. Defining dicta. Stanford Law Review, 56,2005

STONE, Julius. The ratio of the ratio decidendi.

STALEV, Zhivko. Fundamental guarantees of litigants in civil proceedings: a survey of the laws of the European people's democracies, in Les Garanties Fondamentales des Parties dans le Procès Civil. Milano: Giuffrè, 1973.

TAGGART, Michael. Should Canadian judges be legally required to give reasoned decisions in civil cases? University of Toronto Law Journal, 33. Toronto: University of Toronto, 1983.

TALAMINI, Eduardo. Coisa Julgada e sua Revisão. São Paulo: Revista dos Tribunais, 2005.

. Novos Aspectos da Jurisdição Constitucional Brasileira: repercussão geral, força vinculante, modulação dos efeitos do controle de constitucionalidade e alargamento do objeto do controle direto. Tese de Livre-Docência. Faculdade de Direito. Universidade de São Paulo, 2008.

TAMANAHA, Brian Z. A concise guide to the Rule of Law. St. John's University School of Law: Legal Studies Research Paper Series, 07-0082. New York, 2007. Versão eletrônica disponível em: http://ssrn.com/abstract=1012051, acessada em 28 de maio de 2011.

On the Rule of Law: history, politics, theory. New York: Cambridge University, 2010 .

. The dark side of the relationship between the Rule of Law and liberalism. St. John's University School of Law: Legal Studies Research Paper Series, 08-0096. New 
York, jan./2007. Versão eletrônica disponível em: http://ssrn.com/abstract=1087023, acessada em 28 de maio de 2011.

TARUFFO, Michele. Considerazioni su prova e motivazione, in Os Poderes do Juiz e o Controle das Decisões Judiciais: estudos em homenagem à Professora Teresa Arruda Alvim Wambier. São Paulo: Revista dos Tribunais, 2008.

. Il significato costituzionale dell'obbligo di motivazione, in Participação e Processo.

Coord. Ada Pellegrini Grinover, Cândido Rangel Dinamarco, Kazuo Watanabe. São Paulo: Revista dos Tribunais, 1988.

. La Motivazione della Sentenza Civile. Padova: Cedam, 1975.

. Legalità e giustificazione della creazione giudiziaria del diritto. Rivista Trimestrale di Diritto e Procedura Civile. Milano: Giuffrè, mar. 2001.

. L'obbligo di motivazione della sentenza civile tra diritto comune e illuminismo. Rivista di Diritto Processuale, 29. Padova: CEDAM, 1974.

. Precedente e Giurisprudenza. S.1.: Editoriale Scientifica, 2007.

. Senso Comum, Experiência e Ciência no Raciocínio do Juiz. Trad. Cândido Rangel Dinamarco. Curitiba: IBEJ, 2001.

TELLES JÚNIOR, Goffredo. Iniciação na Ciência do Direito. 4. ed. São Paulo: Saraiva, 2009.

TORRES, Heleno Taveira. Direito Constitucional Tributário e Segurança Jurídica. São Paulo: Revista dos Tribunais, 2011.

TOUFFAIT, Adolphe; TUNC, André. Pour une motivation plus explicite des décisions de justice notamment de celles de la Cour de Cassation. Revue Trimestrielle de Droit Civil, 72. Paris: Dalloz, 1974.

TROCKER, Nicolò. Il nuovo articolo 111 della costituzione e il " giusto processo 》 in materia civile: profili generali. Rivista Trimestrale di Diritto e Procedura Civile. Milano: Giuffrè, 2001.

. Processo Civile e Costituzione: problemi di diritto tedesco e italino. Milano: Giuffrè, 1974. 
TUCCI, José Rogério Cruz e. A Motivação da Sentença no Processo Civil. São Paulo: Saraiva, 1987.

- Parâmetros de eficácia e critérios de interpretação do precedente judicial, in

Direito Jurisprudencial. Coord. Teresa Arruda Alvim Wambier. São Paulo: Revista dos Tribunais, 2012.

_. Precedente Judicial como Fonte do Direito. São Paulo: Revista dos Tribunais, 2004.

TUCCI, José Rogério Cruz e; AZEVEDO, Luiz Carlos de. Lições de Processo Civil Romano. São Paulo: Revista dos Tribunais, 2001.

TUNC, André ; TOUFFAIT, Adolphe. Pour une motivation plus explicite des décisions de justice notamment de celles de la Cour de Cassation. Revue Trimestrielle de Droit Civil, 72. Paris: Dalloz, 1974.

VALEMBOIS, Anne-Laure. La Constitutionnalisation de l'Exigence de Sécurité Juridique en Droit Français. Paris: L.G.D.J, 2004.

VALIM, Rafael. O Princípio da Segurança Jurídica no Direito Administrativo Brasileiro. São Paulo: Malheiros, 2010.

VANWELKENHUYZEN, A. La motivation des revirements de jurisprudence, in La Motivation des Decisions de Justice. Org. Chaim Perelman e P. Foriers. Bruxelas : Établissements Émile Bruylant, 1978.

VELU, Jacques. La convention européenne des Droits de l'Homme et les garanties fondamentales des parties dans le Procès Civil, in Les Garanties Fondamentales des Parties dans le Procès Civil. Milano: Giuffrè, 1973.

VENOSA, Sílvio de Salvo. Direito Civil: parte geral. 7. ed. São Paulo: Atlas, 2007.

VERDE, Giovanni. Mutamento di giurisprudenza e affidamento incolpevole (considerazioni sul difficile rapporto fra giudice e legge). Rivista di Diritto Processual, LXVII, 1. Milano: CEDAM, 2012.

VESCOVI, Enrique; FERREIRA, Eduardo Vaz. Les garanties constitutionnelles des parties dans le procès civil en Amérique Latine, in Les Garanties Fondamentales des Parties dans le Procès Civil. Milano: Giuffrè, 1973. 
VIEHWEG, Theodor. Tópica e Jurisprudência: uma contribuição à investigação dos fundamentos jurídico-cientificos. Trad. Kelly Susane Alflen da Silva. Porto Alegre: Sergio Antonio Fabris, 2008.

VIGORITI, Vincenzo; CAPPELLETTI, Mauro. Fundamental guarantees of the litigants in civil proceceedings: Italy, in Les Garanties Fondamentales des Parties dans le Procès Civil. Milano: Giuffrè, 1973.

VILLAR, Alfonso Murillo. La motivación de la sentencia en el processo civil romano. Cuadernos de Historia del Derecho, n. 2. Madrid: Complutense, 1995.

VOLTAIRE. Commentaire sur le Livre Des Délits et des Peines: par un avocat de province. S. 1. : s.e., 1766. Obra completa disponível em Google Books.

WALDRON, Jeremy. Is the Rule of an essentially contested concept (in Florida)? Law and Philosophy, n. 21. Dordrecht: Kluwer, 2002.

. The concept and the Rule of Law. New York University School of Law - public law \& legal theory research paper series working paper, n. 08-50, nov./2008. Versão eletrônica disponível em: http://ssrn.com/abstract=1273005, acessada em 28 de maio de 2011.

WAMBAUGH, Eugene. The Study of Cases: a course of instruction. 2. ed. Boston: Little, Brown, and Company, 1894. Obra completa disponível em openlibrary.org.

WAMBIER, Luiz Rodrigues; MEDINA, José Miguel Garcia; WAMBIER, Teresa Arruda Alvim. Segurança jurídica e irretroatividade da norma processual, in O Processo na Constituição. Coord. Ives Gandra da Silva Martins e Eduardo Jobim. São Paulo: Quartier Latin, 2008.

WAMBIER, Teresa Arruda Alvim. Nulidades do Processo e da Sentença. 6. ed. São Paulo: Revista dos Tribunais, 2007.

. Omissão Judicial e Embargos de Declaração. São Paulo: Revista dos Tribunais, 2005.

. Precedentes e evolução do direito, in Direito Jurisprudencial. Coord. Teresa Arruda Alvim Wambier. São Paulo: Revista dos Tribunais, 2012. 
; MEDINA, José Miguel Garcia; WAMBIER, Luiz Rodrigues. Segurança jurídica e irretroatividade da norma processual, in O Processo na Constituição. Coord. Ives Gandra da Silva Martins e Eduardo Jobim. São Paulo: Quartier Latin, 2008.

WATANABE, Kazuo. Da Cognição no Processo Civil. 2. ed. São Paulo: Perfil, 2005.

WATSON, Garry D. Fundamental guarantees of litigants in civil proceedings in Canada, in Les Garanties Fondamentales des Parties dans le Procès Civil. Milano: Giuffrè, 1973.

WESLEY-SMITH, Peter. Theories of adjudication and the status of stare decisis, in Precedent in Law. Org. Laurence Goldstein. Oxford: Oxford University, 1991.

WRÓBLEWSKI, Jerzy. Constitución y Teoría General de la Interpretación Jurídica. Madrid: Civitas, 1985.

. Motivation de la décision judiciaire, in La Motivation des Decisions de Justice. Org. Chaim Perelman e P. Foriers. Bruxelas : Établissements Émile Bruylant, 1978.

YARSHELL, Flávio Luiz. Antecipação da Prova sem o Requisito da Urgência e Direito Autônomo à Prova. São Paulo: Malheiros, 2009.

. Tutela Jurisdicional. 2. ed. São Paulo: DPJ, 2006.

ZAGREBELSKY, Gustavo. Il Diritto Mite. Torino: Einaudi, 2010.

ZANETI JR., Hermes. Democracia e Judiciário na (Re)politização do Direito: notas para o papel dos juízes e do Judiciário em um modelo deliberativo-procedimental de democracia, in Os Poderes do Juiz e o Controle das Decisões Judiciais: estudos em homenagem à Professora Teresa Arruda Alvim Wambier. São Paulo: Revista dos Tribunais, 2008.

ZAVARIZE, Rogério Bellentani. A Fundamentação das Decisões Judiciais. Campinas: Millennium, 2004.

ZOLO, Danilo. Teoria e crítica do Estado de Direito, in O Estado de Direito: história, teoria, crítica. Org. Pietro Costa e Danilo Zolo. Trad. Carlo Alberto Dastoli. São Paulo: Martins Fontes, 2006. 